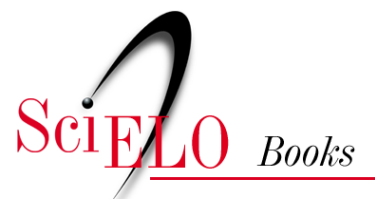

\title{
Foundations of Paleoparasitology
}

\author{
Luiz Fernando Ferreira \\ Karl Jan Reinhard \\ Adauto Araújo \\ (Editors)
}

\section{SciELO Books / SciELO Livros / SciELO Libros}

FERREIRA, L.F., REINHARD, K.J., and ARAÚJO, A., ed. Foundations of Paleoparasitology

[online]. Rio de Janeiro: Editora FIOCRUZ, 2014, 462 p. ISBN: 978-85-7541-598-6. Available from: doi: $\underline{10.7476 / 9788575415986}$. Also available in ePUB from: http://books.scielo.org/id/zngnn/epub/ferreira-9788575415986.epub.

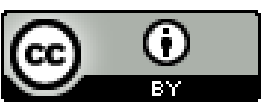

All the contents of this work, except where otherwise noted, is licensed under a Creative Commons Attribution 4.0 International license.

Todo o conteúdo deste trabalho, exceto quando houver ressalva, é publicado sob a licença $\underline{\text { Creative Commons }}$ Atribição 4.0. 
Foundations of Paleoparasitology 
OSWALDO CRUZ FOUNDATION

President

Paulo Gadelha

Vice-President of Teaching, Information, and Communication

Nísia Trindade Lima

EDITORA FIOCRUZ

Director

Nísia Trindade Lima

Executive Editor

João Carlos Canossa Mendes

Scientific Editors

Carlos Machado de Freitas

Gilberto Hochman

Editorial Board

Claudia Nunes Duarte dos Santos

Jane Russo

Ligia Maria Vieira da Silva

Maria Cecília de Souza Minayo

Marilia Santini de Oliveira

Moisés Goldbaum

Pedro Paulo Chieffi

Ricardo Lourenço de Oliveira

Ricardo Ventura Santos

Soraya Vargas Côrtes
INTERNATIONAL FEDERATION FOR

TROPICAL MEDICINE (IFTM)

BOARD (2012-2016)

President (2012-2016)

Cláudio Tadeu Daniel-Ribeiro (Brazil)

Vice-President

Santiago Mas-Coma (Spain)

Treasurer

Jong-Yil Chai (Korea)

Secretary General

Filomeno Fortes (Angola)

Chair of the XIX ICTMM (International Congress for Tropical Medicine and Malaria) Malcolm Jones (Australia)

Past-President (2008-2012) Pierre Ambroise-Thomas (France)

Expanded Board

Zeno Bisoffi (Italy)

Ogobara Doumbo (Mali)

Socrates Herrera (Colombia)

Peter J. Hotez (USA)

Shigeyuki Kano (Japan)

Srisin Khusmith (Thailand)

Xiao-Nong Zhou (China)

Virgilio do Rosário (Portugal) 
Luiz Fernando Ferreira

Karl Jan Reinhard

Adauto Araújo

Editors

\section{Foundations of Paleoparasitology}

Translated from the Portuguese by Christopher Peterson
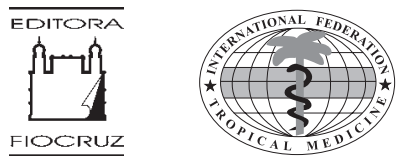
Copyright (C) 2014, English-language edition, by the authors

Copyright (C) 2011, First Portuguese-language edition, by the authors

All rights reserved, Oswaldo Cruz Foundation

Cover design

Eduardo Pucu de Araujo

Layout, final cover artwork, and image processing

Adriana Carvalho Peixoto da Costa and Carlos Fernando Reis da Costa

Revision of the First Portuguese-language edition

Fernanda Veneu Lumb and Irene Ernest Dias

Standardization of references in the First Portuguese-language edition

Clarissa Bravo

English translation

Christopher Peterson

Cataloguing-in-Publication Data

Instituto de Comunicação e Informação Científica e Tecnológica

Biblioteca de Saúde Pública

F383 Ferreira, Luiz Fernando (Editor)

Foundations of Paleoparasitology. / Luiz Fernando Ferreira, Karl Jan Reinhard \& Adauto Araújo, Editors, Rio de Janeiro, Editora Fiocruz, 2014. Translated from the Portuguese by Christopher Peterson.

484 p. il., tab., graphs.

ISBN: 978-85-7541-440-8

1. Paleopathology. 2. Parasitology. 3. Epidemiology. 4. Chagas disease. 5. Arthropods. 6. Mites and Ticks. 7. Bacteria. 8. Viruses. I. Reinhard, Karl Jan (Ed.). II. Araújo, Adauto (Ed.). III. Title.

CDD -616.96

2014

EDITORA FIOCRUZ

Av. Brasil, 4036 - 1 andar - sala 112 - Manguinhos

21040-361 - Rio de Janeiro - RJ - Brazil

Tels.: (55 21) 3882-9039 and 3882-9041

Telefax: (55 21) 3882-9006

http://www.fiocruz.br/editora

e-mail: editora@fiocruz.br 
For José Rodrigues da Silva, an unforgettable teacher, Adolpho Lutz, Lobato Paraense, and José Rodrigues Coura. Because it's good to grow old in Manguinhos. 
Infectious disease is composed of three variables, the host, the pathogen and the environment. It is a constant state of flux, capable of changing in step with any variation in any one of its components. New diseases appear, old ones alter, and some may disappear completely.

Aidan Cockburn 


\section{Authors}

Adauto José Gonçalves de Araújo (Editor)

Physician, PhD in Public Health from the Sergio Arouca National School of Public Health, Oswaldo Cruz Foundation (ENSP/FIOCRUZ), where he works as Senior Researcher.

\section{Alena Mayo Iñiguez}

Biologist, PhD in Parasite Biology from the Oswaldo Cruz Institute, Oswaldo Cruz Foundation (IOC/FIOCRUZ), where she works as Associate Researcher.

\section{Ana Maria Jansen}

Veterinarian, PhD in Microbiology from the Federal University of Rio de Janeiro (UFRJ). Senior Researcher at the Oswaldo Cruz Institute, Oswaldo Cruz Foundation (IOC/FIOCRUZ).

\section{Carlos Maurício de Andrade}

Pharmacist, PhD in Parasite Biology from the Oswaldo Cruz Foundation. Senior Researcher at the Institute of Pharmaceutical Technology (Farmanguinhos/FIOCRUZ).

\section{Daniela Leles de Sousa}

Biologist, PhD in Public Health from the Sergio Arouca National School of Public Health, Oswaldo Cruz Foundation (ENSP/FIOCRUZ). Department of Microbiology and Parasitology, Biomedical Institute, Fluminense Federal University (UFF), Rio de Janeiro.

\section{Diana Maul de Carvalho}

Physician, PhD in Public Health from the Sergio Arouca National School of Public Health, Oswaldo Cruz Foundation (ENSP/FIOCRUZ). Associate Professor I at the Department of Preventive Medicine, School of Medicine, Federal University of Rio de Janeiro (UFRJ).

\section{Ernesto Hofer}

Veterinarian, Professor at the Fluminense Federal University (UFF). Senior Researcher at the Oswaldo Cruz Institute, Oswaldo Cruz Foundation (IOC/Fiocruz). 


\section{Francisco Inácio Bastos}

Physician, PhD in Public Health from the Sergio Arouca National School of Public Health, Oswaldo Cruz Foundation (ENSP/FIOCRUZ). Senior Researcher at the Institute of Scientific and Technological Communication and Information in Health (ICICT/FIOCRUZ).

\section{Françoise Bouchet}

Pharmacist, PhD in Pharmaceutical Sciences from Université de Paris. Professor of Parasitology, member of Académie Nationale de Pharmacie, Comité des Travaux Historiques et Scientifiques au Ministère de l'Éducation Nationale, and Laboratoire de Parasitologie Environnementale et Paléoparasitologie, UFR de Pharmacie, Université de Reims Champagne-Ardenne (France).

\section{Gino Chaves da Rocha}

Veterinarian, PhD in Public Health from the Sergio Arouca National School of Public Health, Oswaldo Cruz Foundation (ENSP/FIOCRUZ). Visiting Professor of Veterinary Parasitology at the School of Agronomy and Veterinary Medicine, University of Brasilia (FAV/UnB), where he heads the Laboratory of Veterinary Parasitology and Parasitic Diseases.

\section{Hermann G. Schatzmayr (in memoriam)}

Veterinarian, Professor at Fluminense Federal University (UFF). Senior Researcher at the Oswaldo Cruz Institute, Oswaldo Cruz Foundation (IOC/FIOCRUZ).

\section{José Dilermando Andrade Filho}

Biologist, PhD in Parasite Biology from the Oswaldo Cruz Institute, Oswaldo Cruz Foundation (IOC/FIOCRUZ). Senior Technology Expert at the René Rachou Research Center (CPqRR/FIOCRUZ).

Joseli Maria da Rocha Nogueira

Biologist, PhD from the Sergio Arouca National School of Public Health, Oswaldo Cruz Foundation (ENSP/FIOCRUZ), where she works as Senior Technology Expert.

\section{Karl Jan Reinhard (Editor)}

Archeologist and biologist, PhD in Sciences from Texas A \& M University, Senior Professor, School of Natural Resources, University of Nebraska, Lincoln, USA.

Katharina Dittmar de la Cruz

Veterinarian, PhD in Parasitology and Ecology from the University of Leipzig, Germany. Professor at the Department of Biological Sciences, State University of New York, Buffalo, USA.

\section{Léa Ferreira Camillo-Coura}

Physician, Professor at the Federal University of Rio de Janeiro (UFRJ). Senior Researcher at the Evandro Chagas Research Institute, Oswaldo Cruz Foundation (IPEC/FIOCRUZ) and Researcher Emeritus at UFRJ.

\section{Lídia Susana Burry}

Biologist, PhD in Natural Sciences from Universidad Nacional de Mar del Plata, Argentina, where she teaches at the School of Exact and Natural Sciences.

Luciana Sianto

Biologist, PhD from the Sergio Arouca National School of Public Health, Oswaldo Cruz Foundation (ENSP/ FIOCRUZ). Researcher at the National Institute of Science and Technology in Archeology, Paleontology, and 
Environment of the Semiarid, and Visiting Researcher at FIOCRUZ under the National Council on Scientific and Technological Development (CNPq).

\section{Luiz Fernando Rocha Ferreira da Silva (Editor)}

Physician, PhD in Medicine from the University of Brazil, Researcher Emeritus at the Oswaldo Cruz Foundation (FIOCRUZ).

\section{Marcelo Luiz Carvalho Gonçalves}

Physician, PhD in Public Health from the Sergio Arouca National School of Public Health, Oswaldo Cruz Foundation (ENSP/FIOCRUZ), Evandro Chagas National Institute of Infectious Diseases, Oswaldo Cruz Foundation.

\section{Marcia Chame}

Biologist, PhD in Zoology from the Federal University of Rio de Janeiro (UFRJ). Senior Researcher at the Sérgio Arouca National School of Public Health, Oswaldo Cruz Foundation (ENSP/FIOCRUZ).

\section{Martín Horácio Fugassa}

Biologist, PhD from Universidad Nacional de Mar del Plata, Argentina, where he is Senior Professor.

\section{Matilde Elena Trivi}

Biologist, Senior Professor at Universidad Nacional de Mar del Plata, Argentina.

\section{Matthieu Le Bailly}

Biologist, PhD in Biological and Pharmaceutical Sciences from Université de Reims Champagne-Ardenne. Maître de Conférences/CNRS, Faculté des Sciences et Techniques de l'Université de Franche-Comté (UFC), France.

\section{Nicolau Maués da Serra-Freire}

Veterinarian, PhD in Veterinary Medicine and Veterinary Parasitology from the Federal Rural University of Rio de Janeiro (UFRRJ). Senior Researcher at the Oswaldo Cruz Institute (IOC/FIOCRUZ).

\section{Paulo Roberto de Figueiredo Souto}

Biologist, PhD in Geology from the Federal University of Rio de Janeiro (UFRJ), Professor at the State University of Rio de Janeiro (UERJ).

\section{Reginaldo Peçanha Brazil}

Pharmacist, PhD in Parasitology from the University of Liverpool (UK). Senior Researcher at the Oswaldo Cruz Institute, Oswaldo Cruz Foundation (IOC/FIOCRUZ).

\section{Ricardo Anibal Guichón}

Anthropologist, PhD in Physical Anthropology from Universidad de Buenos Aires, Argentina. Associate Researcher at the Laboratory of Human Evolutionary Ecology, Universidad Nacional del Centro de la Provincia de Buenos Aires; Department of Biology, Facultad de Ciencias Exactas y Naturales, Universidad Nacional de Mar del Plata, Argentina.

\section{Scott Lyell Gardner}

Biologist, PhD in Parasitology from the University of New Mexico. Professor and Curator at University of Nebraska State Museum, University of Nebraska-Lincoln, USA. 


\section{Sérgio Augusto Miranda Chaves}

Biologist, PhD in Geology of the Quaternary and Human Paleontology from the Museum National d'Histoire Naturelle (France). Senior Researcher at the Sergio Arouca National School of Public Health, Oswaldo Cruz Foundation (ENSP/FIOCRUZ).

Sheila Maria Ferraz Mendonça de Souza

Physician, PhD in Public Health from the Sergio Arouca National School of Public Health, Oswaldo Cruz Foundation (ENSP/FIOCRUZ), where she is Senior Researcher. 


\section{Table of Contents}

Preface

Presentation

Part I: Parasites, Human Hosts, and the Environment

1. An Introduction to Paleoparasitology Luiz Fernando Ferreira

2. The Preservation of Organic Material over Time 43 Luiz Fernando Ferreira

3. The History of Paleopathology in Brazil: skulls, parasites, and diseases from the past 53 Sheila Mendonça de Souza

4. The Dispersal of Homo sapiens and the Peopling of the Continents 69 Sheila Mendonça de Souza

5. Human Occupation of Patagonia

Ricardo A. Guichón, Matilde Elena Trivi, and Lídia Susana Burry

6. Parasitism

Adauto Araújo and Luiz Fernando Ferreira

7. The Origin of Parasites of Humans Luiz Fernando Ferreira, Karl Jan Reinhard, and Adauto Araújo

8. Parasites as Markers of Prehistoric Migrations Adauto Araújo, Karl Jan Reinhard, Scott L. Gardner, and Luiz Fernando Ferreira 
Part II. Parasite Remains Preserved in Various Materials and Technioues in Microscopy and Molecular Diagnosis

9. The Study of Microinclusions in Coprolites

Paulo Roberto de Figueiredo Souto

10. Arthropods and Parasites Found in Amber.

Reginaldo Peçanha Brazil and José Dilermando Andrade Filho

11. Mites, Ticks, and Paleoparasitology

Gino Chaves da Rocha and Nicolau Maués da Serra-Freire

12. Bacteria and Paleoparasitology

Joseli Maria da Rocha Nogueira and Ernesto Hofer

13. Viruses and Paleoparasitology

Hermann G. Schatzmayr

14. Pollen Grains, Landscapes, and Paleoenvironments Sérgio Augusto de Miranda Chaves

15. Paleoparasitological Diagnosis Martín H. Fugassa

16. Coprolite diagnosis, or who made the coprolite? Marcia Chame and Luciana Sianto

17. Paleoserology

Carlos Maurício de Andrade

18. Paleoparasitology and Ancient DNA

Katharina Dittmar

19. Molecular Paleoparasitology

Alena Mayo Iñiguez

Part III. Parasite Findings in Archeological Remains: a paleogeographic view

20. The Findings in South America

Luiz Fernando Ferreira, Léa Camillo-Coura, Martín H. Fugassa, Marcelo Luiz Carvalho Gonçalves, Luciana Sianto, and Adauto Araújo

21. The Findings in North America 341 Karl Jan Reinhard

22. The Findings in Europe 363 Françoise Bouchet and Matthieu Le Bailly

23. The Findings in Asia 389 Adauto Araújo and Luiz Fernando Ferreira 
24. The Findings in Oceania

Luiz Fernando Ferreira and Adauto Araújo

25. The Findings in Africa 403

Adauto Araújo and Luiz Fernando Ferreira

Part IV: Special Studies and Perspectives

26. The Paleoepidemiology of Chagas disease

Adauto Araújo, Ana Maria Jansen, Karl Jan Reinhard, and Luiz Fernando Ferreira

27. Diseases Recorded in Historical Documents 435 Diana Maul de Carvalho

28. Methods in Paleoepidemiology and New Perspectives in Paleoparasitology 453 Francisco Inácio Bastos, Daniela Leles, and Adauto Araújo 


\section{Preface}

Writing the preface to Foundations of Paleoparasitology, edited by Luiz Fernando Ferreira, Karl Reinhard, and Adauto Araújo, is both an honor and a pleasure for me. It is an honor, because such prestigious and internationally renowned specialists have entrusted the task to me. It is a pleasure, because we are friends, very good friends, and sharing something as beautiful as this book with friends is always highly rewarding.

The origins of Paleopathology date back several centuries, but we can only speak of a "systematic" Paleopathology since the early 20th century, when Marc Armand Ruffer conducted pioneering studies on diseases in Egyptian mummies and introduced the technique of rehydration in mummies, still used today with some variations. Since then, tens of thousands of studies have been published around the world on ancient diseases, in addition to hundreds of books and monographs on the general theme or more specific aspects of it. In fact, even a brief review of the more recent history of Paleopathology (a field that necessarily encompasses Paleoparasitology) reveals the huge amount of books published in the last three decades on different facets of the subject: General Paleopathology, Bone Paleopathology, studies on mummies and bodies preserved by other processes, applications of molecular genetics to the analysis of ancient populations, paleoimaging, applications of Paleopathology to Forensic Science, paleohistology, etc., are just a few relevant examples of the impact of various diseases on ancient populations and their study by researchers from widely diverse geographic regions. Nevertheless, we lacked a book dedicated exclusively to one of the most important themes in the field when focusing on studies that encompass demography, population habits, ecology, and health: Paleoparasitology.

Paleoparasitology did not receive special treatment until well into the 20th century. However, the first steps had been taken long before to make a reality of the field as we know it today. The first of these steps was common to all fields that study humans in past times: the birth of modern Archaeology, or that of the archaeological method, founded by Jacques Boucher de Perthes in the mid-19th century.

Without Archaeology, those of us dedicated to the study of health and disease in ancient times would have little to do or say, because Archaeology provides us with the necessary material for our routine research. Along with the birth of modern Archaeology, a series of milestones have marked the development of Paleoparasitology. The first was undoubtedly the recognition of coprolites (a term coined by William Buckland in the early 19th century) as a source of 
abundant and trustworthy information on eating habits, diseases, and ecological and demographic characteristics of ancient cultures. In the late 19th century, Harshberger signaled the potential possibilities of coprolites for analyzing ancient diets, and in 1925 Seton recognized that the shape and content of feces are indicative of the respective animal order. Netolitzky was responsible for the first rehydration techniques, perfected shortly thereafter (in the mid-20th century), first by Van Cleave and Ross, and later and more decisively by Callen and Cameron (1955, 1960), using 0.5\% trisodium phosphate aqueous solution. Much more recently, refined laboratory techniques, especially DNA analysis, have given extraordinary impetus to the development of Paleoparasitology.

Numerous national and international congresses and scientific meetings in Paleopathology have been held, especially since the founding of the Paleopathology Association in the 1970s, thereby fueling publication and debate of paleoparasitological studies conducted in different parts of the planet. As for Latin America, such progress was reinforced in 2005 with the First Congress of the Paleopathology Association in South America (PAMinSA) in the city of Río de Janeiro, with the presence of highly representative groups of scientists from all over the world. I should not and cannot fail to mention an important event in the development of Paleoparasitology in Latin America, in 2004, namely the First International Course on the specialty held at the Quequén-Necochea campus of the Universidad Nacional del Centro de la Provincia de Buenos Aires, Argentina, headed by Ricardo Guichón and Martín Fugassa, two great personal friends and collaborators in courses and research projects in paleopathology.

Finally, this book meets the need for a single volume with abundant information, strict scientific rigor, and contributions by renowned researchers. To be fair, we should highlight that before this magnificent work was published, the authors had already released other related works: Paleoparasitologia no Brasil [Paleoparasitology in Brazil] (1988), edited by Ferreira, Araújo, and Confalonieri; Paleopatologia e Paleoepidemiologia: estudos multidisciplinares [Paleopathology and Paleoepidemiology: multidisciplinary studies (1992), coordinated by Araújo and Ferreira, including articles by various specialists in paleopathology in Brazil, and recently, a more general-interest book entitled Paleoparasitologia [Paleoparasitology] (2008), by Ferreira, Reinhard, and Araújo. All these books, and in my opinion especially the first two, were essential for calling the attention of the international scientific community to the cuttingedge research in Brazil in the field of Paleopathology, and more specifically that of Paleoparasitology.

This book was becoming absolutely necessary, and we contend that the title may be excessively modest. "Foundations" (or "Fundamentals") is too short. The book could very well be entitled a "Treatise", since it analyzes the most current topics in Paleoparasitology. The division in four sections is highly appropriate, separating the different key aspects to make the book more comprehensible.

Thus, the first part ("Parasites, Human Hosts, and the Environment") focuses basically on the history of general observations on the different diseases, including of course parasites, thus greatly elucidating the general picture for unaccustomed readers and including a view of the field's development, besides delving into the origin of parasites of humans, parasitism, and the relations between human migrations and parasitism. The book's second section ("Parasite Remains Preserved in Various Materials and Techniques in Microscopy and Molecular Diagnosis") provides a sufficiently precise and in-depth explanation of the various techniques (light microscopy, immunology, DNA studies, to which great importance is ascribed) for paleoparasitological studies on various materials such as amber and coprolites, besides the importance of analyzing bacteria, viruses, mites, ticks, food remains, and pollen in Paleoparasitology. The third section ("Parasite Findings in Archeological Remains: a paleogeographic view"”) is one of the most interesting in the book and is based on studies of parasites from different parts of the planet: North and South America, Europe, Asia, Oceania, and Africa. The fourth and last section ("Special Studies and Perspectives") is divided into three chapters, of which perhaps the most interesting is that dealing with Chagas disease, highly relevant in South America due to the large numbers of infected individuals and the morbidity and mortality rates. 
To carry out this monumental work, it was necessary (and this is part of the Editors' extraordinary merit) to convene international experts from diverse geographies, featuring those from Brazil, United States, Argentina, France, representing a dozen scientific institutions and more than two dozen researchers from the leading groups in paleoparasitological studies. The authors are named individually in the book itself, but we should recall that they routinely participate in the international forums where new research, new techniques, and new methods are proposed, and above all where essential information is exchanged for opening new fields in Science. In short, it behooves us to congratulate them for carrying out this grand work which (we never tire of repeating) constitutes a veritable milestone not only for expanding knowledge in Paleoparasitology, but also for further interweaving the field with that of Paleopathology.

To the Editors, we not only reiterate our congratulations. On behalf of those of us dedicated to Paleopathology, we thank them for this book, destined for success due to its contributions to knowledge on diseases in the past and their evolutionary history.

Conrado Rodríguez-Martín, M.D. Director, Canary Islands Institute of Bioanthropology Independent Board of Museums and Centers (OAMC), Tenerife Municipality 


\section{Presentation}

7 he following tale, attributed to one Ludovicus Tertinus Guanabarinus, circulates in the laboratories and corridors of Manguinhos (the campus of the Oswaldo Cruz Foundation in Rio de Janeiro).

Before setting off for war, Don Quixote stopped to visit the local tavern. There he met a young man, whom he asked:

"Is your name Sancho?"

"No," replied the man. "My name is Quixote."

Don Quixote found this rather odd, but proceeded:

"I am going to war and need a squire. Will you follow me?"

"Yes," replied the other.

On their journey, they met another character who, oddly enough, was also named Quixote. He came from faraway lands. From Alaska, people said. And the three set out together to wage war for many long years. When they had grown old and could no longer go to war, they would sit in the tavern getting drunk, telling stories, and occasionally taking lecherous looks at the innkeeper's daughter with her generous bosom. One day Don Quixote remarked:

"I no longer remember how many wars we've won and how many we've lost."

"Neither do I," replied the other, and added:

"Nor do I remember if our wars were just or unjust."

"It's true," replied the third, and said:

"But I do remember how much fun we had fighting them."

The tale is highly fitting for the study of paleoparasitology. For thirty years we've had a lot of fun. Otherwise we would never have proceeded with our research. We don't believe that suffering makes good dissertations. We don't 
believe in the labor market. If you enjoy what you do, you do a good job and are therefore successful. In the words of old man Câncio (the uncle of our research colleague Arlindo Fábio), in his clipped gaucho accent: "Peleo porque me gusta pelear." ("I fight because I love to fight.").

The time had come to publish a synthesis of paleoparasitology, drawing on decades of extensive cooperation with our archaeologist colleagues, without whom none of this work would have been possible. When our laboratories joined forces to study archaeological remains, we launched a network that expanded and diversified in other countries. Data accumulated, and the time had come to define the state of the art.

The first section includes eight chapters, focusing on conceptual definitions of the parasitism phenomenon and analyses of aspects pertaining to the human host, especially humans' dispersal around the planet and the parasites that accompanied prehistoric migrations. The section features the peopling of the Americas due to the importance of paleoparasitological findings for elucidating prehistoric migrations. As an example of collaborative research between anthropology, archaeology, and paleoparasitology, there is a chapter on Patagonia, with studies that complement each other to reconstruct prehistoric scenarios and the changes that occurred with the arrival of Europeans.

The second section includes chapters on parasites and their remains preserved in different materials, as well as the description of techniques to recover them and methods to study them. The section features materials which potentially contain parasites or their vectors, such as mineralized coprolites and those preserved by desiccation. Other materials such as amber mainly contain parasite vectors, such as sand flies (phlebotomines) and kissing bugs (triatomines), as well as food remains and various pollens, some of which indicating the use of medicinal herbs or traces of contacts between prehistoric human groups in the Americas and peoples from other continents.

The chapter on diagnosing the coprolite's origin provides details on proper identification of the archaeological remains. The subsequent chapters discuss the diagnosis of helminths, protozoa, viruses, and bacteria, in addition to details on the presence of mites and ticks in ancient material. Molecular diagnosis is the subject of a specific chapter, adding to traditional techniques in microscopy and serology and adding reliability by contributing new approaches to paleoparasitology.

The third section includes data on parasite finds in a wide variety of materials from all the continents. The idea was to produce a paleogeographic study of parasitic infections in the past, showing their distribution with dates in given places where hosts were located, whether they were specific or occasional in maintaining the parasites' life cycle. We began with the Americas, although Africa and Asia may have been the birthplace of many infections that eventually established themselves in the human species. The authors endeavored to demonstrate the possibility of indepth studies based on archaeological knowledge. Whenever possible, as in the case of North America, South America, and Europe, the authors focused on the description of specific situations of prehistoric groups in certain regions, such as the Ancestral Puebloans in Arizona, the Fuegians in Patagonia, and the archaeological region of the Serra da Capivara National Park in Northeast Brazil.

In Asia, intensive work has been done in Korea and Japan, with the publication of articles aiming precisely to construct diversified knowledge in archaeology and anthropology together with paleoparasitology. Such exchange should become even more natural in the future, since paleoparasitology can only make progress with interdisciplinary collaboration.

Finally, the fourth section presents findings on one of the most interesting parasitic infections, Chagas disease, the discovery of which completed a hundred years in 2009. Various techniques have been used to study Chagas disease, but major strides have been made with molecular biology. Next, to illustrate the diversity of studies and their immense possibilities, a chapter focuses on potential revelations from historical documents and various difficulties 
in their interpretation. To conclude the book, nothing could be more stimulating for future studies than to construct new perspectives and approaches that can result from the skill and imagination of students that are just getting started in the laboratory or are even still in secondary school. The Scientific Vocation Program, coordinated by the Joaquim Venâncio Polytechnic Health School (EPSJV) at the Oswaldo Cruz Foundation, seats secondary students next to experienced researchers in the laboratory in order to awaken their curiosity and develop their capacity to formulate questions and answer them with the appropriate methodology.

That was our goal with this book. We don't know whether it will please readers, so we quote barber-surgeon Luís Gomes Ferreira in his Erário Mineral, one of the first treatises on Brazilian medicine, published in 1735:

"If you should find some profit in your discovery, discount the good of such satisfaction from your pains and labors. And if it appears useless, make a better one, and give praise to God, who shared so much with you while giving so little to others."

\section{ACKNOWLEDGMENTS}

We wish to thank our ever-faithful laboratory coworkers: Natalina, Marcus Vinicius, Benjamin (in memoriam), and Miguel (in memoriam).

Natalina, our eternal secretary, who knows everything in our laboratory, is indispensable. Benjamin and Miguel, always essential, were there with us taking the first steps in paleoparasitology. We owe many of the finds to them. Those times are past, but not forgotten.

Marcus Vinicius is now our factotum; we really need him. This team was crucial to the beginning of a new science.

We cannot forget our students, those that came to our laboratory for internships under the Scientific Vocation Program (EPSJV), science initiation program (Pibic/CNPq), Pro-Management Project (FIOCRUZ-FAPERJ), and Master's, PhD, and post-doctoral degrees. Their presence has always been stimulating and their questions pose beautiful challenges.

Many of the findings presented in this book have resulted from research projects funded by the National Council for Scientific and Technological Development (CNPq), the Coordinating Body for Funding Graduate Studies (Capes), with the cooperative agreements Capes-Cofecub (Comité Français d'Évaluation de la Coopération Universitaire avec le Brésil) and Capes-SECyT (Secretaría de Ciencia y Tecnología), involving Brazil-France and Brazil-Argentina, respectively, the Carlos Chagas Filho Rio de Janeiro State Research Foundation (FAPERJ); Fulbright Commission, and FIOCRUZ, with funds from the Program to Support Strategic Research (Papes). Part of the research was also funded by the National Institute of Science and Technology in Archaeology, Paleontology, and the Environment of the Semiarid/ CNPq, to which four of the authors belong (including two of the editors).

The Editors 
part I

\section{Parasites, Human Hosts,} and the Environment 


\title{
An Introduction to Paleoparasitology
}

\author{
Luiz Fernando Ferreira
}

\begin{abstract}
$P_{\text {intan }}$ aleoparasitology is the study of parasites found in the remains of humans and other animal species recovered from archaeological or paleontological sites or any other source in which they have remained preserved. The word derives from the Greek $\pi \alpha \lambda \eta \varsigma$, which means "ancient" or "archaic", and $\pi \alpha \rho \alpha \sigma \tau \tau$, , which can be divided

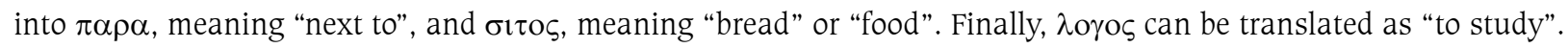

Paleoparasitology emerged as a field of knowledge, splitting off from paleopathology with the finding of parasite forms in archeological material. Sir Marc Armand Ruffer conducted the pioneering work in 1910 when he published his finding of Schistosoma haematobium eggs in the kidney tissue of Egyptian mummies from the $20^{\text {th }}$ Dynasty, dated to circa 1250 to 1100 BC (Ruffer, 1910). Lothar Szidat (Szidat, 1944) later studied two well-preserved Prussian bog bodies and reported finding Trichuris trichiura and Ascaris lumbricoides eggs. These findings marked the beginning of the search for parasites in archaeological material.
\end{abstract}

\section{PALEOPARASITOLOGY AND OTHER SCIENCES}

Paleoparasitology is situated in an interdisciplinary enclave. Its body of practical and theoretical knowledge draws on several other sciences, including medicine, biology, archaeology, anthropology, geography, genetics, and molecular biology. The list should also include history, especially the history of medicine, and the more recently characterized field of the history of diseases (Nascimento, Carvalho \& Marques, 2006). Two major syntheses of medicine and history, published in 1983 by Mirko Grmek (Grmek, 1983) and Jean Bernard (Bernard, 1983), laid the groundwork for this line of research. Both authors combined history and medicine in their studies, seeking the origins and history of the evolution of diseases. Aidan Cockburn (1963) also laid essential groundwork by launching possibilities for research in paleopathology and its various relations with the other sciences.

The study of diseases in the past can also use artistic depictions, skeletal remains, and literary works as sources of information (Wells, 1964). An example of the use of literary sources to diagnose a specific disease at a given time in the past comes from two interesting passages in the classic work by Gabriel Soares de Sousa, written in 1587 (Sousa, 
1974). Soares de Sousa was a sugar cane plantation owner in Jaguaripe and Jiquiriçá, in the Province (now State) of Bahia, Brazil. He died in the hinterlands while prospecting for silver lodes. He was a bandeirante (bushwhacker), botanist, zoologist, geographer, tropicalist, anthropologist, and helminthologist. He recorded diseases and treatments from Brazil's colonial period, as in Chapter 41: "Carimã [manioc flower] is good for children with worms. Give it to them to drink, dissolved in water, and it kills all the worms" (Sousa, 1974: 91).

Chapter 46 goes on to talk about shamans and Indians that ate dirt to kill themselves:

"These savages have another barbaric habit. If they get upset or disillusioned and decide to die, they start eating dirt, a little bit every day, until they wither away and their face and eyes swell up, and they die from it. No one can do anything, or dissuade them from wanting to die. They claim the devil taught them, and that he appears to them and that is why they are determined to eat the dirt." (Sousa, 1974: 175)

The quote clearly refers to geophagy, common in individuals with hookworm infection, as commented by Pirajá da Silva on the work of Sousa (Sousa, 1974: 409): "Gabriel Soares is referring to the Indians that ate dirt and died. In the hookworm infection known as necatoriasis, oppilation, fatigue, or hypoemia, geophagy is the most striking symptom."

Dequeker (2006) cited works of art as sources of information. As an experienced rheumatologist, he quoted, among others, the diagnosis of rheumatoid arthritis in the painting The Painter's Family, by Jacob Jordaen (1593-1678).

The study of parasitic infections in isolated indigenous populations also provides important additional material for knowledge on diseases in the past. In addition to the work of Samuel Darling (Darling, 1921) and Fred Soper (Soper, 1927), there is an excellent book by Olympio da Fonseca Filho (Fonseca Filho, 1972) and studies by Francisco Salzano (Salzano, 1990). Carlos Coimbra Jr. and Ricardo Ventura Santos comment as follows:

"Despite inherent difficulties, there are various reasons for seeking to correlate the epidemiological data pertaining to contemporary indigenous populations with those available from prehistoric groups. First, even with the socioeconomic and biological break caused by the arrival and expansion of Europeans on the American continent, there may be similarities between epidemiological patterns in past and present populations. Second, it would be interesting if we could document spatial and temporal continuities or discontinuities in the epidemiological processes in native populations on the American continent. Third, paleoepidemiologists should take into account the complexity of the epidemiological situation of contemporary indigenous populations when constructing explanatory models for the health/disease process in the past. The reason is that an intrinsic limitation of paleopathological studies is that not all pathological processes leave specific records in the bony and dental remains, the biological materials most commonly analyzed in such studies" (Coimbra Jr. \& Santos, 1992: 169-170).

Another important issue is the study of parasites in the great apes and their relations to humans (Hoeppli, 1959; Dunn, 1970; Hugot, Reinhard \& Gardner, 1999), as we shall see in Chapter 7, on the origin of parasites in the human species.

We have written the following on the relevance of paleoparasitology for medicine and public health:

"Paleoparasitology provides direct evidence of infections in past populations, introducing the time factor into the analysis without the need for the extrapolations required in data from contemporary populations. In addition, depending on the distribution of these findings in time and space, theoretically they allow reconstituting sequences for the progression of a parasitic disease in a region previously unaffected by it. 
Finding parasites in archaeological material, besides fostering better knowledge of the evolution of infections, provides support for researching prehistory by constituting a more sensitive indicator of population contacts from the past rather than the comparison of individuals' cultural traits or physical characteristics. Various researchers have contended that knowledge of diseases in past populations, by providing a historical perspective on the development of current endemics, explains certain obscure aspects of the latter, pointing to new directions for studying their dynamics, with implications for disease control strategies" (Ferreira, Araújo \& Confalonieri, 1988:16).

Paleoparasitology is also the point of departure for studies of parasites preserved in amber, with particular emphasis on findings of parasite vectors (Andrade Filho \& Brazil, 2003) and even the parasites themselves (Poinar, 2005), as well as for studies in coprolites of extinct reptiles (Poinar \& Boucot, 2006). Comparative linguistics can also be used to identify parasites cited in ancient languages (Rodrigues, 2005).

\section{THE FIRST PARASITE FINDINGS IN ARCHAEOLOGICAL MATERIAL}

Paleoparasitology began with the description by Ruffer (1910), and various paths led to the development of a series of pioneering studies (Darling, 1921; Soper, 1927; Taylor, 1955; Callen \& Cameron, 1960; Samuels, 1965; Pike, 1967; Allison et al., 1974; Fry, 1977; Ferreira, Araújo \& Confalonieri, 1979; Jones, 1982; Reinhard, 1985; Ferreira, Araújo \& Confalonieri, 1988).

In particular, the development of studies in coprolites unearthed from archaeological layers during excavations raised a series of pressing methodological questions to ensure robust results. The development of molecular biology thus poses fascinating challenges, especially for diagnosis.

Paleoparasitology data are obviously provisional, since new studies are always on the verge of happening. One can even contend that such studies correspond more to the distribution of the paleoparasitologists (and especially to that of the archaeologists that conduct the excavations) than to the real distribution of parasitic infections in the past. Archaeologists that send material to the laboratory for tests follow their own logic, the objective of which is certainly not to obtain data to paint a paleoepidemiological picture. Diagnoses could not be performed accurately until the advent of relatively recent molecular biology techniques, adapted to ancient material, besides various techniques originally developed in clinical medicine, especially advanced imaging. However, the positive paleoparasitology data are real and allow some considerations.

\section{HUMANS AND THEIR PARASITES}

Having originated in Africa, the human species migrated early, carrying with it the parasites inherited from its prehuman ancestors. In newly occupied regions, the environmental conditions, social organization, sedentary habits, local fauna, eating habits, and other factors led to the persistence or loss of original parasites and to the acquisition of others.

Numerous authors have attempted to associate the current distribution of parasites to late $10^{\text {th }}$ and early $11^{\text {th }}$ century Portuguese and Spanish seafaring voyages, overlooking that humans have been on the move virtually since the species first emerged. The most common parasites in Homo sapiens were already present in New World human populations when the Europeans first arrived, followed soon after by Africans (Araújo, Ferreira \& Confalonieri, 1981; Horne, 1985). 
A certain degree of racism attributed the majority of parasites in America to the African slaves (Freitas, 1935). This may have been the result (although somewhat delayed) of the letters by Pero Vaz de Caminha and Américo Vespúcio, who described America as a paradise free of diseases, and who were certainly fascinated by the indigenous women: "Among them were three or four young and lovely girls with long black hair flowing down their backs, and their private parts were so high and tight and void of hair that no matter how long we stared at them, they were not ashamed" (Caminha, 2002).

Various research groups dedicated to paleoparasitology have emerged, presenting interesting results. Such collaborative efforts have considerably expanded the knowledge on infections in the past, since an important stage is to collect increasing amounts of data in order to steadily build the field of paleoepidemiology on solid foundations (Souza, De Carvalho \& Lessa, 2003). Such is the task of future generations.

As a brief overview of the principal articles that gave rise to (or rather, encouraged and provided the basis for) studies in paleoparasitology, we will now present an annotated bibliography and some milestones in chronological order, starting with the first studies of coprolites and other ancient remains, in order for readers to be able to retrace the paths that led us into these fascinating studies. This review is not intended to be exhaustive, but will touch on the classic studies. We read some of these articles at the beginning of our research, others have become part of our references, and still others (modesty aside) include our own work.

1678 - LISTER, M. Historia animalium Angliae tres tractatus.

This was the first known reference to coprolites. Martin Lister, court physician and English naturalist, Vice-President of the Royal Society, graduated from Cambridge. He established the relationship between the feces' shape and the animal's intestinal tract. In the official language of science of the time, he described mollusk excrement as follows: "Praeterea, ex excrementarum differentia, certum est intestinorum figuram aliam atque aliam esse in diversis speciebus."

1829 - BUCKLAND, W. On the discovery of a new species of pterodactyl; and also of the faeces of the Ichthyosaurus; and of a black substance resembling sepia, or Indian ink, in the Lias at Lyme Regis. Proceedings of the Geological Society of London, I: 96-98, 1829.

An English geologist, William Buckland, was the first to describe a dinosaur, even before the name was coined. He coined the term "coprolite" for fossilized feces of saurians. Various authors adopted the term for feces of extinct animals.

1866 - WUCHERER, O. E. H. A molestia como parte do plano da creação. Gazeta Medica da Bahia, 1:129, 1866.

Otto Edward Henry Wucherer was born in the city of Oporto, Portugal, on July 7, 1820. Son of a German father and Brazilian mother, between six and seven years of age he lived in Salvador, Bahia, where his father was the manager of a trading company. The family then moved to Germany, where he graduated in medicine from the University of Tubingen. He returned to Brazil in 1843, settling in Salvador. Considered the founder of Brazilian helminthology, he was the first to use the microscope in Brazil for the diagnosis and scientific study of diseases coming from Africa (www.museudavida.fiocruz.br). Concerning the speech by Benjamin E. Colting, Secretary of Foreign Affairs of the Massachusetts Medical Society and former member of the Agassiz Expedition in Brazil, he commented: "Coprolites, or petrified feces found inside and outside fossil animals, often reveal to us not only the nature of the ingested matter, displaying parts of other animals consumed, but even the nature of the mucosal surface of the gut, and prove that ingestion occurred in ancient times more or less as in our time" (Wucherer, 1866: 129). 
1896 - HARSHBERGER, J. W. The purposes of ethno-botany. Botanical Gazette, 21: 146-154, 1896.

In this work, John W. Harshberger indicated the possibilities for reconstructing the diets of prehistoric populations by studying their coprolites.

1910 - RUFFER, M. A. Note on the presence of Bilharzia haematobia in Egyptian mummies of the twentieth dynasty (1250-1000). British Medical Journal, part 1: 16, 1910.

Sir Marc Armand Ruffer was definitely the leading pioneer of paleopathology. Born in Lyon, France, in 1859, he graduated in medicine in London in 1887 and received his PhD in 1889. He focused initially on the study of phagocytosis, and in 1891 he was named the first director of the British Institute of Preventive Medicine. He later moved to Egypt, where he taught for years at the Cairo Medical School. He introduced techniques for rehydration of mummified tissues, allowing their histological study. The same techniques are used to this day, with minor modifications. He died in 1917, leaving several unpublished works. Studies in the Paleopathology of Egypt was edited by his wife, Lady Alice Mary Ruffer, and published in the United States by Roy Moodie in 1921. Ruffer coined the definition of paleopathology: "The science of the diseases which can be demonstrated in human and animal remains of ancient times."

1921 - DARLING, S. T. Observations on the geographical and ethnological distribution of hookworms. Parasitology, 12: 217-233, 1921.

Samuel T. Darling discussed the origin of ancylostomiasis in South American indigenous tribes based on the geographic distribution of human Ancylostomidae, making assumptions on prehistoric migrations to America. His work, together with that of Soper (1927) and later Manter (1967) and Fonseca (1970), opened the way for research on prehistoric intestinal parasitic infections in the Americas (Ferreira, Araújo \& Confalonieri, 1988).

1925 - SETON, E. T. On the study of scatology. Journal of Mammalogy, 6: 47-49, 1925.

Ernest Thompson Seton was born in England and migrated with his family to Canada, where he became a naturalist and nature illustrator. He observed that the shape and content of feces are excellent clues for diagnosing the animal's order. Feces from species of the same order display characteristics that group them and reflect a particular anatomy. Feces show little value for diagnosis of the family and none at the genus level. However, Seton highlighted the curious and apparently contradictory fact that the shape of feces is a valuable aid in species diagnosis, as well as in meal size and content, which sometimes separates proximate species. He also conducted important studies on the feeding habits of wild animals. His studies were fundamental for establishing morphological patterns in coprolites diagnosis.

1927 - SOPER, F. L. The report of a nearly pure Ancylostoma duodenale infestation in Native South American Indians and a discussion of its ethnological significance. American Journal of Hygiene, 7: 174-184, 1927.

Fred Soper studied a tribe in the Paraguayan Chaco, the Lengua Indians, far from contact with the colonizers, and found a high prevalence of Ancylostoma duodenale as compared to Necator americanus, with a ratio of 13:1 of adult worms expelled after treatment. He thus concluded that Ancylostoma duodenale infection was already present before the arrival of the Europeans and Africans, while Necator americanus was introduced by the conquerors and slaves. These conclusions were later used in interpretations of prehistoric migrations, together with data from paleoparasitology (Araújo, Ferreira \& Confalonieri, 1981). 
1930 - EAMES, A. J. Report on ground sloth coprolites from Dona Ana County New Mexico. American Journal of Science, 20: 353-356, 1930.

Arthur Eames studied coprolites from extinct ground sloths in New Mexico and was one of the first to differentiate microscopic food remains in coprolites.

1944 - SZIDAT, L. Über die Erhaltungsfähigkeit von Helmintheneierm in vor-und Fühgeschichtlichen Moorleichen. Zeitschrift für Parasitenkunde, 13: 265-274, 1944.

Lothar Szidat studied two bog bodies discovered in Prussia, a man and a woman, dated to 500 AD (Anno Domini) and 600 BP (Before Present). Parasitological examination of the intestinal contents showed Ascaris lumbricoides and Trichuris trichiura eggs in both. In one body he found mite eggs, a plant nematode, and possibly eggs from Diphyllobothrium latum.

1947 - VAN CLEAVE, H. J. \& ROSS, J. A. A method for reclaiming dried zoological specimens. Science, 105:318, 1947.

This method was a milestone in the study of coprolites by allowing the rehydration of helminths kept in museum collections, using trisodium phosphate aqueous solution. The method was later adapted by Callen \& Cameron (1960) - with huge success - for recovering the original consistency of coprolites and facilitating tests for parasites and food remains.

1954 - PIZZI, T. \& SCHENONE, H. Hallazgo de huevos de Trichuris en contenido de un cuerpo arqueológico incaico. Boletín Chileno de Parasitología, 9: 73-75, 1954.

The authors studied the intestinal contents of an Inca child 8 to 9 years old, dated to the period immediately prior to the Spanish Conquest. The body was found frozen in the Andes, close to Santiago, Chile. They found numerous Trichuris trichiura eggs and possible Entamoeba coli cysts.

1955 - TAYLOR, E. L. Parasitic helminths in mediaeval remains. Veterinary Record, 67: 216-218, 1955.

Taylor examined material from the medieval period in Winchester, England, dated to approximately 1100 AD. In the fecal matter from cesspits, he found helminth eggs diagnosed as Trichuris trichiura, Ascaris lumbricoides, and Dicrocoelium dendriticum. He was one of the first to examine the contents of medieval cesspits.

1955 - CALLEN, E. O. \& CAMERON, T. W. M. The diet and parasites of pre-historic Huaca Prieta Indians as determined by dried coprolites. Ottawa, Royal Society of Canada, Proceedings, June 7: 51-52, 1955.

Thomas Cameron and Eric Callen presented a study to the Royal Society of Canada that served as a definitive watershed in studies of coprolites, introducing trisodium phosphate in $0.5 \%$ aqueous solution for rehydration, based on the work of Van Cleave \& Ross (1947). They described the presence of helminth eggs, probably Diphyllobothrium sp., and were the first to identify this parasite in prehistoric Peruvian populations.

1958 - HELBAECK, H. Grauballemandens sidste måltid. Kuml: 83-116, 1958.

In this fascinating article, Helbaeck described what would have been the last meal of the Grauballe Man, distinguishing between the remains of cultivated and uncultivated plants. He also identified numerous Trichuris trichiura eggs. 
1960 - CALLEN, E. O. \& CAMERON, T. W. M. A pre-historic diet revealed in coprolites. The New Scientist, 8: 3537; 39-40, 1960.

Callen and Cameron published the data from a paper presented in a congress in 1955. This is one of the most widely cited articles in the field of paleoparasitology, reporting on the introduction of rehydration in $0.5 \%$ aqueous solution of trisodium phosphate $\left(\mathrm{Na}_{3} \mathrm{PO}_{4}\right)$ for an average of 72 hours. This excellent technique recovers not only the original consistency of fecal matter but also the morphometry of the organic residues. The latter include parasite structures, whose natural dimensions remain unaltered according to experiments with this technique in our laboratory and those of other paleoparasitologists.

1964 - MARTIN P. S. \& SHARROCK, F. W Pollen analysis of pre-historic human feces: a new approach to ethnobotany. American Antiquity, 30: 168-180, 1964.

Martin and Sharrock launched a series of publications on food remains and parasites found in coprolites in North American sites. By observing different pollen species found in prehistoric feces in Utah, they sought to determine the importance of certain plants in the diet of these populations.

1965 - SAMUELS, R. Parasitological study of long dried fecal samples. In: OSBORNE, D. \& KATZ, B. S. (Eds.). Contributions of the Wetherill Mesa Archaeological Project, Society for American Archaeology, 1965 (Memoirs, 19).

The author found Enterobius vermicularis eggs, mites, and free-living nematodes. These were the first eggs from a parasite species found in human coprolites in North America.

1966 - JANSEN, Jr. I. \& OVER, H. J. Observations on helminth infections in a Roman army camp. Rome: International Congress for Parasitology I, Proceedings, II: 791, 1966.

Jansen and Over presented the results of tests in material collected from a Roman fort in Valkenbur-on-Rhine, dated to the first century AD. They found eggs from Trichuris trichiura, Ascaris lumbricoides, and Oxyuris equi, the latter an equine parasite, thereby demonstrating the mixture of archaeological remains from humans and domestic animals.

1967 - BROTHWELL, D. \& SANDISON, A. T. (Eds.). Diseases in Antiquity. Springfield: Charles \& Thomas, 1967.

This book was published in England and is now difficult to find in bookshops, since there was no second edition. It was a milestone for the various studies on infectious diseases in the past. Various pioneering authors contributed to the different chapters, some discussing the presence of helminths in organic material preserved in archaeological sites, highlighting the difficulty in recognizing the human or animal origin of the feces (Pike, 1967). This is one of the main problems faced by paleoparasitologists when they receive material for examination in the laboratory. Field studies are indispensable for the correct diagnosis and differentiation between human coprolites and those of other animals.

1967 - MANTER, H. W. Some aspects of the geographical distribution of parasites. The Journal of Parasitology, 53: 2-9, 1967.

Harold Manter, an American researcher, published this article which became another key reference for paleoparasitology. Parasite findings in coprolites were still just beginning at the time, and his article does not specifically use the term "paleoparasitology". However, his review of Ancylostomidae provided the basis for the study 
of prehistoric human migrations and parasitism, highlighting the importance of paleoparasitology for archaeologists and anthropologists. The University of Nebraska at Lincoln named the Harold W. Manter Laboratory of Parasitology in his honor. The curator is Scott L. Gardner, co-author of Chapter 8 in this book.

1969 - HEIZER, R. F. \& NAPTON, L. K. Biological and cultural evidence from prehistoric human coprolites. Science, 165: 563-568, 1969.

This article by Heizer and Napton systematized the study of coprolites and defined the methodology and applications to archaeology. Studying material from Lovelock Cave, Nevada, the authors reconstructed subsistence patterns from the area.

1969 - HALL, H. J. Rehydration and concentration of parasite ova in human coprolites from the Great Basin, 1969 (Mimeo).

Unpublished manuscript from the archives of the Department of Anthropology, University of Utah, Salt Lake City (abstract in Wilke \& Hall, 1975). The author studied techniques for the parasitological examination of coprolites. He performed rehydration using trisodium phosphate and the Ritchie concentration technique, modified for parasite eggs. He reported finding eggs from acanthocephalans and Enterobius vermicularis.

1969 - DE LUMLEY, H. A Paleolithic camp at Nice. Scientific American, 220: 42-50, 1969.

Henry de Lumley studied the pollen in coprolites from 400,000 year ago, collected at Terra Amata on the Mediterranean coast of France, one of the most important sites in Europe occupied by Homo erectus.

1970 - FRY, G. F. Preliminary analysis of the Hogup Cave coprolites. In: AÏKENS M. (Ed.). Hogup Cave, Appendix III. Salt Lake City: University of Utah, 1970. (Anthropological Papers)

In the Hogup Cave coprolites, Fry found Moniliformis clarki eggs in human material dated 6400 to $2000 \mathrm{BC}$. He discussed false parasitism, but also found Enterobius vermicularis eggs in samples from 2000 to 4500 years BP.

1970 - FONSECA FILHO, O. Parasitismo e Migrações Humanas Pré-históricas. Rio de Janeiro: Mauro Familiar Editor, 1970/1972.

In this comparative study of New World and Old World parasitic infections, Olympio da Fonseca Filho laid the basis for a new line of parasitological research which he called ethnic, geographic, and comparative parasitology. This approach, in addition to providing elements for studying the origin of parasitic associations, is particularly important as an ancillary method in ethnological and anthropological research, to the extent that it helps elucidate the origin of certain indigenous populations in America and their migration routes in the remote past. This was a pioneering work of inestimable value.

1973 - The Paleopathology Association was founded and the Paleopathology Newsletter was launched under the leadership of Aidan Cockburn.

Aidan Cockburn had published two essential books: COCKBURN, A. The Evolution and Eradication of Infectious Diseases. Baltimore: The Johns Hopkins Press, 1963, and COCKBURN, A. Infectious Diseases: their evolution and eradication. Springfield: Charles C. Thomas, 1967. The books highlighted the importance of studying parasites in 
archaeological material. The Association was created during a seminar as a group dedicated to the study of diseases in past times. Participants in the meeting included Aidan Cockburn, Eve Cockburn, Robin Barraco, William Peck, and Theodore Reyman, among others. In 1980 Cockburn, his wife Eve Cockburn, and Theodore Reyman published Mummies, Disease and Ancient Cultures, indispensable reading for researchers in paleopathology. His visit to Brazil in 1981, when we were beginning our own research work, was a priceless source of support for our group. He told stories, visited archaeological sites in the State of Minas Gerais with archaeologist André Prous of the Federal University of Minas Gerais, and participated in the $6^{\text {th }}$ Congress of the Brazilian Society of Parasitology in Belo Horizonte, where he gave a memorable lecture to a full auditorium, thoroughly captivating the audience.

1974 - ALlison, M J.; PEZZIA, A.; HASEGAWA, I. \& GERSZTEN, AND. A case of hookworm infestation in preColumbian America. American Journal of Physical Anthropology, 41: 103-106, 1974.

Marvin Allison, Enrique Gerszten, and colleagues described the presence of adult hookworms in the gut of a Peruvian mummy from 890-950 AD. They founded the Paleopathology Club, using regular mail to send clinical cases from the past (always accompanied by photographs) for discussion by specialists. The journal is now published online.

1975 - WILKE, J. P. \& HALL, H. G. Analysis of ancient feces: a discussion and annotated bibliography. Archaeological Research Facility, Department of Anthropology, University of California, Berkeley, 1975.

This was an annotated bibliography of studies on ancient fecal matter in which the authors analyzed the possibilities for studies based on coprolite contents, such as diet, the population's technology, the local climate during occupation, nature and extent of parasitic infections, and other paleoecological aspects.

1977 - COCKBURN, A. Where did our infectious diseases come from? The evolution of infectious disease. Ciba Foundation Symposium, 49: 103-112, 1977.

The author highlighted the importance of studies on parasites in archaeological material. Cockburn discussed parasitic infections and diseases, their origins, and their evolution over time.

1979 - FERREIRA, L. F.; ARAÚJO, A \& CONFALONIERI, U. Subsídios para a paleoparasitologia do Brasil I - Parasitos encontrados em coprólitos no município de Unaí, MG. CONGRESSO BRASILEIRO DE PARASITOLOGIA, 4, Campinas, 1979. Anais... 1979, p. 56.

The authors described eggs from Ancylostomidae and Trichuris trichiura in pre-Columbian human coprolites from the Gentio II cave in the county of Unaí, Minas Gerais State, from the collection of the Institute of Brazilian Archaeology, headed at the time by Dr. Ondemar Dias Júnior. This was the first such study presented in Brazil and the first to use the term paleoparasitology, marking the beginning of a series of scientific articles, Master's theses, and PhD dissertations.

1980 - ARAÚjo, A. Contribuição ao Estudo dos Helmintos Encontrados em Material Arqueológico no Brasil, 1980. Master's thesis, Rio de Janeiro: Instituto Oswaldo Cruz, 1980.

Supervised by Luiz Fernando Ferreira, this was the first thesis on paleoparasitology in Brazil and the first in the graduate studies program in Parasite Biology at the Oswaldo Cruz Institute. The author studied helminth infections in pre-Columbian America in human coprolites from the Gentio II cave in Unaí, Minas Gerais, and the results in animal coprolites (in this case lacertid lizards) found by Dr. André Prous of the Museum of Natural History at the Federal University of Minas Gerais at the Santana do Riacho archaeological site in Minas Gerais. 
1982 - JONES, A. K. J. Recent finds of intestinal parasite ova at York, England. Presented at the annual meeting of the European Chapter of the Paleopathology Association, 1982 (Mimeo).

The author updated the data on England with his findings from York. He studied quasi- mineralized conserved coprolites and used $10 \%$ hydrochloric acid solution to dissociate them for microscopic examination. His subsequent studies introduced techniques for egg counts in coprolites.

1983 - BERNARD, J. Le Sang et l'Histoire. Paris: Buchet-Chastel, 1983.

Jean Bernard, drawing on his profound knowledge of hematology and history, wrote this fascinating book on various questions in population migrations and culture. He concluded with the chapter entitled "Blood and the Fall of Empires".

1983 - GRMEK, M. D. Les Maladies à l'Aube de la Civilisation Occidentale. Paris: Payot, 1983.

Mirko Grmek used his profound medical and literary erudition and a command of Greek to elaborate on historical sources and data from paleopathology. He established the concept of pathocenosis and sought to define the reality of diseases in the prehistoric, archaic, and classical Greek world. Grmek visited the Oswaldo Cruz Foundation at the invitation of Paulo Gadelha, then director of Casa de Oswaldo Cruz, providing Brazilian researchers with excellent moments of discussion on the origin and evolution of infectious diseases.

1983 - CONFALONIERI, U. Paleoparasitologia do Gênero Trichuris Roederer, 1768 com um Estudo Paleoepidemiológico sobre a Origem do Trichuris trichiura (Linn) na América (Nematoda: Trichuridae), 1983. PhD dissertation, Seropédica: Universidade Federal Rural do Rio de Janeiro.

The dissertation by Ulisses Confalonieri analyzes the origin of parasitism by species from genus Trichuris in humans and animals and the dispersal of the species that infests humans in the Americas. He discusses its introduction by sea in prehistoric times, since the parasite's eggs would not have survived in soil during migration of the hosts from Siberia to Alaska.

1985 - REINHARD, K. J. Recovery of Helminths from Prehistoric Feces: the cultural ecology of ancient parasitism, 1985. Unpublished Master's thesis, Flagstaff, Arizona: Department of Biological Sciences, Northern Arizona University.

Karl Reinhard presents his Master's thesis, one of the first to discuss parasites found in coprolites from North American archeological sites.

1985 - HORNE, P. D. A review of the evidence of human endoparasitism in the pre-Columbian New World through the study of coprolites. Journal of Archaeological Science, 12: 299-310, 1985.

Patrick Horne conducts a review of studies in paleoparasitology in the Americas, using paleoparasitology as the key word in the text. He discusses the question raised in our articles on the introduction of human parasites into the New World by routes other than the Bering Land Bridge. In addition to studying human coprolites, he participated in various necropsies of mummified bodies, including the Cerro El Plomo Boy, one of the most famous mummies in Chile, always studying parasites. After exchanging extensive correspondence, we finally met in person at the Turin congress in 2004. Horne passed away in 2008, leaving a legacy of fundamental contributions on the distribution of parasites in ancient peoples in both the New and Old Worlds (Castro, 2008). 
1986 - The Paleopathology Association, in its $13^{\text {th }}$ Annual Meeting in Albuquerque, New Mexico, devoted a session specifically to paleoparasitology.

Coordinated by Karl Reinhard, the session convened experts on this subject for the first time. Ulisses Confalonieri represented the Brazilian group and presented two papers: "Paleoparasitological research in Brazil: present status and perspectives" and "The origin and pre-historic dispersion of human trichuriasis in the New World".

1987 - REINHARD, K. J.; CONFAlONIERI, U. E. C.; FERREIRA, L. F.; HERMANN, B. \& ARAÚjo, A. Aspects of paleoparasitological technique: recovery of parasite eggs from coprolites and latrines. Homo, 37: 217-238, 1987.

This article provides a review of the techniques used in paleoparasitology. The authors discuss the methods used, with a conclusion on the need for more in-depth studies, especially with a better morphological and morphometric description of the eggs.

1988 - FERREIRA, L. F.; ARAÚJO, A. \& CONFALONIERI, U. Paleoparasitologia no Brasil. Rio de Janeiro: PEC/Ensp/ Fundação Oswaldo Cruz, 1988.

This book, in Portuguese, presents the studies published as of that year by the authors, with the first chapter entitled "The Aim of Paleoparasitology", reporting on the motivations and difficulties in conducting studies, formation of the research group, and the working conditions. The subsequent chapters are: "Findings in Coprolites", "Autopsies in Mummies", "Scientific Disputes", “Technical and Methodological Issues", "Interpreting Results”, and "Teaching Paleoparasitology".

1988 - CHAME, M. Estudo Comparativo de Fezes e Coprólitos Não Humanos da Região Arqueológica de São Raimundo Nonato, Sudeste do Piauí, Brasil, 1988. Master's thesis, Rio de Janeiro: Museu Nacional, Universidade Federal do Rio de Janeiro.

Marcia Chame established a solid basis for the methodology to correlate coprolites with the animals from which they originated. Her Master's thesis aimed to open paths for morphological and morphometric diagnosis of animal feces and macroscopic and microscopic analysis of their content for comparison with coprolites.

1989 - BOUCHET, F. Étude parasitologique des coprolithes et des sédiments de trois ensembles clos médiévaux de la rue de Lutèce (Île de France) à Paris. Revue d'Archéométrie, 13: 13-21, 1989.

In France, Françoise Bouchet published her studies on parasites in ancient latrines and sediments. She founded the Paleoparasitology Laboratory at the University of Reims and established a team of young researchers, including Odile Loreille, Stéphanie Harter, and Matthieu Le Bailly. Françoise Bouchet received the Brazilian doctoral students Gino Chaves da Rocha and Marcelo Luiz Carvalho Gonçalves at her laboratory.

1991 - Founding of the Brazilian Society of Paleopathology.

This was a meeting of Brazilian experts to exchange ideas and conduct collaborative research work, with particular stimulus for training young researchers. Sheila Mendonça de Souza joined the research group on paleoparasitology and paleopathology. The Brazilian Society of Paleopathology was created as a chapter of the Paleopathology Association, and its first meeting took place during the congress of the Brazilian Society of Archaeology in Rio de Janeiro. The first scientific event took place at the National School of Public Health (ENSP/Fiocruz) in 1992, chaired by Marília Alvim 
and then-president Luiz Fernando Ferreira. A memorable discussion on the meaning of "paleo" and "archaeo" took place among participants in the opening round table, including Marília de Melo Alvim, Sheila Mendonça de Souza, and Luiz Fernando Ferreira.

1993 - CAMPILLO, D. Paleopatología: los primeros vestigios de la enfermedad. 2 vols. Fundación Ulrico 1838, Barcelona, Spain, 1993/1994. (Colección Historia de la Salud, 4, 5).

Domingo Campillo published an edition on paleopathology in which he translated the methods and techniques for studies in the past into a language accessible to interested members of diverse fields. He mentioned coprolites as an important source for studies in infectious diseases and showed the results from different continents.

1998 - AUfDERHEIDE, A. \& RODRÍGUEZ-MARTín, C. The Cambridge Encyclopedia of Human Paleopathology. Cambridge: Cambridge University Press, 1998.

Arthur C. Aufderheide and Conrado Rodríguez-Martín published this mandatory reference for experts and students in the field. This encyclopedia includes the state of the art and all aspects involved in research on diseases in the past.

1997-1998 - DESOWITZ, R. Who Gave Pinta to the Santa Maria? Tracking the devastating spread of the lethal tropical diseases into America. Harvest Books, 1997/1998.

Robert S. Desowitz proceeded with a series of books publicizing science, drawing on data from paleoparasitology to explain the origins and evolution of infectious diseases. In one chapter he comments on the issue of the introduction of hookworm infection into the Americas and discusses our articles. The book has an excellent theoretical basis and provides an easy and enjoyable read, recommended for whoever is interested in the origins and spread of infectious diseases.

2001 - DITTMAR, K. Untersuchungen zum Vorkommen von Ektoparasiten bei Domestizierten und wild Leben den Meerschweinchen (Cavia spp.) sowie an Präinkaischen Meerschweinchennmumien in Peru, Südamerika, 2001. PhD dissertation, Leipzig: Universitat Leipzig.

Katharina Dittmar presented this PhD dissertation at the School of Veterinary Medicine, University of Leipzig, Germany. She studied ectoparasites found on the mummified bodies of animals that were buried as funeral companions of humans during the pre-Columbian period. During her post-doctoral studies, Katharina Dittmar visited our laboratories at the Oswaldo Cruz Foundation and University of Nebraska, worked for several years at the University of Utah, Provo. She currently teaches at the State University of New York in Buffalo.

2002 - IÑiguEZ, A. M. Diagnóstico Molecular de Enterobius vermicularis (Linnaeus 1758) em Populações Préhistóricas: análise da região intergênica dos genes ribossomal SS RNA e do gene SL1RNA, 2002. PhD dissertation, Rio de Janeiro: Instituto Oswaldo Cruz.

Through her PhD dissertation, Alena Mayo Iñiguez consolidated the area of molecular paleoparasitology at the Oswaldo Cruz Institute, as one of the key references on this topic. This research continues the work she developed during her Master's thesis, Análise de DNA Ancestral para o Estudo de Infecções Parasitárias em Populações Pré-históricas. 
2003 - Special issue of Memórias do Instituto Oswaldo Cruz, 98, suppl. 1, 2003. Available at <http:// memorias.ioc.fiocruz.br/98sup/98sup.html>. This was the first special issue of a scientific journal dedicated entirely to paleoparasitology. Organized by Ferreira, Reinhard, Bouchet, and Araújo, it contains articles by various paleoparasitologists, with an introduction by Claude Combes and Arthur Aufderheide.

2003 - AUfDERHEIDE, A. The Scientific Study of Mummies. Cambridge University Press, United Kingdom, 2003.

Art Aufderheide published another fundamental book for paleopathology and paleoparasitology.

2004 - First International Course on Paleoparasitology organized and coordinated by Ricardo Guichón and Martín Fugassa, taught by Adauto Araújo, at the Unidad de Enseñanza Universitaria Quequén, Universidad Nacional del Centro (Unicen), Province of Buenos Aires, Argentina.

2005 - First meeting of the Paleopathology Association held in Brazil (and in South America), chaired by Sheila Mendonça de Souza, who also edited the papers published in Memórias do Instituto Oswaldo Cruz, special issue 101, supplement 2, in 2006. Available at <http://memorias.ioc.fiocruz.br/101(supII).html> .

2007 - AVANTIN, F. Paleoparasitologie: contribution à l'étude des paléoenvironnements de sites pleistocenes et holocenes du littoral méditerranean français. Oxford: David Brow Book Company, 2007.

Françoise Avantin turned her PhD dissertation into the first book published in Europe on findings of parasites in archaeological material. The author discusses specific sites, but the book became mandatory reading for archaeologists and paleoparasitologists, based on her recommendations for specific care in collecting material and on the techniques employed in her study.

2008 - FERREIRA, L. F.; REINHARD, K., \& ARAÚJO, A. Paleoparasitologia. Rio de Janeiro: Editora Fiocruz, 2008. (Temas em Saúde)

This edition of public science communication aimed to awaken interest in paleoparasitology among young researchers.

2008 - UJVARI, S. C. A História da Humanidade Contada pelos Vírus, Bactérias, Parasitas e Outros Organismos. São Paulo: Editora Contexto, 2008.

Stefan Ujvari had already published a highly interesting book in 2003, called A História e suas Epidemias: a convivência do homem com os microrganismos (Senac Rio), in which he discussed infectious diseases and hostparasite adaptations. In this more recent publication, Ujvari uses data from paleoparasitology to back some of his theses. An infectious diseases expert at the Oswaldo Cruz German Hospital in the city of São Paulo, he was one of the pioneers in opening the field of studies on the origins and evolution of parasitic infections in Brazil.

2009 - SORENSON, J. L. \& JOHANNESSEN, C. L. World Trade and Biological Exchanges before 1492. New York: iUniverse, 2009.

John Sorenson and Carl Johannessen continued the line of arguments and data they had been collecting since their last publication in 2004, in online format, with evidence of overseas migrations or contacts between Asian and American peoples before the arrival of Europeans and Africans. They drew extensively on the data from paleoparasitology, 
described by our group, concerning the evidence of ancylostomiasis and trichuriasis in pre-Columbian America, as well as on prior data and arguments by earlier parasitologists such as Fred Soper, Samuel Darling, Harold Manter, and Olympio da Fonseca Filho. Sorenson and Johannessen also used data on cultivated plants such as sweet potato and maize, taken from the Americas to Asia prior to the great European seafaring voyages.

2011 - The original Portuguese-language of the current book, with new paleoparasitologists and new ideas. We will stop the reminiscing here. No one is better than students to motivate and encourage their professors, so this book is a tribute to the students.

\section{REFERENCES}

ANDRADE FILHO, J. D. \& BRAZIL, R. P. Relationships of New World phlebotomine sand flies (Diptera: Psychodidae) based on fossil evidence. Memórias do Instituto Oswaldo Cruz, 98, supl. 1: 145-149, 2003.

ALLISON, M. J. et al. A case of hookworm infestation in a pre-Columbian American. American Journal of Physical Anthropology, 41:103-106, 1974.

ARAÚJO, A.; FERREIRA, L. F. \& CONFALONIERI, U. A contribution to the study of helminth findings in archaeological material in Brazil. Revista Brasileira de Biologia, 41: 873-881, 1981.

BERNARD, J. Le Sang et l'Histoire. Paris: Buchet, Chastel, 1983.

CALLEN, E. O. \& CAMERON, T. W. M. A pre-historic diet revealed in coprolites. The New Scientist, 8: 35-37; 39-40, 1960.

CAminHA, P. V. Carta de Pero Vaz de Caminha [1500]. São Paulo: Martin Claret, 2002.

CASTRO, M. Obituário Patrick Horne (1945-2008). Chungará, 40, n. esp.: 243-244, 2008.

COCKBURN, A. The Evolution and Eradication of Infectious Diseases. Baltimore: Johns Hopkins Press, 1963.

COIMBRA JR., C. E. A. \& SANTOS, R. V. Paleoepidemiologia e epidemiologia de populações indígenas brasileiras: possibilidades de aproximação. In: ARAÚJO, A. \& FERREIRA, L. F. Paleopatologia e Paleoepidemiologia. Rio de Janeiro: Fiocruz, 1992.

DARLING, S. T. Observations on the geographical and ethnological distribution of hookworms. Parasitology, 12: 217-233, 1921.

DEQUEKER, J. What can a rheumatologist learn from paintings? Acta Reumatológica Portuguesa, 31: 11-13, 2006.

DUNN, F. Natural infection in primates: helminths and problems in primate phylogeny, ecology, and behaviour. Laboratory Animal Care, 20(2): 383-388, 1970.

FERREIRA, L. F.; ARAÚJO, A. \& CONFALONIERI, U. Subsídios para a paleoparasitologia do Brasil I. Parasitos encontrados em coprólitos no município de Unaí, MG. In: CONGRESSOS BRASILEIROS DE PARASITOLOGIA, IV, Campinas, 1979. Resumos... Campinas, 1979.

FERREIRA, L. F; ARAÚJO, A. \& CONFALONIERI, U. Paleoparasitologia no Brasil. Rio de Janeiro: PEC, Ensp/Fiocruz, 1988.

FONSECA FILHO, O. Parasitismo e Migrações Pré-históricas. Rio de Janeiro: Mauro Familiar, 1972.

FREITAS, O. Doenças Africanas no Brasil. São Paulo: Cia Editora Nacional, 1935. v. II. (Biblioteca Pedagógica Brasileira, Brasiliana, Série V).

FRY, G. F. Analysis of Prehistoric Coprolites from Utah. Salt Lake City: University of Utah, 1977. (Anthropological Papers, 97)

GRMEK, M. Les Maladies à l'Aube de la Civilisation Occidentale. Paris: Payot, 1983.

HOEPPLI, R. Parasites and Parasitic Diseases in Early Medicine and Science. Singapore: University of Malaya Press, 1959. 
HORNE, P. D. A review of the evidence of human endoparasitism in the pre-Columbian New World through the study of coprolites. Journal of Archaeological Science, 12: 299-310, 1985.

HUGOT, J. P.; REINHARD, K. \& GARDNER, S. L. Human enterobiasis in evolution: origin, specificity and transmission. Parasite, 6:201-208, 1999.

JONES, A. Human parasite remains: prospects for a quantitative approach. In: HALL, A. R. \& KENWARD, H. L. Environmental Archaeology in the Urban Context. London: Council for British Archaeology, 1982. (Research Reports, 43)

NASCIMENTO, D. R.; CARVALHO, D. M. \& MARQuES, R. C. Uma História Brasileira das Doenças. Rio de Janeiro: Mauad, 2006. v. 2.

PIKE, A.W. The recovery of parasite eggs from ancient cesspit and latrine deposits: an approach to the study of early parasite infections. In: BROTHWELL, D. \& SANDISON, A. T. Diseases in Antiquity. Springfield: Charles C. Thomas, 1967.

POINAR Jr., G. Triatoma dominicana sp. n. (Hemiptera: Reduviidae: Triatominae), and Trypanosoma antiquus sp. n. (Stercoraria: Trypanosomatidae), the first fossil evidence of a triatomine-trypanosomatid vector association. Vector-Borne Zoonotic Diseases, 5(1): 72-81, 2005

POINAR Jr., G. \& BOUCOT, A. J. Evidence of intestinal parasites of dinosaurs. Parasitology, 133(Pt 2): 245-249, 2006.

REINHARD, K. J. Recovery of Helminths from Prehistoric Feces: the cultural ecology of ancient parasitism, 1985. Unpublished Master's Thesis, Flagstaff: Department of Biological Sciences, Northern Arizona University.

RODRIGUES, A. D. Evidências lingüísticas da antiguidade do piolho e de outros parasitas do homem na Amazônia. Revista de Estudos e Pesquisas, 2: 89-97, 2005.

RUFFER, M. A. Note on the presence of 'Bilharzia haematobia' eggs in Egyptian mummies of the Twentieth Dynasty (1250-1000 B.C.). British Medical Journal, 1(2.557): 16, 1910.

SAlZANO, F. Parasitic load in South American tribal populations. In: SWEDLUND, A. C. \& ARMELAGOS, G. J. (Orgs.). Disease in Populations in Transition. Anthropological and Epidemiological Perspectives. New York: Bergin and Garvey, 1990.

SAMUELS, R. Parasitological study of long-dried fecal samples. In: OSBORNE, D. \& KATZ, B. S. Contributions to the Wetherill Mesa Archaeological Project. Memoirs of the Society for the American Archaeology, 19: 175-179, 1965.

SOPER, F.L. The report of a nearly pure Ancylostoma duodenale infestation in native South American Indians and a discussion of its ethnological significance. American Journal of Hygiene, 7: 174-184, 1927.

SOUSA, G. S. Notícia do Brasil: comentários e notas de Varnhagen, Pirajá da Silva e Edelweiss [1587]. São Paulo: MEC, 1974.

SoUZA, S. M.; DE CARVALHO, D. M. \& LESSA, A. Paleoepidemiology: is there a case to answer? Memórias do Instituto Oswaldo Cruz, 98, supl. 1: 21-27, 2003.

SZIDAT, L. On the preservation of helminth eggs in pre and early historical bog corpses. Zeitschrift fur Parasitenkunde, 13(3): 265-274, 1944

TAYLOR, E. L. Parasitic helminths in mediaeval remains. Veterinary Record, 67(12): 216-218, 1955.

WELLS, C. Bones, Bodies, and Disease. London: Thames \& Hudson, 1964. 


\title{
2
}

\section{The Preservation of Organic Material over Time}

\author{
Luiz Fernando Ferreira
}

$\mathrm{T}$

This chapter is not intended to provide a complete review of the theme of mummification over time, or even of the

processes that led to the preservation of organic remains in which parasites have been found. The objectives are to discuss how parasite findings can occur, alerting parasitologists to the possibilities of studying parasites and their remains, and to remind our archaeologist colleagues of the importance of preserving any materials they find. These include any discarded dust, adhesions, or concretions in the bones, especially those of the pelvis and adjoining areas, pottery and other utensils, and other materials that may contain parasite remains (Fugassa, 2006).

The pioneering mummy studies began with Grafton Elliot Smith (anatomy), Armand Ruffer (parasitology and histology), Alfred Lucas (chemistry), Thomas Pettigrew (history of mummy studies), and Warren Royal Dawson (surgery) in Egypt in the late $19^{\text {th }}$ and early $20^{\text {th }}$ centuries (Peck, 1998). Today, studies on mummies have been resumed successfully, led by Aidan Cockburn, who published two editions of his book Mummies, Disease, and Ancient Cultures, organized with his wife Eve Cockburn and their colleague Theodore A. Reyman (Cockburn \& Cockburn, 1980; Cockburn, Cockburn \& Reyman, 1998), and later by Arthur Aufderheide (Aufderheide \& Rodrigues-Martín, 1998). Both books provide the essentials for studying mummies, their parasites, and their diseases, and are indispensable reading for whoever intends to begin research on the subject (Figures 1 and 2).

The theme sparked such great interest among scientists that the first international congress on mummy studies was organized, coordinated by Conrado Rodríguez-Martín in Tenerife, Canary Islands (Spain), in February 1992. The group has met regularly since then, with growing participation by researchers from a wide range of fields (Atoche Peña, Rodríguez-Martin \& Ramírez Rodríguez, 2008).

Aidan Cockburn defines "mummy" as follows:

Today, the term mummy has been extended to cover all well-preserved dead bodies. The majority of these are found in dry places such as the sands of deserts or dry caves, where desiccation has taken place rapidly, doing naturally what Egyptians did by artifice. The basic procedure in either process is the same: water is extracted rapidly from the tissues (Cockburn, Cockburn \& Reyman, 1998:1). 
Intentional or natural preservation occurred in various parts of the world, where different cultures established themselves and developed. Notwithstanding the different mummification techniques, whether of the Chinchorro in South America (Arriaza, 1995), or in Africa (Egypt and Sudan) (Aufderheide, 2003), specific climatic conditions allowed finding organic remains (including completely preserved bodies) in diverse situations. For example, preservation can occur naturally due to the cold in the Andean altiplanos or in the Arctic. In the bogs of Northeast Europe, the pH and moisture (contrary to conditions in the desert) preserve human and animal bodies, or so-called "bog bodies", without any elaborate artifice or technique (Brothwell \& Sandison, 1967).

One can thus analyze both the processes resulting from techniques developed by cultural groups, mostly as a function of religious values, and natural mummification resulting from favorable climatic conditions. References to mummification processes are found in ancient documents, as in the Old Testament of the Bible, Genesis, Chapter 50:

2 And Joseph commanded his servants the physicians to embalm his father, so the physicians embalmed Israel. 3 forty days were required for it, for so many are required for embalming. (...) 26 So Joseph died, being a hundred and ten years old; and they embalmed him, and he was put in a coffin in Egypt.

Among the ancient classics, Herodotus and Diodorus Siculus refer to mummies. Herodotus was born in Halicarnassus in $480 \mathrm{BC}$, of Dorian ancestry and an illustrious family. His book describes embalming techniques, the organization of medical services, the importance of specialization, and various other considerations on health and disease. Diodorus Siculus was born in Agyrium, Sicily, and spent many years in Egypt. His book is a world history. Ferreira, Reinhard \& Araújo (2008) quote the part that describes embalming techniques, showing the different types used in ancient Egypt, in keeping with each individual's financial status. They show how the techniques varied over time, using the trial-and-error method.

As described by Herodotus, embalming in its most refined form was expensive and had to be simplified to extend the practice beyond the nobility to the non-noble well-to-do: the well-known process of cutting costs to expand the market.

Figure 1 - Elaborately decorated coffin of Sha-Amun-em-su containing the mummy of the priestess/songstress from the temple of Amon in Thebes. This object has been studied with computerized tomography and other techniques

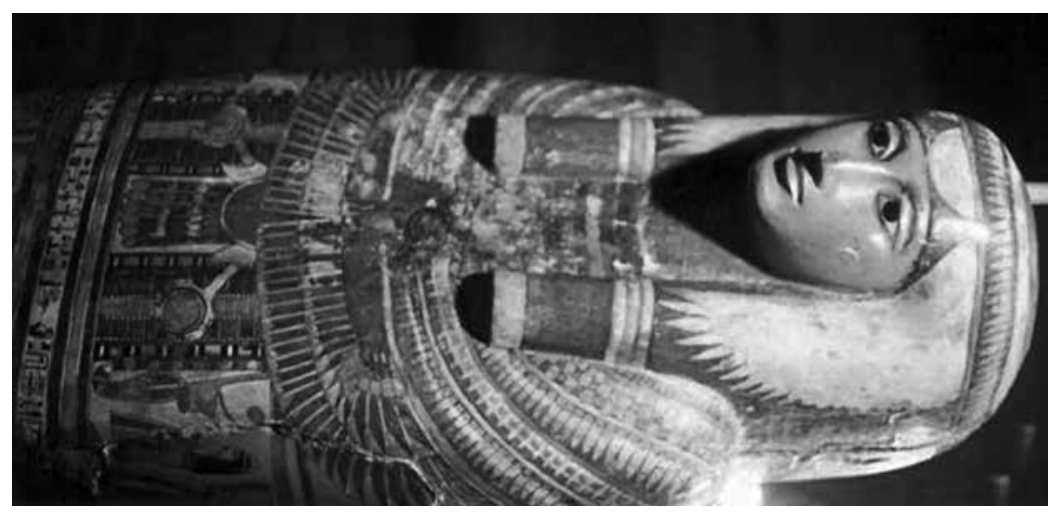

Collection of the National Museum in Rio de Janeiro. Photo by A. Brancaglion and S. M. Souza. 
Figure 2 -3D computerized tomography reconstruction of a child's head recovered from a tomb in Titicaca, Bolivia, probably of Aymara origin, showing a fatal fracture and intentional reshaping of the skull

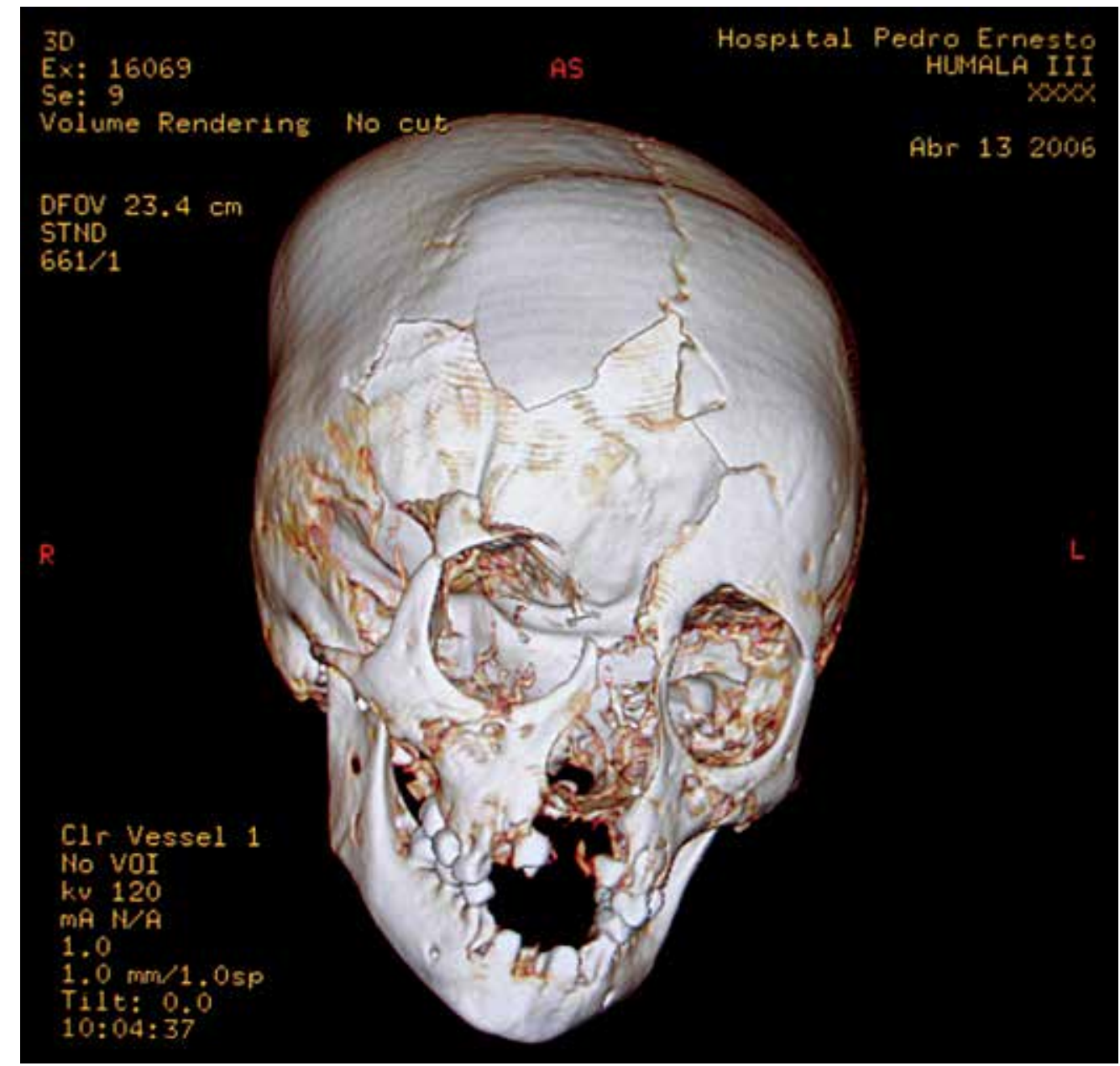

Collection of the National Museum in Rio de Janeiro. Photo by S. M. Souza.

In the Americas, although less known, there are mummies that were preserved with special techniques. The oldest known examples are the Chinchorro mummies, from a culture in the Atacama Desert. The desert in which the Chinchorro lived, ranging from Northern Chile to Southern Peru, was and still is extremely dry.

There are hundreds of archaeological sites in the Andes, and it is common to find archaeological remains while walking across the desert sand (Figure 3). The ancient pre-ceramist inhabitants lived by fishing, hunting, and gathering, obtaining most of their food from the ocean. According to Bernardo Arriaza, an expert on this culture (Arriaza, 1995), the Chinchorro prepared the bodies in different ways, suggesting social differences between individuals, as in Egypt. Alongside natural mummifications one finds bodies in which the viscera and muscles were removed, replaced with straw and wooden artifacts, painted with various colors, and covered with clay masks. 
Figure 3 - Atacama Desert, Northern Chile. Mummified remains preserved in the desert

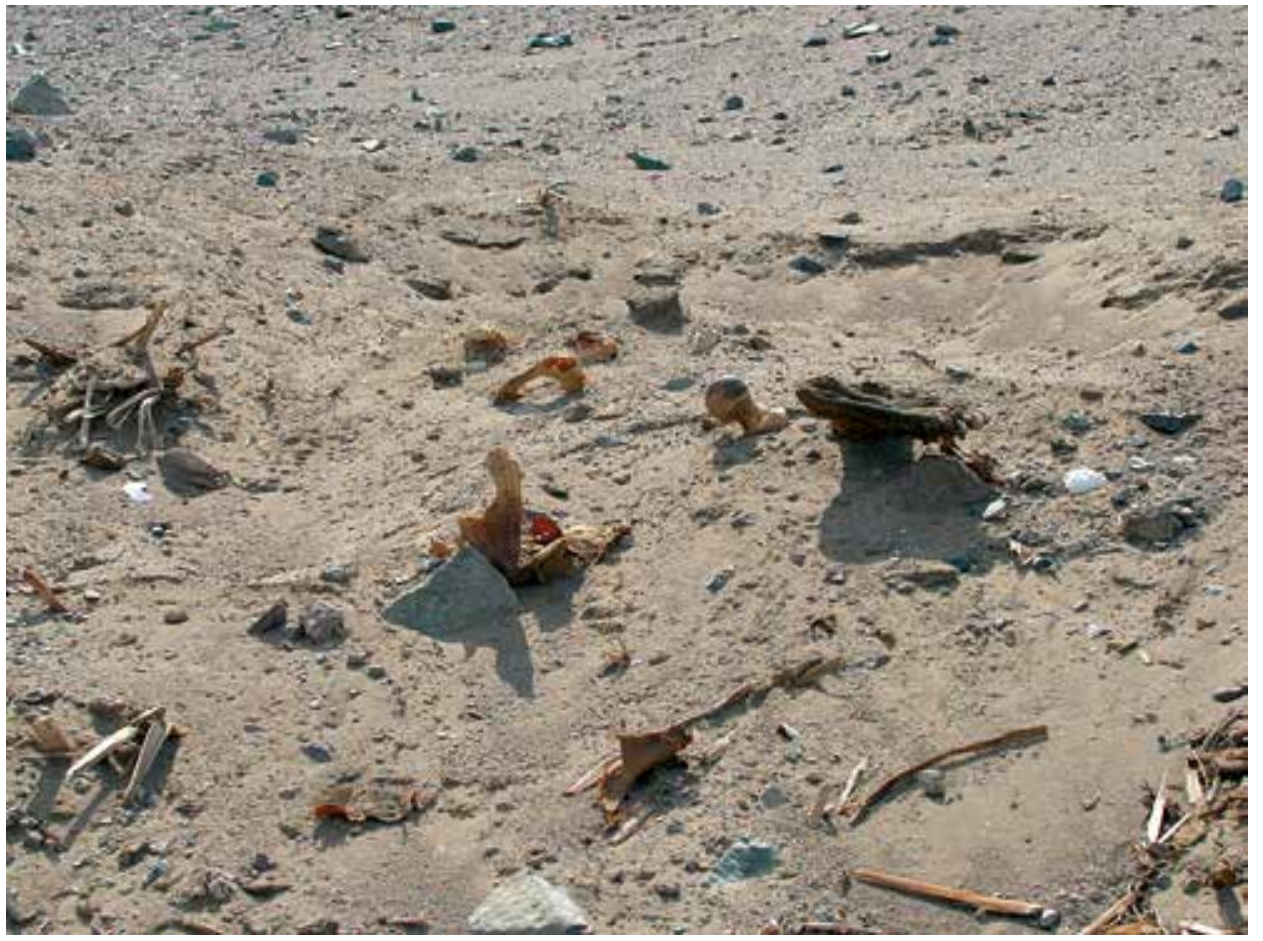

Photograph from the Laboratory of Paleoparasitology (Ensp/Fiocruz).

Figure 4 - Chinchorro mummified body

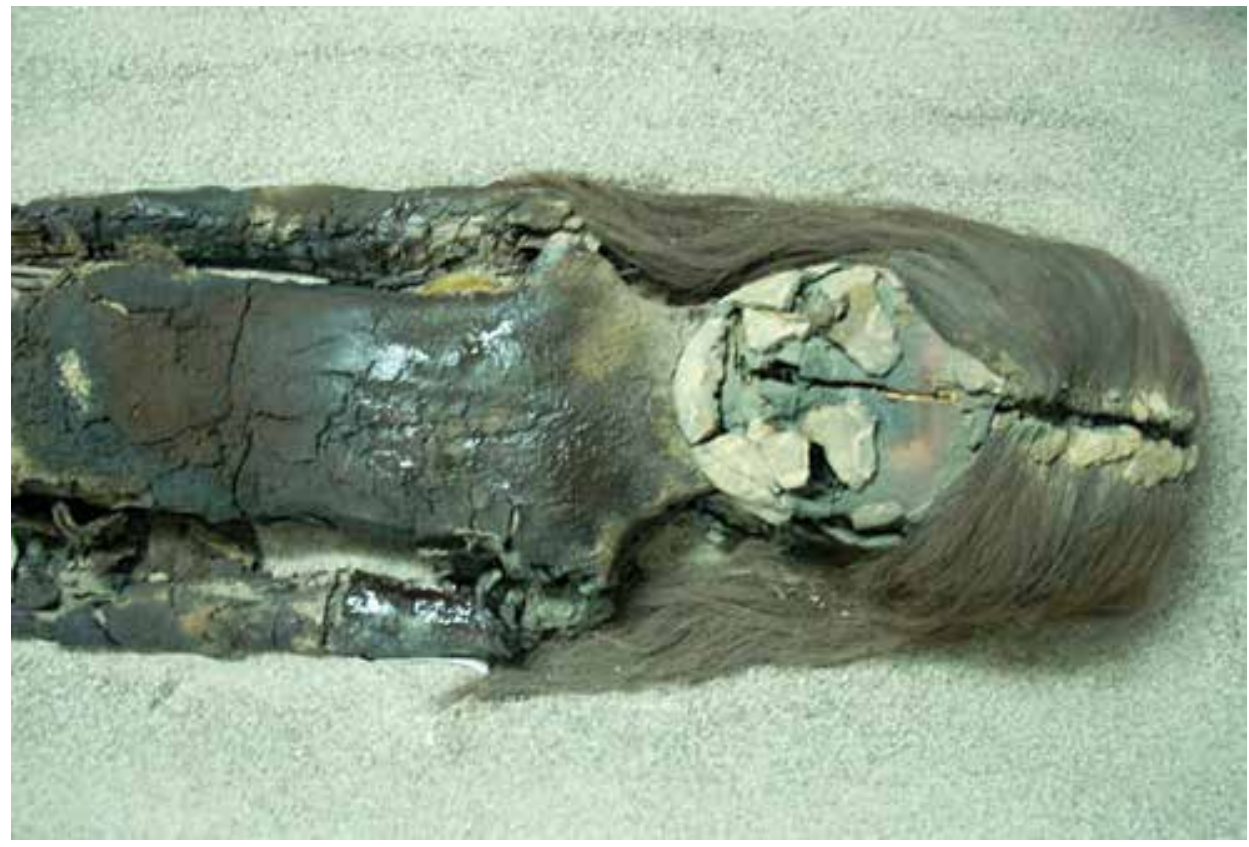

Collection of the Archaeological Museum of San Miguel de Azapa, Arica, Chile. www.uta.cl/masma/, page organized by Bernardo Arriaza. 
Europe has famous peat bogs, swampy areas where the low (acid) pH and anaerobic environment are spectacular for preserving organic remains. Many examples have been described in detail by Cockburn, Cockburn \& Reyman (1998), Aufderheide \& Rodrigues-Martín (1998), and Aufderheide (2003). Some of these bodies still have the individuals' look and facial expression, even though they were not preserved intentionally. On the contrary, many were sacrificed and the bodies were thrown into the bogs. In other regions of Europe, bodies have been found preserved by the intense cold, like the famous Ice Man Ötzi, who provided material for studies by various fields (Rollo et al., 2002).

In South America, on the other side of the Andes, no embalming was used for the dead. Funeral practices varied greatly, but they mainly aimed to release the spirit from the body. Various practices were used, such as cremation and secondary burials, in which the corpses were buried and the remains (mainly the bones) were later transferred either to urns or directly into the ground.

However, once again the climate, especially the aridness in certain areas, led to the rapid desiccation of bodies, thus preventing rotting by microorganisms. Ferreira, Reinhard \& Araújo (2008) quote a passage from the book OS Sertões (Rebellion in the Backlands), by Euclides da Cunha (1902), in which the author describes the finding of the mummified bodies of a soldier and his horse, killed during the War of Canudos in the late $19^{\text {th }}$ century in the hinterlands of Bahia, Northeast Brazil.

The collection of the National Museum of the Federal University of Rio de Janeiro houses several examples of naturally mummified bodies. Some have been studied by experts (Beltrão \& Lima, 1986) (Figure 5). Although they have some well-preserved parts, the abdominal cavity had been partially destroyed by bacterial putrefaction. However, morphologically identifiable mites were still found (Araújo et al., 1986).

Figure 5 - Necropsy of a mummified body at the National Museum, Federal University of Rio de Janeiro, organized by Maria Beltrão and Tânia Andrade Lima

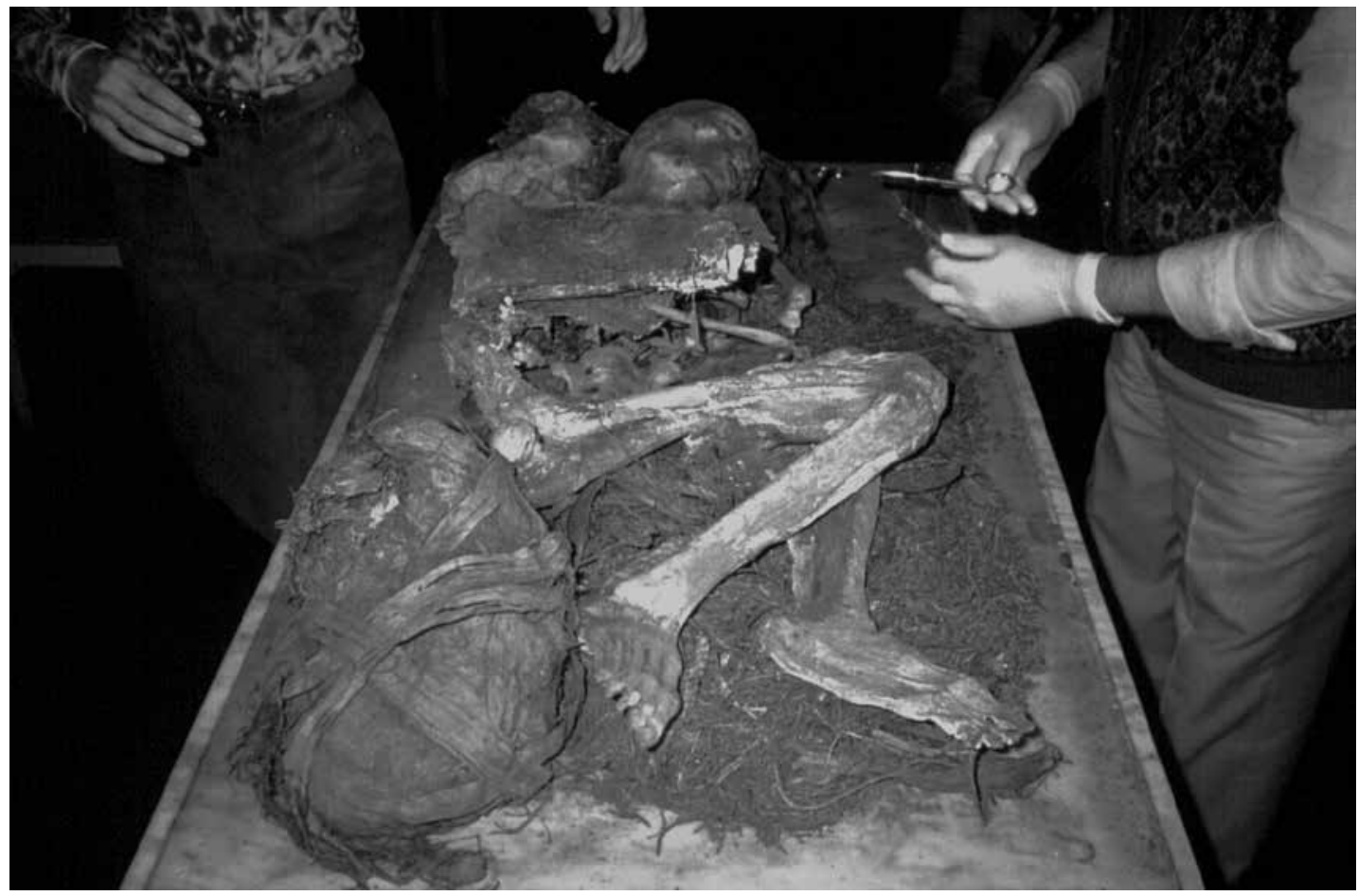

Photograph from the Laboratory of Paleoparasitology (Ensp/Fiocruz). 
Other bodies have been found in specific situations, like those in the church in the town of Itacambira, northern Minas Gerais State, Brazil, another region sufficiently dry to preserve organic matter in good conditions (Figure 6). The corpses were removed from the churchyard when the church was renovated some 300 years after it was built, in the $17^{\text {th }}$ century. During renovation in the early $20^{\text {th }}$ century, when the bodies were found, the priest decided to store them in the church basement, where they were destroyed by time. However, some were removed and preserved by local citizens or individuals from neighboring towns, which allowed studies involving paleopathology and paleoparasitology (Ferreira et al., 1984).

Figure 6 - Naturally mummified child's body. Itacambira, Minas Gerais, Brazilian colonial period

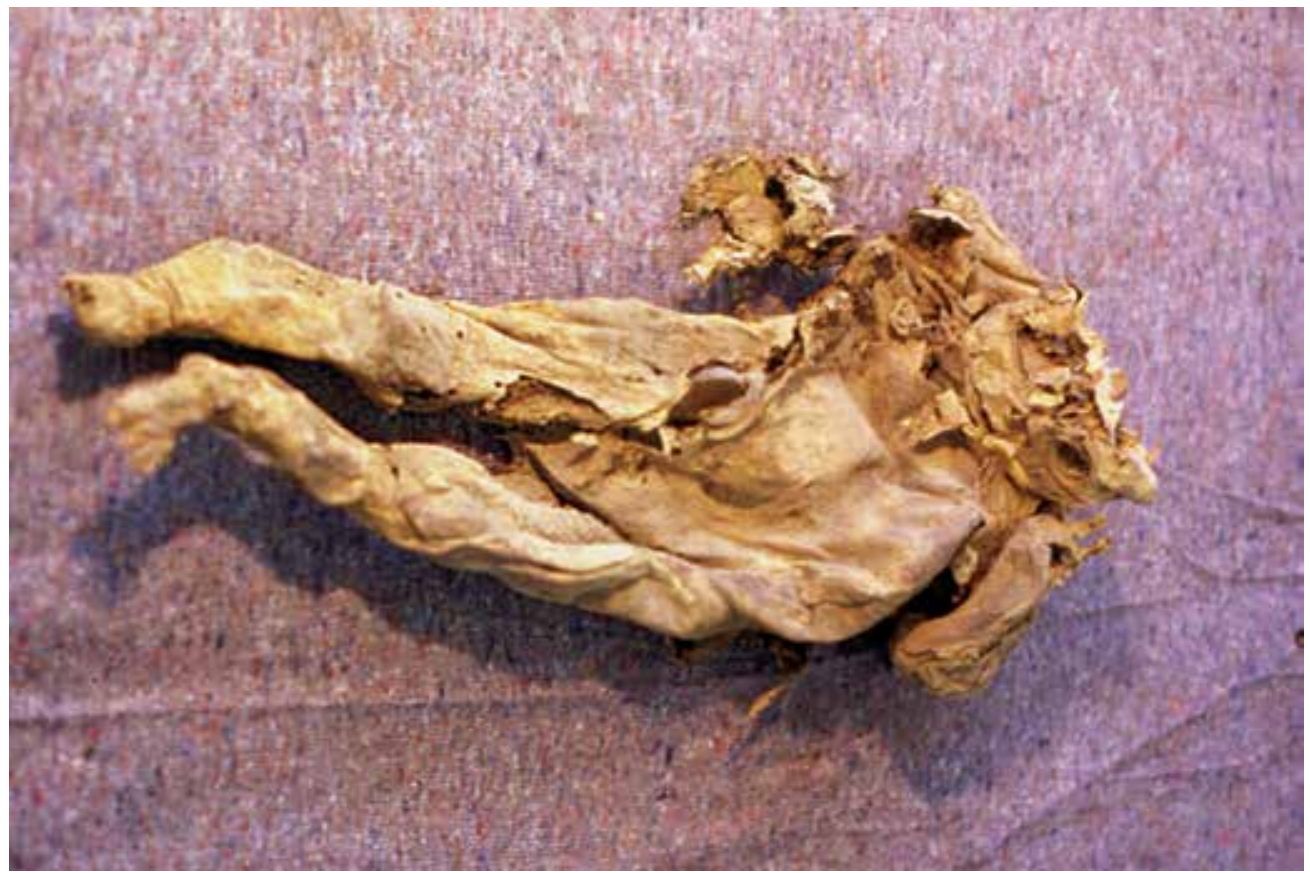

Photograph from the Laboratory of Paleoparasitology (Ensp/Fiocruz).

Organic matter can thus be preserved in diverse situations and by different means. Archaeological sites contain the material that has been studied most extensively for the presence of parasites, namely feces that have been preserved by desiccation or some other process of preservation, called coprolites.

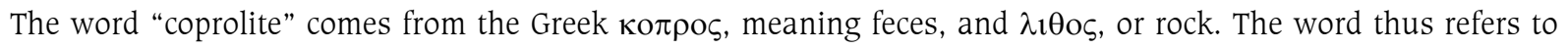
hardened, stony feces. As a function of their time in the environment as well as edaphic and climatic conditions, coprolites may simply be dehydrated by the rapid loss of water, or mineralized, when the organic matter has been replaced and shaped by minerals.

When coprolites are removed directly from human or animal bodies, the researcher has already identified the host, thereby facilitating identification of the parasite (Figure 7). In most cases, however, the coprolite is found loose in the middle of the excavation. Such cases require a series of tests to reach a positive identification. Other times, coprolites are found accumulated in deposits, either naturally formed or constructed for specific purposes, like medieval latrines or those used by the Ancestral Pueblo in the United States. The coprolites may be dispersed or mixed with other 
organic remains, and the farther they are from an association with a possible animal that produced them, the more difficult their zoological diagnosis.

Figure 7 - Egyptian cat mummy. National Museum, Federal University of Rio de Janeiro

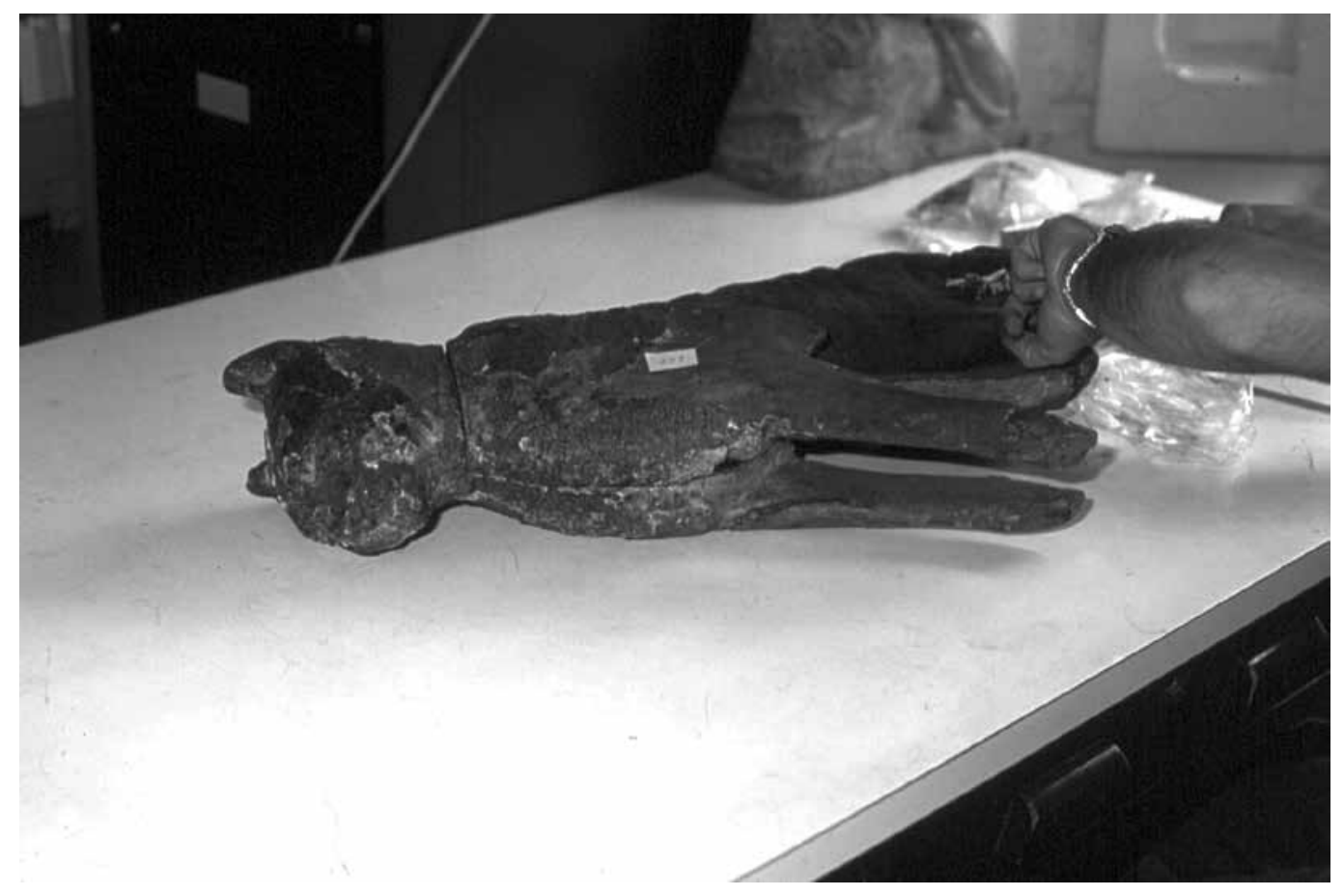

Photo from the Laboratory of Paleoparasitology (Ensp/Fiocruz).

Coprolites can be found in latrines and other deposits, mixed in an amorphous mass consisting of various layers formed over time. In some cases it has been possible to study changes in the profile of parasitism at successive moments in the archaeological site's occupation (Reinhard, 1988; Le Bailly et al., 2007).

Ancient European latrines were studied by Reinhard et al (1986), who reported on the diversity of findings and quantitative studies of helminth eggs found in this type of deposit. Jones (1982) also discussed the preservation of coprolites and helminth eggs, studying material from archaeological sediments in York, England. Both the coprolites and eggs were found in mineralized concretions, requiring appropriate techniques such as the use of hydrochloric acid to separate the material.

Paleontologists have also found coprolites in much more ancient material. Coprolites from an extinct species of hyenas in Italy (Figure 8), dated to 1.5 million years BP, contained a nematode, but diagnosis to the species level was not possible: it was an extinct parasite in an extinct host (Ferreira, Araújo \& Duarte, 1993). Current techniques allow approximations of the group of parasite infestations involved, and more precise phylogenetic studies may be possible in the near future.

The climatic conditions for preservation of coprolites (as with mummified bodies), vary according to the diverse effects of desiccation, cold, and acid or alkaline pH, so that parasites can potentially be retrieved in totally opposite situations of extreme cold or heat. 
Figure 8 - Hyena coprolites, Italy, 1.5 million years BP

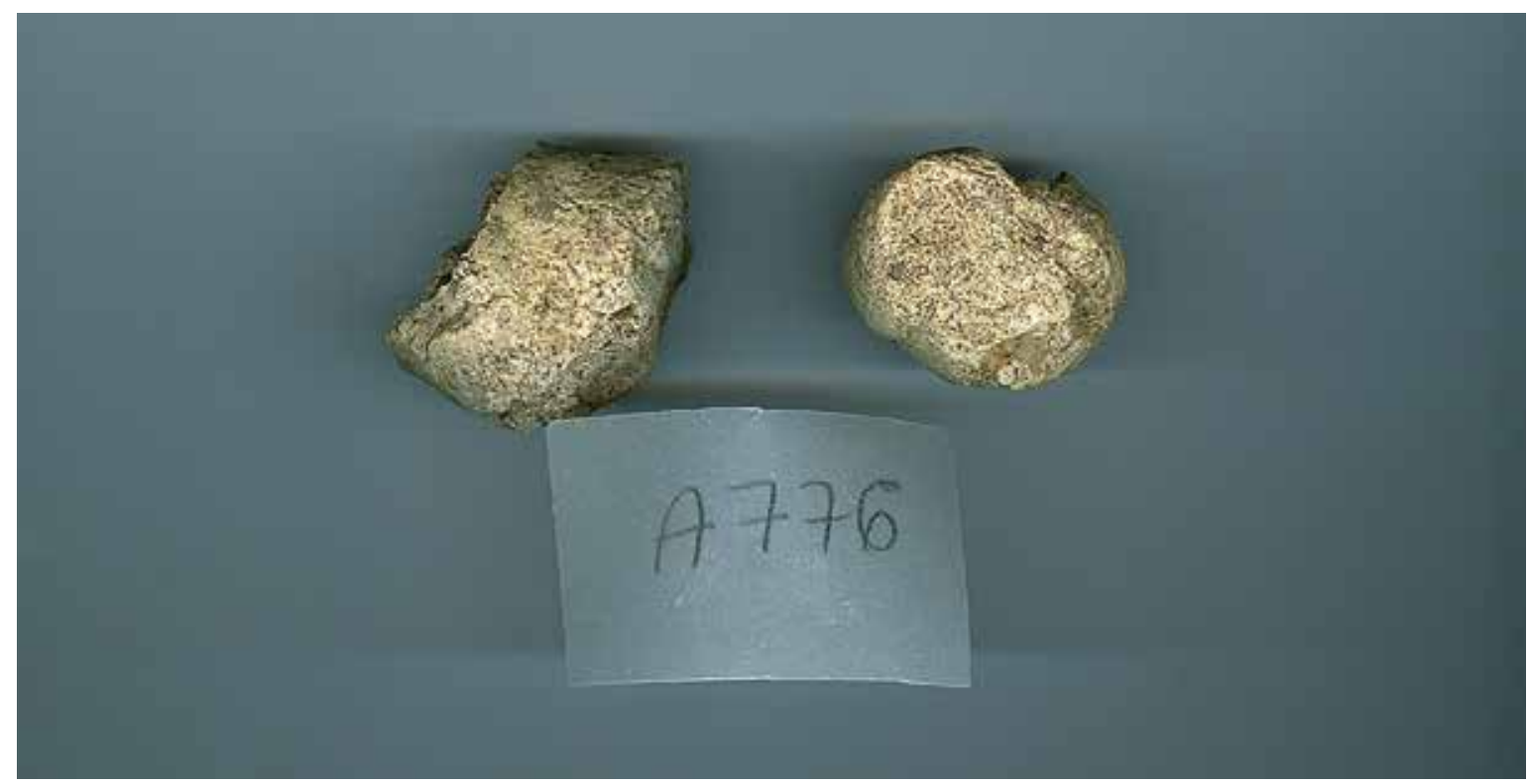

Photo from the Laboratory of Paleoparasitology (Ensp/Fiocruz).

Bouchet, Harter \& Le Bailly (2003) reviewed these issues, discussing how organic remains can be recognizable for years, as long as adequate techniques are used, which now allow a wide range of studies. The processes involved in the preservation of coprolites are the same as with mummified bodies, differing according to climatic conditions and cultural situations (Ferreira, Reinhard \& Araújo 2008).

Coprolites vary greatly: some remain morphologically recognizable, sunk in a moist environment or even immersed in water, as in peat bogs or anaerobic environments, while others are completely desiccated, as in the Atacama Desert, or exposed to the arid and stormy climate of southern Patagonia. Paleoparasitological tests are possible from one extreme to the other, as demonstrated by Bouchet, Harter \& Le Bailly (2003) and Fugassa et al (2006).

Cultures that occupied different parts of the world obviously differed from each other. Many such cultures left their remains inadvertently. Others used devices that allowed the preservation of feces, e.g., latrines or specific waste deposits. Various artifacts, especially in Europe and Colonial America, can contain parasites or interesting remains. When archaeologists collect materials, it is extremely important not to clean them before testing for parasites or genetic material. Various pieces of pottery, including those used for personal hygiene, are important sources of material (Lima, 1996), as are bones, even when stored in museums for long periods of time, as shown by Fugassa et al (2007).

Important findings of parasite forms include fungal spores, bacteria, viral capsules, protozoan cysts, helminth eggs or larvae, and other forms from parasites' life cycles. Equally important are sequences of genetic material that can be recovered using molecular techniques. Deoxyribonucleic acid (DNA) is extremely special material, and studies have already proven that DNA is maintained better in field conditions (i.e., in the original sites) than in collections in museums or other institutions (Pruvost et al., 2007). 


\section{REFERENCES}

ARAÚJO, A. et al. Exame parasitológico: mumificações naturais na pré-história brasileira. Boletim do Museu Paraense Emilio Goeldi. Série Antropologia, 1: 32-33, 1986.

ARRIAZA, B. Beyond Death: the Chinchorro mummies of ancient Chile. Washington: Smithsonian Institute Press, 1995.

ATOCHE PEÑA, P.; RODRIGUEZ-MARTÍN, C. \& RAMÍREZ RODRÍGUEZ, A. Mummies and science: world mummies research. In: VI WORLD CONGRESS ON MUMMY STUDIES, Teguise, Lanzarote, February 20-24, 2007. Proceedings... Academia Canaria de la Historia, Islas Canarias, Santa Cruz de Tenerife, 2008.

AUfDERHEIDE, A. C. The Scientific Study of Mummies. Cambridge: Cambridge University Press, 2003.

AUfDERHEIDE, A. C. \& RODRIGUES-MARTÍN, C. The Cambridge Encyclopedia of Human Paleopathology. Cambridge: Cambridge University Press, 1998.

BELTRÃO, M. C. M. C. \& LIMA, T. A. Mumificações naturais na pré-história brasileira: um estudo de caso. Revista de Arqueologia, 3: 3-36, 1986.

BRothWELL, D. \& SANDISON, A.T. Diseases in Antiquity. Springfield, Illinois: Charles C. Thomas Publisher, 1967.

BOUCHET, F.; HARTER, S. \& Le BAILLY, M. The state of the art of paleoparasitological research in the Old World. Memórias do Instituto Oswaldo Cruz, 98, supl. 1: 95-101, 2003.

COCKBURn, A. \& COCKBURn, E. Mummies, Diseases and Ancient Cultures. Cambridge: Cambridge University Press, 1980.

Cockburn, T. A.; Cockburn, E. \& Reyman, T. A. Mummies, Disease and Ancient Cultures. $2^{\text {nd }}$ Edition, Cambridge: Cambridge University Press, 1998.

FERREIRA, L. F.; ARAÚJO, A. \& DUARTE, A. N. Nematode larvae in fossilized animal coprolites from lower and middle Pleistocene sites, central Italy. The Journal of Parasitology, 79(3): 440-442, 1993.

FERREIRA, L. F.; REINHARD, K. \& ARAÚJO, A. Paleoparasitologia. Rio de Janeiro: Editora Fiocruz, 2008.

FERREIRA, L. F. et al. Enterobius vermicularis eggs in pre-Columbian human coprolites from Chile. Paleopathology Newsletter, 46: 4-5, 1984.

FUGASSA, M. Enteroparasitosis en Poblaciones Cazadoras-Recolectoras de Patagonia Austral, 2006. PhD dissertation, Mar del Plata: Departamento de Biología, Universidad Nacional de Mar del Plata.

FUGASSA, M. H. et al. Paleoparasitological records in a canid coprolite from Patagonia, Argentina. The Journal of Parasitology, 92:1.110-1.113, 2006

FUGASSA, M. H. et al. Nuevas fuentes de evidencia para la paleoparasitología y la antropología biológica en Patagonia. Revista Argentina de Antropología Biológica, 9: 51-57, 2007.

JONES, A. Human parasite remains: prospects for a quantitative approach. In: HALL, A. R. \& KENWARD, H. L. Environmental Archaeology in the Urban Context, Council for British Archaeology, 1982. (Research Report, 43)

LE BAILLY, M. et al. Crise économique au Néolithique à la transition Pfyn-Horgen (3400 BC): contribution de la paléoparasitologie. Anthropozoologica, 42(2): 175-185, 2007.

LIMA, T. A. Pratos e mais pratos: louças domésticas, divisões culturais e limites sociais no Rio de Janeiro, século XIX. Anais do Museu Paulista, História e Cultura Material (Nova Série), São Paulo, 3: 129-191, 1996.

PECK, W. M. Mummies of ancient Egypt. In: COCKBURN, T. A.; CockBURN, E. \& REYMAN, T. A. Mummies, Disease, and Ancient Cultures. Cambridge: Cambridge University Press, 1998.

PRUVOST, M. et al. Freshly excavated fossil bones are best for amplification of ancient DNA. Proceedings of the National Academy of Sciences, 104: 739-744, 2007. 
REINHARD, K. J. Cultural ecology of prehistoric parasitism on the Colorado Plateau as evidenced by coprology. American Journal of Physical Anthropology, 77: 355-366, 1988.

REINHARD, K. et al. Recovery of parasite remains from coprolites and latrines: aspects of paleoparasitological technique. Homo, 37: 217-239, 1986.

ROLLO, F. et al. Otzi's last meals: DNA analysis of the intestinal content of the Neolithic glacier mummy from the Alps. Proceedings of the National Academy of Sciences, 99(20): 12.594-12.599, 2002. 


\title{
3
}

\section{The History of Paleopathology in Brazil: skulls, parasites, and diseases from the past}

\author{
Sheila Mendonça de Souza
}

Paleopathology in Brazil is part of a scenario that has witnessed enormous transformations, as in many other
countries. The roots of Brazilian paleopathology lie partly in classificatory studies of human skulls, but the field has also grown to formulate explanatory models for the peopling of the continents and human living conditions, based on signs of diseases from the past. The field relates to the study of normal morphological variability, but has been modulated by anthropology and archaeology and linked to medicine at various times.

Paleopathology is a hybrid, interdisciplinary, multidisciplinary, and transdisciplinary field, sharing medical and archaeological studies. Amidst skulls, parasites, and signs of ancient diseases, paleopathology still shows signs of separation between the disciplines (i.e., non-integrated use of areas of knowledge). In Brazil, the consequences of such a non-linear history involve not only the nature of the field itself, but also the string of facts and social and academic conditions that framed the initial research, discoveries, and (of course) professional training. In recent decades, North American paleopathology has become the center of bioarchaeology, and Brazil has followed these same steps.

Bioarchaeology is a relatively new concept. The name is currently used for the field of studies on the archaeological remains of human bodies. Contrary to previous practice, the term is no longer applied generically to the study of all biological remains in an archaeological site. Bioarchaeology seeks to tell the history of diseases by relating them to lifestyles, human behaviors, and the origins of groups from the past (Larsen, 1997).

One of the innovative characteristics of bioarchaeology is that by extrapolating the physical confines of laboratories, its work begins in the field, in archaeological excavations. Until the mid- $20^{\text {th }}$ century, the study of human archaeological remains focused mainly on the racial question and attempts at typological and evolutionary classification. Since the 1970s, greater attention has focused on the development of approaches using health as a biocultural indicator, becoming one of the driving forces in studies of human remains. The concept of bioarchaeology is now based primarily on the possibilities offered by paleopathology. 
However, the history of bioarchaeology (and obviously that of paleopathology) in Brazil cannot be dissociated from the international scenario. It is thus interesting to observe the relative independence between the scientific fields of anthropology and paleopathology.

As a spinoff of what was then the recently founded field of pathological anatomy, paleopathology predated anthropology and was closely related to the emergence of modern scientific medicine. Eighteenth-century morphologists, anxious for new possibilities to demonstrate the power of their tools, explored the normal and the pathological (Canguilhem, 1990), identifying lesions and anomalies. The human goal of diagnosing diseases is quite recent, but the concepts of pathology and disease are mutable, as are the fields that study them (Carvalho, 1996). Paleopathology emerged from scientific pathology, but it also changed over time.

Johann Friedrich Esper published one of the first studies in 1774, describing a pelvic fracture in a fossil mammal from the Pleistocene. At the time, paleopathology was still virtually limited to the study of extinct animals. The $19^{\text {th }}$-century fathers of medical pathology, including Rudolf Virchow, began to explore the diagnostic possibilities of archaeological findings, proving that their new science was so powerful that it could even diagnose diseases and lesions in ancient beings. Before anthropology could surpass taxonomic or evolutionary views, physicians were already applying techniques like radiology and histology to study mummies and bones preserved by fossilization or embalming.

Paleopathology in Brazil began in the $19^{\text {th }}$ century, as in many other countries, but unlike elsewhere it developed slowly and was always closely linked to the medical field (Souza \& Guichon, in press). The scarcity of researchers and professors dedicated to the theme certainly contributed to the delay in scientific output, so that the field's history in Brazil was long and gradual. However, recent decades have witnessed a multiplication of researchers and institutions dedicated to paleopathology and bioarchaeology, as well as the growing internationalization of research output. Along with Brazil's pioneering role in such fields as paleoparasitology and the fast growth of our academic faculty, these developments have given Brazil a leading position in the Americas, making paleopathology a thriving discipline in the country.

For a century, Brazilian research on the archaeological remains of human bodies was performed basically within physical anthropology, but in the last five decades the studies on history and prehistory have been greatly enriched by knowledge associating health, lifestyles, and the environment. Although experiencing late development as a field of research, paleopathology in Brazil skipped the long pathographic stage, which mainly constituted the second period in the history of paleopathology (Jarcho, 1966; Buikstra \& Cook, 1980).

When Brazilian paleopathology reemerged vigorously in the 1970s, it was influenced by the third period in the field's scientific output, focusing on more population-based and anthropological approaches, despite maintaining roots in medicine. Influenced by the paths identified since the 1960s by Lawrence Angel (Buikstra, 1990), paleopathology in Brazil is heavily oriented towards paleoepidemiology.

In Brazil, classical themes in paleopathology such as syphilis, tuberculosis, and cranial trepanations received little attention, probably due to the characteristics of Brazilian collections. The training of researchers under the paleoepidemiology school (represented by Della Cook) and the close proximity to the public health field contributed to increasingly population-based approaches to the health of ancient human groups.

This chapter provides a brief history of when and how paleopathology has been practiced in Brazil, and by whom. The chapter also honors the memory of several nearly forgotten researchers, highlighting their contributions to the field. 


\section{IN THE BEGINNING WAS PHYSICAL ANTHROPOLOGY}

Physical anthropology in Brazil began as a science in Rio de Janeiro in the mid-19th century (Faria, 2000). The motivation appears to have been the finding of the first human remains contemporary with the extinct Pleistocene fauna, in Minas Gerais State. The mineralized bones were among the first to be found in the world, after Neanderthal in Lazareto, France, in 1826. The finding of such ancient humans at a time when creationist ideas still prevailed had a huge impact on the scientific community.

According to Alfredo Mendonça de Souza (Souza, 1991), despite publication of descriptions of skulls from Lagoa Santa, Minas Gerais, systematic anthropological studies only began in the late $19^{\text {th }}$ century, aimed at explaining differences between humans from the so-called Lagoa Santa "race" and the sambaqui (shell mound) builders (Lacerda, 1885).

These early human archaeological remains in Brazil were discovered by naturalist Peter Wilhelm Lund, who worked in Brazil from 1824 to 1829, financed by the King of Denmark. After excavating and extensively studying the fossil fauna from limestone caves in Lagoa Santa, Minas Gerais, Lund sent his collection to the Copenhagen Museum of Natural History, thereby concluding his scientific mission. Having fallen in love with Brazil, in 1834 he settled for good in the country, where he died many years later. In 1840 he described the human bones from Lapa do Sumidouro, Minas Gerais in Memórias (Lund, 1950). The skulls caught his attention due to their less "mongolized" shape as compared to those of other Native Americans, and they immediately sparked the first debates on the peopling of America (Souza et al., 2006).

Attuned to the work in Europe, Peter Lund observed several paleopathological characteristics, highlighting the intense wear on the teeth, tooth loss in life, and signs of presumed skull fractures. He used these characteristics to defend the position that this was ancient material, representing a group with an extremely primitive way of life (Lund, 1950). These were probably the first paleopathological reports on Brazilian material. International experts were consulted to discuss these findings, including Rudolf Virchow, who had published his first news on paleopathology in 1856. Human paleopathological studies had begun during this period, launching the second phase in the general history of paleopathology (Armelagos, Mielki \& Winter, 1971).

Craniology and craniometry were still the main targets of anthropological interest in Brazil during the following years. According to Luiz de Castro Faria (Faria, 2000), the first phase of anthropological studies in Brazil lasted from 1860 to 1910. Research groups were organized, encouraging archaeological and anthropological studies. Contacts with Europe were crucial for Brazil for both theoretical-methodological and ideological reasons. But health was still not a key issue for anthropology in Brazil. In North America as well, Ales Hrsdlicka prioritized evolutionary studies, despite having published work in paleopathology (Buikstra \& Beck, 2006). Although the first Brazilian physical anthropologists were also physicians and anatomists, there was little interest in diseases and a greater focus on evolutionary studies (Souza, Codinha \& Cunha, 2006).

The Museu Real (Royal Museum) was founded in Rio de Janeiro in 1818 by King João VI and was maintained and improved in the late 1800 s by his grandson, Emperor Pedro II. Academia and authorities already acknowledged the scientific importance of anthropology, and Emperor Pedro II hired the museum's first anthropologists. Pedro II was an amateur geologist and Egyptologist himself, loved archaeology, and supported anthropological research, encouraging the organization and study of collections. Proud of the tropical country he ruled, Pedro II made it a point of honor to organize the first exhibit in Europe featuring the beautiful Marajó and Tapajós pottery from archaeological finds in the Amazon. This was the context in which anthropological studies were encouraged. 
Brazil's Royal Museum (later renamed the National Museum) was not the institution that backed Lund in his work, but it was there that conditions were created for physical anthropology to flourish. Thus, unlike other countries, the study of ancient human remains in Brazil referred not only to a seminal name, but to a public institution that formally encouraged such studies, recruiting the proper experts for this project. Ladislau Neto, an archaeologist and first director of the museum, headed and promoted research in the area and led the first Anthropological Exposition in Brazil.

The first physical anthropologist at the National Museum was João Baptista de Lacerda, also a physician. He was in charge of the Section on Anthropology, General and Applied Zoology, Comparative Anatomy, and Animal Paleontology beginning in 1870 , heading a laboratory on experimental physiology, where the science of physical anthropology was conducted at the time. He was the first Brazilian to describe the skulls from Lagoa Santa and raise the hypothesis that current Brazilian indigenous peoples were their descendents. Lacerda focused little attention on the skulls' pathological aspects, but his evolutionary metric studies were important. His publications included Documentos para Servir à História do Homem Fóssil do Brasil in 1875, in Mémoires de la Société d'Anthropologie de Paris, and he lectured at the first course on Physical Anthropology in Brazil, in 1877 (Faria, 2000).

João Rodrigues Peixoto was an assistant to João Baptista de Lacerda. Despite his interest in investigating differences between the skulls of the sambaqui builders and those of contemporary indigenous peoples, referred to generically as "Botocudos", he also failed to focus great attention on health aspects. The Botocudos were considered extremely primitive and stereotyped as indocile, serving as a morphological parameter for primitivism.

Using craniometric and cranioscopic techniques prevailing in Germany and France at the time and equipped with imported instruments, anthropologists at the National Museum worked on these materials. By classifying skulls, they attempted to situate each group or individual in the evolutionary landscape. Although they still showed little interest in paleopathology, they established collections represented by Brazilian and international materials, thereby ensuring the diversity of a collection which even today is the object of paleopathological studies.

At the turn of the $20^{\text {th }}$ century, Brazil was undergoing great changes resulting from the Proclamation of the Republic (1889). New objectives and new discourses emerged, and the Royal Museum became what it is today: the National Museum of Rio de Janeiro. After a phase of abandonment, this institution, heir to the collection and academic dreams of the Empire of Brazil, steadily reclaimed its role. At the time there were no other Brazilian institutions with specialists in the study of human skeletons, particularly archaeological ones. The National Museum acted for a long time as the national repository of collections, although the Ipiranga Museum in São Paulo and the Emílio Goeldi Museum in Belém, Pará, also maintained collections (Souza, 1991).

According to Castro Faria, the second phase of physical anthropology in Brazil began after 1910. During this phase there was little interest in the study of archaeological materials, with a shift towards the theme of ethnic miscegenation and its relations with the formation of the Brazilian people (Santos, 2002). Somatometry and somatology gained ground, and the study of bones became temporarily less relevant. The study of Negros, Mulattos, and contemporary Brazilians became the focus of greater interest, replacing that of indigenous peoples and archaeological collections.

A leading scholar at the time was Edgar Roquette-Pinto, an ethnographer who organized the second course on physical anthropology in Brazil, in 1926. He also chaired the First Eugenics Congress in 1929 and published Rondônia, with a rich Nambikwara ethnography. This study resulted in some information on health that ended up feeding one of the most interesting Brazilian dissertations in paleoparasitology (Fonseca Filho, 1972).

Anatomist Álvaro Fróes da Fonseca, one of Roquette-Pinto's assistants, also played an important role in the ongoing development of bone sciences in Brazil. Fróes da Fonseca lectured at the Federal University, becoming professor 
of anthropology at the National Museum. The following generation of anthropologists knew him as a reference in morphology and studies on anatomical variability, which he consistently taught in his medical curriculum.

Although anthropology continued to receive important medical contributions in the early $20^{\text {th }}$ century, paleopathological studies failed to spark interest in Brazil. Meanwhile, scientific output was growing in other countries, especially through contributions from countries in the Northern Hemisphere, but also some in South America. According to a compilation by Armelagos, Mielki \& Winter (1971), over the course of the $19^{\text {th }}$ century some 180 studies were published in paleopathology, while in the early $20^{\text {th }}$ century, from 1900 to 1930 alone, another 560 titles were published. These figures, although approximate, confirm the field's full-blown growth, although without any apparent impact on Brazilian anthropology.

In the 1920s and 1930s, archaeological research missions from the National Museum mobilized anthropologists, providing new materials and questions for discussion. The first and most noteworthy were revisits to the sites at Lagoa Santa, headed by Padberg-Drenkpöl in 1926 and José Bastos de Ávila and Ney Vidal in 1937. Bastos de Ávila, a physician, dedicated himself mainly to anthropometry, but also contributed occasionally to the study of the skulls from Lagoa Santa and other archaeological sites. Reinforcing the teaching of quantitative methods applied to anthropological research, he organized the third course in 1932 and published the first Brazilian technical manual, Antropologia Física (Ávila, 1958).

In the mid-20 $0^{\text {th }}$ century, World War II affected the Americas as a whole, and Brazil was no exception. After the war ended, Brazilian institutions resumed their activities, and a major academic restructuring occurred. During this period the dichotomy between life sciences and the humanities was momentarily attenuated by the inclusion of courses on physical anthropology and human evolution in the humanities. According to Castro Faria (2000), during this period some 40 courses in anthropology were offered at different universities in the country. But courses that depended on biological knowledge for studies in the humanities meant a huge effort, with little return in practice, due to the difficulty in training researchers in the more biological dimensions of anthropology.

Two figures were active at the National Museum in the late 1940s: Tarcísio Torres Messias, a career staff technician at the institution who conducted studies on skeletons of sambaqui builders, and Pedro Estevam de Lima, physician, anatomist, and dentist, attracted by anthropology. Pedro Lima became a staff naturalist at the museum and devoted 16 years of research to indigenous groups, conducting anthropometry and pioneering studies, including indigenous health. Both contributed to the formation of bone collections at the National Museum, and to a more modest degree, to paleopathology. Both also reported observations on health-related and cultural practices, such as dental mutilation (Lima, 1954). Lima was probably also one of the first to exhume bodies from cemeteries of the Guajajara-Tenetehara people for scientific purposes, with this indigenous group's help and support. The skeletons, which were considered contemporary at the time, provided isotope dates nearly two and a half centuries old. Their paleopathological study has provided valuable bioarchaeological information.

This same period also witnessed the first systematic Brazilian and international excavations in various Brazilian archaeological sites. Lagoa Santa was revisited by Wesley Hurt of the University of South Dakota, together with colleagues from the Brazilian National Museum. The sambaqui at Cabeçuda, Santa Catarina, was excavated by Castro Faria, who began his career as a paleoanthropologist at the National Museum. At this time, the first important collections of archaeological human skeletons were formed, which encouraged the study of human bones.

The increase in the number of excavations, the expansion of archaeology and prehistory in academic institutions, and the new legislation on protected heritage sites fueled the field's growth in Brazil. However, this situation was 
affected by changes resulting from the military coup in the 1960s and their impact on the country's anthropological scenario (Souza, 1991; Funari, 2002).

The first great modern paleopathology studies were published in the 1960s, establishing a new paleoepidemiological paradigm. The proposal of comparative population studies segmented by age, sex, and temporal, geographic, and cultural characteristics had begun with Ernest Hooton, who studied the Pueblo of North America (Hooton, 1930), but without major repercussions at the time. In the 1950s and 60s, Lawrence Angel resumed these approaches for discussing the health of ancient Mediterranean peoples (Angel, 1967). By applying these same population approaches, Angel made the initial leap to modern paleopathology and was followed by an entire North American school (Buikstra, 1990).

Meanwhile, in different states of Brazil, archaeologists João Alfredo Röhr in Santa Catarina and Dorath Pinto Uchoa in São Paulo conducted their excavations and published descriptions (albeit simplified) of ancient human skeletons. They included paleopathological data such as the description of dental caries, abrasion, and calculus, and some macroscopic bony lesions like healed fractures. Although lacking the kind of specialization that would have allowed them to accompany what was already being developed by experts outside of Brazil, these Brazilian archaeologists and anthropologists made their contribution to studies on prehistoric health. The first review of the Brazilian literature that compiled dispersed paleopathological data was presented at the International Congress of Anthropological and Ethnological Sciences in Chicago in the 1970s (Souza \& Ferraz, 1974). Resulting in a limited systematization, this review showed how much work remained to be done.

During this same period, after years of contributions to somatometry, physical anthropology at the National Museum resumed its role of formulating models and interpretations of Brazilian prehistory. Through increasing dialogue with archaeologists, osteological studies gained new importance, while also opening room for paleopathological studies. Marília Carvalho de Mello e Alvim was the main figure in this transition. Having graduated in geography and history in the 1950s, Marília was first attracted to ancient history and later to ethnography (Powell et al., 2006) and eventually focused mainly on the osteometric and osteoscopic study of prehistoric skeletons. Searching for the biological relations among prehistoric populations as a way of understanding the peopling of Brazilian territory, she became the principal reference in the area for some 30 years, reviewing old hypotheses and new interpretative proposals for the human skeletons of Lagoa Santa and the Brazilian sambaquis.

Marília Alvim contributed more to paleopathology than her predecessors or contemporaries. Her work, some of which published with paleopathologists, frequently mentioned relevant data for studies on health. She authored several pioneering observations such as the impact of batoques (lip plates) on the mandibles of the Botocudos (Alvim, 1963). She was entirely devoted to human osteology and provided the exception confirming the rule that training physical anthropologists in courses in the humanities was very difficult.

Although she visited numerous archaeological sites and worked with many archaeologists, she did not conduct excavations, but was essentially a laboratory researcher. Her most important contribution was the painstaking study of cribra orbitalia and porotic hyperostosis in the skulls of sambaqui builders and other groups (Alvim, Uchoa \& Gomes, 1991). Although she remained cautious in studies on paleopathology, since she considered herself insufficiently qualified to work in a field in which she lacked specific training, Marília produced highly relevant data for bioarchaeological studies.

Although she was not very scientifically daring, she seriously questioned the model of sambaqui builders as essentially gatherers and eaters of shellfish, against which she used an irrefutable nutritional argument. As an anthropologist at the National Museum and professor at the State University of Rio de Janeiro, she participated directly 
or indirectly in training the current generation of senior Brazilian researchers in the area. Together with Cleber Bidegain Pereira (University of Santa Maria, Rio Grande do Sul), she published the first Manual para Estudos Craniométricos e Cranioscópicos in Portuguese (www.cleber.com.br). A second book, on bones other than skulls, containing a chapter on paleopathology, was awaiting publication when she died in 1995 and still remains unpublished. She opened the collections of the National Museum to different researchers, as for the first Brazilian thesis on bone paleopathology, by Jorge Ferigolo, under her supervision (Ferigolo, 1987).

Another figure that contributed substantially to paleopathology in Brazil beginning in the 1970s was Lilia Cheuiche Machado, a student and collaborator of Marília Alvim. Her main affiliation was with the Institute of Brazilian Archaeology, also in Rio de Janeiro (Powell et al., 2006). Dedicated to bioarchaeological studies, Lilia was one of the first to take interest in bone and dental paleopathology. She did an internship at the Smithsonian Institution in Washington, D.C., and worked with Douglas Ubelaker, Jane Buikstra, and Christy Turner II. When she returned to Brazil in the 1980s, she brought new methodologies and unprecedented results from the paleopathological perspective. She applied scanning electron microscopy for the first time to studies of dental abrasion, allowing the proposal of new interpretations on diet and economy in a prehistoric group on the coast of Brazil (Turner II \& Machado, 1983; Machado, 1984). She introduced Brazil to the use of cortical bone histology to estimate age in adults and paleodemographic studies based on life tables (Machado, 1984).

Lilia, like Marília, had no medical training, making her interpretations and analyses more timid. She was an equally important reference for Brazilian archaeologists, maintaining close relations with the first teams specializing in paleopathology at the Oswaldo Cruz Foundation (Machado et al., 1984).

Walter Neves was another anthropologist who began his work in the 1970s. Together with Lilia, he represents the first generation that trained abroad, returning with the experience of internationalization, new paradigms, techniques, and methods that reinforced his scientific and academic contribution. Both Lilia and Walter participated in the transition to a scientific osteology that was more attuned to the new theoretical frameworks, influenced by the New Anthropology. Breaking with the relative professional isolation of bioarchaeological studies in Brazil, both scholars made key contributions to studies on the health of prehistoric Brazilian groups. Although neither specialized exclusively in paleopathology, the two researchers moved more easily than their predecessors in the expanded field of studies on human skeletal biology.

Walter began his studies at the University of São Paulo's Institute of Prehistory, further developing his training in osteology in the United States. For more than two decades he has focused mainly on microevolutionary studies (Neves, Hubbe \& Piló, 2007). He made his pioneering contribution to bioarchaeology in the 1980s, while studying the materials from the Le Paige Museum in San Pedro de Atacama, Chile, especially the periods that preceded, accompanied, and succeeded Tiwanaku rule over the Atacama peoples.

In Brazil, Walter set up and maintained for years a new research center in bioanthropology at the Goeldi Museum in Pará. Settling later in São Paulo, he created the Laboratory for Human Evolutionary Studies, where he conducts research and supervises graduate students, but without totally abandoning paleopathological themes such as dental caries (Neves \& Kipnis, 2004) and stress indicators (Neves \& Wesolowski, 2002). Having always preferred to work with quantitative methodologies, his contribution to paleopathology has not prioritized osteobiographic approaches or differential diagnosis.

Alfredo Mendonça de Souza (Souza, 1988) published a scientometric study on Brazilian archaeology in the 1970 s and 80 s, calling attention to the country's relative isolation in terms of research output in archaeology, which he considered numerically limited and often provincial and unrefined. During the decades described by Souza, the 
situation was beginning to change, including some growth in paleopathology. According to Souza, despite the small number of researchers studying human remains in Brazil, some $15 \%$ of the studies published during this period were already on bioarchaeology. Of these, $6 \%$ focused on paleopathology. This proportion sounds surprising if one considers the incipient nature of bioarchaeology as a field. It reflects the new impetus in research output on human remains. By focusing on authors and published themes, this same study shows that in parallel to the accumulation of traditional academic institutions, some studies in paleopathology were already starting to appear elsewhere, including a decisive contribution by physicians.

The emergence of paleopathology as a professional specialty in Brazil originated in three different and independent places, all in Rio de Janeiro. The first center to produce research in paleopathology in the 1960s was led by Ernesto de Mello Salles Cunha, a professor of dental pathology at Fluminense Federal University (UFF). Devoting years of study to archaeological skulls, he published the first specialized work on paleopathology in Brazil. He studied and painstakingly described the dental conditions of the series from Lagoa Santa and some sambaquis such as Cabeçuda, in Santa Catarina. He developed the dental pathology models that allowed Brazilian archaeologists to characterize such groups in prehistoric interpretations. He was the first to call attention to the exceptionally good dental conditions and absence of caries in some prehistoric coastal sites, raising the hypothesis that genetic factors linked to the development of enamel could explain this rare condition (Cunha, 1963). Having personally conducted excavations in different sites, he built collections and even organized a museum at the Dentistry School in Niterói, Rio de Janeiro State. He studied the teeth of slaves and discussed African cultural practices such as dental mutilations (Cunha, 1968), Tupi-Guarani burials (Cunha, 1960), and other archaeological findings. His studies include biocultural interpretations, correlating dental conditions, daily habits, cultural practices, and diet. He was a key reference for Brazilian archaeologists and osteologists like Marília Alvim, and his work continued to influence other researchers after his death in 1977.

The second independent center with research and training in paleopathology was the undergraduate course in archaeology, functioning initially at Faculdade Marechal Rondon and later at Faculdades Integradas Estácio de Sá. Created in the 1970s based on a proposal for an initial basic curriculum for undergraduate studies in archaeology in Brazil, this course filled a gap in professional training in the country and produced several real innovations in the field. In the original curriculum, two particular disciplines provided impetus for the field of bioarchaeology: anthropometry and paleopathology.

Proposed as a discipline within the basic curriculum in keeping with international models, paleopathology was promoted by Alfredo Mendonça de Souza. He personally participated in the first research efforts (Souza \& Ferraz, 1974), which included encouraging me in my professional career. International publications by renowned authors like Marvin Allison, Calvin Wells, and Don Brothwell inspired the initial course contents. Supported by cooperation with Claudio Lemos, a medical pathologist at the Pathology Department of the Rio de Janeiro State Employees' Hospital [IASERJ] and with the "Bones Club", I conducted the first studies on prehistoric skeletons while obtaining my specialization degree in bone pathology. Claudio Lemos participated in the first research work, helping lay the groundwork for the course. I received a scholarship from the Brazilian National Research Council (CNPq) and supervision by Castro Faria and Marília Alvim at the Department of Anthropology at the Brazilian National Museum, opening the doors for research on the museum's large prehistoric collections.

The third center of paleopathology emerged in the largest health research institution in Brazil, the Oswaldo Cruz Foundation (Fiocruz), thanks to the vision of Luiz Fernando Ferreira, a medical parasitologist. Under the inspiration of Olympio da Fonseca Filho and Marc Armand Ruffer, a pioneering group was formed, determined to invest in a new field of research: paleoparasitology. 
Followed by students who rose to the challenge of writing their theses and dissertations on human health in the past, such as Adauto Araújo, Diana Maul, Ulisses Confalonieri, and others, Luiz Fernando laid the foundations for paleoparasitology. His group became one of the first in the world to study parasite eggs and larvae in coprolites. Aidan Cockburn, Mirko Grmek, and Arthur Aufderheide are among the non-Brazilians that supported this initiative from day one. From the beginning of their work, the group at Fiocruz established archaeological partnerships with the following: the School of Archaeology through collaboration with Alfredo Mendonça and myself; the Institute of Brazilian Archaeology with Ondemar Dias and Lilia Cheuiche; with André Prous at the Museum of Natural History at the Federal University of Minas Gerais; with Niéde Guidon at the Fundação do Homem Americano; and with Maria da Conceição Beltrão and Marília Alvim at the National Museum in Rio de Janeiro.

Originally created under the Department of Biological Sciences at the National School of Public Health (Ensp/ Fiocruz) and later moved to the school's Samuel Pessoa Department of Endemic Diseases, the group received encouragement and access to archaeological material, developing a prolific line of research and professional training.

Unlike the other two centers, which lasted no longer than 15 years each, the group formed by Luiz Fernando Ferreira maintained its vitality. Pursuing the production of knowledge and multiplying a body of highly trained researchers, the group succeeded in responding to the challenges of a new interdisciplinary field, persisting for the last 30 years and becoming a national and international reference.

In the State of Santa Catarina, the dental bioarchaeology center created by Salles Cunha practically stopped producing research after his death, although it did inspire other experts such as Edson Medeiros de Araújo. Dental studies were gradually incorporated into studies by general paleopathologists after the 1990s. The center for general paleopathology, created within the archaeology course, gradually approached the paleoparasitologists at Fiocruz, particularly consolidating this exchange after the activities were closed at the School of Archaeology, also in the late 1990 s.

Thus, from 1970 to the 1990s, intense academic exchange laid the foundations for paleopathology in Brazil. North America and Europe were also experiencing changes, with the speed-up in scientific output and the consolidation of some of the leading names in the field. The growth of new interdisciplinary fields applied to archaeology, a new approach to biomedical technologies, attention to biocultural questions, and other issues fueled the interest in studies on health and its relations to ancient ways of life.

Importantly, as in Brazil, the field of paleopathology in the Northern Hemisphere was also closely linked to medicine. According to a compilation based on the review by Armelagos, Mielki \& Winter (1971), until the early 1970s only $15 \%$ of the publications in paleopathology were from the anthropological area, but this proportion began to increase slowly in the following decades.

Jarcho (1966) and others discussed the history of paleopathology, calling attention to its different phases or stages. They identify the initial phase of interest in fauna, the one focusing on human beings and some specific diseases or practices, and finally that of essentially pathographic diagnoses and the application of new techniques.

In Brazil, the interest in such themes and objects did not follow the same chronological order, and the main research thrust related to the more recent period, still not described by these authors. Several years later, Buikstra and Cook (1980), reflecting on this field of research in the Americas, highlighted the growing trends in paleoepidemiology. When Della Cook came to Brazil to give the first course on Specialization in Paleopathology at Ensp/Fiocruz, she provided Brazilian researchers with the conditions for the definitive expansion of this field in the country, while of course bringing a strong North American and paleoepidemiological influence. Her visit also strengthened the 
association between faculty and alumni/ae from the School of Archaeology and the paleoparasitology group at Fiocruz, contributing definitively to the establishment of what is now a stable and productive research center at the latter institution.

\section{PALEOPATHOLOGY: WHAT'S NEW ON THE HORIZON?}

Having published its work since the 1970s and significantly increased its research output since the 1990s, the Fiocruz team currently collaborates with academic graduate studies programs in epidemiology, public health, molecular biology, and parasite biology that accept themes for theses and dissertations in paleopathology.

The group regularly offers a specialization course, in addition to participating in course content, ad hoc courses, conferences, events, scientific exhibits, and other activities, thereby fueling interest in the subject inside and outside of Fiocruz. Regular international cooperation with colleagues from Europe, the United States, and the Americas in general provides further impetus to the teaching and research work. Thanks to funding from Brazilian research agencies such as Capes and CNPq and specific international agreements such as Capes-Cofecub (Comité Français d'Évaluation de la Coopération Universitaire avec le Brésil) and Capes-SECyT (Secretaría de Ciencia y Tecnología), colleagues from abroad come to Brazil and Brazilian researchers and students travel abroad for collaborative studies and research work. Renowned experts such as Della Cook and Karl Reinhard (USA), Ricardo Guichon and Martín Fugassa (Argentina), Françoise Bouchet (France), Eugénia Cunha (Portugal), Bernardo Arriaza (Chile), and others have collaborated in projects. Although the course is situated in an institution of excellence in the medical field, interaction with anthropology and archaeology is reflected in both the research output and the profile of alumni/ae from our courses.

Contrary to predictions, the study of human remains continues to make progress in Brazil. There is already a demand for professional experts to provide consultancy and conduct temporary projects. Related issues such as studies in taphonomy and funerary archaeology are already themes for research, monographs, and theses, encouraged by the new undergraduate and graduate courses in archaeology. Bioarchaeological approaches have become more frequent, and specific projects have begun to receive funding. Ease in travel, funding for research, domestic and international cooperation, participation in events, more agile scientific output, and other factors have reduced the endogeny, thereby contributing to the improvement of Brazilian research in paleopathology and to the contribution by Brazilian experts to international paleopathology (Souza, Codinha \& Cunha, 2006; Lessa, 2006). New methodologies and techniques developed by Brazilian experts are accepted and applied elsewhere in the world. Biocultural models, some unprecedented, are contributing effectively to a better reconstitution of Brazil's prehistory (Lessa \& Scherer, 2008; Rodrigues-Carvalho \& Souza, 1998; Souza, 1992, 1995, 1999; Wesolowski et al., 2007).

In the early $21^{\text {st }}$ century, bioarchaeology has been increasingly incorporated into archaeological projects. The questions emerging from field or laboratory research are answered through multiple approaches and collaboration between disciplines. The specificity of preservation of materials, taphonomic processes, challenges in the mediumand long-term preservation of samples, and issues of curatorship are all present in paleopathological research. The inclusion of ethical issues related to studies of human remains, as well as the search for procedures that reduce invasive and destructive technologies, have already begun to be performed in bioarchaeological research. Part of the effort involves the adjustment of excavation projects and opportunistic and systematic collections by applying specific protocols for food microresidues, paleoparasitology, paleogenetics, and others, thereby ensuring better quality and 
reliability in the data. Paleopathology is already a definitive part of archaeological research, making the invisible visible and reconstituting histories on health and ancient ways of life.

Currently, in various States of Brazil, groups of archaeologists have incorporated at least one temporary specialist dedicated to the study of human remains. Studies of human remains and the analysis of funerary structures, skeletons, and teeth have multiplied in the literature, gaining greater visibility in archaeological research. Some professionals from medicine and biology already work fulltime in this field, gaining professional expertise and adding techniques, experience, and interests to those of archaeologists, joining efforts to unveil the biological past of humans and their cultural relations.

The possibility of an association between radiologists, geneticists, dentists, biologists, physicians, parasitologists, anthropologists, historians, geographers, archaeologists, and others is now a much richer and more complex interdisciplinary reality than could have been imagined by Castro Faria or others who conceived the field of anthropology as an encounter between biology and the humanities. Ever since the skulls with dental wear called attention to health, all the way to the current painstaking studies on diet through microscopic food residues from dental calculus, we have come nearly two centuries on our research journey in paleopathology in Brazil.

The main researchers currently working in Brazil and who received their basic training in osteometry (osteology), including knowledge on epigenetic traits, are prepared to conduct basic studies on mortality and osteobiographic identification, and depending on their backgrounds, they focus on different areas of paleopathology with varying degrees of specialization.

Meanwhile, professionals that specialize mainly in microevolutionary research, conducting osteometric studies, also have experience in basic research in paleopathology. In practice there has been extensive integration between these two fields of bioarchaeology. Archaeologists and other professionals trained in the humanities have been receiving their training in medical institutions such as Fiocruz in Rio de Janeiro, thus benefiting from a rich and perhaps unanticipated interdisciplinary interface.

Professionals originally trained in the biomedical specialties have also participated increasingly in archaeological work, from the field to the laboratory, with greater presence in the institutions housing collections and in the anthropological laboratories, establishing more balanced and interdisciplinary work relations. Joint efforts in the last 15 years have ensured the growth of paleopathology in Brazil. An intense network of cooperation between researchers from biomedicine and the human sciences (both Brazilians and non-Brazilians) has worked on themes and problems of common interest, thus fostering progress in the field.

The main Brazilian centers for training and research in paleopathology are still in Rio de Janeiro and São Paulo, but smaller groups (originally spinoffs from these centers) are working in other places and institutions to ensure the continuity of their work, while considerably decentralizing the field's knowledge output.

The interests are more diversified at Fiocruz, including morphological, molecular, and immunological paleoparasitology, with studies ranging from taphonomy to oral health conditions and diet, thereby multiplying the group's scientific potential. Participation by teams of experts from the Oswaldo Cruz Institute have allowed maintaining these lines of research and opening new ones, accompanying trends in other centers or even innovating in techniques and themes. The following is a list of names from both Fiocruz itself and individuals from other institutions that are associated with the Foundation's research groups in paleopathology and paleoparasitology: Adauto Araújo, Alena Mayo Iñiguez, Sheila Mendonça de Souza, Luciana Sianto, Daniela Leles, and Andréa Lessa, among others. Some 
of these, alumni/ae of Fiocruz, have created new research groups, for example Claudia Rodrigues Carvalho (National Museum, Federal University of Rio de Janeiro), Verônica Wesolowski (Museum of Archaeology and Ethnology, University of São Paulo), and Olívia Carvalho (Federal University of Sergipe), among others. A relevant number of theses and dissertations and more than 300 publications on paleopathology have thus emerged in the last 20 years.

Other research centers in Rio de Janeiro have proceeded with or launched their own work. At the Institute of Brazilian Archaeology, Laura da Piedade Ribeiro and Gláucia Malerba Sene continued the line of research work by Lilia Cheuiche. In the Department of Anatomy at the Federal University in Rio de Janeiro, Adilson Salles, following the tradition of anthropological anatomists, has been conducting and supervising studies on osteology, mummified materials, and paleopathology, in collaboration with Fiocruz and the National Museum. Jorge Ferigolo, with a small team, has done similar research at the Rio Grande do Sul State Zoobotanical Foundation.

At the University of São Paulo (São Paulo city campus), three groups affiliated with different research centers are producing research in osteology, funerary archaeology, human evolution, and paleopathology. At the Institute of Bioscience, Walter Neves and Sabine Eggers lead their research groups, training Master's and PhD students on different topics. Graduates of these centers include Max Hubbe, Mercedes Okumura, Célia Boyadjian, and Pedro Tótora da Glória, among others.

At the Museum of Archaeology and Ethnology, new PhDs like Sérgio Francisco da Silva conduct part of their research in paleopathology. In Belém, Pará State, at the Federal University of Pará, the group led by Andrea Kelly Ribeiro-dos-Santos and Sidney Santos, at the Laboratory of Medical Genetics, does research in human and parasite paleogenetics, having studied samples from practically all over Brazil.

Some of the research themes in paleopathology include: violence and conflicts between prehistoric human groups in Brazil and Chile and their relations with cultural transitions and contacts; economic, dietary, and health changes; the distribution of infections and their demographic relations; migrations and changes in the prevalence of human parasitic infections; musculoskeletal changes and daily activities; dental problems and diet; and congenital anomalies and their genetic and environmental determinants. Brazilian researchers in all these specialties participate in events in Brazil and abroad and produce studies on materials from Brazil and also from other countries including the United States, Chile, Portugal, France, Belgium, and Argentina.

The approach to paleopathology in Brazil began with skulls and eventually reached parasites, opening up a wide range of research in the last two decades. Medicine, which played an important role in the first phase of physical anthropology, when paleopathological approaches were still taking their early steps, remained as a sort of reserve for anthropological training for many years. The consolidation of the first studies on human evolution in the humanities in the 1960s laid the basis for the first non-medical callings in bioarchaeology. During this same period, within the various medical specialties, new perspectives motivated studies on health and disease in ancient populations. An international scenario ripe with archaeological and anthropological studies began to influence Brazil and motivated these parallel developments.

Today, the training centers for experts in paleopathology in Brazil are mainly based in the biomedical field, although extensively permeated by anthropology. Most of the professionals with their main specialization in paleopathology no longer have basic biomedical training, but originally graduated in archaeology or other human sciences. The process that began in the mid- $20^{\text {th }}$ century finally appears to have come full circle, although by unforeseen paths.

This increasing interdisciplinary collaboration suggests that we may be approaching what Castro Faria would have liked to witness during the early efforts to introduce physical anthropology into teaching of the humanities. News 
challenges continue to emerge for researchers, teachers, and students of human remains, but the situation in the early $21^{\text {st }}$ century is certainly promising. The field's growth already allows us to refute Marília Alvim, who bemoaned during her more pessimistic phase, "Anthropologists that study human bodies are a dying species in Brazil."

It's not true, Marília! Even having traveled unforeseen roads, bioarchaeology and paleopathology are alive and well in Brazil!

\section{REFERENCES}

ALVIM, M. C. de M. Diversidade morfológica entre os índios 'botocudo', do Leste Brasileiro (séc. XIX) e o Homem de Lagoa Santa. Boletim do Museu Nacional, 23: 1-70, 1963. (Antropologia Nova Série)

ALVIM, M.C. de M.; UCHOA, D. P. \& GOMES, J. C. de O. Cribra orbitalia e lesões cranianas congêneres em populações pré-históricas da costa meridional do Brasil. Revista do Museu de Arqueologia e Etnologia, 1: 21-53, 1991.

ANGEL, J. L. Porotic hyperostosis, anemias, malarias and marshes in the prehistoric Eastern Mediterranean. Science, 153: 760-763,

ARMELAGOS, G. J.; MIELKE, J. H. \& WINTER, J. Bibliography of Human Paleopathology. Massachusetts: University of Massachusetts, 1971. (Research Reports, 8)

ÁVILA, J. B. Introdução. In: ÁviLA, J. B. Antropologia Física. Rio de Janeiro: Agir, 1958. (Coleção do Instituto de Estudos Políticos e Sociais IV da Pontifícia Universidade Católica do Rio de Janeiro)

BUIKSTRA, J. E. A Life in Science: papers in Honour of Dr. Lawrence Angel. Center for American Archaeology, 1990. (Scientific Papers, 6)

BUIKSTRA, J. E. \& BECK, L. A. Bioarchaeology: the contextual analysis of human remains. New York: Academic Press, 2006.

BUIKSTRA, J. E. \& COOK, D. C. Paleopathology: an American account. Annual Review of Anthropology, 9: 433-476, 1980.

CANGUILHEM, G. Le normal et le pathologique. Paris, Galien, 1966.

CARVALHO, D. M. Epidemiologia de Atenas e História de Doenças. Possibilidades e limites: o caso do escorbuto e da peste de Atenas, 1996. PhD dissertation, Rio de Janeiro: Escola Nacional de Saúde Pública, Fundação Oswaldo Cruz.

CUNHA, E. M. S. Afecções alvéolo-dentárias em mandíbulas de aborígenes da Ilha do Governador (Guanabara). Revista do Sindicato de Odontologia do Rio de Janeiro, 6(17): 13-18, 1960.

CUNHA, E. M. S. Sambaquis e outras Jazidas Arqueológicas: paleopatologia dentária e outros assuntos. Rio de Janeiro: Editora Científica, 1963.

CUNHA, E. M. S. Mutilações dentárias no negro no Brasil. In: JORNADA FLUMINENSE DE ODONTOLOGIA PROFESSOR COELHO DE SOUZA, 6, 1968, Niterói. Anais... Niterói: UFF, 1968.

FARIA, L. C. Antropologia. Escritos Exumados: dimensões do conhecimento antropológico. Niterói: Eduff, 2000. v. 2.

FERIGOLO, J. Paleopatologia Comparada de Vertebrados: 'Homem de Lagoa Santa', 'Homem do Sambaqui de Cabeçuda' e mamíferos pleistocênicos, 1987. PhD dissertation, Porto Alegre: Departamento de Paleontologia e Estratigrafia, Universidade Federal do Rio Grande do Sul.

FONSECA FILHO, O. Parasitismo e Migrações Humanas Pré-históricas. Rio de Janeiro: Mauro Familiar Editor, 1972.

FUNARI, P. P. A. Desaparecimento e emergência dos grupos subordinados na arqueologia brasileira. Horizontes Antropológicos, 8: 131-153, 2002.

HOOTON, E. A. Indians of Pecos Pueblo. New Haven: Yale University Press, 1930.

JARCHO, S. Human Paleopathology. New Haven: Yale University Press, 1966. 
LACERDA, J. B. O homem dos sambaquis. Arquivos do Museu Nacional, 6: 175-203, 1885.

LARSEN, C. S. Bioarchaeology: interpreting behaviour from the human skeleton. Cambridge: Cambridge University Press, 1997.

LESSA, A. Ampliación de las discusiones sobre los conflictos en el oasis atacameño durante la era de los pukaras: análisis de la muestra esquelética de Catarpe. Diálogo Andino, 27: 9-22, 2006.

LESSA, A. \& SCHERER, L. Z. O outro lado do paraíso: Novos dados e reflexões sobre violência entre pescadores-coletores précoloniais. Revista do Museu de Arqueologia e Etnologia, 18: 89-100, 2008.

LIMA, P. E. Deformações tegumentares e mutilação dentária entre os índios tenethara. Boletim do Museu Nacional, 16: 1-22, 1954. (Antropologia Nova Série)

LUND, P. W. Memórias sobre a Paleontologia Brasileira Revistas e Comentadas por Carlos de Paula Couto. Rio de Janeiro: Instituto Nacional do Livro, 1950.

MACHADO, L. M. C. Análise de remanescentes ósseos humanos do sítio arqueológico Corondó, RJ, aspectos biológicos e culturais. Boletim do Instituto de Arqueologia Brasileira, 1, 1984. (Série Monografias).

MACHADO, L. M. C. et. al. Estudo prévio de práticas funerárias e o encontro de parasitos humanos na gruta do Gentio II, Unaí, MG. Boletim do Instituto de Arqueologia Brasileira, 2, 1984. (Série Ensaios)

NEVES, W. A. \& KIPNIS, R. Further evidence of a highly cariogenic diet among late paleoindians of Central Brazil. Current Research in the Pleistocene, 21: 81-83, 2004.

NEVES, W. A. \& WESOLOWSKI, V. Economy, nutrition and disease in prehistoric coastal Brazil: a case study of the State of Santa Catarina. In: STECKEL, R. H. \& ROSE, J. C. The Backbone of History: health and nutrition in the Western Hemisphere. Cambridge: Cambridge University Press, 2002.

NEVES, W. A.; HUBBE, M. \& PILÓ, L. B. Early Holocene human skeletal remains from Sumidouro Cave, Lagoa Santa, Brazil: history of discoveries, geological, chronological context and comparative cranial morphology. Journal of Human Evolution, 52: 16-30, 2007.

POWELL, M. L. et al. Invisible hands: women in bioarchaeology. In: BUIKSTRA, J. E. \& BECK, L. A. (Eds.). Bioarchaeology: the contextual analysis of human remains. Oxford: Elselvier, 2006.

RODRIGUES-CARVALHO, C. \& SOUZA, S. M. F. M. Uso de adornos labiais pelos construtores do sambaqui de Cabeçuda, Santa Catarina, Brasil: uma hipótese baseada no perfil dentopatológico. Revista da Sociedade de Arqueologia Brasileira, 11: 43-56, 1998.

SANTOS, R. V. Mestiçagem, degeneração e a viabilidade de uma nação: debates em antropologia física no Brasil (1870-1930). In: PENA, S. D. J. Homo brasilis: aspectos genéticos, linguísticos e socioantropológicos da formação do povo brasileiro. Ribeirão Preto: Funpec, 2002.

SouZA, A. A. C. M. Arqueologia Brasileira (1975-1985): análise bibliométrica da literatura, 1988. Master's thesis, Rio de Janeiro: Escola de Comunicação/Ibict, Universidade Federal do Rio de Janeiro.

SOUZA, A. A. C. M. História da arqueologia brasileira. Pesquisas, 46: 1-157, 1991.

SOUZA, A. A. C. M. \& FERRAZ, S. M. Paleopatologia do homem do sambaqui. In: INTERNATIONAL CONGRESS OF ANTHROPOLOGICAL AND ETHNOLOGICAL SCIENCES (ICAES), 9, 1974, Chicago. Anais... St. Louis: Washington University, 1974.

SOUZA, S. M. F. M. Traumatismos vertebrais como indicadores de atividade física na população da Furna do Estrago, Pernambuco, Brasil. In: ARAÚJO, A. J. G. \& FERREIRA, L. F. Paleopatologia \& Paleoepidemiologia: estudos multidisciplinares. Rio de Janeiro: Ensp/Fiocruz, 1992.

SOUZA, S. M. F. M. Um caso pré-histórico de osteomielite generalizada: treponematose ou infecção piogênica? In: BELTRÃo, M. C. Arqueologia do Estado do Rio de Janeiro. Rio de Janeiro: Arquivo Público, 1995.

SOUZA, S. M. F. M. Anemia e adaptabilidade em um grupo costeiro pré-histórico: uma hipótese patocenótica. In: TENóRIO, M. C. (Org.). Pré-história da Terra Brasilis. Rio de Janeiro: Eduferj, 1999. 
SOUZA, S. M. F. M. \& GUICHON, R. Paleopathology in Argentina and Brazil. In: BUIKSTRA, J. E. \& ROBERTS, C. Global History of Paleopathology. Oxford Press, in press.

SOUZA, S. M. F. M.; CODINHA, S. \& CUNHA, E. The girl from the Church of Sacrament: a case of congenital syphilis in XVIII century Lisbon. Memórias do Instituto Oswaldo Cruz, 101, supl. II: 119-128, 2006.

SoUZA, S. M. et al. Revisitando a discussão sobre o Quaternário de Lagoa Santa e o povoamento das Américas: 160 anos de debates científicos. In: SILVA, H. \& RODRIGUES-CARVALHO, C. Nossa Origem: o povoamento das Américas, visões multidisciplinares. Rio de Janeiro: Vieira \& Lent, 2006.

TURNER II, C. \& MACHADO, L. C. A new dental wear pattern and evidence for high carbohydrate consumption in a Brazilian archaic skeletal population. American Journal of Physical Anthropology, 61: 125-130, 1983.

WESOLOWSKI, V. et. al. Grânulos de amido e fitólitos em cálculos dentários humanos: contribuição ao estudo do modo de vida e subsistência de grupos sambaquianos do litoral do Brasil. Revista do Museu de Arqueologia e Etnologia, 17: 191-210, 2007. 


\title{
4
}

\section{The Dispersal of Homo sapiens and the Peopling of the Continents}

\author{
Sheila Mendonça de Souza
}

\begin{abstract}
$\mathrm{A}_{\mathrm{o}}^{\mathrm{lot}}$ look at ancient human history shows that we were a wandering species. Now pandemic, our species differs from others due to our enormous potential to explore and our capacity to develop adaptive strategies over thousands of years that allowed us to disperse and colonize a wide range of environments.
\end{abstract}

Homo habilis may possibly have engaged in migratory behavior, but such behavior was definitely present among the first archaic humans, and it intensified in Homo sapiens, whose mobility led the species to span greater and greater distances, often following known paths. Such behavior itself posed frequent challenges, forcing the human species to deal with changes in environmental pressures and interactions. At each stage in human history, such changes produced new life situations and contact with different parasite species, and thus with different health conditions due to the appearance and disappearance of diseases.

Cultural constructions, whether adaptive or not, have brought relief from and compensation for challenges from the environment and health risks, whenever and wherever humans lived. Human responses of adaptation and adaptability have emerged from millenary interaction with other species and environments, whether natural or modified (Moran, 1982). In some periods and places, diseases were selected because they favored adaptive success; genes were modulated to interact with the environment, causing or repressing diseases (Moalem \& Prince, 2007); microorganisms turned into parasites that were more or less aggressive or successful. News diseases emerged, while others disappeared and later reemerged (Cockburn, 1967; Sournia \& Ruffié, 1984; Verano \& Ubelaker, 1992; Fóller \& Hansson, 1996).

A significant part of the history of health problems that have affected human populations can be understood by the ways our species has either followed or swayed from paths over hundreds of thousands of years. In the process of interrelating with different environments, in survival strategies, in ways of life, and in interactions with other life forms, the human species both incorporated and expunged diseases, differentiated itself from other more phylogenetically proximate species, and harbored species inside itself that were undergoing evolution themselves. Humans developed strategic polymorphisms, retained ancestral parasites, eradicated old parasites, and saw others 
emerge. In our more recent journey, we have even created modified organisms capable of producing diseases. While following paths and going astray, along the way humankind has inscribed the risks, benefits, and harms that this journey has produced for the health of our restless, creative, and wayfaring species.

In the human species, as in any other, the health-disease condition is the result of a history. It should be interpreted on the basis of some organizing dimensions: time, space, changes in human culture and behavior, and changes in the natural environment. A view across the timeline or time's arrow sheds light on the sequences of changes in the conditions leading to health and disease. Over time, we can perceive and seek explanations for various forms of transition and permanence.

Paleopathology focuses on the timeline and health and disease conditions in human populations. Considering the other dimensions, but always looking across time, paleopathology seeks archaeological and historical data that allow understanding how human populations fall ill and die.

Paleopathology has developed for more than two centuries, beginning with the work of Esper in the $17^{\text {th }}$ century (Aufderheide \& Rodriguez-Martin, 1998). It now has a strong basis in anthropology (Buikstra \& Cook, 1980). Based on paleopathological studies, we demystify the notion that healthy living results simply from living in the natural environment. Combined with genetics, studies of human evolution, and more recently ecology, paleopathology has helped unveil the history of human health.

By going backwards in time in human evolution, or by studying other primates, we can formulate the physiological, anatomic, genetic, phylogenetic, or even behavioral models needed to understand human health today and in the past.

Physiological and pathological conditions found in other species can provide important clues to our species' inheritance. Such studies shed light on host-parasite relations based on ecological and phylogenetic principles and processes of coevolution and other mechanisms. Our species' evolutionary history and its relationship to other species with which we share phylogenetic proximity or with which we simply live contain the essential explanations to many of our health-disease processes. Since parasitism and adaptability are inseparable, in some situations anemia can mean the possibility to survive. Much of what has been defined as normal by modern scientific medicine (Canguilhem, 1966) is explained by evolutionary or adaptive processes that we have only recently begun to understand in greater depth. Understanding each step of this process also helps us define health.

When we have achieved a better understanding of the history of human diseases, we may also be able to understand their impact on our evolution. We are currently taking our first looks at our wayfaring species' ancient past and the paths and shortcuts in history of which diseases are an inseparable part (Barnes, 2005; Cavalli-Sforza, 2005; Moalem \& Prince, 2007; Stearns \& Koella, 2008; Trevathan, Smith \& McKeena, 2008).

\section{OUR PRIMATE HERITAGE IN A WORLD OF MICROBES}

Our origin is that of primates. We belong to the family of monkeys, apes, lemurs, and other animals with which we share an extraordinarily interesting set of characteristics (Foley, 1987, 1995). Although most studies in paleopathology and paleoparasitology discuss the more recent periods of human evolution, i.e., anatomically modern humans, others have already reported on our archaic ancestors.

Although the study of our evolutionary past is fragmented and imprecise, theoretical formulations based on paleontological studies, morphology, and genetics, for example, propose models that are currently under discussion. 
Other studies (zoological and behavioral) of free or captive primates (Goodall, 1990; Fouts, 1997) shed greater light on their behavior and health, providing evolutionary, phylogenetic, ecological, and epidemiological models. Studies on ancient and current DNA of microorganisms furnish information on evolutionary processes in viruses, bacteria, protozoa, helminthes, and others, helping explain current or past epidemiological conditions, contributing to our understanding of the parasite-host-environment and evolutionary processes (Araújo et al., 2003; Nozais, 2003; Iniguez et al., 2003; Ebert \& Bull, 2008; Woolhouse \& Antia, 2008; Koella \& Turner, 2008). The scientific data accumulated in these and other types of studies allow discussing our species' health-disease processes from a temporal and evolutionary perspective.

Compared to the evolution of life on earth, human evolution is a very recent event. Vertebrates have already evolved for 500 million years, having undergone great extinctions and catastrophic climatic transitions. Even if one considers the overall evolution of mammals since the Triassic, some 250 million years ago, we have existed for very little time. Primates were among the last families to appear in the evolutionary sequence, dating to the early Paleocene, some 65 million years ago (Martin, 2005). During that period, the expansion of subtropical and tropical forests favored tree-dwelling adaptations and the emergence of primates and other taxa.

Human evolutionary processes rely on some peculiar characteristics, notably the genetic variability expressed in multiple polymorphisms, great mobility, intense genetic drift, and a strong component of invented, taught, and learned behaviors that increases the species' adaptability. Paleontological evidence suggests that this is a tendency of hominids, due to their morphological variability, which is interpreted as speciation but could also express major intraand inter-group genetic and phenotypic variability (Foley, 1995). The concept of speciation in human paleontology is still based on bone morphology. Thus, the variety of hominids tends to increase through progress in research, maintaining a polemical field with a multiplicity of names and concepts.

In evolutionary terms, humans are close to the so-called anthropomorphous monkeys or great apes. The group is represented by the orangutans in Asia and the gorillas and chimpanzees in Africa. We share some $98 \%$ of our genetic material with the latter, in addition to great morphological and behavioral identity (Fouts, 1997). The process of speciation during which humans separated from our primate ancestors is represented by numerous extinct branches. Since the availability of fossils varies, with some species represented by only a few fragments of bones or teeth, we have only an approximate model of the position of these ancestors in the human lineage. The morphology and chronology of primates in the Miocene and Pleistocene provide the basis for the proposed stages of hominization (Foley, 1987).

When considering human evolution, some still imagine life in nature as a guarantee of health, and the primordial stages of life as a state of equilibrium in which all survivors were strong and healthy. Thus, studies of current primates help reflect on the health of our ancestors. A comparative study of skeletons of great apes (Lovell, 1990) found 14\% of chimpanzees in nature with caries, a higher prevalence than in gorillas and orangutans. Intense tooth wear appears to contribute to tooth loss before death, bone resorption, and abscesses. Dental calculus is also common. According to the same author, traumatic bone lesions, mostly fractures, occur in some $70 \%$ of individuals. In chimpanzees, injuries are mostly related to fights and aggression, while in orangutans they are accidental, which can certainly be explained by the social structure of the former, more gregarious and bellicose, and by the form of locomotion in the latter, virtually all by swinging from tree to tree.

Infections are a fascinating subject, since humans and other primates share numerous infectious diseases. The same study by Lovell (1990) describes signs of bone infection in $10 \%$ of individuals, while calling attention to signs of infection consistent with treponematoses. The finding of this type of lesion in the bones of great apes is consistent 
with proposals by Cockburn (1963) and other authors. According to them, the existence of treponematoses in large primates is indicative of the antiquity of this disease, inherited by the phylogenetic route from common hominid ancestors. Another category of lesions was that of arthroses, found in $20 \%$ of the skeletons. Osteophytes, or 'bone spurs', calluses, erosions, and collapses of joint surfaces are well-known in human rheumatism and are also shared. Finding them in hominid bones confirms that they predate the emergence of the human species, as do congenital anomalies and tumors (Krause, 2004; Martín, 2005; Barnes, 2005).

Findings indicate that both primates and hominid ancestors already had their health affected by different processes. The latter were related to ways of life, environmental risks, diet, weaknesses in physical build, and congenital factors, among others.

We definitely share some of our health problems with our ancestors. But which aspects of human evolution can help understand our current health condition?

Isolation of the savannahs in the Rift Valley in Africa was crucial to the process of speciation that preceded the emergence of genus Homo. Type of diet, sexual selection, and thermal regulation, as well as regulation of ultraviolet exposure must have been factors that pressured selection and favored life in that savannah. Other aspects, such as the capacity to manipulate objects and explore the environment, the capacity to move and carry materials, and structuring of stable family groups were also determinant factors in our evolution. All these changes produced impacts on our physiology and morphology, but they must also have brought various health problems. These are also among the most highly valued factors for explaining the selection of adaptive characteristics linked to biped walking and later hominization. Over the course of this process, these factors would also have modulated host-parasite interactions, redefining the natural path of human health across evolution.

Species from genus Proconsul, fossils from catarrhines, and the first in the human lineage are found in Africa and Europe, beginning in the Oligocene. They begin to occur in paleontological sites just over 20 million years ago. Proconsul specimens have no tail, but they already have proportionally large brains for primates of the period, and their frontally positioned eyes would have given them stereoscopic sight, similar to ours.

Kenyapithecus, successors in the same lineage, made their expansion 15 million years ago, and two Asian forms are known: Ramapithecus, considered the ancestors of genus Pongo (orangutans), and Sivapithecus, purportedly related to our lineage. A European form of these primates received the name Oreopithecus (Simons, 1979).

The period between 15 million and 7 million years ago represents a major paleontological silence. With the exception of genus Pongo, whose ancestry in Asian sites can be traced until some 12 million years ago, we know nothing about the immediate ancestors of the great apes. However, molecular models based on the comparison of genetic diversity and frequency of mutations help build hypotheses for this evolutionary period, estimating the antiquity of the Oligocene primates. Based on these models, the emergence of the first hominids is estimated at the transition from the Miocene to the Paleocene, some 7 million years ago (Martin, 2005). In fact, starting 7 million years ago, when the fossil record again began to provide information on human evolution, much more complex and larger primates already inhabited Africa.

The ancestors of gorillas, chimpanzees, and humans also lived in hot and wet tropical environments like woods and gallery forests, as well as in savannahs. Paleoenvironmental reconstitution until the late Miocene shows that their environment was subject to intense tectonic and volcanic activity. There would also have been episodes of temperature drops and the formation of drier regions, with the modification of geographic barriers. Thus, our species' ancestors, although tropical, were also exposed to drier and colder environments, under successive and sudden climatic and 
ecological changes. These alternating climatic cycles coincide with the emergence of the first hominids, suggesting that our lineage emerged under drastic adaptive pressures and challenges.

Judging by the predominantly accepted classification of hominids, East Africa, east of the Rift, was stage to an important species diversification. Another hominid called Ardipithecus ramidus was found in this same region of Ethiopia, as published recently (White et al., 2009), drawing great interest. The discovery has changed the interpretation of our evolution and its relationship to the African great apes, confirming that the evolutionary trends that distinguish the human species were already under way long before, e.g., patterns in locomotion, skull structure, etc.

The largest known hominoid in the region belongs to genus Gigantopithecus, whose bones are found in layers dated 9.5 million to 7 million years ago. This genus was followed by Australopithecus, whose oldest fossils date 5 million to 4.5 million years ago, distributed east and north of Lake Victoria in Kenya and around Lake Turkana in Ethiopia (Foley, 1995). Although the genus is described for Africa, the current literature also records findings of examples of Gigantopithecus in Asia, thus indicating a wider dispersal than proposed by the conventional models (Wang, 2009).

Australopithecus have been the icons of hominization, as bipeds with heads similar to modern-day chimpanzees and bodies similar to humans. These hominids are characterized by their erect gait, greater stature and robustness than their other contemporary primates, increased relative brain size, and a reduction in the masticatory system. The most famous Australopithecus is 'Lucy', a well-preserved skeleton that allowed the first detailed study of the lower limbs of this genus, helping confirm the morphological and functional similarity of its skeleton to that of genus Homo.

The hypothesis that bipedalism preceded genus Homo was later confirmed by the finding of Australopithecus tracks in Laëtoli, Tanzania. The tracks, left by different individuals in a dated layer of volcanic ash, confirmed what the bones suggested. Bipedalism appears to have represented an adaptive advantage, as a more energy-sparing form of locomotion and also by reducing the body area exposed to the sun, thus minimizing body heat in the savannah. Freeing the forelimbs would also have allowed the development of grasping and handling, care for offspring, and physical struggles, substantial evolutionary advantages in combination with the social and cultural development provided by encephalization (Napier, 1979).

Australopithecus, known for their distribution and variety, had a skull capacity of 400 to $500 \mathrm{~cm}^{3}$. They are classified as robust versus graceful, based on their larger or smaller physical build, and they display varied morphology, including their foot bone anatomy, with some variants more adapted to bipedalism. Their teeth vary in shape, with different patterns of wear, suggesting the consumption of distinct foods. This may indicate varied occupation of ecological niches as an adaptive strategy. The principal variants known today and which most paleoanthropologists consider species are: A. ramidus, A. anamensis, A. afarensis, A. africanus, A. aethiopicus, A. boisei, A. crassidens, and $A$. robustus.

According to the current paleontological record, the Australopithecines occupied the savannahs of East Africa for some 4 million years before they reached Southern Africa. The Rift Valley Barrier appears to have prevented their expansion northward and westward. Even so, they dispersed across a considerable geographic area and lived in diverse environments. There is now relatively wide agreement with the hypothesis that $A$. afarensis, the species to which "Lucy" belongs, was the most likely predecessor to genus Homo (Foley, 1995).

Some 3 million years, a new cycle of warming of the Earth led to a new forest expansion, even reaching regions where only tundra now exists. The sea reached 30 meters above the current level, and the African and Asian deserts were greatly reduced. 
The emergence of genus Homo some 2.5 million years ago coincided with this new climatic cycle. It is assumed that the first representative of this genus had a face with little forward projection and a lighter skull than Australopithecus, without the bony abutments that supported the latter's powerful masticatory muscles. The dentition was delicate, the brain proportionally larger, and the lower limbs fully adapted to walking erect. Findings of their bones were associated with rudimentary chipped stone tools such as choppers and chopping tools and animal bones with marks suggesting intentional cuts or breaks, confirming a differentiated skillful behavior and the regular use of handmade tools.

Although the capacity to make and use tools is common to many animals (Bonner, 1983), it is generally associated with occasional and opportunistic intuitive behaviors, without characterizing technological patterns or chains transmitted and improved across generations. Meanwhile, some rare examples, mainly in primates like chimpanzees, point to the potential of these animals to develop creative solutions to problems they encounter in their natural environment. Since the principal adaptive characteristic of these animals appears to have been their exploratory potential, they have proven capable of learning, teaching, and modifying their behavior and environment as a function of their experiences and needs, even in free-living conditions (Goodall, 1990). This potential was certainly an important adaptive factor in the large primates and developed in the evolution of the human species.

The specimens from Olduvai and Lake Turkana were called Homo habilis, exactly because they systematically manufactured tools. Their emergence, as well as that of other mammals, coincides with the beginning of the great glaciations, or Pleistocene, and from this period on there is a reduction in the fossil record of Australopithecus, suggesting that the latter became progressively less adapted or competitive until extinction (Foley, 1995).

This is a period for which there are no findings of human fossils anywhere else in the world, leading one to suppose that the representatives of genus Homo remained limited to Africa for more than 1 million years. Archaeological sites without skeletons, but with chipped stone artifacts from the Olduvai tradition, indicate that Homo expanded to occupy Northern as well as Sub-Saharan Africa (Foley, 1995). Two species, H. habilis and H. rudolfensis, even shared the savannah with species of Australopithecus before the latter disappeared.

Some 2 million years ago another archaic species also emerged in Africa, called Homo ergaster. The existence of this new species, with a very heavy skull and more robust bone structure, with an evolutionary tendency towards larger bodies and brains, would only have been feasible due to an increase in the availability of energy-rich foods, i.e., the regular use of high-calorie foods. According to most current authors, this condition would have been provided by the regular consumption of bone marrow, animal fat, and game. According to some, these skills would have been associated initially with the exploitation of an available food source in the savannahs, namely animal carcasses. Even after consuming all the flesh and viscera from a carcass, the marrow inside the long bones is a rich source of potential energy, and it is extremely rare for animals to access it. Hyenas, for example, with extraordinarily strong jaws and teeth, are able to break the long bones to eat the marrow. But the stone tools already made and handled by our ancestors allowed breaking and opening the long bones.

Paleontological findings in African sites suggest that this activity was indeed performed by those members of Homo. A higher proportion of animal fat in the diet would have brought nutritional and metabolic advantages, as a concentrated energy source.

However, feeding on the carcasses of other animals would also have introduced new health risks and adaptive pressures, especially from parasitic infections (Reinhard \& Urban, 2003; Sianto et al., 2005). Thus, the increasing consumption of meat and fat, based on the establishment first of carrion scavenging and then a hunter diet, would have produced the epidemiological conditions for the emergence of new infectious diseases and thus resulting in adaptive pressures. 
H. erectus, like other hominids, showed morphological variants that have led paleoanthropologists to propose their speciation. According to some authors, this tendency towards variability, observed in Africa but also on other continents, is the expression of the polymorphic and polytypical potential that was present since the beginning of human evolution and that is maintained in modern humans. According to other authors, this variety represents different species that emerged as a result of the processes of dispersal and adaptation. Increased stature, greater skull capacity, a more robust build, and technological progress in manufacturing stone tools by bifacial flaking, known as the Acheulean Industry, are characteristic of this human evolutionary stage.

These archaic humans were armed with greater cultural accumulation and considerably expanded their territories, reaching the Middle East, Europe, and Asia (Cervera et al., 2001; Foley, 1995; White et al., 2009). They colonized a diversity of environments and crossed relatively important geographic barriers. They occupied both rainy tropical areas and high, cold lands, becoming practically pandemic. In this process, they were exposed to new adaptive cycles and biodiversity conditions in completely different climates from the savannah. The transitions and different selective pressures experienced by archaic humans in their evolutionary process certainly contributed to their genetic diversity. Without ever becoming extremely specialized, they probably also maintained the potential to deal with varied exposures to different health problems, undergoing an extremely wide range of selective pressures.

From the genetic point of view, the question for the present is the apparent absence of any contribution by archaic humans to the constitution of modern humankind. All evidence indicates that all these groups that left Africa in the first Great Diaspora of $H$. erectus and their variants disappeared and were replaced by modern humans slightly more than 100,000 years ago.

Thus, two great Diasporas or dispersals of genus Homo occurred, repeating the adventure of a wandering genus. One consisted of archaic humans whose classifications are multiplying today, and another of modern humans, physically and culturally different from their predecessors, a single species despite their many cultural and biological differences. Related only in their remote African ancestry, these two species traveled similar paths and probably shared health risks and conditions, parasites of similar phylogenetic origin.

The entire adaptive process accumulated over the course of hundreds of thousands of years of existence of archaic humans, except for those who remained in Africa, was lost by the complete replacement of populations with a new genetic stock.

Modern humans are believed to have evolved from archaic humans that stayed in Africa, and that already had their current physical shape when they left the African continent to occupy new lands (Guégan, Prognolle \& Thomas, 2008). The new travelers, now H. sapiens, or modern humans, retraced many of their ancestors' steps, were exposed to similar environments, and faced different health-disease conditions. Armed with more sophisticated technologies, they also had a greater advantage in adaptively overcoming the challenges raised by the colonization of planet Earth.

\section{THE FIRST GREAT DISPERSAL: ARCHAIC HUMANS AND THEIR RISKS}

The impact of the use of tools certainly changed access to some high-energy food sources such as bone marrow, serving as a differential milestone for the dispersal of human groups across greater distances. It is believed, therefore, that it was no coincidence that the first great human expansion, with $H$. erectus as the protagonist, only occurred after the development of more advantageous nutritional patterns.

According to Leonard \& Robertson (1994), the availability of high-energy foods also allowed the development of larger brains, the voracious consumers of 20 to $25 \%$ of daily energy demand. The brains of other mammals consume 
only 3 to $5 \%$ of the energy produced in a normal diet. In other primates, this consumption ranges from 8 to $10 \%$. According to calculations by Leonard (2008), for a resting Australopithecus, $11 \%$ of the energy would have been consumed by the brain, increasing to $16 \%$ in $H$. erectus. This means that at least $250 \mathrm{Kcal}$ per day were necessary for the proper functioning of the brain in the first representatives of genus Homo. The association between brains with higher energy demand and the change in diet is consistent with the rapid expansion of H. erectus within and outside of Africa. The demand for more meat and animal fat and the development of meat-eating habits, as carrion scavengers or hunters, would have increased the pressure for larger territories, while also allowing greater adaptive flexibility, since the consumption of meat or carcasses would make the diet more universal: bison, gnus, horses, mammoths, wolves, bears, and so many other large, mediums-sized, or small mammals became just blood, flesh, fat, viscera, and bones to be consumed.

The ingestion of other animal parts, especially those not processed by cooking, would have increased the exposure to microorganisms, larvae, eggs, and even adult helminths, saprophytes, and decomposers present in carcasses.

Depending on the respective life cycles, these organisms could persist in the mucosa, skin, digestive tract, blood, and other body parts of the consumers before being eliminated or digested.

There are some 1,400 known species of microorganisms that are potentially pathogenic to humans. Of these, humans share approximately 800 with other animal species. In the last 30 years alone, some 50 new parasites of humans, including viruses, bacteria, prions, and others have been identified and combated. Most infectious human diseases are shared with other animals, and genetic studies have shown that few human parasites have their diversity associated with human evolution. This means that most of the diversity in these microorganisms was acquired before adapting to the human species, and that such diversity is shared with different animal host species. Some of the resulting interactions, such as shared feeding, manipulation, use of common spaces, physical contacts, and other forms of contagion certainly allowed the occurrence of co-evolutionary processes and provided (and continue to provide) for the emergence of new health-disease conditions.

We know, for example, that a high proportion of parasites in domestic animals do not affect our species, protected by the species barrier, which certainly means that over the course of all this evolutionary contact, part of this exposure was neutralized by natural inter-specific barriers (Woolhouse \& Antia, 2008).

Situations of false parasitism, or the presence of parasite forms (including their reproduction) inside organisms that would not normally be their hosts, have been described as the result of exotic food practices and have posed health problems, including in recent prehistoric peoples, as demonstrated by Araújo et al. (2003), Sianto et al. (2005), and others. Therefore, the increase in animal protein in the hominid diet would have been both an adaptive advantage and a new type of risk. The evolutionary success of genus Homo certainly showed that the overall gains outweighed the losses. Humans evolved as omnivores, with the consumption of other animal species as an important dietary source.

Many current studies on human health can be elucidated from an evolutionary perspective. Infections, different forms of symbiosis and commensalism, parasitic diseases, endemic or epidemic infections, and other disease processes that have been studied (e.g., AIDS, Ebola, and SARS, among others) reflect recent situations in which animal infections have become epidemic in humans (Woolhouse \& Antia, 2008), reminding us that this is an on-going process.

Although hominid data are limited by the lack of complete findings, some paleopathological models based on the study of peoples whose life could be compared to Paleolithic peoples, as well as models obtained from the study of natural primate populations, confirm that mechanical injuries threatened their health more seriously than infections (Lovell, 1990; DeGusta \& Milton, 1998). 
Development of the frontal and temporal brain is characteristic of human evolution. The brain of an Australopithecus was similar in size and shape to that of a modern chimpanzee (Holloway, 1979) and capable of performing a series of sophisticated functions, just as the brain of the gorilla or orangutan. The more sophisticated functions include recognizing the individual's own image, awareness of individuality, distinguishing oneself from the group, formulating thoughts, articulating ideas, developing empathy, performing inter-subjective communication with sound or mime (gestural or facial), planning actions, problem-solving, and learning and teaching in general (Fouts, 1997). The organization of social and family units and the adoption of behaviors including political strategies and skills and other characteristics also result from this development. Serving as a model for understanding hominization processes, primates offer good examples of how social behavior, group and family culture, feelings, political alliances, and social support among individuals affect the possibilities for survival (Goodall, 1990).

Thus, hominid expansion, in which the greatest challenge was survival in new and changing environments, was directly related to the complexification of behavior. According to Foley (1995), two important characteristics established during our species' dispersal were the maintenance of male kinship ties and greater investment in the offspring. The literature refers to this behavior as the "costly offspring" strategy. Strong political ties between males, social organization in bands, reinforcement of kinship ties, the existence of stable families, and special care to ensure the survival of small, frail, and physically dependent offspring bore a direct relationship to progressive encephalization.

As evolution favored larger brains, skull size also increased. Meanwhile, standing upright led to the evolution of a horizontal and straight pelvis, making the birth canal a veritable evolutionary tunnel. In humans, labor is more difficult, more prolonged, and riskier than in other primate species, because the child passes through a bony ring narrowed by evolution. The inherent contradiction in the evolutionary tendency towards larger head size and a smaller pelvic ring is believed to have led to the birth of increasingly premature (and immature) infants from the neuromotor point of view (Campbell, 1974).

Dependent on adults to move, feed, and keep warm, human offspring required increased attention and protection, as well as more time to learn. In the evolutionary sense, this would have favored families that were better structured and more stable with their offspring, while conferring greater adaptive flexibility to members of the species, increasingly dependent on learned rather than inborn behaviors.

Thus, armed with a set of biological, sociocultural, and cognitive attributes, archaic humans occupied all the lands on Earth except for the subarctic areas, Oceania (including Australia), and America. Each new environment brought contact with new vectors and pathogens, predators, toxins, and foods that helped maintain polymorphisms and modulate the potential for phenotypic adaptability.

However, not everything in the course of human evolution accumulated in the form of genes. An important part of our adaptive process comes from memories and cultural experiences. The control of fire and its use for cooking, for example, were among the oldest and most useful techniques developed by humankind. Fire was used not only to keep warm and ward off predators, but also to allow the preservation and increase the use of foods. Even tougher vegetables like tubers can be digested and absorbed better after softening by fire.

Cooking must have contributed progressively to the reduction of food contamination, impacting the ingestion of viable eggs, larvae, and microorganisms. Although only confirmed archaeologically for more recent periods (200,000 years in Europe), evidence suggests that the use of fire is much older, having accompanied the Asian expansion of $H$. erectus.

Some authors have raised the hypothesis of cannibalism among archaic hominids, defending this evidence for sites up to 780,000 years old. Examples include H. ancestor of Atapuerca, Spain (Cervera et al., 2001); H. neanderthalensis 
of Krapina and Vindija, Croatia, and Moula-Guercy, France (White, 1992). Different studies suggest that consumption of bodies from the same species also occurs in other primates (Goodall, 1990), and among human groups it became a routine procedure in various cultures. Archaeological and ethnographic references for $H$. sapiens describe forms of ritual cannibalism (funerary or not) all over the world (Arens, 1940; White, 1992; Torres, 2006). Such practices are characteristic of the South American lowlands (Métraux, 1947), including in Brazil (Vilaça, 1992). Cannibalism may have accompanied human evolution on a scale as yet unknown, and its consequences for health would bear a relationship to some diseases caused by retroviruses, which have only recently begun to be studied in the human species (Lindenbaum, 1979).

Some 700,000 years ago, the first changes in the skeletal pattern of archaic hominids began to appear in Africa (Rightnure, 2009). About 300,000 years ago, the brain volume of archaic humans was already more than a thousand cubic centimeters. The development of variant forms of archaic humans in different parts of the world points to a slow process of evolution to modern man, apparently from $H$. rhodesiensis and H. heildebergensis (Balter, 2009).

Some 250,000 years ago, the most well-known species of archaic humans emerged: Neanderthal. He colonized Europe, North Africa, and the Middle East and was the most specialized of the hominids, physically adapted to living in the glacial old World environment. This species received the scientific name of Homo neanderthalensis, with an average brain size of some $1,520 \mathrm{~cm}^{3}$, reaching $1,750 \mathrm{~cm}^{3}$. This was the largest absolute and relative brain size ever reached by genus Homo. As could be expected, reaching the extreme in the human evolutionary tendency of encephalization, this species also became noteworthy for its cultural advances in the so-called Mousterian culture (Krause, 2004), only surpassed eventually by modern humans.

In addition to unique chipped stone technology, the Neanderthals developed polished bone, horn, and wooden artifacts, as well as adapted rock shelters. The fact that some burials were performed, even including ritual depositing of flowers, suggests that Neanderthals experienced thoughts and feelings related to magical and spiritual conceptions. The skull base conformation, hyoid bone, and development of Broca's area in the brain attest to the anatomical potential for a spoken language similar to ours.

The survival of seriously injured and mutilated individuals, as demonstrated by bioarchaeological studies, indicates a well-developed social structure, even capable of supplying for the less fit (Krause, 2004).

All evidence suggests that the Neanderthals had a huge energy demand, which would have been supplied by a diet based heavily on hunting the Pleistocene fauna. An approximation to this pattern can be obtained by observing the human groups now inhabiting the Arctic (Moran, 1982). This adaptation is a highly interesting evolutionary fact and also suggests a peculiar pathocenosis, about which we know very little, mainly due to the small number of wellpreserved skeletons.

A more recent hypothesis suggests the species' great brain development also led to the need for a diet that provided a large energy supply, easily obtained by hunting the megafauna, but which must have become more difficult as climate changes from the thaw made their main food sources disappear.

According to some, the Neanderthals' large brains and their bodies adapted to the cold required a much higher calorie supply as compared to modern humans, and this may have contributed to their extinction when the climate changed and the megafauna, their staple diet, died out, forcing them to turn to alternative diets with fewer calories (Leonard, 2008).

of the known problems that affected fitness and health during this period, the most prevalent were certainly injuries resulting from the inherent risks in daily activities, especially hunting the megafauna. Other specimens such 
as those from Shanidar also show signs of violent injuries that may have resulted from intra-species interaction or social tension with other members of genus Homo. In some regions such as the Near East there are archaeological sites suggestive of contact between modern and archaic humans (Bosinski, 2004).

The last Neanderthals were found in the extreme south of the Iberian Peninsula, in the Gibraltar area, just less than 30,000 years ago. They lived in milder climates, but in marginal conditions, and their diet included marine life (Krause, 2004). As different species, they would have competed; the extinction of Neanderthal, more specialized biologically and technologically, may also have been accelerated by inter-species tensions with modern humans.

An on-going question concerns the possibility (and extent) of interbreeding between Neanderthal and $H$. sapiens during the more recent period. According to a study by Pennisi (2009), no evidence had been obtained that current human DNA contains contributions from Neanderthal DNA. However, a first draft of the Neanderthal genome published in May 2010 (Green et al., 2010) indicates that interbreeding may indeed have occurred. According to co-author David Reich, "The proportion of Neanderthal-inherited genetic material is about 1 to 4 percent. It is a small but very real proportion of ancestry in non-Africans today." New developments in this area clearly demonstrate the challenges and potential of paleogenetics.

The rapid transition from a dry, cold glacial climate to a hotter and more humid environment would have been accompanied by an increase in biodiversity, particularly insects and numerous forms of potentially pathogenic invertebrates and microorganisms. This change alone exposed the Neanderthals to a third important pathological factor in the new environments they inhabited. But it is also possible that even discontinuous contact between modern and archaic humans led to a new epidemiological situation. By living for the first time in the same region, H. sapiens and $H$. neanderthalensis would have faced different pathocenoses. Bearers of different evolutionary histories and different genetic stocks, and hosting different macro and microorganisms, their bodies underwent separate adaptations for hundreds of thousands of years.

H. sapiens had recently emerged from tropical Africa, where all its ancestry was located. The species was not as physically specialized and could thus carry more polymorphisms. It was also better adapted to dealing with the pathogenic biodiversity of tropical and temperate environments as compared to humans of the glaciations, adapted to sterile frozen environments. This contact would certainly have posed a health risk, due to the approximation of different genotypic potentialities, immunological experiences, and parasite stocks. Entering with tropical parasites into an environment sterilized by glacial decades, modern humans probably helped spread new vectors, parasites, and pathogens across Europe. Climate warming and new conditions of humidity would have favored the invasion of new species, exposing both the fauna and the Neanderthals to new health risks.

\section{THE SECOND GREAT DISPERSAL: MODERN HUMANS AND THEIR RISKS}

Some 150,000 years ago, a new African Diaspora began: that of anatomically modern hominids. This dispersal of modern humans was more rapid than that of their archaic forerunners. Although we lack demographic data for archaic humans, the geographic amplitude and amount of existing archaeological sites from just a few tens of thousands of years confirms that modern population expansion was demographically overwhelming, changing the species' demographic scenario.

Principally beginning 30,000 years ago, when great land expanses in Europe and Asia were already free of ice, the multiplication of Cro-Magnon sites shows a sophisticated culture, including expressions of rock art like the Levantine. Cro-Magnon painted caves are located in well-known sites such as Altamira, in Spain, and Lascaux, in France. 
From Europe and Asia, modern humans reached the other continents, although more recently. Thus, only $H$. sapiens dispersed worldwide as a pandemic Homo species. Based on current archaeological evidence, the crossing of the major geographic barriers like the oceans only occurred in the last 60,000 years. Before the end of the last great Ice Age and the European domain of the Cro-Magnons, other modern humans, armed with technological resources that already included navigation, reached places like Australia, and shortly afterwards America. Commanding increasingly sophisticated technologies, humans became capable of exploring and manipulating plants and animals, storing goods, building shelters adapted to different climates, and manufacturing tools and instruments that greatly expanded their adaptive capacity. With an increasingly complex social organization and elaborate language, they dominated diverse environments, foraging, hunting, and fishing. They explored diverse economic possibilities and occupied various lands, limited only by their own capacity to obtain natural foods (Bocquet-Appel \& Najji, 2006).

Modern humans diversified even more than their archaic ancestors, since they dispersed and settled ecologically diverse regions. Their polymorphous nature provided the flexibility they needed to adapt. As they adapted, becoming extremely polytypical, they established phenotypes with favorable characteristics for diverse living conditions. These characteristics include some conditions corresponding to phenotypic expressions now classified as "diseases". Even so, some of these phenotypic expressions would not have emerged if the cultural and environmental changes of recent decades had not turned successful millenary adjustment mechanisms into difficulties in adapting to our current diets and lifestyles.

Biochemical, physiological, or morphological variations that favored human evolution became pathological or less adaptively favorable conditions as new environments and ways of life were adopted (Dobzanski, 1966; Comas 1967; Moalen \& Prince, 2007; Stearns \& Koella, 2008; Trevathan, Smith \& McKeena, 2008).

Some geographic areas became important foci of genetic diversity or dispersal of characteristics that emerged from mutations, concentrated through founding effects or genetic drift, or through pressure from natural selection. Important haplotypic variants of the human species represent evolutionary or microevolutionary health-related conditions, such as thalassemia, sickle cell anemia, cystic fibrosis, lactase deficiency, and others. The geography of current health thus also contains part of the human species' evolutionary history.

Some of the more recent changes in health conditions probably date to the period in which humans managed to cross the last great geographic barriers. When H. sapiens reached Australia, some Pacific islands, and America in the last tens of thousands of years, or more recently, the hundreds of South Pacific islands, including Easter Island, modern humans again had to deal with new ecosystems and environments, in some cases very different from those previously known. Many of these lands, new and subject to intense volcanic and tectonic activity, would have kept the human evolutionary scenario in constant change.

The peopling of Australia appears to have occurred between 120,000 and 60,000 years ago, by sea (Nile \& Clerk, 1996). Moving from Sundaland, an area that encompassed Borneo, Indonesia, Philippines, and other lands in Southeast Asia, human groups reached the Timor region, from where they could have crossed stretches of shallow sea a few dozen kilometers long until they reached Kimberley, in what is now Australia. This continent, in turn, was connected to New Guinea, forming what is called Sahul. Another possible path for the first settlers would have been directly from Sundaland to New Guinea and from there to Australia. The existence of archaeological sites dated to some 60,000 years ago in Australia and of sites only half that old in New Guinea suggests that the first hypothesis is probably correct. 
This crossing would have been possible because during the last great glacial period the sea was about 60 meters below the current level, thus posing a less formidable barrier. Even though a direct view of the lands on the horizon was not possible, coastal and seafaring peoples would have observed signs of other such lands, as they do today.

Findings of very ancient boats and human dispersal to so many islands in Asia and Oceania (Ashby, 2004) prove the existence of knowledge of the technology needed for maritime crossings. There is consensus that different groups made the crossings at different times before the Holocene. According to Nile and Clerk (1996), the cultural, linguistic, and biological diversity in Australia supports this hypothesis.

Most authors contend that Oceania and America were only peopled by H. sapiens (Lahr \& Foley, 1987). However, physical characteristics of the Australian aborigines have led some to defend other possibilities and suggest interbreeding with archaic humans (Hawks et al., 2000).

With the end of the Pleistocene, the oceans reached their highest level again. Great expanses of sea separated the lands comprising Sahul and Sundaland, isolating the peoples that had settled in New Guinea, New Zealand, and Australia.

The peoples living in Australia, despite their simple economic system and restricted nomadism, survived and developed sophisticated belief and art systems, in addition to intense exchange. Although there are more than 500 different tribal groups and more than 200 linguistic variations on the Australian continent, records show great integration among the Aboriginal peoples, for whom a complex system of exchange and contact appears to have prevailed in recent times. As a function of their unique history in the last 10,000 years, the Aborigines are considered the set of peoples in the entire world that developed with the least outside influence, making them the oldest continuous culture with know. This condition remained uninterrupted until the $18^{\text {th }}$ century, with European colonization (Nile \& Clerk, 1996).

The peopling of America is believed to have occurred through different migratory waves over the course of the last 20,000 years (Lima, 2006). In addition to great differences in the fauna and flora, with an impact on the economy, the rapid transition of environments in America led to exposure to new pathogens. Although controversial, the rapid occupation of the territory, confirmed by the existence of very ancient dates in South America, suggests that the coastline was a preferential entry route. Recent studies, especially discoveries in Monte Verde, Chile (Dillehay, 1992; Dillehay et al., 2009), prove that the coastal adaptations are much older than previously assumed. Exposed to different risks, in inland or coastal areas, these populations developed diverse adaptive responses, undergoing a new cycle of parasite-host-environment interactions.

There are few archaeological data that allow linking Asia to America, and thus little is known about the human waves that migrated from one continent to the other. We do not know exactly how many migratory waves occurred or which ethnic groups or cultures were involved. Much of what has been proposed in recent decades was based on linguistic, anthropological, and genetic studies, leading to the model of the three migratory waves.

The Eskimo-Aleuts certainly entered in the last six millennia. This interpretation is supported not only by archaeological and linguistic data, but also by more recent genetic data. However, the first settlers and the date of entry into America are still controversial. Archaeological, bioanthropological, and genetic studies all point to Asia as the origin of the peoples that reached the Americas. The date of occupation of Central Asia by modern humans was around 40,000 years ago, although there is little archaeological proof of this chronology. The mitochondrial and $\mathrm{Y}$ chromosome genetic variations found between American and Asian groups point to a genetic separation, that is, a first entry into Beringia, about 20,000 years ago. Meanwhile, dispersal southward of the continental glaciers only occurred between 16,000 and 11,000 years ago (Goebel, Waters \& O'Rourkes, 2009). 
Morphological variations in the human skulls in the oldest sites, such as Spirit Cave, Keneewick, and Lagoa Santa, Brazil, have led to the proposal of a differentiated and much older migration, later replaced by more recent groups, referred to as "mongoloid" (Neves et al., 2004, Lahr \& Souza, 2006). However, genetic studies show a reduced haplotypic variation, suggesting that the origin of all modern and ancient Native Americans involves a single founding population. The ancient dates for South America, the existence of two cranial morphologies, and the DNA data, suggesting a precise biological clock, lead to the interpretation that despite the differences, Paleoindians and more recent prehistoric groups, although having entered America at different moments, had their origin in the same founding population (Goebel, Waters, \& O'Rourkes, 2009).

The emergence of mongoloid cranial morphology in Asia is proposed as a recent fact (Lahr, 1995). A group that was still not mongoloid may have entered America first. The division of Asian groups into two main dental types, sinodonts and sundadonts, appears consistent with this hypothesis and with findings in America. Paleoindians have sundadont dental characteristics (Powell \& Neves, 1998), and studies based on chromosome Y show two distinct patterns for America, one of them much older, reinforcing the idea of two primordial entries (Stix, 2008).

In America, as on the other continents, technological progress was a synonym for territorial expansion and increased mobility/circulation. As populations expanded, exposure to new conditions of natural or cultural risk created new pathocenoses (Grmek, 1983), related to different lifestyles and the colonized environments. Genetic variability, enhanced by the species' polymorphisms, helped make health conditions increasingly diversified, including as a response to the need to adapt. In recent millennia, disease as an adaptive response appears to have assumed a wide variety of expressions (Stearns \& Koella, 2008).

Despite some moments of species exchange between Asia and America, the New and old Worlds remained separate for millennia. When populations reached America, they would have found new foods, plants with peculiar pharmacological properties, and specific zoonoses (Reinhard, Fink \& Skiles, 2003; Gonçalves, Araújo \& Ferreira, 2003). Some characteristics observed among Native American peoples relate to a common ancestry. An example is lactase deficiency (Wiley, 2008), brought from Asia and maintained by the absence of domestication and use of milk and dairy products among the American peoples. Others, like the absence of forms of adaptive anemia, are probably due to the lack of adaptive pressure that was exerted for thousands of years by the more severe forms of malaria in Europe, Asia, and Africa.

Many of the differences, including those related to health, have only been elucidated recently. Paleopathology has studied diseases that originated in America, diseases brought from other continents, recent and ancient diseases, and parasitic infections resulting from eating habits developed in America. Recent studies have also focused on the genetic variety of current and ancient Amerindian populations and the evolutionary and health-related consequences. The prevalence and even the occurrence of some diseases were modified by migration itself.

Most authors agree that the crossing to the New World occurred from northernmost Siberia (Lima, 2006) by land, along the Bering Bridge, or navigating across the Kurila and Aleutian archipelagos. There is consensus that for successive generations the groups that crossed to America would have been forced to inhabit the cold regions of Siberia, the latitudes of the Arctic Polar Circle. This long process would have acted as a filter, partially modifying the repertoire of pathogens. However, this process would have been modulated by the capacity of humans to create their own microenvironments, like houses and shelters, ensuring the persistence of some parasites or the transmission of some pathogenic conditions which would have been unable to persist in the natural environment.

Thus, the environmental filter always added to culture, so that some diseases occurred more in some human groups than in others. Some infectious diseases, for example, would only have important population consequences 
if the human groupings reached a given size and density. Others depended on specific subsistence strategies, and while still others were favored by cultural habits. Examples of biocultural interactions that explain the prevalence of diseases in human groups are unlimited.

Meanwhile, health-related human evolution cannot be separated from the evolution of disease-causing parasites and organisms. The evolutionary study of microorganisms points to the emergence, over time, of numerous evolutionary strategies by which parasites ensured their multiplication and success (Stearns \& Koella, 2008). Causing acute or chronic problems, leading to death or not, these organisms optimized their own dispersal and perpetuation. From this perspective, infections that produce a permanent immune response, but which lead to rapid death in susceptible individuals, such as those involving certain types of virus, appear to be incompatible with the maintenance of infection in small populations, for example. In large groups occupying extensive territories, there would always be individuals somewhere without previous contact with the disease, forming a sufficient reserve of susceptible individuals to maintain the disease in circulation.

This model helps explain why in America and other areas there was no experience with such viral diseases as smallpox and measles. After such infections were naturally eliminated by the death of susceptible individuals or the immunity of survivors, geographic isolation from the old World would have maintained the American groups away from new cycles of contagion.

Although some urban areas were already developed in America when the Europeans arrived, they were free from the viral diseases affecting Europe and Africa and were thus susceptible to contagion.

When paleopathologists began their studies on this topic in the 1960s, they believed that this model would serve for other infections, such as tuberculosis. Currently, however, it has already been confirmed that TB can maintain itself even in small populations, which helps explain its antiquity in prehistoric America (Roberts \& Buikstra, 2003).

When dispersing across the planet, the human species carried some diseases and eliminated others, but also entered into contact with new parasites. In America, for example, Chagas disease (Reinhard, Fink \& Skiles, 2003; Souza et al., 2009) was a zoonotic disease on the continent that became an endemic human disease.

However, the expansion of knowledge in paleopathology does not always prove the proposed epidemiological models. The presence of tuberculosis in America nearly 3,000 years ago greatly predates colonial contacts (Prat \& Souza, 2003; Wilbur \& Buikstra, 2006). For more than three decades, this confirmation by Marvin Allison of the Medical College of Virginia in 1973 has forced researchers to rethink epidemiological models.

\section{THE LAST MILLENNIA: CULTURE, COSTS, AND BENEFITS}

Humans lived in small groups in the most basic form of social organization throughout a million years in their evolution. Based on contemporary primitive groups, $20^{\text {th }}$-century anthropology referred to this structure as "bands" (Service, 1966; Sahlins, 1968), considering this model of organization as a good approximation of how our ancestors lived. Bands are groups formed by individuals that maintain close kinship ties, living in extended families. They usually have 25 to 125 members, sometimes reaching 300. This limit appears to be explained by the possibilities of their leadership system, distribution of authority, and limitation of their linguistic structure, generally very simple and reduced to vocabularies of up to 600 words. Bands were the structure by which humankind developed and dispersed throughout the planet for hundreds of thousands of years. 
Between 10,000 and 5,000 years ago, on different continents, changes in the environment announced the definitive transition from the geological period known as the Pleistocene, or that of the great glaciations, to the Holocene, or the current warmer period. On all the continents, changes occurred in response to the need for a new balance between population density and environmental sustainability. Domestication, or the cultural control of plants and animals, profoundly changed human evolutionary history. Allowing the privileged production of foods that ensured higher calorie content in the diet and controlled storage of surpluses, domestication freed human groups from spontaneous supply. It also led to a rapid reduction in the mobility of human groups, shrinking their territories, crowding, new social and political orders, and many other changes in an extremely short time.

Domestication, combined with food preservation techniques, allowed the development of increasingly larger groupings and higher population concentrations. Domestication was also used for the production of other material goods besides food and generated surpluses that could be used for barter and trade, spreading rapidly in areas like the Middle East, leading to more sedentary living, which unprecedented health impacts.

Escaping the dictates of environment constraints, modern human groups began a transition that would affect their health conditions more seriously than ever, forcing them into new adaptive cycles. This process, known as the Neolithic Transition, based on the European periodic division of prehistory, occurred very quickly, and the health changes in human groups occurred on most of the continents (Cohen \& Armelagos, 1984; Dittmar \& Teegen, 2003; Geigl \& Pruvost, 2004). With the diversity of economic strategies developed in the last millennia and the everincreasing variety of environments occupied by humans, in addition to the human sociocultural divergence that developed in this final phase of our prehistory, health conditions and their relations with subsistence strategies and lifestyles multiplied.

Paleopathology provides an approximate idea of the diversity of health conditions over prehistoric time and space, as well as the repercussions on the current distribution of human health conditions.

Thus, the transition to agriculture was also the first great epidemiological transition experienced by the species. Humans' progressive dependence on diets based on cultivated carbohydrates as the principal source of calories brought the settlement of family groups to the places where the food was produced, in permanent dwellings. Larger groups became possible and even desirable, allowed by agricultural activities and new forms of social organization. Birth and death rates and longevity changed, rapidly transforming the population growth rate (Hassan, 1981).

In areas where it was possible to compare paleodemographic studies, the population growth rate increased rapidly with the advent of agriculture. Increased food production allowed more growth; meanwhile, in order to grow more food, humans needed more growth. Throughout the Northern Hemisphere, paleodemographic studies of these transition periods point to a rapid increase in population growth rates (Bocquet-Appel \& Najji, 2006).

Sedentary and numerically larger groups suffered huge health impacts, mainly from infectious diseases and nutritional disorders (Cohen \& Armelagos, 1984). Greater social complexity brought economic systems and political organizations that allowed adding ever-increasing numbers of individuals. Other levels of organization, such as tribes, chieftainships, and states, have been proposed to explain this growth (Sahlins, 1968). Groups formed by large states expanded across territories in cycles of political dominance over less powerful or smaller groups. Values, ideological systems, economic strategies, cultures, and languages were thus transferred, transformed, or reproduced. In each region on Earth, the history of expansion of states, empires, and kingdoms armed with greater persuasive, economic, bellicose, and other forms of power led land ownership to alternate, individuals and groups to shift, large population contingents to migrate, and new economic strategies to be implemented in large areas. 
Subsequent moments witnessed intensive economic exploitation and the construction of human works with great impact on the natural scenario. Manipulation of the landscape for economic purposes or as a sign of power led to new living conditions and also impacted on health. By damning up waters, irrigating land for planting, shifting the course of rivers, and interconnecting previously separated environments still in the prehistoric period, humans modified the distribution of (or contact with) vectors, pathogenic agents, and natural risks.

Another example of the impact of Neolithic cultural changes is the capacity to digest milk. Until the Paleolithic, humans, like other mammals, only used milk from their own species and during early childhood. Domestication in some regions of the world led to the use of milk from goats, sheep, cows, and other animals, consumed in natura or in the form of yogurt, cheese, curds, and other dairy products. Cultural processing of milk makes it easier to digest, attenuating problems resulting from the lack of lactase, which allowed consolidating this cultural habit, even among groups that were genetically less fit for it. Milk is a very rich and complete foodstuff and became a staple in some areas, such as Northern Europe. As a result, the capacity to digest milk through lactase production came to be selected positively.

The mutation that produces lactase is very recent and dominant. Its frequency varies in different human populations and is consistent with the history of herding. The highest percentages of lactase-positive individuals are in Northern Europe (95\%), African herders (80 to 85\%), and herders from Central Asia and Arabia (70\%). The lowest percentages are among peoples of Sub-Saharan Africa (10\%), East and Southeast Asia (0 to 5\%), the Pacific Islands (15 to 20\%), and America (0 to 38\%). Since Western habits have spread worldwide, and with the growing encouragement for the consumption of milk and dairy products, we have the paradox of a "healthy diet", recommended on the basis of a product to which most of humankind was not adapted by evolution (Wiley, 2008).

By creating the means for increasingly rapid migration and intensifying mobility, for economic exploitation of natural resources or for trade and contact, human groups increased the spread of transmissible diseases. Exchanging goods, products, practices, beliefs, and habits, the shifting of persons to regions for which they were not adapted, or where they did not know how to protect themselves from natural risks, fostered new endemic and epidemic cycles. The concentration of human groups in areas for producing with successful agricultural techniques drew people much closer together, facilitating routine contact, especially through barter and trade that developed with the production of surpluses and with productive specialization. Settlement of productive lands and the growing complexity of societies led to more overwhelming forms of violence, through ritual or war.

For the first time in human history, cultural changes impacted health on the population scale. In prehistoric cities such as Catayulk or Cahokia in North America, the benefits, changes, and advantages (but also the problems) reached the thousands. Deaths were routine, mainly affecting young men, among the Moches in Peru, the Mayas in Central America, the Romans in Europe, and the Egyptians in Africa. Some health changes directly related to lifestyle and the resulting risks became permanent and endemic. War, famine, and disease produced apocalyptic historical cycles and left records in history.

Written records exist, but some still lack a clear explanation, for example, for the plague in Athens, the plagues of Egypt, or the colerica passio of Garcia da Orta (Carvalho, 1992). The changes resulting from these processes profoundly affected human health on unprecedented scales, contributing to the distribution of the health conditions known until recent historical times.

In the Late Middle Age, a grand cycle of technological development accelerated health changes with a global impact. As a result of accumulated experiences and advancements, a cycle of great navigations began, placing the 
different continents in definitive contact in a very short time. Although occasional contacts through early navigation and other movements had already opened the passage between continents, long-distance contacts were sporadic and limited population flow was possible. Successful navigation, with rapid ocean crossings and reaching distant lands, led to the first regular contact between places and peoples separated by millennia, thus redistributing diseases, political projects, and cultural influences. The American continent opened up to contact with other peoples (from Europe and later Africa and Asia) beginning in the $15^{\text {th }}$ century, producing intense biological and cultural exchange, hugely significant for health on both sides of the Atlantic (Verano \& Ubekaler, 1992).

An exception on the American continent was the crossing of the North Atlantic by the Vikings in the $11^{\text {th }}$ century. Excellent sailors and navigators, the Vikings, led by the successful epic seafaring journeys of Erik, the Red, already maintained colonies on Iceland and Greenland before they ventured further to North America, led by Erik's son, Leif Erikson. They managed to reach Cumberland Pen. They proceeded from there, exploring the coast until Hudson Bay and Chesapeake Bay. They established their westernmost colony in North America, taking domesticated animals with them and maintaining contact with the indigenous peoples for decades.

However, difficulties in the ocean crossings, the distance from Europe, frequent hostilities with the indigenous groups, and other factors prevented the project from continuing, and the colony was eventually abandoned after several decades (Pohl, 1966).

Contact across the Atlantic, but especially the regular journeys and the colonial project, implemented in fact beginning in the $17^{\text {th }}$ century, accelerated this process of changes. Added to this process the last great African Diaspora, that of slavery. The forced transfer of millions of human beings of different ethnic groups from Africa to America, as slave labor, together with the heavy mortality of indigenous groups in colonized areas, constitutes one of the most drastic demographic processes in history. This process, reaching its peak between the $17^{\text {th }}$ and $19^{\text {th }}$ centuries, was accompanied by a major modification of the worldwide health scenario, extended by the impacts of emerging technology and science.

The Industrial Revolution in the late $18^{\text {th }}$ and early $19^{\text {th }}$ centuries was accompanied by a new epidemiological transition. Life became urbanized at a fast pace, and people became subject to conditions of intense work, confined and far from food production and the autonomy of small rural places. Population density increased with the large agglomerations of individuals in diverse environments, in both factories and urban dwellings. There were even faster lifestyle changes in the following decades. Despite progress in medical and sanitary knowledge, with both preventive and curative effects, changes that harmed human health appear to have moved more easily than those improving quality of life. Antibiotics and basic hygiene had an important impact on mortality; however, persistent inequalities in food, housing, and access to goods made various clinical and pathological conditions endemic. And there was no more biological time for adaptation: the changes took place in just a few years.

Traditional peoples changed in just a few years to economies and lifestyles that included numerous industrialized diet items and tools. Bodies that had adapted for thousands of years to a certain energy and metabolic balance now became ill, due to the difficulty in adjusting to such changes. Throughout human evolution, for millions of years, slow adjustments have helped maintain the balance between health and living conditions. Movements and changes in lifestyle have accelerated in recent decades, making adaptability (and especially adaptation) a permanent challenge.

One of the most interesting questions in the peopling of America is the so-called New World Syndrome, with a high prevalence of three chronic conditions among Native Americans that have become veritable endemics: diabetes, obesity, and gallstones. Contact by Native American groups with the Western lifestyle and diet in the last century and the profound impact they have suffered since contact have led to extremely high rates of overweight and diabetes. 
A new energy balance has resulted from the reduction in the effort expended to obtain foods (which are now also more energy-dense), with severe metabolic and cumulative effects. A widely accepted explanation is the "thrifty genotype" hypothesis, according to which the millennia-old selection that allowed successful survival under a regimen of irregular food supply in the Paleolithic (the "feast and famine" phenomenon) led to a metabolic mechanism which now (given our modern abundance of food) causes health problems such as high cholesterol and diabetes. Throughout human evolution, there was an adaptive advantage to rapid insulin release, favoring energy storage during periods of abundance. In a situation of excessive calorie supply, this mechanism causes obesity and diabetes.

According to Lieberman (2008), evolution conditioned a situation of frequent food deprivation, the consequences of which included triggering the impulse to eat whenever food was available. In cultures in which the food supply increased, this also led to consumption far above necessary levels and difficulty in controlling or reducing food intake, even through voluntary restrictions such as diets, thus further aggravating individual nutritional status.

Many themes have been discussed in this line of evolutionary medicine. For example, an evolutionary perspective helps explains our eating preferences. The human species prefers sweet flavors and fatty foods. This apparently bears a coherent relationship to the search for high-energy foods, a determinant factor for our survival. In a species with such a crucial organ as the human brain, this would certainly be an adaptive advantage (Turner et al., 2008).

Our sleep patterns are another issue under discussion. Worthman (2008), comparing sleep in different animal species and in different traditional human cultures, discusses such aspects as sleep duration and continuity, the setting in which one sleeps, darkness, silence, and the role of television as a replacement for the bonfires or noise that have rocked humans to sleep throughout evolution.

Evolutionary medicine has investigated other issues. Paleopathological studies complement such research in many cases. Such discussion includes problems never previously considered from an evolutionary perspective, such as eclampsia, an exclusively human disease, drug addiction, and altitude sickness (Trevathan, Smith \& McKeena, 2008). Looking to the past through archaeological testimony, genetic processes, and other types of data increasingly help explain our current health condition and develop future strategies to deal with what we refer to as diseases.

\section{REFERENCES}

ARAÚJO, A. et al. Parasitism, the diversity of life, and paleoparasitology. Memórias do Instituto Oswaldo Cruz, 98, supl.: 5-11, 2003.

ARENS, W. The Man-Eating Myth. Oxford: Oxford University Press, 1940.

ASHBY, S.P. Understanding human movement and interaction through the movement of animals and animal products. In: MONDINI, M.; MUNOZ, S. \& WICKLER, S. (Eds.). Colonization, Migration and Marginal Areas: a zooarchaeological approach. Oxford: Oxbow Books, 2004.

AUFDERHEIDE, A. C. \& RODRIGUEZ-MARTIN, C. The Cambridge Encyclopaedia of Human Paleopathology. Cambridge: Cambridge University Press, 1998.

BARNES, E. Diseases and Human Evolution. Albuquerque: University of New Mexico Press, 2005.

BALTER, M. New work may complicate history of Neanderthal and H. sapiens. Science, 326(5.950): 224, 2009.

BONNER, J. T. The Evolution of Culture in Animals. Princeton Science Library, 1983.

BOCQUET-APPEL, J-P \& NAJJI, S. Testing the hypothesis of a worldwide Neolithic demographic transition. Corroboration for American cemeteries. Current Anthropology, 47(2): 341-365, 2006. 
BOSINSKI, H. Sépultures et cimitières. In: KRAUSE, E.-B. Les Hommes de Neanderthal. Le Feu sous la Glace: 250.000 ans d'histoire européenne. Paris: Éditions Errance, 2004.

BUIKSTRA, J. E. \& COOK, D. C. Paleopathology: an American account. Annual Review of Anthropology, 9: 433-476, 1980.

CAMPBELL, B. In Search of Man: some questions and answers in African archaeology and primatology. São Francisco: Leakey Foundation, 1974.

CARVAlho, D. M. Cólera e Garcia da Orta. In: ARAúJo, A. J. G. de \& FERREIRA, L. F. Paleopatologia \& Paleoepidemiologia: estudos multidisciplinares. Rio de Janeiro: ENSP, 1992. (Série Panorama)

CANGUILHEM, G. Le normal et le pathologique. Paris, Galien, 1966.

CAVALLI-SFORZA, L. Évolution Biologique, Évolution Culturelle. Paris: Odile Jacob, 2005.

CERVERA, J. et al. Atapuerca: un millón de años de historia. Madrid: Complutense, 2001.

COCKBURN, A. Infectious Diseases: their evolution and eradication. Springfield: Charles C. Thomas, 1967.

COHEN, M. \& ARMELAGos, G. Paleopathology at the Origins of Agriculture. New York: Academic Press, 1984.

COMAS, J. Unidad y Variedad de la Especie Humana. Ciudad de México: Universidad Autónoma de México, 1967.

DeGUSTA, D. \& MILTON, K. Skeletal pathologies in a population of Alouatta palliata: behavioral, ecological, and evolutionary implications. International Journal of Primatology, 19(3): 615-650, 1998.

DILLEHAY, T. Sobre el poblamiento inicial de Sudamérica. Chungará, Revista Chilena de Antropología, 11: 13-19, 1992.

DILLEHAY, T. et al. Monte Verde: seaweed, food, medicine and the peopling of South America. Science, 320: 784-785, 2009.

DiTTMAR, K. \& TEEGEN, W. R. The presence of Fasciola hepatica (liver fluke) in humans and cattle from a 4,500-year-old archaeological site in the Saale Unstrut Valley, Germany. Memórias do Instituto Oswaldo Cruz, 98, supl. I: 141-143, 2003.

DOBZANSKI, T. L'Homme en Évolution. Paris: Flammarion, 1966.

EBERT, D. \& BULL, J. J. The Evolution and Expression of Virulence. In: STEARNS, S. C. \& KOELLA, J. C. Evolution in Health and Disease. Oxford: Oxford University Press, 2008.

FOLEY, R. Another Unique Species: Patterns in Human Evolutionary Ecology. Longman Science and Technology, 1987.

FOLEY, R. Humans Before Humanity. Oxford: Blackwell Publishers, 1995.

FÓLLER, M. L. \& HANSSON, L. Human Ecology and Health: adaptation to a changing world. Gotebörg: Gotebörg University, 1996.

FOUTS, R. Next of Kin: My Conversations with Chimpanzees. William Morrow, 1997.

GEIGL, E. M. \& PRUVOST, M. Plea for a multidisciplinary approach to the study of Neolithic migrations: the analysis of biological witnesses and the input of palaeogenetics. In: MONDINI, M.; MUÑOZ, S. \& WICKLER, S. (Eds.). Colonization, Migration, and Marginal Areas: a zooarchaeological approach. Oxford: Oxbow Books, 2004.

GOEBEL, T.; WATERS, M. R. \& O'ROURKES, D. H. The late Pleistocene dispersal of modern humans in the Americas. Science, 319: 1497-1502, 2008.

GONÇALVES, M. L. C.; ARAÚJO, A. J. G. de \& FERREIRA, L. F. Human intestinal parasites in the past: new findings and a review. Memórias do Instituto Oswaldo Cruz, 98, supl. I:103-118, 2003.

GOODALL, J. Through a Window: 30 years observing the Gombe chimpanzees. London: Weidenfeld \& Nicholson, 1990.

GREEN, R.E. et al. A draft sequence of the Neanderthal genome. Science, 328 (5979): 710-722, 2010.

GRMEK, M. D. Les Maladies à l'Aube de la Civilisation Occidentale. Payot: Paris, 1983.

GUÉGAN, J. F.; PRUGNOLLE, F. \& THOMAS, F. Global spatial patterns of infectious diseases and human evolution. In: STEARNS, S. C. \& KOELLA, J. C. (Eds.). Evolution in Health and Disease. Oxford: Oxford University Press, 2008. 
HASSAN, F. Demographic Archaeology. New York: Academic Press, 1981.

HAWKS, J. et al. Population bottlenecks and Pleistocene human evolution. Molecular Biological Evolution, 17: 2-22, 2000.

HOLLOWAY, R. L. The casts of fossil hominid brains. In: ISAAC, G. \& LEAKEY, R. E. F. Human Ancestors. San Francisco: Freeman WH and Company, 1979.

INIGUEZ, A. M. et al. Enterobius vermicularis: ancient DNA from North and South American coprolites. Memórias do Instituto Oswaldo Cruz, 98, supl. I: 67-69, 2003.

KOElla, J. C. \& TURner, P. Evolution of parasites. In: STEARNS, S. C. \& KOELLA, J. C. (Eds.). Evolution in Health and Disease. Oxford: Oxford University Press, 2008.

KRAUSE, E. B. Les Hommes de Néanderthal. Le Feu sous la Glace: 250.000 ans d'histoire européenne. Paris: Éditions Errance, 2004.

LAHR, M. M. Patterns of modern human diversification. Implications for Amerindian origins. Yearbook of Physical Anthropology, 38: 163-198, 1995.

LAHR, M. M. \& FOLEY, R. A. Multiple dispersals and modern human origins. Evolutionary Anthropology, 3: 48-60. 1994.

LAHR, M. M. \& SOUZA, R. G. Populações no Tempo e no Espaço: a origem da diversidade humana nas Américas. In: RODRIGUEZCARVAlHO, C. \& SILVA, H. (Orgs.). Nossa Origem: o povoamento das Américas, visóes multidisciplinares. Rio de Janeiro: Vieira \& Lent, 2006.

LEONARD, W. R. Lifestyle, diet and disease comparative perspectives on the determinants of chronic health risks. In: STEARNS, S. C. \& KOELLA, J. C. Evolution in Health and Disease. Oxford: Oxford University Press, 2008.

LEONARD, W. R. \& ROBERTSON, M. L. Evolutionary perspectives on human nutrition: the influence of brain and body size on diet and metabolism. American Journal of Human Biology, 6: 77-88, 1994.

LIEBERMAN, L. S. Diabesity and Darwinian medicine: the evolution of an epidemic. In: TREVATHAN, W. R.; SMITH, E. O. \& McKEENA, J. J. (Eds.). Evolutionary Medicine and Health: new perspectives. Oxford: Oxford University Press, 2008.

LIMA, T. A. O povoamento inicial do continente americano: migrações, contextos, datações. In: RODRIGUEZ-CARVALHO, C. \& SILVA, H. (Orgs.). Nossa Origem: o povoamento das Américas, visões multidisciplinares. Rio de Janeiro: Vieira \& Lent, 2006.

LINDEnBAUM, S. Kuru Sorcery: diseases and danger in the New Guinea highlands. Palo Alto: Mayfield Publishing Company, 1979. LOVELL, N. C. Patterns of Injury and Illness in Great Apes: a skeletal analysis. Washington: Smithsonian Institution, 1990.

MARTIN, F. D. El Largo Viaje: arqueología de los orígenes humanos y las primeras migraciones. Barcelona: Ediciones Bellaterra, 2005. MÉTRAUX, A. Mourning rites and burial forms of the South American Indians. América Indígena, 7: 7-44, 1947.

MORAN, E. F. Human Adaptability: an introduction to ecological anthropology. Boulder, Colorado: Westview Press, 1982.

MOALEM, S. \& PRINCE, J. A Survival of the Sickest: The Surprising Connections between Disease and Longevity, William Morrow, 2007.

NAPIER, J. The evolution of the hand. In: ISAC, G. \& LEAKEY, R. E. F. (Eds.). Human Ancestors. San Francisco: Freeman WH \& Co., 1979.

NEVES, W. A. et al. Early Holocene human skeletal remains from Cerca Grande, Lagoa Santa, Central Brazil, and the origins of the first Americans. World Archaeology, 39: 479-501, 2004.

NILE, R. \& CLERK, C. Cultural Atlas of Australia, New Zealand and the South Pacific. Oxfordshire: Andromeda Oxford, 1996.

NOZAIS, J. P. The origin and dispersion of human parasitic diseases in the old world (Africa, Europe and Madagascar). Memórias do Instituto Oswaldo Cruz, 98, supl. I: 13-19, 2003.

PENNISI, E. Wanted: clean Neanderthal DNA. Science, 323(5.916): 868, 2009.

POHL, F. J. The Viking Explorers. Crowell, 1966. 
POWELL, J. \& NEVES, W. A. Dental diversity of early new world populations: taking a bite out of the tripartite model. American Journal of Physical Anthropology, suppl. 26: 179-180, 1998.

PRAT, J. G. \& SOUZA, S. M. F. M. Prehistoric tuberculosis in America: adding comments to a literature review. Memórias do Instituto Oswaldo Cruz, 98, suppl. I: 151-162, 2003.

REINHARD, K. J. \& URBAN, O. Diagnosing ancient diphyllobothriasis from Chinchorro mummies. Memórias do Instituto Oswaldo Cruz, 98, suppl. II: 191-194, 2003.

REINHARD, K. J.; FINK, M. \& SKILES, J. A case of megacolon in Rio Grande Valley as a possible case of Chagas disease. Memórias do Instituto Oswaldo Cruz, 98, supl. I: 165-172, 2003.

RIGHTNURE, G. P. Middle and late Oleistocene hominids in Africa and Southwest Asia. Proceedings of the National Academy of Sciences of the United States of America, 106(38), 2009.

ROBERTS, C. A. \& BUIKSTRA, J. E. The Bioarchaeology of Tuberculosis: a Global Perspective on a Re-emerging Disease. Gainesville: University Press of Florida, 2003.

SAHLINS, M. D. Tribesmen, Prentice-Hall Foundations of Modern Anthropology Series, 1968.

SERVICE, E. R. The Hunters, Prentice-Hall Foundations of Modern Anthropology Series, 1966.

SIANTO, L. et al. The finding of Echinostoma (Trematoda: Digenea) and hookworm eggs in coprolites collected from a Brazilian mummified body dated 600-1,200 years before present. The Journal of Parasitology, 91: 972-975, 2005.

SIMONS, E. L. The early relatives of man. In: ISAC, G. \& LEAKEY, R. E. F. Human Ancestors. San Francisco: Freeman WH \& Co., 1979. p. 22-42.

SOURNIA, J.-C. \& RUFFIÉ, J. Les Epidemies dans l'Histoire de l'Homme. Paris: Flammarion, 1984.

SOUZA, S. M. F. M. et al. Sepultamento IV do sítio arqueológico Lapa do Boquete, MG: patologias ósseas, parasitoses e doença de Chagas. Arquivos do Museu de História Natural Jardim Botânico - UFMG, 19: 209-230, 2009.

STEARNS, S. C. \& KOELLA, J. C. (Eds.). Evolution in Health and Disease. Oxford: Oxford University Press, 2008.

STIX, G. Traces of a distant past. Scientific American, 299: 56-63, 2008.

TORRES, Y. G. El Sacrificio Humano entre los Mexicas. Ciudad de México: Conaculta, Inah, Fondo de Cultura Económica, 2006.

TREVATHAN, W. R.; SMITH, E. O. \& MCKEENA, J. J. (Eds.). Evolutionary Medicine and Health: new perspectives. Oxford: Oxford University Press, 2008.

TURNER, B. L. et al. Human evolution, diet and nutrition: when the body meets the buffet. In: TREVATHAN, W. R.; SMITH, E. O. \& MCKEENA, J. J. (Eds.). Evolutionary Medicine and Health: new perspectives. Oxford: Oxford University Press, 2008.

VERANO, J. W. \& UBELAKER, D. H. Disease and Demography in the Americas. Washington: Smithsonian Institution, 1992.

VILAÇA, A. Comendo como Gente: formas do canibalismo Wari. Rio de Janeiro: Eduferj, 1992.

WANG, W. New discoveries of Gigantopithecus blacki teeth from Chuifeng Cave in the Bubing Basin, Guangxi, South China. Journal of Human Evolution, 57(3): 229-240, 2009.

WHITE, T. D. Prehistoric Cannibalism at Mancos 5MTUMR-2346. Princeton: Princeton University Press, 1992.

WHITE, T. D. et al. Ardipithecus ramidus and the paleobiology of early hominids. Science, 326(5.949): 75-86, 2009.

WILBUR, A. K. \& BUIKSTRA, J. E. Patterns of tuberculosis in the Americas - how can modern biomedicine inform about the ancient past? Memórias do Instituto Oswaldo Cruz, 101, suppl. II: 59-66, 2006.

WILEY, A. S. Cow's milk consumption and health. An evolutionary perspective. In: TREVATHAN, W. R.; SMITH, E. O. \& McKENNA, J. J. (Eds.). Evolutionary Medicine and Health. Oxford: Oxford University Press, 2008. 
WOOLHOUSE, M. \& ANTIA, R. Emergence of new infectious diseases. In: STEARNS, S. C. \& KOELLA, J. C. (Eds.). Evolution in Health and Disease. Oxford: Oxford University Press, 2008.

WORTHMAN, C. M. After dark. The evolutionary ecology of human sleep. In: TREVATHAN, W. R.; SMITH, E. O. \& MCKEENA, J. J. (Eds.). Evolutionary Medicine and Health: new perspectives. Oxford: Oxford University Press, 2008. 


\title{
Human Occupation of Patagonia
}

\author{
Ricardo A. Guichón • Matilde Elena Trivi • Lídia Susana Burry
}

$\mathrm{T}^{\mathrm{h}}$

he archaeology and ethnography of Patagonia can be characterized by analyzing the local social contexts and scientific communities in relation to events at each successive moment in the international context. This perspective allows conceiving of a "past" mutable sociocultural variability and another "current" mutable sociocultural (scientific) variability.

Many bioanthropologists consider Patagonia a peripheral area. It was one of the last regions on the planet to be occupied by humans. To a major extent, the study of Patagonia has adopted theoretical models proposed elsewhere but applied differently to analyze the local record.

The southernmost tip of South America boasts a rich history of research conducted by Chilean and Argentine scientists $^{1}$ as well as by international missions (especially French, north American, British, and Spanish), ${ }^{2}$ in some of the latter cases fostering cooperative projects with local scientists.

Studies on the paleoenvironment in Patagonia began in the extreme south with Von Post (1929) and Auer (1933, 1952, 1958, 1965) in Tierra del Fuego, with pollen analyses in turf bogs before the beginning of radiocarbon dating.

This chapter aims to summarize some currently discussed aspects of interethnic contact and the peopling of Patagonia. The Pathagonian environment can be viewed as a series of scenarios with restrictions and facilities. In these scenarios, which varied over time, human populations developed various ways of life, and it is necessary to describe their general characteristics, both current and past. We thus analyze the variation in the environment in the last 13,000 years (up to the present) and in the evidence of human occupations before and after interethnic contact in Patagonia.

\footnotetext{
${ }^{1}$ Ortiz Troncoso (1971a, 1971b, 1972, 1980/81); Munizaga (1978); Orquera et al. (1978); Orquera \& Piana (1990); Borrero (1979, 1983, 1989/90); Borrero \& Casiraghi (1980); Borrero, Casiraghi \& Hernández Llosas (1981); Massone (1982, 1983); Martinic (1982); Prieto (1984).

${ }^{2}$ Hyades \& Deniker (1891); Vignati (1927); Bird (1938, 1946); Emperaire (1963); Laming-Emperaire (1968a, 1968b, 1968c); Laming-Emperaire, Lavallée \& Humbert (1972); Saxon (1976); Hernandez, Lalueza Fox \& García-Moro (1997).
} 


\section{THE CURRENT ENVIRONMENT}

South America can be viewed as a wedge between the Atlantic and Pacific oceans, with a backbone - the Andes Mountain Range or Cordillera - close to the Pacific coast, running from north to south until Tierra del Fuego, where it changes direction from west to east. These geographic characteristics help partially understand the variety of environments in the region. One example of such variation is Patagonia, located in the extreme south, with approximately one million square kilometers. In territorial terms, the area belongs to Chile and Argentina.

The Argentine portion of Patagonia extends from the Rio Colorado, at approximately $37^{\circ} \mathrm{S}$, to the southernmost tip of the continent, at $55^{\circ} \mathrm{S}$, and between $63^{\circ}$ and $74^{\circ} \mathrm{W}$. Patagonia consists of two geomorphological regions: the Andes or Cordillera region, circumscribed by the western border to the southern tip of Tierra del Fuego and adjacent islands, and the extra-Andean territory, which includes the rest of the Patagonian territory. The latter features a landscape of broken mesetas that slope down towards the river valleys, accompanied by the low Cordilleras and some sharp depressions partially covered by volcanic (pyroclastic) gravel and sand. The most important climatic characteristics of the extra-Andean region are the sparse precipitation and strong winds, which cause high evaporation rates (Walter \& Box, 1983) and thus an arid environment (Beeskow, Del Valle $\&$ Rostagno, 1987). From the ecological point of view, it can be considered a cold semidesert (Soriano, 1983). Due to the extreme latitude of southern Patagonia (more than $48^{\circ} \mathrm{S}$ ), the length of days varies greatly between the summer and winter months.

Most of Patagonia receives air masses from the Pacific. The region is located between the permanent anticyclones of the Pacific and Atlantic $\left(30^{\circ} \mathrm{S}\right)$ and the sub-polar low-pressure belt $\left(60^{\circ} \mathrm{S}\right)$ (Prohaska, 1976), so that seasonal trends in the low and high pressure systems and the marine currents determine the precipitation patterns (higher in the winter). The Andes also play an important role in determining the climate, since their north-south direction poses a barrier to the humid air masses from the Pacific (Paruelo, Beltran \& Jobbagy, 1998). The region is commanded by the winds from the west, or westerlies, which extend from $30^{\circ}$ to $60^{\circ} \mathrm{S}$. Gusts greater than $100 \mathrm{~km} / \mathrm{h}$ are common.

Temperature in the region is temperate to cold-temperate (Paruelo, Beltran \& Jobbagy, 1998), varying according to the relief (Beeskow, Del Valle \& Rostagno, 1987) and distance from the sea. There is an important west-to-east temperature increase. Thus, the decrease in altitude and proximity to the coast lead to a gradual warming and narrower thermal variation, or degree of continentality. The El Niño phenomenon is one of the main sources of inter-annual variability in meteorological variables; summer temperatures tend to be higher than average in El Niño years (Kiladis \& Diaz, 1989).

As for precipitation, the overall circulation pattern of the atmosphere, the influence of Pacific air masses, and the Andes Cordillera jointly cause a strong west-to-east rain gradient (Barros, Sian \& Mattio, 1979). The Cordillera prevents the passage of moist winds from the Pacific, causing the humid air masses to rise and therefore cool. This phenomenon leads to unloading of moisture in the form of heavy rain or snow in the narrow hollow of the Cordillera environment, concentrated on the western slopes.

On the eastern slopes, the air masses drop to warmer lands, becoming extremely dry (Walter \& Box, 1983). Thus, in the western area of extra-Andean Patagonia, the precipitation drops rapidly from 600 to $200 \mathrm{~mm}$, remaining below this level (100-200 mm) in the central region and producing the area's driest environment.

This rapid transition involves an abrupt change of vegetation and a clear limit between the Patagonian forests and the steppe. Meanwhile, precipitations in the extra-Andean environments are related contributions of moisture from the Atlantic (Barros, 1976). 
The diversity of altitudes in the Cordillera at these latitudes also influences the climatic conditions. The climate is temperate and humid in the north, and cold and humid in the south. Mean temperature ranges from $9.5^{\circ} \mathrm{C}$ in the north to $5.4^{\circ} \mathrm{C}$ in the south. Annual precipitation ranges from 800 to $4000 \mathrm{~mm}$ in the north and decreases to $500 \mathrm{~mm}$ in the south.

The Chilean portion of Patagonia has a peculiar geography, consisting of a highly fragmented section of islands, channels, gulfs, peninsulas, archipelagos, estuaries, and fiords, which result from tectonic processes of sinking, action by glaciers, and the sea's penetration through the western valleys. The coastal zone is the largest in the Southern Cone. These geographic conditions and the great north-south extension of Chilean Patagonia result in a wide variety of climates: semiarid cold steppe, high-altitude cold, cold temperate and humid tundra, and cold ocean climates (Paskoff, 1996).

The diversity of climates is associated with a wide variety of soils, which sustain distinct types of plant formations. The soils in the extra-Andean region are mostly poor in organic matter. The strong winds lead to erosion and consequently the turnover, transportation, and deposition of materials, giving the pedogenic processes a continuous embryonic state (Scoppa, 1998). In the Andean region, the mountainous relief is impacted by glaciers, and the original lithological composition was altered through rejuvenation of the relief by the last glaciation and later filling with pyroclastic deposits (Figure 1).

The soils in the archipelago zone are swampy, with abundant organic matter and moisture content. These soils favor the formation of turf bogs and are mainly found in depressions in the terrain. The more exposed zones have rocky tundra soils, heavily eroded by the ice and climate, reaching a situation in which rock is found on the surface. The area also has highly fertile soils originating from volcanic ash. Finally, the Isla Grande de Tierra del Fuego, shared by the two countries, is the largest island in South America. It is covered by broad pampas that originated from glacial erosion. Erosion was extensive in some areas, to the point of forming impressive geomorphic landscapes like the Strait of Magellan (Scoppa, 1998; Soriano, 1983).

Figure 1 - Perito Moreno Glacier (A) and Patagonian shrub steppe (B)
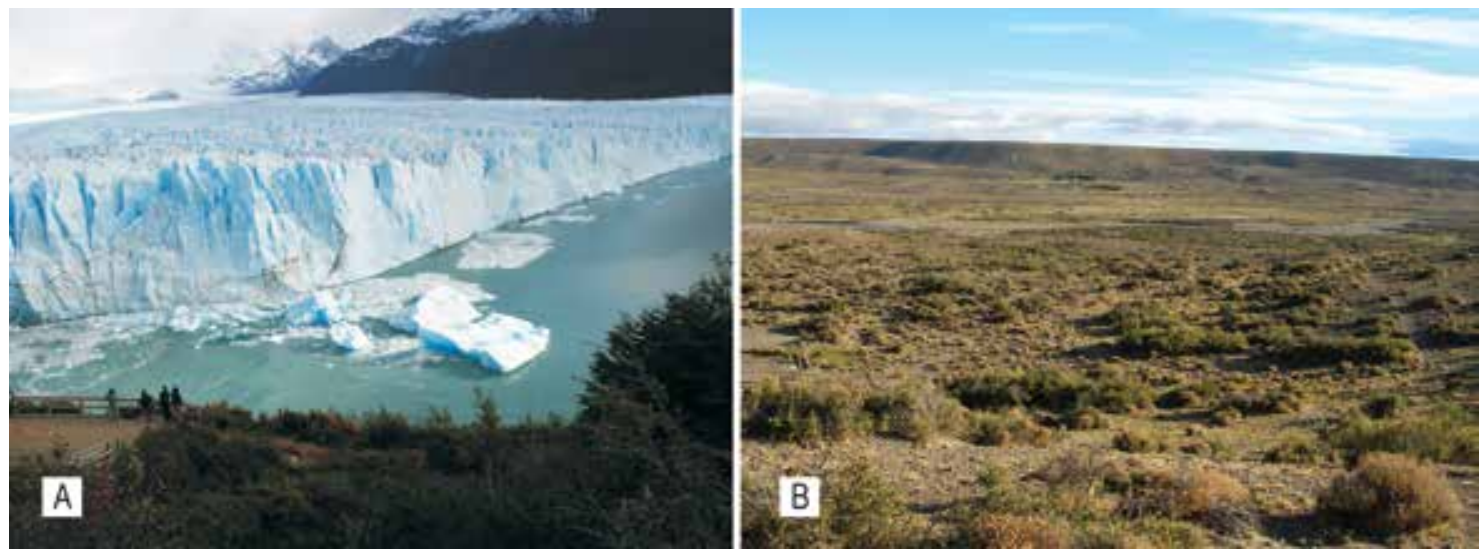

Finally, the types of vegetation in Patagonia (Figure 2) show a clear division between the Andean area (mainly forests) and the extra-Andean area (characterized by shrub and grassy steppes) (Soriano, 1956; Dimitri, 1972; Hueck \& Seibert, 1981; Cabrera, 1976; León et al., 1998). 
The forest composition changes along the Andes, from north to south and from west to east. The peaks have high-altitude Andean vegetation, and to the southwest are the ventisqueros (subject to rain, sleet, and snow) and snowfields. The extra-Andean area features the mountainous shrub steppe to the north and the Patagonian steppes and semideserts to the south, including distinct sectors running from west to east, the Sub-Andean and Western and Central and San Jorge sectors, and towards the south the Magellan and Tierra del Fuego sectors, with different landscapes associated with diverse conditions of temperature and humidity (Hueck \& Seibert, 1981).

Figure 2 - Types of Vegetation in Patagonia

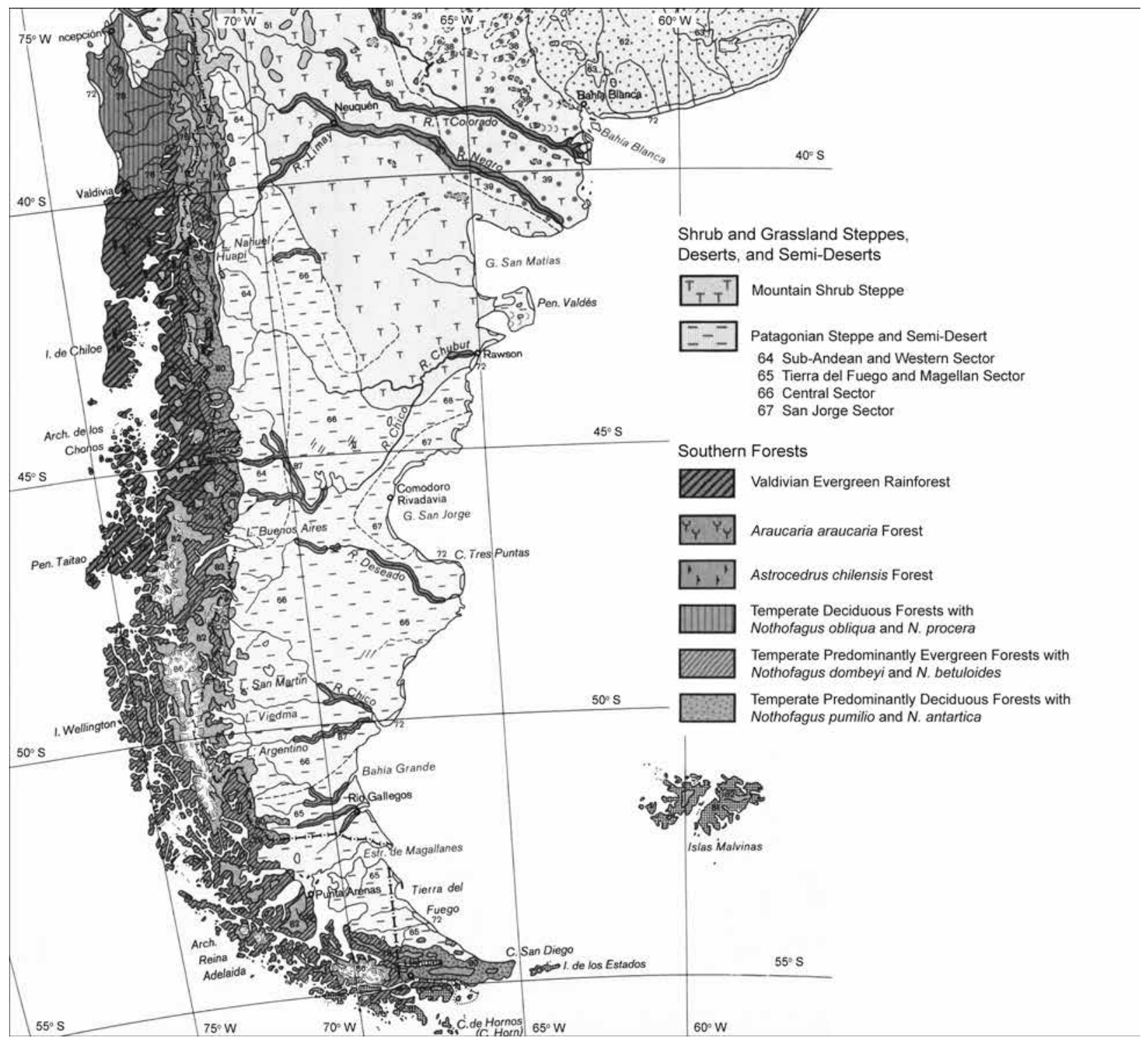




\section{PALEOENVIRONMENTS}

Since the transition from the last glacial period, the high latitudes of South America generally underwent changes in vegetation, the volume of ice masses, and sea surface conditions. This period of drastic environmental variations also witnessed the extinction of the Pleistocene megafauna.

Studies of the paleoenvironment show changes in the size of the various units of vegetation in Patagonia: forest, grassy steppe, and shrub steppe, associated with variations in temperature and/or humidity during the Holocene.

It is now known that during the Holocene, the ice masses in the Southern Hemisphere underwent fluctuations and changes, but it has not been possible to group many of these oscillations through radiocarbon dating. Clapperton (1992) elaborated a preliminary sequence based on his work and studies by Gellatly, Chin, and Rothlisberger (1988), establishing the principal intervals in climate changes in the Holocene, based on glacial fluctuations and environmental indicators. Thus, in the Southern Hemisphere, cold and humid intervals with glacier advance occurred as follows: ca. 8,400-7,500 (?) BP (before present); ca. 6,300-6,000 BP; ca. 5,200-5,000 BP; ca. 4,700-3,800 BP; ca. 3,500-2,900 BP; ca. 2,700-2,000 BP; and from 1250 to $1930 \mathrm{AD}$. Clapperton (1990) associates hot and dry periods (with glacier retreat) as follows: ca. 9,700-8,600 BP and after 6,500 BP. However, this classification is based on the currently available data and is subject to change based on future studies (Clapperton, 1990).

Pollen studies in archaeological sites from the Patagonian steppe in Santa Cruz and Chubut provided the basis for determining alternating dry and humid periods (D’Antoni, 1978; Burry \& D’Antoni, 2001; Paez, Prieto \& Mancini, 1999; Trivi, 2003).

Pendall et al (2001), based on variations observed in the pollen sets and analysis of stable hydrogen isotopes in a turf bog in the Beagle Channel, found that ca. 2000 BP there was a period of intense cold that lasted approximately 200 years. Meanwhile, Myoral, D'Antoni \& Daleo (1991) studied the paleotemperatures using racemization analyses of amino acids from proteins in fossil plants, suggesting a temperature elevation between 2,600 and 1,500 BP. More recently, Huber, Markgraf \& Schäbitz (2004) studied the post-glacial history of Tierra del Fuego along transects in southern Patagonia and Tierra del Fuego, showing considerable variations in humidity.

Lakes also serve as a source of information on continental climates, and fluctuation in their water levels is an indicator of climatic variations, especially in closed valleys. Thus, during the Holocene, various lakes in extraAndean Patagonia recorded alternating events of moisture and drought (Mayr et al., 2005; Stine \& Stine, 1990; Stine, 1994; Markgraf et al., 2003). The so-called "medieval climate anomaly" corresponds to a temperature rise and/or decrease in precipitation around 700 to 450 years BP (Haberzettl et al., 2005). According to Stine (1994), in America the anomaly began around 1,080 years BP. For periods between ca. 900 and 700 years BP, in the lowerlatitude lakes of Patagonia, and between 450 and 300 years BP at the higher latitudes, it is possible to detect the start of an increase in the water levels, indicating a decrease in temperature and consequently a decrease in evaporation, probably related to the "Little Ice Age". Finally, the last century witnessed a decrease in the water levels in all the lakes studied in extra-Andean Patagonia.

Added to the instability described in the previous paragraphs were stochastic events such as the deposition of ash from volcanic activity since the Quaternary (Stern \& Naranjo, 1998), which must have impacted resources and the human population. 


\section{CONTACT, EUROPEANS, INDIGENOUS PEOPLES, AND FRONTIERS}

In the broad and varied Patagonian environments, the first travelers, public servants, missionaries, and ethnographers that reached Patagonia (from the $16^{\text {th }}$ century onward) established knowledge on the groups inhabiting the region, identified as "uncivilized" and associated with "barbarianism".

According to the traditional model for Patagonia: 1) the nomadic groups were exclusively hunter-gatherers (their main activity was hunting large prey, complemented by gathering); 2) their movements (and life) were not programmed, since they were conditioned by the environment; 3) they limited their economic activities to subsistence; and 4) they were "savages" because they did not practice agriculture or form villages. However, in later periods (from the $15^{\text {th }}$ to the $19^{\text {th }}$ centuries, approximately), in northern Patagonia, more sedentary groups with agricultural practices (the Mapuche) interacted with the nomadic groups (Tehuelche) (Nacuzzi, Lucaioli \& Nesis, 2008).

The indigenous peoples in northern Patagonia received different names: Günü küne, Gününa këna, or Gününa küne ou Tehuelche. Those in the south were called Aóeni kénk Aônükün'k (Nacuzzi, Lucaoli \& Nesis, 2008).

Concerning the heterogeneity of environments on Isla Grande de Tierra del Fuego, the first Europeans that reached the region found populations of hunter-gatherers mainly using continental resources, the Selk'nam, and populations specialized in exploring marine resources: Yámana and lup. The relationship between the languages spoken by the latter two is subject to debate (Canals Frau, 1953).

According to Viegas Barros (1990), there was a kinship between the canoe peoples of the western Patagonian channels and those of the Beagle Channel. Meanwhile the Selk'nam language has been associated with that of the Tehuelche continental hunters (Canals Frau, 1953; Gusinde, 1982; Viegas Barros, 1990). At least one study has discussed the presence of another group, the Haush, in the southeasternmost part of Isla Grande (Gusinde, 1982).

Importantly, evidence points to cultural changes both before and after the Europeans' arrival in the region. ${ }^{3}$ Patagonia can be viewed overall as a very large space with difficult access that was incorporated late into the Spanish domain, where the frontier between indigenous peoples and Europeans did not act as a boundary. As shown in situations of contact, these frontiers constituted spaces of interaction that allowed the indigenous groups to exert strategies aimed at maintaining their autonomy through political and economic adaptations, biological miscegenation and cultural admixture, and ethnic reconfigurations. In practice, relations with the Europeans occurred through chiefs, whose roles did not fit the European model, in which economic and political power were related to leadership (Nacuzzi, Lucaioli \& Nesis, 2008).

The first European settlements in Patagonia date to the late $18^{\text {th }}$ century (Nuestra Señora de Patagones, Florida Blanca). With the first contacts, a variety of resources arrived and dispersed across Patagonia: cattle, sheep, and horses. Thus, the indigenous peoples, in addition to their autochthonous resources such as large prey (guanacos, deer, rheas) and plant species such as calafate or Magellan barberries, Schinus molle wood, reeds, and grasses, among others, rapidly incorporated the new resources both into their diet and for trade among themselves and with the Europeans (Nacuzzi, Lucaioli \& Nesis, 2008).

Based on the archaeological and ethnographic evidence, both before and after the arrival of the Europeans, the territories and categories of actions by human populations varied in time and space (Barberena, 2008).

\footnotetext{
${ }^{3}$ We will refer to this point later in the chapter.
} 
Nacuzzi, Lucaioli \& Nesis (2008:65) highlight the importance of bartering surpluses as currency:

"The indigenous peoples of northern Patagonia sold cattle and horses stolen from the fields of Buenos Aires (AGN IX 16-3-10) to the Spanish at Rio Negro Fort in exchange for flour, tobacco, liquor, cloth, hats, and maté. In Valdivia, Chile, these same Indians received bridles, knives, and spears in exchange for horses and ponchos (Villarino [1782-83], 1972), which they must have received in turn from other groups, the Aucas and Mapuches from the Pampa. In addition, for horses and guanaco hides they could obtain piñon seeds and sheep raised by more sedentary groups like the Pehuenches of Neuquén (Villarino [1782-83] 1972). The Tehuelche groups farther to the south gave guanaco hides (often guanaco fetuses) to those from the north in exchange for horses, so highly prized, but used by so few of themselves (A. de Viedma [1780-83], 1972)."

In Tierra del Fuego, territorial occupation by each of the indigenous groups and mobility within each territory and interaction with neighboring groups were not a static phenomenon. For example, Manzi (1991) suggests that substantial changes occurred after 1880, with the introduction of the haciendas and the Salesian Mission in Rio Grande. The author proposes two ethnographic models of mobility for the region of the "pedestrian hunter-gatherers", one for 1520 to 1880 and the other for 1880 to 1931. It is possible to suggest that the canoe peoples' habitat also changed through phenomena such as interaction with European navigators and the founding of Punta Arenas (officially in 1848) and the Anglican Mission (now Ushuaia) in the Beagle Channel, in 1869 (Emperaire, 1963).

\section{THE PEOPLING OF PATAGONIA}

Until the 1970s, research in the archaeology and physical anthropology of Argentine Patagonia was largely influenced by the "historical-cultural" school. This meant maintaining a highly coherent fit (with a similar basis in both specialties) sustained by an emphasis on diffusion (the arrival in Patagonia of other peoples and other cultural traditions), miscegenation as a factor for change, and an intimate relationship between a given biological morphology and a way of life (Guichón, 1994).

However, since the 1970s, some of the questions in archaeology that are currently under discussion concerning the peopling of Patagonia are partially a product of the mixture of the Historical Cultural School with new approaches. This happens with: a) continuity beginning with the first occupations; b) relative uniformity in the use of space; $c$ ) continuity since the first occupations until the historical populations; d) intimate relationship between biology and culture (examples: terrestrial hunters associated with a more robust and relatively tall physical build, and canoe peoples associated with a robust but shorter build); e) continuity in the canoe groups from the first occupations until historical times in the Beagle Channel; and f) the Andes Cordillera and river valleys considered geographic barriers to human populations (Borrero, 1995).

Around the late 1970 s and early 80 s, the physical anthropology ${ }^{4}$ of Patagonia began to incorporate some ideas outlined by the synthetic theory of evolution from the 1950s. This means the concept of population more than race, and change as a constant in time associated with evolutionary factors (drift, migration, selection, and mutation). By considering the idea of multiple paths in the evolution of populations, and rejecting the relationship between morphology and culture, the field incorporated an interest in representing "variability". These ideas began to be applied through univariate and multivariate statistical designs, analyzing the variation in skull morphology

\footnotetext{
${ }^{4}$ In the mid-1980s, it began to be known in Argentina as biological anthropology, with the work of Cocilovo, Carnese, and Pucciarelli (Carnese, Cocilovo \& Goichoechea, 1991-1992).
} 
in materials from Patagonian collections deposited in museums in Chile and Argentina (Guichón, 1994). One limitation to these studies, probably applicable to all studies of the past, involves problems related to the quality of samples. Any definition of population assumes the control of what we could call coordinates of variation in "time" and "space". For the case of Patagonia, as in other regions, such information is not always available. Thus, operationally, the units of analysis function in many cases as "data clusters" ${ }^{5}$ used to study the behavior of phenotypic variables.

For example, Guichón et al (1989-90) used a data cluster attributed to six regions of Patagonia (in Chile: Guaitecas Archipelago, Última Esperanza Magallanes, San Gregorio and in Argentina: Deseado, in northern Santa Cruz, northern Tierra del Fuego, and Beagle Channel). Based on this information, they studied the biological relations and affinities using morphometric data. ${ }^{6}$ Their study provided evidence for the possible existence of two biological stocks, one "Atlantic" and the other "Pacific", involved in the peopling of Tierra del Fuego (Guichón et al., 1989-90). The validity of the inferences is based on the assumption that the samples are representative of the populations. In general, for Patagonia, the majority of studies that have used collections have assumed that most of the samples probably correspond to late or post-contact moments (Cocilovo \& Guichón, 1985-86, 1999-2000; Guichón et al., 1989-1990; Hernández, Lalueza Fox \& García-Moro, 1997). On this basis, the samples that were studied received the names of the ethnographic group inhabiting the respective area, and it was not totally clear whether the samples corresponded to individuals of these ethnic groups or to the areas they came from. Considering this situation, we have insisted on using geographic rather than ethnographic location (Cocilovo \& Guichón, 1985-86, 1999-2000; Guichón et al., 1989-1990).

In 1989, Borrero proposed a general model for the peopling of Tierra del Fuego, oriented towards presenting phases rather than chronological stages. ${ }^{7}$ This scheme assumes a slow dispersal and proposes a non-linear process: ${ }^{8}$ “a) exploration, or initial dispersal to an empty zone, b) colonization, or consolidation of human groups in given sectors in space, with a specific area of action, and c) effective occupation, or the moment in which the entire desirable space is being used" (Borrero, 1989-1990: 134).

As the author points out, the incorporation of ecological references establishes:

a) a separation between the cultural and the biological (similar to that proposed by biological anthropology);

b) the possibility of local extinctions of human populations;

c) that the indigenous peoples from historical periods do not descend from others that occupied the region in more ancient times; and

\footnotetext{
${ }^{5}$ What we refer to as "clusters" are normally sets of skull morphology data which in some cases come from systematic archaeological excavations and which generally allow a spatial identification with a site or location (in the best of cases), or else a region in the other case.

${ }^{6}$ When studying biological relations and affinities between populations based on phenotypic (morphological) variables, some of the differences or similarities relate to problems in the environment (diet, health, physical activity). Lifestyle studies in Patagonia in the 1990s began to focus on these aspects (see below in this chapter).

${ }^{7}$ From other perspectives, the terms "exploration" and "colonization" have been used again to discuss the peopling of Patagonia, but referring to chronological stages (Barrientos \& Pérez, 2004; Miotti \& Salemme, 2004).

${ }^{8}$ The proposal does not assume a progressive adaptation in the sense that a population in a colonization stage does not necessarily function less efficiently than in later stages.
} 
d) that the environment's heterogeneity generates expectations on the differential use of spaces, the existence of more or less translucent barriers or filters, and thus discontinuous human distributions. ${ }^{9}$

Borrero (2001) highlights two characteristics of the environment's heterogeneity, namely glacier retreat and the possible significance of the river valleys. In the first case, from the biogeographical perspective, the author highlights the opposing effect of glacier retreat on one part of what is now continental Patagonia, ${ }^{10}$ producing "an increase in the conditions for contact, an increase in opportunities for territorial expansion, and conditions for the formation of social networks" (Borrero, 2001: 820). Meanwhile, isolation of populations occurred in Tierra del Fuego due to the Strait of Magellan. The river valleys and coast of the Strait of Magellan are considered possible organizing circuits for human populations, while the mesetas between the rivers acted as filters or intermediate spaces (Borrero, 2001).

In the far north of Patagonia, the lack of abrupt changes in the archaeological record and in the environment (see the description of the environment in this chapter) allowed suggesting the existence of an extensive region of transition and interaction. Specifically, recent studies have developed the hypothesis of a late population expansion from northeastern Patagonia to the southeastern Pampas and southern Cuyo region (Barrientos \& Pérez, 2004). The coastline of northern Patagonia shows evidence of human occupations since 5,000 BP. Barrientos \& Pérez (2004) have studied the large number and diversity of sites with human burials (one of the region's archaeological characteristics) in relation to the reduction in mobility and the population growth, as well as the increase in social tension $^{11}$ (clashes within and between groups) in hunter-gatherer populations in conjunction with the so-called "medieval climatic anomaly"12 (800-1320 AD).

In this new context, and from the perspective of biological anthropology, various possible scenarios are considered for the peopling of Patagonia and interaction between different potential microevolutionary factors (González et al., 2004). Specifically: a) genetic drift in Fuegian groups soon after the formation of the Strait of Magellan; b) evolution of different adaptive strategies (marine versus terrestrial hunting and gathering), and c) the effect of gene flow from groups coming from central Chile that expanded to eastern Patagonia in historical times (Araucanization). In relation to the latter, a question is whether Araucanization was limited to a process of cultural diffusion or it produced a displacement of populations and gene flow as a consequence. The discussion includes various models (adaptive isolation, geographic isolation, attenuated geographic isolation) and different degrees of Araucanization. ${ }^{13}$ Craniofacial

\footnotetext{
${ }^{9}$ This context incorporates the discussion on the concept of meta-populations associated with complex interactions and population substitutions in the region (Borrero, 2001).

${ }^{10}$ On continental Patagonia there was circulation between the two sides of the Cordillera in various areas. At $41^{\circ} \mathrm{S}$ and to the south, at 51 $30^{\circ}$ 'S. Monte Verde $\left(41^{\circ} 30^{\prime} \mathrm{S}\right.$, in Chile) is the site in Patagonia with the oldest dates. The southernmost part of the continent has several ancient sites, such as Cuevas Fell (Bird, 1983, 1988), Medio (Nami, 1987; Nami \& Nakamura, 1995), and Sofia Lake (Prieto, 1991). In more recent times, the sites recorded between $46^{\circ} \mathrm{S}$ and $46^{\circ} 20^{\prime} \mathrm{S}$ (Ibáñez River Valley, General Carrera Lake-Buenos Aires Lake) are part of a probable corridor (Borrero, 2001).

${ }^{11}$ Vignati (1947) and Gómez Otero \& Dahinten (1997-1998) report evidence of traumatic lesions, especially projectile heads embedded in bones in at least 14 bones (em Barrientos \& Pérez, 2004)

${ }^{12}$ In Patagonia, this event is associated with the increase in temperature and prolonged droughts (Barrientos \& Pérez, 2004).

${ }^{13}$ González et al. (2004) analyzed 230 skulls from collections in various institutions in Argentina, Chile, France, Italy, and Switzerland, considering only the individuals without cranial deformation. Methodologically, they numerically classified three models for the Tierra del Fuego-Patagonia area and subsequently assessed the degree of association between the biological variability and the models' predictions.
} 
variables were used to estimate biological variability, represented in the form of a distance matrix, applying matrix correlation tests (González et al., 2004).

Based on this analysis, and drawing on archaeological, ethnographic, and linguistic models, the authors propose a model for the peopling of Patagonia which considers the following:

1. The Fuegian and Patagonian groups share a common ancestor who led the ancient peopling of the region.

2. Tierra del Fuego was initially peopled by groups with an undifferentiated economy, at some time between 12,000 and $10,000 \mathrm{BP}$.

3. The Fuegian populations remained isolated from the continent during the last 8,000 years, except for a hypothetical connection between canoe-faring groups from the Chilean archipelago and from the south of the continent.

4. The Fuegian populations maintained high levels of gene flow, limited by the geographic distance in the center of Patagonia, probably between the Gallegos river basin and the Negro and Colorado rivers.

5. The important Araucanian migration from beyond the Andes modified the pattern of distances and internal variability of the Patagonian groups that received the impact of this flow for a long period of time: the groups from the northern pre-Cordillera and the Pampas. (González et al., 2004: 93)

Thus far, this study by González et al. (2004) is the one that best portrays the complexity in the problem of the peopling of Patagonia, using morphological data. As we also highlighted in Guichón et al (1989-1990), these important efforts at unveiling the variability of the human populations and their changes over time also had to approach the problems of the samples' location in time and space. New designs are needed to improve the degree of resolution of the available samples and thereby test various hypotheses, for example, the possibility of local extinctions of human populations, or that current indigenous peoples did not necessarily descend from earlier groups in the same territory (as proposed by archaeology).

Research work in archaeology, biological anthropology, and paleoenvironmental is not distributed homogeneously in Patagonia. The far south of Patagonia, including Tierra del Fuego, probably concentrates more than 50\% of the above-mentioned research projects. This produces a bias that has still not been resolved. The human bone record is larger on the Patagonian coast than in the interior (Guichón, Barberena \& Borrero, 2001). In recent years, radiocarbon dates have been obtained from skeletons with different types of cranial deformations, allowing a first chronological scheme for these important practices of skull-binding in Patagonia. The data suggest a probable time link with an important set of remains (round cranial deformation from 8,000 to 3,000 BP, oblique flat 3,000-2,000 BP, and straight flat 652-285 BP) (Barrientos \& Pérez, 2004).

In the 1980s, the academic scenario of biological anthropology in Patagonia, in Argentina, promoted interest in studies on interaction between human populations and the environment in the past. ${ }^{14}$ The first studies focused

\footnotetext{
${ }^{14}$ On the one hand, the projects involving scientific collaboration in biological anthropology between Chile, Brazil, Uruguay, and Argentina, launched in the mid-1980s, stimulated the incorporation of new lines of research in Argentina. Thus, under the framework of the project on Genetics and Microevolution of South American Indigenous Populations, the course on Biology and Culture, Functional Anatomy, and Lifestyle was given by Walter Neves (from Brazil) in 1987 in Buenos Aires. This course helped promote studies on subsistence, organization of work, and social tension. Thus, the experimental research lines developed by Pucciarelli beginning in the 1970s provided the basis for morphological studies such as the importance of environmental factors that affect phenotype (Carnese, Cocilovo \& Goicoechea, 1991/1992). In archaeology, the interaction between hunter-gatherers and their environment provided fertile ground for fomenting such studies.
} 
on biological indicators of quality of life (following the work of Wing, Antoinette \& Brown, 1979; Huss-Ashmore, Goodman \& Armelagos, 1982; Larsen, 1987; Powell, 1985, 1988). Research basically began to focus on the remains used in studies on biological distance, but which had skeletal remains in addition to skulls to explore the variety of diet (e.g., with an emphasis on the presence of caries, tooth wear) and health of populations (studies on hypoplasia lines and porotic hyperostosis, among others). The archaeological and ethnographic information produced some alternative hypotheses for the existence of differences between the regions (Pérez-Pérez \& Lalueza-Fox, 1992; Guichón, 1994).

Meanwhile, archaeology developed a special interest in human remains for performing studies of stable isotopes and thus evaluating the dietary consumption of marine and land resources in Tierra del Fuego (Yesner et al., 1991, 2003; Guichón et al., 2001; Schinder et al., 2003; Schinder \& Guichón, 2003). The same occurred with studies on lifestyle and stable isotopes, allowing the discussion of the populations (based on direct evidence of the consumption of such resources) of the traditional dichotomy between marine and terrestrial adaptations in Southern Patagonia. ${ }^{15}$ Thus, the dispersal of isotope values allowed analyzing some aspects of mobility ${ }^{16}$ (Borrero \& Barberena, 2006).

In the 1990s, molecular studies were performed on the bone remains from Southern Patagonia (Lalueza-Fox et al., 1993-1994; Lalueza-Fox, 1995; García-Bour et al., 1998) confirming the hypothesis that at least two haplotypes, C and D, were present in Patagonia. Added to these findings was the presence of haplotype B at the Baño Nuevo site in Chilean Patagonia (Moraga et al., 1999). Some samples studied by Lalueza-Fox and the remains found at Baño Nuevo have associated radiocarbon dates, which allowed proposing the existence of haplotypic and dietary variability from the Middle Holocene in Southern Patagonia (Borrero et al., 2001).

Despite the important contributions of these study designs, some authors have suggested that the complexity of the so-called health-disease process requires a dialectic methodology, with the convergence of detailed descriptions, formulation of diagnostic hypotheses, and multi-causality (Buikstra \& Cook, 1980). This perspective began to develop in Argentina in recent years, led by forensic physicians such Bosio et al. and colleagues from Brazil like Araújo and Mendonça de Souza and from Spain, like Rodríguez Martín. More than specific diseases, these diagnostic hypotheses emphasized the assignment to major etiological categories of lesions, such as infectious, nutritional and metabolic, musculoskeletal, traumatic, and vascular. From a broader perspective, the complexity is related to the "ecology of diseases" as a way of understanding aspects of the context and proposing probable paleoepidemiological scenarios (Greenblatt \& Spigelman, 2003).

Several projects with this paleopathological perspective have been launched in Patagonia: Guraieb (northern Santa Cruz Province), Luna (southern Pampa), Flengobord (northeast of the Rio Negro). In Southern Patagonia, Fugassa, Suby, Burry, Casali, Palacio, and Guichón are producing information on the health of human populations at the

\footnotetext{
${ }^{15}$ There are two important aspects to highlight in relation to stable isotopes. First, the virtual absence of C4 plants in southern Patagonia, which allows a clearer discrimination between land and marine diets. Added to this is the relatively good preservation of bones in cold, dry areas such as extra-Andean Patagonia.

${ }^{16}$ If populations are moving constantly along the coast and across the interior, their diets should not vary on average. The results of stable isotopes do not support this hypothesis (Borrero \& Barberena, 2006). The use of marine resources is acknowledged on the Pacific Coast, or the so-called Wet Coast, while the Atlantic Coast, or Dry Coast, displays a wide variety of cases that have been the object of study in recent years.
} 
following moments: (a) prior to contact between indigenous peoples and Europeans, ${ }^{17}$ (b) initial contact ${ }^{18}$, and (c) final contact between indigenous peoples and Europeans. ${ }^{19}$

\section{FINAL REMARKS}

The development of anthropological research in Patagonia apparently does not respond to a model of paradigms and crises, as proposed by Kuhn (1991) and used by one of us to explain the history of such research in the region (Guichón, 1994). Rather, this complex history gradual appears to be better explained by changes, mixtures, diversity, and the undermining of perspectives.

Archaeology, social anthropology (or ethnography, for some), biological anthropology, and studies in environmental reconstruction appear to have followed parallel paths in Patagonia. From the 1970s to date, the fusion of perspectives appears to have been a constant, with greater emphasis on the study of variability and changes at all levels.

As mentioned, an important climatic division exists between the western and eastern watersheds of the Cordillera. The former has high precipitation and narrow temperature variations, while the latter has low precipitation and a wider temperature range. The western watershed shows a west-to-east gradient in which precipitation and moisture decrease, with related changes in vegetation. Importantly, the arid environment characteristic of extra-Andean Patagonia offers excellent conditions for the preservation of fossils, whether bone, pollen, or plant remains. The same is not true for the Cordillera zone or for the western watershed of the Andes, with much higher humidity.

We have presented an overview of current discussions ranging in time from the ancient peopling of Patagonia to the process of interethnic contact. It is difficult to sustain that such a large and varied territory as Patagonia provided only few forms of exploration of ecosystems, since "it does not require spears and canoes to explore the sea, or bows and arrows and slings to hunt guanacos" (Borrero, 2001: 830). Considering that the human species has the capacity to respond to the same problem in different ways, then as Borrero states (2001), we should remain alert to unforeseen forms of such responses.

\section{ACKNOWLEDGMENTS}

The authors wish to thank Dr. Adauto Araújo for inviting us to participate and for his patience, Patricia I. Palácio for her collaboration, and the Department of Biology at Facultad de Cs.Ex y Naturales, Universidad Nacional de Mar del Plata (UNMdP) and Laboratory of Human Evolutionary Ecology, Unidad de Enseñanza Universitaria Quequén, Faculdad de Ciencias Sociais, Universidad Nacional del Centro, Província de Buenos Aires, Facultad de Ciencias Sociales (UNCPBA), the Project for Research in Science and Technology (Pict / 01520), and our families.

\footnotetext{
${ }^{17}$ Fugassa (2006); Suby (2007).

${ }^{18}$ Based on the study of skeletons recovered from the first Spanish settlement in southern Patagonia, Nombre de Jesús, 1584 (Guichón et al., 2006; Suby et al., 2006; Senatore et al., 2005; Suby, 2007; Fugassa, Araújo \& Guichón, 2006).

${ }^{19}$ Casali, Fugassa \& Guichón (2006); Casali (2008).
} 


\section{REFERENCES}

AUER, V. Verschiebungen der Wald und Steppengebiete Feuerlands in Postglazialer Zeit. Acta Geographica, 5: 1-313, 1933.

AUER, V. Las capas volcánicas como base de la cronología postglacial de Fuegopatagonia. Ministerio de Agricultura y Ganadería, 9: 1-208, 1952.

AUER, V. The Pleistocene of Fuegopatagonia, part II: The history of the flora and vegetation. Annales Academiae Scientiarum Fennicae, 100: 1- 194, 1958.

AUER, V. The Pleistocene of Fuego Patagonia, part IV. Bog profiles. Annales Academiae Scientiarum Fennicae, AIII 50: 1-239, 1965.

BARberenA, R. Arqueología y Biogeografía Humana en Patagonia Meridional. Buenos Aires: Sociedad Argentina de Antropología, 2008.

BARRIENTOS, G. \& PÉREZ, S. I. La expansión y dispersión de poblaciones del norte de Patagonia durante el Holoceno Tardío: evidencia arqueológica y modelo explicativo. In: CIVALERO, T.; FERNÁNDEZ, P. \& GURAIEB, G. (Eds.). Contra Viento y Marea: arqueología de Patagonia. Buenos Aires: Instituto Nacional de Antropología y Pensamiento Latinoamericano, Sociedad Argentina de Antropología, 2004.

BARROS, V. R. Informe climatológico sobre el sudeste de la provincia del Chubut. Idia, suppl. 35. Caperas / Inta. Buenos Aires, 1976.

BARRoS, V. R.; SIAN, B. V. \& MATTIO, H. F. Campos de precipitación de la provincia de Chubut (1931-1960). Geoacta, 10: 175192, 1979.

BIRD, J. Antiquity and migrations of the early inhabitants of Patagonia. Geographical Review, 28: 250-275, 1938.

BIRD, J. The archeology of Patagonia: handbook of South American Indians. Bureau of American Ethnology Bulletin, 143: 17-24, 1946.

BIRD, J. Enterratorios paleo-indios con cremación en las cuevas de Pali-Aike y Cerro Sota en Chile Meridional. Anales del Instituto de la Patagonia, 14: 55-65, 1983. (Ciencias Sociales).

BIRD, J. Travels and Archaeology in South Chile. Iowa: University of Iowa Press, 1988.

BEESKOW, A. M.; DEL VAlLE, H. E. \& ROSTAGNO, C. M. Los Sistemas Fisiográficos de la Región Árida y Semiárida de la Provincia de Chubut. Puerto Madryn: Secretaría de Ciencia y Técnica, Delegación Regional Patagónica, 1987.

BORRERO, L. A. Excavaciones en el alero 'Cabeza de León'. Isla Grande de Tierra del Fuego. Relaciones, 13: 255-271, 1979. (Nueva Serie).

BORRERO, L. A. On cultural adaptation in the Subantartic Zone. Current Anthropology, 24: 241-242, 1983.

BORRERO, L. A. Sites in action: the meaning of guanaco bones in Fueguian Archaeological sites. Archaeozoologia, 3: 9-24, 1989.

BORRERO, L. A. Evolución cultural divergente en la Patagonia Austral. Anales del Instituto de la Patagonia, 19: 133-140, 1989 1990. (Ser. Ciencias Sociales).

BORRERO, L. A. Historia reciente de la arqueología patagónica. Runa, 22: 151-176, 1995.

BORRERO, L. A. Tafonomía regional en el istmo Bahía Inútil-Bahía San Sebastián (Tierra del Fuego), 2001. Available at: <www. naya.org.ar>.

BORRERO, L. A. \& BARBERENA, R. Hunter-gatherer home ranges and marine resources. An archaeological case from Southern Patagonia. Current Anthropology, 47: 855-867, 2006.

BORRERO, L. A. \& CASIRAGHI, M. Excavaciones en el Sitio Bloque Errático I. San Sebastián, Tierra del Fuego. Relaciones de la Sociedad Argentina de Antropología, 14(1): 129-142, 1980. (Nueva Serie).

BORRERO, L. A.; CASIRAGHI, M. \& HERNANDEZ LLOSAS, M. I. Arqueología del norte de la Isla Grande de Tierra del Fuego. Revista del Museo Territorial, 1: 1-23, 1981. 
BORRERO, L. A. et al. Dieta a partir de isótopos estables en restos óseos humanos de Patagonia Austral: estado actual y perspectivas. Anales Instituto Patagonia, 29: 119-127, 2001. (Ciencias Humanas).

BUIKSTRA, J. E. \& COOK, D. C. Paleopathology: an American account. Annual Review of Anthropology, 9: 433-470, 1980.

BURRY, L. S. \& D’ANTONI, H. L. Análisis de polen en el sur de Chubut (Argentina): reinterpretación del perfil del Alero del Cañadón de las Manos Pintadas. Asociación Paleontológica Argentina, 8 (Publicación Especial): 65-72, 2001.

CABRERA, A. L. Regiones fitogeográficas argentinas. In: ENCICLOPEDIA ARGENTINA DE AGRICULTURA Y JARDINERÍA. Buenos Aires: Editorial Acme Saci, 1976. v. II.

CANALS FRAU, S. Poblaciones Indigenas de la Argentina. Buenos Aires: Ed. Sudamericana, 1953.

CARNESE, F. R.; COCILOVO, J. A. \& GOICOECHEA, A. S. Análisis histórico y estado actual de la antropología biológica en la Argentina. Runa Buenos Aires, 20: 35-67, 1991-1992.

CASALI, R. Contacto interétnico en el norte de Tierra de Fuego: estrategias de resistencia Selk'nam en la misión salesiana La Candelaria. Magallania, 36(2): 45-61, 2008.

CASALI, R.; FUGASSA, M. H. \& GUICHÓN, R. A. Aproximación epidemiológica al proceso de contacto interétnico en el norte de Tierra del Fuego. Magallania, 34(1): 141-155, 2006. Edición electrónica.

CLAPPERTON, C. M. La última glaciación y deglaciación en el Estrecho de Magallanes: implicaciones para el poblamiento de Tierra del Fuego. Anales del Instituto de Patagonia, 21: 113-128, 1992. (Serie Ciencias Humanas)

COCILOVO, J. A. \& GUICHÓN, R. A. Propuesta para el estudio de las poblaciones aborígenes del extremo austral de Patagonia. Anales del Instituto de la Patagonia, 16: 111-123, 1985-1986. (Serie Ciencias Sociales)

Cocilovo, J. A. \& GUICHón, R. A. La variación geográfica y el proceso de micro-diferenciación de las poblaciones aborígenes de Patagonia Austral y de Tierra del Fuego. Revista Chilena de Antropología, 15: 9-28, 1999-2000.

D’ANTONI, H. L. Palinología del perfil del Alero del Cañadón de las Manos Pintadas (Las Pulgas, Provincia de Chubut). Relaciones de la Sociedad Argentina de Antropología, 12: 249-262, 1978.

DIMITRI, M. J. La Región de los Bosques Andino-Patagónicos. Buenos Aires: Instituto Nacional de Tecnología Agropecuaria, 1972. (Colección Científica Inta, 10)

EMPERAIRE, J. Los Nómades del Mar. Santiago del Chile: Universidad de Chile, 1963.

FUGASSA, M. H. Enteroparasitosis en Poblaciones Cazadoras-Recolectoras de Patagonia Austral, 2006. PhD dissertation, Mar del Plata: Facultad de Ciencias Exactas y Naturales, Universidad Nacional de Mar del Plata.

FUGASSA, M. H.; ARAÚJO, A. \& GUICHÓN, R. A. Quantitative paleoparasitology applied to archaeological sediments. Memórias do Instituto Oswaldo Cruz, 101, supl. II: 29-33, 2006.

GARCÍA-BOUR, J. et al. Secuencias de mtDNA de aborígenes de la Tierra del Fuego-Patagonia y el origen de los fueguinos. Anales del Instituto de la Patagonia, 26: 69-75, 1998.

GELLATLY, A. F.; CHINN, T. J. I. \& ROTHLISBERGER, F. Holocene glacier variations in New Zealand: a review. Quaternary Science Reviews, 7: 227-242, 1988.

GÓMEZ OTERO, J. \& DAHINTEN, S. Costumbres funerarias y esqueletos humanos: variabilidad y poblamiento en la costa nordeste de la provincia de Chubut (Patagonia Argentina). Relaciones de la Sociedad Argentina de Antropología, 22-23(n.s.): 101-124, 1997-1998.

GONZÁLEZ, R. J. et al. Hipótesis acerca del poblamiento de Tierra del Fuego-Patagonia a partir del análisis genético-poblacional de la variación craneofacial. Magallania, 32: 79-98, 2004.

GREEnBlatT, C. L. \& SPIGELMAN, M. Archaeology, Ecology, and Evolution of Infectious Disease. New York: Oxford University Press, 2003. 
GUICHón, R. A. Antropología Física de Tierra del Fuego: caracterización biológica de las poblaciones prehispánicas, 1994. PhD dissertation, Buenos Aires: Facultad de Filosofía y Letras, Universidad de Buenos Aires.

GUichón, R. A.; BARBERENA, R. \& BORRERo, L. A. ¿Dónde y cómo aparecen los restos óseos humanos en Patagonia Austral? Anales Instituto Patagonia, 29: 103-118, 2001. (Ciencias Humanas)

GUICHÓn, R. A. et al. Contribución al conocimiento de las relaciones biológicas entre las poblaciones aborígenes de Patagonia Austral y Tierra del Fuego. Runa, 19: 27-39, 1989-1990.

GUichón, R. A. et al. Nuevas determinaciones de isótopos estables para Tierra del Fuego. Revista Argentina de Antropología Biológica, 3: 113-126, 2001.

GUICHÓN, R. A. et al. Health at the time of native-European contact in Southern Patagonia. Memórias do Instituto Oswaldo Cruz, 101, suppl. II: 97-105, 2006.

GUSINDE, M. Los Indios de Tierra del Fuego. Buenos Aires: Centro Argentino de Etnología Americana (Conicet), 1982.

HABERZETTL, T. et al. Climatically induced lake level changes during the last two millennia as reflected in sediments of Laguna Potrok Aike, southern Patagonia (Santa Cruz, Argentina). Journal of Paleolimnology, 33: 283-302, 2005.

HERNÁNDEZ, M.; LALUEZA FOX, C. \& GARCÍA-MORO, C. Fueguian cranial morphology: the adaptation to a cold, harsh environment. American Journal of Physical Anthropology, 103: 103-117, 1997.

HUBER, U. M.; MARKGRAF, V. \& SCHÄBITZ, F. Geographical and temporal trends in Late Quaternary fire history of Fuego-Patagonia, South America. Quaternary Science Reviews, 23: 1.079-1.097, 2004.

HUECK, K. \& SEIBERT, P. Vegetationskarte von Südamerika. Stuttgart, New York: Gustav Fischer, Verlag, 1981.

HUSS ASHMORE, R.; GOODMAN, A. H. \& ARMElAGOS, G. J. Nutritional inference from paleopathology. Advances in Archeological Method and Theory, 5: 395-474, 1982.

HYADES, P. \& DENIKER, J. Anthropologie et ethnographie. In: HYADES, P. \& DENIKER, J. Mission Scientifique du Cap Horn, 18821883. Paris: Gauthier-Villars et Fils, 1891. v. VII.

KILADIS, G. N. \& DIAZ, H. F. Global climate anomalies associated with extremes of the Southern oscillation. Journal of Climate, 2: 1.069-1.090, 1989.

KUHN, T. S. The Structure of Scientific Revolutions, University of Chicago Press, 1962.

LALUEZA-FOX, C. Recuperación de DNA Mitocondrial y Caracterización de Variabilidad en Poblaciones Antiguas, 1995. PhD dissertation, Barcelona: Universitat de Barcelona.

LALUEZA-FOX, C. et al. Ausencia de la deleccion de 9bp COII/tRNAlys en aborígenes de Fuego-Patagonia mediante análisis de DNA antiguo. Anales del Instituto de la Patagonia, 22: 181-191, 1993-1994. (Ciencias Sociales)

LAMING-EMPERAIRE, A. Quelques étapes de l'ocupation humaine dans l'extrême sud de l'Amérique australe. In: CONGRÈS INTERNATIONAL DES AMÉRICANISTES III BUENOS AIRES, XXXVII, 1968a, Buenos Aires.

LAMING-EMPERAIRE, A. Missions archéologiques françaises au Chili austral. Quelques datations des sites par le radiocarbone. Journal de la Societé des Américanistes, 57(n.s.): 77-99, $1968 \mathrm{~b}$.

LAMING-EMPERAIRE, A. Le Site Marassi en Terre de Feu. Rehue: Universidad de Concepción, 1968c.

LAMING-EMPERAIRE, A.; LAVALLEÉ, D. \& HUMBERT, R. Le site de Marazzi en Terre de Feu. Objets et Mondes, 12: 225-244, 1972.

LARSEN, C. S. Bioarchaeological interpretations of subsistence economy and behavior from human skeletal remains. Advances in Archaeological Method and Theory, 10: 339-445, 1987.

LEón, R. J. C. et al. Grandes unidades de vegetación de la Patagonia extra andina. Ecología Austral, 8: 125-144, 1998.

MANZI, L. M. De cómo y dónde se movían los grupos cazadores-recolectores pedestres de la Isla Grande de Tierra del Fuego. In: CONGRESO NACIONAL DE ARQUEOlogíA ARGEnTINA, X, 1991, Catamarca. Anais... Catamarca: Comunicaciones de Patagonia y Tierra del Fuego, 1991. Tomo 3. 
MARKGRAF, V. et al. Holocene palaeoclimates of southern Patagonia: limnological and environmental history of Lago Cardiel, Argentina. The Holocene, 13: 581-591, 2003.

MARTINIC, M. B. La Tierra de los Fuegos: historia, geografia, sociedad, economía. Municipalidad de Porvenir, Tierra del Fuego: Museo Municipal, 1982.

MASSONE, M. M. Cultura Selk'nam (Ona). Santiago del Chile: Departamento de Extensión Cultural del Ministerio de Educación, 1982. (Serie el Patrimonio Cultural Chileno, Colección Culturas Aborígenes)

MASSONE, M. M. 10400 años de colonización humana en Tierra del Fuego. Revista Infórmese, 14, ano III: 24-32, 1983.

MAYORAL, A.; D'ANTONI, H. L. \& DALEO, G. Present state of studies on amino acid racemization in fossil plant proteins. Bamberger Geographische Schriften, 11: 229-234, 1991.

MAYR, C. et al. Palaeoenvironmental changes in southern Patagonia during the last millennium recorded in lake sediments from Laguna Azul (Argentina). Palaeogeography, Palaeoclimatology, Palaeoecology, 228: 203-227, 2005.

MiOTTI, L. \& SAlEMmE, M. Poblamiento, movilidad y territorios entre las sociedades cazadoras-recolectoras de Patagonia. Complutum, 15: 177-206, 2004.

MORAGA, M. et al. Análisis de DNA en esqueletos humanos del arcaico temprano y fauna asociada excavados en la estepa patagónica. In: JORNADAS NACIONALES DE ANTROPOLOGíA BIOLÓGICA, IV, 1999, Jujuy. Programa y Resúmenes... Jujuy: Universidad Nacional de Jujuy, 1999.

MUNIZAGA, J.R. Paleoindio en Sudamérica (restos óseos humanos de la las cuevas de Palli Aike y Cerro Sota, provincia de Magallanes, Chile) 1. Anales de la Universidad del Norte, 10: 19-30, 1978.

NACUZZI, L. R.; LUCAIOLI, C. P. \& NESIS, F. S. Pueblos Nómades en un Estado Colonial, Chaco, Pampa, Patagonia, Siglo XVIII. 1. ed. Buenos Aires: Editorial Antropofagia, 2008.

NAMI, H. Cueva del Medio: perspectivas arqueológicas para la Patagonia Austral. Anales del Instituto de la Patagonia, 17: 73106, 1987.

NAMI, H. \& NAKAMURA, T. Cronología radiocarbónica con AMS sobre muestras de huesos procedentes del sitio Cueva del Medio (Última Esperanza, Chile). Anales del Instituto de la Patagonia, 23: 125-133, 1995.

ORQUERA, L. A. \& PIANA, E. L. Canoeros del extremo austral. Ciencia Hoy, 6: 18-27, 1990.

orQuerA, L. A. et al. Lancha Packewaia, Arqueología de los Canales Fueguinos. Buenos Aires: Huemul, 1978.

ORTIZ TRONCOSO, O. R. Reconocimiento arqueológico del fiordo Parry, Tierra del Fuego. Anales del Instituto de la Patagonia, 1-2: 28-34, 1971a.

ORTIZ TRONCOSO, O. R. Antecedentes históricos y prospección arqueológica de las islas Isabel, Santa Marta, Magdalena y Contramaestre, Estrecho de Magallanes. Anales del Instituto de la Patagonia, 1: 83-85, 1971b.

ORTIZ TRONCOSO, O. R. Nota sobre un yacimiento arqueológico en el archipiélago del cabo de Hornos. Anales del Instituto de la Patagonia, III(1-2): 83-85, 1972.

ORTIZ TRONCOSO, O. R. Inventory of radiocarbon dates from Southern Patagonia and Tierra del Fuego. Journal de la Société des Americanistes, 67: 185-211, 1980-1981.

PAEZ, M. M.; PRIETO, A. R. \& MANCINI, M. V. Fossil pollen from Los Toldos locality: a record of the Late-glacial transition in the Extra-Andean Patagonia. Quaternary International, 53/54: 69-75, 1999.

PARUELO, J. M.; BELTRAN, A. \& JOBBAGY, E. The climate of Patagonia: general patterns and controls on biotic processes. Ecología Austral, 8: 85-101, 1998.

PASKOFF, R. Atlas de las Formas de Relieve de Chile. Santiago del Chile: Instituto Geográfico Militar, 1996. 
PENDALL, E. et al. Multiproxy record of late Pleistocene-Holocene climate and vegetation changes from a peat from Patagonia. Quaternary Research, 55: 168-178, 2001.

PÉREZ-PÉREZ, A. \& LALUEZA FOX, C. Indicadores de presión ambiental en aborígenes de Fuego-Patagonia. Reflejo de la adaptación a un ambiente adverso. Anales del Instituto de la Patagonia, 21: 99-108, 1992. (Ciencias Humanas)

POWEL, M. L. The analysis of dental wear and caries in dietary reconstruction. In: GILBERT, R. I. \& MIELKE, J. H. (Eds.). The Analysis of Prehistoric Diets. New York: Academic Press, 1985.

POWELL, M. L. Status and Health in Prehistory: a case of study of the Moundville Chiefdom. Washington: Smithsonian Institution Press, 1988.

PRIETO, A. Cuadro cronológico de referencias bioambientales para Patagonia Austral y Tierra del Fuego. Anales del Instituto de la Patagonia, 15: 47-51, 1984. (Ser. Ciencias Sociales)

PRIETO, A. Cazadores tempranos y tardíos en Cueva Lago Sofía 1. Anales del Instituto de la Patagonia, 22: 91-100, 1991.

PROHASKA, F. The climate of Argentina, Paraguay, and Uruguay. In: SCHWERDTFEGER, W. (Ed.). Climates of Central and South America. Amsterdam: World Survey of Climatology Elsevier 2, 1976.

SAXON, E. C. La prehistoria de Fuego-Patagonia: colonización de un hábitat marginal. Anales del Instituto de la Patagonia, 7: 6373, 1976.

SCHINDER, G. \& GUICHÓN, R. A. Isótopos estables y estilo de vida en muestras óseas humanas de Tierra del Fuego. Magallania, Anales del Instituto de la Patagonia, 31:33-44, 2003. (Serie Ciencias Humanas)

SCHINDER, G. et al. Inferencias paleodietarias mediante isótopos estables en restos óseos humanos provenientes de Tierra del Fuego, Argentina. Revista Argentina de Antropología Biológica, 5: 15-23, 2003.

SCOPPA, C. O. Los Suelos. In: CORREA, M. (Ed.). Flora Patagónica. Buenos Aires: Instituto Nacional de Tecnología Agropecuaria, 1998. (Colección Científica Inta, VIII)

SENATORE, M. X. et al. Arqueología en la Ciudad del Nombre de Jesús: vida y muerte en el Estrecho de Magallanes hacia fines del siglo XVI. In: JORNADAS DE ARQUEOLOGía DE LA PATAGONIA, VI, 2005, Punta Arenas. Anais... Punta Arenas, 2005.

SORIANO, A. Los distritos florísticos de la provincia Patagónica. Revista de Investigaciones Agrícolas, 10: 321 - $357,1956$.

SORIANO, A. Deserts and semi-deserts of Patagonia. In: WEST, N. E. (Ed.). Temperate Deserts and Semi-Deserts. Amsterdam: Elsevier Publishing Company, 1983.

STERN, C. \& NARANJO, J. Summary of the Holocene eruptive history of the Hudson Volcano: la erupción del volcán Hudson en agosto de 1991. In: BITSCHENE, P. R. \& MENDíA, J. (Eds.). The August 1991 Eruption of the Hudson Volcano (Patagonian Andes): a thousand days after. Rivadavia: UNPSJB - Servicio Geológico Nacional, 1998.

STINE, S. Extreme and persistent drought in California and Patagonia during medieval time. Nature, 369: 546-549, 1994.

STINE, S. \& STINE, M. A record from Lake Cardiel of climate change in southern South America. Nature, 345: 705-707, 1990.

SUBY, J. A. Propiedades Estructurales de Restos Óseos Humanos y Paleopatología en Patagonia Austral, 2007. PhD dissertation, Mar del Plata: Facultad de Ciencias Exactas y Naturales, Universidad Nacional de Mar del Plata.

SUBY, J. A. et al. Possibilities and limitations of human bone record in Southern Patagonia. In: SIMPÓSIO O POVOAMENTO DAS AMÉRICAS, 2006, Piauí.

TRIVI, M. Paleoecología del Noroeste de Santa Cruz, 2003. PhD dissertation, Buenos Aires: Universidad de Buenos Aires.

VIEGAS BARROS, J. P. Dialectología qawasqar. Amerindia, 15: 43-73, 1990.

VIGNATI, M. Arqueología y antropología de los conchales fueguinos. Revista del Museo de La Plata, 30: 79-143, 1927.

VON POST, L. Die Zeichenschrift der Pollenstatistik. Geologie fören Stockholm, 51: 543-565, 1929. 
WALTER, H. \& BOX, E. O. Climate of Patagonia. In: WEST, N. E. (Ed.). Deserts and Semideserts of Patagonia, Temperate Deserts and Semideserts. Amsterdam: Elsevier, 1983.

WING, E. S.; \& ANTOINETTE, Y. In: BROWN, B. Paleonutrition: method and theory in prehistoric foodways. New York: Academic Press, College of Studies in Archaeology, 1979.

YESNER, D. R. et al. Análisis de isótopos estables en esqueletos humanos: confirmación de patrones de subsistencia etnográfica para Tierra del Fuego. Shincal, 3: 182-191, 1991.

YESNER, D. R. et al. Stable isotope analysis of human bone and ethnohistoric subsistence patterns in Tierra del Fuego. Journal of Anthropological Archaeology, 22: 279-291, 2003. 


\title{
6
}

\section{Parasitism}

\author{
Adauto Araújo • Luiz Fernando Ferreira
}

$P^{a}$ arasitism is a natural phenomenon, inherent to life (Ferreira, 1973). No living species exists without parasites. According to Cockburn (1963), the complex system formed by the three elements parasite, host, and environment is in a constant evolutionary process and can either remain unaltered, change over time, or die out completely. Parasitology is a branch of ecology and follows its general principles (Ferreira, 1973). Parasitism is an interaction between organisms and the product of natural selection, and should thus be understood as selective responses to pressures from the environment (Poulin, 2007).

Hutchinson (1980) describes an ecological niche as a hyper-volume in multidimensional space determined by a number of environmental variables in which a species is capable of existing. A parasite thus finds its ecological niche in another organism (Araújo et al., 2003). This establishes an interaction which can be more or less close, dependent, temporary, or permanent, according to the species involved.

This definition of parasitism includes all varieties of interspecies associations, with different degrees of interdependence. Using this broad concept to define parasitism means that associations traditionally defined as commensalism, mutualism, and symbiosis, among others, represent variations of the same phenomenon: parasitism (Araújo et al., 2003; Roberts \& Janovy Jr., 2009).

Samuel Pessoa, in the first edition of Parasitologia Médica, in 1945, already reminded parasitologists that "parasitism, commensalism, and symbiosis are categories created by our spirit, emphasizing different aspects of the same general laws" (Pessoa, 1951: 5).

When German scientists Karl Georg Friedrich Rudolf Leuckart, and Heinrich Anton de Bary respectively and independently created the concepts of parasitism and symbiosis (both in 1879), they made no mention of diseases or harm that could come from the relationship between species. Various authors focused again on the same issue, including French parasitologist Émile Brumpt (Brumpt, 1913). Since the first editions of his books, Brumpt emphasized that parasitism and symbiosis merged into a single concept, that is, both parasites and symbionts or commensals could cause either harm or benefit to their hosts. 
A hundred years after the definitions by Leuckart and Bary, Whitfield (1979) criticized the various terms used for relations between beings, calling them "semantic anarchy". He proposed a return to the "classical" concept of parasitism and symbiosis as synonyms.

The definition of parasitism as the parasite's finding of its ecological niche in the host has consequences of a logical order. What we define as parasites now ranges from genetic sequences capable of reproducing in a relationship characterized by dependence on other sequences of genetic material all the way to higher vertebrates and plants, including (along the way) viruses, bacteria, protozoa, worms, arthropods, and any other life form that finds its ecological niche in another living being.

Several important authors discuss this interesting issue, including Anderson \& May (1978), who classify microparasites and macroparasites according to their capacity to multiply in the host.

It is still common (due mainly to tradition) to separate the study of fungi, bacteria, and viruses into their respective sciences, and to refer to the study of protozoa, helminths and arthropods as parasitology, without great systematic criteria, as highlighted by the editor of the journal Parasitology in its special centennial edition (Cox, 2009).

However, parasitism is a branch of ecology, and it is thus much more interesting to study the phenomenon in all its complexity, i.e., as the study of parasite-host-environment relations when one, the parasite, finds its ecological niche in the other, its host. There are numerous examples. Many parasites are influential in maintaining or modifying communities of hosts, studied in the line of research called the ecology and evolution of parasitism (Lebarbenchon, Poulin \& Thomas, 2009).

\section{MOLECULAR PARASITES}

Many authors contend that the definition of parasites includes fragments of genome identified as external to the cell in which they are found (Walisko \& Ivics, 2006).

Mobile gene sequences called transposable elements or transposons are fragments of deoxyribonucleic acid (DNA) that move and replicate in a host cell's genome. When they insert themselves into genes, they can induce unstable mutations, but the latter are generally reversible (Van Sluys, Scotercci \& Costa, 2001). Like viruses, they use the cell's resources to multiply. According to Walisko \& Ivics (2006), just as viruses developed strategies to interact and survive in the host cell, transposons produced mechanisms capable of modulating the cell cycle to their advantage.

Another example of parasites are small molecules of ribonucleic acid (RNA) called satellite RNAs (satRNAs), which act as molecular parasites in certain plant RNA viruses (Maramorosch, 1991). These satellite RNAs need helper viruses to replicate in host cells.

SatRNAs are encapsulated by the coat protein of the helper viruses. The presence of a satRNA can alter the symptoms caused by the helper viruses, usually attenuating them but in some cases intensifying them (Osman \& Buck, 1991). Examples of this case of parasitism are the satellite viruses of tobacco mosaic and tobacco necrosis (Tobavirus and Necrovirus), used in agriculture (Romano \& Monte-Neshich, 1996).

Another aspect of parasitism that has still received little research attention is the infection of organisms by prions. A prion is defined as a "proteinaceous infectious particle" (= prion) that lacks genetic material (DNA or RNA); prions multiply rapidly and can convert protein molecules into substances with the potential to cause harm to the host, simply by altering its spatial structure (Cantarino Costa \& Borges, 2001). 
Prions may have given rise to the first viral particles by incorporating themselves into cells' nucleic acid, causing protein adherence and their encapsulation. According to this theory, the capsids formed by the prion's proteins surrounding the RNA formed the first RNA viruses (Lupi, Dadalti \& Goodheart, 2007).

Other molecular parasites consist of genetic material external to the cell. Viruses, plasmids, and bacteriophages are extrachromosomal transmissible genetic elements, or genomic fragments that depend on a host cell to multiply (Romano et al., 2001).

These elements played an important role in the origin and evolution of life on Earth, which only became possible as a consequence of parasitism in what was still a molecular world, some 4.4 to 3.8 billion years ago (Chang, 1999; Nisbet \& Sleep, 2001). In this molecular world, proto-organisms associated with and related to each other in such a way that they were able to multiply by reproducing their molecular composition, using parts of another protoorganism's composition.

Since extra or intrachromosomal transmissible genetic elements depend on a host cell to multiply, they cannot have preceded it (Lederberg, 1997). These elements may have given rise to nuclear DNA and other cell organelles (Lederberg, 1998). Thus, extrachromosomal genetic elements and transposons represent relics of primitive molecular parasites. They played (and still play) an important evolutionary role, since their inclusion in the genome of host cells promotes genetic diversity. Many of the alterations resulting from this interaction were certainly deleterious, but various others proved advantageous to their hosts (Sverdlov, 1998).

As an important factor in biodiversity, beginning at the molecular level and subsequently in the intracellular milieu, parasitism fostered the diversification of life forms and species radiation, resulting from multiple associations.

Organelles originating from these associations allowed the origin and evolution of cells. (Corsaro et al., 1999) suggest that the eukaryotic cell may have emerged as the consequence of a frustrated episode of predation or parasitism. Due to the associations established during the evolution of life, not only the nucleus but the entire cell is a chimera, a poly-heterogenomic state derived from a long history of parasitic associations. The associations between microorganisms that resulted in the mitochondria, hydrogenosomes, chloroplasts, and other intracellular bodies guaranteed a significant increase in the complexity between organisms that resulted in growing capacity to occupy new ecological niches (Andersson et al., 1998; Roger et al., 1998). These important events provided cells with sources of bioenergy and biosynthesis (Dyall, Brown \& Johnson, 2004). However, and above all, the advent of the cell offered possibilities for new parasite niches (Thompson, 1999).

One of the most interesting aspects in the study of these associations is the contribution by the host cell itself to the constitution of the genome in these organelles, through horizontal gene transfer (Dyall, Brown \& Johnson, 2004). Ancient invasions of other cells by bacteria provided the emergence of mitochondria, chloroplasts, and other organelles. Parasite interaction was so great that it is impossible to survive separately.

\section{AT THE OTHER EXTREME: VERTEBRATE PARASITES AND HIGHER PLANTS}

Life on Earth thus results from the phenomenon of parasitism. All life forms are parasitized, and that is why they exist (Araújo et al., 2003). One of the most interesting aspects of this phenomenon is the evolution of life. For example, the evolution of mammals: assuming the broad definition of parasitism, the fetus can be considered a parasite (at least a temporary parasite) of the mother that maintains it during gestation. 
Some species of birds that do not build nests are considered parasites because they use other species' nests to lay their eggs. The foster parents (i.e., hosts) incubate the eggs and care for the nestlings, sometimes to the detriment of their own brood (Smith, 1979). Parasitism between bird species occurs all over the planet.

In Central America, Smith (1979) conducted elucidating experiments on the relations between parasitic bird species, host birds, and flies. These organisms established interesting and complex interrelations.

In some species, when the female lays her egg in the host nest and the foster parents are away, she throws out the host mother's eggs. In others, the parasite nestling itself hatches first and takes charge of dumping out the host species' eggs.

Other species eliminate their foster siblings after they hatch. Still, in some species the parasite and host nestlings live together in the same nest. Since the latter are usually smaller, the parasitic nestling develops better and faster, well fed by the host parents, opening its beak wider and attracting their attention.

Zahavi et al (1999) discuss the evolution of such relations between such bird species and report that host couples previously experienced with parasitic birds are able to recognize the odd eggs and throw them out of the nest.

These examples illustrate deleterious effects in the host population, but this is not the rule. Smith (1968) demonstrated that the offspring of host birds are attacked by flies whose larvae, when numerous, lead to their death. However, the offspring of parasitic birds feed on fly larvae and are able to control infection in their foster siblings. The survival of the latter in the presence of parasitic birds becomes successful when compared to nestlings without foster siblings. This shows how parasite-host-environment relations establish mutual nuances which make it difficult to set limits between harm and benefit.

The higher plants also include examples of parasitism. Some relations are highly complex, for example between the parasite Cuscuta pentagona and its host. C. pentagona, a small vine, is capable of using volatile "cues" to locate the host plant, the tomato (Runyon, Mescher \& Moraes, 2006).

Carrenho, Trufem \& Bononi (2001) explore the relations between mycorrhizal fungi and various plants. Purin \& Rilling (2008) discuss parasite-host relations, reviewing the concept of parasitism. According to some authors (Corsaro et al., 1999), the orchid parasitizes the mycorrhizal fungus and not vice versa, since the plant uses the fungus to germinate its seed and develop the seedling (Pereira et al., 2005).

Other examples of parasitism in higher plants include the so-called tree-strangler trees. The seeds of these species germinate on other trees, using their trunk or branches as substrate. The roots seek the ground, while the branches reach the upper tiers of the forest canopy more quickly. Little by little they envelope the host tree, which finally succumbs to the parasite's "embrace" (we recommend reading the short story "O mata-pau", or "The Tree Strangler", in the book Urupês, by Brazilian author Monteiro Lobato).

\section{BETWEEN THE EXTREMES: BACTERIA, FUNGI, PROTOZOA, WORMS, AND MUCH MORE...}

The parasite does not have the exclusive capacity to cause harm or benefit to the host. The manifestations that can occur in the parasite-host-environment interaction result from specificities in each of the system's components. Parasites can in fact benefit individuals of a given host species, while others are harmed by (or indifferent to) the parasitic infection. This complexity varies according to the parasite and host species and the environment in which they live. 
In the case of host species living in societies, other factors are involved. Especially in the human species, these factors are inherent to social, political, and even economic moments, besides relevant cultural aspects in each ethnic group and human community and emotions and ways of reacting to stimuli, both individually and collectively. The determinants of health and disease thus depend not only on the parasite's presence in the host, but also on a series of events resulting from complex interaction in the parasite-host-environment system. In the human species, a series of factors can lead to changes in equilibrium. The parasite is thus a necessary (but not sufficient) condition for triggering a parasitic disease (Ferreira, 1973).

Individual or regional differences commonly occur in the behavior of parasitic diseases. For example, toxoplasmosis can display absolutely benign and asymptomatic forms, but also more severe clinical forms (Machado, Silva \& Pinto, 1968). Other examples include regional variations in Chagas disease, schistosomiasis, and amoebiasis, among others, in which the infection is present, but not the disease. Among a large number of individuals infected with the tuberculosis bacillus, only a few actually become ill (Ferreira, 1973).

Parasitic infection and parasitic disease are distinct phenomena. Infection is defined as the parasite's presence in the host, in which it spends part or all of its life cycle. Parasitic disease involves the appearance of signs and symptoms resulting from parasite-host-environment interaction in a given individual (Araújo et. al., 2003).

Parasites can be more or less virulent and more or less pathogenic. As categories, virulence and pathogenicity can be separated or combined in relation to the parasite-host-environment system. Some authors use the two terms as synonyms, while others make a distinction between them (Poulin \& Combes, 1999, 2000). The ecological focus of parasitism emphasizes the difference: while virulence prioritizes the parasite's capacity to multiply and transmit to other hosts, pathogenicity refers to the capacity to cause characteristic signs and symptoms of clinical states in parasitic diseases.

A typical example is Entamoeba invadens, which parasitizes snakes. This protozoan species lives in the gut of snakes without causing any harm, feeding on the intestinal content and multiplying. However, if the temperature increases, it can cause an increase in the intestinal transit by injuring the mucosa, or become invasive, leading to the host's death. Barrow \& Stockton (1960) observed eight species of snakes infected with this parasite at different temperatures, from $13^{\circ} \mathrm{C}$ to $25^{\circ} \mathrm{C}$. At lower temperatures the researchers did not observe lesions, although they continued to isolate Entamoeba invadens in culture. Snakes kept at higher temperatures presented lesions, and even those that had not manifested symptoms at low temperatures became sick when placed at $25^{\circ} \mathrm{C}$.

Classic articles by Noble $(1962,1966)$ also showed the different influences the environment can have on each parasitized individual. Squirrels infected with protozoa (Trichomonas) and helminths (Syphacia) were exposed to different stimuli such as heat, light, noise, confinement, hunger, and others, and later compared to animals that were also infected, but not exposed to these stressors. In the stressed animals, the number of parasites retrieved was significantly higher than in those kept under normal conditions of captivity.

There are numerous examples between such parasites and the human species. Petrin et al. (1998) show the relationship between emotional status and the clinical manifestations of trichomoniasis. The appearance and intensification of symptoms from Trichomonas vaginalis infection depend on factors involving the parasite, the human host, and the environment. Infection with Trichomonas vaginalis is classified as a sexually transmissible infection (or disease) (STI-STD). Some women infected with the parasite can transmit the infection without manifesting symptoms, while others become ill, with clinical states ranging from a mild or intermittent vaginal discharge or intensified by the menstrual cycle, to dyspaurenia and more serious symptoms, generally associated with emotional disorders and lifestyle changes (Sobel, 1992). 
Dogs infected with Dioctophyma renale can survive to a late age, without more serious symptoms from the renal degeneration caused by the giant roundworm lodged in one of the kidneys (Nakagawa et al., 2007).

The same happens with the giant roundworm of humans, which reaches approximately $40 \mathrm{~cm}$ in the host's gut. Parasitism with Ascaris lumbricoides can go entirely unnoticed. Individuals sometimes realize they are infected when they pass live, moving worms, both in the stool and by the mouth, nose, or even ears, in the latter with perforation of the eardrum (Rey, 2001).

Such varied situations with parasites that infect humans and other host species increasingly explain the use of the expanded concept of parasitism. How does one explain the limits imposed by definitions of "commensals" and "parasites" in the case of protozoa and helminths found in the human gut?

Aucott \& Ravdin (1993) described clinical manifestations resulting from pathogenic processes caused by Entamoeba coli, a protozoan classified as an intestinal "commensal". Meanwhile, Dixon (2007) described other protozoa viewed as harmless commensals, such as Cryptosporidium parvum, which cause serious clinical states in their hosts under specific circumstances. Other authors (Dworkin et al., 2007; Visvesvara, Moura \& Schuester, 2007) have described serious clinical states caused by protozoa previously considered free-living or harmless in the human host.

Some bacteria such as Helicobacter pylori illustrate how the majority of the human population is infected, but asymptomatic. However, some individuals can develop clinical states in which the bacteria's presence is associated with chronic gastritis, ulcers, and gastric carcinoma (Figueiredo \& Silva, 2005).

As for parasitism with intestinal helminths, a curious phenomenon occurred with infection by Trichuris trichiura. This helminth was associated with a clinical condition, common in colonial America, called maculo or mal del culo, in Spanish: rectal prolapse with abundant "worms". Although we cannot be certain whether "worm" referred to helminths, since at the time of such descriptions the term could have meant either helminths or insect larvae, the fact is that this disease disappeared or became rare after the colonial period.

Rectal prolapse associated with Trichuris trichiura infection is part of modern clinical manifestations, although very rare and limited to individual host situations, more common in undernourished children and the elderly.

In conclusion, parasitism is a branch of ecology and should be studied as such. Infection, or the presence of a given parasite in a given host, does not necessarily mean parasitic disease. The appearance of signs and symptoms associated with a given parasite results from a set of factors that are inherent to the parasite and host and to the environment in which they are found. Aidan Cockburn described this very well when he gave examples of the different relations between the parasite, host, and environment in a dynamic and evolutionary process (Cockburn, 1963). Anderson \& May (2004) considered Aidan Cockburn one of the first to discuss the impact of parasitic infections on prehistoric hunter-gatherer peoples whose bands varied from twenty to a hundred individuals (Hassan, 1981). According to Cockburn (1971), some parasite species would have been able to survive in such a number of individuals, even if some died or became immune. Meanwhile, others could only emerge as parasites in humans after a series of events, such as the emergence of villages and the first cities, agriculture, domestication of animals, and population growth, which increased the number of susceptible hosts and contact between persons, thereby facilitating the transmission of parasites.

The ecological focus of parasitism facilitates understanding the events involved in the origin and evolution of parasitic diseases. And to recover precious data from the past, nothing is more appropriate than studies in paleoparasitology. 


\section{REFERENCES}

ANDERSON, R. M. \& MAY, R. M. Infectious Diseases of Humans: dynamics and control. Oxford: Oxford University Press, 2004.

ANDERSSON, S. G. E. et al. The genome sequence of Rickettsia prowazekii and the origin of mitochondria. Nature, 396: 133-140, 1998.

ARAÚJo, A. et al. Parasitism, the diversity of life, and paleoparasitology. Memórias do Instituto Oswaldo Cruz, 98, supl. 1: 5-11, 2003.

AUCOTT, J. N. \& RAVDIN, J. I. Amebiasis and 'nonpathogenic' intestinal protozoa. Infectious Diseases Clinics of North America, 7(3): 467-485, 1993.

BARROW JR, J. H. \& STOCKTON, J. J. The influences of temperature on the host-parasite relationships of several species of snakes infected with Entamoeba invadens. Journal of Protozoology, 7: 377-383, 1960.

BRUMPT, E. Précis de Parasitologie. Paris: Masson, 1913.

CANTARINO COSTA, L. M. \& BORGES, J. R. J. Aspectos da encefalopatia espongiforme bovina. Ciência e Tecnologia de Alimentos, 35(1/2): 1-6, 2001.

CARRENHO, R.; TRUFEM, S. F. B. \& BONONI, V. R. L. Fungos micorrízicos arbusculares em três espécies de fitobiontes instaladas em área de Mata Atlântica ciliar revegetada. Acta Botanica Brasilica, 15: 115-124, 2001.

CHANG, S. Planetary environments and the origin of life. Biology Bulletin, 196: 308-310, 1999.

COCKBURN, A. The Evolution and Eradication of Infectious Diseases. Baltimore: The Johns Hopkins Press, 1963.

COCKBURN, A. Infectious diseases in ancient populations. Current Anthropology, 12: 45-62, 1971.

CORSARO, D. et al. Intracellular life. Critical Reviews in Microbiology, 25: 39-79, 1999.

COX, F. E. G. George Henry Falkiner Nuttal and the origins of parasitology and parasitology. Parasitology, 136: 1.389-1.394, 2009.

DIXON, B. Cryptosporidium education. Lancet Infectious Diseases, 10: 635, 2007.

DWORKIN, M. S. et al. Prevalence of intestinal microsporidiosis in human immunodeficiency virus-infected patients with diarrhea in major United States cities. Revista do Instituto de Medicina Tropical de São Paulo, 49(6): 339-342, 2007.

DYALL, S. D.; BROWN, M. T. \& JOHNSON, P. J. Ancient invasions: from endosymbionts to organelles. Science, 304: 253-257, 2004.

FERREIRA, L. F. O fenômeno parasitismo. Revista da Sociedade Brasileira de Medicina Tropical, 4: 261-277 1973.

FIGUEIREDO, F. A. F. \& SILVA, L. M. Helicobacter pylori. In: COURA, J. R. (Ed.). Dinâmica das Doenças Infecciosas e Parasitárias. Rio de Janeiro: Guanabara Koogan, 2005. v. 2.

HASSAN, F. A. Demographic Archaeology: studies in archaeology. New York: Academic Press, 1981.

HUTCHINSON, G. E. An Introduction to Population Ecology. New Haven and London: Yale University Press, 1980.

LEBARBENCHON, C.; POULIN, R. \& THOMAS, F. Parasitism, biodiversity, and conservation biology. In: THOMAS, F.; GUÉGAN, J. \& RENAUD, F. (Eds.). Ecology \& Evolution of Parasitism. Oxford: Oxford University Press, 2009.

LEDERBERG, J. Infectious disease as an evolutionary paradigm. Emerging Infectious Diseases, 3: 417-423, 1997.

LEDERBERG, J. Emerging infections: an evolutionary perspective. Emerging Infectious Diseases, 4: 366-371, 1998.

LUPI, O.; DADALTI, P. \& GOODHEART, C. Did the first virus self-assemble from self-replicating prion proteins and RNA? Medical Hypothesis, 69: 724-730, 2007.

MACHADO, J. O.; SILVA, S. \& PINTO, L. A. Dados preliminares relativos ao stress na toxoplasmose crônica experimental. O Hospital, 74: 145-153, 1968.

MARAMOROSCH, K. (Ed.). Viroids and Satellites: molecular parasites at the frontier of life. Boca Ratón: CRC Press, 1991. 
NAKAGAWA, T. L. et al. Giant kidney worm (Dioctophyma renale) infections in dogs from Northern Paraná, Brazil. Veterinary Parasitology, 145(3-4): 366-70, 2007.

NISBET, E. G. \& SLEEP, N. H. The habit and nature of early life. Nature, 409: 1.083-1.091, 2001.

NOBLE, G. A. Stress and parasitism II - effect of crowding and fighting among ground squirrels on their Coccidia and Trichomonades. Experimental Parasitology, 12: 368-371, 1962.

NOBLE, G. A. Stress and parasitism III - reduced night temperature and the effect on pinworms of ground squirrels. Experimental Parasitology, 18: 61-62, 1966.

OSMAN, T. A. M. \& BUCK, K. W. Detection of the movement protein of red clover necrotic mosaic virus in a cell wall fraction from infected Nicotiana clevelandii plants. Journal of General Virology, 72: 2.853-2.856, 1991.

PEREIRA, O. L. et al. Isolamento e identificação de fungos micorrízicos rizoctonioides associados a três espécies de orquídeas epífitas neotropicais. Revista Brasileira de Ciências do Solo, 29: 191-197, 2005.

PESSOA, S. B. Parasitologia Médica. Rio de Janeiro: Guanabara, Waissman Koogan, 1951.

PETRIN, D. et al. Clinical and microbiological aspects of Trichomonas vaginalis. Clinical Microbiology Reviews, 11: 300-317, 1998.

POULIN, R. Evolutionary Ecology of Parasites. Princeton, Woodstock: Princeton University Press, 2007.

POULIN, R. \& COMBES, C. The concept of virulence: interpretations and implications. Parasitology Today, 15: 474-475, 1999.

POULIN, R. \& COMBES, C. The concept of virulence - Reply. Parasitology Today, 16: 218, 2000.

PURIN, S. \& RILLING, M.C. Parasitism of arbuscular mycorrhizal fungi: reviewing the evidence. FEMS Microbiology Letters, 279: 8-14, 2008.

REY, L. Parasitologia. 3. ed. Rio de Janeiro: Guanabara Koogan, 2001.

ROBERTS, L. S. \& JANOVY JR., J. Foundations of Parasitology. New York: McGraw-Hill International Edition, 2009.

ROGER, A. J. et al. A mitochondrial-like chaperonin 60 gene in Giardia lamblia: evidence that diplomonads once harbored an endosymbiont related to the progenitor of mitochondria. Proceedings of the National Academy of Sciences, 95: 229-234, 1998.

ROMANO, E. \& MONTE-NESHICH, D. C. ABCTP notícias, Jul 1996. Available at: <www.cnph.embrapa.br/laborato/biocel/abctp24. htm $>$. Accessed Mar 2009.

ROMANO, E. et al. Extreme resistance to two Brazilian strains of potato virus Y (PVY) in transgenic potato, cV. Achat, expressing the PVYo coat protein. Horticultura Brasileira, 19: 118-122, 2001.

RUNYON, J. B.; MESCHER, M. C. \& MORAES, C. M. Volatile chemical cues guide host location and host selection by parasitic plants. Science, 313: 1.964-1.967, 2006.

SMITH, N. G. The advantage of being parasitized. Nature, 219: 690-694, 1968.

SMITH, N. G. Alternate responses by hosts to parasites which may be helpful or harmful. In: NICKOL, B. B. (Ed.). Host Parasite Interfaces. Symposium UNL. New York: Academic Press, 1979.

SOBEL, J. D. Vulvovaginitis. Dermatology Clinics, 10: 339-359, 1992.

SVERDLOV, E. D. Perpetually mobile footprints of ancient infections in human genome. FEBS, 428: 1-6, 1998.

THOMPSON, J. N. The evolution of species interactions. Science, 284: 2.116-2.118, 1999.

VAN SLUYS, M.; SCOTERCCI, K. C. \& COSTA, A. P. P. O genoma instável, sequências genéticas móveis. In: MATIOLI, S. R. (Ed.). Biologia Molecular e Evolução. São Paulo: Holos, 2001.

VISVESVARA, G. S.; MOURA, H. \& SCHUSTER, F. L. Pathogenic and opportunistic free-living amoebae: Acanthamoeba spp., Balamuthia mandrillaris, Naegleria fowleri, and Sappinia diploidea. FEMS Immunology and Medical Microbiology, 50: 1-26, 2007. 
WALISKO, O. \& IVICS, Z. Interference with cell cycle progression by parasitic genetic elements: sleeping beauty joins the club. Cell Cycle, 5(12): 1.275-1.280, 2006.

WHITFIELD, P. J. The Biology of Parasitism: an introduction to the study of associating organisms. London: Edward Arnold, 1979.

ZAHAVI, A. et al. The Handicap Principle: a missing piece in Darwin's puzzle. Oxford: Oxford University Press, 1999. 


\title{
The Origin of Parasites of Humans
}

\author{
Luiz Fernando Ferreira • Karl Jan Reinhard • Adauto Araújo
}

$\mathrm{T}^{\mathrm{h}}$

he origin of parasites of humans is subject to interesting speculation. Paleoparasitology has contributed extensively with its data and findings of parasites in ancient material, shedding light on some questions while raising others concerning the origin and evolution of parasitic infections.

Two main routes are discussed for the origin of parasites in the human species. The first was the so-called ecological route, by which new parasites acquired from the environment began to infect humans as the latter conquered new spaces. This happened during the exploration of new territories and contact with different animal species and their parasites, in addition to free-living species potentially capable of adapting to parasitism. The second route was phylogenetic, by which various parasite species persisted in Homo sapiens, inherited ancestrally and originating during pre-hominid times (Ferreira, 1973). In the latter case, these parasite species are also found in phylogenetically proximate hosts, like the apes of the superfamily Hominoidea, family Hominidae, since the parasites were inherited from a common ancestor. Protozoan species that parasitize humans show greater phylogenetic affinity with those that parasitize primates as compared to those that parasitize other mammals (Hegner, 1928). Thus, phylogenetically inherited parasites include those now found in species Homo sapiens and shared with close primate species like gorillas, chimpanzees, bonobos, and gibbons. When Homo sapiens emerged as a species, some parasites were already ecologically and physiologically adapted to infect us (Ferreira, 1973).

Pinworm infection (Enterobius vermicularis), discussed later in this chapter, illustrates the case of parasites inherited from ancestors. However, other parasites began to infect our species through contamination of different environments that humans began to inhabit, in a dynamic adaptive process. Some parasites are unable to infect humans, or only do so partially. For example, when larvae from hookworms of canids (Ancylostoma caninum and Ancylostoma braziliense) penetrate the human skin, they are unable to complete their life cycle, remaining in the skin tissue and causing a dermatosis called cutaneous larva migrans or creeping eruption due to the itchy trail left by the larvae. The same occurs with larvae of Toxocara canis, which hatch from eggs ingested by the human host. Similar to infection with Ascaris lumbricoides, the eggs hatch in the intestine, but unlike the parasite of humans, their larvae 
cannot complete the cycle and lodge in the liver or other organs, occasionally causing visceral larva migrans in the human host (Queiroz et al., 2006).

The human species and some of its ancestors have always distinguished themselves by extensive mobility and conquering new ecosystems. Another characteristic of humans, the invention and constant improvement of new technologies, created extraordinary changes while simultaneously offering opportunities for other parasite species to enter into contact with and install themselves in the human host, due to another human characteristic, namely constant contact with animals.

\section{THE ORIGIN OF HELMINTH PARASITES}

Systematic studies on the origin of helminth parasites gained important impetus with the work of Baer (1951) and Cameron (1956). These authors speculated on the domestication of animals and plants and the passage of parasites to the human species. According to Pearce-Duvet (2006), the origin of various human parasites, such as the etiological agents of tuberculosis, measles, smallpox, tapeworm infection, and others were associated with the emergence of agriculture and domestication of animals that accompanied human clustering.

However, this idea does not apply to all parasite species, since (as discussed above) some were inherited by humans from their ancestors, as shown by cladistic studies (Hugot, 1999) and paleoparasitological data (Araújo \& Ferreira, 2000).

\section{THE CONTRIBUITION OF PALEOPARASITOLOGY TO STUDIES ON THE ORIGIN OF HUMAN PARASITES}

Paleoparasitology provides the means to trace the origin and dispersal of parasites using various methods. Direct evidence of fossil parasites can be obtained from coprolites, latrines, mummies, sediment from archaeological sites, and a wide variety of other materials (Gonçalves, Araújo \& Ferreira, 2003; Bouchet, Harter \& Le Bailly, 2003). After dating with adequate techniques, the results show the paleogeographic distribution of parasitic infections. Interaction with various other scientific fields has been crucial for paleoparasitological studies. Collaboration with archaeologists, paleontologists, and other specialists is essential for obtaining material and interpreting results. Thus, anthropology, genetics, and molecular biology combine to seek more consistent answers to the evidence from paleoparasitology. Results obtained by recovering genetic material from parasites in archaeological remains provide answers in paleophylogeography, the phylogenetic relations among species over time (Dittmar, Souza \& Araújo, 2006).

Another approach involves the relations of current parasites through cladistic studies. Cladistics, or cladism, is the study of kinship between species, based essentially on the analysis of evolutionary relations (Rey, 2003), using morphology or molecular biology, and inferring the species' origins. Some studies resulted in parasite phylogenies using these mechanisms (Iñiguez et al., 2002). The appearance of given parasite species was determined using the molecular clock, a genetic technique capable of determining when two species diverged. Scientists have used the technique to determine how long species took to evolve, and it is still used to study parasitic infections of public health importance (Salemi et al., 2008).

A potentially powerful approach is the study of fossil parasites using molecular biology techniques. This adds a third dimension to findings from paleoparasitology and cladistic studies by reconstructing changes and permanence in gene sequences over time, using molecular biology techniques (Greenblatt \& Spigelman, 2003). 
Another method to date the emergence of parasites and relate them to host speciation is to superimpose parasites' phylogeny on that of their hosts. If the phylogenies are congruent, one can infer a mutual evolution of the parasite and host species. In such cases, identifying the emergence of parasite species in time and space is based on dating host fossils, either by finding parasite forms in the archaeological or paleontological record or by retrieving genetic material to determine the parasite and host species identification, in a dynamic process of the history of the evolutionary process for each relationship between certain parasite and host species (Araújo et al., 2003).

Parasites found in extinct host species illustrate this line of investigation. Finding nematode larvae in coprolites from a species of hyena that inhabited northern Italy opened this field of investigation (Ferreira, Araújo \& Duarte, 1993). Even older parasites were found in Belgium in dinosaurs (iguanodons) from the Cretaceous. Protozoan cysts and helminth eggs were described in coprolites from these animals, dated to millions of years before present (Poinar Jr. \& Boucot, 2006).

Possible new parasite species were described in dinosaur coprolites, and protozoan parasites were described in insects preserved in amber, thus demonstrating the potential preservation achieved by these ancient remains (Poinar Jr., 2007, 2008).

When studying the evolution of parasites, it is important to view them as part of the a complex system consisting of the parasite, the host, and the environment in which they are situated, if possible understanding the relationship between a parasite species and its host and how this relationship is affected by the environment. One can thus infer aspects of the ecology of diseases in ancient peoples, or pathoecology (Reinhard, 1992). Therefore, when approaching the various aspects of parasite-human host relations, many situations can be examined and the results can contribute to a better understanding of the origin and evolution of infectious diseases.

\section{ANTIQUITY OF HUMAN PARASITES}

Ever since humans emerged as a species several million years ago, we have been parasitized by various organisms such as viruses, bacteria, protozoa, helminths, arthropods, and others. As with all other living beings, human life does not exist without the presence of parasites.

Transmission of a parasitic infection from host to host occurs in various ways, according to the parasite species, and the mechanisms have undergone adaptations throughout the evolution of the parasite-host-environment triad. Such mechanisms can include direct host- to-host transmission, contamination of the environment with infective forms of the parasite, or transmission by vectors like arthropods, mollusks, or other invertebrates, as well as so-called parathenic hosts (Rey, 2003).

Some parasites are transmitted between hosts, unimpeded by factors from the macroenvironment in which the host lives, such as climate, $\mathrm{pH}$, or soil moisture, since they develop alternative strategies. Among the nematode parasites of humans, Enterobius vermicularis is transmitted from one host to another without necessarily passing through the soil. In the E. vermicularis life cycle, gravid females migrate from the large intestine to the anal region (especially when the infected person is resting), causing perianal discomfort and itching. The females, full of eggs, burst due to degeneration or when the host scratches, releasing the eggs. Since the eggs are already embryonated, the larvae can hatch and migrate back into the intestine. The eggs can then contaminate the host's hands, infecting him again through hand-to-mouth movements. Other persons thus become infected through close or direct physical contact with the host. One can imagine how many adults have acquired pinworm infection by holding infected children in their laps; the infected children playfully touch the adult's mouth with their hands full of eggs under the fingernails! 
Eggs are found in dust and especially in bed clothes, dispersing in the wind and on air currents. In orphanages, barracks, prisons, hostels, and other places with collective sleeping quarters, making up beds and shaking the bed sheets disperses the eggs throughout the environment, quickly contaminating everyone.

Pinworm infection is so well-adapted to humans that it is distributed worldwide, in the widest diversity of biomes, regardless of temperature, humidity, or other transmission factors. The same pinworm species infects the Inuit of Alaska, indigenous peoples from the Amazon rainforest, Australian Aborigines, and indigenous peoples from Patagonia (Araújo et al., 1988).

The history of the evolution of pinworms that parasitize humans has been traced by various paleoparasitological approaches. In association with paleoparasitology, cladistic studies have provided a successful method. Brooks \& Glen (1982) and Hugot, Reinhard \& Gardner (1999) obtained results from refined cladistic analyses of pinworms of apes and other primates. These studies show that pinworm phylogeny runs parallel to primate phylogeny. Pinworms thus evolved mutually with humans and previously with hominid hosts. The conclusion is that the origin of pinworms predates humans, having evolved in pre-hominid human ancestors.

The paleoparasitological record shows data whose antiquity dates back 10,000 years, in North American indigenous groups from the Great Basin Region (Fry \& Hall, 1969). The presence of E. vermicularis in such ancient periods confirms that pinworms were introduced into the Americas with the first migrants. Findings have also been recorded in Egyptian mummies, prior to the great Portuguese and Spanish seafaring voyages (Horne, 2002; Bouchet, Harter \& Le Bailly, 2003).

Morphologically, the eggs found in archaeological material are identical to those in the current human population. However, some differences have been found in their genetic makeup in certain South American human populations (Iñíguez et al., 2002). These studies point to distinct origins of the parasite strains in the Americas, with implications for the peopling of the American continent.

Reinhard (1990) showed that the characteristics of interactions with the environment adopted by certain groups facilitated the conditions for the increase or decrease in risk of pinworm infection. In some groups of huntergatherers, a diet rich in plants with anthelmintic activity apparently limited various helminths infections, including E. vermicularis. In contrast, the construction of buildings, as in the case of the Ancestral Pueblos in Arizona and the Incas in Chile, along with the reduction in the ingestion of plants with anthelmintic activity, caused a significant increase in E. vermicularis infection.

The construction of apartment-style buildings in densely grouped (although relatively small) populations, combined with the fact that pinworm infection can be transmitted by egg transport on air currents, created a new ecological situation that favored pinworm parasitism. Thus, the evolution of pinworm transmission was intimately related to human behavior and characteristics during a period in which human populations were sparse and small. Changes in human ecology, like the adoption of collective dwellings, enhanced the parasite's transmission by concentrating more hosts in confined spaces (Reinhard, Ambler \& McGuffie, 1985; Ferreira et al., 1989).

E. vermicularis is one example among many, like other nematodes that live their cycle in the soil, called geohelminths, which took their evolutionary paths by following the human host ever since the species emerged on the African continent. 


\section{LICE IN HUMANS}

Lice are another interesting example of parasites inherited from pre-human ancestors. Like pinworms, lice of humans are transmitted directly between hosts, and the infection is found in human populations in the most diverse places on the planet. The same louse species or phylogenetically proximate subspecies can infect the Inuit in Alaska, indigenous peoples in the Amazon, and Australian Aborigines (Araújo et al., 1988; Light et al., 2008).

Lice have parasitized primates for at least 25 million years. Approximately 6 million years ago, when chimpanzees and humans diverged, the two host species inherited and shared genus Pediculus (Reed et al., 2007; Raoult et al., 2008). Various studies have traced the origins of lice infection in humans, showing that head lice, Pediculus humanus, coevolved with humans since a pre-hominid, and as occurred with Enterobius vermicularis, spread to other parts of the world, when humans dispersed out of Africa. Paleoparasitological findings have confirmed these assumptions. Lice have been found in archaeological sites in the Southeast United States, Central Mexico, the Aleutian Islands, Peru, Brazil, and Greenland, in times prior to Christopher Columbus' arrival in the Americas (Rick et al., 2002a).

Like Enterobius vermicularis, lice of humans suffered less influence from conditions in the macroenvironment but had to adapt to changes introduced by their host in the microenvironment. For example, when humans began to wear clothes, change hygiene habits, and adopt haircuts or use wigs and elaborate hairdos that went months without changing, the human host changed the microenvironment in which the parasite lived.

Paleoparasitological findings show that lice were present in what is now Brazilian territory some 10,640 \pm 80 years ago (Araújo et al., 2000). These data, as well as the oldest data for E. vermicularis (Fry \& Moore, 1969), indicate that human lice infection was introduced into the Americas with the first migrants more than 10,000 years before the arrival of the first Europeans on the continent (Araújo et al., 2000).

Archaeological and paleoparasitological reconstructions of the archaeological site where lice were found in what is now Arizona, USA, dated 600 AD (Reinhard, unpublished data), indicate that this human group consisted of numerous adults and children that subsisted on diversified agriculture.

Meanwhile, studies in the Great Basin, where lice infection was also found, showed that the infected population consisted of small groups of nomadic hunter-gatherers that fed on a limited variety of animals and plants. The data thus show that lice infection existed in societies with different degrees of complexity.

Lice infection in Andean societies that used sophisticated hairdos was common and perhaps related to the trade and control of groups dominated by Inca society. There are documents referring to taxes paid with tiny bags of nits and adult lice (Souffez, 2001).

An interesting aspect of lice infection is that geographic isolation provided distinct opportunities for evolution of the head and body lice strains. Some researchers in systematics have even postulated variations of the current species Pediculus humanus when comparing indigenous peoples of North and South America (Ewing, 1926). These studies have continued recently with the work of Yong et al (2003), Kittler, Kayser \& Stoneking (2003), Leo \& Barker (2005), and Leo et al (2005).

The lice that parasitize human hair, belonging to genus Pediculus, present two distinct lineages. One is only found parasitizing hair, while the other can be found in both hair and clothing. The louse species that parasitizes chimpanzees, Pediculus schaeffi, and the lineage of Pediculus humanus found in both the hair and on the body shared a common ancestor some 6 million years, consistent with the their host species' diversification (Reed et al., 2007). The other lineage of Pediculus humanus, found only in hair, parasitizes humans in the New World, having diversified 
by geographic isolation some 1 million years ago (Reed et al., 2004). The latter research group has studied the genetic diversity of modern louse specimens collected in diverse regions, concluding that three lineages exist, A, B, and C, with different geographic origins on the various continents. They concluded that lineage B has an American origin (Light et al., 2008).

Such diversification can be used for lice found in archaeological material, especially in studies using molecular biology techniques, comparing genetic sequences between modern and ancient lineages to elucidate the geographic origin of the parasites and human groups.

The discussion should include another genus of lice, Pthirus, including species Pthirus pubis, a parasite of humans, and Pthirus gorillae, a parasite of gorillas. While species from genus Pediculus are only found in humans and chimpanzees, genus Pthirus is found in humans and gorillas, but not in chimpanzees. There are some inconsistencies in the time at which the two Pthirus species separated, failing to coincide with the divergence of their hosts (Reed et al., 2007).

Specimens of the two genera have been found in human remains in both the old and New Worlds (Rick et al., 2002b; Mumcuoglu et al., 2003). An interesting line of study focuses on nits in well-preserved hair from mummified bodies, as found in the Atacama Desert in Chile, some cases in Brazil and the United States, and even on some shrunken heads, used as trophies by some South American indigenous groups. As shown by Linardi et al (1988), the eggs remain attached to the hair shaft for a long time and can be studied to estimate the time of infection of the individual according to the position in relation to the hair root.

\section{EXAMPLES OF OTHER PARASITES}

Trichuris trichiura or whipworm, a geo-helminth nematode that parasitizes the large intestine of humans, also reached the human species through pre-hominid ancestors. Trichuris eggs are transmitted by fecal contamination. They require specific environmental conditions like soil characteristics - moisture, $\mathrm{pH}$, and temperature - for a period of time, until embryonating and becoming infective, and are ingested by (and infect) a new human host. The eggs are resistant but remain infective for a limited time.

There were two alternative hypotheses for the origin of human infection with Trichuris trichiura, reviewed by Confalonieri et al (1985). According to one, Trichuris trichiura infection originated with the domestication of pigs (Sus scrofa), and the species is derived from Trichuris suis (Samsonov, 1969). According to this hypothesis, the two species diverged recently and thus display very similar morphological characteristics, although detailed analyses show that they are distinct species. The two parasite species have completely diverse hosts.

The parasite of swine is found in Sus scrofa domestica and Sus scrofa nigripes, respectively domestic swine and wild boars (European boar). Trichuris trichiura infects great apes in nature, including species from genera Pongo, Pan, and Hylobates, and two Cercopithecoidae, Macaca and Papio.

Other Trichuris species evolved in Old World prosimians and primates. Trichuris cynocephalus parasitizes Papio hamadryas and Papio cynocephalus, Trichuris presbyticus is found in Prespytis arvunculus, and Trichuris lemuris in Cheiroglaeus major, Lemur catta, Lemur macaco, and Daubentonia madagascariensis (Ooi et al., 1993).

The distribution of Trichuris species in primates indicates mutual evolution with the primate hosts. The diversification of Trichuris species parallels the adaptive radiation of primates (Sarwar, 1959). 
Trichuris trichiura speciated with the evolution of Hominoidea, and like Enterobius vermicularis, it already existed in hominids when they appeared.

Paleoparasitological findings of Trichuris trichiura eggs in mummified bodies and human coprolites support the hypothesis that the species precedes the estimated date for the domestication of pigs. The famous mummy Ötzi from the Tyrolean Alps was infected with Trichuris trichiura, as were mummified bodies found in European turf bogs before the presumed dates for the domestication of pigs (Bouchet et al., 2003). In the New World, Trichuris trichiura eggs were found in human coprolites dated to 5,000 BP (Confalonieri, 1988).

The necessary environmental conditions for maintaining the parasite's life cycle point to an origin in tropical regions. For embryonation to occur, the eggs must be in soil with adequate humidity, temperature, and shade. Such conditions are consistent with the tropical and subtropical environment in which hominids evolved and where humans parasitized by this species are currently found.

\section{PLEISTOCENE DATING OF PARASITISM BY ASCARIS LUMBRICOIDES}

In other cases, paleoparasitological studies have refuted assumptions on the origin of certain parasites. The morphological similarity between the intestinal nematodes Ascaris lumbricoides and Ascaris suum, the ascarid parasites of humans and swine, respectively, led researchers to accept that the evolution of these parasites was somehow related. Genetically, the two parasites differ very little from each other and can be considered sibling species. In fact, it was proven that Ascaris suum can experimentally infect humans and that Ascaris lumbricoides can experimentally infect swine (Leles et al. 2008). The evolutionary separation may have occurred more recently, and there are doubts as to whether they are really two distinct species.

Since Cameron's pioneering work on Ascaris lumbricoides, it was accepted that the parasite originated from the species found in swine. The domestication of pigs was thought to have provided human contact with ascarids, and that Ascaris lumbricoides subsequently emerged as a species.

However, infection with Ascaris lumbricoides has been confirmed in archaeological sites in North and South America. The oldest known date for this parasite is 5,000 BP. As far as we know, Ascaris suum does not infect South American wild pigs under natural conditions (Artiodactyla, Tayassuidae). In addition, no record of Ascaris lumbricoides has been found in regions where wild pigs were autochthonous. The domestication of pigs must have occurred in the old World around 7,000 years ago. Therefore, the presence of Ascaris lumbricoides in the New World is inconsistent with an evolutionary origin of Ascaris lumbricoides from Ascaris suum with the domestication of pigs.

The data suggest that the evolutionary origin of Ascaris lumbricoides is older than previously believed. However, the data from America are circumstantial. Direct evidence from the Old World was needed to definitively confirm infection with Ascaris lumbricoides in humans prior to the domestication of pigs.

Such evidence was finally found in human coprolites excavated in France, dated 28,000 BP (Loreille \& Bouchet, 2003). The analyses were positive for Ascaris lumbricoides eggs, thus proving that Ascaris lumbricoides parasitized humans since the Pleistocene, long before the domestication of pigs.

One can conclude that if Ascaris lumbricoides and Ascaris suum had a common evolutionary history, the latter would have originated from the human parasite after the domestication of swine, through human contact with these animals. In other words, precisely the opposite of what was believed. 
Ascaris eggs remain infective in the soil for many months or even years, depending on conditions in the environment (Rey, 2008), but resisting changes from intense heat to intense cold, for example on the European continent. While the macroenvironment changed, the microenvironment (i.e., the host's organism) remained the same. This allowed infection with Ascaris lumbricoides to be maintained in the small bands of hunter-gatherers that characterized human prehistory.

If a temporary camp were contaminated, the parasites' eggs could remain viable and infective for more than a year and infect new hosts. This parasite-host-environment relationship was enhanced when human populations became urban.

Paleoparasitological data on Ascaris lumbricoides indicate a long history of infection in Europe, since very ancient periods, still in the Neolithic. However, the infection became much more common under the unhealthy conditions and crowding of Medieval Europe (Fernandes et al., 2005). After establishing itself as the most common helminth infection in humans, it dispersed with the Europeans that colonized other regions of the globe. Disordered urbanization, fostering conditions of environmental contamination by fecal matter, made Ascaris lumbricoides infection an inevitable part of urban life.

An interesting aspect of Ascaris lumbricoides is its relative scarcity in parts of the prehistoric world where Trichuris trichiura is commonly found. Both during the medieval period and in modern times, Ascaris lumbricoides and Trichuris trichiura are frequently associated. The two have similar life cycles, as well as resistant eggs that can remain infective for long periods, months or years (Rey, 2005). Both proliferate in crowded and unhealthy conditions.

Even so, in prehistoric times they were not always associated or their eggs were not preserved identically in archaeological sites, indicating a subtle difference in the two species' parasite-host-environment relations or in their preservation in the archaeological record.

Ascaris lumbricoides eggs have only been found in two prehistoric sites in the New World, one in the Southwest United States and the other in Northern Peru. There was also a single finding in Southeast Brazil (Gonçalves, Araújo \& Ferreira, 2003). In contrast, Trichuris trichiura eggs are found in many sites in the Americas.

Ascaris lumbricoides was absent from Japan until the introduction of rice farming, although Trichuris trichiura was present in the ancient Jomon cultures (Matsui, Kanehara \& Kanehara, 2003). Considering the ubiquity of Ascaris lumbricoides infection in ancient urban settlements and in the modern world, its scarcity or absence in certain parts of the world and during certain periods requires explanation. Conditions in the parasite-host-environment system may have made human infection relatively rare until urban settlements and agricultural practices developed.

Meanwhile, the taphonomic process influences organic structures of diverse origins in different ways (Timothy et al., 2003). Thus, in South American sites previously considered negative for Ascaris lumbricoides eggs (Gonçalves, Araújo \& Ferreira, 2003), molecular biology techniques showed positive results with the recovery of genetic material from the parasite (Loreille \& Bouchet, 2003; Leles et al., 2008, 2009).

Considering only the dates, Ascaris lumbricoides infection most likely spread across Europe during the Pleistocene, was introduced into parts of the Americas in the Holocene, but only penetrated into Japan with rice farming (50 AD). Thus far we lack data on Africa that allow a more precise evaluation on its origin in pre-hominids or in human ancestors closer to our species.

Finally, Ascaris lumbricoides is more susceptible to anthelmintics than Trichuris trichiura. Adult Ascaris lumbricoides worms live in the small intestine and remain there due to muscle movements. Adult Trichuris trichiura 
burrow their thinner anterior portion into the mucosa of the large intestine, leaving the posterior portion projecting into the lumen. Some anthelmintics temporarily paralyze the parasites. Temporary paralysis of Ascaris lumbricoides leads to its expulsion from the intestine, which may not occur with Trichuris trichiura, since it remains attached to the intestinal mucosa. Thus, by using plants with active ingredients that cause paralysis in worms, human populations could have altered the environmental conditions for Ascaris lumbricoides, limiting infection by the parasite, but the use of these same plants would have no effect on Trichuris trichiura (Chaves \& Reinhard, 2003).

\section{THE ANTIQUITY OF HOOKWORM INFECTION AND ITS ANCIENT DISTRIBUITION}

The clinical condition known as ancylostomiasis is associated with the presence of Ancylostoma duodenale or Necator americanus in the human intestine. These species can be found alone or in association in the same individual. Ancylostoma duodenale and Necator americanus are considered anthropophilic, thus more adapted to the human host. However, parasitism can occur with adult forms of Ancylostoma ceylanicum, and by larvae and rarely adult forms of Ancylostoma caninum and Ancylostoma braziliense (Rep, 1963).

The Southeast region of the Sahara Desert in Africa is considered the center for the dispersal of human infection with Necator americanus. Dispersal of Ancylostoma duodenale began from some point in Northern Africa, Southern Europe, or Southern Asia. After the increase in communication among peoples, especially during the $19^{\text {th }}$ century, the limits in the distribution of the two species became less clear (Manter, 1967).

Cameron (1927) was the first to discuss the origin of hookworm species that parasitize humans. According to him, wild canids and later domestic dogs were the source of an ancestral species of Ancylostoma duodenale. Humans would thus have acquired this parasite after the domestication of dogs.

According to Zeuner (1963), the first relations between wolves, wild dogs, and hunter-gatherer humans could not have been very close, given the presumed competition between them. The author hypothesized that domestication of the dog occurred in Europe, possibly during the Paleolithic, but certainly by the Mesolithic, some 9,000 years ago. Canine and human skeletons have been found in association, dated to 11,000 BP in Arabia and 11,500 BP in Persia (Protsch \& Berger, 1973).

According to one hypothesis, Necator americanus originated from parasites of African ungulates, and a prehominid ancestor was parasitized in the savannah-forest ecotone, in the same habitat as zebras and gnus. Thus, Ancylostoma duodenale would have emerged in Homo sapiens, while Necator americanus already infected human ancestors. However, this view was not unanimous. Fonseca, Filho (1972) contended that both parasite species were already found in Homo sapiens when the latter speciated, since they exist in African great apes (Pan (Homo) troglodytes, Gorilla gorilla). These primates thus acquired the parasite from a common ancestor. Meanwhile, this common ancestor became parasitized, probably by the ecological route, by occupying habitats with infected hosts, since the closest species to Necator americanus are found in animal hosts that are not phylogenetically close to primates, such as the ungulates (Chitwood, 1970; Dunn, 1970).

Hoagland \& Schad (1978) studied the origin of parasite species inherited by the phylogenetic route, using the biological characteristics and parasite-host relations observed in Necator americanus. Their results point to the parasite's long association with humans. The parameters verified in the comparison included infection and reproduction strategies, as well as low pathogenicity and virulence. 
The presence of Ancylostoma duodenale in prehistoric populations in the Americas, especially in Northeast Brazil, dated $7,230 \pm 80 \mathrm{BP}$, is strongly indicative of an older association between dogs and humans than previously assumed if Cameron's hypothesis (1927) were correct. In this case, the origin of Ancylostoma duodenale would have been long before 7,000 BP, since both the human host and the parasite originated in the Old World (Araújo, 1988).

In nematode parasites, it is possible to assess the antiquity of parasite-host relations according to the parasite's ontogenic characteristics and pathogenicity (Chabaud, 1955). Hoagland \& Schad (1978) studied these characteristics in Ancylostoma duodenale and Necator americanus. They aimed to determine which species was better adapted to the human host, basing their analysis on the $\mathrm{r}$ and $\mathrm{K}$ selection characteristics (MacArthur \& Wilson, 1967). More opportunistic species are more involved in a process of conquering new habitats, and are considered to be dominated by r selection patterns. K-selected species are more stable in the environment. The analysis concluded that Necator americanus displays patterns of greater stability when compared to Ancylostoma duodenale. However, this analysis is limited by the fact that it compares parasite species that are not closely related.

Therefore, the same procedure was adopted with Ancylostoma duodenale, a parasite of humans, and Ancylostoma caninum, a parasite of canids (Araújo, 1988). The two species' morphological and biological patterns were compared to determine which was better adapted to its specific host. The results showed that the canine parasite has more $\mathrm{r}$ selection attributes than Ancylostoma duodenale in humans.

Other data favoring the hypothesis of an ancient association between Ancylostoma duodenale and humans is the finding of this species (or very closely related species) in other members of the Hominidae family (Dunn, 1966).

Genus Ancylostoma is distributed across carnivores, primates, edentates, rodents, and swine (Lichtenfels Jr., 1980). It probably emerged as a parasite of carnivores, acquiring other hosts over the course of its evolution. However, Ancylostoma caninum does not appear to be older or better adapted to parasitism in canids than Ancylostoma duodenale in Homo sapiens (Araújo, 1988).

The origin of parasitism by Ancylostoma duodenale in humans must be found (as with Necator americanus) in a phylogenetic route coming from pre-hominids. Recent phylogenetic studies based on DNA sequences appear to confirm these hypotheses by showing phylogenetic relations that proved an older history for Ancylostoma duodenale than for Necator americanus (Blaxter, 2000).

In summary, paleoparasitological findings indicate that a large share of current human parasites have lived for a long time with the human species. In the Old World, malaria parasites and Trypanosomatidae have a long evolutionary history with hominids. Thus, human populations emerged and evolved concomitantly with a whole complex of parasites.

\section{THE EVOLUTION OF TRYPANOSOMATIDAE}

Paleoparasitologists have described several more complex relations between parasite, host, and environment in detail. Lambrecht (1985) studied paleontological evidence on species of genus Glossina (tsetse fly) in Africa. Glossina species act as the vector for Trypanosoma rhodesiense and Trypanosoma brucei, the etiological agents of sleeping sickness. His analysis showed that genus Glossina originated in the Pliocene. Based on the characteristics of human resistance to different species of Trypanosoma, Lambrecht (1985) presents convincing evidence that at least one species of Trypanosoma parasitized hominids for millions of years. The author's arguments thus suggest that genus Trypanosoma is another ancestral parasite of the group of hominids. However this was not the route in 
the case of $T$. cruzi, since this parasite only began to be transmitted to humans after the peopling of the Americas, according to the paleoparasitological data.

The reconstruction by Lambrecht (1985) was verified by molecular analysis of some species of Trypanosoma. Stevens, Noyes \& Gibson (1998) analyzed rRNA sequences from four species of Trypanosoma of human and nonhuman primates. The studies showed that T. brucei originated between five and 15 million years ago and coevolved with hominids.

A comprehensive study on the origins of human infection began in the Americas, developed independently by different research teams. Suspected clinical cases of Chagas disease were described in South American mummies (Fornaciari et al., 1992), marking preliminary paleopathological studies in mummified bodies. Some were partially proven by histopathology, but without confirmation as to whether the observed structures were in fact amastigote forms of Trypanosoma cruzi.

The advent of molecular biology techniques has led to great progress in this field, exemplified by the chapter dedicated to the origin and evolution of infection with T. cruzi (see Chapter 26, dedicated to Chagas disease).

Capasso (1998) conducted an evolutionary study on mosquito vectors preserved in amber. Analyzing the diseases transmitted by different genera of mosquito vectors with infectious agents, he deduced the antiquity of important human parasitic diseases. His analysis showed that the genera of mosquito vectors evolved in the Pliocene and inferred that malaria was prevalent in hominids. Thus, by analyzing the vector's antiquity, he reached a conclusion on the antiquity of parasitism by Plasmodium in human populations.

Studies also began in Brazil with insect vectors preserved in amber, leading to the description of new sand fly species (see Chapter 10, on Arthropods and Parasites in Amber).

\section{PARASITES OF ANIMALS IN HUMAN COPROLITES}

As humans began to conquer a wide range of environments, they encountered parasites that infected other animals. Such parasites are called etiological agents of zoonoses, or diseases of animals that are transmitted to humans. However, in the case of helminth infections, we prefer to call them parasites of animals with the potential to infect humans, since the archaeological material does not allow distinguishing between true infections (when the parasite actually establishes itself in the host) and so-called false infections (when helminth eggs from parasites of animals are excreted in the human feces for several days, but without true infection) (Carvalho-Costa et al., 2009). Paleoparasitological data in the Americas have shown the wide distribution of zoonotic parasites among preColumbian hunter-gatherers. One can only speculate on the range of these or similar parasitic infections in Africa, where the paleoparasitological data are scarce (Dittmar \& Steyn, 2004; Horne, 2002).

In the Americas, the following parasites have been found in populations of hunter-gatherers: Moniliformis clarki, Diphyllobothrium pacificum, Echinococcus granulosis, Trichinella spiralis, Paragonimus mexicanus, Echinostoma sp., Parapharyngodon sceleratus, and an unknown tapeworm species. These parasites circulate in wild animals, infecting humans that eat poorly cooked meat or insects (Rey, 2008).

Infection with Moniliformis clarki results from ingesting raw or poorly cooked insects. Its focus of infection in prehistory was situated in the Great Basin Region of North America. The ingestion of raw or poorly cooked marine life can result in infection with Diphyllobothrium pacificum, which appears to be distributed mainly on the South 
American Pacific Coast (Ferreira et al., 1984; Reinhard \& Urban, 2003), but with cases described in populations on the Aleutians Islands (Bouchet et al., 1999).

Hydatic cyst results from ingesting Echinococcus granulosus eggs. The highest prevalence rates of hydatidosis are found in modern-day Africa, where some human groups eat dog intestine slightly seared over flames. This cooking process is light and insufficient to kill the embryos inside the eggs, leading to the ingestion of thousands of the tapeworm's eggs (Garcia, Moro \& Schantz, 2007).

Trichinella spiralis generally causes a severe disease, and infection in humans appears to date to very ancient times (Owen et al., 2005). Infection with Paragonimus mexicanus results from eating poorly cooked freshwater crustaceans. Abundant eggs from Echinostoma sp. were found in a coprolite associated with megacolon in a mummified body in which the presence of T. cruzi was diagnosed with molecular biology techniques. Species of this parasite are found in mammals that ingest fish or crustaceans contaminated with its larvae and thus develop the infection. The infection is common in modern-day Asian countries, but has still not been reported in the Americas, except for the case described above in prehistory (Sianto et al., 2005).

Eggs from an unidentified tapeworm species were found in prehistoric sites in Arizona and Utah, in human coprolites and latrine sediments. The eggs may be from Dipylidium caninum, which has canids as its definitive hosts and rodents as its intermediate hosts. Humans are rarely infected, but some cases have been described (Neafie \& Marty, 1993).

Zoonoses in Europe during the Neolithic and Post-Neolithic must have been a real problem for human groups whose subsistence strategies included raw or poorly cooked meat (Le Bailly et al., 2005, 2007). Foraging cultures have been particularly well-studied in the Americas and can provide general analogies for other parts of the world where there are no available data. Studies in prehistoric American populations suggest that ancient African huntergatherers were also exposed to similar infections. Certain species of Echinococcus and Trichinella are endemic in Africa. Other agents of zoonoses such as Toxocara canis, Toxoplasma gondii, and various tapeworms must have infected the ancestral African populations.

In relation to infection with Toxoplasma gondii, it is interesting that there are no records in ancient populations of humans or animals, although it is now one of the most widely disseminated infections in the world (Tamma, 2007). Genetic material has been successfully recovered from the tissues of experimentally infected and mummified rodents (Terra et al., 2004), and the same technique is still being tested in ancient material. Toxoplasmosis could be one of the oldest infections in humans and other animals ever since the dawn of Africa, but we still lack concrete data to confirm this hypothesis.

Bouchet et al (2003) found Toxocara canis eggs in organic sediments of human and other animal origins, dated 500,000 to 300,000 BP in Europe. Carnivores such as hyena and wolf species, together with humans, inhabited the same cave in which the eggs were found. Since they shared the space, even though at different moments, it is assumed that toxocariasis (Larva migrans visceralis) occurred in humans since this time. These data are consistent with findings that show Homo neanderthalensis butchering animals inside caves in Europe (Mellars, 2006; Metcalfe, 2007).

\section{THE DAWN OF AGRICULTURE AND THE DISSEMINATION OF INFECTIONS BY FECAL MATERIAL}

Cockburn (1973) demonstrated that agriculture led to the exposure of populations to various levels of health risk. Changes in parasite ecology with the introduction of horticulture have been well-studied by paleoparasitology. Various studies have proven Cockburn's view on the influence of horticulture. The horticulturists of the Colorado Plateau, 
United States, were parasitized by a much wider range of species than the ancient hunter-gatherers (Reinhard, 1988; Reinhard, Hevly \& Anderson, 1987). Diseases from fecal contamination intensified with agriculture, and some of them must have emerged in humankind during this period. Anal-oral infection became a problem in the emerging small villages, as exemplified by pinworm infection, discussed in the next chapter (Hugot et al., 1999).

During the medieval period, infections with Ascaris lumbricoides and Trichuris trichiura were so common in Europe that Andrew Jones found concentrations of up to 400 eggs per ml of soil sediment (Jones, 1985). Diseases of fecal contamination had apparently become a common and normal characteristic of urban life. Various records performed by paleoparasitologists confirm this point on parasitism in the medieval period (Bouchet, Harter \& Le Bailly, 2003).

In North America, infection with Hymenolepis nana and Hymenolepis diminuta was probably associated with agriculture. These tapeworm species follow two different types of cycles to maintain their circulation in their hosts (Rey, 2008). One cycle in the case of Hymenolepis diminuta involves a two-host system, with a vertebrate as the definitive host and an invertebrate as the intermediate host. It parasitizes rodents, generally ruderal mice and rats. This type of association usually involves a species of weevil that is commonly found in stored grain and rodents. As discussed by Reinhard, Hevly \& Anderson (1987), agriculture and grain storage facilitated this life cycle. A direct transmission cycle developed in Hymenolepis nana, so the parasite is transmitted between humans, but cases of autoinfection also occur.

The direct life cycle of Hymenolepis nana is unique among tapeworms that parasitize humans. All other tapeworm parasites of humans have a multiple life cycle, with more than one host. The direct cycle of Hymenolepis nana probably emerged recently from the two-host cycle. This emergence was associated with human behavior. Analyses of interspecific variations in isoenzyme patterns between different species of Hymenolepis showed that Hymenolepis microstoma was the common ancestor of Hymenolepis diminuta and Hymenolepis nana (Novak, Taylor \& Pip, 1989). This analysis showed that Hymenolepis nana emerged more recently and that Hymenolepis diminuta is an intermediate form. Later studies on cross-immunity confirmed this hypothesis. The two hymenoleptids of humans, Hymenolepis nana and Hymenolepis diminuta, display phylogenetic proximity, but Hymenolepis nana emerged more recently (Palmas, Ecca \& Gabriele, 1993).

Paleoparasitology made new contributions to the understanding of evolutionary pressures that gave rise to the direct cycle of Hymenolepis nana. The limiting factor for the maintenance of this species' transmission is that the eggs are highly dependent on conditions in the environment. Under hot and humid conditions, the eggs can remain viable for many weeks, but in dry environments they are only viable for a few hours. Thus, in the ecology of the parasitehost-environment system for Hymenolepis nana, the environment determines the likelihood of infection.

Hymenolepis nana eggs have only been found thus far in New World archaeological sites. They were present in prehistoric coprolites in Arizona, on the coast of Peru, in the Atacama Desert in Chile, and in the semiarid region of Northeast Brazil (Gonçalves, Araújo \& Ferreira, 2003). Importantly, all these sites correspond to societies of horticulturists/farmers, and hunter-gatherers in Northeast Brazil.

Eggs of this parasite were also found in latrine sediments in Arizona (Reinhard, Hevly \& Anderson, 1987). Two sites, one in Arizona and the other in Chile, were positive for nematode parasites with a direct cycle. Thus, for the two sites, fecal transmission must have been an efficient mechanism of infection. However, in two other sites, one of which was also in Arizona and the other in Peru, there is no evidence of other parasites transmitted by direct contamination from fecal matter. This may suggest that direct transmission was not effective in these locations. Thus, for these sites, the cycle involving two hosts, insect and rodent, would have maintained the infection cycle, 
and humans would have become infected by fortuitously ingesting the intermediate host arthropod, probably grain weevils or fleas (Reinhard, Hevly \& Anderson, 1987).

\section{OTHER PARASITES OF ANIMALS CAPABLE OF INFECTING HUMANS}

The environment is the determinant factor for infection by parasites. Population concentration causes sanitary problems that affect parasites, both specific to humans and those of animal origin. When more feces of infected individuals accumulate, the environment is more likely to be contaminated with eggs. This potentiates infection by certain zoonoses. For example, $16^{\text {th }}$-century paleoparasitological findings in Japan (Matsui, Kanehara \& Kanehara, 2003) show that humans were infected with Metagonimus yokogawai and Clonorchis sinensis, among other parasite species. Metagonimus yokogawai has two intermediate hosts, first a snail (Semisulcospira) and later various species of freshwater fish.

Likewise, human infection with Clonorchis sinensis is limited by the distribution of the snail, generally Parafossarulus manchouricus, and a fish species, serving as intermediate hosts. The fact that the intermediate host is restricted to the Far East means that distribution of the infection is ecologically limited. However, a case was described in the United States during the period of Chinese migration to America (Reinhard et al., 2008). In $16^{\text {th }}$ century Japan the population was already considerably large, and fecal deposition was widespread, with no sanitary infrastructure (Matsui, Kanehara \& Kanehara, 2003). Fish were an important source of protein and were consumed raw. The parasite-environment subsystem thus generated a major risk of infection for the human host.

It is not surprising to find eggs of parasites of animals in human coprolites, due to eating habits that changed over time (thus representing cases that could be either false parasitism or true infection). For example, the fact that fragments of arthropods or even nearly entire specimens are found in human coprolites demonstrates intentional ingestion by the individuals, which could lead to infection by microorganisms (Johnson et al., 2008).

Paleoparasitology can contribute greatly to studies on the origins of parasitic infections, both in humans and in other animals. The review by Sianto, Chame \& Silva (2009) shows the first steps to understanding these relationships, offering possibilities for dating the appearance of certain eating habits in the prehistoric population according to the presence of specific parasites of animals.

\section{REFERENCES}

ARAÚJO, A. Origem dos ancilostomídeos parasitos do homem. In: FERREIRA, L. F. ARAÚJO, A. \& CONFALONIERI, U. Paleoparasitologia no Brasil. Rio de Janeiro: PEC, Ensp/Fiorawz, 1988.

ARAÚJO, A. \& FERREIRA, L. F. Paleoparasitology and the antiquity of human host-parasite relationships. Memórias do Instituto Oswaldo Cruz, 95, supl. 1: 89-93, 2000.

ARAÚJO, A. et al. Hookworms and the peopling of America. Cadernos de Saúde Pública, 2: 226-233, 1988.

ARAÚjO, A. et al. Ten thousand years of head lice infection. Parasitology Today, 7: 269, 2000.

ARAÚjo, A. et al. Parasitism, the diversity of life, and paleoparasitology. Memórias do Instituto Oswaldo Cruz, 98, supl. 1: 5-11, 2003.

BAER, J. G. Ecology of Animal Parasites. Urbana: University of Illinois Press, 1951.

BLAXTER, M. Genes and genomes of Necator americanus and related hookworms. International Journal for Parasitology, 30: $347-$ $355,2000$. 
BOUCHET, F.; HARTER, S. \& LE BAILLY, M. The state of the art of paleoparasitological research in the Old World. Memórias do Instituto Oswaldo Cruz, 98, suppl. 1: 95-101, 2003.

BOUCHET, F. et al. First paleoparasitological analysis of a midden in the Aleutian Islands (Alaska): results and limits. The Journal of Parasitology, 85: 369-372, 1999.

BROOKS, D. R. \& GLEN, D. R. Pinworms and primates: a case study in coevolution. Proceedings of the Helminthological Society, 49: 76-85, 1982.

CAMERON, T. W. M. The helminth parasites of animals and human disease. Proceedings of the Royal Society of Medicine, 20: 547 556, 1927.

CAMERON, T. W. M. Parasites and Parasitism. London: Methuen, 1956.

CAPASSO, L. The origin of human malaria. International Journal of Anthropology, 13: 165-175, 1998.

CARVAlHo-COSTA, F. A. et al. Pseudoparasitism by Calodium hepaticum (syn. Capillaria hepatica; Hepaticola hepatica) in the Negro river, Brazilian Amazon. Transactions of the Royal Society of Tropical Medicine and Hygiene, 103(10): 1.071-1.073, 2009.

CHABAUD, A. G. Essai d'interpretation phylétique des cycles évolutifs chez les nématodes parasites des vertébrés: conclusions taxonomiques. Annales de Parasitologie Humaine et Comparée, 30: 85-126, 1955.

CHAVES, S. A. M. \& REINHARD, K. Paleopharmacology and pollen: theory, method, and application. Memórias do Instituto Oswaldo Cruz, 98, supl. I: 207-211, 2003.

CHITWOOD, M. Comparative relationships of some parasites of man and old and New World subhuman primates. Laboratory Animal Care, 20: 389-394, 1970.

COCKBURN, A. Death and disease in ancient Egypt. Science, 181: 470-471, 1973.

CONFALONIERI, U. Paleoepidemiologia de T. trichiura na América. In: FERREIRA, L. F.; ARAÚJO, A. \& CONFALONIERI, U. Paleoparasitologia no Brasil. Rio de Janeiro: PEC, Ensp/Fiocruz, 1988.

CONFALONIERI, U. E. et al. The experimental approach to paleoparasitology: desiccation of Trichuris trichiura eggs. Paleopathology Newsletter, 51: 9-11, 1985.

DITTMAR, K. \& STEYN, M. Paleoparasitological analysis of coprolites from K2, an Iron Age archaeological site in South Africa: the first finding of Dicrocoelium sp. eggs. The Journal of Parasitology, 90: 171-173, 2004.

DITTMAR, K.; SOUZA, S. M. M. \& ARAÚJO, A. Challenges of phylogenetic analyses of aDNA sequences. Memórias do Instituto Oswaldo Cruz, 101, supl. 2: 9-13, 2006.

DUNN, F. L. Fur, lice, and history. Science, 154: 846-847, 1966.

DUNN, F. L. Patterns of parasitism in primates: phylogenetic and ecological interpretations, with particular reference to the Hominoidea. Folia Primatologica, 4: 329-345, 1970.

EWING, H. E. A revision of the American lice of the genus Pediculus, together with a key with a consideration of the significances of their geographical and host distributions. Proceedings of the United States National Museum, 68: 1-30, 1926.

Sp. ?? FERNANDES, A. et al. Intestinal parasite analysis in organic sediments collected from a $16^{\text {th }}$ Century Belgium archaeological site. Cadernos de Saúde Pública, 21: 329-332, 2005.

FERREIRA, L. F. O fenômeno parasitismo. Revista da Sociedade Brasileira de Medicina Tropical, 4: 261-277, 1973.

FERREIRA, L. F.; ARAÚJO, A. \& DUARTE, A. N. Nematode larvae in fossilized animal coprolites from lower and Middle Pleistocene sites, Central Italy. The Journal of Parasitology, 79: 440-442, 1993.

FERREIRA, L. F. et al. The finding of eggs of Diphyllobothrium in human coprolites (4,100-1,950 B.C.) from Northern Chile. Memórias do Instituto Oswaldo Cruz, 79: 175-180, 1984. 
FERREIRA, L. F. et al. Infecção por Enterobius vermicularis em populações agropastoris pré-colombianas de San Pedro de Atacama, Chile. Memórias do Instituto Oswaldo Cruz, 84, supl. 4: 197-199, 1989.

FONSECA FILHO, O. Parasitismo e Migrações Pré-Históricas. Rio de Janeiro: Mauro Familiar, 1972.

FORNACIARI, G. et al. Chagas' disease in Peruvian Inca mummy. The Lancet, 339: 128-129, 1992.

FRY, G. F. \& HALL, H. J. Parasitological examination of prehistoric human coprolites from Utah. Proceedings of the Utah Academy of Sciences and Art Letters Part 2, 46: 102-105, 1969.

FRY, G. F. \& MOORE, J. G. Enterobius vermicularis: 10,000-year-old human infection. Science, 166: 1620, 1969.

GARCIA, H. H.; MORO, P. L. \& SCHANTZ, P. M. Zoonotic helminth infections of humans: echinococcosis, cysticercosis and fascioliasis. Current Opinion on Infectious Diseases, 20: 489-494, 2007.

GONÇALVES, M. L. C.; ARAÚJO, A. \& FERREIRA, L. F. Human intestinal parasites in the past: new findings and a review. Memórias do Instituto Oswaldo Cruz, 98, supl. 1: 103-118, 2003.

GREEnblatT, C. \& SPIGELMAN, M. Emerging Pathogens: the archaeology, ecology, and evolution of infectious disease. Oxford: Oxford University Press, 2003.

HEGNER, R.W. The evolutionary significance of the protozoan parasites of monkeys and man. The Quaternary Reviews of Biology, 3: 225-244, 1928.

HOAGLAND, K. E. \& SCHAD, G. A. Necator americanus and Ancylostoma duodenale: life history parameters and epidemiological implications of two sympatric hookworms of humans. Experimental Parasitology, 44: 36-49, 1978.

HORNE, P. D. First evidence of enterobiasis in ancient Egypt. The Journal of Parasitology, 88: 1.019-1.021, 2002.

HUGOT, J. P. Primates and their pinworm parasites: the Cameron hypothesis revisited. Systematics Biology, 48: 523-546, 1999.

HUGOT, J. P.; REINHARD, K. \& GARDNER, S. L. Human enterobiasis in evolution: origin, specificity and transmission. Parasite, 6: 201-208, 1999.

IÑIGUEZ, A. et al. Enterobius vermicularis: specific detection by amplification of an internal region of $5 \mathrm{~S}$ ribosomal intergenic spacer and trans-splicing leader RNA analysis. Experimental Parasitology, 102: 218-222, 2002.

JOHNSON, K. L. et al. A tick from a prehistoric Arizona coprolite. The Journal of Parasitology, 94(1): 296-298, 2008.

JONES, A. K. G. Trichurid ova in archaeological deposits: their value as indicators of ancient faeces. In: FIELLER, R. J.; GISBERTSON, D. D. \& RALPH, N. G. A. (Eds.). Paleobiological Investigations: research design, methods and data analysis. Heslington: Symposia of the Association for Environmental Archaeology, 1985. (British Archaeological Reports International Series, 5b).

KITTLER, R.; KAYSER, M. \& STONEKING, M. Molecular evolution of Pediculus humanus and the origin of clothing. Current Biology, 13: $1.414-1.417,2003$.

LAMBRECHT, F. L. Trypanosomes and hominid evolution. BioScience, 35(10): 640-646, 1985.

LE BAILLY, M. et al. Diphyllobothrium: Neolithic parasite? The Journal of Parasitology, 91: 957-959, 2005.

LE BAILlY, M. et al. 'Crise économique' au Néolithique à la transition Pfyn-Horgen (3400 BC): contribution de la paléoparasitologie. Anthropozoologica, 42: 175-185, 2007.

LELES, D. et al. Molecular paleoparasitological diagnosis of Ascaris sp. from coprolites: new scenery of ascariasis in pre-Columbian South America times. Memórias do Instituto Oswaldo Cruz, 103: 106-108, 2008.

LELES, D. et al. Molecular diagnosis of ascariasis from human feces and description of a new Ascaris sp. genotype in Brazil. Veterinary Parasitology, 163(1-2): 167-170, 2009.

LEO, N. P. \&, BARKER, S. C. Unraveling the evolution of the head lice and body lice of humans. Parasitology Research, 98: 44-47, 2005.

LEO, N. P. et al. The head and body lice of humans are genetically distinct (Insecta: Phthiraptera, Pediculidae): evidence from double infestations. Heredity, 95: 34-40, 2005. 
R. C.; CHABAud, A. G. \& WILlmotT, S. (Eds.). Keys to Nematode Parasites of Vertebrates n. 8. Wallingford: Commonwealth Agricultural Bureau, 1980.

LIGHT, J. E. et al. Geographic distributions and origins of human head lice (Pediculus humanus capitis) based on mitochondrial data. The Journal of Parasitology, 94: 1.275-1.281, 2008.

LINARDI, P. M. et al. Prevalence of nits and lice in samples of cut hair from floors of barbershops and beauty parlors in Belo Horizonte, Minas Gerais State, Brazil. Memórias do Instituto Oswaldo Cruz, 83(4): 471-474, 1988.

LOREILLE, O. \& BOUCHET, F. Evolution of ascariasis in humans and pigs: a multi-disciplinary approach. Memórias do Instituto Oswaldo Cruz, 98, supl. 1: 39-46, 2003.

MACARTHUR, R. \& WILSON, E. O. The Theory of Island Biogeography. Princeton, New Jersey: Princeton University Press, 1967.

MANTER, H.W. Some aspects of the geographical distribution of parasites. The Journal of Parasitology, 53: 1-9, 1967.

MATSUI, A.; KANEHARA, M. \& KANEHARA, M. Palaeoparasitology in Japan: discovery of toilet features. Memórias do Instituto Oswaldo Cruz, 98, supl. 1: 127-136, 2003.

MELLARS, P. A new radiocarbon resolution and the dispersal of modern humans in Eurasia. Nature, 439: 931-935, 2006.

METCALFE, N. H. In what ways can human skeletal remains be used to understand health and disease from the past? Postgrad Medicine Journal, 83: 281-284, 2007.

MUMCUOGLU, K. Y. et al. Body louse remains found in textiles excavated at Masada, Israel. Journal of Medical Entomology, 40: 585-587, 2003.

NEAFIE, R. C. \& MARTY, A. M. Unusual infections in humans. Clinical Microbiology Review, 6: 34-56, 1993.

NOVAK, M.; TAYLOR, W. R. \& PIP, E. Interspecific variation of isoenzyme patterns in four Hymenolepis species (Cestoda). Canadian Journal of Zoology, 67: 2.052-2.055, 1989

OOI, H. K. et al. Comparative study of Trichuris trichiura from non-human primates and from man, and their difference with T. suis. Journal of Veterinary Medical Science, 55: 363-366, 1993.

OWEN, I. L. et al. Trichinella infection in a hunting population of Papua New Guinea suggests an ancient relationship between Trichinella and human beings. Transactions of the Royal Society of Tropical Medicine and Hygiene, 9: 618-624, 2005.

PALMAS, C.; ECCA, A. R. \& GABRIELE, F. Specific cross-immunity between Hymenolepis nana and H. diminuta: effects of transfer of immunity with homologous and heterologous immune mesenteric lymph node cells in BALB/c mice. Parasitologia, 35(1-3): 73-76, 1993.

PEARCE-DUVET, J. M. The origin of human pathogens: evaluating the role of agriculture and domestic animals in the evolution of human disease. Biological Review of Cambridge Philosophical Society, 81: 369-382, 2006.

POINAR JR., G. Early Cretaceous trypanosomatids associated with fossil sand fly larvae in Burmese amber. Memórias do Instituto Oswaldo Cruz, 102(5): 635-637, 2007.

POINAR JR., G. Leptoconops nosopheris sp. n. (Diptera: Ceratopogonidae) and Paleotrypanosoma burmanicus gen. n., sp. n. (Kinetoplastida: Trypanosomatidae), a biting midge-trypanosome vector association from the Early Cretaceous. Memórias do Instituto Oswaldo Cruz, 103(5): 468-471, 2008.

POINAR JR., G. \& BOUCOT, A. J. Evidence of intestinal parasites of dinosaurs. Parasitology, 133: 245-249, 2006.

PROTSCH, R. \& BERGER, R. Earliest radiocarbon dates for domesticated animals: Europe is added to the Near East as another early center of domestication. Science, 179: 235-239, 1973.

QUEIROZ, M. L. et al. Frequency of soil contamination by Toxocara canis eggs in the south region of São Paulo municipality (SP, Brazil) in an 18-month period. Revista do Instituto de Medicina Tropical de São Paulo, 48: 317-319, 2006. 
RAOULT, D. et al. Molecular identification of lice from pre-Columbian mummies. The Journal of Infectious Diseases, 197: 535-543, 2008.

REED, D. L. et al. Genetic analysis of lice supports direct contact between modern and archaic humans. Plos Biology, 2: 1.972$1.983,2004$.

REED, D. L. et al. Pair of lice lost or parasites regained: the evolutionary history of anthropoid primate lice. BMC Biology, 5: 7, 2007.

REINHARD, K. J. Cultural ecology of prehistoric parasitism on the Colorado Plateau as evidenced by coprology. American Journal of Physical Anthropology, 77: 355-366, 1988.

REINHARD, K. Archaeoparasitology in North America. American Journal of Physical Anthropology, 82: 145-163, 1990.

REINHARD, K. Parasitology as an interpretative tool in archaeology. American Antiquity, 57: 231-245, 1992.

REINHARD, K. \& URBAN, O. Diagnosing ancient diphyllobothriasis from Chinchorro mummies. Memórias do Instituto Oswaldo Cruz, 98, supl. 1: 191-193, 2003.

REINHARD, K. J.; AMBlER, J. R. \& MCGUfFIE, M. Diet and parasitism at Dust Devil Cave. American Antiquity, 50: 819-824, 1985.

REINHARD, K. J.; HEVLY, R. H. \& ANDERSON, G. A. Helminth remains from prehistoric Indian coprolites on the Colorado Plateau. The Journal of Parasitology, 73: 630-639, 1987.

REINHARD, K. J. et al. Chinese liver flukes in latrine sediments from Wong Nim's property, San Bernardino, California: archaeoparasitology of the Caltrans District Headquarters. The Journal of Parasitology, 94(1): 300-303, 2008.

REB, B.H. On the polyxenia of Ancylostomidae and the validity of the characters for their differentiation (II). Tropical and Geographical Medicine, 12: 271-316, 1963.

REY, L. Dicionário de Termos Técnicos de Medicina e Saúde. 2. ed. Rio de Janeiro: Guanabara Koogan, 2003.

REY, L. Nematelmintos parasitos do homem. In: COURA, J. R. Dinâmica das Doenças Infecciosas e Parasitarias. Rio de Janeiro: Guanabara Koogan, 2005. v. 1.

REY, L. Parasitologia. 4. ed. Rio de Janeiro: Guanabara Koogan, 2008.

RICK, F. M. et al. A saga dos piolhos na América do Sul. Ciência Hoje, 31: 35-40, 2002a.

RICK, F. M. et al. Crab louse infestation in pre-Columbian America. The Journal of Parasitology, 88: 1.266-1.267, 2002b.

SALEMI, M. et al. High-resolution molecular epidemiology and evolutionary history of HIV-subtypes in Albania. Plos One, 3(1): 1.390, 2008.

SAMSONOV, A. V. Origins of Ascaris and Trichuris of man. Problems in Parasitology, part I, p. 212-213, 1969.

SARWAR, M. M. Reconstruction of the genus Trichuris and a short review of its taxonomy and morphology. Biologia (Lahore), 5: 19-35, 1959.

SIANTO, L.; CHAME, M. \& SILVA, C. S. Animal helminths in human archaeological remains: a review of zoonoses in the past. Revista do Instituto de Medicina Tropical de São Paulo, 51(3): 119-130, 2009.

SIANTO, L. et al. The finding of Echinostoma sp. (Trematoda: Digenea) and hookworm eggs in coprolites collected from a Brazilian mummified body dated of 600-1,200 years before present. The Journal of Parasitology, 91: 972-975, 2005.

SOUfFEZ, M. Des Insects et des Homes: représentations du poux dans la culture andine, 2001. Thèse, Paris: Université de Paris X Nanterre.

STEVENS, J.; NOYES, H. \& GIBSON, W. The evolution of trypanosomes infecting humans and primates. Memórias do Instituto Oswaldo Cruz, 93: 669-676, 1998.

TAMMA, P. Toxoplasmosis. Pediatric Reviews, 28: 470-471, 2007.

TERRA, M. A. et al. Detection of Toxoplasma gondii DNA by polymerase chain reaction in experimentally desiccated tissues. Memórias do Instituto Oswaldo Cruz, 99: 185-188, 2004. 
TIMOTHY, D. et al. Feature. Fossil parasites: a case of identity. Geology Today, 19: 136-142, 2003.

YONG, Z. et al. The geographical segregation of human lice preceded that of Pediculus humanus capitis and Pediculus humanus humanus. Comptes Rendus Biologies, 326(6): 565-574, 2003.

ZEUNER, F. E. A History of Domesticated Animals. London: Hutchison, 1963. 


\title{
Parasites as Markers of Prehistoric Migrations
}

\author{
Adauto Araújo • Karl Jan Reinhard • Scott L. Gardner • Luiz Fernando Ferreira
}

$\mathrm{N}$ ew theories on the peopling of the Americas have been supported by clinical research, field experiments, and laboratory tests. Olympio da Fonseca Filho (1972) made a particularly important contribution to the study of parasitism and prehistoric migrations, and his pioneering study happened to be published in Portuguese.

Curiously, Fonseca Filho did not refer to parasite findings in archaeological material, because at the time of his work there were already some articles published on mummies of South America (Pizzi \& Schenone, 1954). His work was published in the 1970s (the first edition was in 1970, with a second edition two years later, following an abstract published in 1968 in a Portuguese-language scientific journal),

Fonseca Filho even quoted Thomas W M. Cameron's inaugural address as president of the American Society of Parasitology, in which he stated, "Parasites leave no skeletons, and attempts to trace their antiquity must rest partly on their modern anatomy and partly on the paleontology of their hosts." (1950: 20). However, the work of Fonseca Filho is fundamental for any study on the origin and evolution of parasitic infections in antiquity, unparalleled in the world literature. The publication raised questions on the presence of certain parasitic infections among preColumbian indigenous groups, in contrast to then-prevailing positions. Some scientists at the time attributed the origin of nearly all parasitic diseases in the Americas to the arrival of the Africans (Freitas, 1935). One cannot fail to mention the letters by Américo Vespúcio and Pero Vaz de Caminha, who encountered indigenous people living in what the Europeans considered Paradise. The same happened with the Jesuits, who only later discovered how different reality was.

The first articles referring to parasites and human migrations included the work of Ewing (1924), comparing nits and adult lice found in the hair of mummies and on scalps of Native Americans deposited in museums. Ewing (1926) proposed new species corresponding to geographic regions and human "races" (according to the prevailing concept of his time), attributing morphological adaptations to the lice species based on the characteristics of hair shafts in different individuals and populations. Human migrations purportedly spread the human louse species to other continents, where it subsequently underwent changes until diversifying into new species or subspecies. 
Olympio da Fonseca referred to geographic and comparative parasitology as a new method for studying human prehistory. He began this line of research in 1924, as he recalled in the preface to his book, an anthology of his work (Fonseca Filho, 1972). He refocused on the question of the human louse species and discussed the relations between hosts and their origin on the American continent, however with this species having spread across the other continents from a single focus. He discussed Tinea imbricata, a very peculiar dermatosis of the native islanders of Oceania, but also of the Asian continent. He then commented on the travel diaries of Marshall Cândido Mariano da Silva Rondon and Edgar Roquette-Pinto, who described typical lesions of this mycosis among the Nambikwara in Brazil. Fonseca Filho (1924, 1925) visited indigenous groups in Rondônia, describing the skin lesions and isolating the etiological agent, which was described at the time as a new species with the name Endodermophyton roquettei. He went on to discuss the dispersal of this parasitic infection from Oceania and Southwest Asia to the American continent in preColumbian times (Fonseca, Filho, 1930). His line of argument included other parasitic infections such as epidemic exanthematic typhus and murine typhus, as well as black piedra, a superficial mycosis of the hair shaft.

However, the main contribution by Fonseca Filho (1972) to the emergence of paleoparasitology was his extensive discussion of his reasoning for the antiquity of hookworm infection in the Americas, in an attempt to prove preColumbian maritime contacts. He started with the findings by Darling (1921) and Soper (1927), who found a proportion of 13:1 between Ancylostoma duodenale and Necator americanus among the Lengua Indians of the Chaco Region in Paraguay. The proportion was the opposite of that found in settlers of European origin. Darling and Soper argued that such a proportion was strongly indicative of the presence of Ancylostoma duodenale infection on the American continent prior to the arrival of Europeans and Africans, suggesting its introduction into the Americas by pre-Columbian transpacific migrations.

Olympio da Fonseca Filho died while still an active researcher at the Oswaldo Cruz Foundation, a year before the creation of the institution's Paleoparasitology Department (Ferreira, Araújo \& Confalonieri, 1979).

\section{THE DISCOVERY AND PEOPLING OF THE NEW WORLD}

A longstanding and intense debate has focused on the arrival of human populations in the New World (Neves, Bernardo \& Okumura, 2007), with studies comparing ancient skeletons found in South American archaeological sites, seeking data on their antiquity and the determination of their sex (Hubbe et al., 2007). Ever since the discovery of the New World, Europeans sought explanations on the origin of the native peoples, with strong religious connotations: Where could these people have come from? From which branch of Noah did they descend after the Great Flood? (Laming-Emperaire, 1980). During exploration of the new territory, the natives soon came to be seen by the colonizers no longer as inhabitants of the Garden of Eden, but as soulless creatures, subject to being enslaved and hunted like any other animal. It was not until Pope Paul III issued his Papal Bull in 1537 that the natives were restored to the category of humans, which however failed to avoid their extermination on the continent. Yet questions and investigations always remained as to their origin and antiquity.

Aleš Hrdlicka (1915) conducted the first scientifically based attempts in this direction. Hrdlicka was a Czech scientist whose family had settled in the United States in 1881, when he was 13 . He graduated in medicine in the United States and anthropology in France. He founded the American Journal of Physical Anthropology. Since then, various disciplines have contributed to knowledge on the peopling of the Americas. Some challenged the accepted theory that the only way prehistoric Asian peoples reached the Americas was by crossing the Bering Region more than 15,000 years ago, when climatic conditions created the "Bering Land Bridge" between Siberia and Alaska. 
Alternative hypotheses were proposed by other researchers, such as French physician and anthropologist Paul Rivet, founder of various museums in France (especially the Musée de l'Homme in Paris) and elsewhere in world. Rivet visited Brazil and met with Paulo Duarte and Olympio da Fonseca Filho at the University of São Paulo. He raised the hypothesis of transpacific migrations to the Americas, based on similarities in artifacts found on the American and Asian continents (Rivet, 1925).

Another researcher that proposed an alternative theory to the Bering Crossing was Portuguese physician and anthropologist António Augusto Esteves Mendes-Correia, who defended the hypothesis of the passage of human groups from Africa to the Americas, crossing land on Antarctica (Mendes-Correia, 1926).

Thor Heyerdahl's famous voyages in the 1940s crossed the Pacific Ocean from Peru to Polynesia and to the Galapagos Islands and Easter Island using replicas of rafts built by ancient South Americans. Heyerdahl was born in Norway in 1914 and became a great navigator and archaeologist, interested in the peopling of Polynesia (Heyerdhal, 1958).

In fact, human groups did use alternative paths, thereby avoiding the extreme cold in the Arctic. From a parasitological perspective, this was demonstrated by findings of intestinal parasites in archaeological sites in South America and North America. The life cycle of some intestinal parasites that are exclusive to the human species could not have been maintained in the populations that crossed from Siberia to Alaska by the Bering Route.

\section{DISEASES IN PREHISTORIC AMERICA}

Which diseases existed in Pre-Columbian America, and which were introduced by the European conquerors, either themselves or through the African slave trade somewhat later (Williams, 1909; Hoeppli, 1959; Cockburn, 1963, 1967)? The answers to these questions were traditionally based on speculative data. Authors like Freitas (1935) referred to the absence of the majority of parasitic diseases among South American Indians, attributing to the African slave trade the introduction of practically all the parasitic infections known at his time, based on circumstantial inferences. All this purportedly occurred as if human groups had not crossed and conquered new territories before the great navigations, as if the land had not been peopled before.

Other questions demanded answers: once the infections that were considered to exist in Pre-Columbian America had been introduced, which route(s) did infected individuals take and how were the infections spread across the continent?

Hookworm infection became the most widely used example for the possibility of transoceanic migrations or contacts between populations of the Old and New Worlds. According to this theory, the hookworm's life cycle would have been interrupted by the passage of human hosts through the "Arctic filter" in the path across Beringia (Stewart, 1960). But other parasites from the group of geo-helminths also show evidence of alternative routes, as discussed later in this chapter.

Arguments for the pre-Columbian presence of hookworm infection began (as mentioned above) on the basis of the different proportions between the two most common etiological agents, Ancylostoma duodenale and Necator americanus, among an indigenous people of Paraguay (Darling, 1921; Soper, 1927; Manter, 1967; Fonseca Filho, 1972).

Determination of the hookworm species is fundamental for studies on the origin of populations. Even in human groups that are now isolated, contacts may have occurred with other groups in the past, which would have been sufficient for contamination by a given parasite, in this case a hookworm species (Araújo et al., 1988). The assumption was that an indigenous group lived in proximity with Europeans during a short period at the time of contact, and 
that the group was contaminated by hookworms. If the indigenous group was forced to move inland, isolating itself from contact due to wars or cultural differences, it could have carried the infection and potentially contaminated other groups inhabiting the hinterlands.

Paleoparasitology made a decisive contribution to answering this question. The finding of adult worms in the intestine of a Peruvian mummy from 900 BC (Allison et al., 1974) and hookworm larvae and eggs found in human

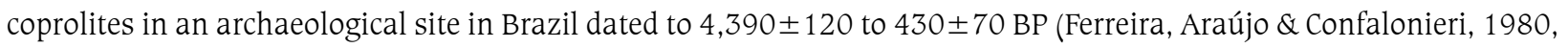
1983) proved that hookworm infection was present in indigenous peoples in pre-Columbian America, which allowed the resumption of discussion on its origin (Araújo, 1980).

Based on these findings, Araújo, Ferreira \& Confalonieri (1981) concluded that only seafaring migrations would have been capable of introducing hookworms into America, as proposed by Meggers \& Evans (1966), dating the introduction to $3,200 \mathrm{BC}$.

Hookworm eggs and larvae have been found in archaeological sites worldwide (Gonçalves, Araújo \& Ferreira, 2003). The oldest dates are in South America. Human coprolites positive for hookworm eggs, dated 7,230 \pm 80 BP, were found in the Pedra Furada archaeological site in Piauí State, Northeast Brazil (Ferreira et al., 1987). Hookworm eggs were also found in human coprolites dated to c. 5,000 BP in Minas Gerais State, Brazil (Ferreira, Araújo \& Confalonieri, 1982), and in Tiliviche, Chile, dated to 6,000 BP (Gonçalves, Araújo \& Ferreira, 2003), thus confirming the antiquity of this parasitic infection in South America.

North America has yielded one finding with a pre-Columbian date, c. 2,177 \pm 145 BP (Faulkner \& Patton, 2001).

In Europe, hookworm eggs in human coprolites and latrine sediments have been dated from 5,600 to 4,400 BP, in France (Dommelier-Espejo, 2001), and in the Czech Republic, dated to 3,600 BP (Sebela, Vojtková \& Vojtek, 1990 apud Aspock, Auer \& Pischer, 1999).

Hookworm larvae only evolve to the infective stage in environments with very specific temperatures (Rey, 2008; Roberts \& Janovy Jr., 2009). Current data and paleoclimatic models both show that the routes from North Asia to the far North of North America never provided an environment with such climatic conditions (Montenegro et al., 2006).

We use the paleoparasitological record from a complex of intestinal parasites to challenge the hypothesis that overland migration through Beringia some 13,000 years ago was the only human migratory flow prior to the arrival of Europeans.

Assuming for a moment that this was the only migratory flow, the pre-Columbian presence of hookworms on the American continent could be explained by the following scenarios: a) migrations across extremely cold regions, where the parasite's life cycle could not have been maintained, occurred so rapidly that the adult worms persisted in the human hosts. All this necessarily occurred in the limited period of eight years, corresponding to the mean life span of adult worms in the intestine of the human host (Cheng, 1986); b) migrants made stops and were reinfected at specific sites where the prevailing temperature was sufficiently high for the larvae to develop; and/or c) the hookworm population brought by migrants was different from the present, with larvae capable of developing at lower temperatures.

We can rule out scenario 'c', because no hookworm varieties could exist that would be capable of surviving such cold temperatures, either in Asia or the Americas. Scenario 'b' implies that the migrants routinely used shelters where the temperatures were significantly higher than in the outdoor environment, specifically at the higher latitudes. Such conditions would have been highly unlikely in the caves on route from Siberia to Alaska. Even at present, temperatures inside such caves are significantly lower than $17-20^{\circ} \mathrm{C}$, the lowest survival threshold for hookworms. 
As for scenario 'a', no precedent exists for the speed at which prehistoric migrants would have had to walk from Siberia to Alaska. Nomadic bands of hunter-gatherers would have left regions of Asia where the hookworm life cycle would have been maintained and walked directly to North America, to regions with a sufficiently warm climate (Montenegro et al., 2006).

\section{STRONGYLOIDES STERCORALIS}

The presence of another parasite, Strongyloides stercoralis (threadworm), in prehistoric America has demanded explanations for years (Reinhard, 1985; Dorris, Viney \& Blaxter, 2002). The threadworm's dual life cycle makes it highly peculiar among human parasites. The cycle involves alternating generations, free-living and parasitic. Females are parthenogenetic, and in the environment outside the host they produce larvae that develop into free-living males or females. After copulation, new larval forms emerge, undergoing two rhabditiform larval stages until developing into new free-living adults. We now know that Strongloides stercoralis has only one free-living generation. For unknown reasons, some first-stage rhabditiform larvae develop into another type, known as filariform larvae. The latter are highly active, capable of remaining in the soil for many days, but they only complete their evolution when they find a new host (Lok, 2007; Rey, 2008).

Only parthenogenetic females are found in the human intestine, particularly in the duodenal mucosa and initial portions of the jejunum. The eggs are deposited in the mucosa and soon release larvae, excreted in the stool. These larvae can develop through a direct or indirect life cycle.

In the direct cycle, rhabditiform larvae excreted in the stool become infective filariform larvae. This can occur in the soil, on the skin of the perineum, or in the host's own intestine. In the indirect cycle, after successive transformations in the soil, rhabditiform larvae become free-living males and females. The females deposit eggs that produce rhabditiform larvae, which finally develop into infective filariform larvae. Both cases can be a factor for maintaining infection in the host (Lok, 2007; Rey, 2008).

Threadworm infection is currently endemic in the tropics and subtropics. The archaeological record shows threadworms in three prehistoric American sites, all in the Southwest United States (Hall, 1972; Reinhard, Ambler \& McGuffie, 1985; Reinhard, 1990). As with Trichuris trichiura and hookworm, the introduction of Strongyloides stercoralis infection into the Americas would not have been consistent with human migrations via Beringia.

\section{EVIDENCE OF MIGRATIONS BASED ON A COMPLEX OF PARASITES}

As discussed previously, parasites are defined as biological species or gene sequences capable of reproducing and that find their ecological niche in other species. They are thus subject to the same biological pressures of natural selection (Araújo et al., 2003). Like all biological species, parasites could not emerge simultaneously in different geographic regions. The parasite species currently existing in humans consist of parasites inherited from ancestors, as well as parasites acquired over the process of human biological and social evolution.

Criticism has been raised against the paleoparasitological evidence for only one of the parasites mentioned above (Fuller, 1997). Analysis of the three species of nematodes, namely human hookworms, Trichuris trichiura, and Strongyloides stercoralis (all geo-helminths), helps support the hypothesis of transpacific prehistoric human migrations (Reinhard et al., 2001). 
Hawdon \& Johnston (1996) argue that hookworms have hypobiotic potential capable of allowing their migration across the Arctic route. Hypobiosis is the capacity of hookworm larvae to remain viable in tissues until favorable conditions stimulate the resumption of their biological cycle. This argument fails to hold up if one considers the passage from Siberia to Alaska, when human groups dispersed slowly across the region, taking hundreds of years.

Hypobiosis does not exist in trichurids, yet evidence remains for trichurids in prehistoric New World populations. Even considering the durability of Trichuris eggs, the cold Arctic conditions could not have allowed their survival and evolution in the soil.

The possibility of autoinfection with Strongyloides stercoralis favors the persistence of this parasitic infection for several years in the human host after the initial infection, but this occurs mainly in the severe forms and with host immunodeficiency. Thus, the parasite's natural cycle would not explain its persistence throughout the migratory process in the peopling of the Americas.

Combined, the three intestinal parasites require a given type of soil and favorable temperature, which would have been impossible in Beringia during the long trek by their human hosts from the tropics to the tropics, i.e., from Asia to the Americas.

The parasitological evidence points to an alternative human migratory route during prehistoric times. People infected with geo-helminths could have reached the Pacific Coast of the Americas by crossing the ocean in boats or rafts. They may not have created new colonies, but they infected persons that already lived in the Americas. Since these individuals probably had the same Asian origin, no outstanding genetic trace remained, but only their parasites. These ocean crossings date to more than 7,000 BP (Ferreira et al., 1987).

\section{PINWORM INFECTION IN PREHISTORIC AMERICA}

Pinworm eggs are common in archaeological sites in various parts of the Americas. Enterobius vermicularis is the species found among the oldest prehistoric populations of the Americas (Hall, 1972). More than any other parasite, pinworm phylogeny is consistent when associated with primate phylogeny (Hugot et al., 1999; Sorci et al., 2003). This shows that pinworms and their primate hosts evolved in parallel. Genetic drift occurred in pinworm species as human populations dispersed geographically. Divergence and drift resulted in the emergence of at least one new species, Enterobius gregori, in human populations in Asia and Africa (Hugot, 1999).

Alena Iñiguez et al $(2002,2003)$ investigated the possibility that genetic drift occurred in pinworms in different parts of the Americas. They raised the hypothesis that human migration across Beringia brought a different strain of Enterobius vermicularis than migrations by other routes. They demonstrated differences in the parasite's genome sequences recovered from archaeological sites in North America and Chile, and thus pointed to different origins of Enterobius vermicularis strains.

\section{CONCLUSIONS}

How did parasites reach the New World? Montenegro et al (2006) tested the hypothesis that migrations occurred over a brief period, allowing these parasites (adapted to the tropical and subtropical climate) to be brought from the old World to the Americas. The distribution of hookworms, Trichuris trichiura, and Strongyloides stercoralis in prehistoric America was also tested with a coastal migration model, along the North of the continent. 
Montenegro et al (2006) used hookworm findings in archaeological material, climatic data, and paleoclimatic modeling to test the hypothesis that human groups from areas in Asia consistent with the hookworm life cycle crossed Beringia quickly enough to maintain the infection and introduce it into the Americas.

The authors used their model to test the hypothesis that before European contact, all inhabitants of the Americas (except the Arctic and Subarctic) descended from migrants to the continent using inland terrestrial routes, across the land and ice bridge of Beringia some 13,000 years ago.

Various authors have gradually used paleoparasitological data for proposals on the peopling of the Americas. Thus, Sorenson \& Johannessen (2006) used paleoparasitological data as the basis for their arguments, combined with genetics, botany, and the knowledge of agriculture among ancient peoples as new evidence of prehistoric seafaring migrations. Their results showed that the ancient migrant peoples that used the route across Beringia to North America did not cross this environment (hostile to hookworm survival) quickly enough to introduce the infection into prehistoric America. Montenegro et al (2006) contended that introduction of hookworms into the Americas by overland migrations some 13,000 years ago could only have occurred under extraordinary conditions, and even then at a speed of migration inconsistent with what we know from the continent's archaeology. They concluded that although migration of the Clovis culture (North American prehistoric culture) may have been the first, it was not the only migratory wave to the Americas. Based on the paleoclimatic and paleoparasitological evidence, they concluded that other migratory routes may have been used, such as costal or transoceanic navigation.

Paleoparasitological data can be a highly useful source for specialists and researchers on the peopling of the Americas (Santos, Leite \& Santos, 2010). The parasites discussed in this chapter are excellent markers for tracing human migrations in the past (Araújo, Reinhard \& Ferreira, 2008; Araújo et al., 2008).

\section{REFERENCES}

ALLISON, M. J. et al. A case of hookworm infestation in a pre-Columbian American. American Journal of Physical Anthropology, 41: 103-106, 1974.

ARAújo, A. Contribuição ao Estudo de Parasitos Encontrados em Material Arqueológico no Brasil, 1980. Master's thesis, Rio de Janeiro: Instituto Oswaldo Cruz, Fundação Oswaldo Cruz.

ARAÚJO, A.; FERREIRA, L. F. \& CONFALONIERI, U. A contribution to the study of helminth findings in archaeological material in Brazil. Revista Brasileira de Biologia, 41: 873-881, 1981.

ARAÚJO, A.; REINHARD, K. \& FERREIRA, L. F. Parasite findings in archaeological remains: diagnosis and interpretation. Quaternary International, 174: 1-4, 2008.

ARAÚjo, A. et al. Hookworm and the peopling of the Americas. Cadernos de Saúde Pública, 2: 226-233, 1988.

ARAÚJO, A. et al. Parasitism, the diversity of life, and paleoparasitology. Memórias do Instituto Oswaldo Cruz, 98, supl. 1: 5-11, 2003.

ARAÚjo, A. et al. Parasites as probes for prehistoric migrations? Trends in Parasitology, 24: 112-115, 2008.

ASPOCK, H.; AUER, H. \& PICHER, O. Parasites and parasitic diseases in prehistoric human populations in Central Europe. Helminthologia, 36: 139-145, 1999.

CAMERon, T. W. M. Parasitology and evolution. Presidential Address. Transactions of the Royal Society of Canada, S. 3(44), section $5,1: 20,1950$.

CHENG, T. C. General Parasitology. Orlando: Academic Press, 1986. 
COCKBURN, T. A. The Evolution and Eradication of Infectious Diseases. Baltimore: Johns Hopkins Press, 1963.

COCKBURN, T. A. Infectious Diseases: their evolution and eradication. Thomas Springfield, 1967.

DARLING, S.T. Observations on the geographical and ethnological distribution of hookworms. Parasitology, 12: 217-233, 1921.

DOMMELIER-ESPEJO, S. Contribuition à l'Étude Paléoparasitologique des Sites Néolitiques en Environnement Lacustre dans les Domaines Jurassien et Pèri-Alpin, 2001. Thesis, Reims: Université de Reims.

DORRIS, M.; VINEY, M. E. \& BLAXTER, M. L. Molecular phylogenetic analysis of the genus Strongyloides and related nematodes. International Journal for Parasitology, 32: 1.507-1.517, 2002.

EWING, H. E. Lice from human mummies. Science, 60: 389-390, 1924.

EWING, H. E. A revision of the American lice of the genus Pediculus, together with a consideration of the significance of their geographical and host distribution. Proceedings of the United States National Museum, 68: 1-30, 1926.

FAULKNER, C. T. \& PATTON, S. Pre-Columbian hookworm evidence from Tennessee: a response to Fuller (1997). Medical Anthropology, 20: 92-96, 2001.

FERREIRA, L. F.; ARAÚJO, A. \& CONFALONIERI, U. Subsídios para a Paleoparasitologia do Brasil - I. Parasitos encontrados em coprólitos no município de Unaí, Minas Gerais. In: CONGRESSO DA SOCIEDADE BRASILEIRA DE PARASITOLOGIA, 1979, Campinas. Anais... Campinas, 1979.

FERREIRA, L. F.; ARAÚJO, A. \& CONFALONIERI, U. Finding of helminth eggs in human coprolites from Unaí, Minas Gerais, Brazil. Transactions of the Royal Society of Tropical Medicine and Hygiene, 76: 798-800, 1980.

FERREIRA, L. F.; ARAÚJO, A. \& CONFALONIERI, U. Subsídios para a paleoparasitologia do Brasil - IV. Sobre a presença de ovos de ancilostomídeos e Trichuris em múmia encontrada na Gruta do Gentio II - Minas Gerais, Brasil. In: CONGRESSO DA SOCIEDADE BRASILEIRA DE PARASITOLOGIA, VII, 1982, Porto Alegre. Resumos... Porto Alegre, 1982.

FERREIRA, L. F.; ARAÚJO, A. \& CONFALONIERI, U. The finding of helminth eggs in a Brazilian mummy. Transactions of the Royal Society of Tropical Medicine and Hygiene, 77: 65-67, 1983.

FERREIRA, L. F. et al. Encontro de ovos de ancilostomídeos em coprólitos humanos datados de 7.230 \pm 80 anos, Piauí, Brasil. Anais da Academia Brasileira de Ciências, 59: 280-281, 1987.

FONSECA FILHO, O. Sobre a etiologia do 'chimberê', dermatose endêmica dos índios do rio S. Miguel. Sciencia Médica, 2: 1-3, 1924.

FONSECA FILHO, O. Sur l'étiologie du chimbéré, nouveau type de dermatose endémique des Indiens du fleuve S. Miguel, Endodermophyton roquettei. Comptes Rendus des Séances de la Societé de Biologie, 92: 305-306, 1925.

FONSECA FILHO, O. Afinidades parasitológicas e clínicas entre o Tokelau da Polinésia e o chimberê dos indígenas de Matto Grosso. Boletim da Academia Nacional de Medicina, 102: 212-228, 1930.

FONSECA FILHO, O. Parasitismo e Migrações Humanas Pré-históricas. Rio de Janeiro: Mauro Familiar, 1972.

FREITAS, O. Doenças Africanas no Brasil. São Paulo: Companhia Editora Nacional, 1935. v. 51. (Brasiliana, 51)

FULLER, K. Hookworm: not a pre-Columbian pathogen. Medical Anthropology, 17: 297-308, 1997.

GONÇALVES, M. L.; ARAÚJO, A. \& FERREIRA, L. F. Human intestinal parasites in the past: new findings and a review. Memórias do Instituto Oswaldo Cruz, 98, supl. 1: 103-118, 2003.

HALL, H. J. Diet and Disease at Clyde's Cavern, 1972. Thesis, Salt Lake City: Department of Anthropology, University of Utah.

HAWDON, J. M. \& JOHNSTON, S. A. Hookworms in the Americas: an alternative to trans-Pacific contact. Parasitology Today, 12: $72-74,1996$.

HEYERDAHL, T. Aku-Aku: The Secret of Easter Island. London: George Allen \& Unwin, 1958. 
HOEPPLI, R. Parasites and Parasitic Infection in Early Medicine and Science. Singapore: University of Malaya Press, 1959.

HRDLICKA, A. The peopling of America. Journal of Heredity, 6: 79-91, 1915.

HUBBE, M. et al. Brief communication: 'Zuzu' strikes again: morphological affinities of the Early Holocene human skeleton from Toca dos Coqueiros, Piauí, Brasil. American Journal of Physical Anthropology, 134: 285-291, 2007.

HUGOT, J. P. Primates and their pinworm parasites: the Cameron hypothesis revisited. Systematic Biology, 48: 523-546, 1999.

HUGOT, J. P. et al. Human enterobiasis in evolution: origin, specificity and transmission. Parasite, 6: 201-208, 1999.

IÑIGUEZ, A. M. et al. Enterobius vermicularis: specific detection by amplification of an internal region of $5 \mathrm{~S}$ ribosomal RNA intergenic spacer and trans-splicing leader RNA analysis. Experimental Parasitology, 102: 218-222, 2002.

INIIGUEZ, A. M. et al. Enterobius vermicularis: ancient DNA from North and South American human coprolites. Memórias do Instituto Oswaldo Cruz, 98, supl. 1: 67-69, 2003.

LAMING-EMPERAIRE, A. Le problème des origins américaines: theories, hypotheses, documents. Cahiers d'Archéologie et d'Ethnologie d'Amérique du Sud. Éditions de la Maison des Séances de l'Homme - Presses Universitaires de Lille, 1980.

LOK, J. B. Strongyloides stercoralis: a model for translational research on parasitic nematode biology. WormBook, 17: 1-18, 2007.

MANTER, H.W. Some aspects of the geographical distribution of parasites. The Journal of Parasitology, 53: 2-9, 1967.

MEGGERS, B. J. \& EVANS, C. A transpacific contact in 3000 BC. Scientific American, 214: 28-35, 1966.

MENDES-CORREIA, A. A. E. Homo: os modernos estudos sobre a origem do homem. 2. ed. Coimbra: Atlântida, Livraria Editora, 1926.

MONTENEGRO, A. et al. Parasites, paleoclimate and the peopling of the Americas: using the hookworm to time the Clovis migration. Current Anthropology, 47: 193-198, 2006.

NEVES, W. A.; BERNARDo, D. V. \& OKUMURA, M. M. M. A origem do homem americano vista a partir da América do Sul: uma ou duas migrações? Revista de Antropologia USP, 50: 9-44, 2007.

PIZZI, T. \& SCHENONE, H. Hallazgo de huevos de Trichuris trichiura en un cuerpo arqueológico incaico. Boletín Chileno de Parasitologia, 9: 73-75, 1954.

REINHARD, K. J. Strongyloides stercoralis in the prehistoric Southwest. In: MERBS, C. F. \& MILNER, R. J. (Eds.). Health and Disease in the Prehistoric Southwest. Tempe: Arizona State University, 1985.

REINHARD, K. J. Archaeoparasitology in North America. American Journal of Physical Anthropology, 82: 145-162, 1990.

REINHARD, K. J.; AMBLER, J. R. \& MCGUfFIE, R. J. Diet and parasitism at Dust Devil Cave. American Antiquity, 50: $20-24,1985$.

REINHARD, K. J. et al. American hookworm antiquity. Medical Anthropology, 20: 97-101, 2001.

REY, L. Parasitologia. Rio de Janeiro: Guanabara Koogan, 2008.

RIVET, P. Les origines de l'homme Américain. L'Anthropologie, 25: 293-319, 1925.

ROBERTS, L. S. \& JANOVY, J. Foundations of Parasitology. Dubuque: McGraw-Hill International Edition, 2009.

SANTOS, A. K. C. R.; LEITE, D. S. \& SANTOS, S. E. B. DNA mitocondrial em populações humanas pré-colombianas da Amazônia e as interações do passado (paleogenética). In: PEREIRA, E. (Org.). Arqueologia da Amazônia. 1. ed. Belém: Museu Paraense Emilio Goeldi, 2010. v. 1.

SOPER, F. L. The report of a nearly pure Ancylostoma duodenale infestation in native American Indians and a discussion of its ethnological significance. American Journal of Hygiene, 7: 174-184, 1927.

SORCI, G. et al. Correlated evolution between host immunity and parasite life histories in primates and oxyurid parasites. ProceedingS of the Royal Society of Biological Sciences, 270: 2.481-2.484, 2003. 
SORENSON, J. L. \& JOHANNESSEN, C. L. Biological evidence for pre-Columbian transoceanic voyages. In: MAIR, V. H. Contact and Exchange in the Ancient World. Honolulu: University of Hawai'i Press, 2006.

STEWART, T. D. A physical anthropologist's view of the peopling of the New World. Southwestern Journal of Anthropology, 16: 259$273,1960$.

WILLIAMS, H. U. The epidemic of the Indians of New England, 1616-1620, with remarks on the native American infections. Johns Hopkins Hospital Bulletin, 20: 340-349, 1909. 
part II

Parasite Remains Preserved in Various Materials and Techniques in Microscopy and Molecular Diagnosis 


\title{
The Study of Microinclusions in Coprolites
}

\author{
Paulo Roberto de Figueiredo Souto
}

$\mathrm{C}$ oprolites nearly always contain undigested residues from feeding activity. These may include the hard parts of prey (bones, teeth, scales, otoliths, keratins, and chitins) and plant remains (wood fragments, cuticles, phytoliths, and seeds). These inclusions are in fact the best proof of the identity of these structures.

The occurrence and investigation of organic microstructures in coprolites more than 3 million years old are more complex, when compared to the analysis of excreta in mummified state. The advanced state of lithification that the structure undergoes during fossilization requires a more painstaking process to recover these remains. The analysis of included organic particles in this case depends on the degree of dissociation allowed by the coprolite's matrix and involves more complex methodologies.

When the ingested organic microparticles withstand environmental conditions, the cell structures and tissues can be preserved inside the coprolite and thus be separated from the matrix and examined individually.

When permineralization has occurred with calcite, dissolution with acid treatment can damage or even destroy identifiable structures. However, when the particles are resistant, for example in carapaces, spores, and plant cuticles, the possibility of identification increases. Thus, most studies of coprolite microinclusions begin with thin sections; even though the material loses its three-dimensional structure, one can identify a significant variety of organic material.

Renault \& Bertrand (1895) were the first to report the presence of microorganisms in coprolites produced by vertebrates during the Permian in France, identifying an estimated 12 to 140 thousand bacteria per $\mathrm{mm}^{3}$. Later, in the $20^{\text {th }}$ century, two studies were published on fossil microbial activity in coprolites from the Triassic in Arizona (Lipman \& McLees, 1940) and in coprolites from the Eocene in Wyoming (Bradley, 1946), USA, in which the coprolite matrix was laminated and dissolved, allowing the identification of silicified enteric bacteria in the form of cocci, rods, and ovoids, as well as fungal spores and freshwater unicellular algae.

Also in the $20^{\text {th }}$ century, Stokes (1964) and Chin \& Gill (1996) used the thin section technique to reveal the inside of herbivorous dinosaur coprolites with the presence of plant fragments and large amounts of silicified amorphous material, attributed to possible bacterial structures. 
In recent years, studies using chemical dissolution of the coprolite matrix (Hollocher et al., 2001; Baszio \& Richter, 2001) revealed biomineralized inclusions associated with feeding and decomposing activity produced by bacteria and invertebrates (Wilby \& Martill, 1992; Richter \& Baszio, 2001; Prasad et al., 2005). More recently, molecular studies have proven to be a promising field of research in the area of parasitology by providing evidence on the presence of intestinal parasites in coprolites (Poinar Jr., 2007; Poinar Jr. \& Boucot, 2006). Such evidence indicates that insects were the vectors of pathogens such as the etiological agents of malaria and leishmaniasis, and that associated with other intestinal parasites like protozoa and helminths, such pathogens acted as one possible cause of the extinction of many groups, including dinosaurs.

\section{METHODOLOGY}

Preservation of material in the form of a coprolite is such a rare event that it requires the adoption of analytical procedures that allow maximum yield from the material (Amstutz, 1958; Häntzschel, El-Baz \& Amstutz, 1968).

One of the most widely used procedures in studying coprolite microinclusions is thin sections. Longitudinal sections (i.e., along the longest plane) are recommended for the best yield. The specimen is cut in half with an electric saw, and each half is cut again in one or two sections. The sections are attached to glass slides with epoxy glue and polished down to a thickness of approximately 1.5 to $3.5 \mathrm{~mm}$, according to the degree of translucidity allowed by the section (Hirsch, 1979).

If the specimen is larger than a conventional slide, larger glass slides should be made in advance, adapted to the specimen's size. The sections are later exposed to transmitted and polarized light under a binocular light microscope coupled to a digital camera, photographing with lenses of different magnifications to investigate for the presence of organic inclusions.

Petrified microorganic inclusions in the feces are separated by chemical treatment, i.e., application of $10 \%$ HCL (hydrochloric acid) to dissolve the carbonate crystals. The particles are later washed and centrifuged. The residues are subsequently resuspended twice in 40\% HF (hydrofluoric acid) to remove silicates, allowing them to settle for 12 hours. The precipitate is washed at least twice with bidistilled water, centrifuged, and examined under light microscopy (Hansen \& Gudmundsson, 1979).

\section{MICROINCLUSIONS IN COPROLITES FROM ARCOSAURS}

The coprolites from Pinheiros in the municipality of Candelária, Rio Grande do Sul State, Brazil, date to 230 million years at the beginning of the Mesozoic (Middle Triassic). These coprolites are single or clustered masses in excellent state of preservation, with predominantly clustered ovoid shapes associated with a smaller number of single cylindrical shapes.

The paleofauna found in this sediment consists mainly of dicynodons (mammal-like reptiles). When these coprolites were first discovered, they were mistakenly thought to be eggs or concretions (Von Huene, 1990). However, later studies revealed their true biological nature (Souto, 2000). In addition to the peculiar structural appearance of large clusters, these coprolites provide important information for understanding paleoecological relations during Gondwana. Specimens analyzed with the thin section technique displayed palynomorphs and plant remains belonging to the Cycadaceae (Plate 1: figures 1a, 1b, 1c, 1d). 


\section{MICROINCLUSIONS IN FISH COPROLITES}

Fish coprolites are frequently found in many sedimentary units in Brazilian territory. The most important and representative record of fish coprolites belongs to the Araripe Basin in Ceará State. Located in Northeast Brazil, this basin contains the majority of the outcrops in Ceará. Its origin is related to the opening of the South Atlantic Ocean, characterizing an epicontinental sea at that time. These sediments contain the preservation of both numerous amounts of fish and fossil records of pterosaurs, chelonians, and dinosaurs.

The main sedimentary unit with abundant coprolites belongs to the Santana Formation (Lower Cretaceous). They are found mainly in the Ipubi members, included between black shale layers and the Romualdo Formation, preserved inside limestone nodules. Cylindrical and ovoid structures are present in both units.

The coprolites in this region are mainly associated with fossil fish. The specimens' good state of preservation indicates autochthonous origin. As for the fossilization process, they display permineralization of the internal structures by calcite minerals. The chemical composition, determined by X-ray fluorescence, consists of calcium phosphate. Thin section microscopic analysis revealed the presence of radiolarians, ostracods, and worms (Plate 1: figures 1e, 1f, 1g, 1h; Plate 2: figures 2a, 2b, 2c).

\section{MICROINCLUSIONS IN REPTILE COPROLITES}

Reptile coprolites have been found in the Paraná and São Luís Basins. The Paraná Basin includes Northeast Argentina, Central-South Brazil (from Mato Grosso to Rio Grande do Sul State), Eastern Paraguay, and Northern Uruguay. The São Luís Basin is located in northern Maranhão State. In both cases, the coprolites are associated with sediments deposited during the Upper Cretaceous.

In the São Luís Basin, coprolite specimens were collected in the outcrop known as Laje do Coringa, corresponding to the Itapecuru Formation of the same basin. The site is located in the eastern part of Cajual Island, in the Bay of São Marcos in the State of Maranhão. The lithology of Laje consists mainly of rudaceous deposits varying from lithic conglomerates (pebbles, cobbles, and fragments) to extensive bone beds. The coprolites occur included or loose in the sediment of the Laje and are associated with abundant bone fragments from dinosaurs, crocodylomorphs, and fish. Some fifty specimens have been described, identifying coprolites with ovoid, cylindrical, conical, and spiral shapes. Thin section examination revealed (in addition to permineralization with ferrous oxide crystals) the presence of scales, worms, and plant remains included in the coprolite matrix (Plate 2, figures 2d, 2e, 2f, 2g).

The coprolites found in the Paraná Basin are associated with reptiles, mainly the group of crocodylomorphs. The material comes from sediments that correspond lithologically to the Adamantina Formation, deposited during the Upper Cretaceous, and have been collected in different outcrops in the western region of the State of São Paulo. Numerous macroscopic food traces have been observed. However, thus far thin section examination has only revealed the presence of micro-bivalves.

\section{MICROINCLUSIONS IN MAMMALIAN COPROLITES}

During the Cenozoic, the majority of coprolite findings are related to the expansion of mammals on dry land environments. The most significant records include the São José de Itaboraí Basin, located in São José in the town of Itaboraí, Rio de Janeiro State. 
This basin consists of banded limestones vertically cut by fissures, filled with dark clays and marls. The basin is known for the fossil assemblage consisting of a rich fauna of mammals and pulmonate gastropods, besides plant remains (Bergqvist, Moreira \& Pinto, 2006), and more recently by the presence of fossilized feces (Souto, 2007).

Coprolites were collected in the southern part of the basin, in the layers of grayish banded limestones in the dissolution channels, where vertebrate bones are also present. In stratigraphic terms, these layers belong to lower levels of the sequence and correspond to the episode of sedimentation that occurred during the Paleocene, in the Early Cenozoic.

In terms of their origin, the fact that the majority of the coprolites display breaks or are fragmented allows them to be classified as para-allochthonous. Preserved on the outer part of some specimens are marks from the excretory musculature, compaction cavities, and pin-shaped polarities that show the material's biological identity. Since the internal structure is too brittle, observations were made with chemical treatment, revealing the presence of spores and grass phytoliths. The latter is an unprecedented element for this sequence of the fossil record (Plate 2, figures $2 \mathrm{~h}, 2 \mathrm{i}$ ).

\section{FINAL REMARKS}

The relevance of coprolites for research has only recently emerged in the scientific scenario, when compared to the longer existence of other areas in paleontology. The implementation of new techniques (Poinar et al., 1998) such as molecular coproscopy and the specialization of studies on coprolites elsewhere in the world have fostered new and highly relevant research paths for understanding the biological interactions of the past. In Brazil, although coprolite findings have increased significantly (Souto, 2008), only in recent years has it been possible to establish adequate and permanent work procedures for highly petrified specimens. The findings cited above bear witness to future directions in the field of paleoparasitology. The presence of parasite microinclusions thus appears as a promising research trend for the coming years. 
Plate 1 - coprolites of mammal-like reptile and fish
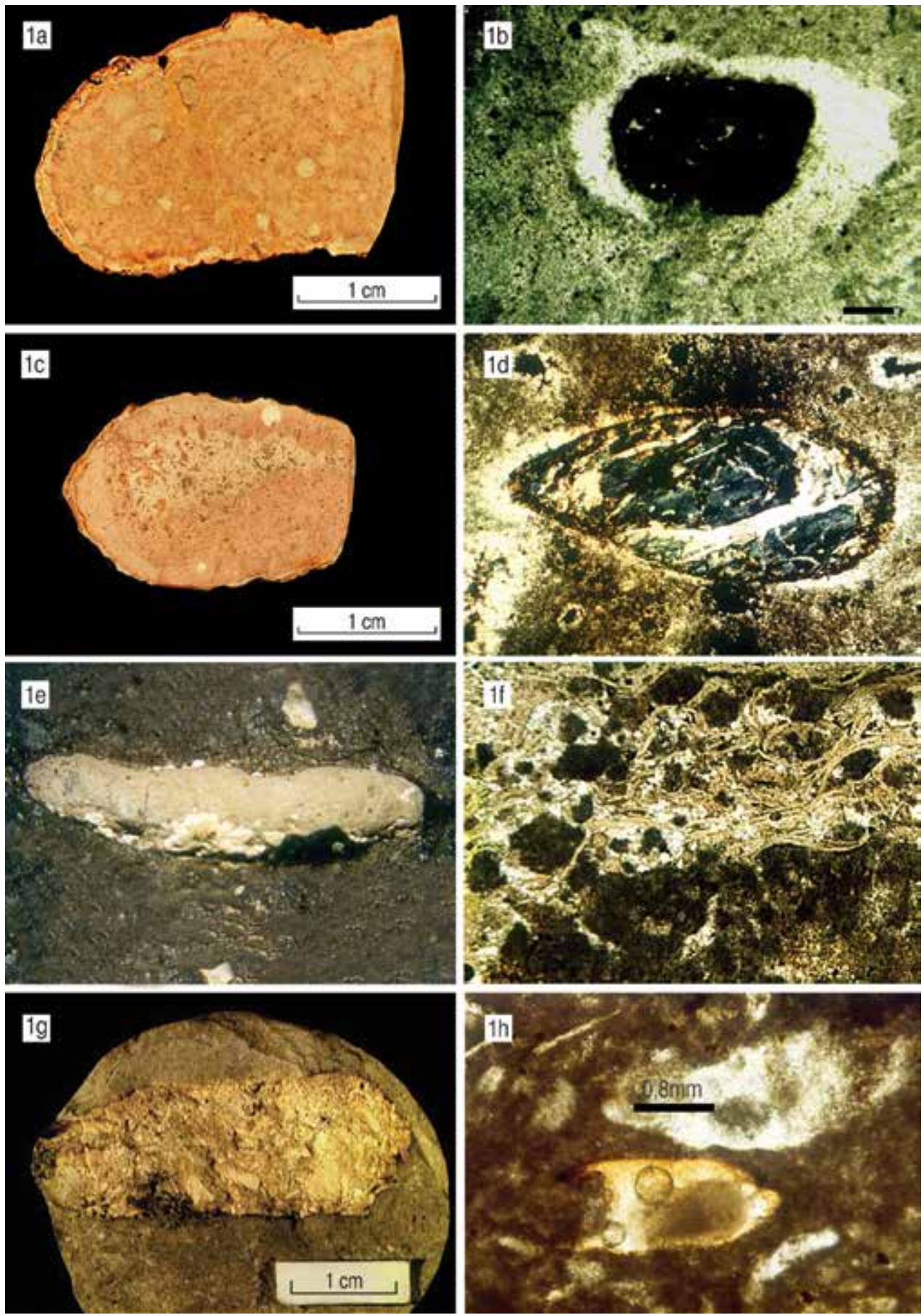

1a: Coprolite MCT 1517r, longitudinal section.

$1 b$ : Fern sporangium under transmitted light, magnified 200x. 1c: Coprolite MCT 1528r, longitudinal section.

1d: Conifer seed under transmitted light, 100x magnification. 1e: Coprolite UFRJ-DG 213-IcV, associated with limestone nodule. 1f: Ostracod shells under transmitted light, magnified 250x. 1g: Coprolite UFRJ-DG 290-IcV, associated with limestone nodule. 1h: Radiolarians under transmitted light, 100x magnification. 
Plate 2 - Coprolites and food remains
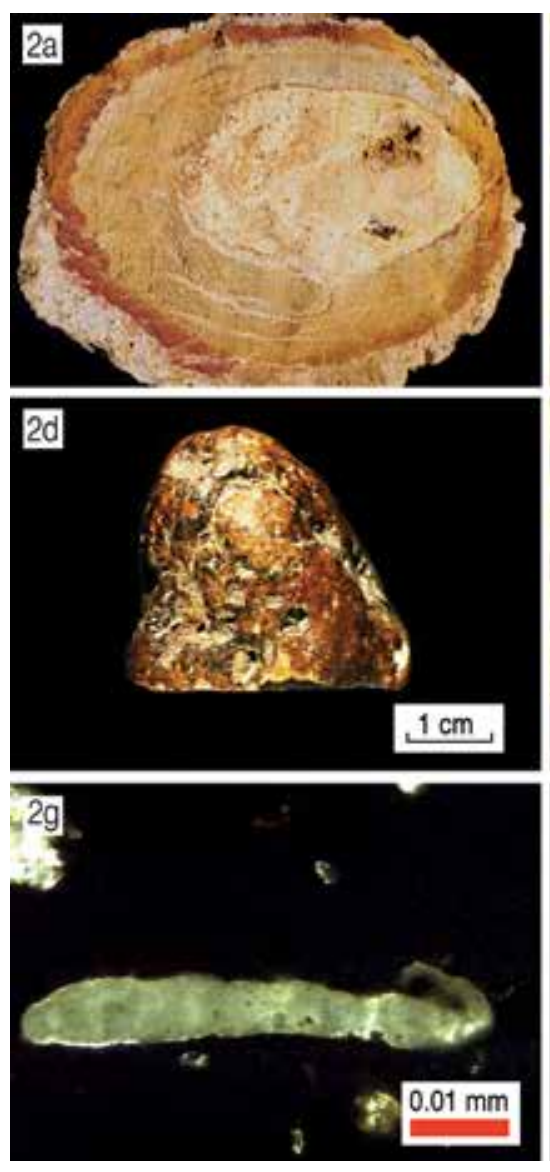

2a: Coprolite UFRJ-DG 291-IcV, included in limestone nodule.

2b: Scolecodont under transmitted light, 100x magnification.

2c: Body of worm under transmitted light, 250x.

2d: Coprolite UFRJ-DG 265-IcV.

2e: Xylem of Paradoxopteris sp. fern under transmitted light, 200x.

2f: Coprolite UFRJ-DG 260-ICV.

2g: Worm-like element in transmitted light,100x.

2h: Herbivore coprolite MCT 3066m.

2i: Fungal spore and grass phytolith under transmitted light, 250x.
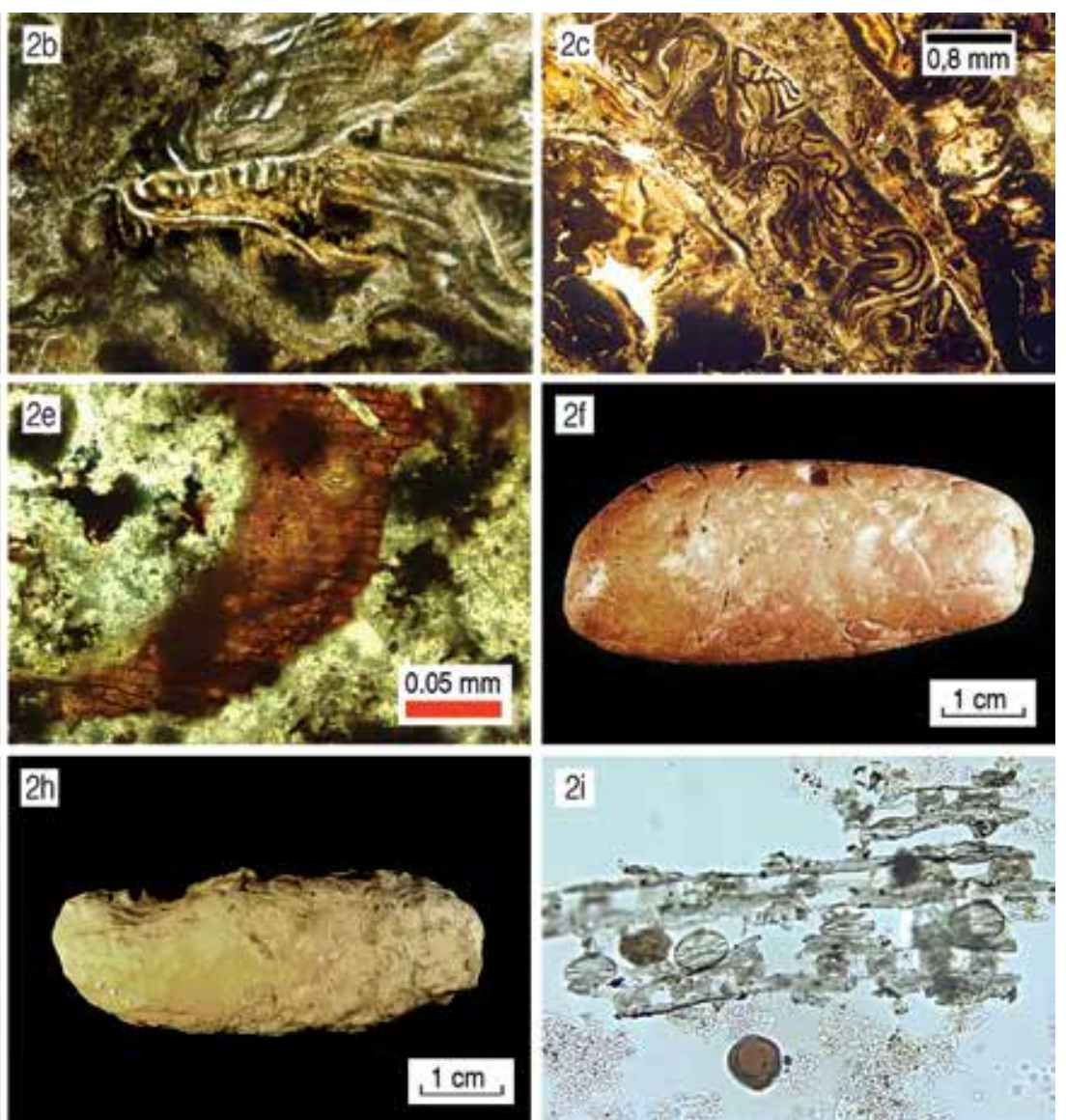


\section{REFERENCES}

AMSTUTZ, G. C. Coprolites: a review of the literature and a study of specimens from Southern Washington. Journal of Sedimentary Petrology, 28: 498-508, 1958.

BASZIO, S. \& RICHTER, G. Traces of a limnic food web in the Eocene Lake Messel: a preliminary report based on fish coprolite analyses. Palaeogeography, Palaeoclimatology, Palaeoecology, 166 (3-4): 345-368, 2001.

BERGQVIST, L. P.; MOREIRA, A. L. \& PINTO, D. R. Bacia de São José de Itaboraí: 75 anos de história e ciência. Rio de Janeiro: Serviço Geológico do Brasil, CPRM, 2006.

BRADLEY, W. H. Coprolites from the Bridger formation of Wyoming: their composition and microorganisms. American Journal of Science, 244: 215-239, 1946.

CHIN, K. \& GILL, B. D. Dinosaurs, dung beetles and conifers: participants in a Cretaceous food web. Palaios, 11(3): 280-285, 1996.

HANSEN, J. \& GUDMUNDSSON, L. A method for separating acid-insoluble microfossils from organic debris. Micropaleontology, 25(2): 113-117, 1979.

HÄNTZSCHEL, W.; EL-BAZ, F. \& AMSTUTZ, G. C. Coprolites, an annotated bibliography. Memoirs of the Geological Society of America, 108: 1-132, 1968.

HIRSCH, K.F. The oldest vertebrate egg? Journal of Paleontology, 53(5): 1.068-1.084, 1979.

HOLLOCHER, T. Bacterial residues in coprolites of herbivorous dinosaurs: role of bacterial in mineralization of feces. Palaios, 16: $547-565,2001$.

LIPMAN, C. B. \& MCLEES, E. A new species of sulfur-oxidizing bacteria from a coprolite. Soil Science, 50: 429-433, 1940.

POINAR JR., G. Early cretaceous Trypanosomatids associated with fossil sand fly larvae in Burmese amber. Memórias do Instituto Oswaldo Cruz, 102: 635-637, 2007.

POINAR JR., G. \& BOUCOUT, A. J. Evidence of intestinal parasite of dinosaurs. Parasitology, 133: 245-249, 2006.

POINAR, H. N. et al. Molecular coproscopy: dung and diet from of the extinct ground sloth Nothrotheriops shastensis. Science, 281: 402-406, 1998.

PRASAD, V. et al. Dinosaur coprolites and the early evolution of grasses and grazers. Science, 310: 1.170-1.180, 2005.

RENAULT, B. \& BERTRAND, C. E. Premières observations sur des bacterias coprophiles de l'époque permiènne. Comptes Rendues de l'Association Française Avance du Science Caenoizoique, 1.894: 583-587, 1895.

SOUTO, P. R. F. Tetrapod coprolites from the Middle Triassic of Southern Brazil. Gaia Geociences Journal, 16: 51-57, 2000.

SOUTO, P. R. F. Os coprólitos da bacia de São José de Itaboraí, estado do Rio de Janeiro. In: CARVALHO, I. S. et al. (Orgs.). Paleontologia: cenários da vida. Rio de Janeiro: Interciência, 2007. v. 1.

SOUTO, P. R. F. Coprólitos do Brasil, Principais Ocorrências e Estudo. Rio de Janeiro: Publit Soluções Editoriais, 2008.

STOKES, W. L. Fossilized stomach contents of sauropod dinosaur. Science, 143(3.606): 576-577, 1964.

VON HUENE, F. F. Répteis Fósseis do Gondwana Sul-Americano: resultado das escavações no Brasil meridional em 1928/29. Trad. Carlos Burger. Santa Maria: Editora Universidade Santa Maria, 1990.

WILBY, P. R. \& MARTILL, D. M. Fossil fish stomachs: a microenvironment for exceptional preservation. Historical Biology, 6: 25236, 1992. 


\title{
Arthropods and Parasites Found in Amber
}

\author{
Reginaldo Peçanha Brazil • José Dilermando Andrade Filho
}

mber is a fossilized resin resulting from the transformation of resins produced by various plant species that
existed in ancient times. Amber occurs in various parts of the world.

Amber generally consists of small deposits with no commercial importance but of great scientific relevance. Amber has been known since prehistoric times, used as an amulet or object of worship. Over the centuries, humans have used amber as a jewel, objects of art, or even objects of daily use. Various amber products were also used in the past in making varnish, soap, bath salts, or medicinal products.

The oldest indication of the use of amber by humans is a piece of amber found in a cave in the Pyrenees in France, plus pieces found elsewhere in Europe, with no sign of having been carved.

Carved amber beads date to the Paleolithic $(9,000 \mathrm{BC})$, found in a cave in the South of England. Beginning in the Neolithic, in the Bronze Age (4,000-1,000 BC) there was a major expansion in the trade and distribution of Baltic amber. The amber trade routes were established during this time.

During the Iron Age, carved amber flourished in quality, and pieces discovered in archaeological sites vary from sculpted figures to veritable jewels that remain stunning to this day.

Phoenicians, Etruscans, Greeks, and Romans used amber both for trade and to make objects of art. During the Medieval Period, amber reappeared when the Teutonic Knights, in 1283, became absolute lords of Prussia and used their monopoly over amber production on the Samland Peninsula to produce religious articles, especially Paternoster beads. The knights kept an iron grip on the amber industry, to the point of prohibiting amber combing on the Baltic beaches, subject to the death penalty. In the $14^{\text {th }}$ century, Bruges became the largest amber manufacturing center in Europe, with more than 300 registered amber craftsmen.

Although amber is not a mineral, many consider it a semiprecious stone, especially due to the ease in carving it. Its color ranges from yellow to orange, becoming transparent after polishing and prized as a jewel. The original resin served to protect plants from microorganisms and even from insects attempting to penetrate the wood of trees. Resin 
can seep from any wound to a tree, and even a simple insect attack is sufficient to form it. Resin protects the tree by acting as a healing agent, and its antiseptic properties also protect against microorganisms.

Different types of trees produce different types and amounts of resin. The conifers were always the main producers of resin, but other plants can also exude this substance. At present, only two types of trees can produce stable resin that would eventually fossilize into amber over time. They are the Kauri pines (Agathis australis) of New Zealand (Figure 1) and some species of Hymenaea legumes from East Africa and South and Central America.

Figure 1 - Kauri pines (Agathis australis) of New Zealand

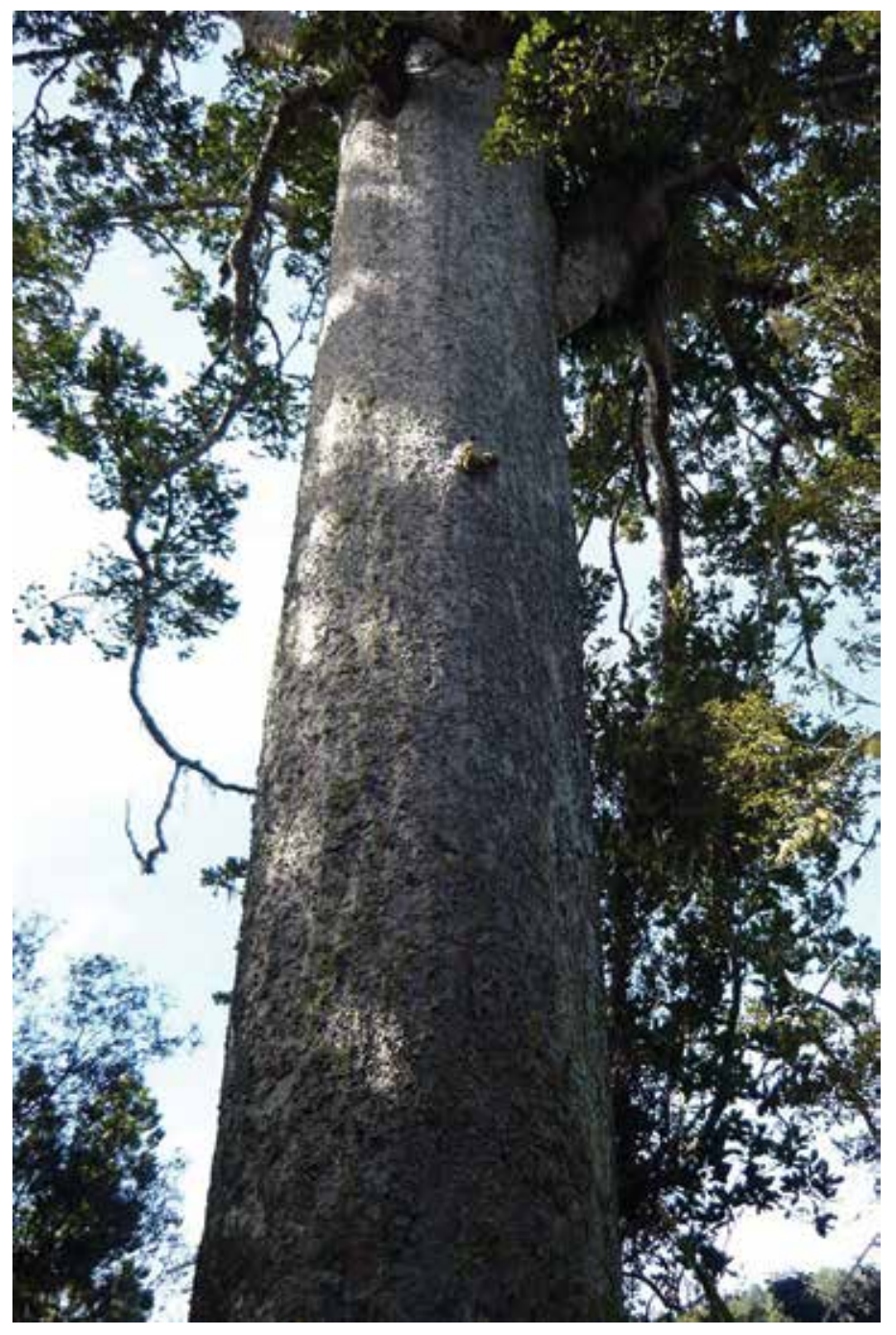

The transformation of resin into amber depends on various factors. When resin seeps from the tree, the hardening process begins, with the loss of volatile products. The resin contains substances like oils, acids, alcohols, and aromatic compounds responsible for the 'resinous' smell. The process is also known as polymerization: organic molecules cluster together to form larger molecules called polymers. This process takes 2 to 10 million years until the resin now 
called amber is completely polymerized, without any volatile substance. The intermediate product is copal, which is also hardened resin, but which has still not lost all its volatile substances. Although copal is a relatively old resin, it is much younger than amber and is thus known as a sub-fossil resin. As mentioned above, fossilization of resin into amber takes some 2 to 10 million years, although many factors are involved in estimating its formation with certainty. Copal is often confused with amber, but when exposed to light and air it forms polygonal cracks on its surface, reacts to alcohol, and has a low melting point when compared to amber.

From the paleontological point of view, amber with plant or animal inclusions is extremely valuable for studying organisms and environments from 15 to 150 million years ago.

\section{AMBER DEPOSITS}

Resin production by plants dates as far back as the Paleozoic. However, more abundant amounts of amber are only found since the Triassic. The Cretaceous was extremely important in the history of the Earth, since flowering plants appeared and replaced the old conifers and ferns and became the dominant plants.

Ambers with inclusions are found mainly in the Baltic Region, Dominican Republic, Mexico, Burma (Myanmar), Lebanon, and New Jersey, USA. Among the ambers with inclusions, those from the Baltic and the Dominican Republic are the most common. Baltic amber is of marine origin and dates to the Upper Eocene or Lower Oligocene. Meanwhile, amber from the Dominican Republic can vary from the Upper Eocene to the Middle Miocene and is found in mines in the interior of the island.

\section{BALTIC AMBER}

Baltic amber is one of the world's most famous ambers and is found in the countries in the countries around the Baltic Sea. It represents some $80 \%$ of all amber found in the world. The largest deposits are on the Samland Peninsula, part of Russia between Poland and Lithuania.

This amber comes from underwater deposits in the Baltic Sea and washes up on the coast after the frequent storms that release the pieces. Despite some doubts about the type of tree that produced the Baltic amber, plants and insects preserved inside it indicate that it originated from different types of trees (Pinaceae and Araucariceae) that would have been common in a subtropical forest. The forest apparently occupied a large area of what is now Europe. Amber can now be found in Poland, Germany, Lithuania, Estonia, Denmark, Sweden, Netherlands, and even Great Britain.

Baltic amber is usually lemon-yellow or orange and can be opaque or slightly transparent. The presence of large amounts of succinic acid (3-8\%) gave this amber its other name, succinite. The more transparent form usually presents inclusions with insects. Baltic amber was extensively studied for its entomological fauna, of which more than five thousand species have been described. Amber from the Dominican Republic, with a typically tropical fauna, has fewer species described.

\section{AMBER FROM THE DOMINICAN REPUBLIC}

Dominican amber (referring to the Dominican Republic) comes from the island of Hispaniola in the Caribbean. Although known since Columbus discovered America, it has only been explored since 1960, in various mines. 
There are numerous mines on the island, where Dominican amber is marketed freely and sold as a semiprecious stone or amber with inclusions (Figure 2, plate). It is generally light-colored, but with a wide variety of hues. Most pieces range from yellow to orange, some with different tones in the same piece.

Figure 2 - Amber with insects, Dominican Republic
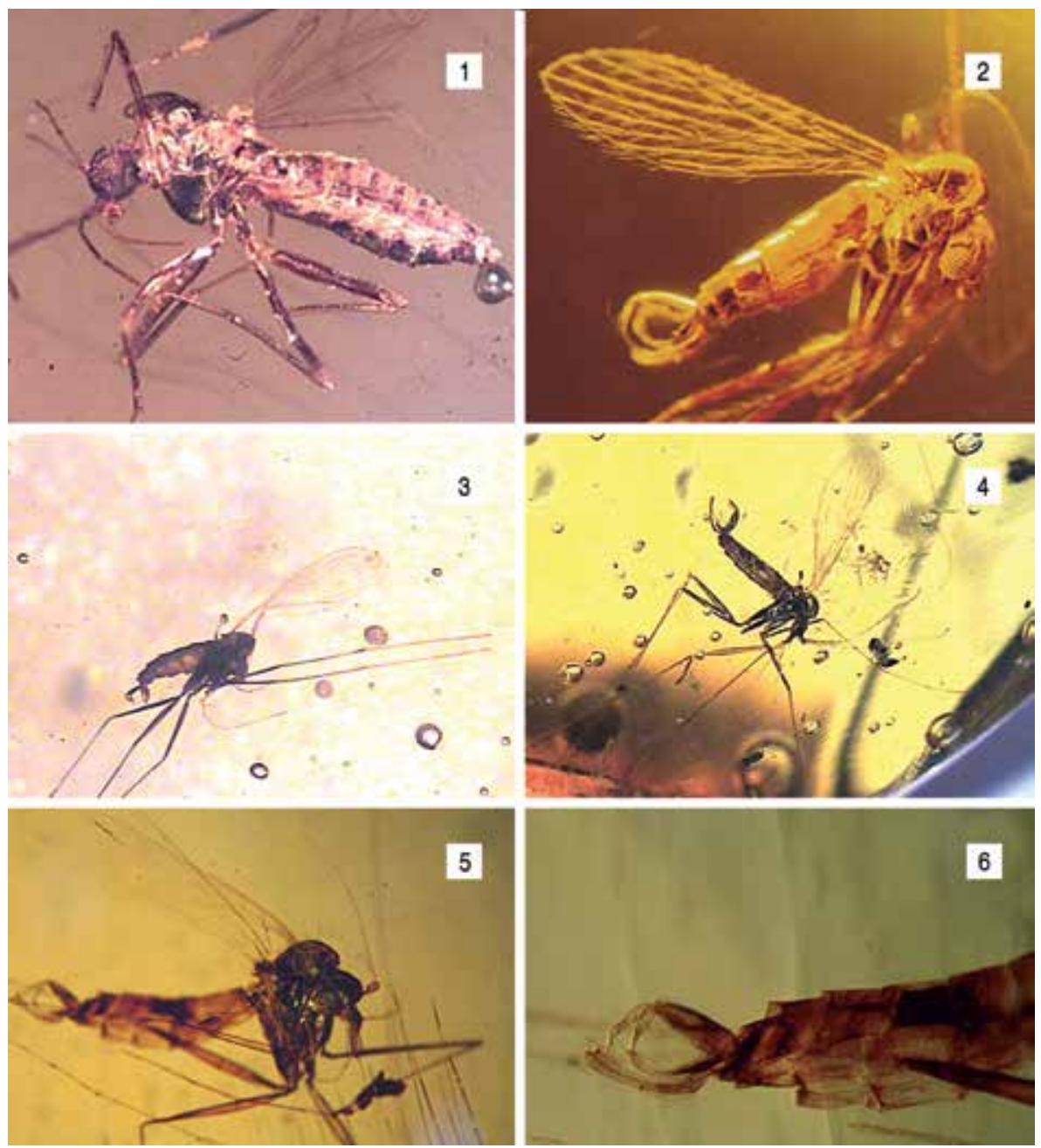

1 - Ceratopogonidae (biting midge).

2, 3, 4, 5, 6- Phlebotominae (sand fly).

Photographs: Reginaldo Peçanha Brazil and José Dilermando Andrade Filho, 2008.

The mines in the Dominican Republic are located on the higher parts of the island, known as the Cordillera Septentrional. The mines are actually narrow tunnels dug by the local inhabitants to find the amber. The pieces are taken to the cities of Santiago and Santo Domingo, where they are polished and sold. The age of Dominican amber varies from the Lower Eocene to the Middle Miocene. Chemically, Dominican amber is similar to East African copal, having been produced by the same type of trees from genus Hymenaea. In the Dominican Republic, the plant that produced the resin for amber ( $H$. protera, now extinct) is different from that existing today. 
Dominican amber presents a variety of inclusions. The insects are widely diversified and are preserved better than in other ambers. The presence of numerous tropical insects in Dominican amber indicates that the island of Hispaniola consisted of a tropical forest not very different than at present.

\section{INCLUSIONS IN AMBER}

Different ambers accurately reflect the types of resin that originally seeped from the respective plants. These resins vary chemically according to their origin. They consist of different terpenes at various concentrations, determining the preservation of organisms in the amber. As mentioned above, insects found in Dominican amber are better preserved than in amber from the Baltic or elsewhere (Mexico and Myanmar).

Animals and plants are not the only inclusions found in amber. Air bubbles and water droplets are also common. However, inclusions of plants and animals are highly important for studying the flora and fauna of the past and even the relations between them.

Size is a question that should be considered in amber inclusions, since animals larger than $2 \mathrm{~cm}$ such as tree frogs, scorpions, spiders, and large insects are generally strong enough to crawl out of the resin before it hardens.

It is common to find insect legs or wings or spider legs that broke off when these animals tried to escape the resin. Some animal products are also observed in amber: feces from small animals, hairs, feathers, insect molting, etc.

\section{Plants}

Plants are quite common in amber, although not all plant inclusions are easily identifiable. Baltic amber commonly contains plant fragments, especially bark and bristles from oak blossoms, probably from the trees that produced the amber. Pollen and spores occur frequently but can only be observed under the microscope. The flora from Baltic amber has been classified much more extensively than that of Dominican amber.

Fossil plants in amber cover a wide variety. Plant specimens in Dominican amber are mainly angiosperms (flowering plants), while Baltic amber contains both angiosperms and gymnosperms (Poinar Jr. \& Poinar, 1999).

\section{Arthropods}

Amber is extremely important for identifying fossils of terrestrial animals, mainly small insects that are not normally well-preserved in sedimentary rocks. Together with the sedimentary rocks that are effective at preserving large insects such as dragonflies (Odonatoptera) and grasshoppers and locusts (Orthoptera), but which are not observed frequently in amber, we can reconstruct the forests of the past. As for other arthropods, biological vectors of parasites, the findings are also scarce, although some groups are more frequent. The following important groups of arthropods have been found preserved in amber:

TRIATominae - Triatomines are insects belonging to the order Hemiptera, suborder Heteroptera. The family, Reduviidae, is much older, and the presence of fossil forms suggests that the predators originated in the Late Permian and Early Triassic (245-290 million years ago). Hematophagous hemipters probably emerged soon after the appearance of the first mammals. Although various species of predators from the Reduviidae family have been found in amber, the same is not true for the subfamily Triatominae, in which thus far only one triatomine species is known, Triatoma 
dominicana Poinar Jr., 2005. This fossil is included in amber from the Dominican Republic, and the species was described based on the molting from the fifth larval instar of a nymph. Since it is only the molting, and also since some structures were lost (e.g., rostrum), the author that described it included it in this genus with doubts, and new records are necessary to confirm the presence of this genus in the Miocene. When it was trapped in the amber, the insect released a droplet of feces, which contains a trypanosomatid, described as Trypanosoma antiquus Poinar Jr., 2005. Poinar Jr. (2005a) suggests that this kissing bug fed on an infected bat, since there are bat hairs close to the insect.

PHTHRAPTERA - The fossil record for lice is quite fragmented and controversial. Saurodectes vrsanskyi Rasnitsyn \& Zherikhin 1999 was described as the first fossil biting louse, found in Russia (Lower Cretaceous) and included in a new family (Saurodectidae). It has been suggested that this louse was a parasite of pterosaurs (Kumar, 2004). Although thus far there is no evidence of the presence of lice from this order in amber, adult winged specimens from the order Psocoptera, family Liposcelididae, have been found in amber from the Cretaceous in Myanmar (Cretoscelis burmica) and from the Miocene in the Dominican Republic (Belaphopsocus dominicus). Genus Cretoscelis is an extinct group of Liposcelidae, a family of free-living lice, considered a sibling group of true lice (Phthiraptera), ectoparasites of birds and mammals. Nits on hairs conserved in amber from the Baltic prove the presence of ectoparasites on small mammals from the Eocene (Galati, 2003; Grimaldi \& Engel, 2006).

SipHonAPtera - As with lice, fossil fleas are quite uncommon. After all, these insects have a very close relationship with their hosts. Thus, the odds that they would become buried or trapped in resin are virtually zero. Fleas appeared some 140 million years ago, in parallel with their mammalian hosts, and thus far only five fossil species have been identified: three from Baltic amber (Palaeopsylla baltica, Palaeopsylla dissimilis, and Palaeopsylla klebsiana) and two from Dominican amber (Pulex larimerius and a species of Rhopalopsyllus still not described). These fleas probably tormented rodents and bats in the Eocene and Miocene.

IXoDIDAE AND ARGASIDAE - Ticks have been found in amber from the Cretaceous to the Miocene. Despite diverse speculations on the origin of the ticks, the oldest fossil found thus far dates to the Cretaceous (90-44 million years ago). Some ticks described in amber are from genera like Amblyomma, but most belong to extinct genera.

CULICIDAE - Culicids or mosquitos present a cosmopolitan distribution. Females of the species are blood-feeding and serve as the vectors for a huge variety of parasites. Fossil species are not common, much less in amber inclusions. The species described belong to amber from the Eocene/Oligocene in the Baltic and from the Miocene in the Dominican Republic. Four species of Aedes have been identified in amber from the Baltic: A. damzeni Szadziewski, 1998, A. hoffeinsorum Szadziewski, 1998, A. serafini Szadziewski, 1998, and A. perkunas Podenas, 1999.

Until recently it was believed that anopheline mosquitos only appeared in the New World in the late Tertiary. However, the description of Anopheles (Nyssorhynchus) dominicanus Zavortink, T. J. \& Poinar Jr., 2000 in Dominican amber reinforces their earlier presence.

Other extinct genera of mosquitos have been found in amber from both Myanmar and the Dominican Republic. In genus Culex, a recent description was $C$. malariager Poinar Jr., 2005, which fed on birds. An interesting detail with this specimen is that it was infected with a species of protozoan, described as Plasmodium domiminicana Poinar Jr., 2005, as will be discussed later.

CERAtopogonidae - Ceratopogonidae have been found in resins from the Cretaceous in various regions of the world and in amber from the Tertiary in Mexico and the Dominican Republic. The family includes some 253 fossil species. The most well-known fauna is from the Baltic (Eocene). Importantly, a ceratopogonid (probably from the 
extinct genus Protoculicoides) was found in Burmese amber, naturally infected with what the authors identified as a monogenetic trypanosomatid.

Phlebotominae - The subfamily was created by Rondani in 1840. For many years it was thought to include only a single genus: Phlebotomus. In 1948, Theodor proposed that the subfamily be divided into four genera: Phlebotomus (Rondoni) and Sergentomyia França for the Old World species, Brumptomyia França \& Parrot and Lutzomyia França for the New World species. The subfamily Phlebotominae includes the majority of the blood-feeding Psychodidae, including some disease vector species. This subfamily is found on practically all of the continents with a long evolutionary history, having appeared in the Late Paleozoic or Early Mesozoic (Andrade Filho \& Brazil, 2003; Azar \& Nel, 2003).

The genus Pintomyia was created by Costa Lima in 1932 as a subgenus of Phlebotomus and raised to the genus category by Galati in 1995. The latter author divides Pintomyia into two subgenera: Pintomyia and Pifanomyia. Both include living and extinct species. The living species are found mainly in the Andes Region and Central America and are usually associated with woods or forests. Speciation in this group with such wide distribution is the result of biogeographic and climatic events that affected the region's flora and fauna in the last 15 million years.

With the growing interest in amber with insect inclusions, various fossil Phlebotominae have been studied. Our group described a new species based on the first description of a sand fly from Dominican amber (Brazil \& Andrade Filho, 2002; Andrade Filho, Galati \& Falcão, 2006). The majority of the fossil species described in amber from the Dominican Republic belong to genus Pintomyia, subgenus Pifanomyia, while only one sand fly species (Trichopygomyia killickorum) from the Dominican Republic falls outside this group (Andrade Filho, Falcão \& Brazil, 2004). The other three species already described by our team belong to this group of species.

Peñalver \& Grimaldi (2005) recently described five fossil sand fly species from the Dominican Republic. The authors only fit one species inside Pifanomyia [as the verrucarum group of Young \& Duncan (1994)]; however, the other four species apparently also belong to this group. A detailed study of the description of these sand flies or a study conducted directly on the fossils themselves is necessary to elucidate this problem.

Most modern-day species in subgenus Pifanomyia are found in Central America, including the Caribbean islands, mainly in forest areas. This may indicate that the extinct species also lived in this type of habitat, and that this was the predominant vegetation in the Dominican Republic 20 million years ago.

In addition to adult sand flies, other interesting discoveries have been made. Poinar Jr. (2007) found two sand fly larvae some 100 million years old in amber from Myanmar. Found on one larva was a fungus that could have been serving as food when the insect was trapped by the sap. As it struggled to free itself from the sap, the larva excreted a bit of feces containing a trypanosomatid, probably an ancestor of the digenetics. A primitive genus of trypanosomatid parasite of the sand fly was also described by Poinar Jr. \& Poinar (2005) in Burmese amber, leading the authors to the hypothesis that Paleomyia burnitis Poinar, 2004, a primitive sand fly, transmitted Paleoleishmania proterus to vertebrates in the Cretaceous.

\section{Parasites of arthropods}

Fossil arthropods parasitized by fungi, bacteria, protozoa, or nematodes are quite rare, but not impossible to find. Entomofungi are apparently more common, since the fact that these fungi are on an arthropod's exoskeleton when it is trapped in amber makes their identification easier than for an internal parasite. Various types of ectoparasitic fungi have been observed in amber from both the Dominican Republic and Myanmar (Poinar Jr. \& Poinar, 2005). 
The feces of Triatoma dominicana, a triatomine from some 20 million years ago, contained trypomastigotes of Trypanosoma antiquus - according to Poinar Jr. (2005a), a parasite of bats in the forest of the Dominican Republic. Other trypanosomatids also appear in Ceratopogonidae and sand flies. In Ceratopogonidae (Protoculicoides) discovered in amber from Myanmar (from some 100 million years ago), a monogenetic trypanosomatid was identified, and the promastigote forms found in the sand fly Palaeomyia burmitis Poinar, 2004 were considered a genus of the primitive leishmania Paleoleishmania proterus (Poinar Jr. \& Poinar, 2004).

As mentioned above, Poinar Jr. (2007) found two sand fly larvae from some 100 million years ago in amber from Myanmar. Found on one larva was a fungus that could have been serving as food when the insect was trapped by the sap. As it struggled to free itself from the sap, the larva excreted a bit of feces containing a trypanosomatid, probably an ancestor of the digenetics.

In Dominican amber, the same author describes the species Culex malariager (Poinar Jr., 2005b). Birds were probably the food source for the specimens belonging to this species. An interesting detail in this specimen is that it was infected with a species of protozoa, Plasmodium dominicana (Poinar Jr., 2005c). The description of this Plasmodium species is based on oocysts, sporozoites, ookinetes, and microgametocytes found in the body cavity of the female Culex malariager. According to the author, this protozoan was probably responsible for avian malaria and would have been involved in malaria of primates. In this case, it would have originated in the Americas (Poinar Jr., 2005c).

Fossil nematodes are rare, and most of those found in amber are indicative of a phoretic or parastitic association with insects or arthropods (Poinar \& Buckley, 2006).

Other important discoveries have been made in addition to adult sand flies. A primitive genus of a trypanosomatid parasite of sand flies was also described by Poinar Jr. \& Poinar (2005) in Burmese amber, leading the authors to suggest that Paleomyia burnitis Poinar, 2004, a primitive sand fly, transmitted the species Paleoleishmania proterus to vertebrates during the Cretaceous.

\section{REFERENCES}

ANDRADE FILHO, J. D. \& BRAZIL, R. P. Relationships of new word phlebotomine sand flies (Diptera: Psychodidae) based on fossil evidence. Memórias do Instituto Oswaldo Cruz, 98, supl. 1: 145-149, 2003.

ANDRADE FILHO, J. D.; FALCÃO, A. L. \& BRAZIL, R. P. A new phlebotomine fossil species Trichopygomyia killickorum sp. n. (Diptera: Psychodidae), found in the Dominican Republic amber. Parasite, 11(1): 71-73, 2004.

ANDRAdE FILHO, J. D.; GALATI, E. A. B. \& FALCÃO, A. L. Description of Pintomyia (Pifanomyia) brazilorum sp. nov. a new fossil species from the Dominican Republic (Diptera: Psychodidae: Phlebotominae). Memórias do Instituto Oswaldo Cruz, 101: 141142, 2006.

AZAR, D. \& NEL, A. Fossil psychodoid flies and their relation to parasitic diseases. Memórias do Instituto Oswaldo Cruz, 98 , suppl. $1: 35-37,2003$.

BRAZIL, R.P. \& ANDRADE FILHO, J. D. Description of Pintomyia (Pifanomyia) falcaorum sp. n. (Diptera: Psychodidae: Phlebotominae), a fossil sand fly from Dominican Amber. Memórias do Instituto Oswaldo Cruz, 97: 501-503, 2002.

GALATI, E. A. B. Classificação de Phlebotominae. In: RANGEL, E. F. \& LAINSON, R. (Ed.). Flebotomíneos do Brasil. Rio de Janeiro: Fiocruz, 2003.

GRIMALDI, D. \& ENGEL, M. S. Fossil Liposcelididae and the lice ages (Insecta: Psocodea). Proceedings. Biological Sciences, 273: 625-33, 2006. 
KUMAR, P. Antiquity of Phthiraptera: fossil evidence. Journal of the Palaeontological Society of India, 49: 159-168, 2004.

PEÑALVER, E. \& GRIMALDI, D. Assemblages of mammalian hair and blood-feeding midges (Insecta: Diptera: Psychodidae: Phlebotominae) in Miocene amber. Transactions of the Royal Society of Edinburgh: Earth Sciences, 96: 177-195, 2005.

POINAR JR., G. Triatoma dominicana sp. n. (Hemiptera: Reduviidae: Triatominae), and Trypanosoma antiquus sp. n. (Stercoraria: Trypanosomatidae), the first fossil evidence of a triatomine-trypanosomatid vector association. Vector Borne Zoonotic Diseases, 5: 72-81, 2005a.

POINAR JR., G. Culex malariager n. sp. (Diptera: Culicidae) from Dominican amber: the first fossil mosquito vector of Plasmodium. Proceedings of the Entomological Society of Washington, 107: 548-553, 2005b.

POINAR JR., G. Plasmodium dominicana n. sp. (Plasmodiidae: Haemospororida) from Tertiary Dominican amber. Systematic Parasitology, 61: 47-52, 2005c.

POINAR JR., G. Early cretaceous trypanosomatids associated with fossil sand fly larvae in Burmese amber. Memórias do Instituto Oswaldo Cruz, 102: 635-637, 2007.

POINAR JR., G. \& BUCKLEY, R. Nematode (Nematoda: Mermithidae) and hairworm (Nematomorpha: Chordodidae) parasites in early cretaceous amber. Journal of Invertebrate Pathology, 93(1): 36-41, 2006.

POINAR JR., G. \& POINAR, R. The Amber Forest: a reconstruction of a vanished world. New Jersey: Princeton University Press, 1999.

POINAR JR., G. \& POINAR, R. Paleoleishmania proterus n. gen., n. sp., (Trypanosomatidae: Kinetoplastida) from Cretaceous Burmese amber. Protist, 155: 305-310, 2004.

POINAR JR., G. \& POINAR, R. Fossil evidence of insect pathogens. Journal of Invertebrate Pathology, 89: 243-250, 2005. 


\title{
Mites, Ticks, and Paleoparasitology
}

\author{
Gino Chaves da Rocha • Nicolau Maués da Serra-Freire
}

T

he reconstitution of Earth's evolutionary history, of living and extinct beings, fundamentally involves three fields

of study: geology, paleontology, and biology. In the late $20^{\text {th }}$ century, biochemical and molecular techniques were increasingly applied to studies in evolutionary genetics, phylogenetic analyses, and molecular systematics (Navajas \& Fenton, 2000). The study of geological layers, fossil records, and morphological and genetic characteristics to identify relations between organisms produces valuable knowledge on the history and diversity of planetary life or planetary biology, as suggested by Benner et al (2002).

Since the dawn of life on Earth, between 4.4 and 3.8 billion years ago (Chang, 1999), the various levels of competition for ecotopes (spatial niches) and the struggle for the establishment of trophic niches (food resources) have woven a complex web of biochemical relations among organisms (Forattini, 2004). The life and survival of species result from constant adaptation to the challenges raised by favorable or unfavorable conditions in the environment.

In this long history of irradiation and evolutionary adaptation, microorganisms, plants, and animals have developed mechanisms for absorbing and transferring energy (Chart 1) and "adopting" other organisms through an association of interspecific energy and biochemical dependence. Conceptually, parasitism thus exists when an organism finds its ecological niche in another life form. Parasitism is considered an ecological phenomenon (Zelmer, 1998; Rey, 2001; Ferreira, Reinhard \& Araújo, 2008). Araújo et al. (2003) and Ferreira \& Araújo (2005) present the arguments and foundations for host-parasite-environment relations, stating that "parasitism is inherent to life".

The use of available energy in the troposphere became a condition for the survival of living species, including parasites and decomposers, with a key role in ecosystems. 
Chart 1 - The energy cycle of living organisms on Earth: the energy pyramid in the modern age

\begin{tabular}{|c|c|c|c|c|c|c|c|}
\hline $\begin{array}{c}\text { Source and use of } \\
\text { energy }\end{array}$ & $\begin{array}{l}\text { Energy released } \\
\qquad\left(\mathrm{Kcal} / \mathrm{m}^{3}\right)\end{array}$ & $\begin{array}{l}\text { Used for } \\
\text { respiration } \\
\left(\mathrm{Kcal} / \mathrm{m}^{3}\right)\end{array}$ & $\begin{array}{l}\text { Used for growth } \\
\qquad\left(\mathrm{Kcal} / \mathrm{m}^{3}\right)\end{array}$ & $\begin{array}{c}\% \text { used for } \\
\text { growth/released }\end{array}$ & $\begin{array}{l}\text { Unused } \\
\left(\mathrm{Kcal} / \mathrm{m}^{3}\right)\end{array}$ & $\begin{array}{l}\text { Transferred } \\
\left(\mathrm{Kcal} / \mathrm{m}^{3}\right)\end{array}$ & $\begin{array}{l}\% \text { transferred/ } \\
\text { total released }\end{array}$ \\
\hline Produced by sun & $1,700,000$ & - & - & - & - & - & 100 \\
\hline Not absorbed by Earth & $1,209,000$ & - & - & - & $\begin{array}{r}880,000 \\
(68.22 \%)\end{array}$ & 410,00 & 24.118 \\
\hline Photosynthesis & 410,000 & 389,190 & 20,810 & 5.08 & $\begin{array}{r}12,977 \\
(62.36 \%)\end{array}$ & 8,833 & 0.520 \\
\hline Plant respiration & 20,810 & 11,997 & 8,833 & 42.45 & $\begin{array}{r}5,463 \\
(61.85 \%)\end{array}$ & 3,370 & 0.198 \\
\hline Herbivorous animals & 3,370 & 1,890 & 1,480 & 43.92 & $\begin{array}{r}1,500 \\
(79.37 \%)\end{array}$ & 390 & 0.023 \\
\hline Carnivorous animals & 390 & 316 & 74 & 18.97 & $\begin{array}{r}53 \\
(71.62 \%)\end{array}$ & 21 & $0 / 001$ \\
\hline Omnivorous animals & 21 & 13 & 8 & 38.10 & $\begin{array}{r}7,999 \\
(99.99 \%)\end{array}$ & 0.001 & $5 \times 10^{-10}$ \\
\hline Decomposers & 20,001 & 18,183 & 1,818 & 9.09 & $\begin{array}{r}80 \\
(4.40 \%)\end{array}$ & 1,738 & 0.102 \\
\hline
\end{tabular}

This chapter discusses the ecological relations ruling the "parasitism phenomenon" and analyzes them according to paleoparasitological interpretations of paleontological and archaeological finds. We specifically present a line of research focusing on mites and ticks from the past. Didactically, but no less technically and scientifically, we describe these animals and their biological and anatomical similarities and differences between them and insects.

We also take an epidemiological approach to debate the importance of these invertebrates, emphasizing the complexity of ecological models for the transmission of infectious agents by Acari. In order to review and describe the records and reconstruct what may have occurred in the past, we conduct a systematic classification to establish the conditions for interpreting the importance of paleoacarological finds and their ecological context.

\section{PARASITES OF ARTHROPODS}

Of all parasites, fossil or living, those of phylum Arthropoda (the largest phylum in kingdom Animalia) definitely include the widest variety of forms, occupy the most different ecotopes, and display the widest range of biological and parasitic behavior (Giribet \& Ribera, 2000; Hickman, Roberts \& Larson, 2006; Serra-Freire \& Mello, 2006). The group is highly heterogeneous, but with the following basic morphological characteristics: a segmented or metameric body, bilateral symmetry, jointed appendages (including for locomotion), and a chitinous or sclerotized exoskeleton (chitin is a stiff, resilient, and water-insoluble nitrogenated polysaccharide, and sclerotin is another nitrogenated polysaccharide, resilient yet pliable, but also water-insoluble). In geological time, the evolution of Arthropoda began in the Paleozoic, in the Cambrian period or even earlier (Pre-Cambrian), more than 600 million years ago (Weygoldt, 1998). 
An in-depth analysis of the debate on the phylogenetic origins of arthropods is beyond the scope of this chapter (many authors defend a monophyletic origin, i.e., that all arthropods originated from a common ancestor on the evolutionary scale) (Weygoldt, 1998). Briefly, however, two major groups (subphyla) are recognized as having emerged from Arthropoda: the group of Mandibulata, which have mandibles as part of their mouthparts, and the group of Chelicerata, which have six pairs of jointed appendages, with one pair of chelicerae, a pair of leg-like appendages or pedipalps, and four pairs of walking legs (Hickman, Roberts \& Larson, 2006).

The subphylum Mandibulata, which some authors classify as subphylum Uniramia, includes the following respective subgroups: Crustacea (with a hard "crust"-type carapace and two pairs of antennae), Myriapoda ("a thousand legs, feet”, or walking appendages), and Hexapoda (three pairs of legs). In subphylum Chelicerata, one of the largest classes is Arachnida (head fused to the thorax - cephalothorax and abdomen, no antennae or mandibles), which includes mites and ticks (Weygoldt, 1998; Wheeler \& Hayashi, 1998; Giribet \& Ribera, 2000; Hickman, Roberts $\&$ Larson, 2006). Among the mandibulates and chelicerates, two groups have great parasitological importance for both human and veterinary medicine: class Insecta (insects) and class Arachnida (which includes the mites and ticks).

\section{EPIDEMIOLOGICAL IMPORTANCE, PRESENT AND PAST}

Many of these arthropod species can serve as winged or wingless vectors in epidemiological transmission chains, as mechanical and biological transmitters of infectious agents (e.g., viruses, rickettsiae, bacteria, protozoa, fungi, and helminths). Through their bites and blood meals they inoculate and participate in the dissemination and dispersal of pathogenic bioagents to susceptible organisms, thus leading to diseases. Different processes can occur, depending on various other factors related to the time between emergence of cases and the characteristics of the geographic space in which they take place. Such processes can be epidemic (e.g., exanthematic typhus, Brazilian spotted fever, scabies), endemic (Lyme disease, babesiosis), or pandemic (rickettsiosis, ixodidiosis). Epidemiologically, they can also act as reservoirs and intermediate hosts of these same potentially pathogenic agents for humans and species of domestic and wild animals (Rey, 2001; Forattini, 2004; Coura, 2005).

Blood-feeding insects, mites, and ticks (adult ectoparasites and their larval and nymphal forms) are also responsible for debilitation through infestations such as botfly lesions, myiases, and other dermatoses. Considering the serious social and economic impacts of these diseases in modern times, especially in developing countries, one can imagine their impact on human and animal populations in the past.

Importantly, the dynamics of infectious diseases involve complex ecoepidemiological chains, which combine with socioeconomic and cultural determinants of infectious processes to directly or indirectly affect humans; humans also help generate such processes (through anthropogenic actions). When these processes involve humans and other animals (zoonoses) and arthropod vectors, the biological and parasitic relations become highly intricate (Coura, 2005).

\section{THE PALEOSCENARIO AND PALEOPATHOCENOSIS}

Vectors transmit parasites to their vertebrate hosts during feeding (blood meals or hematophagy). The biological characteristics (anatomical, physiological, and behavioral) of Acari are different from those of Insecta. Distinct biological attributes, including adaptive responses to biotic and abiotic factors in the environment, determine differences between these groups in their epidemiological performance as vectors (Randolph, 1998). The latter 
author thus proposes that systems of parasite transmission by vectors that are used for insects should not be applied to mites (and especially not to ticks).

Parasitic strategies display similarities between distant phylogenetic groups - strategies considered in studies of systematics and phylogenetics (Poulin, 1995). However, the spatial distribution (dispersal and diffusion), temporal distribution (seasonality), and density of vectors and susceptible individuals (among other factors) determine the survival and perpetuation of many vectors (during the non-parasitic phase) and thus their success in reaching a new host. The risks of infection to animal and human hosts were and are directly related to their parasitic and vector strategies. Importantly, the establishment of the parasite-host relationship depends on the entire complex ecological dynamics of these hosts (Poulin, 1995; Randolph, 1998; Coura, 2005).

\section{ACAROLOGY}

Studies on mites and ticks were traditionally included within entomology (the field of biology/zoology that studies insects). However, mites and ticks do not fly. At most, tick larvae perform aeronautism (moving on the wind, i.e., by aeolian force), thus constituting a spatial strategy to guarantee their dissemination and long-distance dispersal. The fact that they are wingless is only one of many differences in relation to insects.

Acarology is thus the field of zoology that studies invertebrate organisms belonging to subclass Acari. These are chelicerates that have an undivided body (idiosoma) - the fusion of the cephalothorax and the abdomen - and the mouthparts forming another set, the gnathosoma or capitel connected to the idiosoma. Signs of primary segmentation are present in the embryonic phase during metamerization (Oliveira \& Serra-Freire, 1994), and can be seen in the post-embryonic phase in the sulci of the exoskeleton (Serra-Freire \& Mello, 2006). Three major lineages are accepted: Opilioacariforms, Parasiforms (the latter constituting the cohort of Parasitiforms Reuter, 1909), and Acaritiforms, forming the cohort of the same name. The first is considered the most primitive lineage of mites. At present, the members of the other two are important for human and veterinary medicine and are the most extensively studied.

The following are the main classical characteristics used and accepted by most acarologists for purposes of taxonomic identification, and which we find practical and didactic (Flechtmann, 1975; Hickman, Roberts \& Larson, 2006; Wooley, 1988; Oliver, 1987 apud Serra-Freire \& Mello, 2006; Dunlop \& Alberti, 2007; Krantz \& Walter, 2007):

- Parasitiform cohort: forms that present respiratory stigmata on the posterior tagma (hysterosoma) and sensory organs on the propodosoma. Ticks and mites are included. Another characteristic that served as the basis for classifying them as superorder Anactinotrichida is the nature of the cuticle, optically inactive, since it does not stain with iodine. This cohort includes the following orders: Opilioacarida Hammen, 1968, the most primitive Acari, which colonize semiarid spaces; Holothyrida Thon, 1909, which are lethal to birds and highly toxic to humans both by contact and when ingested; Ixodida Leach, 1815, which survive and reproduce on the blood they obtain from hosts; and Gamasida Hammen, 1968, which includes parasitic, predatory, and free-living decomposer species.

- Acariform cohort: forms that do not present respiratory stigmata on the hysterosoma, and in which the propodosomal sensory organs either do not exist, or when present, take the form of trichobothria, or more specialized structures such as rhabdomeres. This cohort constitutes the group of mites per se. Under the other systematic classificatory proposal, the group belongs to superorder Actinotrichida, since the cuticle is optically active - staining a yellowish color with iodine. This cohort includes the following orders: Astigmata Canestrini, 
1891, which includes the majority of bioagents for scabies in animals and humans; Oribatida Hammen, 1968, including an extremely wide variety of decomposer mites that serve as intermediate hosts to helminth parasites of vertebrates; Actinedida Hammen, 1968, with the widest biological diversity among the Acari, with predatory species, parasites of vertebrates and invertebrates, and free-living species, including many decomposers. Decomposers are important in the energy pyramid because they reinsert energy (that would otherwise have been lost) to recirculate among living beings (Chart 1).

In the acarological literature, the most detailed textbook on Acari taxonomy is A Manual of Acarology (Krantz, 1978), which provides classification keys down to the family taxon, including information on their biology, behavior, evolutionary relations, and economic importance. This work has now been replaced by the latest edition, presenting the most recent concepts on the classification of mites (Krantz \& Walter, 2009). According to this more recent systematic proposal, for example, the Acariforms are only divided into the orders Prostigmata (= Trombidiforms) and Sarcoptiforms.

Considering the geological time scale (Figure 1), the Acari are an ancient group belonging to the Upper Devonian (390 million years BP). These primitive mites were also considered terrestrial forms and classified as the single species Protacarus crani by Hirst in 1923 (Poinar \& Poinar, 1998). Studies on the origin and formation of the current groups of Acari show that they probably had Euripterides as their ancestors in the Ordovician period (Serra-Freire 2003), and that ticks appeared on the evolutionary scale at a time that coincided with the evolution of primitive reptiles. Mites and ticks form the largest diversified known group among the Arachnida, with slightly more than 48 thousand species (Harvey, 2002 apud Dunlop \& Alberti, 2007). Currently, a list of 889 valid names is proposed for tick genera and species (Barker \& Murrell, 2004), although there is no consensus on acarological systematics, and other proposals exist for their taxonomic classification (Horak, Camicas \& Keirans, 2002), especially when molecular, biochemical, and numerical systematics are considered, often disconnected from the classical morphological and morphometric taxonomy with biological considerations.

\section{PALEOACAROLOGY}

Parasitic infections and diseases that affected populations in the past can be diagnosed and studied by finding parasites, their evolutionary forms and their signs, in human and animal vestiges or remains found in archaeological and paleontological material, as well as in historical documents (Ferreira, Araújo \& Confalonieri, 1988; Araújo \& Ferreira, 1992). Paleoparasitology, a term proposed by Ferreira, Araújo \& Confalonieri (1979), has emerged as a branch of paleopathology (biological and health sciences) and is defined as the study of the parasite finds and their meaning in material from the past (Araújo \& Ferreira, 1997).

The specific study of the presence of parasite mites and ticks in ancient material is known as the branch of paleoacarology. By relating Acari finds in prehistoric or historical material to their parasitic biological characteristics and to the ecology of diseases caused by them or with bioagents for which they serve as vectors, one can infer the importance of these arthropods in the epidemiological scenario of the past. Such studies also make an important contribution to reconstruction of the paleofauna, possible ecological models, and the dynamics of existing infections. 
Figure 1 - Chronology of animal life with evolution of the Arachnidae, Acari, Ixodida, and Ixodidae related to the evolution of the higher vertebrates

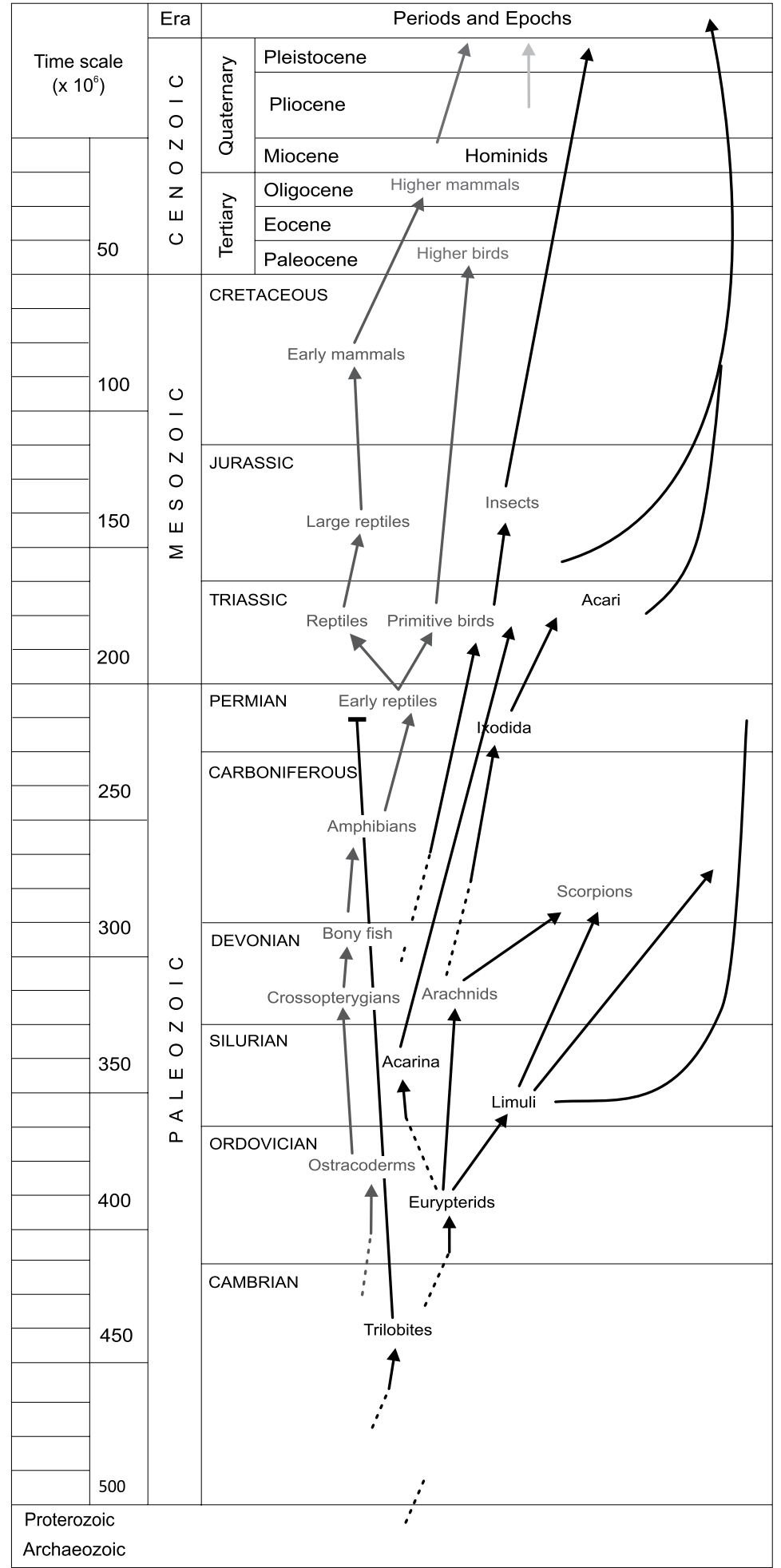




\section{A BRIEF HISTORY}

In the historical context, mites and ticks have been known (or at least suspected) since Antiquity. Aristotle (355 $\mathrm{BC}$ ) coined the term akari. In the $16^{\text {th }}$ century, the Latinized term acari began to be used, giving rise to the genus called Acarus siro by Linnaeus, in 1758, in his Systema Naturae (Dunlop \& Alberti, 2007).

According to the historical review by Krantz (1978), the existence of parasites with ticks as vectors is suggested by records of a "tick fever" in Egyptian papyri (Ebers Papyrus), dated to 1550 BC (Krantz, 1978; Obenchain \& Galum,1982). This was most likely a rickettsiosis (an infection caused by microorganisms of genus Rickettsia), although the pathogen was only observed in tissue smears from ticks several millennia later, when ixodids were identified as the vector in the epidemiological transmission chain for that infectious agent.

One of the first references to ticks is attributed to Homer in $850 \mathrm{BC}$, when he cited the presence of these ectoparasites on Ulysses' dog, Argus. Some 500 years later, Aristotle wrote about a mite of locusts (probably Eutrombidium), thrombiculid mite larvae, and mites colonizing old beehives in his treatise De Animalibus Historia Libri. He was also familiar with ticks of dogs, goats, sheep, and other domestic animals. He further claimed that ticks are generated from "couch grass".

Other ancient references to Acari appeared in the writings of Hippocrates, Plutarch, Aristophanes, and Pliny. The latter, in $77 \mathrm{AD}$, in his treatise Historia Naturalis, cites an animal that lives off the blood of cattle and dogs, but never of asses. The tick attaches its head to those animals, then swells up and bursts, engorged with its blood meal.

This quote indicates the existence of ticks and characterizes both their feeding habits and possible hosts. Mites and ticks were frequently referred to as "lice", "beesties", or "little insects" during the Age of Darkness and Renaissance. The terms akari and "mite" appeared around $1650 \mathrm{AD}$. As mentioned above, Linnaeus used the generic name "Acarus" in the first edition of Systema Naturae, using the type A. siro in 1758 (Krantz, 1978).

Historically, after the formation of Ixodida on Earth, the evolutionary process maintained its course, and during the Triassic Period, in the Paleocene Age, a major differentiation must have occurred, giving rise to the diversity we know today, as illustrated in Figure 2.

The hypothesis presented in Figure 1 considers the absence of fossil evidence (so far) allowing a phylogenetic evaluation of Arachnida in general or particular. However, there are indications that arachnids were already well represented on Earth since the Middle Paleozoic - during the Devonian or Silurian period (Krantz, 1978). Furthermore, the oldest fossil record of mites, Protacarus crani Hirst, dates to this time (440-360 million years). The record further indicates that the greatest adaptive leap in Acari occurred during the Late Mesozoic (146 million years) (evolutionary synergism) and Recent Cenozoic (65 million). 
Figure 2 - Evolution of Ixodida from the Paleocene to present, considering their primary origin in trilobites

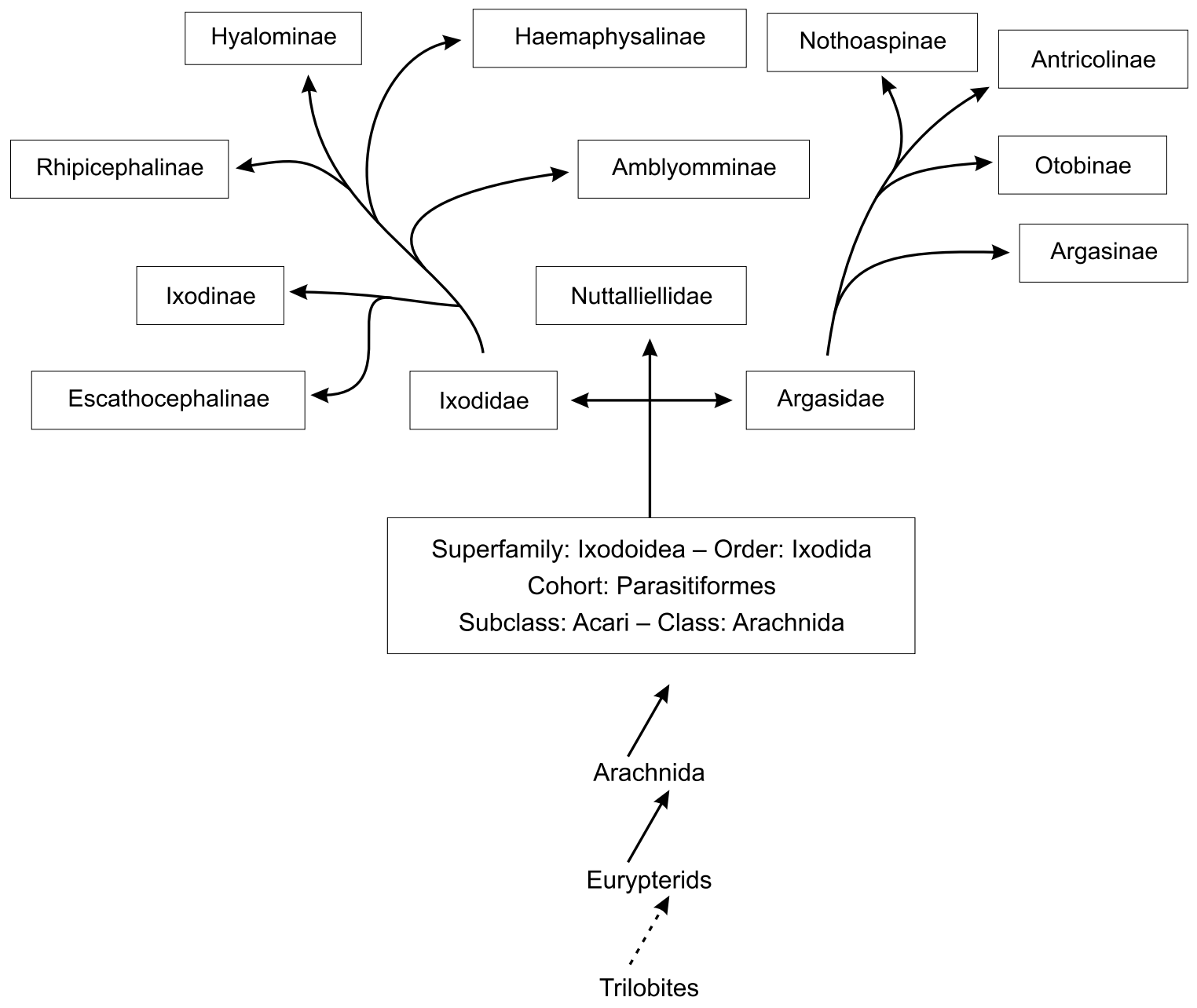

\section{FOSSIL MATERIAL}

Fossil records of insects are found in large numbers, but there are few mite and tick finds in paleozoological studies. Fossils are defined as material remains of ancient living organisms or remains of their activities (ichnofossils or trace fossils, e.g., trails, tracks, coprolites, tubes, perforations). To be considered fossils, organic remains must date to more than $13,000 \mathrm{BP}$, corresponding to the last glaciation.

Fossilization (chemical and physical modifications that occur over a period of time) is a rare and complex event (less than $1 \%$ of situations) that allows the preservation of evidence (remains) of the remote existence of living organisms. The process consists of the substitution of dead organic compounds with other more stable ones like calcite, silica, pyrite, carbon, and others. Usually only the hard parts (trunks, shells, carapaces, bones, and teeth) undergo fossilization.

There are various modes of fossil transformation: unaltered preservation (inclusion in amber), recrystallization (growth of minerals or change in the crystalline structure), replacement or substitution (silicification), permineralization 
(filling of pores and cavities with mineral), carbonization, incrustation (covering with a mineral film), molds (casts), or impressions (counter-molds and replicas) (De la Fuente, 2003; Oliveira \& Serra-Freire, 2008). More specifically, in relation to unaltered preservation, amber is a fossil resin produced by conifer trees that existed around the Carboniferous Period (Paleozoic Age) - between 280 and 345 million years BP - with the increasing predominance of these plants during the Upper Permian - 250 to 280 million years BP. This fossil resin underwent limited chemical alterations in relation to the original plant resin, and those in the Americas with preserved arthropods vary in age from 15 to $150 \times 10^{6}$ years. The process occurred over time as follows:

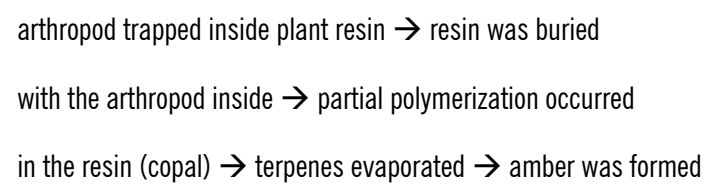

The principal tree species that released resins was the group of legumes, especially locust tree (genus Hymenaea), which preserved many specimens in amber.

Mites and ticks can also be found in ancient material inside natural cavities (nasal fossae and diverticula, auditory canals), or even on the surface (skin, hairs) of naturally mummified bodies. They can also be found in both the stomach content of mummified animals and in coprolites. Unlike fossils, specimens can be recovered in these conditions in paleontological or archaeological material that dates more recently than the 13,000 years that characterizes fossilization.

\section{PALEOACAROLOGICAL RECORDS}

Concerning fossil Acari finds, we present the records in the scientific literature based on the review by Guerra (2002). To date, the latter is the first thesis on the subject in Brazil. The researcher's doctoral dissertation featured an ecological analysis of mites associated with coprolites recovered from an archaeological site in Northeast Brazil. We will also cite other reviews, in addition to more current records, in order to provide an overview of paleoacarology and the meaning of its findings. We opted to present them according to the systematic classification for Acari, i.e., first the paleoacarological records on members of the Parasitiform cohort, followed by the Acariform cohort.

The greatest adaptive advance in Acari occurred during the Late Mesozoic (146 x $10^{6}$ years) (evolutionary synergism) and Recent Cenozoic (65 x $10^{6}$ years) (Krantz, 1978). Among the Parasitiforms, various specimens from the orders Holothyrida, Gamasida, and Ixodida were found from the Mesozoic to the Cenozoic, beginning at $245 \times 10^{6}$ years, according to a review article by Krivolutsky \& Druk (1986), when dinosaurs, mammals, and modern groups of reptiles and amphibians appeared.

From order Ixodida (ticks), the following finds were recorded, in the reviews by Lane \& Poinar Jr. (1986), Guerra (2002), and De la Fuente (2003), shown in Chart 2. 
Chart 2 - Fossil tick finds according to taxa, host, stage, origin, and bibliographic reference for the genus

\begin{tabular}{|c|c|c|c|c|}
\hline Genus and/or species & Current hosts for genus ${ }^{a}$ & Stage/ Sex (Family) & Origin ${ }^{b}\left(\times 10^{6}\right.$ years $)$ & References \\
\hline Carios jerseyi & Birds, mammals & Larva (Argasidae) & $\begin{array}{l}\text { New Jersey amber } \\
\text { (Cretaceous, 90-94) }\end{array}$ & Klompen \& Grimaldi, 2001 \\
\hline Ixodes succineus & Birds, mammals & Female (Ixodidae) & $\begin{array}{c}\text { Baltic amber } \\
\text { (Tertiary, 35-50) }\end{array}$ & Weidner, 1964 \\
\hline Ixodes spp. & Birds, mammals & $\begin{array}{c}\text { Larva } \\
\text { (Ixodidae) }\end{array}$ & $\begin{array}{c}\text { Baltic amber } \\
\text { (Tertiary, 35-50) }\end{array}$ & De la Fuente, 2003 \\
\hline Hyalomma spp. & Mammals, reptiles, birds & $\begin{array}{c}\text { Male } \\
\text { (Ixodidae) }\end{array}$ & $\begin{array}{c}\text { Baltic amber } \\
\text { (Tertiary, 35-50) }\end{array}$ & De la Fuente, 2003 \\
\hline $\begin{array}{l}\text { Amblyomma } \\
\text { (A. testudinis) }\end{array}$ & Reptiles, birds, mammals & $\begin{array}{c}\text { Male } \\
\text { (Ixodidae) }\end{array}$ & $\begin{array}{l}\text { Dominican amber } \\
\text { (Tertiary, 35-50) }\end{array}$ & Lane \& Poinar, 1986 \\
\hline Amblyomma spp. & $\begin{array}{c}\text { Amphibians, reptiles, birds, } \\
\text { mammals }\end{array}$ & $\begin{array}{c}\text { Larva } \\
\text { (Ixodidae) }\end{array}$ & $\begin{array}{l}\text { Dominican amber } \\
\text { (Tertiary, 15-40) }\end{array}$ & Poinar, 1992 \\
\hline Amblyomma spp. & $\begin{array}{c}\text { Amphibians, reptiles, birds, } \\
\text { mammals }\end{array}$ & $\begin{array}{c}\text { Larva } \\
\text { (|xodidae) }\end{array}$ & $\begin{array}{l}\text { Dominican amber } \\
\text { (Tertiary, 15-40) }\end{array}$ & Amberdepot Inc. \\
\hline Unknown & Unknown & $\begin{array}{c}281^{\text {st }} \text { instar larvae } \\
\text { (Ixodidae) }\end{array}$ & $\begin{array}{l}\text { Dominican amber } \\
\text { (Tertiary, 15-40) }\end{array}$ & Amberdepot Inc. \\
\hline Amblyomma spp. & $\begin{array}{c}\text { Amphibians, reptiles, birds, } \\
\text { mammals }\end{array}$ & $\begin{array}{c}\text { Adult } \\
\text { (|xodidae) }\end{array}$ & $\begin{array}{l}\text { Dominican amber } \\
\text { (Tertiary, 15-40) }\end{array}$ & Amberdepot Inc. \\
\hline Unknown & Unknown & $\begin{array}{c}\text { Adult } \\
\text { (Argasidae) }\end{array}$ & $\begin{array}{l}\text { Dominican amber } \\
\text { (Tertiary, 15-40) }\end{array}$ & Amberdepot Inc. \\
\hline Ornithodorus antiquus & Amphibians, reptiles, birds & $\begin{array}{c}\text { Female } \\
\text { (Argasidae) }\end{array}$ & $\begin{array}{l}\text { Dominican amber } \\
\text { (Tertiary, 15-40) }\end{array}$ & Poinar, 1995 \\
\hline Ixodes terciarius & Birds, mammals & $\begin{array}{l}\text { Not reported } \\
\text { (Ixodidae) }\end{array}$ & $\begin{array}{c}\text { Not reported } \\
\text { (Tertiary, Oligocene, 30) }\end{array}$ & De la Fuente, 2003 \\
\hline Dermacentor reticulatus & Mammals & $\begin{array}{c}\text { Male } \\
\text { (Ixodidae) }\end{array}$ & $\begin{array}{l}\text { Auditory canal of wooly rhinoceros } \\
\text { (Tertiary, Pliocene, 2-5) }\end{array}$ & De la Fuente, 2003 \\
\hline Amblyomma spp. & $\begin{array}{c}\text { Amphibians, reptiles, birds, } \\
\text { mammals }\end{array}$ & $\begin{array}{l}\text { Larva } \\
\text { (|xodidae) }\end{array}$ & $\begin{array}{c}\text { Felid coprolites } \\
\text { (Holocene, } 11,000 \text { yrs.) }\end{array}$ & $\begin{array}{l}\text { Guerra et al., 2001; } \\
\quad \text { Guerra, } 2002\end{array}$ \\
\hline Ixodes spp. & Birds, mammals & $\begin{array}{l}\text { Larva } \\
\text { (Ixodidae) }\end{array}$ & $\begin{array}{c}\text { Felid coprolites } \\
\text { (Holocene, 11,000 yrs.) }\end{array}$ & $\begin{array}{l}\text { Guerra et al., 2001; } \\
\quad \text { Guerra, } 2002\end{array}$ \\
\hline
\end{tabular}

a List of hosts from Klompen et al. (1996).

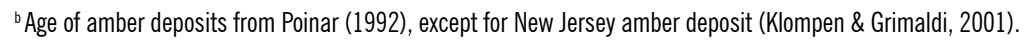

Source: Adapted from De la Fuente (2003).

Evaluating the impact of the finds listed in Chart 2, we begin by analyzing the finding of Ornithodorus antiquus, described by the author, who also found remains of feces and fibrous plant material included in amber (Poinar, 1995). Poinar (1995) emphasized that the material's characteristics, in addition to knowledge of the tick's life cycle, allow suggesting that the host was a rodent. According to the author, these ticks may even have been vectors of spirochetes, considering the current epidemiological models in which many species of genus Ornithodorus are vectors of these microorganisms. 
The Carios jerseyi larva finding (Klomplen \& Grimaldi, 2001) does not mention the larval instar of this argasid tick. According to current knowledge on representatives of Argasidae, the larval stage is the only one that remains attached to the host for several days, until engorging. Fasting larvae remain in hiding places in the nests of hosts, mostly Chiroptera mammals, which allows finding various larvae due to the etology of the stage; engorged larvae or those with feeding interrupted by any cause could be isolated and far from the host's nest, even very far away, being transported by the winged host. A more detailed description is needed of the material preserved in the amber together with the tick for a better understanding of the scenario, as done by Poinar (1995).

Guerra et al (2001) and Guerra (2002) found specimens of genera Amblyomma and Ixodes in felid coprolites from the same archaeological site (Furna do Estrago) in the county of Brejo da Madre de Deus, Pernambuco State, Brazil. They attributed the presence of ixodid ticks in felid coprolites to the animal's predation of tick-parasitized prey. Occupation of the site dates from 11,000 to some 2,000 years BP, during which the archaeological records show the presence of hunter-gatherer groups in the region. In this region, presence of the following wild felids has been described: jaguar (Panthera onca), mountain lion (Puma concolor), jaguarundi or eyra cat (Herpailurus yagouaroundi), and oncilla or little spotted cat (Leopardus tigrinus). Also described are animals from the following families: Myrmecophagidae (anteater), Cervidae (deer), Caviidae (capybara, rock cavy, guinea pig), Taiassuidae (peccary), and Echimyidae (spiny rat), all considered prey of those felids.

Most fossil ticks have been recorded in amber from the Baltic or the Dominican Republic, from deposits where the largest number of fossilized specimens have been studied. According to De la Fuente (2003), many pieces of amber containing tick specimens are mined and sold by amber traders, sometimes without allowing correct classification of the inclusions. Numerous ticks may have gone undiscovered because the amber pieces are in the hands of merchants and private collectors, unbeknownst to the scientific community.

The finding of Dermacentor reticulatus in the auditory canal of a woolly rhinoceros (Schille, 1916) from 2-5x10 $\mathrm{BP}$ is interesting in light of current knowledge on Ixodidae. In relation to the taxonomic position, there are persistent scientific discussions on the validity of the genus. Some experts include it as a subgenus of genus Dermacentor. From the morphological point of view, the strong taxonomic character to separate the two genera is the number of aeropiles on the peritrematic plate (Serra-Freire \& Mello, 2006). The number has been shown to vary from 6 to 15 in Anocentor nitens (Gazeta \& Serra-Freire, 1995, 1996; Gazeta et al., 2001), with bilateral asymmetry and the possibility of regional variation and cline formation, while in Dermacentor spp. there are always more than two dozen aeropiles. Another difference is the preference for the site of parasitism in the host, which for A. nitens is the auditory canal both in equids and felids (Flechtmann, 1975; Amaro et al., 1999), while genus Dermacentor displays a preference for non-cavitary areas on the host's skin. Such differences, taxonomic and in parasite etology, can raise the following question: could $A$. nitens descend from $D$. reticulates in terms of behavior? A possible attempt to answer this question would be studying this fossil's peritrematic plate. In the context of this paleoacarological finding, one intriguing doubt remains: why was only the male tick found in the site?

The conditions in which ixodids (hard ticks) are found in ancient material potentially leads to some epidemiological inferences. Based on the accumulated knowledge from the $19^{\text {th }}$ century to the present, hard ticks do not display nesting habits, i.e., they do not live in hosts' nests, dens, or shelters. Rather, they live in open habitats such as savannahs, forest vegetation, scrub forests, and in the peri- or intradomicile. One exception is genus Ixodides, in which some species display nesting behavior, like the argasids (soft ticks), which show nesting behavior, colonizing the nests of hosts.

Finding these ectoparasites indicates the antiquity of parasitism by ticks and the potential for transmission of pathogenic bioagents vectored by them to animals and even to humans. Their presence in modern times helps 
understand how the conditions in remote times were favorable and highlights their adaptive capacity. It is thus important to know details of the climatic alterations that took place and thus the characteristics of the modern-day biomass, including vegetation, and their hosts in order reconstruct what happened (the paleoscenario) or still happens for the perpetuation or extinction of species.

In the Acariform cohort, most of the known fossils belong to order Oribatida. Members of this order are not usually associated with other organisms such as other arthropods or vertebrates and humans. The known oribatids are free-living mites and are the most predominant representatives of the edaphic (soil-dwelling) fauna, thus present in forest ecosystems, observed in lichens, humus (facilitating cultivation of the soil), fungi, plants, and as secondary fauna of decomposers. This diversity of habitats and niches in different ecosystems makes them an essential compoment in recycling energy for the biomass, even in environments in which sunlight contributes less to the energy pyramid (Chart 1). This group's biodiversity is high when compared to Gamasida, Actinedida, and Astigmata mites. Considering their feeding habits, species belonging to Oribatida are different. They are thus classified among the macrophytophagous, microphytophagous, panphytophagous, coprophagous, zoophagous, and necrophagous organisms (Wallwork, 1983).

The review by Krivolutsky \& Druk (1986) lists records of oribatids in the Mesozoic (Jurassic and Cretaceous periods), from 208 to 66 million years ago, and in the Cenozoic, Tertiary Period, in the Paleocene, Miocene, and Pleistocene ages, from 66 to $1 \times 10^{6}$ years ago. The review shows the wide diversity and temporal distribution of these mites. Some species died out, while others survived to this day, indicating that this group can be a reference for evolutionary studies of mites. Chart 3 shows the records of mite finds in fossil material.

Chart 3 - Fossil mite finds according to taxa, niche, stage, origin, and bibliographic reference

\begin{tabular}{|c|c|c|c|c|}
\hline Mites & Current niche(s) & Stage & Origin & References \\
\hline Family Anoetidae & Free-living mites & Hypopus & $\begin{array}{l}\text { Coprolites from pelvis of mummified } \\
\text { body (Nevada, USA) }\end{array}$ & Radovsky, 1970 \\
\hline Family Acaridae & $\begin{array}{l}\text { Free-living mites; } \\
\text { parasites of mammals }\end{array}$ & Tritonymph & $\begin{array}{l}\text { Coprolites from pelvis of mummified } \\
\text { body (Nevada, USA) }\end{array}$ & Radovsky, 1970 \\
\hline Family Lardoglyphidae & $\begin{array}{l}\text { Free-living mites; } \\
\text { stored products }\end{array}$ & Hypopus & $\begin{array}{l}\text { Coprolites from pelvis of mummified } \\
\text { body (Nevada, USA) }\end{array}$ & Radovsky, 1970 \\
\hline Family Cheyletidae & $\begin{array}{l}\text { Parasites of carnivorous and herbivorous } \\
\text { mammals; predators of arthropods }\end{array}$ & Adults & $\begin{array}{l}\text { Hair and tissues from mummified body } \\
\text { (Minas Gerais, Brazil) }\end{array}$ & Araújo et al., 1986 \\
\hline Order Astigmata & $\begin{array}{l}\text { Parasites of vertebrates; } \\
\text { free-living mites }\end{array}$ & Adults and eggs & $\begin{array}{l}\text { Desiccated tissues of Peruvian and } \\
\text { Aleutian mummies }\end{array}$ & Kliks, 1988 \\
\hline $\begin{array}{l}\text { Family } \\
\text { Lardoglyphidae }\end{array}$ & Free-living mites; stored products & Not mentioned & $\begin{array}{l}\text { Intestinal content of North American and } \\
\text { Chilean mummies }\end{array}$ & Baker, 1990 \\
\hline $\begin{array}{l}\text { Order Actinedida } \\
\text { Family Tarsonemidae }\end{array}$ & $\begin{array}{l}\text { Free-living mites; parasites of vertebrates, } \\
\text { invertebrates, and humans }\end{array}$ & Not mentioned & $\begin{array}{l}\text { Coprolites from Furna do Estrago } \\
\text { (Pernambuco, Brazil) }\end{array}$ & Guerra et al., 2001 \\
\hline Order Gamasida & $\begin{array}{l}\text { Free-living mites; parasites of vertebrates, } \\
\text { invertebrates, and humans }\end{array}$ & Not mentioned & $\begin{array}{l}\text { Coprolites from Furna do Estrago } \\
\text { (Pernambuco, Brazil) }\end{array}$ & Guerra et al., 2001 \\
\hline $\begin{array}{c}\text { Order Astigmata } \\
\text { Family Atopomelidae }\end{array}$ & $\begin{array}{l}\text { Free-living mites; } \\
\text { related to diseases in felids }\end{array}$ & Not mentioned & $\begin{array}{l}\text { Coprolites from Furna do Estrago } \\
\text { (Pernambuco, Brazil) }\end{array}$ & Guerra et al., 2001 \\
\hline
\end{tabular}


Chart 3 - Fossil mite finds according to taxa, niche, stage, origin, and bibliographic reference (continued)

\begin{tabular}{|c|c|c|c|c|}
\hline Mites & Current niche(s) & Stage & Origin & References \\
\hline $\begin{array}{l}\text { Order Astigmata } \\
\text { Family Acaridae }\end{array}$ & $\begin{array}{l}\text { Free-living mites; parasites of felids, } \\
\text { cavies, and humans }\end{array}$ & Not mentioned & $\begin{array}{l}\text { Coprolites from Furna do Estrago } \\
\text { (Pernambuco, Brazil) }\end{array}$ & Guerra et al., 2001 \\
\hline $\begin{array}{l}\text { Order Astigmata } \\
\text { Family Glycyphagidae }\end{array}$ & $\begin{array}{l}\text { Free-living mites; } \\
\text { related to diseases in felids }\end{array}$ & Not mentioned & $\begin{array}{l}\text { Coprolites from Furna do Estrago } \\
\text { (Pernambuco, Brazil) }\end{array}$ & Guerra et al., 2001 \\
\hline $\begin{array}{l}\text { Order Astigmata } \\
\text { Family Pyroglyphidae }\end{array}$ & $\begin{array}{l}\text { Free-living mites; } \\
\text { related to diseases in cavies }\end{array}$ & Not mentioned & $\begin{array}{l}\text { Coprolites from Furna do Estrago } \\
\text { (Pernambuco, Brazil) }\end{array}$ & Guerra et al., 2001 \\
\hline $\begin{array}{l}\text { Order Astigmata } \\
\text { Anoetidae }\end{array}$ & $\begin{array}{l}\text { Free-living mites; } \\
\text { related to diseases in felids }\end{array}$ & Not mentioned & $\begin{array}{l}\text { Coprolites from Furna do Estrago } \\
\text { (Pernambuco, Brazil) }\end{array}$ & Guerra et al., 2001 \\
\hline $\begin{array}{l}\text { Order Actinedida } \\
\text { Family } \\
\text { Tarsonemidae }\end{array}$ & $\begin{array}{l}\text { Free-living mites; } \\
\text { related to diseases in felids and deer }\end{array}$ & Not mentioned & $\begin{array}{l}\text { Coprolites from Furna do Estrago } \\
\text { (Pernambuco, Brazil) }\end{array}$ & Guerra et al., 2001 \\
\hline $\begin{array}{l}\text { Order Oribatida } \\
\text { Family Hypochthoniidae }\end{array}$ & $\begin{array}{l}\text { Free-living mites; } \\
\text { related to diseases in felids }\end{array}$ & Not mentioned & $\begin{array}{l}\text { Coprolites from Furna do Estrago } \\
\text { (Pernambuco, Brazil) }\end{array}$ & Guerra et al., 2001 \\
\hline $\begin{array}{l}\text { Order Oribatida } \\
\text { Family Cosmochthoniidae }\end{array}$ & $\begin{array}{l}\text { Free-living mites; } \\
\text { related to diseases in humans and felids }\end{array}$ & Not mentioned & $\begin{array}{l}\text { Coprolites from Furna do Estrago } \\
\text { (Pernambuco, Brazil) }\end{array}$ & Guerra et al., 2001 \\
\hline $\begin{array}{l}\text { Order Oribatida } \\
\text { Family Ctenacaridae }\end{array}$ & $\begin{array}{l}\text { Free-living mites; } \\
\text { related to diseases in felids }\end{array}$ & Not mentioned & $\begin{array}{l}\text { Coprolites from Furna do Estrago } \\
\text { (Pernambuco, Brazil) }\end{array}$ & Guerra et al., 2001 \\
\hline $\begin{array}{c}\text { Order Oribatida } \\
\text { Family Perlohmannidae }\end{array}$ & $\begin{array}{l}\text { Free-living mites; } \\
\text { related to diseases in felids }\end{array}$ & Not mentioned & $\begin{array}{l}\text { Coprolites from Furna do Estrago } \\
\text { (Pernambuco, Brazil) }\end{array}$ & Guerra et al., 2001 \\
\hline $\begin{array}{l}\text { Order Oribatida } \\
\text { Family Eutegaeidae }\end{array}$ & $\begin{array}{l}\text { Free-living mites; } \\
\text { related to diseases in felids }\end{array}$ & Not mentioned & $\begin{array}{l}\text { Coprolites from Furna do Estrago } \\
\text { (Pernambuco, Brazil) }\end{array}$ & Guerra et al., 2001 \\
\hline
\end{tabular}

Some of records (up to Guerra et al., 2001) are quoted from the review by Guerra (2002). 7

According to Radovsky (1970), mites in the coprolites were probably transported to the feces by coprophilic insects. Anoetid and acarid mites (order Astigmata) display free-living habits and are associated with stored products such as grain, bran, and flour (Serra Freire \& Mello, 2006) and can also be swallowed with food and eliminated in the excreta. As for lardoglyphids, based on what is now known of their biology, they reached the body during the advanced stage of desiccation, but before mummification. The presence of these mites suggests that the pelvic region did not remain intact, but it is also possible that they either were ingested or entered the corpse through the anus. Remains of saprophytic arthropods (which feed on dead matter) are frequently found in the intestinal content of mummified human bodies but are not properly recorded (Kliks, 1988). The author goes on to state that they are ancient or recent invaders of dead organic tissues. In the case of lardoglyphid mites found in the intestinal content of the mummies examined by Baker (1990), the researcher states categorically that they were ingested with food, since in the desiccation of the bodies a protein concentrate was found called pemmican (a mixture of meat jerky, raisins, lard, and sugar). Besides the fact that the bodies showed no signs of orifices caused by insects, pemmican is consistent with the feeding preferences of these mites.

The descriptions of mite specimens found by Guerra (2002) and listed in Chart 3 are classified at the family level. For readers interested in species-level descriptions, we suggest directly consulting the researcher's dissertation, since her finds include mites from the family Tarsonemidae (order Actinedida). Representatives of this family are 
generally associated with other arthropods (beetles), where the species display phoretic activity, or use arthropods for transportation, or are even parasitoids (parasitizing other parasites). Considering the biology of these mites, we can conclude that finding them in coprolites indicates that they invaded the excreta after defecation.

\section{REFERENCES}

AMARO, A. L. et al. Otite purulenta em Felis catus L., 1758 induzida por Anocentor nitens (Neumann, 1897). Entomologíay Vectores, 6: 501-507, 1999.

ARAÚJo, A. \& FERREIRA, L. F. (Orgs.). Paleopatologia e Paleoepidemiologia: estudos multidisciplinares. Rio de Janeiro: Panorama Ensp, 1992.

ARAÚJO, A. \& FERREIRA, L. F. Homens e parasitos: a contribuição da paleoparasitologia para a questão da origem do homem na América. Revista da Universidade de São Paulo, 34: 58-70, 1997.

ARAÚJO, A. et al. Microscopia de varredura de larvas de ancilostomídeos encontradas em coprólitos humanos datados de $3490 \pm 120$ a $430 \pm 70$ anos. In: SIMPÓSIO DE TÉCNICAS ESPECIAIS EM MICROSCOPIA ELETRÔNICA, Caxambu, 1986.

ARAÚJO, A. et al. Exame parasitológico: mumificações naturais na pré-história brasileira. Boletim do Museu Paraense Emilio Goeldi, Antropologia, 1: 32-33, 1986.

ARAÚJO, A. et al. Parasitism, the diversity of life, and paleoparasitology. Memórias do Instituto Oswaldo Cruz, 98, supl. 1: 5-11, 2003.

BAKER, A. S. Two new species of Lardoglyphus Oudemans (Acari: Lardoglyphidae) found in the gut contents of human mummies. Journal of Stored Product Research, 26: 139-147, 1990.

BARKER, S. C. \& MURRELL, A. Phylogeny, evolution and historical zoogeography of ticks: a review of recent progress. Experimental and Applied Acarology, 28: 55-68, 2002.

BARKER, S. C. \& MURRELL, A. Systematics and evolution of ticks with a list of valid genus and species names. Parasitology, 129 (supl.): 815-836, 2004.

BENNER, S. A. et al. Planetary biology: paleontological, geological, and molecular histories of life. Science, 296: 863-868, 2002.

CHANG, S. Planetary environments and the origin of life. Biology Bulletin, 196: 308-310, 1999.

COURA, J. R. Dinâmica das Doenças Infecciosas e Parasitárias. Rio de Janeiro: Guanabara Koogan, 2005.

DE LA FUENTE, J. The fossil record and the origin of ticks (Acari: Parasitiformes: Ixodida). Experimental and Applied Acarology, 29: 331-344, 2003.

DUNLOP, J. A. \& ALBERTI, G. The affinities of mites and ticks: a review. Journal of Zoological Systematics and Evolutionary Research, 1: 439-469, 2007.

FERREIRA, L. F. \& ARAÚJO, A. Parasitismo, doença parasitária e paleoparasitologia.In: Coura, J. R. Dinâmica das Doenças Infecciosas e Parasitárias. Rio de Janeiro: Guanabara Koogan, 2005.

FERREIRA, L. F.; ARAÚJO, A. \& CONFALONIERI, U. Subsídios para a paleoparasitologia do Brasil: parasitos encontrados em coprólitos no município de Unaí, MG. In: CONGRESSO DA SOCIEDADE BRASILEIRA DE PARASITOLOGIA, 5, 1979.

FERREIRA, L. F.; ARAÚjo, A. \& CONFALONIERI, U. Paleoparasitologia no Brasil. Rio de Janeiro: PEC/Ensp, 1988.

FERREIRA, L. F.; REINHARD, K. \& ARAÚJO, A. Paleoparasitologia. 1 ed. Rio de Janeiro: Editora Fiocruz, 2008.

FLETCHMANN, C. H. W. Elementos de Acarologia. São Paulo: Nobel, 1975.

FORATTINI, O. P. Ecologia, Epidemiologia e Sociedade. São Paulo: Artes Médicas, 2004.

GAZETA, G. S. \& SERRA-FREIRE, N. M. Anocentor nitens (Neumann, 1897) na região sudeste do Brasil: constatação da assimetria entre placas peritremáticas e reavaliação do caráter festões. Revista Brasileira de Medicina Veterinária, 17: 21-25, 1995. 
GAZETA, G. S. \& SERRA-FREIRE, N. M. Reavaliação dos caracteres da placa peritremática para diagnose de Anocentor nitens (Neumann, 1897), na região sudeste, Brasil. Arquivos Brasileiros de Medicina Veterinária e Zootecnia, 48: 133-140, 1996.

GAZETA, G. S. et al. Seasonal analysis of the number of aeropiles in Anocentor nitens (Neumann, 1897) (Acari: Ixodidae) from the State of Rio de Janeiro, Brazil. Memórias do Instituto Oswaldo Cruz, 96: 733-736, 2001.

GIRIBET, G. \& RIBERA, C. A. Review of arthropod phylogeny: new data based on ribosomal DNA sequences and direct character optimization. Cladistics, 16: 204-231, 2000.

GUERRA, R. M. S. N. C. Análise Ecológica de Ácaros Associados a Coprólitos Provenientes do Sítio Arqueológico da Furna do Estrago, Município do Brejo da Madre de Deus, Estado de Pernambuco, Brasil, 2002. PhD dissertation, Rio de Janeiro: Instituto Oswaldo Cruz, Fundação Oswaldo Cruz, 2002.

GUERRA, R. M. S. N. C. et al. Mites associated with coprolites from the archaeological site of Furna do Estrago, Pernambuco state, Brazil. Entomología y Vectores, 8: 463-479, 2001.

HICKMAN, C. P.; ROBERTS, L.S. \& LARSON, A. Integrated Principles of Zoology. 13 ${ }^{\text {th }}$ Edition, McGraw-Hill, 2006.

HORAK, I. G.; CAMICAS, J. L. \& KEIRANS, J. E. The Argasidae, Ixodidae and Nuttalliellidae (Acari: Ixodida): a world list of valid tick names. Experimental and Applied Acarology, 28: 27-54, 2002.

KLIKS, M. McK. Paleoparasitological analysis of fecal material of Amerindian (or New World) mummies: evaluation of saprophytic arthropod remains. Paleopathol News, 164: 7-11, 1988.

KLOMPEN, H. \& GRIMALDI, D. A. First Mesozoic record of a parasitiform mite: a larval argasid tick in Cretaceous amber (Acari: Ixodida: Argasidae). Annals of the Entomological Society of America 94: 10-15, 2001.

KRANTZ, G. W. A Manual of Acarology. $2^{\text {nd }}$ Ed. Corvallis: Oregon State University Press, 1978.

KRANTZ, G. W. \& WALTER, D. E. A Manual of Acarology. $3^{\text {rd }}$ Ed. Lubbock: Texas Tech University Press, 2009.

KRIVOLUTSKY, D. A. \& DRUK, A. Y. Fossil oribatid mites. Annual Review of Entomology, 31: 533-545, 1986.

LANE, R. S. \& POINAR Jr., G. First fossil tick (Acari: Ixodidae) in New World amber. International Journal of Acarology, 12 : 75-78, 1986.

NAVAJAS, M. \& FENTON, B. The application of molecular markers in the study of diversity in acarology: a review. Experimental and Applied Acarology, 24: 751-774, 2000.

OBEnCHAIn, F. D. \& GALUM, R. Physiology of Ticks. Oxford: Pergamon Press, 1982.

OLIVEIRA, H. H. \& SERRA-FREIRE, N.M. Embriogênese de Amblyomma cajennense. Revista Entomología y Vectores, 1: $139-141,1994$.

POINAR Jr., G. O. Life in Amber. Palo Alto: Stanford University Press, 1992.

POULIN, R. Evolution of parasite life history traits: myths and reality. Parasitology Today, 2: 342-345, 1995.

RADOVSKY, F. Mites associated with coprolites and mummified human remains in Nevada. Archaeological Research Facility, 10: 186-190, 1970.

RANDOLPH, S. E. Ticks are not insects: Consequences of contrasting vector biology for transmission potential. Parasitology Today, 14: 186-192, 1998.

REY, L. Parasitologia. Rio de Janeiro: Guanabara Koogan, 2001.

SERRA-FREIRE, N. M. Planejamento e Análise de Pesquisas Parasitológicas. Niterói: Eduff, 2002.

SERRA-FREIRE, N. M. Considerações sobre o bem-estar animal. In: VALLE, S. \& TELLES, J.L. Bioética e Biorrisco: Abordagem transdisciplinar. Rio de Janeiro: Interciência, 2003.

SERRA-FREIRE, N. M. \& MELLO, R. P. Entomologia e Acarologia na Medicina Veterinária. Rio de Janeiro: L.F. Livros, 2006.

WALLWORK, J. A. Oribatids in forest ecosystems. Annual Review of Entomology, 28: 109-130 1983. 
Foundations of Paleoparasitology

WEIDNER, H. Eine Zecke, Ixodes succineus sp. n., im Baltischen Bernstein. Veroff Uberseemuseum, Bremen, 3: 143-151, 1964.

WEYGOLDT, P. Evolution and systematics of the Chelicerata. Experimental and Applied Acarology, 22: 63-79, 1998.

WHEELER, W. C. \& HAYASHI, C. Y. The phylogeny of the extant chelicerate orders. Cladistics, 14: 173-192, 1998.

WOOLEY, T. A. Acarology: mites and human welfare. New York: Wiley, 1988.

ZELMER, D. A. An evolutionary definition of parasitism. International Journal for Parasitology, 28: 532-533, 1998. 


\title{
Bacteria and Paleoparasitology
}

\author{
Joseli Maria da Rocha Nogueira • Ernesto Hofer
}

\begin{abstract}
A ccording to studies on ancient material, DNA from parasites can remain preserved together with the host for
thousands of years. Not only frozen and mummified soft tissues, but also bones, tooth pulp, and coprolites can be used to study such microorganisms. In the environment, natural materials like resin and amber (Lambert et al., 1998) can also preserve useful material for studying bacteria.
\end{abstract}

Research techniques for ancient bacteria include microscopy, cell culture, immunology, and molecular biology. These techniques can also assist molecular typing in the epidemiological reconstruction of past epidemics and help improve current epidemiological models for emerging infections, thus contributing to the development of current preventive measures.

German naturalist Christian Gottfried Ehrenberg (1795-1876) introduced the word Bacteria (Bacterium) as a scientific term in 1838. The word originates from the Greek Backterion ( $\beta \alpha \kappa \tau \eta \rho \imath o v)$, which is the diminutive of baktron, or rod. The choice of the term is associated with the first observations of bacteria under the microscope, since the scientists thought such organisms looked like small rods. The nomenclature is used to this day (Harper, 2001).

Bacteriological paleoparasitology thus aims primarily to identify the bacterial agents that probably infected our ancestors. This allows a better understanding of the various habits and customs involved in ancient health-disease processes, thus identifying the origins of different bacterial infections and the main routes by which these agents spread among peoples and environments (Palhano-Silva \& Nogueira, 2005).

We can diagnose diseases in extinct or ancient populations using various sources, such as ancient sculptures, drawings, and texts, abnormalities in bone records, tissues, and biological markers detected in coprolites or other organic remains (Oriel, 1973; Soulie, 1982; Duarte, Ferreira \& Araújo, 2002; Manchester \& Roberts, 1989).

Coprolites (Greek copros, feces; litos, rock), a vast source for these studies, are ancient feces naturally preserved by desiccation or mineralization. They often maintain physical or even molecular remains of organisms that were present in the intestines of the humans and/or animals that produced them (Araújo \& Ferreira, 2000). Coprolites provide 
data on health, diet, and agricultural practices (Rollo et al., 2002) and allow recovering extensive information on the paleoenvironment, even reconstructing part of the food chain among organisms (Andrews \& Fernandez-Jalvo, 1998).

Until recently, bacteriological paleoparasitology was limited to the direct investigation of bone and tissue anomalies and their association with known diseases such as bartonellosis (Allison et al., 1974), syphilis (Rothschild \& Rothschild, 1995), leprosy (Boldsen, 2001; Andersen, 1969), and tuberculosis (Morse, 1961; Allison, Mendoza, \& Pezzia, 1973; Hartney, 1981). Most previous paleoparasitological studies with the detection of the etiological agent involved the microscopic identification of helminths. They used classic techniques of parasitological examination such as rehydration in trisodium phosphate aqueous solution (Callen \& Cameron, 1960) followed by spontaneous sedimentation (Lutz, 1919) or some other concentration technique for microscopic examination of parasites eggs or cysts, or histological techniques with tissue preparation by paraffin inclusion or freezing (Ruffer, 1921; Reyman \& Dowd, 1980; Ferreira, Araújo \& Confalonieri, 1988).

Although these techniques are highly effective for the parasitological detection of helminth eggs and larvae, they overlook important groups of organisms such as protozoa, bacteria, and viruses, not detectable by these methods. The expansion of molecular biology and serological reactions opened new possibilities for studying previously undetectable organisms. Thus, interdisciplinary scientific collaboration provides the most feasible option for studies aimed at the detection and characterization of these agents (Araújo et al., 1998; Pääbo, 1991; Nogueira, 2008).

With the discovery of these new techniques, multidisciplinary studies around the world began to focus on the search for these organisms in an attempt to standardize methods and correlate findings with ancient epidemiological information.

\section{CURRENT TECHNIQUES AND RECENT HISTORY}

The use of serological techniques to identify bacteria in ancient feces allowed the successful indirect detection of Salmonella antigens (Sawicki, Allison \& Dalton, 1976). With advances in the field, new possibilities have emerged.

ELISA (enzyme-linked immunosorbent assay) (Voller, Bidwell \& Bartlett, 1976) with monoclonal antibodies has been used with promising results in studies of antigens in ancient material. In Brazil, Gonçalves (2002) used this technique and concluded that its sensitivity exceeded that of microscopic examination to detect Giardia duodenalis. The researcher, with collaborators (Gonçalves et al., 2004), used a commercial kit with Entamoeba histolytica antiadhesin antibodies conjugated with peroxidase and showed the presence of protozoa in ancestral samples from 5,300 before present (BP), thereby raising the possibility of also detecting bacteria with this method in the same type of material.

A milestone in the history of bacterial detection in archaeological material was the discovery of deoxyribonucleic acid (DNA) from Mycobacterium tuberculosis in a skeleton found in an archaeological site (Spigelman \& Lemma, 1993). This unprecedented work encouraged other groups to conduct molecular studies (Salo et al., 1994; Baron, Hummel \& Herrmann, 1996; Donoghue et al., 2004). Various studies had already been performed to detect bacterial diseases in mummies, but the majority were limited to searching for evidence from bone morphology (Larsen, 2002), potentially raising confusion with other diseases causing similar lesions. Adopting the same line, Rafi et al (1994) and later other researchers demonstrated the presence of Mycobacterium leprae in bones.

With advances in these techniques, researchers used materials such as feces (Ubaldi et al., 1998), mummified tissues (Lowenstein, 2004; Castillo-Rojas, Cerbon \& Lopez- Vidal, 2008), and dental pulp (Raoult et al., 2000) to detect various bacteria. 
In Brazil, Iñiguez (1998) demonstrated the possibility of retrieving bacterial DNA from artificially desiccated feces using PCR. After inoculating Vibrio cholerae and Bacillus sphaericus, she successfully viewed identifiable genetic material from these microorganisms.

Prat \& Mendonça de Souza (2003) published a commentated review on findings of tuberculosis in populations from the prehistoric Americas.

Various studies investigating bacteria in these materials have been conducted in Brazil, based mainly on molecular biology (Chart 1).

Chart 1 - Summary of various findings in bacteriological paleoparasitology and the possibility of methodological authenticity

\begin{tabular}{|c|c|c|c|c|c|}
\hline Source & Site in body & Mode of preservation & Date & Method & Strength/ quality of evidence \\
\hline \multicolumn{6}{|c|}{ Mycobacterium tuberculosis } \\
\hline $\begin{array}{c}\text { Bison } \\
\text { (Rothschild et al., 2001) }\end{array}$ & Metacarpus & Buried & $17,000 \mathrm{BP}$ & Molecular biology & $A / l$ \\
\hline $\begin{array}{c}\text { Human } \\
\text { (Salo et al., 1994) }\end{array}$ & Lung, lymph node & Mummified & $1,000 \mathrm{BP}$ & Molecular biology & $\mathrm{B} / \mathrm{II}$ \\
\hline $\begin{array}{c}\text { Human } \\
\text { (Crubézy et al., 1998) }\end{array}$ & Bone & Mummified & $5,400 \mathrm{BP}$ & Molecular biology & $\mathrm{A} / \mathrm{III}$ \\
\hline $\begin{array}{c}\text { Human } \\
\text { (Taylor et al., 1999) }\end{array}$ & $\begin{array}{l}\text { Metacarpus, lumber } \\
\text { vertebra }\end{array}$ & Buried & Medieval & $\begin{array}{l}\text { Molecular biology and } \\
\text { spoligotyping }\end{array}$ & $\mathrm{B} / \mathrm{II}$ \\
\hline $\begin{array}{c}\text { Human } \\
\text { (Mays, Fysh \& Taylor, 2002) }\end{array}$ & Rib & Buried & Medieval & Molecular biology & $\mathrm{B} / \mathrm{II}$ \\
\hline $\begin{array}{c}\text { Human } \\
\text { (Arriaza et al., 1994) }\end{array}$ & Vertebra & Buried & $1,000 \mathrm{BP}$ & Molecular biology & $B / I I$ \\
\hline $\begin{array}{c}\text { Human } \\
\text { (Haas et al., 2000a) }\end{array}$ & Mandible & Buried & $1400-1800$ AD & Molecular biology & $B / I I$ \\
\hline $\begin{array}{c}\text { Human } \\
\text { (Haas et al., 2000b) }\end{array}$ & $\begin{array}{l}\text { Vertebra, femur, } \\
\text { ankle, rib, pleura }\end{array}$ & Buried & $7^{\text {th }}-8^{\text {th }}, 17^{\text {th }}$ century & Molecular biology & $\mathrm{B} / \mathrm{III}$ \\
\hline $\begin{array}{c}\text { Human } \\
\text { (Donoghue et al., 1998) }\end{array}$ & Lung, pleura & Buried & $600 \mathrm{AD}$ & $\begin{array}{l}\text { Chromatography, } \\
\text { molecular biology }\end{array}$ & $\mathrm{B} / \mathrm{III}$ \\
\hline $\begin{array}{c}\text { Human } \\
\text { (Gernaey et al., 2001) }\end{array}$ & Bone & Buried & $1,000 \mathrm{BP}$ & $\begin{array}{l}\text { Chromatography, } \\
\text { molecular biology }\end{array}$ & $\mathrm{B} / \mathrm{II}$ \\
\hline $\begin{array}{c}\text { Human } \\
\text { (Mays \& Taylor, 2003) }\end{array}$ & Vertebra, rib & Buried & $400-230 \mathrm{BC}$ & $\begin{array}{l}\text { Molecular biology, } \\
\text { spoligotyping }\end{array}$ & $B / I I$ \\
\hline $\begin{array}{c}\text { Human } \\
\text { (Zink et al., 2003) }\end{array}$ & Bone, soft tissues & Mummified & $2050-500 \mathrm{BC}$ & Molecular biology & $\mathrm{A} / \mathrm{l}$ \\
\hline $\begin{array}{c}\text { Human } \\
\text { (Spigelman \& Lemma, 1993) }\end{array}$ & Bone & Buried & Not informed & Molecular biology & $\mathrm{C} / \mathrm{III}$ \\
\hline $\begin{array}{c}\text { Human } \\
\text { (Fletcher et al., 2003) }\end{array}$ & $\begin{array}{l}\text { Lung, pleura, abdomen, } \\
\text { tooth, ribs, hair }\end{array}$ & Mummified & $18^{\text {th }}-19^{\text {th }}$ century & Molecular biology & $A / l$ \\
\hline $\begin{array}{c}\text { Human } \\
\text { (Taylor et al., 1996) }\end{array}$ & Lung, lumbar vertebra & Buried & $14^{\text {th }}-16^{\text {th }}$ century & Molecular biology & $\mathrm{C} / \mathrm{II}$ \\
\hline
\end{tabular}


Chart 1 - Summary of various findings in bacteriological paleoparasitology and the possibility of methodological authenticity (continued)

\begin{tabular}{|c|c|c|c|c|c|}
\hline Source & Site in body & Mode of preservation & Date & Method & Strength/ quality of evidence \\
\hline \multicolumn{6}{|c|}{ Mycobacterium leprae } \\
\hline $\begin{array}{c}\text { Human } \\
\text { (Montiel et al. 2003) }\end{array}$ & Foot bones & Buried & $12^{\text {th }}$ century & Molecular biology & $B / I I$ \\
\hline $\begin{array}{c}\text { Human } \\
\text { (Spigelman \& } \\
\text { Donohue, 2001) }\end{array}$ & Metacarpi & Buried & $300-600 \mathrm{AD}$ & Molecular biology & $B / I I$ \\
\hline $\begin{array}{c}\text { Human } \\
\text { (Donoghue, Holton \& } \\
\text { Spigelman, 2001) }\end{array}$ & Nasal bone tissue & Buried & $1,100 \mathrm{BP}$ & Molecular biology & $B / I I$ \\
\hline $\begin{array}{c}\text { Human } \\
\text { (Donoghue, Holton \& } \\
\text { Spigelman, 2001) }\end{array}$ & Skulls & Buried & $1400-1800$ AD & Molecular biology & $B / I I$ \\
\hline $\begin{array}{c}\text { Human } \\
\text { (Haas et al. 2000a) }\end{array}$ & Hard palate and skulls & Buried & $\begin{array}{l}1400-1800 \mathrm{AD}, 10^{\text {th }} \\
\text { century }\end{array}$ & Molecular biology & $B / I I$ \\
\hline \multicolumn{6}{|c|}{ Enteric bacteria } \\
\hline $\begin{array}{l}\text { Mastodon } \\
\text { (Rhodes et al., 1998) }\end{array}$ & Intestine & Frozen & $12,000 \mathrm{BP}$ & Culture & $\mathrm{C} / \mathrm{II}$ \\
\hline $\begin{array}{c}\text { Human } \\
\text { (Zink et al., 2000) }\end{array}$ & Metatarsus & Mummified & $1400 \mathrm{BC}$ & Molecular biology & $B / I I$ \\
\hline $\begin{array}{c}\text { Human } \\
\text { (Fricker, Spigelman \& } \\
\text { Fricker, 1997) }\end{array}$ & Stomach content & Bog & $300 \mathrm{BC}$ & Molecular biology & $\mathrm{C} / \mathrm{II}$ \\
\hline \multicolumn{6}{|c|}{ Treponema pallidum } \\
\hline $\begin{array}{c}\text { Human } \\
\text { (Kolman et al. 1999) }\end{array}$ & Bone & Buried & $240 \mathrm{BP}$ & $\begin{array}{l}\text { Immunodetection; } \\
\text { Molecular biology }\end{array}$ & $B / I I$ \\
\hline \multicolumn{6}{|c|}{ Borrelia burgdorferi } \\
\hline $\begin{array}{c}\text { Ticks } \\
\text { (Matuschka et al. 1996) }\end{array}$ & & Dry & $1884 \mathrm{AD}$ & Molecular biology & $\mathrm{A} / \mathrm{III}$ \\
\hline $\begin{array}{c}\text { Rodents } \\
\text { (Marshall et al., 1994) }\end{array}$ & & Dry & $19^{\text {th }}$ century & Molecular biology & $B / I I$ \\
\hline \multicolumn{6}{|c|}{ Other spirochetes } \\
\hline $\begin{array}{c}\text { Termite } \\
\text { (Wier et al., 2002) }\end{array}$ & Intestinal tissue & Amber & Miocene & Microscopy & $A / I I$ \\
\hline \multicolumn{6}{|c|}{ Bartonella quintana } \\
\hline $\begin{array}{c}\text { Human } \\
\text { (Drancourt et al., 2005) }\end{array}$ & Dental pulp & Buried & $4,000 \mathrm{BP}$ & Molecular biology & $A / I I$ \\
\hline \multicolumn{6}{|c|}{ Bartonella henselae } \\
\hline $\begin{array}{c}\text { Cat } \\
\text { (La et al., 2004) }\end{array}$ & Dental pulp & Buried & $13^{\text {th }}-18^{\text {th }}$ centuries & Molecular biology & $\mathrm{A} / \mathrm{II}$ \\
\hline
\end{tabular}


Chart 1 - Summary of various findings in bacteriological paleoparasitology and the possibility of methodological authenticity (continued)

\begin{tabular}{|c|c|c|c|c|c|}
\hline \multicolumn{5}{|c|}{ Yersinia pestis } & \\
\hline $\begin{array}{c}\text { Human } \\
\text { (Drancourt et al., 2004) }\end{array}$ & Dental pulp & Buried & $5^{\text {th}}-14^{\text {th }}$ centuries & Molecular biology & A/II \\
\hline $\begin{array}{c}\text { Human } \\
\text { (Drancourt et al., 1998) }\end{array}$ & Dental pulp & Buried & $1590-1722$ AD & Molecular biology & B/III \\
\hline $\begin{array}{c}\text { Human } \\
\text { (Raoult et al., 2000) }\end{array}$ & Dental pulp & Buried & $1348 \mathrm{AD}$ & Molecular biology & A/II \\
\hline
\end{tabular}

BC - Before Christ; AD - Anno Domini; BP - Before Present

A - High evidence of authenticity; B - Moderate evidence of authenticity; C - Low evidence of authenticity

I - Independent teams and concordant protocols; II - Single team and concordant protocols; III - Single team without protocol concordance.

Source: Drancourt \& Raoult (2005).

Importantly, the results do not always truly express the detection of ancient bacteria. Drancourt \& Raoult (2005) highlight the importance of extremely painstaking work, since any contamination with contemporary material can shed doubt on the research.

Rigorous control of the results' authenticity and quality is extremely important. Level A strength of evidence is defined as the detection of one or more original identified sequences, two identified and unrelated sequences, or at least one detected original sequence and another unrelated molecule. Level B is defined as moderate authenticity, with the identification of a specific sequence or biological molecule. Level C expresses low evidence of authenticity, in studies with the detection of a sequence or biological molecule with low specificity. As for the quality of evidence, the same authors proposed index I for studies in which two independent teams worked with concordant protocols, II for a single team using concordant protocols, and III for a team not using protocol concordance.

Importantly, when searching for bacteria in archaeological material that has already been handled, such as coprolites, the sample should be pretreated with UV irradiation to avoid contemporary contamination (Santos, 1996; Nogueira et al., 2006a).

According to a new and simple line of research for potential isolation of bacteria in ancient material, various studies have suggested isolating viable bacteria from organic material preserved in ice, salt crystals, or amber, considering the tolerance of spores to heat and low humidity over time (Seaward, Cross \& Unsworth, 1976; Vreeland, Rosenzweig \& Powers, 2000; Nicholson, 2003; Christner et al., 2003; Gatson et al., 2006; Cano \& Borucki, 1995).

In Brazil, Nogueira (2008) used external cleaning, irradiation, perforation, direct isolation, and culture to successfully retrieve viable bacteria from bacterial spores inside ancient South American coprolites in the Paleoparasitology Collection of the Sergio Arouca National School of Public Health, Oswaldo Cruz Foundation (ENSP/FIOCRUZ). After isolating the bacterial colonies in solid medium, she conducted biochemical studies to identity each of these microorganisms (Nogueira, 2007). She then performed molecular tests including PCR, cloning, and sequencing to indicate the various species in this material. The same researcher suggested the presence of different species from those currently circulating, due to the impossibility of typing them with the currently available methods (Nogueira, 2008).

Considering the possibilities raised by these findings and recently introduced techniques, including molecular biology, the search for bacteria in archaeological material has huge potential to produce new data in the area of 
epidemiological bacteriology, combining such detection with the search for evidence of infection and probable pathological manifestations in human or animal remains (Nogueira et al., 2006b).

In Brazil, the research group in paleoparasitology and paleoepidemiology at ENSP/FIOCRUZ now includes a variety of researchers and students interested in the knowledge generated by data obtained from ancient material. Bacterial studies in paleoparasitology are an integral part of this context, and as they develop they complement the findings from related lines of research.

Researchers are currently analyzing coprolites from the collection of the Paleoparasitology Laboratory at ENSP using monoclonal antibodies, molecular examination, and direct culture to detect bacteria and standardize the techniques for future studies. Further objectives include mapping the frequency of these agents in the material, correlating with the respective archaeological sites, co-infection with other agents, eating habits, and possible dispersal routes of the agents based on geographic data, besides dating the samples (Nogueira et al., 2005a).

Genomic analysis of these microorganisms should improve our understanding of the determination of infections and diseases in light of the complexity of parasite-host-environment relationships, as well as coevolution of the respective species.

\section{INTERESTING PERSPECTIVES}

The possibility of recovering bacterial spores from coprolites raises more new prospects. Even though a coprolite is a metabolically inactive structure, its interior maintains all of the microorganism's genetic information. The latent form, when cultivated using microbiological techniques, evolves to a vegetative form. The spores are made up of dipicolinic acid associated with calcium, and when compared to vegetative cells, they are extremely resistant to physical and chemical agents, and are refringent and highly tolerant to thermal alteration, oxidation, and desiccation, thus displaying a survival strategy (Setlow, 1999; Nicholson et al., 2000; Nicholson, 2003).

The bacterial organisms of clinical importance and capable of producing these structures include genera Bacillus and Clostridium. However, various other related bacterial genera such as Paenibacillus, Amphibacillus, Desulfotomaculum, Sporosarcina, Sporolactobacillus, Sporohalobacter, Oscillospira, and Thermoactinomyces also display this capacity (Bergey \& Holt, 1994) and can be isolated, even after having been maintained in an inadequate environment for bacterial organisms (Nogueira, 2008)

\section{ETHICAL ISSUES RELATED TO RESEARCH IN PALEOEPIDEMIOLOGY}

Another increasingly important area in this new scientific frontier involves ethical reflections pertaining to the use of such ancestral material. An analysis of the current ethical concepts and research projects in biomedical fields shows that these issues have drawn growing attention, especially when they involve human beings and their mortal remains, meanwhile reflecting researchers' concern and interest in this issue (Coimbra \& Santos, 1996; Schramm, 1995).

Holloway (1995) discusses the interaction between researchers, curators, and living descendants, the latter often demanding that the material used for research or museum exhibits be returned to the community. The author criticizes the measures that have been taken to protect disinterred remains. Once exposed, information that has remained buried for thousands of years can be lost rapidly. The main scientific commitment should be to the preservation of such material. 
A proper ethical approach to the preservation of our ancestral cultural heritage should include all possible steps to preserve such materials not only for the coming generations, but also for future research and interpretation. We should give special emphasis to the documentation produced, since it lends meaning to the collections and allows the production of scientific knowledge. Such documentation should remain available and under safe conditions in the long term (Lima, 1997).

These essential issues must not be neglected, since they reflect the role of science in modern life, besides providing new ways to produce scientific knowledge (Nogueira et al., 2005b).

\section{CONCLUSIONS}

Based on the evidence and discussions above, the preservation of ancestral material and its use as a source for study can become allies in the reconstruction of ancestral history.

Part of the development of different causes in the health-disease process can be unveiled by the diverse data collected in these studies, ranging from historical records to new molecular techniques. However, such research can only be guaranteed if the researchers using the ancient material as a wellspring of knowledge take all the necessary steps to preserve and avoid destroying it, thus benefiting related fields in a conscientious and virtually never-ending process.

\section{REFERENCES}

ALLISON, M. J.; MENDOZA, D. \& PEZZIA, A. Documentation of a case of tuberculosis in pre-Columbian America. American Review of Respiratory Diseases, 107: 985-991, 1973.

ALLISON, M. J. et al. A Case of Carrion's disease associated with human sacrifice from the Huari culture of Southern Peru. American Journal of Physical Anthropology, 41: 295-300, 1974.

ANDERSEN, J. G. Studies on the medieval diagnosis of leprosy in Denmark: an osteoarchaeological, historical and clinical study. Danish Medical Bulletin, 16: 1-142, 1969.

ANDREWS, P. \& FERNANDEZ-JALVO, Y. Palaeobiology: 101 uses for fossilized faeces. Nature, 393: 629-630, 1998.

ARAÚJO, A. \& FERREIRA, L. F. Paleoparasitology and the antiquity of human host-parasite relationships. Memórias do Instituto Oswaldo Cruz, 95: 89-93, 2000.

ARAÚjo, A. et al. Paleoparasitology: perspectives with new techniques. Revista do Instituto de Medicina Tropical de São Paulo, 40: 371-376, 1998.

ARRIAZA, B. T. et al. Pre-Columbian tuberculosis in Northern Chile: molecular and skeletal evidence. American Journal of Physical Anthropology, 98: 37-45, 1995.

BARON, H.; HUMMEL, S. \& HERRMANN, B. Mycobacterium tuberculosis complex DNA in ancient human bones. Journal of Archaeological Science, 23: 667-671, 1996.

BERGEY, D. H. \& HOLT, J. G. Bergey's Manual of Determinative Bacteriology. $9^{\text {th }}$ Ed. Baltimore: Lippincott Williams \& Wilkins, 1994.

BOLDSEN, J. L. Epidemiological approach to the paleopathological diagnosis of leprosy. American Journal of Physical Anthropology, 115: 380-387, 2001.

CALLEN, E. O. \& CAMERON, T. W. M. A prehistoric diet as revealed in coprolites. New Scientist, 8: 35-40, 1960.

CANO, R. J. \& BORUCKI, M. K. Revival and identification of bacterial spores in 25-to 40-million-year-old Dominican amber. Science, 268: 1.060-1.064, 1995. 
CASTILLO-ROJAS, G.; CERBON, M. A. \& LOPEZ-VIDAL, Y. Presence of Helicobacter pylori in a Mexican pre-Columbian mummy. BMC Microbiology, 8: 119, 2008.

CHRISTNER, B. C. et al. Bacterial recovery from ancient glacial ice. Environmental Microbiology, 5: 433-436, 2003.

COIMBRA JR, C. E. \& SANTOS, R.V. Ética e pesquisa biomédica em sociedades indígenas no Brasil. Cadernos de Saúde Pública, 12: 417-422, 1996.

CRUBÉZY, E. et al. Identification of Mycobacterium DNA in an Egyptian Pott's disease of 5,400 years old. Comptes Rendus de l'Académie des Sciences, Série III, 321: 941-951, 1998.

DONOGHUE, H. D.; HOLTON, J. \& SPIGELMAN, M. PCR primers that can detect low levels of Mycobacterium leprae DNA. Journal of Medical Microbiology, 50: 177-182, 2001.

DONOGHUE, H. D. et al. Tuberculosis: from prehistory to Robert Koch, as revealed by ancient DNA. The Lancet, 4: 584-592, 2004.

DONOGHUE, H. D. et al. Mycobacterium tuberculosis complex DNA in calcified pleura from remains 1,400 years old. Letters in Applied Microbiology, 27: 265-269, 1998.

DRANCOURT, M. et al. Detection of 400-year-old Yersinia pestis DNA in human dental pulp: an approach to the diagnosis of ancient septicemia. Proceedings of the National Academy of Sciences, 95: 12.637-12.640, 1998.

DRANCOURT, M. \& RAOULT, D. Palaeomicrobiology: current issues and perspectives. Nature Reviews - Microbiology, 3: 23-35, 2005.

DRANCOURT, M. et al. Genotyping, Orientalis-like Yersinia pestis, and plague pandemic. Emerging Infectious Diseases, 10: 1.585$1.592,2004$.

DRANCOURT, M. et al. Bartonella quintana in a 4,000-year old human tooth. The Journal of Infectious Diseases, 191: 607-611, 2005.

DUARTE, N. A.; FERREIRA, L. F. \& ARAÚJO, A. Paleoepidemiologia e paleoparasitologia. In: MEDRONHO, R. A. (Ed.). Epidemiologia. São Paulo: Atheneu, 2002.

FERREIRA, L. F.; ARAÚJO, A. \& CONFALONIERI, U. Paleoparasitologia no Brasil. Rio de Janeiro: PEC/Ensp, 1988.

FLETCHER, H. A. et al. Widespread occurrence of Mycobacterium tuberculosis DNA from $18^{\text {th }}-19^{\text {th }}$ century Hungarians. American Journal of Physical Anthropology, 120: 144-152, 2003.

FRICKER, E. J.; SPIGELMAN, M.; FRICKER, C. R. The detection of Escherichia coli DNA in the ancient remains of Lindow Man using the polymerase chain reaction. Letters in Applied Microbiology, 24: 351-354, 1997.

GATSON, J. W. et al. Bacillus tequilensis sp. nov., isolated from a 2000-year-old Mexican shaft tomb, is closely related to Bacillus subtilis. International Journal of Systematic and Evolutionary Microbiology, 56: 1.475-1.484, 2006.

GERNAEY, A. M. et al. Mycolic acids and ancient DNA confirm an osteological diagnosis of tuberculosis. Tuberculosis (Edinburgh), 81: 259-265, 2001.

GONÇALVES, M. L. C. Helmintos, Protozoários e Algumas Ideias: novas perspectivas na paleoparasitologia, 2002. PhD dissertation, Rio de Janeiro: Escola Nacional de Saúde Pública, Fundação Oswaldo Cruz.

GONÇALVES, M. L. C. et al. Amoebiasis distribution in the past: first steps using an immunoassay technique. Transactions of the Royal Society of Tropical Medicine and Hygiene, 98: 88-91, 2004.

HAAS, C. J. et al. Detection of leprosy in ancient human skeletal remains by molecular identification of Mycobacterium leprae. American Journal of Clinical Pathology, 114: 428-436, 2000a.

HAAS, C. J. et al. Molecular evidence for different stages of tuberculosis in ancient bone samples from Hungary. American Journal of Physical Anthropology, 113: 293-304, 2000b.

HARPER, D. Online Etymology Dictionary, 2001. Available at: <www.etymonline.com>. accessed 27/Oct/2005.

HARTNEY, P.C. Tuberculosis lesions in a prehistoric population sample from southern Ontario. In: BUIKSTRA, J. E. Prehistoric Tuberculosis in the Americas, Northwestern University Archaeological Program, Evanston, 1981. 
HOLLOWAY, M. The preservation of the past. Scientific American, 272: 78-81, 1995.

IÑigueZ, A. M. Análise do DNA Ancestral para o Estudo de Infecções Parasitárias em Populações Pré-históricas, 1998. Master's thesis, Rio de Janeiro: Instituto Oswaldo Cruz, Fundação Oswaldo Cruz.

KOLMAN, C. J. et al. Identification of Treponema pallidum subspecies pallidum in a 200-year-old skeletal specimen. The Journal of Infectious Diseases, 180: 2.060-2.063, 1999.

LA, V. D. et al. Molecular detection of Bartonella henselae DNA in the dental pulp of 800-year-old French cats. Clinical Infectious Diseases, 39(9):1.391-1.394, 2004.

LAMBERT, L. H. et al. Staphylococcus succinus sp. nov., isolated from Dominican amber. International Journal of Systematic Bacteriology, 48: 511-518, 1998.

LARSEN, C. S. Bioarchaeology: the lives and lifestyles of past people. Journal of Archaeological Research, 10: 119-166, 2002.

LIMA, T. A. A ética que temos e a ética que queremos (ou como falar de princípios neste conturbado fim de milênio). CONGRESSO DA SOCIEDADE BRASILEIRA DE ARQUEOLOGIA, 9, 1997. Rio de Janeiro.

LOWENSTEIN, J.E. Paleodermatoses: lessons learned from mummies. Journal of the American Academy of Dermatology, 50: 919 936, 2004.

LUTZ, A. O Schistosomum mansoni e a schistosomatose segundo observações, feitas In Brazil. Memórias do Instituto Oswaldo Cruz, 11: 121-155, 1919.

MANCHESTER, K. \& ROBERTS, C. The palaeopathology of leprosy in Britain: a review. World Archaeology, 21: 265-272, 1989.

MARSHALL III, W. F. et al. Detection of Borrelia burgdorferi DNA in museum specimens of Peromyscus leucopus. The Journal of Infectious Diseases, 170: 1.027-1.032, 1994.

MATUSCHKA, F. R. et al. Characteristics of Lyme disease spirochetes in archived European ticks. The Journal of Infectious Diseases, 174: 424-426, 1996.

MAYS, S. \& TAYLOR, M. A first prehistoric case of tuberculosis from Britain. International Journal of Osteoarchaeology, 13: 189$196,2003$.

MAYS, S.; FYSH, E. \& TAYLOR, G.M. Investigation of the link between visceral surface rib lesions and tuberculosis in a medieval skeletal series from England using ancient DNA. American Journal of Physical Anthropology, 119: 27-36, 2002.

MONTIEL, R. et al. DNA sequences of Mycobacterium leprae recovered from ancient bones. FEMS Microbiology Letters, 226: 413414, 2003.

MORSE, D. Prehistoric tuberculosis in America. The American Review of Respiratory Disease, 83: 489-504, 1961.

NICHOLSON, W. L. Using thermal inactivation kinetics to calculate the probability of extreme spore longevity: implications for paleomicrobiology and lithopanspermia. Origins of Life and Evolution of the Biosphere, 33: 621-631, 2003.

NICHOLSON, W. L. et al. Resistance of Bacillus endospores to extreme terrestrial and extraterrestrial environments. Microbiology and Molecular Biology Reviews, 64: 548-572, 2000.

NOGUEIRA, J. M. R. et al. Paleobacteriologia: novas possibilidades em estudos paleoparasitológicos. In: JORNADA CIENTÍFICA DE PÓS-GRADUAÇÃO DA FUNDAÇÃO OSWALDO CRUZ, 9, 2005, Rio de Janeiro. Anais... Rio de Janeiro, 2005 a.

NOGUEIRA, J. M. R. et al. The importance of ethical aspects in paleoparasitological research. In: PALEOPATHOLOGY ASSOCIATION MEETING IN SOUTH AMERICA - PAMINSA - HUMAN MIGRATIONS AND DISEASES, 1, 27-29 jul.2005, Rio de Janeiro: Anais... Rio de Janeiro: Ensp/Fiocruz, 2005b.

NOGUEIRA, J. M. R. et al. Paleogenômica exploratória: sequenciamento aleatório de fragmentos de DNA de coprólitos oriundos do nordeste brasileiro. V Bienal de Pesquisa da Fiocruz, 2006a. 
NOGUEIRA, J. M. R. et al. Paleoparasitologia: revisão bibliográfica e novas perspectivas em estudos microbiológicos. Revista de Patologia Tropical, 35: 87-102, 2006b.

NOGUEIRA, J. M. R. Paleoparasitologia bacteriana: recuperação de Bacillus sp. de esporos viáveis presentes em coprólitos sulamericanos. In: JORNADA DE PÓS-GRADUAÇÃO/REUNIÃO ANUAL DE INICIAÇÃo CIENTÍFICA DA FIOCRUZ, X/XV, 2007, Rio de Janeiro. Novas Fronteiras da Educação e Saúde... Rio de Janeiro, 2007.

NOGUEIRA, J. M. R. Paleoparasitologia: estudos associados à recuperação de organismos bacterianos de esporos viáveis presentes em coprólitos sul-americanos, 2008. PhD dissertation, Rio de Janeiro: Escola Nacional de Saúde Pública Sergio Arouca, Fundação Oswaldo Cruz, 2008.

ORIEL, J. D. Gonorrhea in the ancient world. Paleopathology Newsletter, 4: 7-9, 1973.

PÄÄBO, S. Amplifying DNA from archaeological remains: a meeting report. PCR Methods and Applications, 1: 107-110, 1991.

PALHANO-SILVA, C. S. \& NOGUEIRA, J. M. R. Novas possibilidades em estudos paleoparasitológicos. Revista da Sociedade Brasileira de Medicina Tropical, 38, supl. 1: 253, 2005.

PRAT, J. G. \& MENDONÇA DE SOUZA, S. M. F. Prehistoric tuberculosis in America: adding comments to a literature review. Memórias do Instituto Oswaldo Cruz, 98, suppl. 1: 151-159, 2003.

RAFI, A. et al. Mycobacterium leprae DNA from ancient bone detected by PCR. The Lancet, 343: 1.360-1.361, 1994.

RAOULT, D. et al. Molecular identification by 'suicide PCR' of Yersinia pestis as the agent of medieval black death. Proceedings of the National Academy of Sciences, 97: 12.800-12.803, 2000.

REYMAN, T. A. \& DOWD, A.M. Processing of mummified tissue for histological examination. In: COCKBURN, A. \& COCKBURN, E. (Eds.). Mummies, Disease, and Ancient Cultures. Cambridge: Cambridge University Press, 1980.

RHODES, A. N. et al. Identification of bacterial isolates obtained from intestinal contents associated with 12,000-year-old mastodon remains. Applied and Environmental Microbiology, 64: 651-658, 1998.

ROLLO, F. et al. Ötzi's last meals: DNA analysis of the intestinal content of the Neolithic glacier mummy from the Alps. Proceedings of the National Academy of Sciences, 99: 12.594-12.599, 2002.

ROTHSCHILD, B. M. \& ROTHSCHILD, C. Treponemal disease revisited: skeletal discriminators for yaws, bejel, and venereal syphilis. Clinical Infectious Diseases, 20: 1.402-1.408, 1995.

ROTHSCHILD, B. M. et al. Mycobacterium tuberculosis complex DNA from an extinct bison dated 17,000 years before the present. Clinical Infectious Diseases, 33: 305-311, 2001.

RUFFER, M. A. Studies in Paleopathology of Egypt. New York, Chicago: University of Chicago Press, 1921.

SALO, W. L. et al. Identification of Mycobacterium tuberculosis DNA in a pre-Columbian Peruvian mummy. Proceedings of the National Academy of Sciences, 91: 2.091-2.094, 1994.

SANTOS, A. K. C. R. Diversidade de Linhagens de DNA Mitocondrial de Ameríndios da Amazônia: populações contemporâneas e ancestrais, 1996. PhD dissertation. Ribeirão Preto: Universidade de São Paulo.

SAWICKI, V. A.; ALLISON, M. J. \& DALTON, H. P. Presence of Salmonella antigens in feces from a Peruvian mummy. Bulletin of the New York Academy of Medicine, 52: 805-813, 1976.

SCHRAMM, F. R. A terceira margem da saúde: a ética 'natural'. Ciência, História e Saúde-Manguinhos, 1: 54-68, 1995.

SEAWARD, M. R. D.; CROSS, T. \& UNSWORTH, B. A. Viable bacterial spores recovered from an archaeological excavation. Nature, 261: 407-408, 1976.

SETLOW, P. Bacterial spore resistance. In: STORZ, G. \& HENGGE-ARONIS, R. (Eds.). Bacterial Stress Responses. Washington: American Society for Microbiology, 1999.

SOULIE, R. Brucellosis: a case report dating from 650-700 AD. Paleopathology Newsletter, 38: 7-10, 1982. 
SPIGELMAN, M. \& DONOGHUE, H. D. Brief communication: unusual pathological condition in the lower extremities of a skeleton from ancient Israel. American Journal of Physical Anthropology, 114: 92-93, 2001.

SPIGELMAN, M. \& LEMMA, E. The use of Polymerase Chain Reaction (PCR) to detect Mycobacterium tuberculosis in ancient skeletons. International Journal of Osteoarchaeology, 3: 137-143, 1993.

TAYLOR, G. M. et al. Detection of Mycobacterium tuberculosis bacterial DNA in medieval human skeletal remains using polymerase chain reaction. Journal of Archaeological Science, 23: 789-798, 1996.

TAYLOR, G. M. et al. Genotypic analysis of Mycobacterium tuberculosis from medieval human remains. Microbiology, 145: 899904, 1999.

UBALDI, M. et al. Sequence analysis of bacterial DNA in the colon of an Andean mummy. American Journal of Physical Anthropology, 107: 285-295, 1998.

VOLLER, A.; BIDWELL, D. E. \& BARTLETT, A. N. N. Enzyme immunoassays in diagnostic medicine: theory and practice. Bulletin of the World Health Organization, 53: 55-65, 1976.

VREELAND, R. H.; ROSENZWEIG, W. D. \& POWERS, D.W. Isolation of a 250 million-year-old halotolerant bacterium from a primary salt crystal. Nature, 407: 897-900, 2000.

WIER, A. et al. Spirochete and protist symbionts of a termite (Mastotermes electrodominicus) in Miocene amber. Proceedings of the National Academy of Sciences, 99: 1.410-1.413, 2002.

ZINK, A. et al. Molecular evidence of bacteremia by gastrointestinal pathogenic bacteria in an infant mummy from ancient Egypt. Archives of Pathology and Laboratory Medicine, 124: 1.614-1.618, 2000.

ZINK, A. R. et al. Molecular study on human tuberculosis in three geographically distinct and time delineated populations from ancient Egypt. Epidemiology and Infection, 130: 239-249, 2003. 


\title{
Viruses and Paleoparasitology
}

\author{
Hermann G. Schatzmayr
}

$\mathrm{R}$ ecent years have witnessed important growth in the field of paleoparasitology, or the study of infectious diseases in ancient humans and animals. A recent review by Nogueira et al. (2006) gives a precise description of the evolution of knowledge in the field, initially using tools from forensic medicine to describe signs of diseases in mummies from various countries. Such studies have recently gained great impetus with the availability of advanced methods for detecting nucleic acids and proteins in organic material (Konomi, Lebwohl \& Zhang, 2002). These methodologies have allowed confirming (sometimes definitively) the macroscopic and microscopic data obtained from the study of preserved human tissues.

This development is particularly important when investigating data on viral infections, since viruses are fragile structures consisting of nucleic, ribonucleic, or deoxyribonucleic acid and protein envelopes. Viruses do not display resistant forms such as spores, which occur in various types of bacteria and other microorganisms.

Signs of viral infections have been found in human mortal remains in various parts of the world. This chapter briefly reviews the knowledge from paleoparasitology on several viral diseases.

\section{SMALLPOX}

Evidence shows that smallpox existed in Africa since 3,700 BC and in China since 1,100 BC, although it has not been possible to define exactly where the disease first appeared. According to the most widely accepted theory on the origin of smallpox, an animal virus from the Poxvirus group probably adapted specifically to humans.

When smallpox spread across Europe and the Americas along trade routes and through colonization, it became a major public health problem. Smallpox caused death and irreversible skin lesions, especially on the face, in millions of people over the course of the centuries, affecting all segments of the population. In Europe, smallpox killed monarchs, like Louis XV of France in 1775 (he thus escaped the guillotine, unlike his successor Louis XVI, executed by the French Revolution that began four years later). 
The Spanish Conquistadores of Mexico used smallpox infection as a powerful biological weapon. The disease did not exist previously in the Americas. When the Europeans arrived, the virus was introduced deliberately into the continent by the English armies, for military purposes. This led to the decimation of indigenous populations in both Mexico and the United States. In Brazil, the same method was used to eliminate indigenous peoples that resisted construction of the Northwest Railway in the State of São Paulo. Due to the eclectic spread of smallpox, mummies of persons of higher social status have been found with viral particles or skin lesions indicative of the infection. During the $20^{\text {th }}$ Egyptian Dynasty, a smallpox epidemic swept across the region. Lesions found on the face of the mummy of Ramses V (1156 BC), indicative of the infection, were one of the first observations of a viral infection in the field of paleoparasitology. Ruffer \& Ferguson (1911) first reported these findings in the early $20^{\text {th }}$ century.

The reign of Ramses $\mathrm{V}$ coincided with the exodus of the Jewish tribes to Israel, led by Moses. In the Old Testament, Leviticus chapters 13,14, and 15 refer to skin lesions like pustules (boils), with recommendations for avoiding contagion to others, isolating the sick and requiring priests to examine infected individuals during their clinical course. The data suggest that the epidemic reached those population groups during their journey to Israel.

In the last three decades, studies on diseases in mummies from various regions of Italy have sparked great interest, describing calcification in large blood vessels, fibrotic pulmonary lesions suggestive of tuberculosis infection, diverticulitis, parasitic skin infections, tertiary syphilis, neoplasms, hernias, and other events (Fornaciari, 2006).

Fornaciari \& Marchetti (1986) identified a smallpox infection based on macroscopic characteristics, indirect immunofluorescence, and scanning electron microscopy. They detected particles characteristic of the virus in one of these $16^{\text {th }}$ century mummies, a two-year-old child from Naples. Other researchers (Marennikova et al., 1990) confirmed this finding.

Attempts failed to induce infections in the laboratory using original material, thus demonstrating that the virus lost its capacity to infect cells. This finding was important, since some smallpox victims have died and been buried in cold regions of the planet like northern Russia and Alaska, raising the hypothesis that infectious virus could be recovered from these sources, with potential implications for illegal activities such as bioterrorism.

Kieron et al. (2006) later found lesions attributed to smallpox in mummified tissues deposited in the British Museum.

Due to the characteristic lesions of smallpox, nearly always on the patient's face, and the relative resistance of the virus, hopefully more data will be obtained in the future on smallpox infection in preserved human tissues.

\section{INFLUENZA}

The influenza virus has caused successive epidemics and epizootics over the centuries, with birds and domestic animals as its main reservoirs. The human disease appears and spreads rapidly, due to mutations and molecular rearrangements in the virus, in its two surface proteins, $\mathrm{H}$ (hemagglutinin) and $\mathrm{N}$ (neuraminidase), generating virulent strains for humans. These modifications have emerged in Asia and spread elsewhere, as occurred recently with the H5N1 strain in China and even more recently with H1N1. Better knowledge of these mutations is highly important for predicting future epidemics and reducing their impact.

Influenza has characteristic signs and symptoms, a seasonal pattern, and often high case-fatality, thus allowing recognition of clinical descriptions of influenza since remote antiquity. The name suggests a relationship with various types of "influences" that were blamed for the epidemics, such as the position of the stars and similar inferences (Schatzmayr \& Corrêa, 2005). 
Lesions caused by the influenza virus are not recognized specifically in mummified tissues. However, as mentioned above, research methods for viral nucleic acids have made a major contribution to unlocking the genetic composition of viral samples in human tissues.

The most important contribution of paleoparasitology in influenza involved studies to retrieve the viral genome in patients that died during the great pandemic of 1918-1919.

From September 1918 to April 1919, at least 20 million people died across the globe, the equivalent of nearly $4 \%$ of the world population at the time. In Rio de Janeiro alone, influenza killed 15 thousand people in only a few months, including President Rodrigues Alves. People initially believed that the virus showed such high case fatality because it found a population debilitated by World War I, without adequate hospitals or medicines. However, mortality was equally high in the United States and in other countries like Brazil, which had not suffered directly from the war in Europe.

The longstanding dream of unveiling the structure of the strain responsible for the 1918 pandemic was achieved by retrieving fragments of the viral genome from paraffin blocks containing lung samples from fatal cases in New York and fragments from the remains of an Inuit woman buried in Alaska.

The Inuit woman was buried in the permafrost on Seward Peninsula on the western coast of Alaska, close to the Bering Strait, together with 72 other members of the same village, all of whom had succumbed to influenza (Lederberg, 2001).

Fragments of viruses present in the lung were sequenced in the laboratory. That is, their internal structure was determined and several of their genes were studied by their insertion into modern influenza viruses.

As occurred with fragments of smallpox virus found in the Italian mummy, the influenza virus was not capable of infecting animals, using the original fragments. More recently, a research group demonstrated that the addition of various genes from the 1918 sample to current influenza samples leads to a significant increase in the new sample's virulence (Tumpey et al., 2004).

In fact, the simple knowledge that the virus from 1918 presented the basic H1N1 composition, a structure still circulating today in nature, was a major stride, calling attention to the potential risk of this presentation of the viral genome.

\section{HEPATITIS B}

Hepatitis virus infections are a serious public health problem in Asia that has been reduced in places that have implemented widespread vaccination, such as Japan. However hepatitis is still an important problem in the other Asian countries.

According to available data for South Korea, some $12 \%$ of the population carries the hepatitis B virus, a figure far above the world average of around 5\%. Recent paleoparasitological studies in South Korea have contributed important knowledge on the evolution of HBV infection in the region.

Until recently, no mummies were known to exist in South Korea. For religious reasons, preservation techniques are not applied to the bodies of deceased persons. However, in 2007, when a cemetery was being moved during an urban renewal project in Seoul, exceptionally well-preserved mummies were found, dated to c. $1400 \mathrm{AD}$.

In the decade prior to the deaths, the region had been ruled by a Buddhist state with the monks' absolute power. In 1392 the Confucionists took power. This period, known as the Joseon Dynasty, ushered in techniques for 
treating mortal remains, according to the religious tenets that the corpse should disintegrate naturally, without the influence of worms or other external agents.

Corpses were thus kept on ice for several days and then placed in wooden coffins that seeped resins, and were buried in alkaline soil. These factors led to mummification of the corpses, not originally intended. The tissues remained pliable and in a better state of preservation than the Egyptian mummies, which were treated chemically to the point of total dehydration of the tissues.

Among the Korean mummies, researchers managed to recover the genome from hepatitis B virus from a child's liver. This finding raises the possibility of studying the evolution of hepatitis viruses, potentially elucidating the infection's pathogenesis.

\section{HTLV-1 VIRUSES}

A lymphoproliferative disease characterized as adult T-cell leukemia/ lymphoma was identified in the 1970s in Southwest Japan. In 1980 the first human retrovirus was isolated in the United States, called HTLV-I, the etiological agent of lymphomas similar to those observed in Japan.

In 1985 , the same virus was shown to be related to a syndrome called tropical spastic paraparesis in Caribbean patients. Other geographic foci were discovered, and it was proven that the neurological disease could also be found in non-tropical regions.

The HTLV-1 viruses, belonging to the Retroviridae family, are the etiological agents of these severe human infections, in addition to uveitis and other manifestations like infectious dermatitis. These infections occur in welldefined regions of Japan (where the infection has been studied intensively), South America, and some regions of the Caribbean, besides Sub-Saharan Africa, Melanesia, and the Middle East.

Considering the distribution of the disease and the widely accepted hypothesis of Asian migration across the Bering Land Bridge to South America, mummies of inhabitants of Chile dated to 1,000 to 1,500 BP were studied, and fragments of HTLV-1 were identified in two of them (Hong-Shuan et al., 1999; Sonoda et al., 2000).

Molecular studies identified a significant similarity between the genome segments found in the mummies from Chile and the genome of HTLV-1 samples identified in Japan, as well as in the modern Andean population. These data confirm the arrival of this virus on the American continent before the Spanish conquerors, during Asian migration to the Americas.

\section{OTHER OCCURRENCES AND CONCLUSIONS}

Human papilloma virus, now definitively associated with carcinoma of the uterine cervix, was found in a $16^{\text {th }}$ century Italian mummy, demonstrating its ancient adaptation to humans (Fornaciari et al., 2003).

Another important finding involved orbital lesions in skeletons from Aborigine populations in Australia, indicating chronic eye infection. When these lesions are related to the distribution of trachoma in current populations from the same region and to other data such as the consistently advanced age of the affected individuals, one can conclude that this infection existed in Australia since remote times (Webb, 2005). 
Another piece of information obtained from Italian mummies was the presence of the HLA-DRB allele in tissues from an individual dated to the $16^{\text {th }}$ century. This allele expresses epitopes associated with Epstein-Barr virus glycoprotein 110, suspected to be responsible for the development of rheumatoid arthritis, also found in the same mummy (Fontecchio et al., 2006). The finding is also relevant to the origin of the disease, which previous paleopathological studies contended to have originated in America, in the Tennessee region, between 5000 and 500 BC.

In conclusion, the study of viruses within the field of paleoparasitology is just beginning. Hopefully, the use of advanced methodologies on a broader scale will help us learn more about the natural history of viral diseases, their distribution, and the evolution of viral genomes throughout the history of human diseases.

\section{REFERENCES}

FONTECCHIO, G. et al. HLA-DRB genotyping of an Italian mummy from the $16^{\text {th }}$ century with signs of rheumatoid arthritis. Annals of the Rheumatic Diseases, 65: 1.676-1.677, 2006.

FORNACIARI, G. Italian mummies, 2006. Available at: <www.paleopatologia.it>. Accessed in July 2008.

FORNACIARI, G. \& MARCHETTI, A. Italian smallpox of the Sixteenth century. The Lancet, 8.521/8.522: 1.469-1.470, 1986.

FORNACIARI, G. et al. Human papillomavirus in a 16 th $^{\text {c }}$ century mummy. The Lancet, 362: 1.160, 2003.

HONG-CHUAN, L. et al. The presence of ancient human T-cell lymphotropic virus type 1 provirus DNA in an Andean mummy. Nature Medicine, 5: 1.428-1.432, 1999.

KIERON, S. et al. Skin disease in mummies. International Journal of Dermatology, 45: 161-163, 2006.

KONOMI, N.; LEBWOHL, E. \& ZHANG, D. Comparison of DNA and RNA extraction methods for mummified tissues. Molecular and Cellular Probes, 16: 445-451, 2002.

LEDERBERG, J. H1N1-influenza as Lazarus: genomic resurrection from the tomb of an unknown. Proceedings of the National Academy of Sciences, 98: 2.746-2.751, 2001.

MARENNIKOVA, S. S. et al. Smallpox diagnosed 400 years later: results of skin lesions examination of $16^{\text {th }}$ century Italian mummy. Journal of Hygiene, Epidemiology, Microbiology, and Immunology, 34: 227-231, 1990.

NOGUEIRA, J. et al. Revista de Patologia Tropical, 35: 87-102, 2006.

RUFFER, M. A. \& FERGUSON, A. R. Note on an eruption resembling that of variola in the skin of a mummy of the twentieth dynasty (1200-1100 BC). The Journal of Pathology and Bacteriology, 15: 1-3, 1911.

SCHATZMAYR, H. G. \& CORRÊA, J. C. Influenza In: COURA, J. R. (Ed.). Dinâmica das Doenças Infecciosas e Parasitárias. Rio de Janeiro: Editora Guanabara, 2005.

SONODA, S. et al. Ancient HTLV type 1 Pro-virus DNA of Andean Mummy. AIDS Research and Human Retroviruses, 16: 1.753$1.756,2000$.

TUMPEY, T. M. et al. Pathogenicity and immunogenicity of influenza virus with genes from the 1918 pandemic virus. Proceedings of the National Academy of Sciences, 101: 3.166-3.172, 2004.

WEBB, S.G. Prehistoric eye disease (trachoma?) in Australian Aborigines. American Journal of Physical Anthropology, 81: 91-100, 2005. 


\title{
Pollen Grains, Landscapes, and Paleoenvironments
}

\author{
Sérgio Augusto de Miranda Chaves
}

$\mathrm{P}$ alynology is the branch of botany that studies pollen grains and spores. Palynology textbooks such as Wodehouse (1935), Faegri \& Iversen (1950), and Erdtman (1952) represent the phase of diversification of palynological studies and the technical and theoretical foundations for the different lines of research developed since then.

Pollen grains and spores have been studied since the early $20^{\text {th }}$ century with the aim of contributing to taxonomic studies and, more recently, to studies on the environment and paleoenvironments.

Erdtman (1952) laid the groundwork for current studies in palynology. His pioneering graphically represented the morphological details of pollen grains and spores and laid the foundations for basic methodological procedures for their extraction, still used today.

Palynology has increasingly proven to have great potential for contributing to research in applied botany. The various current studies in paleopalynology shed light on the "fossil" plants and plant associations and help reconstruct their history. According to Renault-Miskovsky \& Petzold (1992), pollen grains are particularly resistant thanks to exine, or their outer "membrane". They can thus be preserved indefinitely over the course of geological time. They also withstand the inherent chemical aggressions from methods used to extract pollen from sediments. According to the authors, the grain's structure, size, shape, or even position, the type and number of germinal openings, and the description of the exine's sculpture allow the identification of a plant's family, genus, or even species under light microscopy.

Pollen analysis specifically provides diverse data on the pollen rain from the surrounding vegetation, subject to seasonal variations. To determine the floral evolution of given vegetation, we should turn to pollen analysis of elements of diverse origins, such as turf bogs and lacustrine sediments. Such sediments reflect evolution in the regional vegetation over a longer period, sometimes thousands of years (Salgado-Labouriau, 1973; Faegri \& Iversen, 1989).

Pollen analysis of coprolites is also a highly interesting tool, both in paleoenvironmental studies and those related to paleodiet and the medicinal use of given plants, among others. The limits of this type of analysis are related to the seasons of the year and the plants' flowering period in the past (Chaves \& Renault-Miskovsky, 1996; Chaves, 1997). 
Specialists from Europe and the Americas met at the Feces Facies Symposium in London in 2002. The symposium featured a rich series of contributions, ranging from environmental approaches to paleodiets, paleopharmacology of prehistoric populations, and coprological studies. The relevance of this meeting was consolidated in 2006 with the publication of a special issue of the Journal of Palaeogeography, Palaeoclimatology, Palaeoecology: advances in the interpretation of pollen and spores in coprolites. More recently, in September 2009, at the $5^{\text {th }}$ International Symposium on Ethnobotany, scientists presented various research methodologies in coprology, paleobotany, and different studies on the plants used by prehistoric populations, especially in South America.

Importantly, the science of palynology has increasingly proven to contribute greatly to research on vegetation from the past and interdisciplinary studies with parasitology and paleoparasitology.

Thus, palynology and these other sciences represent veritable guiding threads in applied research on the reconstruction of paleoenvironment and important tools in current lines of research in applied ecology, especially related to the evolution of the human species and its environment, creating a new perspective that we refer to here as historical ecology. We now have a relevant body of published work on these themes by researchers involved in projects linking paleopalynology and parasitology. In the studies related to archaeology, pollen analysis aids researchers in the interpretation of data on various occupations by prehistoric populations. Pollen analysis of socalled anthropic sediments also allows evaluating human impact on the environment in activities related to the development of agriculture and various cultivars (Carrión et al., 2004; Sears, 1982; Faegri \& Iversen, 1989; Lima Ribeiro \& Barbieri, 2005).

The history of human occupation of the American continent is closely linked to another important history: that of the occupation of diverse and often inhospitable ecosystems in this new and final space of conquest, America. Without a doubt, part of the human migratory waves that peopled our continent followed the same path as their contemporary megafauna. Probably coming from Siberia, these human waves crossed the Bering Land Bridge and traversed the extensive tundra formations there, as well as in the Alaska region. They followed the corridor already open between the glaciers during the Wurm interglacial on the sandy-clay plains of North America; they passed the Amazonian equatorial vegetation until they reached the Northeast and Center of Brazil and moved on to the distant coastal areas of the Atlantic and Pacific in South America (this route is purely speculative, since new archaeological discoveries point to at least two more access routes to the continent!). A new model is needed to elucidate the peopling of America, especially since the recent publication of evidence on the Clovis industry and its real representativeness in the cultural history of the peopling of this continent (Waters \& Stafford, 2007).

During the Holocene (10,000 BP), herbivorous mammals thrived in America due to the expansion of "pasture" land. This was the same period in which Homo sapiens sapiens expanded his territorial conquest, spreading across the American continent and developing countless cultural transformations related to the tropical ecosystems of South America.

Even in the Late Pleistocene, between 13,000 and 10,000 BP, such waves of human migrations to the American continent already achieved enormous adaptive success, especially in their subsistence economy based on hunting wild animals, fishing, and even gathering plants. According to Roberts (1994), in order to survive in a given territory, in a migratory movement that undoubtedly depended on natural resources like water, these hunter-fisher-gatherers needed an area of at least $75 \mathrm{~km}^{2}$ for a group of 25 individuals. By the Late Pleistocene, a large and representative population of human beings (estimated at more than two million) moved in greatly relevant migratory flows across the five continents. 
In addition to the adaptability of these human groups to the new ecological scenarios, other questions can be addressed, such as their way of life and subsistence, or their various relations with closely "related" groups, as well as the existence of possible intragroup hierarchical levels. But in-depth discussion of such questions is beyond our scope here. Just to present an overview of the importance of some sciences in the reconstitution of paleoenvironments is a difficult task in itself!

\section{PALEOENVIRONMENTS}

The reconstitution of Holocene and even Pleistocene paleoenvironments now relies on numerous sciences, indispensable for the enhancement of paleoenvironmental studies. These include dendrochronology, or the study of tree "rings" and their relations to climate changes, palynology, the study of pollen grains and spores, paleomalacology, the study of fossil mollusks, the study of phytoliths - silica particles deposited in the epidermis of plant leaves and stems, the study of diatomaceae, or microscopic algae (excellent indicators of environmental changes), and even the study of certain coleopters, insects that respond rapidly to climate changes.

Pollen and spores provide important information on past environments and possible floral arrays existing in a given geological period, helping answer questions on ancient climates, environments, and vegetation. Pollen grains, microstructures responsible for the fertilization of flowering plants, are scattered yearly in amounts that vary according to the type of plant. They can be carried to places distant from the area in which they were produced by air currents, insects, animals, even human beings. However, most pollen grains fall close to their original site, thus characterizing the local flora. Such pollen deposition can be accumulated on "traps" (slides smeared with petroleum jelly) placed near the ground to collect "pollen rain".

We can extract pollen grains from recent land or lacustrine sediments or even from archaeological sediments using specific chemical procedures, and later analyze the relative frequency of their appearance in the samples, separating them into arboreal pollen (AP) and non-arboreal pollen (NAP). Therein begins the reconstruction of ancient environments (or paleoenvironments) by analyzing and interpreting pollen diagrams. Such diagrams are constructed using the identification of taxon markers for given plant types and/or plant associations representing various environments: very dry, very wet, flooded, forest, savannah, and others. Importantly, the sediments submitted to such analyses should be previously dated using methods such as $\mathrm{C}^{14}$, for samples up to 40,000 years old.

\section{PRESERVATION OF POLLEN}

The preservation of pollen grains is a chapter in itself. Pollen has a virtually indestructible envelope, sexine, which consists of sporopollenin, a compound that resists even the strongest acids (like sulfuric and hydrofluoric). However, this outer layer does not resist sediments in which oxygen is present. Peat sediments, lakes, lagoons, and swamps provide excellent environments for its preservation (as long as these sediments have not undergone phases of drying, which would destroy the pollen grains due an aerobic medium).

Archaeological excavations can uncover pollen grains: inside the sediments; in funeral urns from various burials, especially in the stamens of flowers, often used as offerings (Chaves \& Brancaglion, 2005); on the surface of objects handled by humans, such as wooden, pottery, or stone utensils; or on the surface and inside fossilized feces, known as coprolites. 
Coprolites can contain pollens and spores on the inside or on the surface, when the pollen grains are deposited on the outer side, functioning as a veritable organic pollen trap (Chaves, 1996; Chaves \& Reinhard, 2006). The pollen content and macroscopic and microscopic remains found in this rich organic material thus provides information on human and animal diet (Chame, 1988; Sobolik \& Gerik 1992; Reinhard, Mrozowski \& Orloski, 1986; Reinhard, Hamilton \& Hevly, 1991; Chaves, 1994; Carrión et al., 2004; Chaves \& Reinhard, 2006; Reinhard, Chaves \& Iñiguez, 2008).

A more in-depth analysis of a coprolite requires identifying the animal that produced it, whether herbivore or carnivore, since the environmental interpretation resulting from this type of information is closely linked to the animal's eating habits.

Paleocoprology, or the study of coprolites, also yields precious data on the ancient demography of a given site, since it is possible to extract specifically male and female steroids from coprolites, in addition to mitochondrial DNA (mtDNA), used for taxonomic studies and studies on kinship and evolution (Sobolik et al., 1996). Paleoparasitology, a science that works closely with coprology, also produces information on parasitic diseases and possible migratory routes travelled by ancient human and animal populations (Araújo et al., 1988; Araújo, Rangel \& Ferreira, 1993; Ferrreira et al., 1987).

By studying the pollen in coprolites, palynologists obtain information that they analyze together with other tests to allow paleoenvironmental reconstruction, even constructing a possible scenario in which the prehistoric humans lived, relating them to given time periods. The study of pollen grains and other microresidues in coprolites allows inferences on diet and the medicinal uses of specific plants (Sobolik \& Gerik, 1992; Reinhard, Mrozowski \& Orloski, 1986; Reinhard, Hamilton \& Hevly, 1991; Chaves, 1994, 2000a; Carrión et al., 2004; Chaves \& Reinhard, 2006). When making paleoecological interpretations based on coprolites, the palynologist should be alert to two important methodological issues. The first is when the pollen is found inside the coprolite, meaning that it was ingested with the solid and/or liquid food of the human or animal that produced the coprolite.

The second is when the pollen rain was deposited on the coprolite's outer surface. In this case the feces that turned into a coprolite acted as a "trap", collecting the pollen from plant species in the immediate environment (mainly trees), as well as from plants found at long distances. The latter pollens were brought by air currents. If produced by a carnivorous animal, the coprolite can contain pollens from the stomach of prey consumed by it, herbivores for example. Birds and insects ingested by carnivores can represent vegetation located many kilometers away from the collection site. Pollen recovered from a coprolite's surface can indicate the taxa of plants that grew at (or close to) the point where the coprolite was found (Carrión et al., 2004; Putman, 1984).

Great caution is thus needed when making environmental interpretations based on coprolites. A mistaken diagnosis, especially failing to consider these two types of impregnation of coprolites by pollens, can lead ecological (or paleoecological) interpretations to erroneous and hasty conclusions.

Phytoliths are also excellent microresidues used for paleoenvironmental reconstruction. The application of phytolith analyses and the examination of these silicon particles increased considerably beginning in the 1970s. According to Jones \& Handreck (1967), the silica constituting phytoliths is deposited in the epidermis and other parts of the plants.

In the different taxa, phytoliths display distinct shapes, which allow diagnosing them and consequently identifying the plant. According to Piperno (1991) and Pearsall (1989), various families of monocotyledons and dicotyledons produce abundant amounts of phytoliths. Piperno (1991) identified some current phytoliths in the following families of monocotyledons: Bromeliaceae, Cannaceae, Cyperaceae, Poaceae, Heliconiaceae, Marantaceae, Musaceae, Orchidaceae, Arecaceae, and Zingiberaceae. This same study also indicated the production of phytoliths in the following 
families of dicotyledons: Acanthaceae, Annonaceae, Aristolochiaceae, Burseracerae, Cannabaceae, Chloranthaceae, Chrysobalanaceae, Asteraceae, Cucurbitaceae, Dilleniaceae, Euphorbiaceae, Loranthaceae, Magnoliaceae, Moraceae, Piperaceae, Rosaceae, Sterculiaceae, Ulmaceae, Urticaceae, and Verbenaceae.

Piperno (1991), Alexandre, Colin \& Meunier (1994), and Alexandre (1996) describe phytolith analyses aimed at palaeoenvironmental reconstruction. These articles present research conducted in the tropics and contribute substantially to the reconstruction of tropical environments, since certain taxa are even 'invisible' in a palynological diagnosis. Under scanning electron microscopy (SEM), the surface of phytoliths from a soil stratigraphic profile shows that marks of changes, and consequently their age, increase regularly with depth. Their distribution can be interpreted with paleogeographic studies (Alexandre, 1996). Piperno (1991) reported evidence that phytolith analysis can distinguish corn from teosinte. Mulholland (1989) also separated types of corn and wheat in North America. Piperno (1991), Pearsall (1989), and Pearsall \& Piperno (1990) published a method for maize identification in the New World.

Phytolith analysis can also identify other cultivars: arrowroot (Canna edulis) (Cannaceae), (Maranta arundinacea L.) (Marantaceae), and tigernut (Cyperus esculentus L.) (Cyperaceae) (Pearsall, 1989). According to Piperno (1991), phytolith analysis identifies a significant number of wild species used by prehistoric New World human populations, e.g., some palm trees, bamboos, and wild plantains or Heliconia (Musaceae). Unfortunately, many New World root cultivars such as manioc and potato cannot be diagnosed by phytolith analysis.

Parasite eggs, larvae, and DNA can also be recovered from preserved coprolites. However, in other sites, when the coprolites are "contaminated" by rain, a sporadic type of decomposition occurs in aerobic circumstances. Coprolites in such open environments display low preservation or "pollen richness", and mites, fungal spores, and hyphae of various forms. Active growth of hyphae occurs in such deposits, and archaeologists have acquired pulmonary infections at least once, apparently from excavating coprolites (Bouchet et al., 2003).

Well-preserved coprolites do not differ morphologically from recently deposited feces. They can be fragmented or even dissolved in the archaeological layers or in the soil, as in the case of latrines. After defecation, the feces are exposed to many climatic factors. As mentioned, rain and moisture can alter the fecal morphology, potentially leading to erroneous paleoenvironmental interpretations.

\section{PALEOPHARMACOLOGY, PALYNOLOGY STUDIES, AND THE BRAZILIAN PHARMACOPEIA}

Paleopharmacology studies residues with medicinal uses found in places such as archaeological sites (Reinhard, Hamilton \& Hevly, 1991; Chaves \& Reinhard, 2003, 2006).

The groundbreaking theoretical work for this field of study was by Ortiz de Montellano (1975), who conducted a detailed survey of medicinal plants used by the Aztecs and identified in a historical codex. Coprolite analysis has obvious implications for this field of research and can extend our knowledge on the ancient use of medicinal plants. As reviewed by Riley (1993), numerous researchers have drawn on seeds to identify the prehistoric use of anthelminthics.

Parasitism is a complex relationship. Ancient peoples and civilizations developed medicinal "treatments" aimed at eliminating various parasitic infections based on knowledge of a given pharmacopeia. We believe it is possible recover the type of use and/or evidence of use of a given purportedly medicinal plant in archaeological sites, as well as to establish relationships between its use and specific circumstances. This type of study should adopt a multidisciplinary approach, involving paleoethnobotanists, paleoparasitologists, paleopathologists, and pharmacologists, among others. 
The archaeology of the sertão or semiarid backlands of Brazil provides a rich source of information on the first American cultures. The sertão includes the caatinga or scrub forest region encompassing parts of the current States of Piauí, Ceará, Rio Grande do Norte, Alagoas, Paraíba, Pernambuco, Sergipe, Bahia, and Minas Gerais. In the sertão, the cultural tradition of Northeast Brazil was documented by burials, rock art, and the presence of associated artifacts in various well-dated locations (Guidon et al., 1994; Martin, 1996; Lessa \& Guidon, 2002).

Human coprolites, dated 8,500 to 7,000 BP, were collected from the rock shelter at the Boqueirão da Pedra Furada site in Piauí State, Brazil. These dates correspond to the Serra Talhada I and II cultural traditions, the Northeast tradition, or a Paleoindian culture from Northeast Brazil. Parasitological analysis of these coprolites identified parasite eggs. Analysis of the skeletons and hair of individuals from this tradition shows a variety of diseases such osteodistrophy, dental deformations, and head lice.

Palynological analysis of the coprolites showed 12 potentially medicinal genera. The data obtained from the pollen analyses were critically assessed to identify the therapeutic potential of the plants represented by the pollens.

The most representative cases involved the presence of three genera, Anacardium, Borreria, and Terminalia, with these plants used for medicinal purposes such as treatment of symptoms from intestinal parasites (Chaves \& Reinhard, 2006).

Analysis of the coprolites, skeletons, and hair samples provided evidence of ancient diseases that required knowledge of the use of traditional medicinal plants to treat this population related to the Northeast tradition. Araújo et al. (2000) found louse eggs on single hair shafts dated 10,000 BP. The repellents or so-called "remedies" would have reduced the discomfort caused by these parasites.

According to Reinhard et al. (2001), the oldest hookworm infections were diagnosed in coprolites from the Northeast tradition. According to the authors, some other helminths also parasitized individuals from this culture (Gonçalves, Araújo \& Ferreira, 2003). Anthelmintics and treatments for symptoms of this infection would have been necessary. Lessa $\&$ Guidon (2002) found evidence of both a degenerative disease and an oral disease that required the use of analgesics.

Reinhard, Hamilton \& Hevly (1991) proposed the use of pollen concentration to identify medicinal plants in coprolites and burials. According to the authors, the discovery of Salix (willow), Larrea (creosote), and Ephedra (Mormon tea) in high percentages and concentrations indicated their use for specific treatments. A principle established by these studies is the value of pollen concentration to identify intentional consumption of anemophilous plants (airborne pollination) and entomophilous plants (pollination by insects). Knowledge of pollen concentration is needed to determine whether the amenophilous types were aggregated by chance in the coprolites or consumed intentionally with pollen-rich medicinal plants.

Much is known about current American and Brazilian indigenous pharmacopeia (Gonzalez, 1965; Martius, 1939; Pardal, 1937; Vogel, 1973), but paleopharmacology is still taking its first steps towards elucidating the prehistoric use of medicinal plants (Chaves \& Reinhard, 2006).

The Código Farmacêutico Lusitano, or Lusitanian Pharmaceutical Code, dated 1835, written by Dr. Agostinho Albano da Silveira Pinto, was approved as Brazil's official pharmacopeia. However, the first official pharmacopeia written by physicians and pharmacists was the Farmacopeia Portuguesa, or Portuguese Pharmacopeia, dated 1876. 


\section{PALEOENVIRONMENTAL RESEARCH IN BRAZIL}

Paleoecological studies aimed at the paleoenvironmental reconstitution of the Brazilian Quaternary through palynomorphs have been conducted in various regions of the country. Thus, the existence of different scenarios and the development of a variety of landscapes led to various theories on the installation of inter-tropical vegetation.

Beginning in the Holocene, the development of tropical vegetation, plant species migrations, and at the same time the expansion of dry vegetation from Brazil were determined by edaphic and climatic factors and anthropic influences (Ab'Saber, 1980).

The following is a summary of some representative studies on paleoclimates in the Brazilian territory.

\section{The South region}

Palynological studies in sediments from the coastal plain in Capão do Leão, Rio Grande do Sul State, Brazil, showed changes in the vegetation and increase in temperature and humidity at 6,700 BP. Around 5,000 BP, there was a peak rise in sea level, followed by the development of tropical flooded forest similar to the present (Neves \& Lorscheitter, 1997).

Studies by Behling (1998) in Santa Catarina State in southern Brazil showed low slopes on the Rio do Rastro and Boa Vista mountain ranges with a phase of subtropical climate and evidences of frosts between 14,000 and 10,000 BP.

In these same areas, and in low-lying regions of the hill known as Morro da Igreja, the climate was tropical from 10,000 to 3,000 BP, and in the higher regions the climate was dry and hot. In Poço Grande, during this same period, the climate was also tropical, and there was a climate variation that began with a dry period at 4,840 to 4,590 BP, followed by an increase in humidity around 4,590 to $4,260 \mathrm{BP}$, and reaching a phase with high humidity between 4,260 and 3,525 BP. From 3,000 BP until today, a tropical climate was established in the lowlands. From 2,900 to $1,000 \mathrm{BP}$, on the upper part of the mountains and Morro da Igreja, there was a cooler and more humid climate than in the previous period. From 1,000 BP to the present it has remained cool, but with an increase in humidity.

Analyses of sediments collected along the Paraná River showed a dry phase from 40,000 to 8,000 BP, followed by a more humid phase from 8,000 to 3,500 BP. From around 3,500 to 1,500 BP, the dry conditions returned, followed by a new increase in humidity after 1,500 BP, reaching current conditions (Stevaux, 1997).

In studies in the Campos Gerais Mountains, Behling (1997a, 1998) observed a phase between 12,480 and 9,660 BP with cold and dry climate and harsh frosts in the winter in the higher regions. In the valleys, from 9,660 to 2,850 $\mathrm{BP}$, the climate was tropical and relatively humid, with long dry seasons, which probably favored the expansion of Araucaria in an area of field vegetation. There was a humid climate with a dry season from 2,850 to 1,530 BP, followed by an increase in humidity.

Studies by Behling, Coehn \& Lara (2001) in São Francisco de Paula, in the South of Brazil, recorded a period from around 7,500 to $4.000 \mathrm{BP}$ with a markedly drier climate than at present. Around 4,000 BP, milder climatic conditions were observed, with the appearance of field vegetation and areas with the installation of Araucaria forest. The forest's expansion is documented since 1,060 BP and the expansion of Araucaria angustifolia (Bert.) Kentz trees since 850 BP. The region currently presents fields of pastures and altered Araucaria forest.

Behling (2002) published an interesting summary of the open landscapes in the Late Quaternary in the South and Southeast of Brazil. In regions currently covered by mixed rainforest, with individual Araucaria trees, an expansion occurred from so-called refuges, occupying field areas. This process has been relatively recent, beginning around 4,000 BP. 


\section{The Southeast region}

Studies in the São Paulo Basin by Takiya \& Ybert (1991) showed a dry phase from 5,500 to 2,500 BP.

In the Middle Paraíba do Sul River Valley in São Paulo State, Garcia (1994) suggested a cold and dry climate in the Late Pleistocene, with irregular and intense rains, and a more humid climate on the mountaintops. There was a hot and humid climate around 9,500 BP, with heavier precipitation than at present. From 9,500 to 8,000 BP, the climate changed to hot and dry, and in the following phase, from 8,000 to 6,400 BP, it changed to cooler and more humid.

Barros et al. (1993), in Bananal, São Paulo State, in the Middle Paraíba do Sul Valley, found similar situations to the present (namely humid) in the Early Holocene. In a phase prior to the Holocene, the drier climate was characterized by elements of open vegetation.

In the same region, Barros (1996) suggests that the transition from the Pleistocene to the Holocene was marked by instability in the climate and vegetation, with evidence of an open swampy or marshy environment with soaked soils. The same author identifies an attempt at the installation of plant cover with the presence of various pioneering species, but without evidence of a dense forest.

Analyses by Behling $(1997 b$, 1998) in the Morro de Itapeva region in São Paulo State covering the period between 35,000 and 17,000 BP detected the existence of a cooler and drier climate than at present. The climate remained cool, but drier, between 17,000 and 10,000 BP, while in the following phase, from 10,000 to 3,000 BP, it was hotter and more humid on the eastern slope, and hot and dry on the higher ground. An increase in humidity was observed beginning at 3,000 BP, with large numbers of Araucaria and Podocarpus.

Luz (1997), analyzing a core from Lagoa de Cima, Rio de Janeiro State, suggested a hot and relatively humid phase prior to 6,000 BP. In the following phase, in the millennium starting at 6,000 BP, the climate remained hot, but seasonally dry. Around 4,000 BP there was an increase in humidity, followed by the beginning of a drier period.

In the Middle Rio Doce Valley, Minas Gerais State, from 10,000 to 8,900 BP, Ybert, Albuquerque \& Turcq (1997) suggested a dry climate with cerrado (savannah) vegetation, followed by a period with higher humidity around 8,500 BP, as evidenced by elements of semi-deciduous and gallery vegetation, in addition to the development of a lake.

Chaves (1997), analyzed deposits from the slopes of the Middle Paraíba do Sul Valley, also in Bananal, on the border between São Paulo and Rio de Janeiro States, and identified pollen grains that mark environmental changes associated with anthropic processes in the late $19^{\text {th }}$ century, at the peak of the replacement of native forests with coffee plantations.

Analyses of sediments from Lagoa Salgada, Rio de Janeiro State, showed a dry period around 2,500 BP between humid periods (Toledo, 1998).

Based on studies in Lago do Pires, Minas Gerais State, Behling (1998) suggested five climatic phases: 1) 9,720 to $8,810 \mathrm{BP}$, dry climate with low precipitation; 2) higher humidity around 8,810 to 7,500 BP; 3) the same conditions as the first phase from 7,500 to $5,530 \mathrm{BP} ; 4$ ) less dry from 2,780 to $140 \mathrm{BP}$; and 5) the last phase, from $140 \mathrm{BP}$ to the present, characterized by deforestation and the use of fire attributed to human presence in the region.

Coelho (1999), analyzed sediments from Sepetiba Bay, Rio de Janeiro State, and observed four climate changes: 1) 6,300 to 4,650 BP, a humid phase indicated by elements of dense rainforest; 2) 4,650 to 1,350 BP, a drier period shown by the expansion of open vegetation; 3) 1,350 to $45 \mathrm{BP}$, a return to characteristics of higher humidity, identified by an increase in forest elements; and 4) from $45 \mathrm{BP}$ to the present, characteristics of a drier environment were attributed to the greenhouse effect (artificial decrease in humidity) and to changes in the vegetation due to deforestation by man. 
Barth et al. (2004) and Barth, São-Thiago \& Barros (2006) analyzed sediments from Guanabara Bay, Rio de Janeiro, dated 4,210 and $1.760 \pm 50 \mathrm{BP}$, respectively, the latter study attesting to the existence of mangroves during this period.

\section{The Central-West region (Central Plateau)}

In the Middle Holocene, the intense action of fire contributed greatly to the appearance of the cerrado (savannah) landscape in Brazil. The installation of this type of vegetation in the Central Plateau of Brazil was due mainly to the arid summer season and fire in that region (Vernet et al., 1994).

Ledru (1998) found evidence of climatic oscillations in the Central Plateau, including a milder and more humid climate around 9,000 BP.

In the region around Brasília, pollen analyses by Ribeiro (1994) showed an initial humid and cool phase from 25,790 to 23,380 BP. From 23,380 to 21,450 BP there was an increase in humidity and a decrease in temperature. Characteristics of a dry climate appeared from 21,450 to $7,220 \mathrm{BP}$, followed by a hot, humid phase, quite similar to the present.

Pollen analyses by Ferraz-Vicentini \& Salgado-Labouriau (1996) and Salgado-Labouriau (1997) in Cromínia, Goiás State, showed vegetation similar to the present and a hot and semi-humid climate in the period prior to $32,400 \mathrm{BP}$. From 32,400 to 20,000 BP, the decrease in tree and bush pollen types was attributed to a phase that was probably more humid and cooler than the present. From 18,500 to 11,300 BP, the decrease in the concentration of palynomorphs suggests a drier and perhaps cooler phase in the Late Pleistocene. This climatic condition also lasted from 10,500 to 7,700 BP, with a slight increase in temperature.

From 6,680 to 3,500 BP, recovery of the vegetation suggests an increase in humidity. Pollen analyses in animal coprolites from the archaeological site in Santa Elina, Mato Grosso, dated 4,000 to 2,000 BP, showed transitional vegetation (from cerrado to cerradão) during this period (Chaves, 2000b).

\section{The North and Northeast regions}

In the Amazon region, pollen analyses published by Martin et al. (1993) indicate four periods of dry climate in the last 60,000 years. According to the authors, the numerous climatic oscillations were caused by El Niño-type phenomena.

Also in the Amazon, studies by Sifeddine et al. (1994) in palynology and sedimentology showed that the fluctuations observed in the vegetation during the climatic events of the Early Holocene persisted during the recent Holocene, but with less intensity.

Authors like Colinvaux (1996), Oliveira (1996), and Behling (1998), using palynological studies, suggested a cooler climate in the Amazon forest from 40,000 to 10,000 BP compared to the present. Colinvaux, Oliveira \& Bush (2000) review the past existence of refuges in the region.

According to Behling (1996), the large amount of carbonized particles found in sediments prior to 9,530 BP was due to human presence in the Amazon.

Behling \& Costa (2001) analyzed the pollen content of sediments from Lago Crispim (in northeastern Pará State) dated to 7,640 BP and observed variations in the vegetation close to the study area, controlled by oscillation in the sea level. Along the core that was analyzed, the sedimentological and palynological records and geochemical elements assisted the interpretation of the floral composition controlled by the marine regression and transgression, 
as evidenced by the advance and retreat of mangroves and the moment of installation of palm tree vegetation. The presence of carbonized particles on the coastal region during the Late Holocene was interpreted as manmade.

Studies by Behling, Coehn \& Lara (2001) used pollen analysis of three sediment cores to evaluate changes and the dynamics of the mangrove ecosystem on the Bragança Peninsula, a coastal region in northeastern Pará. Installation of the mangrove vegetation began at different times in three sites: 5,120 BP in Campo Salgado, 2,170 BP in Bosque de Avicennia, and 1,440 BP in Furo do Chato, characterizing the Middle Holocene on the Bragança Peninsula as having its higher areas covered by mangroves. The change from mangrove to tidal vegetation in these higher areas around $420 \mathrm{BP}$ was interpreted as natural encroachment of the sea level rather than the result of human action.

Sifeddine et al. (2003) analyzed a core from Lagoa do Caço, Maranhão, and observed higher frequencies of Podocarpus in the Late Pleistocene than at present. The increase in Podocarpus, followed by successive increases in various pioneering species such as Didymopanax, Melastomataceae/Combretaceae, and Cecropia, suggests a progressive increase in humid and cool climatic conditions.

For the Northeast region, the paleoclimatic data are still scarce. Guerin et al. (1993), Chaves (1994), and Chaves \& Renault-Miskovisky (1996) have documented the existence of a humid regional phase in the Late Pleistocene and between 9,000 and 7,000 BP.

Chaves \& Renault-Miskovsky (1996) used pollen analysis of animal coprolites to provide data that allowed tracing a paleoclimatic and paleoenvironmental picture for the region of São Raimundo Nonato, Piauí. The authors suggest attenuation in the last Holocene arid crisis between 8,700 and 7,000 BP. At that time, the landscape in the São Raimundo Nonato region was very different from today, with cerrado-cerradão-type vegetation. These records also reveal a climate that was slightly cooler and less dry than today.

One of the few specific studies on the paleoenvironment in what is now the State of Ceará was on the coastal area $90 \mathrm{~km}$ from the capital city of Fortaleza. Pollen was analyzed from marine sediments, showing glacial episodes and climate changes.

Pollen analyses by Oliveira Barreto \& Suguio (1999) in turf bogs dated 10,990 \pm 80 BP provided a history of changes in the vegetation and climate in the Icatu River Valley in the central São Francisco River region.

The palynological profile of Saquinho (in the São Francisco Valley) can be divided into five zones. The first, called zone SA1, corresponding to the period from 10,990 to 10,540 BP, showed pollen from taxa currently found in the Amazon and Atlantic forests, as well as mountain taxa, suggesting humid climatic conditions and lower temperatures. From 10,540 to 6,790 BP (zone SA2), the predominance of Mauritia and Ilex pollen type suggests a progressive warming and high humidity. From 8,910 to $6,790 \mathrm{BP}$, there was a progressive decline in forest taxa and a gradual increase in caatinga (scrub forest) and cerrado taxa in the landscape. From 6,790 to 6,230 BP (zone SA3), no palynomorphs were found, which was attributed to seriarid conditions. The period from 6,320 to 4,535 BP (zone SA4) was marked by the return of gallery forest, caatinga, and cerrado taxa, indicating a more humid climate. Finally, zone SA5, from 4,535 BP to the present, shows stabilization of the current climate and vegetation.

To conclude this chapter, we can say that palynology and the other disciplines discussed here are veritable guiding threads in applied research on paleoenvironmental reconstruction, serving as important tools in current studies in applied ecology, especially related to the evolution of humans and their environment, thus establishing a new approach that we refer to here as historical ecology. 


\section{METHODOLOGY FOR POLLEN ANALYSIS IN ARCHAEOLOGICAL MATERIAL}

Samples of sediments selected for pollen analysis receive the following chemical treatment:

1. Place $2.0 \mathrm{~cm}^{3}$ of sediment in a $100 \mathrm{ml}$ beaker and add $50 \mathrm{ml}$ distilled water to dissolve the material.

2. Sift the material in a $200 \mu \mathrm{m}$ screen to remove plant remains, sand, and other materials. Then add two tablets of exotic spore (Lycopodium - each with 12,100 spores, for subsequent calculation of the absolute frequency of palynomorphs - Stockmarr, 1971).

3. Transfer the solubilized material to plastic centrifuge tubes to discard the water.

4. Add hydrofluoric acid (HF) $40 \%$ to eliminate silicates and let stand for 24 hours (repeat this step when necessary).

5. Add hydrochloric acid ( $\mathrm{HCl}) 50 \%$ to eliminate fluorosilicates formed in the previous reaction; boil for 15 minutes.

6. Add potassium hydroxide $(\mathrm{KOH}) 10 \%$ to eliminate unwanted plant elements.

7. Add acetic acid $\left(\mathrm{CH}_{3} \mathrm{COOH}\right)$ for dehydration of the material (repeat this step).

8. Add $5 \mathrm{ml}$ of mixture for acetolysis: $4.5 \mathrm{ml} \mathrm{HOOC}-\mathrm{COOH}$ P.A. (acetic anhydride) and $0.5 \mathrm{ml} \mathrm{H}_{2} \mathrm{SO}_{4}$ P.A. (sulfuric acid), for dissolving part of the organic matter, especially the cellulose, and acetylation of the exine (Erdtman, 1952); boil for 4 minutes.

9. Wash the material in the tube with $10 \mathrm{ml}$ distilled water (repeat this step).

10. Add $5 \mathrm{ml}$ of zinc chloride $\left(\mathrm{ZnCl}_{2}\right)$ to separate palynomorphs from the remaining material, transfer supernatant with palynomorphs to another centrifuge tube (this is the only step in which the supernatant is saved).

11. Add hydrochloric acid $(\mathrm{HCl}) 10 \%$ to allow sedimentation of palynomorphs, recovering them.

12. Wash the material in the tube with $10 \mathrm{ml}$ distilled water (repeat this step).

13. Add glycerinated water (1:1), let stand for 30 minutes before mounting slides.

14. Mount permanent slides with glycerin gel (Kisser, 1935 apud Erdtmanm, 1952).

Note: at the end of each step, centrifuge for 5 minutes $(1500 \mathrm{rpm})$ and discard supernatant, except in the zinc chloride phase.

The following are some examples of results from slides prepared with this technique. Figure 1 shows sweet potato pollen from a site in Mato Grosso, Brazil, dated 2,000 BP. 
Figure 1 - Pollen from sweet potato Ipomoea batatas (x 1.000), from archaeological sediments dated to 2,000 BP from site in Santa Elina, Mato Grosso, Brazil

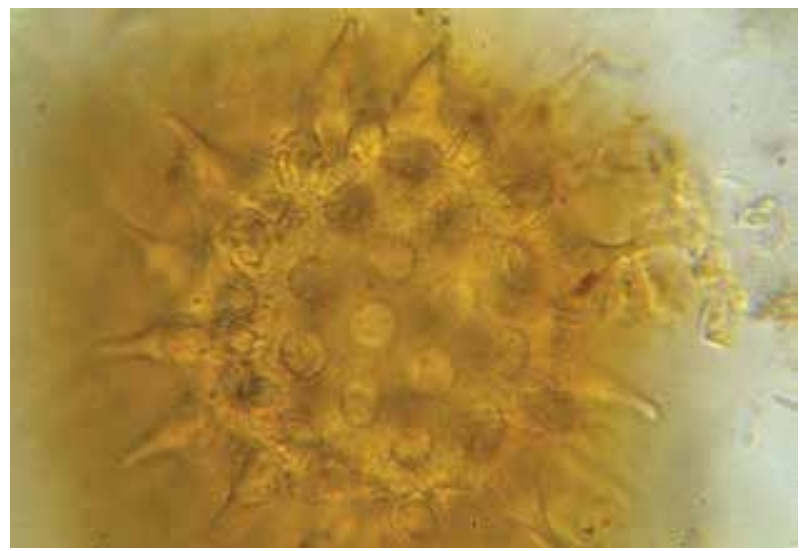

Photograph: Sérgio de Miranda Chaves.

Figure 2, however, shows a phytolith under scanning electron microscopy, and Figure 3 is pollen from the archaeological region in southeastern Piauí, both dated c. 8,000 BP.

Figures 2 and 3 - Phytolith of Poaceae and pollen of Justicia sp. (Acanthaceae) (x 1.000) found in sediments from Quari Lagoon, Piauí, dated 8,770 \pm 55 BP
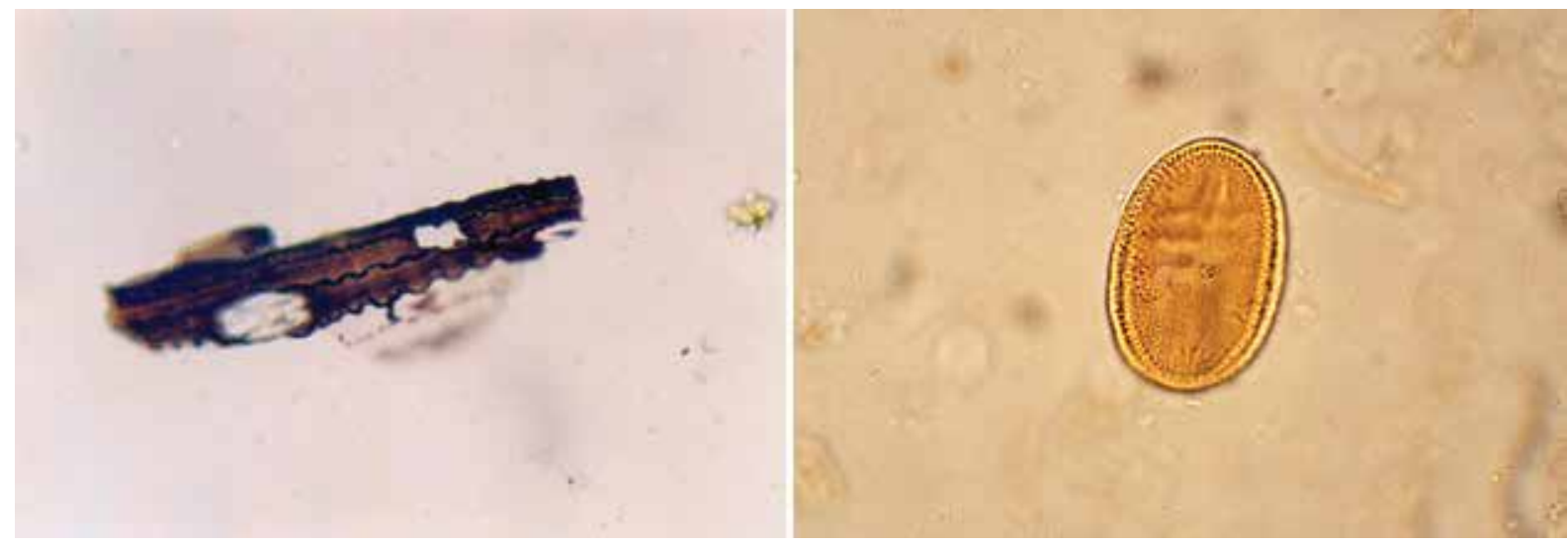

Photograph: Sérgio de Miranda Chaves. 
Figure 4 shows another phytolith from the same region of Piauí, still unidentified.

Figure 4 - Unidentified phytolith (x 400) found in sediments from Quari Lagoon, Piauí, dated 8,770 \pm 55 BP

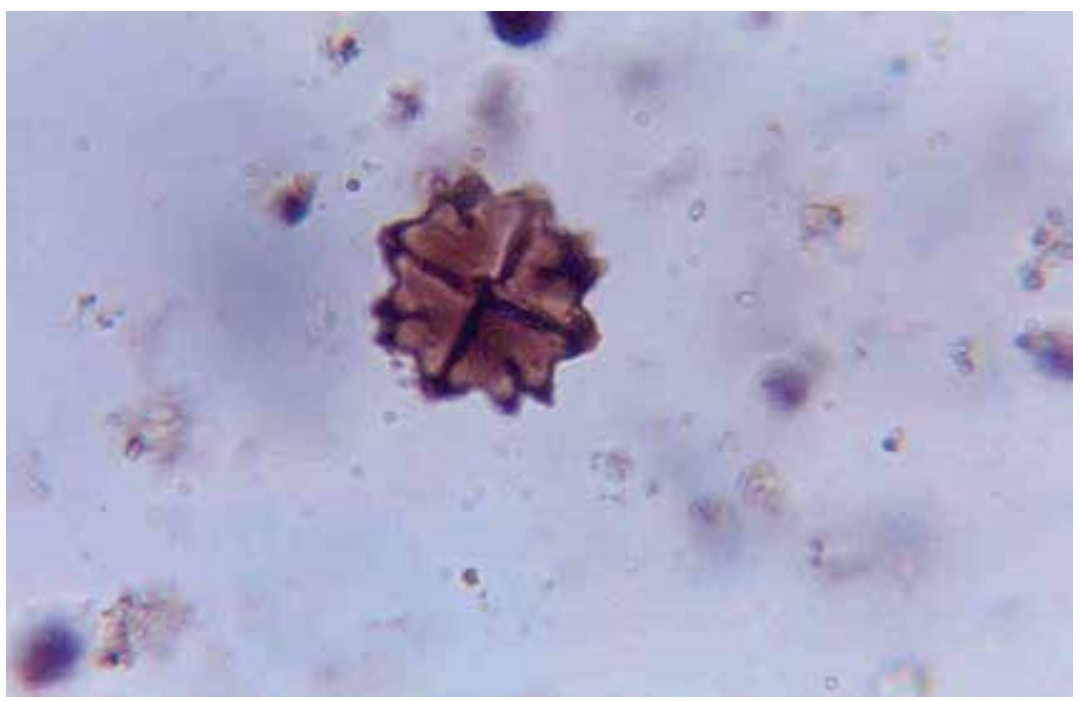

Photograph: Sérgio de Miranda Chaves.

Figures 5 and 6 show recent pollen grains with characteristic morphology, easy to diagnose.

Figure 5 - Bauhinia sp. (recent pollen), polarized light (x 400)

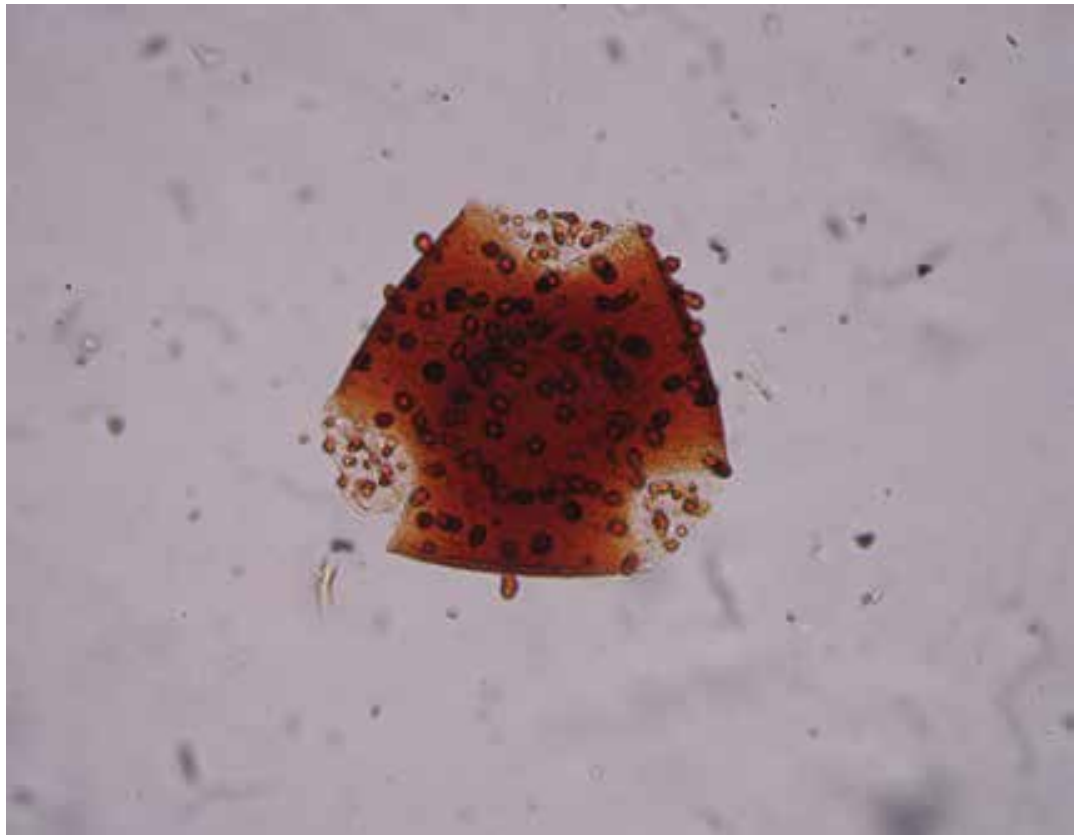

Photograph: Sérgio de Miranda Chaves. 
Figure 6 - Zea mays (recent pollen) (x 400)

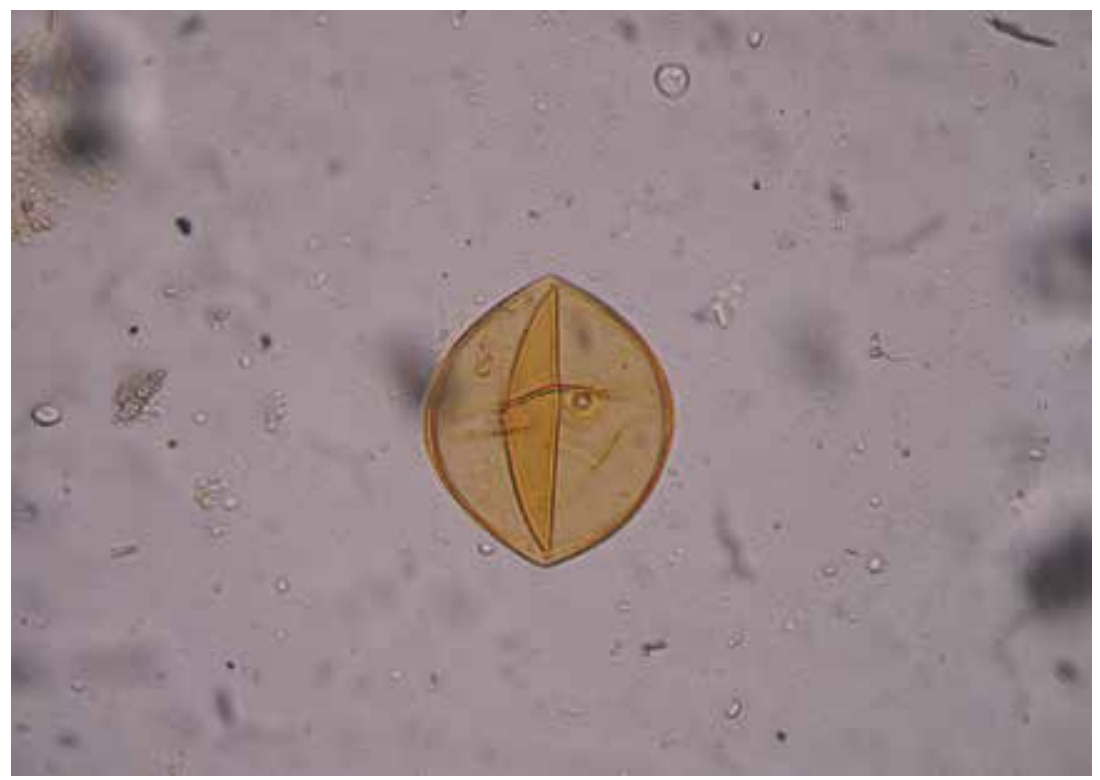

Photograph: Sérgio de Miranda Chaves.

\section{REFERENCES}

AB'SABER, A. N. Espaços ocupados pela expansão dos climas secos na América do Sul por ocasião dos períodos glaciais quaternários. Craton e Intracraton, 3: 1-18, 1980.

ALEXANDRE, A. Phytolithes, Interactions sol-plante et Paléoenvironnements, 1996. Thèse de Doctorat, Marseille: Université de Droit, Économie et des Sciences d'Aix-Marseille III.

ALEXANDRE, A.; COLIN, C. \& MEUNIER, J. P. Les phytolithes, indicateurs du cycle biogéochimique du silicium en forêt équatoriale. Comptes Rendus de l'Académie de Sciences, Paris, série II, 319: 453 -458, 1994.

ARAÚjo, A. J. G.; RANGEL A. \& FERREIRA, L. F. Climatic change in Northeastern Brazil paleoparasitological data. Memórias do Instituto Oswaldo Cruz, 88(4): 577-579, 1993.

ARAÚjo, A. et al. Hookworms and the peopling of America. Cadernos de Saúde Pública, 2(4): 226-233, 1988.

ARAÚjo, A. et al. Ten thousand years of head lice infection. Parasitology Today, 16: 269, 2000.

BARros, M. A. Estudos Palinológicos na Região de Bananal, São Paulo: Reconstrução Paleoambiental no Médio Vale do Rio Paraíba do Sul, 1996. Master's thesis, Rio de Janeiro: Instituto de Geociências, Universidade Federal do Rio de Janeiro.

BARROS, M. A. et al. Estudos palinológicos na avaliação das transformações ambientais recentes em áreas degradadas: médio vale do rio Paraíba do Sul, Bananal (SP/RJ). In: CONGRESSO DE GEOGRAFIA FÍSICA APLICADA, V, 1993, São Paulo.

BARTH, O. M.; SÃO-THIAGO, L. E. U. \& BARROS, M. A. Paleoenvironment interpretation of a 1760 years B.P. old sediment in a mangrove area of the Bay of Guanabara, using pollen analysis. Anais da Academia Brasileira de Ciências, 78(2): 227-229, 2006.

BARTH, O. M. et al. P. Pollen record and paleoenvironment of a 4210 years B.P. old sediment in the Bay of Guanabara, Rio de Janeiro, Brazil. Anais da Academia Brasileira de Ciências, 76: 549-551, 2004.

BEHLING, H. First report on new evidence for the occurrence of Podocarpus and possible human presence at the mouth of the Amazon during the Late-glacial. Vegetation History Archeobotany, 5(3): 241-246, 1996. 
BEHLING, H. Late Quaternary vegetation, climate and fire history in the Araucaria forest and Campos region from Serra Campos Gerais (Paraná), South Brazil. Review of Palaeobotany and Palynology, 97: 109-121,1997a.

BEHLING, H. Late Quaternary vegetation, climate and fire history from the tropical mountain region of Morro do Itapeva, SE, Brazil. Palaeogeography, Palaeoclimatology, Palaeoecology, 129: 407-422, 1997b.

BEHLING, H. Late Quaternary vegetational and climatic changes in Brazil. Review of Paleobotany and Palynology, 99: 143-156, 1998.

BEHLING, H. South and Southeast Brazilian grasslands during Late Quaternary times: a synthesis. Palaeogeography, Palaeoclimatology, Palaeoecology, 177: 19-27, 2002.

BEHLING, H. \& COSTA, M. L. Holocene vegetational and coastal environmental changes from the Lago Crispim record in north eastern Pará State, Eastern Amazonia. Review of Palaeobotany and Palynology, 114: 145-155, 2001.

BEHLING, H.; COEHN, M. C. L. \& LARA, L. J. Studies on Holocene mangrove ecosystem dynamics of the Bragança Peninsula in north-eastern Pará, Brazil. Palaeogeography, Palaeoclimatology, Palaeoecology, 167: 225-242, 2001.

BOUCHET, F. et al. Parasite remains in archaeological sites. Memórias do Instituto Oswaldo Cruz, 98(I): 47-52, 2003.

CARRIÓN, J. S. et al. Perspectivas del análisis polínico de coprolitos y otros depósitos biogénicos útiles en la inferencia paleoambiental. Miscelánea en Homenaje a Emiliano Aguirre: Paleontología. Alcalá de Henares: Museo Arqueológico Regional, 2004.

CHAME, M. Estudo Comparativo das Fezes e Coprólitos Não Humanos da Região Arqueológica de São Raimundo Nonato, Sudeste do Piauí, 1988. Master's thesis, Rio de Janeiro: Universidade Federal do Rio de Janeiro.

CHAVES, S. A. M. Étude Palynologique des Coprolithes Humains Recueillis sur le Site 'Pedra Furada', Piauí (Brésil): interprétations paléoethnologiques et paléobotaniques, 1994. Mémoire de D.E.A, Paris: Museum National d'Histoire Naturelle.

CHAVES, S. A. M. Metodologia utilizada para a extração de grãos de pólen de coprólitos humanos: um estudo comparativo. Revista do Museu de Arqueologia e Etnologia, 6: 394-395, 1996.

CHAVES, S. A. M. Données palynologiques d'un millieu végétal dégradé dans la Vallée Moyenne du Rio Paraíba do Sul, Brésil. Quaternaire, 8(1): 49-54, 1997.

CHAVES, S. A. M. Pólen decifra hábito e vegetação da pré-história. Ciência Hoje, encarte especial, 2000 a.

CHAVES, S. A. M. New paleovegetational and paleoethnobotanical perspectives on Brazil's Central Plateau: a palynological proposal. Revista da Universidade de Guarulhos, n. esp: 164-167, 2000 b.

CHAVES, S. A. M. \& BRANCAGLION, A. JR. Pollen Analysis from the resin used for embalming a mummy from the Roman period of I century B.C. Museu Nacional (MN/UFRJ). Brazil. Journal of Biological Research, 80(I): 139-140, 2005.

CHAVES, S. A. M. \& REINHARD, K. J. Paleopharmacology and pollen: theory, method, and application. Memórias do Instituto Oswaldo Cruz, supl. 1(98): 207-211, 2003.

CHAVES, S. A. M. \& REINHARD, K. J. Critical analysis of coprolite evidence of medicinal plant use, Piauí, Brazil. Palaeogeography, Palaeoclimatology, Palaeoecology, 237: 110 -118, 2006. (Special issue on 'Advances in the interpretation of pollen and spores in coprolites', ed. Owen K. Davis)

CHAVES, S. A. M. \& RENAULT-MISKOVSKY, J. Paléoethnologie, paléoenvironnement et paléoclimatologie au Piauí, Brésil: apport de l'étude pollinique de coprolithes humains recueillis dans le gisement préhistorique Pléistocène de 'Pedra Furada'. Comptes Rendus de l'Académie de Sciences, série IIa, 322: 1.053-1.060, 1996.

COElHo, L. G. Variações Climáticas e do Nível do Mar na Região da Baía de Sepetiba (RJ) nos Últimos Seis Mil Anos: um registro palinológico, 1999. Master's thesis, Rio de Janeiro: Faculdade de Geologia, Universidade do Estado do Rio de Janeiro.

COLINVAUX, P. A. A long pollen record from lowland Amazonia Forest and cooling in glacial times. Science, 274: 85-87, 1996.

COLINVAUX, P. A.; OLIVEIRA; P. A. \& BUSH, M. B. Amazonian and neotropical plant communities on glacial time-scales: the failure of the aridity and refuge hypotheses. Quaternary Science Reviews, 19: 141-169, 2000. 
ERDTMAN, G. Pollen Morphology and Plant Taxonomy: angiosperms. Stockholm: Almquist and Wiksell, 1952.

FAEGRI, K. \& IVERSEN, J. Text Book of Modern Pollen Analysis. Copenhagen: Ejanar Munkasgaard, 1950.

FAEGRI, K. \& IVERSEN J. Textbook of Pollen Analysis. New York: John Wiley and sons, 1989.

FERRAZ-VICENTINI, K. R. \& SALGADO-LABOURIAU, M. L. Palynological analysis of a palm swamp in Central Brazil. Journal of South America Sciences, 9(3-4): 207-219, 1996.

FERREIRA, L. F. et al. Encontro de ovos de ancilostomídeos em coprólitos humanos datados de 7.230 280 years, Piauí, Brasil. Anais da Academia Brasileira de Ciências, 59: 280 -281, 1987.

GARCIA, M. J. Palinologia de Turfeiras Quaternárias do Médio Vale do Rio Paraíba do Sul, 1994. PhD dissertation, São Paulo: Instituto de Geociências, Universidade do Estado de São Paulo.

GONÇALVES, M. L. C.; ARAÚJO, A. \& FERREIRA, L. F. Human intestinal parasites in the past: new findings and a review. Memórias do Instituto Oswaldo Cruz, 98: supl. 1: 103-118, 2003.

GonZALEZ, G. La medicina guarani-tupi precolonial. Revista del Ateneo Paraguayo, 1: 1, 1965.

GUÉRIN, C. et al. Paléoenvironnement pléistocène dans l'aire archéologique de São Raimundo Nonato (Piauí-Brésil): apport des mammifères et des oiseaux. Documents Laboratoire Géologie Lyon, 125: 187-202, 1993.

GUIDON, N. et al. Le plus ancien peuplement de l'Amérique: le Paléolitique du Nordeste brésilien. Bulletin de la Societé de Préhistoire Française, 91(4-5): 246-250, 1994.

JONES, L. H. \& HANDRECK, K. A. Silica in soils, plants and animals. Advances in Agronomy, 19: 107-149, 1967.

LEDRU, M.-P. Late Quaternary environmental and climatic changes in Central Brazil. Quaternary Research, 39: 90-98, 1998.

LESSA, A. \& GUIDON, N. Osteobiographic analysis of skeleton I, Sítio Toca dos Coqueiros, Serra da Capivara National Park, Brazil, 11,060 BP: First results. American Journal of Physical Anthropology, 118: 99-110, 2002.

LIMA RIBEIRO, M. S. \& BARBIERI, M. Análise palinológica: fundamentos e perspectivas na pesquisa arqueológica. Habitus, 3: 261-290, 2005.

LUZ, C. F. P. Estudo Palinológico dos Sedimentos Holocênicos da Lagoa de Cima, Município de Campos, Norte do Estado do Rio de Janeiro, 1997. Master's thesis, Rio de Janeiro: Instituto de Geociências, Universidade Federal do Rio de Janeiro.

MARTIN, G. Pré-história do Nordeste do Brasil. Recife: Editora Universitária, 1996.

MARTIN, L. et al. Southern oscillation signal in South American palaeoclimatic data of the last 7,000 years. Quaternary Research, 39: 338-346, 1993.

MARTIUS, C. F. P. Natureza, Doenças e Remédios dos Índios Brasileiros. São Paulo: Cia. Editora Nacional, 1939.

MULHOLLAND, S. C. Phytolith shape frequencies in North Dakota grasses: a comparison to general patterns. Journal of Archaeological Science, 16: 489-511, 1989.

NEVES, P. C. P. \& LORSCHEITTER, M. L. Palinologia de sedimentos de uma mata tropical paludosa na planície costeira sul do Rio Grande do Sul, Brasil. In: CONGRESSO DA ASSOCIAÇÃO BRASILEIRA DE ESTUDOS DO QUATERNÁRIO E REUNIÃO SOBRE O QUATERNÁRIO DA AMÉRICA DO SUL, 6, 1997, Curitiba.

OLIVEIRA, P. E. Glacial cooling and forest disequilibrium in Western Amazonia. Anais da Academia Brasileira de Ciências, 68(1): 129-138, 1996.

OLIVEIRA, P. E.; BARRETO, A. M. F. \& SUGUIO, K. Late Pleistocene/Holocene climatic vegetational history of the Brazilian caatinga: the fossil dunes of the Middle São Francisco River. Palaeogeography, Palaeoclimatology, Palaeoecology, 152 (3-4): 319-337, 1999.

ORTIZ DE MONTELLANO, B. Empirical Aztec medicine. Science, 188: 215-220, 1975.

PARDAL, R. Medicina Aborigen Americana. Buenos Aires: Humanior, 1937. 
PEARSALL, D. M. Paleoetnobotany: a handbook of procedures. San Diego: Academic Press, 1989.

PEARSALL, D. M. \& PIPERNO, D. R. Antiquity of maize cultivation in Ecuador: summary and re-evaluation of the evidence. American Antiquity, 55: 324-337, 1990.

PIPERNO, D. R. The status of phytolith analysis in the American tropics. Journal of World Prehistory, 5: 155-191, 1991.

PUTMAN, R. J. Facts from faeces. Mammal Revue, 14: 79-97, 1984.

REINHARD, K. J.; CHAVES, S. A. M. \& IÑIGUEZ, A. Evaluating chloroplast DNA in prehistoric Texas coprolites: medicinal, dietary, or ambient ancient DNA? Journal of Archaeological Science, 35: 1.748-1.755, 2008.

REINHARD, K. J.; HAMILTON, D. L. \& HEVLY, R. H. Use of pollen concentration in paleopharmacology: coprolite evidence of medicinal plants. Journal of Ethnobiology, 11: 117 -134, 1991.

REINHARD, K. J.; MROZOWSKI, S. A. \& ORLOSKI, K. A. Privies, pollen, parasites and seeds, a biological nexus in historic archaeology. Journal MASCA, 4: 31-36, 1986.

REINHARD, K. J. et al. American hookworm antiquity. Medical Anthropology, 20: 97-101, 2001.

RENAULT-MiSKOVSKY, J. \& PETZOLD, M. Spores et Pollen. Paris: Éditions Delachaux et Niestlé, 1992.

RIBEIRO, M. B. Paleovegetação e Paleoclima no Quaternário Tardio da Vereda de Águas Emendadas - DF, 1994. Master's thesis, Distrito Federal: Instituto de Geociências, Universidade de Brasília.

RILEY, T. J. Ascarids, American Indians and the modern world: parasites and the prehistoric record of a pharmacological tradition. Perspectives in Biology and Medicine, 36: 369-375, 1993.

ROBERTS, N. The Holocene. Oxford, Cambridge: Blackwell, 1994.

SAlgado-labouriaU, M. L. Contribuição à Palinologia dos Cerrados. Rio de Janeiro: Academia Brasileira de Ciências, 1973.

SAlgado-LabouriaU, M. L. A dry climatic event during the Late Quaternary of tropical Brazil. Review of Paleobotany and Palynology, 99: 115-129, 1997.

SEARS, P. B. Fossil maize pollen in Mexico. Science, 216: 932-934, 1982.

SIFEDDINE, A. et al. La sédimentation lacustre indicateur de changements des paléoenvironnements au cours des 30.000 dernières années (Carajás, Amazonie, Brésil). Comptes Rendus de l'Académie de Sciences Paris, série II, 318: 1645-1652, 1994.

SIFEDDINE, A. et al. A 2100 cal years paleoclimatic record from Caço Lake, Northern Brazil: evidence from sedimentary and pollen analyses. Palaeogeography, Palaeoclimatology, Palaeoecology, 189: 25-34, 2003.

SOBOLIK, K. D. \& GERIK, D. J. Prehistoric medicinal plant usage: a case study from coprolites. Journal of Ethnobiology, 12: 203211, 1992.

SOBOLIK, K. D. et al. Sex determination of prehistoric human paleofeces. American Journal of Physical Anthropology, 101: 283 $-290,1996$.

STEVAUX, J. C. Climatic events during the Late Pleistocene and Holocene in the upper Paraná river and their correlation with northeastern Argentina and Central and Southern Brazil. In: CONGRESSO DA ASSOCIAÇÃO BRASILEIRA DE ESTUDOS DO QUATERNÁRIO E REUNIÃO SOBRE O QUATERNÁRIO DA AMÉRICA DO SUL, 6: 1997, Curitiba.

TAKIYA, H. \& YBERT, J.-P. Evidência palinológica de uma fase climática seca durante o Holoceno na bacia de São Paulo. In: SIMPÓSIO DE GEOLOGIA Do SUDESTE, 2: 1991, São Paulo.

TOLEDo, M. B. Evolução Ambiental da Lagoa Salgada, Sudeste do Brasil, com Base em Estudos Palinológicos, 1998. Master's thesis, Rio de Janeiro: Universidade Federal Fluminense

VERNET, J. L. et al. Feux, climats et végétations au Brésil central durant l'Holocène: les données d'un profil de sol à charbons de bois (Salitre, Minas Gerais). Comptes Rendus de l'Académie de Sciences Paris, série II, 319: 1.391-1.397, 1994. 
VOGEL, V. J. American Indian Medicine. New York: Ballantine Books, 1973.

WATERS, M. R. \& STAFFORD, J. R. Redefining the age of Clovis: implications for the peopling of the Americas. Science, 315: 1.123$1.124,2007$.

WODEHOUSE, R. P. Pollen Grains. New York: McGraw Hill Book, 1935.

YBERT, J.-P.; ALBUQUERQUE, A. L. S. \& TURCQ, B. Evolução paleoclimática e paleoambiental na região do Vale Médio do Rio Doce (Minas Gerais, Brasil). In: CONGRESSO DA ASSOCIAÇÃO BRASILEIRA DE ESTUDOS DO QUATERNÁRIO E REUNIÃO SOBRE O QUATERNÁRIO DA AMÉRICA DO SUL, 6, 1997, Curitiba. 


\title{
Paleoparasitological Diagnosis
}

\author{
Martín H. Fugassa
}

$P_{b}^{a}$ aleoparasitology emerged in the early $20^{\text {th }}$ century using light microscopy studies. Although numerous tools have been added since then, light microscopy is still the most widely used method for paleoparasitological examination and study of microfossils.

Paleoparasitology has made significant progress in nearly a hundred years, partly through the adoption and adaptation of methodologies developed in other fields such as clinical parasitology and biology molecular. However, the inherent difficulties of archaeological materials require on-going improvement of methods and the introduction of new ones.

In the coming years, the extent to which paleoparasitology contributes to paleoecological and anthropological studies will depend largely on increasing the number of samples for examination. It is thus necessary to multiply the range of evidence beyond conventional sources like coprolites and mummified tissues. This will also require expanding the availability of powerful methods and techniques for recovering parasitological information. The following is a description of various methodologies and applied techniques in paleoparasitology, some still in the experimental stage.

\section{SAMPLING}

Enteroparasites (helminths and protozoa, or parasites of the gastrointestinal tract) commonly release eggs or other forms for dispersal in the feces. Helminth parasites of the respiratory tract can also be dispersed by passage of eggs into the host's digestive system when they are transported with mucous, as in the case of Eucoleus aerophillus and Metastrongylus sp. (Miyazaki, 1991).

Coprolites and various archaeological sediments provide the clearest source of evidence in the paleoparasitological study of enteroparasites, while mummified tissues and bones are generally associated with paleopathological and tissue parasite studies. 
Regardless of their nature, paleoparasitological samples should be extracted and handled under aseptic conditions, because molecular and optical studies of microfossils involve a certain risk of contamination from current and ancient sources. Thus, the sample design should consider not only the necessary statistical aspects, but also the aseptic conditions for procedures.

The following is a list of general recommendations for handling samples in fieldwork:

- Use sterile, hermetic, and resistant recipients.

- Use new sterile and preferably disposable instruments (spoons, spatulas, tweezers, scalpels, etc.).

- Depending on the sampling conditions, in the field or laboratory, and on the type of sample, it is necessary to use a cap and mask to protect the face and hair. During excavations, one should use gloves without talcum powder (to avoid contamination with starch, which can influence the diagnosis of the use of corn by the prehistoric group), at least during the removal of samples for paleoparasitological examination and especially when they involve food remains.

- Samples should be extracted as quickly as possible to avoid leaving the sampling area uncovered for prolonged periods. One should avoid extracting samples under adverse weather conditions such as heavy wind or rain.

- Both in the field and in museums or other institutions where archaeological collections are kept, sample collection equipment and the resulting samples must be kept in clean, hermetic recipients, specific for the purpose.

- It is best if at least one subsample in each case is kept refrigerated at $0^{\circ} \mathrm{C}$ for molecular studies (Alena Iñiguez, personal communication).

For statistical purposes, collecting samples from coprolites and sediments require a prior design. This design should be conducted carefully in order to reflect as closely as possible the properties of the sampled population from which one intends to obtain inferences. Extraction of samples from sediments or coprolites should consider the spatial distribution and density of the parasite remains. It is thus possible to establish some basic hypotheses: 1) coprolites contain more parasites than free sediments, with the exception of latrine deposits; 2) distribution of parasites in the coprolites may not be random; and 3) distribution of parasites within a particular sector of the stratigraphic unit is random, or steps can be taken for random distribution to occur. These assumptions mean establishing different sampling plans for free sediments and for coprolites and other concretions.

\section{Extracting samples from coprolites}

Before extracting samples for the study of microfossils, one should macroscopically examine and describe the coprolites. This procedure is useful for both identifying them and for the detection of hairs, feathers, bone fragments, or any other remain from the individual's diet and which could be associated with parasites.

Macroscopic observation also allows obtaining taphonomic data on the sample's state of preservation, e.g., the presence of fungi or perforations resulting from scatophagous insects.

In order to interpret the distribution of parasites in coprolites, one must investigate the phenomena that allowed or inhibited their preservation over time. Morphometric studies of wildlife coprolites allowed obtaining criteria for the zoological identification of coprolites (Chame, 1988), while various experimental studies have helped assess the effects of desiccation and rehydration on the dimensions of the parasite remains (Confalonieri, 1988b; Araújo, 1988).

In current samples, Martín \& Beaver (1968) showed that particles entering the digestive tract mix uniformly with the feces at the upper colon or slightly before. Likewise, Ye et al. (1997) found a uniform distribution of Trichuris 
trichiura and Ascaris lumbricoides eggs inside and on the surface of current human feces. One can thus expect that the eggs of parasites living in the upper portion of the intestine, as well as parasites found in animals ingested as food, will be distributed uniformly in the fecal mass. However, parasite species located distally in the digestive tract, like Enterobius vermicularis and the tapeworms that release proglottids containing eggs, may be located mostly on the coprolite's surface.

Therefore, in coprolites and concretions found in pelvic sediment - called enteroliths - it is useful to obtain a surface sample and another from the interior (Fugassa, 2006). Since parasite remains may be aggregated, it is convenient to sample small amounts from various sites, both on the surface and inside the coprolite.

Usually, paleoparasitological examination is only done on parts of the coprolite, which often means finding a small number of eggs (Confalonieri et al., 1988b). The preservation of parasite remains can vary greatly between archaeological sites and between taxonomic groups of parasites. As a result, coprolite examination can yield a limited total number of parasites or of ones that preserve taxonomically valuable structures for identification.

Coprolite size can vary greatly, thus requiring different sampling strategies. As mentioned, parasites can be found both inside and on the surface of sample, or they can concentrate in one of these parts. Both inside and on the surface, parasite remains can be distributed in an aggregated way as the result of differential taphonomic processes. One strategy might be to examine the entire coprolite, but this would impede future studies such as the application of molecular biology techniques and investigation of other microfossils in the same sample.

Therefore, the suggested strategy is to take a small sample from the surface and another from the interior, about 0.5-1.5 g each, consisting of numerous subsamples representing the entire coprolite. Exceptionally, in very large coprolites such as those of megafauna, one could use a design including the removal of more and larger samples (Fugassa, 2006).

Thus, as we will describe below for free sediments, coprolites also require controls for adequate interpretation of the parasitological information recovered from them. A subsample from the coprolite surface can function as a control for the internal sample, supposedly less disturbed. Ideally, the sediment from the coprolite's setting (in a radius of about $4 \mathrm{~cm}$ ) would be highly useful as a control. The sediment removed from under the coprolite would serve to assess whether there was vertical migration of parasite remains, carried by water or other liquids (Dommelier-Espejo, 2001).

\section{Sampling of sediments}

To date, the most widely used objects of study in paleoparasitology have been coprolites and enteroliths (Reinhard et al., 1988). However, paleoparasitological analysis of sediments can help elucidate the use of deposits such as latrines, garbage heaps, silos etc. (Bouchet, 1995). Pike (1968) was the first to propose the use of parasitological tests in archaeology as indicators of the use of space.

Taylor was the first to conduct paleoparasitological studies in latrines and wells, in the mid-20 $0^{\text {th }}$ century (Fernandes et al., 2005). Numerous studies were done on other free sediments. Specifically, the antecedents for the study of archaeological sediments rely on records in latrines and other soils from human occupation (Bouchet, 1995; Bouchet et al., 1999, 2002; Fernandes et al., 2005; Fugassa \& Barberena, 2006; Moore, 1981; Pike, 1968; Taek Han et al., 2003), middens (Bathurst, 2005), various jars and other recipients (Harter et al., 2003), and skeletons (Aspock, Auer \& Picher, 1996; Bouchet et al., 2001; Dittmar \& Teejen, 2003; Fugassa, Araújo \& Guichón, 2006). 
Free sediments are generally assumed to involve greater dispersal and exposure to deterioration of parasites, with low probability of finding parasite specimens (Confalonieri et al., 1988b). For example, the sandy sediments of the Patagonian steppe display a greater degree of complication, such as the percolation and hydraulic and thermal stress to parasite remains (Fugassa, 2006). These taphonomic events affect the expected paleoparasitological yield and should be included in the sampling design for sediments, both from skeletons and those representing the archaeological soil.

Parasite vestiges inside the sediment sample (e.g., from the sacrum) can display random, uniform, or aggregated distribution. Defining the type of distribution of such remains allows establishing a sampling plan. Jones (1990) found concretions of fecal matter greater than $1 \mathrm{~mm}$ in diameter during excavations from 1983 to 1987 in York, England, might suggest contamination or aggregation in the sample. However, this depends on the size of the selected sample unit and the size of the concretions. For example, when extracting a $10 \mathrm{~g}$ sample, the sampling unit is many times greater than these concretions and will definitely behave as a random distribution. To ensure that the sample is random, one should first homogenize it.

Before sampling, the sediment should be observed with the naked eye, since it can contain interesting remains such as rodent coprolites (Fugassa, Araújo \& Guichón, 2006; Fugassa, 2006) or coprolite fragments from the individual himself.

As emphasized by Jones (1992), any comparative study requires using the same testing techniques on all the samples. This allows comparisons to assess the presence of parasites from distinct locations within the archaeological site using the chi-square $\left(\chi^{2}\right)$ test (Daniel, 2008). In this case, the test of independence is intended to test the hypothesis of dependence of the presence of parasites in relation to the samples' location.

Sampling of sediments in deposits associated with the archaeological site's occupation (such as dwelling or foodprocessing areas) requires more controls due to the diverse origins of the parasite remains. Such remains can come from different stratigraphic units or sectors from the same level, due to highly complex processes in the formation of the archaeological record.

\section{SEDIMENTS ASSOCIATED WITH SKELETONS}

Starting with the natural or artificial deposition of the corpse, taphonomic processes condition the fate of the bony remains and soft tissues. After the individual's death, the digestive system is generally deposited on the pelvic bones (Reinhard et al., 1992). Reinhard et al. (1992) and later Berg (2002) proved that remains of intestinal contents are usually deposited on the sacrum in skeletons, including those placed in the vertical position at the time of death (Shafer, Marek \& Reinhard, 1989).

Studies on sediments from the pelvic cavity in human skeletons showed the presence of parasite eggs together with food remains. Examination of the pelvic cavity also revealed coprolites inside mummified bodies (Sianto et al., 2005). However, unlike the situation in mummified bodies, coprolites in skeletonized remains undergo greater dispersal due to various factors such as fragmentation and compression (Reinhard et al., 1992), although enteroliths can occasionally be found in skeletonized bodies (Shafer, Marek \& Reinhard, 1989). It is thus recommended to extract the sediment without disaggregating the concretions that may be present.

Remains of parasites can be identified in various excavations and in sediments associated with pelvic bones (Bouchet et al., 2001; Dittmar \& Teejen, 2003; Jones 1982b; Reinhard et al., 1992). Using palynological studies, macrobotanical remains, and fauna, Berg (2002) also demonstrated the importance of sediments from the sacrum, particularly from the sacral foramina, for studying digestive remains in skeletons. 
Although sediments from skeletal remains usually display a lower density of parasite remains when compared to other deposits, they offer an opportunity to contribute results to the elaboration of epidemiological studies. In some regions there are more skeletons than coprolites available, and they can be used to establish sex and age by osteological examination, as well as information on location in time and space, allowing an ideal association between parasites and individuals. Thus, the analysis of a larger number of individuals allows interpreting this information from a population perspective.

The samples examined by Reinhard et al. (1992) were obtained from a column of sediment located between the sacrum and the pubic symphysis (Figure 1), in supine position. The sample close to the sacrum showed the largest amount of intestinal content.

Figure 1 - 0btaining sediment from the pelvic girdle of a skeleton

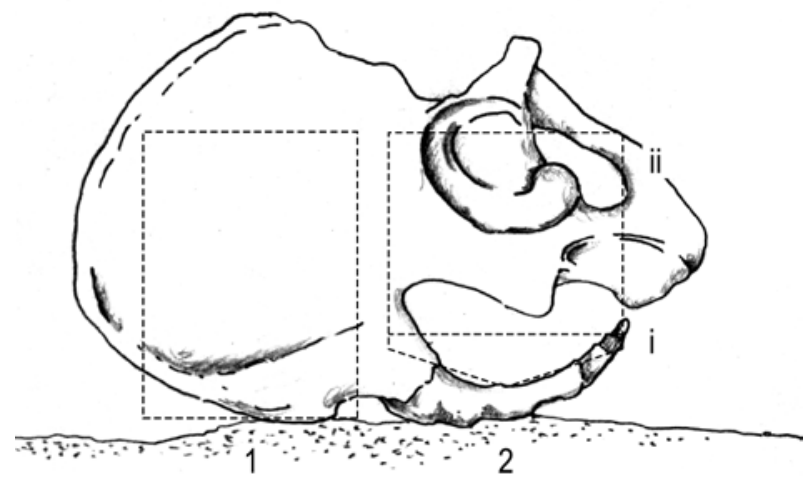

\footnotetext{
(1) sediment at the level of the last lumbar vertebrae

(2) column of sediment over the sacrum, separated into two fractions: i) sacral concavity and ii) over the sacrum.

Modified from Reinhard et al. (1992).
}

It is possible to add a column of sediment at the level of the $4^{\text {th }}$ and $5^{\text {th }}$ lumbar vertebrae and the hepatic region (Figure 2) to this sampling scheme, although these locations have the disadvantage of lacking a bony structure to surround the deposited remains. As for the individual's position, the sacrum can also retain material in bodies close to the anatomical position (Reinhard et al., 1992). 
Figure 2 - Distribution of samples and controls in sediments associated with human skeletons

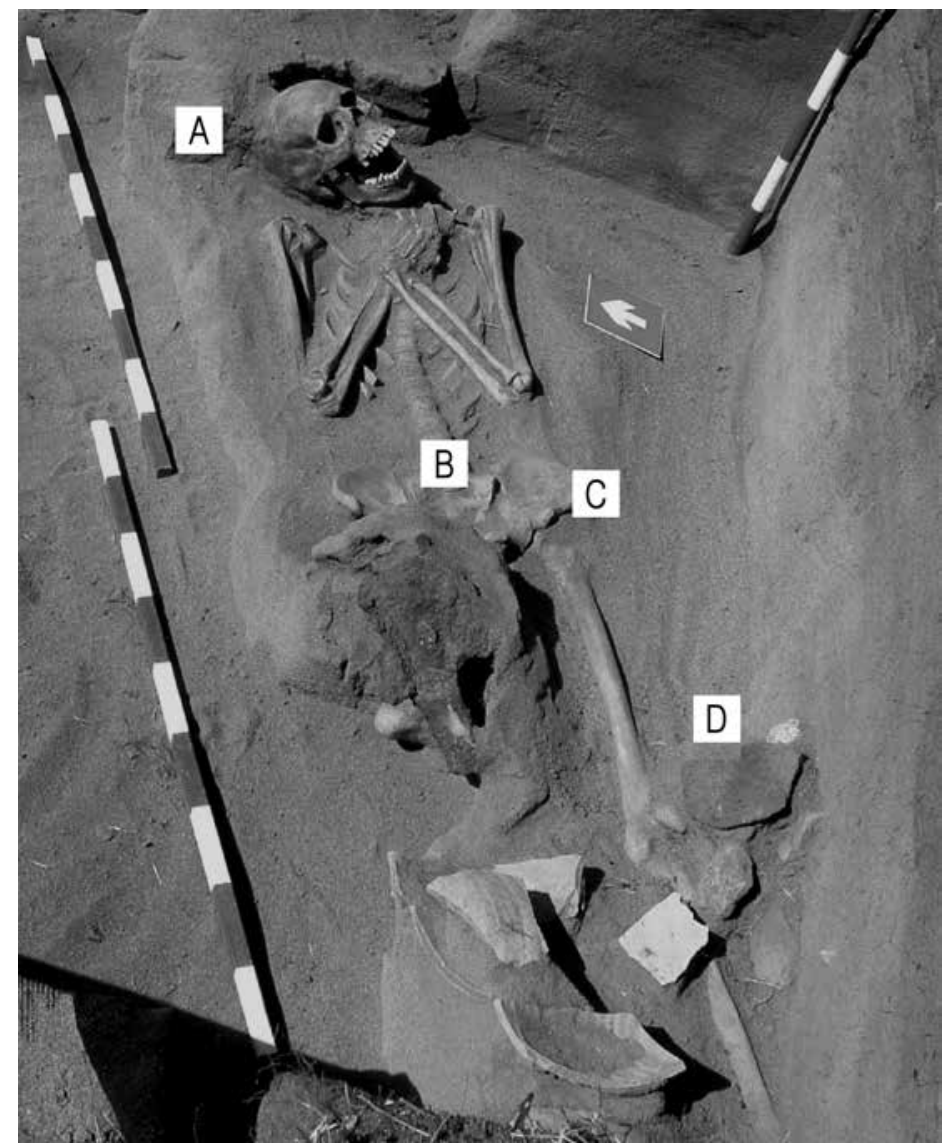

(A) Control next to skull

(B) Sample from sacrum

(C) Sample from pelvis

(D) Control from femur

Photograph: Martín Fugassa.

The use of controls facilitates the discussion on possible sources of contamination (Berg, 2002; Reinhard et al., 1992). Sediment samples are also exposed to changes resulting from infiltration of water and erosive processes. In free sediments, the water flow can carry parasites and other microfossils to lower strata by percolation (Bouchet et al., 2003; Dommelier-Espejo, 2001; Pike, 1968; Reinhard et al., 1988). This phenomenon is probably more intense in sandy soil from open-air sites than in caves or rock shelters.

It is important to conduct sampling at different depths, ideally using probes to minimize impact and contamination with sediments from other strata. This permits a comparative reading between different levels and interpretation of results (Bathurst, 2005; Dommelier-Espejo, 2001). In human remains, one should also examine sediments removed from below the skeleton due to the probable leaching of microfossils (Fugassa \& Barberena, 2006).

In processing samples, in addition to sediments that are observable under the microscope, one should also examine the macroscopic remains. A stereoscopic microscope can also be used to examine remains retained in the screen or gauze immediately after the paleoparasitological processing (see below). However, before proceeding to 
paleoparasitological techniques, one should examine the sediments to separate potentially interesting remains, such as small bones, seeds, fragments of insects, and others, which could be lost during the processing. This preliminary observation has been important for identifying rodent feces in pelvic sediments from skeletons (Fugassa et al., 2006b; Fugassa \& Barberena, 2006), including the pupae of flies and other insects, indicative of the individual's funeral conditions (Fugassa et al., 2008a; Reinhard et al., 1992). Observation of sediments should be systematized, as suggested by Jouy-Avantin (2003) for coprolites.

\section{FIRST STEPS FOR PROCESSING SAMPLES}

Before processing and studying samples, one should consider the molecular and microscopic studies that can be altered by the presence of contaminants of different origins:

- contaminated materials introduced into the laboratory (clothing, hands, articles, shoes, instruments, etc.);

- inefficient cleaning of the study instruments.

Cleaning should thus be performed in microbiology laboratories, with the following most important precautions:

- reduce the exposure of samples outside their recipients;

- preferably use disposable material and instruments;

- wear mask, gloves, and cap;

- restrict the circulation of persons inside the laboratory;

- use a protocol for historical follow-up of samples with a daily laboratory log (Dommelier-Espejo, 2001).

\section{Rehydration and separation of microfossils}

Regardless of the origin of the samples (coprolites or sediments), they should all be properly stored to allow submitting them to some of the techniques for concentration and enrichment of parasite remains.

Organic sediments are usually aggregated. Disaggregation is the process of separation of carbonates and/or humic acids by chemical or mechanical means (Bouchet, 1995; Coil et al., 2003). The alternatives include a commercial detergent solution (Kruger apud Reinhard et al., 1988), but the group of Françoise Bouchet (France) uses a porcelain mortar after rehydration and later exposes the sample to ultrasound for a period of 20 seconds to a maximum of 3 minutes (Bouchet et al., 1999, 2002).

The nature of the soil in question is important for determining whether other techniques are necessary. For example, limestone soils may need treatment with hydrochloric acid to recover parasite remains from the carbonate matrix. Jones added the use of diluted hydrochloric acid to dissolve possible carbonate concretions and retain microfossils (Reinhard et al., 1992). Hydrochloric acid may also be necessary in mineralized coprolites (Ferreira, Araújo \& Duarte, 1993).

According to Coil et al. (2003), glacial acetic acid can be a less aggressive alternative that avoids loss of mineral microfossils like calcium oxalate phytoliths. Although the focus here is parasite remains, the possible inclusion of other studies requires contemplating a multidisciplinary protocol design.

Coil et al. (2003) distinguish between disaggregation and deflocculation, defined as the separation (by electric repulsion) of mineral particles the size of clay (less than $4 \mu \mathrm{m}$ ) that can hinder observation. If disaggregation and deflocculation are ineffective, the subsequent filtrate may retain microfossils, making them absent to microscopic observation. 
Rehydration has been attempted by various means, like distilled water, EDTA and sodium hydroxide, alcohol, and others (Harter et al., 2003, Hidalgo Arguello, 2006), although aqueous trisodium phosphate is still the most popular. Initially applied by Van Cleave \& Ross (1947), as well as by Van Cleave \& Delinger and Benninghoff in microfossils (Figuerero Torres, 1982), and soon thereafter by Callen \& Cameron (1960), rehydration in aqueous sodium phosphate solutions also allows deflocculation of the sediments (Coil et al., 2003). Certain groups in paleoparasitology, like Françoise Bouchet, use rehydration in aqueous trisodium phosphate and add 5\% glycerin (Le Bailly, 2005), a technique used successfully by other groups.

Rehydration time varies by author and the material's conditions. Typical rehydration time is usually three days to a week and can be extended if the material is very dry or hard (Le Bailly, 2005). During rehydration, the sample should be observed to avoid proliferation of fungi or bacteria. Any such growth can be stopped by adding $10 \%$ alcohol.

The choice of a fixing method should include the possibility of applying specific molecular, immunological, or staining tests. Therefore, researchers increasingly attempt to keep the samples refrigerated in order to prevent formalin (an inhibitor of the polymerase chain reaction, PCR) from interfering in the latter technique.

Rehydration and preservation with refrigeration, without using fixing solutions, has allowed recognizing the natural smell of rehydrated coprolites, especially from canids and felines dated to 6,500 BP (Fugassa, 2006; Fugassa et al., 2006). It is thus recommended that both the processing and observation be done without fixing solution and with refrigeration (from 0 to $4^{\circ} \mathrm{C}$ ). However, this cold storage should not be maintained for too many days, because microorganisms can proliferate despite it in some samples. It is recommended to add ethanol $70 \%$ to the sediments, since it is the preserving agent that causes the fewest problems for molecular techniques. In addition, the design of immunological tests should include refrigeration of rehydrated sediments rather than preservation with formalin solutions, due to possible interferences in antigens and antibodies (Le Bailly, 2005).

To separate particles larger than $300 \mu \mathrm{m}$ from those that may contain parasite remains, the sample is sifted with screens soon after rehydration. Importantly, the sediment should be completely rehydrated and disaggregated, or the microfossils could be trapped or adhered to other particles and become lost during filtration.

Bouchet et al. (1999) use a series of metal screens $(315 \mu \mathrm{m}, 160 \mu \mathrm{m}, 50 \mu \mathrm{m}$, and $25 \mu \mathrm{m})$ through which the rehydrated sediment is sifted to recover remains retained in the last screens, with $50 \mu \mathrm{m}$ and $25 \mu \mathrm{m}$ meshes, respectively. The particles retained in the larger screens (from 315 to $160 \mu \mathrm{m}$ ) serve for studies on diet and sedimentology (DommelierEspejo, 2001), but they can retain eggs of trichostrongylidae such as Nematodirus sp., recorded in coprolites from Patagonia (Fugassa, 2006).

After sifting the rehydrated sediment, according to Coil et al. (2003) the elimination of clay avoids its interference in flotation solutions that can be applied, besides facilitating viewing under the microscope. In experiments with coprolites from Patagonia, visibility was hampered by fecal compounds that darkened the solution (Fugassa, 2006). For both sediments and coprolites, the sediment should be washed several times, eliminating these substances, plus the clay and possibly grains of sand (Coil et al., 2003). Thus, several rounds of washing should be performed in the rehydrated sediment and filtrate to improve the visibility, always taking care not to lose any microfossils that may be present.

\section{Enrichment techniques used in paleoparasitology}

Coproparasitological studies target the presence of parasites (larvae, eggs, and cysts) in fecal remains. The most commonly recommended techniques are flotation and sedimentation, which allow concentrating the parasite elements in a small fraction of the fecal matter. 
For clinical analyses, Thienpont, Rochette \& Vanparijs (1979) recommend using concentration techniques when direct techniques yield negative results (direct techniques are defined as those that analyze a minimal portion of the sample without concentrating the target elements before observation). The advantages of direct techniques are speed, ease, and minimal disturbance of delicate parasite remains, such as trophozoites of Giardia sp. or Entamoeba sp. (although the latter are relatively uncommon in archaeological samples).

Direct techniques are recommended for tests in recent reptile and bird droppings, but normally not for paleoparasitological tests, although they are used in some cases such as Hidalgo Arguello (2006).

Among the enrichment techniques, sedimentation consists of concentrating parasite remains by deposition in an aqueous solution, less dense than the eggs or other parasite forms. The most important sedimentation techniques in clinical parasitology are spontaneous sedimentation (Lutz, 1919) and the Telemann formalin-ether technique (Thienpont, Rochette \& Vanparijs, 1979). Spontaneous sedimentation involves a prolonged reading time due to the abundance of debris, but it is more sensitive, quick, and economical than other available techniques.

The formalin-ether techniques (Ritchie technique) and its modifications (formalin-acetate [Telemann technique] and formalin-tween) consist of disaggregation of an amount of fecal matter in a solution of an organic substance (ether, tween) in a polar medium (formalin or acetate). These substances should be shaken vigorously with the fecal matter, separating the suspension into two phases (Kaminsky, 2003; Thienpont, Rochette \& Vanparijs, 1979).

The upper, less dense phase is the organic phase, while the lower phase is the polar compound. Parasite eggs and cysts settle on the bottom of the tube, and various debris concentrate in both phases. Horne \& Tuck (1996) used the formalin-ether technique to examine sediments from historical latrines in North America, recovering eggs of Ascaris sp., Trichuris sp., Dicrocoelium dendriticum, and Taenia sp. However, Reinhard, Ambler \& McGuffie (1985) had tested this sedimentation technique, observing that simple or spontaneous sedimentation was more efficient. There is limited paleoparasitological experience with this technique, widely used in clinical parasitology, essentially due to efficient separation of parasite remains from debris and fat.

Enrichment techniques using flotation are based on the relative density of the parasite remains. For the remains to float, the flotation solution must be denser than they are. Various saturated solutions are used, in which one introduces the fecal matter previously sifted in a screen or gauze and rehydrated, in the case of paleoparasitological studies.

It is common to place the sample in the test tube and add a little flotation solution, then mix and fill the tube to the brim with solution, avoiding bubbles that could hamper visualization. The slide cover is placed on the surface such that it makes contact with the solution. After some time, varying from 15 minutes to two hours, the parasite remains float to the surface of the solution. Mild centrifugation can be used to shorten the time for the parasite remains to float (Kaminsky, 2003; Thienpont, Rochette \& Vanparijs, 1979). The slide cover is then removed, and if there are any parasite remains, they are adhered to the lower surface of the slide cover, which is then placed on the slide for observation under the microscope.

Different groups of parasites have different densities and thus behave differently in flotation solutions, with trematode eggs requiring denser solutions (Thienpont, Rochette \& Vanparijs, 1979). In addition, the techniques' effectiveness varies according to the conditions of the sediment being examined. Bouchet et al. (1999) used solutions with specific gravity ranging from 1.1 to 2.0, since taphonomic factors typically make the density of ancient eggs vary greatly from modern ones. Sucrose solutions at various concentrations, sodium chloride, sodium nitrate in sucrose solution and others have been used in archaeological samples in France (Dommelier-Espejo, 2001). Importantly, the eggs tend to warp, fade, and lose the operculum (in the case of operculated eggs) when very dense solutions are used, 
or for a very long time (Thienpont, Rochette \& Vanparijs, 1979). In ancient samples, the use of zinc sulfate causes deformations, breakage, or peeling in eggs of Hymenolepis sp. (Reinhard et al., 1988).

Although the flotation technique in sodium chloride solution (Willis technique) is more common, Marder et al. (2000) found no differences in relation to the Sheather technique (sucrose solution) and Faust (sodium sulfate solution) for the detection of modern Toxoplasma cysts and nematode eggs. However, using the Willis technique, Binda, Moriena \& Alvarez (2003) obtained more negative results and fewer Giardia sp. cysts than using the zinc phosphate technique. Other solutions have been used in paleoparasitology, such as zinc chloride and zinc phosphate (Reinhard et al. 1988), with variations in their osmotic potential and density.

Various authors, like Navone et al. (2005), recommend the simultaneous use of sedimentation and flotation techniques for stool tests in current human samples. In archaeological contexts, the use of two techniques means greater consumption of sediment, which is not recommendable and can only be suggested in specific situations, for example with negative results and an abundant amount of sediment. As an alternative, Bouchet et al. (2001) suggest taking samples from the flotation solution surface and simultaneously from the sediment in the bottom of the tube. Thus, in archaeological sediments, the suggested method is the sequential application of the modified Stoll quantitative technique (Fugassa et al., 2006) and the flotation technique on the same rehydrated sediment (see later in this chapter).

As mentioned, spontaneous sedimentation has the most advantages. However, the final decision depends on various factors like the samples' characteristics, the context from which they come, and the availability of equipment for examination. The selected technique should cause minimum destruction or alteration in the microfossils, especially in parasites.

As for the number of preparations performed for each sample, usually 10 to 20 slides are made (Gonçalves, Araújo \& Ferreira, 2003; Holliday, Guillen \& Richardson, 2003; Taek-Han et al., 2003). More preparations do not appear to increase the number of species recorded (Harter, 2002) and consume more laboratory time. However, since ancient samples suffer various taphonomic processes, parasites are often found in small numbers, and expanding the number of slides increases the likelihood of positive parasite finds.

The number of slide preparations also depends on the study's objectives and availability of samples. For example, when hundreds of coprolites are available, one can plan to examine only a few slides per coprolite. However, when considering the material's limitations and study objectives, one should not overlook the inherent conditions of sampling. If only a few slides are examined they will probably not be very representative. The study design should address these limitations and prioritize the examination of fewer specimens and more slide preparations.

More preparations are needed in free sediments than in coprolites, because (as discussed previously) the dispersal and deterioration of parasite elements are greater. While some 20 slides are prepared for coprolites, in sediments this figure reaches 50 slides per sample location. In sediments from latrines, Fernandes et al. (2005) examined 20 slides per sample, while Taek Han et al. (2003) made 10 slides. Latrine sediments require fewer slides because they usually have a higher concentration of parasites compared to skeletons or soil samples from archaeological sites.

\section{Quantification in paleoparasitology}

Paleoparasitological studies should use a quantitative methodology to obtain comparable results. Quantification in paleoparasitology helps assess the comparative density between locations in the same site and thus discuss possible sources of contamination or the origin of the parasites. 
Both Reinhard et al. (1988) and Araújo et al. (1998) claim that quantification of parasite remains can contribute to a paleoepidemiological reconstruction, since it allows comparing egg density between skeletons from burials in the same site, even though parasite density is not highly related to an individual's parasite burden in life. Likewise, Moore (1981) described findings in a medieval latrine and observed a certain stable quotient between the number of Ascaris sp. and Trichuris sp. eggs. This could suggest comparisons of rates in the number of parasite eggs found, or the use of such an index as a parameter in studying ancient human remains in a given region.

Importantly, quantification does not serve to discuss the intensity of infections, because taphonomic processes extensively modify the initial conditions. Even in current samples, fecal parasite burden is not a good indicator of intensity of infection, since the elimination of eggs, larvae, and cysts in feces depends on numerous parasite, host, and environmental factors, e.g., the number of parasites in the individual, the host immune status, time of year, etc. (Thienpont, Rochette \& Vanparijs, 1979). However, parasite burden may be a useful indicator in some circumstances.

Quantitative techniques were first used by Taylor and soon after by Pike (Reinhard et al., 1988), who estimated the number of eggs per gram of sediment by directly counting the parasite eggs in a gram of sample.

In the search for appropriate methods, Warnock \& Reinhard (1992), Dittmar \& Teejen (2003), and Sianto et al. (2005) used a quantitative palynological technique that consists of adding a known amount of a tracer -Lycopodium spores - to a known amount of sediment. The number of eggs per gram of sediment can by estimated by the formula

$$
H P G=h \times E L M / E L C \times P M
$$

where $\mathrm{h}$ is the number of eggs counted on the slide, ELM is the number of Lycopodium spores in the sample, ELC is the number of spores counted on the slide, and PM is the weight of the sample.

In addition to serving as a quantitative tool, the state of preservation of the Lycopodium spores measures the possible aggressiveness of the paleoparasitological processing conditions on the microfossils, especially parasites. A possible disadvantage to this modified sedimentation technique is that it assumes homogeneous distribution of Lycopodium spores in the column of rehydrated sediment. As with eggs and cysts, spores deposit differentially, and their abundance can vary according to the depth at which the sediment is obtained.

Quantification of sediments can be performed with the use or modification of clinical techniques such as Stoll (Thienpont, Rochette \& Vanparijs, 1979). Jones (1984) first used this procedure to analyze archaeological samples in England. He used $150 \mu \mathrm{l}$ aliquots of a mixture of $3 \mathrm{~g}$ sediment in $42 \mathrm{ml}$ of water, assuming a sediment density of $1 \mathrm{~g} /$ $\mathrm{ml}$. The number of eggs per gram (HPG) is estimated by the formula

$$
H P G=\text { no. of eggs counted } \times 100
$$

As stated previously, the modified Stoll technique (Jones, 1982a) assumes that the sediment density is equal to 1 . However, this assumption has not proven true for sediments of various origins analyzed in Patagonia. This demonstrates the need to measure the sediment density before calculating the number of eggs per gram of sediment and to make the necessary corrections in the HPG formula.

Recently, Fugassa, Araújo \& Guichón (2006) successfully modified the Stoll technique with the following changes: 1) using $5 \mathrm{~g}$ of sediment in $10 \mathrm{ml}$ of solution, which increases the density of sediment in the solution and thus the likelihood of recovering parasites, 2) reducing the size of the aliquot examined per slide, making the technique more operational, and 3) using aqueous trisodium phosphate as the liquid medium instead of water. 
The modified Stoll quantitative technique (Fugassa, Araújo \& Guichón, 2006) showed acceptable sensitivity compared to the technique applied by Jones. Bouchet, Harter \& Le Bailly (2003) suggest that the latter is especially useful in samples with parasite densities greater than 400 eggs per gram.

The quantitative technique also allows quantification of other remains, such as soil mites and pollen grains (Fugassa, Sardella \& Denegri, 2007). The modified technique led to an operational advantage: mean observation time for a $24 \times 36 \mathrm{~mm}$ slide cover was only 13 minutes, due to the uniform density of the material. Equally important is the ease in slide preparation due to the use of an automatic micropipette and absence of grains of sand in preparations of sandy soil samples.

Taek Han et al. (2003) used another modification of Stoll. Samples with $10 \mathrm{~g}$ of sediment were previously rehydrated in $50 \mathrm{ml}$ of trisodium phosphate (TSP), which was then replaced with $20 \mathrm{ml}$ to eliminate the turbidity. The authors used $20 \mu \mathrm{l}$ aliquots for the preparations. Washing the sediments can be a useful modification in soils with large amounts of organic matter, although unnecessary in sandy soils.

The modified Stoll technique has proven to be a useful quantitative tool. However, it should be accompanied by a highly sensitive qualitative technique such as the Sheather flotation technique. If debris is recovered and some parasite remains are deformed, the risk of false negatives decreases. Thus, the combination of a quantitative technique with a qualitative one is highly useful both to expand the results and to prove the former's sensitivity.

In the pelvic sediment of a skeleton from the Alero Mazquiaráns site in Chubut, Argentina, with large amounts of organic matter (Fugassa, 2006), the modified Stoll technique failed to yield positive results, while the Sheather technique proved efficient for recovering helminth eggs. In the latter case, the large amount of organic matter had retained the scarce parasite remains, and the flotation technique thus produced more efficient results.

Ideally, various flotation techniques should be tested, as suggested by Bouchet et al. (2001), although the time spent and the greater consumption of the sample are significant disadvantages.

\section{Observation and diagnosis}

Once the archaeological sample has been properly processed, one should use a small aliquot for microscopic examination. Next, drops of sediment are mounted on slides covered with slide covers, available in various sizes according to the planned use. Small slide covers $(18$ or $20 \mathrm{~mm}$ ) dehydrate less after sealed and are resistant and form a thin layer of solution, especially by adding a small drop of glycerin (Fugassa, 2006). Larger slide covers, 24 to 36 $\mathrm{mm}$, allow the drop of sediment to dehydrate more easily, although they form a layer of preparation that is thinner and easier to examine. Larger slide covers are recommended for quantitative techniques using larger volumes, such as 50 to $150 \mathrm{ml}$ (Fugassa, Araújo \& Guichón, 2006; Jones, 1984).

Slides should be examined exhaustively under magnification 10 in the ocular lens and 10 in the objective lens. Correct measurement of the parasite elements is essential for diagnosis and should be performed under a magnification of 400. Deformed or broken parasite remains should not be measured. In species with operculated eggs as in genera Trichuris and Calodium, the eggs should be measured without considering the polar opercula, since they can vary widely; even more importantly, they are often absent from archaeological material (although many authors consider the measurements of these species with the plugs in opercula, so the measurements should be taken with and without them). Additional measurements such as the width of the operculum or egg wall may be useful in some cases. 
During parasite identification, the use of photographs is indispensable for guaranteeing the results and for consultation with other specialists. Kliks (1990) criticized numerous paleoparasitological findings, sparking an interesting debate (Ferreira \& Araújo, 1996; Hawdon \& Johnston, 1996). His observation emphasized the lack of images to back the diagnoses. Findings should thus be properly recorded, especially when they contain species with numerically low representation in the samples.

Some authors seal the slides with transparent commercial nail polish (Bathurst, 2005; Dittmar \& Teejen, 2003). The paleoparasitology laboratory at the Oswaldo Cruz Foundation in Rio de Janeiro uses a hot mixture of equal parts of beeswax and resin (Araújo, personal communication), which is very useful. However, nail polish is quick and can be used in unexpected situations when the dehydration needs to be stopped. Care should be taken to avoid contamination of the brush.

In samples containing interesting remains, a gelatin-glycerin solution can be used (Ruzin, 1999), which is good for preservation. The mixture should be heated to approximately $50^{\circ} \mathrm{C}$ in water bath, and once fluidity is obtained, one drop of the preparation and one drop of gelatin-glycerin solution are mixed on a slide. The slide cover is then placed on top, and the preparation can be preserved for a long time. Preliminary results indicate that ancient eggs of Ascaris lumbricoides and Trichuris trichiura, as well as current Hymenolepis nana eggs and Giardia sp. cysts are wellpreserved when immersed in gelatin-glycerin.

Eggs and cysts of given taxa have typical characteristics that facilitate their identification. For example, it is relatively easy to diagnose genera Calodium sp. and Trichuris sp. eggs by the opercula on the two extremities, their shape, and the ornamentation on the wall. However, species determination is less simple and should be measured in probabilistic terms (with the eggs' length, width, and morphology as parameters) and comparative ones. The addition of other circumstantial evidence (e.g., diet items, host, parasite biogeography) can lead to a more robust probabilistic diagnosis.

As suggested by Noronha et al. (1994), identification should also consider the coprolite's morphological characteristics and distribution of possible hosts in the region, besides the other above-mentioned circumstantial evidence. Concerning possible hosts, the distribution of both current and past wildlife should be observed.

Eggs from some different parasite species can be confusing. Certain ascarids such as Lamanema and Nematodirus, or Ancylostoma and Trichostrongylus, have similar eggs that require careful measurements of numerous specimens to enable estimating their mean morphometry and if necessary apply an appropriate statistical technique. Other genera can also be confusing if there is no microscopic method to help distinguish between them. For example, Necator and Ancylostoma cannot be distinguished by the appearance of their eggs, nor can species of genus Taenia from other tapeworms such as Echinococcus.

Distinctions within a genus are even more difficult. For example, the egg morphometry of Ascaris suum and A. Lumbricoides or Trichuris suis and T. trichiura does not serve to diagnose the eggs' species. Importantly, the paleoparasitological study of coprolites from wild animals can prove even more complex, since there are fewer parasitological studies that serve as the basis or reference for the paleoparasitological findings. One should also consider the possibility of changes in the parasites' life cycle and morphological alterations in the eggs, larvae, and cysts, which can hinder the correct diagnosis (Dommelier-Espejo, 2001).

Although less common, other difficulties in paleoparasitological diagnosis relate to some parasite remains than can resemble artifacts and other structures like pollen grains, air bubbles, fungal spores, and plant fragments (Thienpont, Rochette \& Vanparijs, 1979). 
Although the dehydration process may not alter the eggs' morphometry (Araújo, 1988; Confalonieri, 1988b; Confalonieri et al., 1988a), taxonomic diagnosis assumes that morphometry is a stable characteristic in each species. Still, some studies have proven that egg size can vary in some helminth species, due to the host among other reasons. For example, Fasciola hepatica eggs differ significantly in size, depending on the host's body mass (Valero et al., 2002). In pseudophyllid cestodes, egg size varies according to the host species and intensity of infection (Andersen \& Halvorsen, 1978). Although this variability cannot be generalized to all helminth taxa, one should recall the morphological plasticity that some species can display.

Eggs containing first-stage larvae can often be found. This is common in such parasites as hookworms, ascarids, and pinworms and is a useful criterion for differentiating them from artifacts and other helminth eggs that are only found embryonated. Third-stage larvae have been found in coprolites and sediments (Ferreira, Araújo \& Confalonieri, 1980; Reinhard et al., 1988), some as old as 1.5 million years (Ferreira, Araújo \& Duarte, 1993), thus demonstrating their potential for preservation, although the diagnosis is difficult.

On this point, Reinhard, Hevly \& Anderson (1987) emphasize the need to differentiate between parasite larvae and free-living nematodes. Kliks (1990) contends that some paleoparasitological diagnoses of parasite larvae may actually correspond to free-living nematodes. However, several characteristics can be used determine whether they are free-living larvae or parasites (Fiel, Steffan \& Ferreyra, 1998), or even to distinguish them from plant parasites (Chaves, Echeverria \& Torres, 1995).

During microscopic observation, it is common to find various mites that can provide important information on ectoparasitism, such as the finding of Demodex sp. in a regurgitation pellet from a bird of prey (Fugassa, Sardella \& Denegri, 2007), or on intermediate hosts, such as oribatid mites, intermediate hosts of Anoplocephalidae tapeworms (Fugassa et al., 2006). The presence of mites in coprolites of diverse zoological origins has provided relevant paleoecological information (Guerra et al., 2003).

The preceding paragraphs highlight some difficulties that can arise during diagnosis and that relate basically to confusion between parasite remains and artifacts, pollen grains, or fungi and errors in species diagnosis. Taxonomic determination of eggs, larvae, and cysts is often difficult in both ancient settings and in modern clinical diagnostic laboratories. For example, in a recent quality control exercise in Spain, human stool samples containing eggs of a helminth species and cysts from two species of protozoa were sent to 200 laboratories. Only $6.9 \%$ identified all three parasites, and in $27.2 \%$ of the samples different parasites were identified from those known to the reference laboratory (SEIMC, 1998).

Observation and identification of parasite remains require great attention and caution at the moment of taxonomic determination. It is important and highly useful to consult several colleagues and discuss the identity of ambiguous findings. A detailed description and illustration should precede a rigorous and solidly based discussion on the possible diagnosis. The erroneous communication of a finding for a given region and time can alter the correct understanding of the biogeographical history of certain parasites and their hosts.

\section{Staining and electron microscopy}

In paleoparasitology, microscopic observation allows diagnosing helminth eggs and only occasionally protozoan cysts (Faulkner, 1991; Ferreira et al., 1992; Fugassa et al., 2008c; Leguía, Casas \& Jane, 1995). The latter is due to the fact that most cyst-producing species are not only differentially preserved, but also difficult to recognize due to their small size or morphological similarity to other microfossils. Pollen grains, fungal spores, crystals, mite eggs, 
free-living nematodes, and phytoliths are present in the sediments, so microscopic analysis involves some degree of uncertainty in identifying the observed structures.

The use of stains that react with given components of microfossils facilitates diagnosis. However, experience with staining in paleoparasitology is very limited and related to a few studies that used Lugol's solution (Moore, 1969; Taylor, 1955), merthiolate-iodine-formalin solution (MIF) (Harter, 2002), or iron hematoxylin (Horne \& Tuck, 1996).

Although trichrome staining has not been recorded in paleoparasitology, it is one of the most widely used stains in modern material. Some studies recommend it for detecting various intestinal parasites in fecal matter (Kellogg \& Elder, 1999), thus suggesting its potential use in ancient samples. Protozoa of the phylum Apicomplexa, like Cryptosporidium sp., Cyclospora sp. and Isospora belli may require special staining techniques, for example with modified acid-fast solutions (Kaminsky, 2003).

The lack of standardized protocols for differential staining in paleoparasitology further increases the complexity of its use in sample testing. Despite limited attempts in paleoparasitology, differential staining deserves inclusion in routine paleoparasitological examination.

Based on the design by Horne \& Tuck (1996), who used iron hematoxylin in three of 15 preparations, this staining can be recommended in $50 \%$ of the slides for each sample, examining under $400 \mathrm{x}$ magnification. Examination of protozoa in current samples uses 20 slide cover fields with magnification of 1,000 (Del Coco et al., 2006).

In archaeological samples, it is recommended to examine a large area due to the expected low density of cysts. The proposal for each stained slide is to examine 20 more fields under magnification of 1000, i.e., a total of 40 fields.

In parasite genera with morphometrically similar eggs, microstructural characteristics can help distinguish between them (Bouchet et al., 1999), as exemplified by scanning electron microscopy (SEM) in ancient Diphyllobothrium tapeworms (Le Bailly et al., 2005) and in current Toxocara sp. eggs (Ubelaker \& Allison, 1975). The authors emphasize that taphonomic factors can alter the surface structure characteristics. SEM can also be used satisfactorily to observe third-stage hookworm larvae in coprolites (Araújo et al., 1988b).

Immunology has contributed other techniques to paleoparasitological research. Direct immunofluorescence uses antibodies marked with fluorescent substances and allows the specific detection of surface antigens in parasite forms (Atías, 1998). In paleoparasitology, it has been used to diagnose Giardia duodenalis (Faulkner, Sharon \& Johnson, 1989), G. duodenalis and Cryptosporidium parvum (Allison, Bergman \& Gerszten, 1999; Le Bailly et al., 2008; Ortega \& Bonavia, 2003), and later Cryptosporidium/Giardia in coprolites from France (Le Bailly, 2005).

\section{INTERPRETATION OF PALEOPARASITOLOGICAL RESULTS}

When one reaches a degree of diagnostic certainty or probability with parasite remains, it is not the end of the job, but only the beginning. The identified remains represent forms of dispersal of a life cycle in a parasite species.

Eggs, larvae, or cysts found in samples can be the result of patent infections or (in the case of eggs and cysts) the ingestion of prey infected with the parasites in question. Thus, the presence of parasites in sediments from archaeological sites involves more possible origins, so their analysis requires both ecological and cultural knowledge. Contamination from unknown sources can introduce a bias into the results. For example, finding rodent coprolites in sediment from the pelvis of human skeletons can alert the researcher to contamination of material with their parasites (Fugassa \& Barberena, 2006; Fugassa, 2006). To reiterate, painstaking planning of sampling and macroscopic observation of the sediment can help predict such situations. 
Even under ideal conditions with highly sensitive and specific methods, false-negative results may occur. For example, in addition to the taphonomic phenomena specific to ancient samples, a mild infection, oviposition behavior as in Enterobius vermicularis, the reduced number of eggs in trichostrongylids of herbivores, intermittent oviposition, elimination of eggs in gravid proglottids, parasites in pre-patent periods, and other situations can lead to underestimation of ancient parasitic infections.

Adequate interpretation of results definitely requires in-depth knowledge of parasite diversity and biogeography, the natural history of the species under study, and the regional archaeology. The latter requires effective communication among paleoparasitologists and archaeologists studying the region.

\section{STATISTICAL ANALYSIS APPLIED TO PARASITE REMAINS}

As discussed previously, paleoparasitological diagnosis poses various challenges, from determination of the coprolite's zoological origin to that of the respective parasite species. We have described various methodological tools to overcome such problems. We will now present some available statistical techniques for analyzing the observed parasite remains.

Egg morphometry is commonly employed for diagnosing intestinal parasites (Thienpont, Rochette \& Vanparijs, 1979). Statistical analysis of egg and cyst measurements can be highly useful for diagnosis in contexts where both human and other animal coprolites are present (Confalonieri et al., 1988b).

To compare eggs measurements between two situations, for example, eggs found in a body and in the surrounding sediment - the chi-square test can be used, with the median as the reference (Araújo, 1988), mounting a contingency table with the eggs' length and width.

When only a single egg is available (a frequent situation in paleoparasitology), Confalonieri et al. (1988b) used the Student t-test separately for length and width to determine whether the egg belonged to a given species. If a frequency table is available for a large population of eggs with length and width measurements, this statistical test can be applied to the species to which the egg supposedly belongs. The authors show that this method is equally useful for the identification of single coprolites.

Mounting these tables requires comparative samples of reliably identified parasite eggs and coprolites.

In another study on the taxonomical determination of a set of parasite remains, Joyner (apud Confalonieri et al., 1988b) used the linear regression coefficient of the measurements obtained from a set of Eimeria sp. oocysts to determine whether they belonged to a given species for which the oocyst morphometry was known. This method can complement other statistical tests.

\section{Case study: discriminant analysis applied to capillarid eggs}

In some cases, the eggs' qualitative characteristics are as important as their morphometric ones. In capillarids, the egg's ornamentation is highly useful for diagnosis (Moravec, 2001). Capillarid species have cycles that include a host from a lower trophic level and a carnivore as disseminator. They are thus commonly identified as parasites in transit in predator feces. Coprological examination in carnivores or omnivores can often show eggs from different capillarid species, some produced by parasites in transit, or false parasitism, and others as true parasitism, causing infection in the host.

Paleoparasitological records of eggs belonging to capillarid species are rare. In the Americas, Confalonieri described eggs from this genus in animal coprolites in Brazil (Confalonieri, 1988a; Araújo, Confalonieri \& Ferreira, 1998). Bouchet 
(1997) later found eggs from this genus in 21 coprolites from France. Still later, Dittmar \& Teejen (2003), Fernandes et al. (2005), and Rocha et al. (2006) also recorded Capillaria sp. in archaeological sediments.

With the exception of an endemic of Pseudocapillaria philippinensis in the Philippines, reports of capillariasis in humans are now rare (Atías, 1998; Benenson, 1992), although risk of infection was probably greater in the past due to different ecological conditions.

Gonçalves, Araújo \& Ferreira (2003) contend that the occurrence of capillariasis in humans is due mainly to the ingestion of raw meat, especially liver, where the eggs of Calodium hepaticum are located (Miyazaki 1991). However, numerous species of capillarids located in the gut are recorded in other mammals, for example Capillaria puttori and Pearsonema plica (Soulsby, 1987). Various stool tests with Capillaria sp. eggs have been recorded in Amerindian groups (Coimbra \& Mello, 1981; Coimbra et al., 1985).

From the trophic point of view, the situation would be similar in canids, although more species of parasites have been reported in these hosts. Capillaria puttori and Eucoleus aerophilus have been recorded in canids (Thienpont, Rochette \& Vanparijs, 1979), and Calodiumm hepaticum was found in necropsies of wild dogs in Brazil (Ruas et al., 2003).

As mentioned, the presence of capillarid eggs in archaeological remains can be interpreted as either true parasitism or the product of parasites in transit. The current impossibility of elucidating the origin of such eggs precludes an interpretation of their cultural and/or ecological meaning. A better diagnosis would allow discussing the presence or absence of true parasitism, thus clarifying the meaning of such findings in the host population.

Fugassa et al. (2006) analyzed morphometric and morphological data from a total of 171 capillarid eggs found in a single coprolite from the province of Santa Cruz, Argentina, attributable to a canid.

The eggs varied greatly in size, diversity of shell ornamentation, and shape of the operculum (Figure 3). Some had a surface with long longitudinal stripes and prominent opercula (type B), others had opercula, but short and with the surface covered with irregular stripes (type D), others with nearly flat opercula and the surface ornamented with small radially arranged dots (type A), and still other eggs with larger circular orifices on the surface (type $\mathrm{C}$ ). There were also eggs in which the appearance of the shell could not be determined, and they were excluded from the analysis. Table 1 summarizes each group's dimensions.

Figure 3 - Morphotypes of capillarid eggs viewed in M8
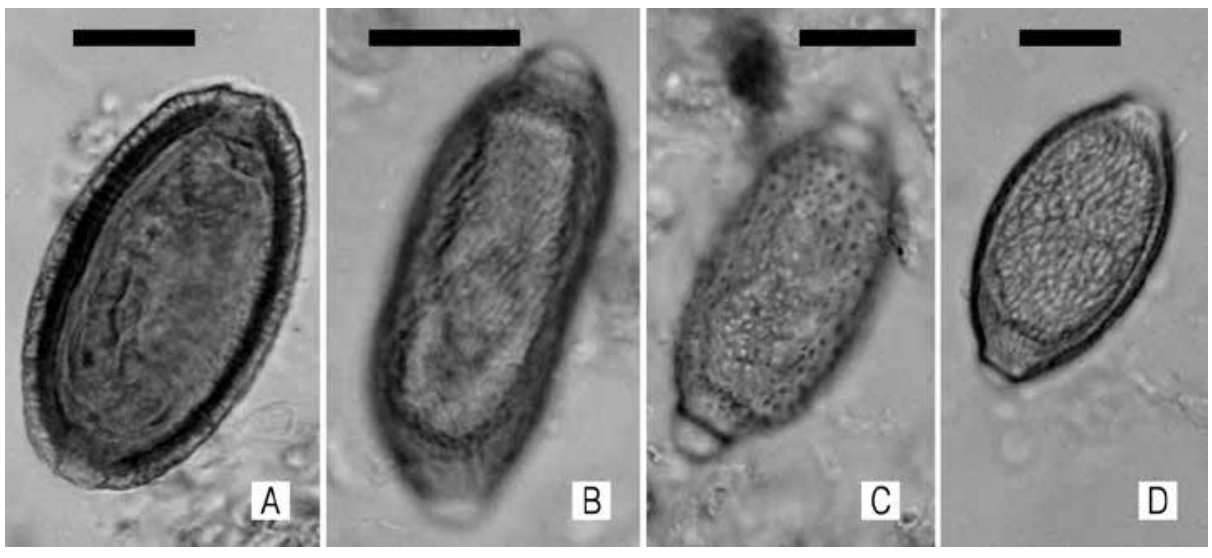

Letters indicate the morphotype. Black bar $=20 \mu \mathrm{m}$.

Source: Fugassa et al. (2008b). 
Legendre \& Legendre (1998) analyzed whether morphometric differences explain the morphological groups observed under light microscopy, testing whether the differences between groups were significant in multivariate space. They examined the width and length by linear analysis of the original variables that best discriminated the groups, using discriminant analysis.

Table 1 - Morphometry of the different morphological groups

\begin{tabular}{c|c|c|c|c|c|c}
\hline \multirow{2}{*}{ Morphology } & \multirow{2}{*}{$\mathbf{n}$} & \multirow{2}{*}{$\%$} & \multicolumn{2}{|c|}{ Length $(\mu \mathrm{m})$} & \multicolumn{2}{c}{ Width $(\mu \mathrm{m})$} \\
\cline { 4 - 7 } & & & Mean & Range & Mean & Range \\
\hline A & 20 & 13.4 & 63.7 & $57.5-75.0$ & 38.1 & $33.8-41.3$ \\
\hline B & 85 & 57.0 & 59.8 & $42.5-67.5$ & 28.8 & $22.5-37.5$ \\
\hline C & 19 & 12.8 & 62.1 & $40.0-71.3$ & 32.7 & $27.5-37.5$ \\
\hline D & 25 & 16.8 & 54.2 & $42.5-72.5$ & 29.3 & $22.5-47.5$ \\
\hline
\end{tabular}

Source: Fugassa et al. (2008b).

The results of discriminant analysis suggest that discrimination between groups was significant (Wilks' lambda = $0.419, \mathrm{p}<0.05$ ) (Figure 4). Subsequent calculation of the square of the Mahalanobis distances between groups (Table 2) indicated that the separation between groups A and B was not significant, such that the morphometric variables would not explain the morphological differences between groups A and B (Figure 5).

Figure 4 - Morphotypes of capillarid eggs A (•), B (•), C (०) e D ( $\triangle)$

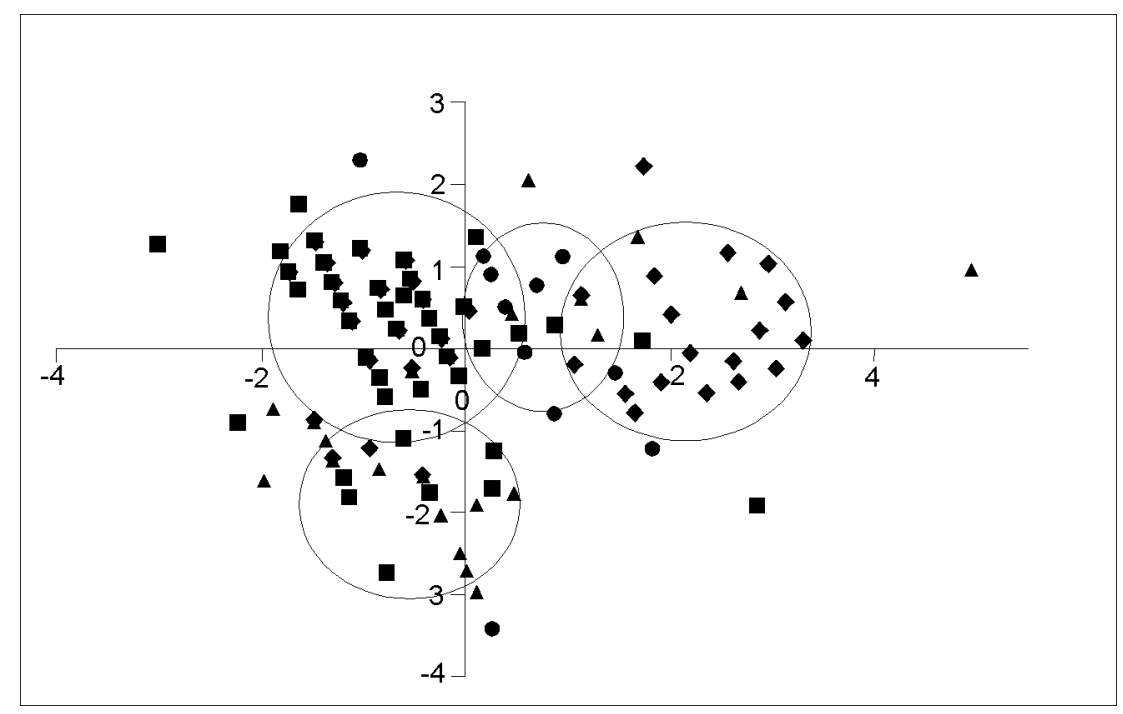

Source: Fugassa et al. (2008b). 
Table 2 - Probability associated with Mahalanobis distance

\begin{tabular}{l|r|r|r|r|r}
\hline & \multicolumn{1}{c|}{$\mathbf{P}$} & $\mathbf{R}$ & $\mathbf{A}$ & $\mathbf{G}$ & $\mathbf{Q}$ \\
\hline $\mathbf{P}$ & 0 & & & & \\
\hline $\mathbf{R}$ & 0.000103533 & 0 & & & \\
\hline $\mathbf{A}$ & 0.005114172 & 0.02267275 & 0 & & \\
\hline $\mathbf{G}$ & 0.000173964 & $5.8133 \mathrm{E}-07$ & 0.13483232 & & \\
\hline $\mathbf{Q}$ & $6.1475 \mathrm{E}-06$ & $1.9853 \mathrm{E}-20$ & $3.5023 \mathrm{E}-12$ & $4.39407 \mathrm{E}-12$ & \\
\hline
\end{tabular}

Figure 5 - Discriminant function 1 and 2 for groups $A$ and $B$

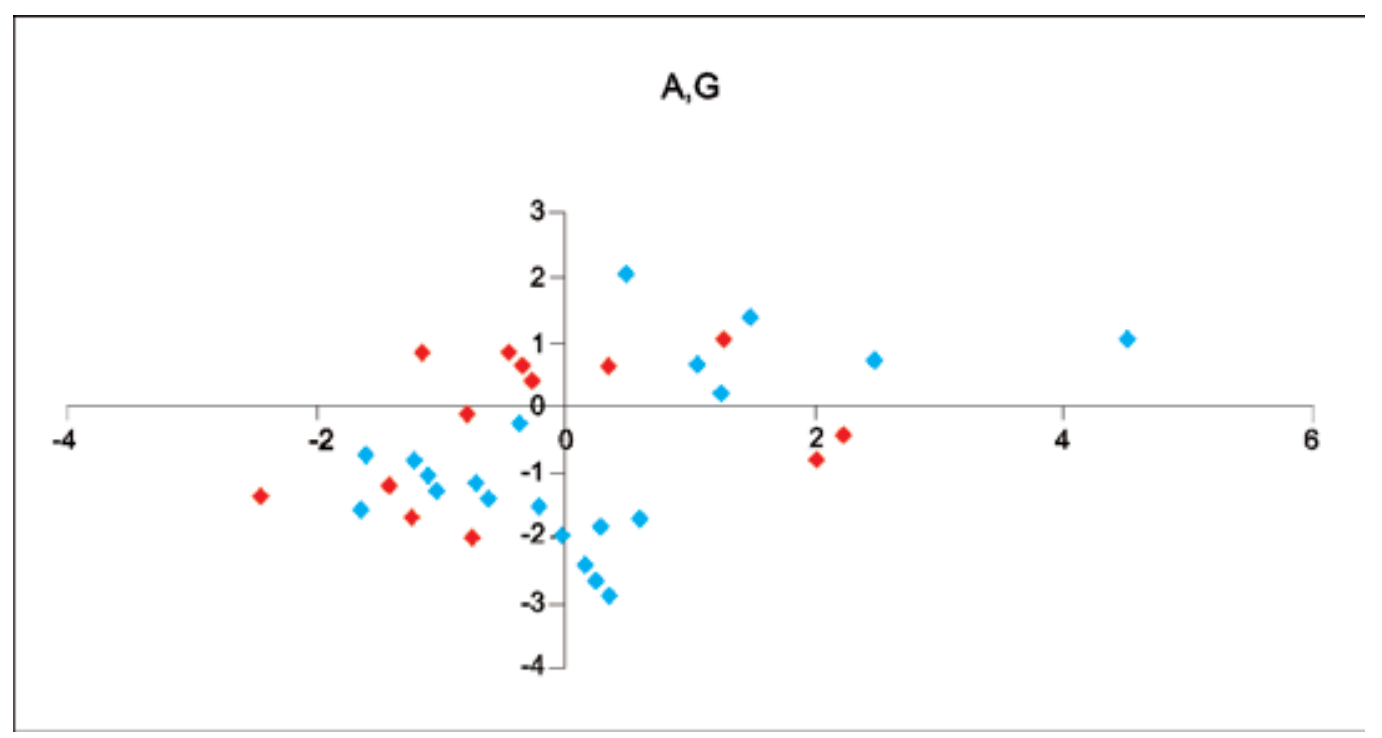

Correlation analysis suggests that the variable making the greatest contribution to discrimination between groups is width (Pearson $=0.950$ ).

The results suggest the existence of three species of capillarids in this coprolite.

The study of the shape, relative abundance, morphology of the polar opercula (when present), and dimensions of the eggs allowed discussing whether the morphological differences correlated with the morphometric differences.

The capillarid species located in the digestive tract in modern canids are Calodium hepaticum and Capillaria putorii. Eucoleus aerophillus locates in the respiratory tract, but the eggs can reach the digestive tract by swallowing. Analysis of the proportions among the four proposed species is: $14.7 \%(A), 50 \%(B), 11.17 \%$ (C), and $11.76 \%$ (D).

For morphotype A, the shape and metric mean fall within the range proposed in the literature for Calodium hepaticum. This parasite locates in the liver. The eggs are also located in the liver and generally do not pass into the intestinal tract, nor are they eliminated with the feces. Thus, the morphology, low relative abundance, and measurements of morphotype D suggest that it is the product of ingesting a truly infected prey. 
Morphotype B could correspond to Capillaria putorii based on its measurements, ornamentation, and relative abundance.

Morphotype $\mathrm{C}$ is within the categories of measurements of Eucoleus aerophilus. The low proportion of eggs can be explained by their location in the airways and their release into the environment through the digestive and respiratory tracts.

Morphotype D cannot be assigned to a known species and probably represents immature eggs from some of the species present, most likely morphotype A.

Discriminant analysis can be useful in the diagnosis of eggs belonging to the Capillaria genus that cannot be classified simply by their morphology, due to taphonomic processes or other causes. Although capillarids are one of the most complex groups of parasites (Moravec, 2001), experience has shown that the combination of morphological and morphometric analysis of capillarid eggs allows improving paleoparasitological diagnosis.

\section{NEW SOURCES OF EVIDENCE}

As shown, coprolites have been the main source of evidence in paleoparasitology, although sediments of various origins have also been used sporadically. Paleoparasitological studies have also used mummified tissues (Araújo et al., 1988a; Araújo, Reinhard \& Ferreira, 2000; Aufderheide et al., 2004; Bastos et al., 1996; Cockburn et al., 1975), intestinal mucosa (Alisson, Pezia \& Hasegawa, 1974), and even taxidermied animals from museum collections (Cantarino, 1998; Persing et al., 1990).

Together with the increase in the number of samples and available techniques, new archaeological materials should be explored for their usefulness as sources of paleoparasitological evidence. The next section presents new sources of evidence for paleoparasitological research based on two case studies.

\section{Case study: sampling in sacral foramina from skeletons deposited in bone collections}

Skeletons deposited in institutions have usually been cleaned, and thus paleoparasitological studies (at least for enteroparasites) cannot be performed. By examining various sacra from collections in Patagonia, the hypothesis has been tested that parasite eggs can be found in the small amounts of sediment remaining on the thighbones and sacrum after the skeletons' excavation and cleaning (Fugassa, 2006; Fugassa, Sardella \& Denegri, 2007).

It is important to study sediments from bones in the pelvic region because paleoparasitological studies can be expanded to more individuals with sufficient bioanthropological and contextual information to increase the sample size needed in paleoepidemiological studies. Fugassa, Sardella \& Denegri (2007) also call attention to the need for preservation strategies that include the recovery of this type of information.

The sediments were recovered in the laboratory, mainly from sacral foramina of skeletons from southern Patagonia (Figure 6, Table 3). The bones had been totally cleaned, and a small sample was taken from the sacral orifices and bony processes. The sediment was weighed and rehydrated in double volume aqueous trisodium phosphate for seven days. Next, the modified Stoll technique was applied, as described previously (Fugassa, Araújo \& Guichón, 2006). 
Figure 6 - Localization of the samples used in the examination of sacral foramina. Skeleton recovered from the Misión La Candelaria cemetery (Río Grande, Tierra del Fuego, Argentina)

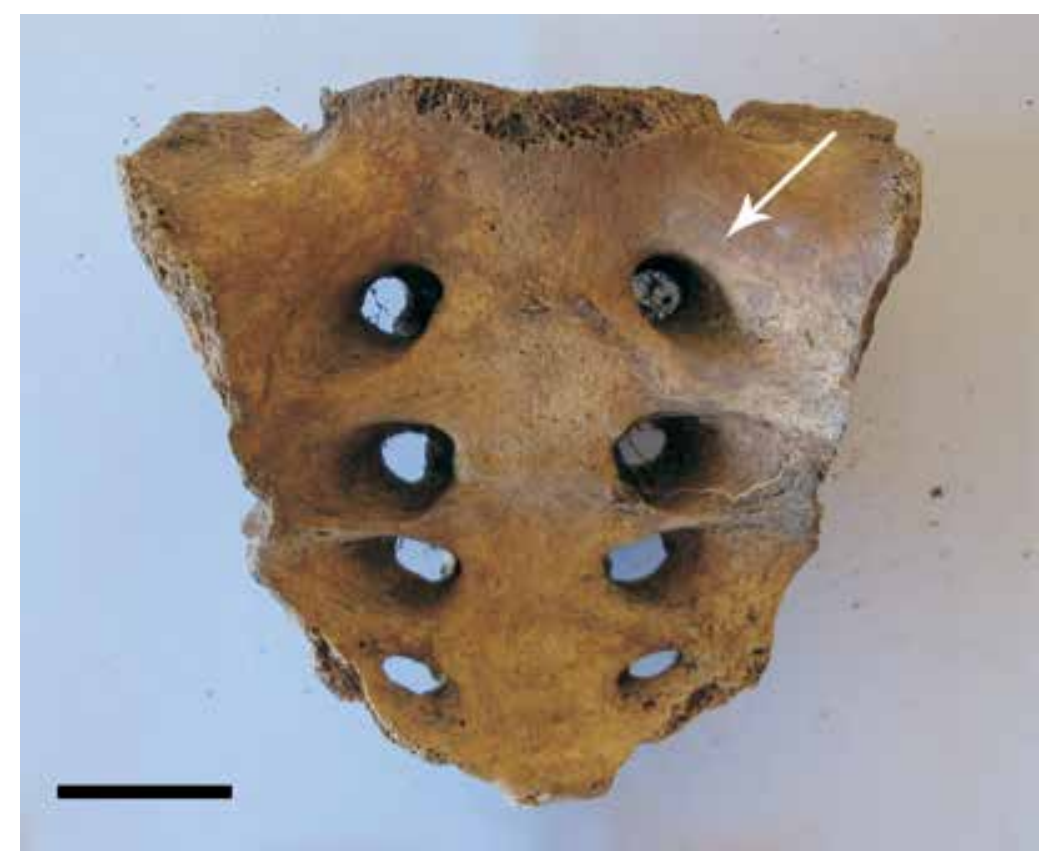

Bar $=50 \mathrm{~mm}$.

Photograph: Martín Fugassa.

Table 3 - Close-up of samples used in parasitological analyses of dry bones

\begin{tabular}{c|c|c|c}
\hline No. & Site & Dating & Weight (g) \\
\hline 1 & Nombre de Jesús-IV (NJ-IV) & Historical & 8.99 \\
\hline 6 & Nombre de Jesús-I (NJ-I) & $515+/-45$ years & 5.02 \\
\hline 7 & Caleta Falsa & 850 years & 0.405 \\
\hline 8 & Las Mandíbulas & Historical & 1.78 \\
\hline 10 & Nombre de Jesús-II (NJ-II) & Historical & 5.84 \\
\hline 12 & Nombre de Jesús-III (NJ-III) & Historical & 7.15 \\
\hline
\end{tabular}

Dating performed in clamshell substrate (Chapman \& Hester, 1973).

Source: Modified from Fugassa et al. (2008a).

In NJ-1, bodies similar to capillarid eggs were recovered. Scarce eggs consistent with Ascaris lumbricoides were also found. No parasites were observed in either NJ-2 or NJ-3. Large amounts of fungi were observed in the latter two cases. At the Las Mandíbulas site, capillarid eggs were found with ornamentation similar to that of Calodium hepaticum. In this case, quantitative analysis showed 120-360 (208土95.5; $\mathrm{n}=5)$ HPG (eggs per gram of sediment). Charcoal and charred fragments were also found. The Caleta Falsa site yielded numerous charcoal particles and capillarid eggs with a density of 0-111.11 (22.22 $\pm 49.69 ; n=5)$ HPG. 
Some Ascaris lumbricoides eggs, although mostly with eroded mamelons, keep their characteristic shell and an opercular region, as described by Ubelaker \& Allison (1975). This finding also provided evidence on the individual's identity, initially described as belonging to the indigenous population; however, the presence of this nematode strongly suggests European origin due to the higher expected prevalence in European populations. Ancient DNA tests later confirmed this hypothesis (Guichón, personal communication). In addition, the Laboratory for Molecular Genetics of Microorganisms at the Oswaldo Cruz Foundation in Rio de Janeiro later reconfirmed the presence of Ascaris sp. using ancient DNA studies for the parasite (Iñiguez, personal communication).

The results corroborated the hypothesis that parasite eggs can be preserved in clean pelvic bones. The observations also suggest that it is possible to simultaneously recover some evidence on eating behavior, such as hair fragments, starch, pollen, charcoal, and bone and plant tissues. As highlighted by Jones (1982b), cleaning archaeological remains destroys valuable information, as also observed during this study. It is thus important to reconcile preservation of archaeological material with the recovery of relevant paleobiological information.

\section{Case study: analysis of regurgitated pellets}

Concretions found in the Cerro Casa de Piedra archaeological site 5, located in the Perito Moreno National Park in Santa Cruz province, Argentina, displayed a smooth texture coated with hairs. Closer examination showed that they were regurgitated pellets, typical of birds of prey that first swallow their prey and then regurgitate the undigested remains through their beaks, including hairs, feathers, scales, and/or bones (Marti, 1987). These particular specimens belonged to a deposit dated to 6,540 110 BP (Aschero, 1996).

The sample was described, measured, and weighed just as coprolites (Jouy-Avantin, 2003). Two samples of approximately $0.5 \mathrm{~g}$ each were extracted from it, corresponding to the surface and interior of the concretion. The samples were then rehydrated in aqueous trisodium phosphate according to Callen \& Cameron (1960). The sediment was later concentrated by spontaneous sedimentation (Lutz, 1919). The macroscopic remains were separated and dried at room temperature. Ten slides each were made from the surface and inner samples.

Very little sediment was obtained by sedimentation, but the sample from inside the pellet showed capillarid eggs. A Demodex sp. mite was also identified, tmeasuring 112.5 x $32.5 \mu \mathrm{m}$. Fragments of rodent hairs predominated on all the slides from both places in the concretion.

Paleoparasitological examination was performed with little hope of finding parasites, since the sample had been identified immediately as a regurgitation pellet. However, examination yielded both enteroparasites and ectoparasites, common in rodents.

The limited amount of sediment and the large amount of hairs and bones are consistent with the diagnosis of a regurgitation pellet (Figuerero Torres, 1981). The size indicates that the zoological source was a large bird of prey. The state of fragmentation of the preys' bones also serves as an indicator of the bird species (Figuerero Torres, 1981). Rock shelters are usually occupied by different owls such as Tyto alba and Bubo virginianus (Narosky \& Yzurieta, 1987). The site is currently occupied by barn owls (T. alba) (Civalero, personal communication).

Capillarid eggs found in the sample are consistent with Calodium hepaticum (Thienpont, Rochette \& Vanparijs, 1979), common parasites of rodents. Numerous species parasitize birds, although dispersal of the eggs generally involves their elimination with the feces and subsequent ingestion by earthworms, as invertebrate hosts (Soulsby, 1987).

The presence of a mite from genus Demodex sp. was recorded for the first time in an ancient sample. Its species identification is usually based on its size and the host in which it is found (Soulsby, 1987). Perez Tort \& Sigal 
Escalada (2006) reported finding eggs of these mites in the fecal matter of infected dogs, so their presence should be investigated in future paleoparasitological studies of mammalian coprolites, since they can be ingested accidentally by these animals when they lick themselves.

Although regurgitated pellets do not reflect the bird's own parasite fauna, they do provide a parasitological record of their prey. Indirectly, it is possible to learn data on parasitism in mammals that inhabited the region around the archaeological site. The capillarid eggs regurgitated by the bird were also probably in the infective stage, thus representing a potential source of infection for humans inhabiting the caves in the past.

\section{TAPHONOMY AND PRESERVATION}

Ancient organic material is preserved when microbial activity is at least partially inhibited (Heizer \& Napton, 1969). Interruption of the process of fecal decomposition must happen quickly in order for the coprolites to form and for their microfossil content to be preserved (Bouchet et al., 2003). Mountainous areas and dry and cold ecosystems provide the best conditions for preservation of fecal matter (Bang \& Dahlstrom, apud Chame, 2003; Reinhard, 1992). However, some events prevent preservation of the material (despite favorable climatic conditions), such as certain changes in the consistency of feces that can be explained by seasonal variations in the availability of various food sources (Jouy-Avantin et al., 1999).

Various types of archaeological sediments, including coprolites, represent microenvironments with a differential impact on the preservation of parasite remains (Bouchet et al., 2003). As occurs with the preservation of a coprolite, anaerobic wet environments such as latrines or cold and dry environments show the best preservation of parasite remains (Gonçalves, Araújo \& Ferreira, 2003).

On the other hand, open-air sites lead to exposure to more intense changes in temperature and humidity, besides the risk of percolation of parasite elements (Reinhard et al., 1988). Percolation from a recent stratum to another deeper and older one can also occur in latrines, due to the water flow inside them (Bouchet, Harter \& Le Bailly, 2003). Differences have also been recorded in the preservation of eggs from different parasites in the same archaeological site. For example, where fungi were present in latrines, Trichuris trichiura eggs showed alterations and cracks that were absent in Ascaris lumbricoides eggs (Reinhard et al., 1988). This same article reports the recovery of rare Taenia sp. eggs in this type of environment.

Coprolites may yield fewer parasites than sediment under certain conditions, possibly due to the percolation of parasite remains (Bouchet, 1995). However, in some nematode species the larvae leave the eggs and migrate through the soil; thus, as commented previously, samples should be taken from the sediment around the coprolite.

Among the most frequently recovered parasite groups, ascarids, capillarids, and trichurids are preserved best, while the eggs of Strongyloides sp., Enterobius vermicularis, and Trichostrongylus sp. are more fragile (Bouchet et al., 2003). In Patagonia, eggs of capillarid species have been found with the greatest frequency. They are commonly found in felines and camelids and have also been recorded in palynological preparations from Patagonian coprolites (Burry, personal communication). Their wide distribution and abundance probably relate more to taphonomic aspects than to a higher prevalence compared to other helminths. These observations may reflect the diversity of factors influencing parasite taphonomy. Several combinations of factors probably affect the preservation of eggs, cysts, and larvae.

Although obvious, it is important to emphasize that paleoparasitology has access to the remains that have survived over time. Likewise, coprolite findings can represent a sample, the product of taphonomic phenomena related to the 
climate and favorable to the preservation of parasites in the environment. As an extreme example, the only species represented in the material may be those with eggs and cysts that resist over time, subject to the coldest and driest episodes in the region's history.

After coprolites are extracted by archaeologists, they are exposed to new sources of deterioration such as disintegration by mechanical pressure during transportation, lack of asepsis in handling, and variable humidity and temperature during storage. Preservation of coprolites should follow similar procedures to those of other dehydrated materials. For example, one should avoid handling dry samples in humid environments, and it is advisable to have a storage facility with controlled temperature and humidity.

Storing flasks with the samples inside hermetically sealed boxes allows controlling the humidity and placing silica gel inside the boxes. The samples should also not be exposed to lower humidity than in their original environment. Thus, samples should be stored under constant conditions, since changes can cause alterations in organic remains (Doro \& Corvalan, 2006).

Paleoparasitological studies result in new materials such as microscope slides, macroscopic remains for studying the diet, and remains from rehydrated sediment, preferably stored in Eppendorf tubes. In all cases, immediately after the paleoparasitological analysis, the sediments from each location that have been exposed to given processes can be preserved, washed, and dried for subsequent storage.

Preservation should include not only maintenance of the sample's initial characteristics, but also protection of the information obtained from the sample and its availability for future studies.

Preservation requires planning an efficient strategy for concentrating and managing the information produced on each sample. Jouy-Avantin (2003) proposes such a strategy, recommending a standardized series of observations on each coprolite. The author proposes a standard descriptive form for future use in order to build a global database that can help determine the zoological origin of new samples. Assembling and maintaining an image bank is also essential.

In summary, the preservation of archaeological materials and their parasitological contents can be designed according to the following recommendations:

1. Use a minimum fraction of the sample in each study.

2. Coordinate the paleoscatological studies (phytoliths, pollen, charcoal, plant tissue, hairs, bones, parasites etc.) so as to allow simultaneous use in the same coprolite fraction to be processed.

3. Keep a subsample in cold storage for molecular studies.

4. Maintain the original sample under stable physical conditions, similar to the original ones.

5.Coprolites and organic remains should be kept in proper areas for avoiding fungal and bacterial proliferation (Dommelier-Espejo, 2001).

6. Store the processed remains from each sample (macroscopic remains, rehydrated sediments, images, hairs, slides, and other preparations).

7.Create an information system connected to each sample (inventories of rehydrated sediment, preparations, unprocessed sediment, macroscopic remains, comparative samples, images, and lab notes).

8. Share the general recommendations for obtaining and preserving samples with archaeologists and anthropologists.

The above list summarizes the highlights in classical paleoparasitological methodology. Studies should also consider various specific situations that are beyond the scope of this chapter. 
As general criteria, before beginning a sampling or examination, it is important to recall that obtaining samples is a unique moment, generally incapable of being repeated. The use of specific methods on a sample will probably prevent the application of other subsequent techniques with that same sample.

\section{METHODOLOGICAL PERSPECTIVES IN PALEOPARASITOLOGY}

In a second paleoparasitological review, Araújo et al. (1998) highlighted that progress in the field depends on the creation of new techniques and their application to new materials. The field first emerged with findings in mummified human tissues (Ruffer, 1910), but most of the later work was done in coprolites.

Various studies have been conducted in mummified tissues. Ferreira, Araújo \& Confalonieri (1983) were the first to employ a rectosigmoidoscope to obtain tissues and sediments from the interior of a mummy in order to avoid damaging the body. It was possible to view tissue helminths such as Taenia solium, Trichinella spiralis, and Echinococcus sp. by detailed histological examination in mummies, and Bruschi et al. (2006) recently described cases of cysticercosis.

Hair and pottery have also been the focus of intense paleoparasitological study in recent years (Harter, 2002; Harter et al., 2003). In addition, the search for ectoparasites was extended to textiles, and Pediculus humanus humanus was recorded in archaeological tissues from Israel (Mumcuoglu et al., 2003). Historical documents can provide further information that proves the results of parasitological tests (Araújo et al., 1988a).

As discussed above, paleoparasitological examination of atypical archaeological materials (regurgitated pellets and sacral foramina) has yielded positive results. Various sediments such as sambaquis (shell middens) and food-processing areas, although still rarely used, have shown important results that reinforce their usefulness for archaeological studies.

Some protozoan parasites have been described on rare occasions in paleoparasitological studies using light microscopy. Such rare findings feature Eimeria sp. in deer coprolites dated 9,000 BP (Ferreira et al., 1992), E. macusaniensis in camelid coprolites (Leguía, 1999; Fugassa et al., 2008c), and Giardia sp. in coprolites from Tennessee (Faulkner, 1991). The scarcity of such evidence is being overcome with immunological techniques for the detection of protozoa in coprolites using specific antibodies or molecular biology techniques such as polymerase chain reaction (PCR).

The inclusion of molecular techniques is a fundamental stage in the set of studies involved in paleoparasitological knowledge at the population level.

Paleogenetics has contributed new and powerful analytical techniques. The finding of DNA from Ascaris sp. in archaeological deposits from $14^{\text {th }}$-century latrines (Loreille et al., 2001) gave great impetus to the development of molecular techniques in paleoparasitology. Later, Iñiguez et al. (2002) demonstrated the usefulness of PCR for the detection of Enterobius vermicularis. Molecular techniques are also useful for the paleoparasitological diagnosis of microparasites such as the etiological agents of Chagas disease and leishmaniasis (Ferreira et al., 2000; Aufderheide et al., 2004; Cantarino, 1998). The presence of Trypanosoma cruzi was recently recorded in Pediculus humanus found in human hairs and coprolites in Chile (Aufderheide et al., 2005), and DNA from Borrelia burgdorferi was detected in fleas found on rodents belonging to museum collections (Persing et al., 1990), which means a new stage in paleogenetics, consistent with the search for new sources of molecular evidence.

Genomic sequencing studies in parasites and the detection of parasite DNA also launched the tracing of phylogenetic studies that include changes in virulence in relation to pathoecological studies (Gonçalves et al., 2002). The molecular studies launched in paleoparasitology are obviously expanding the scope of studies with traditional microscopy. 
Independently, other disciplines are producing ecological and cultural information through the microscopic examination of sediments. Studies of microfossils (pollen, diatomaceae, charcoal, fungi, parasites, phytoliths, starch, spherulites, plant tissues, hairs etc.) have limited interpretative power but are enhanced by the combination of various sources of evidence (Coil et al., 2003).

Palynology is perhaps the field that has developed the most, providing evidence on the consumption of plant species, their seasonality, and other issues such as their possible pharmacological use in the past (Chaves \& Reinhard, 2003; Reinhard, Ambler \& McGuffie, 1985). As an example of the latter, Reinhard, Hevly \& Anderson (1987) discuss the use of anthelminthics by ancient populations given the low occurrence of parasites and the presence of Chenopodium sp. seeds in coprolites that have been analyzed.

Sediments and coprolites also display multiple macrofossils that are objects of study (charcoal, wood, bones, feathers, hairs, seeds, fly pupae, scatophagous insects, etc.). Entomological, zoological, botanical, and anthracological studies have produced important knowledge, thus reinforcing interdisciplinary collaboration as a valuable characteristic of modern paleoparasitology.

Although paleoparasitology promises to produce valuable information in the coming years, the extent of such information is limited by the quality of both the available techniques and the material for study. This limitation relates closely to the fluidity of relations between archaeologists, paleontologists, and paleoparasitologists. The dissemination of paleoparasitology in the archaeological and paleontological arena is indispensable for excavations to include the recovery and preservation of organic sediments.

A comparison of the first published review of paleoparasitological techniques (Reinhard et al., 1988) and the review conducted ten years later (Araújo et al., 1998) highlights the important strides made in the field. Gonçalves, Araújo \& Ferreira (2003) conducted a new review on human paleoparasitology and incorporated new findings from 894 coprolites, offering an overview of the parasites found on the different continents, with the European colonization of the Americas as the timeline.

In short, when planning a new review of another "paleoparasitological decade", the most striking differences may be the incorporation of new research groups, molecular studies in routine paleoparasitological work, and lasting interdisciplinary collaboration in the field's approach. For an overview of new research groups, see Memórias do Instituto Oswaldo Cruz, 98, suppl. I, 2003 and 101, suppl. II, 2006, focusing on paleoparasitological and paleopathological studies.

\section{REFERENCES}

ALLISON, M. J.; BERGMAN, T. \& GERSZTEN, E. Further studies on fecal parasites in antiquity. American Society of Clinical Pathology, 112: 605-609, 1999.

ALliSON, M. J.; PEZIA, A. \& HASEGAWA, I. A case of hookworm infection in a pre-Columbian American. American Journal of Physical Anthropology, 41: 103-106, 1974.

ANDERSEN, K. \& HALVORSEN, O. Egg size and form as taxonomic criteria in Diphyllobothrium (Cestoda, Pseudophyllidea). Parasitology, 76: 229-240, 1978.

ARAÚJo, A. Dessecação experimental de fezes contendo ovos de ancilostomídeos. In: FERREIRA, L. F.; ARAÚJO, A. \& CONFAlONIERI, U. (Eds.). Paleoparasitologia no Brasil. Rio de Janeiro: PEC/ENSP, 1988.

ARAÚJO, A.; FERREIRA, L. F. \& CONFALONIERI, U. A contribution to the study of helminth findings in archaeological material in Brazil. Revista Brasileira de Biologia, 41: 873-881, 1981. 
ARAÚJO, A.; CONFALONIERI, U. \& FERREIRA, L. F. Encontro de ovos de Trichostrongylidae e Trichuris trichiura em corpo mumificado do períoodo colonial brasileiro. In: FERREIRA, L. F.; ARAÚJO, A. \& CONFALONIERI, U. (Eds.). Paleoparasitologia no Brasil. Rio de Janeiro: PEC/ENSP, 1988.

ARAÚJO, A.; REINHARD, K. J. \& FERREIRA, L. F. The role of mummy studies in Paleoparasitology. Chungará, 32: 111-115, 2000.

ARAÚJo, A. et al. Exame paleoparasitológico. In: FERREIRA, L. F.; ARAÚJO, A. \& CONFALONIERI, U. (Eds.). Paleoparasitologia no Brasil. Rio de Janeiro: PEC/Ensp, 1988a.

ARAÚJO, A. et al. Microscopia de varredura de larvas de ancilostomídeos encontradas em coprólitos humanos datados de $3490 \pm 120$ a $430 \pm 70$ anos. In: FERREIRA, L. F.; ARAÚJO, A. \& CONFALONIERI, U. (Eds.). Paleoparasitologia no Brasil. Rio de Janeiro: PEC/ Ensp, 1988b.

ARAÚjo, A. et al. Paleoparasitology: perspectives with new techniques. Revista do Instituto de Medicina Tropical de São Paulo, 40: 371-376, 1998.

ASCHERo, C. A. El área Río Belgrano-Lago Posadas (Santa Cruz): problemas y estado de problemas. In: GÓMEZ OTERO, J. (Ed.). Arqueología: solo Patagonia. Buenos Aires: Conicet, 1996.

ASPOCK, H.; AUER, H. \& PICHER, O. Trichuris trichiura eggs in the Neolithic glacier mummy from the Alps. Parasitology Today, 12: 255-256, 1996.

ATÍAS, A. Parasitología Médica. Santiago de Chile: Mediterraneo, 1998.

AUfDERHEIDE, A. C. et al. A 9,000 year record of Chagas' disease. Proceedings of the National Academy of Sciences, 101: 2.0342.039, 2004.

AUFDERHEIDE, A. C. et al. Aspects of ingestion transmission of Chagas disease identified in mummies and their coprolites. Chungará, 37: 85-90, 2005.

BASTOS, O. M. et al. Experimental paleoparasitology: identification of Trypanosoma cruzi DNA in desiccated mouse tissue. Paleopathology Newsletter, 94: 5-8, 1996.

BATHURST, R. R. Archaeological evidence of intestinal parasites from coastal shell middens. Journal of Archaeological Science, 32: $115-123,2005$

BENENSON, A. S. Control of Communicable Diseases in Man. Washington: Pan-American Health Organization, 1995.

BERG, G. E. Last meals: recovering abdominal contents from skeletonized remains. Journal of Archaeological Science, 29: 1.349$1.365,2002$.

BINDA, J. A.; MORIENA, R. A. \& ALVAREZ, J. D. Comparación de la eficiencia de dos técnicas de diagnóstico de giardiosis canina. Revista de Veterinaria, 14: 88-89, 2003.

BOUCHET, F. Recovery of helminth eggs from archaeological excavations of the Grand Louvre (Paris, France). The Journal of Parasitology, 81: 785-787, 1995.

BOUCHET, F. Intestinal capillariasis in Neolithic inhabitants of Chalain (Jura, France). The Lancet, 349: 256, 1997.

BOUCHET, F.; HARTER, S. \& LE BAILLY, M. The state of the art of paleoparasitology research in the Old World. Memórias do Instituto Oswaldo Cruz, 98, supl. 1: 95-102, 2003.

BOUCHET, F. et al. First paleoparasitological analysis of a midden in the Aleutian Islands (Alaska): results and limits. The Journal of Parasitology, 85: 369-372, 1999.

BOUCHET, F. et al. Identification of parasitosis in a child burial from Adak Island (Central Aleutian Islands, Alaska). Life Sciences, 324: 123-127, 2001.

BOUCHET, F. et al. First recovery of Schistosoma mansoni eggs from a latrine in Europe (15-16th centuries). The Journal of Parasitology, 88: 404-405, 2002. 
BOUCHET, F. et al. Parasite remains in archaeological sites. Memórias do Instituto Oswaldo Cruz, 98, supl.1: 47-52, 2003.

BRUSCHI, F. et al. Short report: cysticercosis in an Egyptian mummy of the Late Ptolemaic period. American Journal of Tropical Medicine and Hygiene, 74: 598-599, 2006.

CALLEN, E. O. \& CAMERON, T. W. M. A prehistoric diet revealed in coprolites. New Scientist, 8: 35-40, 1960.

CANTARINO, L. M. C. Leishmaniose Tegumentar Americana: uso de técnicas da biologia molecular no diagnóstico de infecção de roedores de coleção do Museu Nacional, 1998. Master's thesis, Rio de Janeiro: Escola Nacional de Saúde Pública, Fundação Oswaldo Cruz.

CHAME, M. Estudo Comparativo das Fezes e Coprólitos não Humanos da Região Arqueológica de São Raimundo Nonato, Sudeste do Piauí, 1988. Master's thesis, Rio de Janeiro: Museu Nacional, Universidade Federal do Rio de Janeiro.

CHAME, M. Terrestrial mammal feces: a morphometric summary and description. Memórias do Instituto Oswaldo Cruz, 98 , supl. 1: $71-94,2003$.

CHAPMAN, A. \& HESTER, T. R. New data on the archaeology of the Haush, Tierra del Fuego. Journal de la Societé des Américanistes, 62: 185-208, 1973.

CHAVES, E. J.; ECHEVERRIA, M. M. \& TORRES, M. S. Clave para la Determinación de Nematodes del Suelo de la República Argentina. Mar del Plata: Ediciones Universidad Nacional de Mar del Plata, 1995.

CHAVES, S. A. M. \& REINHARD, K. Paleopharmacology and pollen: theory, method, and application. Memórias do Instituto Oswaldo Cruz, 98, supl. 1: 207-211, 2003.

COCKBURN, A. et al. Autopsy of an Egyptian mummy. Science, 187: 1.155-1.160, 1975.

COIL, J. et al. Laboratory goals and considerations for multiple microfossil extraction in archaeology. Journal of Archaeological Science, 30: 991-1.008, 2003.

COIMBRA JR, C. E. A. \& MELLO, D. A. Enteroparasitas e Capillaria sp. entre o grupo Suruí, Parque Indígena Aripuanã, Rondônia. Memórias do Instituto Oswaldo Cruz, 76: 299-302, 1981.

COIMBRA JR, C. E. A. et al. Estudos epidemiológicos entre grupos indígenas de Rondônia. II. Bactérias enteropatogênicas e gastrenterites entre os Suruí e Karitiána. Revista da Fundação SESP, 30: 111-119, 1985.

CONFALONIERI, U. o diagnóstico da trichuríase humana e animal. In: FERREIRA, L. F.; ARAÚJO, A. \& CONFALONIERI, U. (Eds.). Paleoparasitologia no Brasil. Rio de Janeiro: PEC/Ensp, 1988a.

CONFALONIERI, U. The experimental approach to paleoparasitology: desiccation of Trichuris trichiura eggs. In: FERREIRA, L. F.; ARAÚJo, A. \& CONFALONIERI, U. (Eds.). Paleoparasitologia no Brasil. Rio de Janeiro: PEC/Ensp, 1988b.

CONFALONIERI, U. et al. The use of statistical tests for the identification of heminth eggs in coprolites. In: FERREIRA, L. F.; ARAÚJO, A. \& CONFALONIERI, U. (Eds.). Paleoparasitologia no Brasil. Rio de Janeiro: PEC/Ensp, 1988a.

CONFALONIERI, U. et al. Trends and perspectives in paleoparasitological research. In: FERREIRA, L. F.; ARAÚJO, A. \& CONFALONIERI, U. (Eds.). Paleoparasitologia no Brasil. Rio de Janeiro: PEC/Ensp, 1988b.

DANIEL, W. W. Biostatistics: A Foundation for Analysis in the Health Sciences, John Wiley and Sons, Inc., 9't Edition, USA, 2008.

DEL COCO, v. F. et al. Cryptosporidium spp en terneros de un área rural de la provincia de Buenos Aires. Acta Bioquímica Clínica Latinoamericana, 3, supl.: 208, 2006.

DITTMAR, K. \& TEEJEN, W.R. The presence of Fasciola hepatica (liver fluke) in human and cattle from a 4500 years old archaeological site in the Saale-Unstrut Valley, Germany. Memórias do Instituto Oswaldo Cruz, 98, supl. 1: 141-144, 2003.

DOMMELIER-ESPEJO, S. Contribution à l'Étude Paléoparasitologique des Sites Néolithiques en Enviromement Lacustre dans les Domaines Jurassien et Peri-Alpin, 2001. Thèse Docteur, Reims: Université de Reims.

DORO, R. A. \& CORVALAN, C. P. Aproximación al estudio de los restos momificados, 2006. Available at: <www.momias.com.ar/ articulos/ramomias.htm > (last update Equipo NayA 1996-2008). 
FAULKNER, C. T. Prehistoric diet and parasitic infection in Tennessee: evidence from the analysis of desiccated human paleofeces. American Antiquity, 56: 687-700, 1991.

FAULKNER, C. T.; SHARON, P. \& JOHNSON, S. S. Prehistoric parasitism in Tennessee: evidence from the analysis of desiccated faecal material collected from Big Bone Cave, Van Buren, Tennessee. The Journal of Parasitology, 75: 461-463, 1989.

FERNANDES, A. et al. Intestinal parasite analysis in organic sediments collected from a $16^{\text {th }}$ century Belgian archaeological site. cadernos de Saúde Pública, 21: 329-332, 2005.

FERREIRA, L. F. \& ARAÚJO, A. On hookworms in the Americas and trans-Pacific contact. Parasitology Today, $12: 454,1996$.

FERREIRA, L. F.; ARAÚJO, A. \& CONFALONIERI, U. The finding of eggs and larvae of parasitic helminths in archaeological material from Unaí, Minas Gerais, Brazil. Transactions of the Royal Society of Tropical Medicine and Hygiene, 75: 798-800, 1980.

FERREIRA, L. F.; ARAÚJO, A. \& CONFALONIERI, U. The finding of helminth eggs in a Brazilian mummy. Transactions of the Royal Society of Tropical Medicine and Hygiene, 77: 65-67, 1983.

FERREIRA, L. F.; ARAÚJO, A. \& DUARTE, A. N. Nematode larvae in fossilized animal coprolites from Lower and Middle Pleistocene sites, Central Italy. The Journal of Parasitology, 79: 440-442, 1993.

FERREIRA, L. F. et al. Eimeria oocysts in deer coprolites dated from 9,000 years BP. Memórias do Instituto Oswaldo Cruz, 87: 105-106, 1992.

FERREIRA, L. F. et al. Paleoparasitology of Chagas disease revealed by infected tissues from Chilean mummies. Acta Tropica, 75 : 79-84, 2000.

FIEL, C. A.; STEFfAn, P. E. \& FERREYRA, D. A. Manual para el Diagnóstico de Nematodes en Bovinos. Argentina: Bayer, 1998.

FIGUERERo TORRES, M. J. Análisis del coprolito del sitio Alero del Dique, provincia del Neuquén. Universidad de Buenos Aires, Facultad de Filosofia y Letras. Trabajos de Prehistoria, Publicación, 1: 165 168, 1981.

FIGUERERO TORRES, M. J. Análisis de coprolitos: el caso de Las Buitreras. In: CONGRESO NACIONAL DE ARQUEOLOGÍA, VII, 1982, Colonia del Sacramento, Uruguay.

FUGASSA, M. H. Examen paleoparasitológico de sedimentos de un sitio arqueológico, Río Mayo, Chubut, Argentina. Parasitología Latinoamericana, 61: 172-175, 2006.

FUGASSA, M. H. \& BARBERENA, R. Cuevas y zoonosis antiguas: paleoparasitología del sitio Orejas de Burro 1 (Santa Cruz, Argentina). Magallania, 34: 57-62, 2006.

FUGASSA, M. H.; ARAÚJO, A. \& GUICHÓN, R. A. Quantitative paleoparasitology applied to archaeological sediments. Memórias do Instituto Oswaldo Cruz, 101, supl. 2: 29-33, 2006.

FUGASSA, M. H.; SARDELlA, N. H. \& DENEGRI, G. M. Paleoparasitological analysis of a raptor pellet from Southern Patagonia. The Journal of Parasitology, 93: 421-422, 2007.

FUGASSA, M. H. et al. Paleoparasitological records in Canid coprolite from Patagonia, Argentina. The Journal of Parasitology, 92 : 1.110-1.111, 2006.

FUGASSA, M. H. et al. Paleoparasitological analysis applied to skeletal sediments of Meridional Patagonian collections. Journal of Archaeological Science, 35: 1.408-1.411, 2008a.

FUGASSA, M. H. et al. Capillaria spp. findings in Patagonian archaeological sites: statistical analysis of morphometric data. Memórias do Instituto Oswaldo Cruz, 103: 104-105, 2008b.

FUGASSA, M. H. et al. Eimerid oocysts from archaeological samples in Patagonia, Argentina. The Journal of Parasitology, 94: 1.418-1.420, 2008c.

GONÇALVES, M. L. C.; ARAÚJO, A. \& FERREIRA, L.F. Human intestinal parasites in the past: new findings and a review. Memórias do Instituto Oswaldo Cruz, 98, supl.1: 103-118, 2003. 
GONÇALVES, M. L. C. et al. Detection of Giardia duodenalis antigen in coprolites using a commercially available enzyme-linked immunosorbent assay. Transactions of the Royal Society of Tropical Medicine and Hygiene, 96: 640-643, 2002.

GUERRA, R. M. S. N. C. et al. Ecological analysis of acari recovered from coprolites from archaeological sites of Northeast Brazil. Memórias do Instituto Oswaldo Cruz, 98, supl. 1: 181-190, 2003.

HARTER, S. Implications de la Paléoparasitologie dans l'Étude des Populations Anciennes de la Vallée du Nil et du Proche-Orient: études de cas, 2002. Thèse, Champagne-Ardenne: Université de Reims.

HARTER, S. et al. First paleoparasitological study of an embalming rejects jar found in Saqqara, Egypt. Memórias do Instituto Oswaldo Cruz, 98, supl. 1: 119-121, 2003.

HAWDON, J. M. \& JOHNSTON, S. A. Reply. Parasitology Today, 12: 454, 1996.

HEIZER, R. F. \& NAPTON, L. K. Biological and cultural evidence from prehistoric human coprolites. Science, 165: 563-568, 1969.

HIDALGO ARGUELLO, M. R. New paleoparasitological techniques. Journal of Archaeological Science, 33: 372-377, 2006.

HOLLIDAY, D. M.; GUILLEN, S. \& RICHARDSON, D. J. Diphyllobothriasis of the Chiribaia culture (700-1476 AD) of Southern Peru. Comparative Parasitology, 70: 167-171, 2003.

HORNE, P. D. \& TUCK, J. A. Archaeoparasitology at a $17^{\text {th }}$ Century site in Newfoundland. The Journal of Parasitology, 82: 512-515, 1996.

IÑIGUEZ, A. M. et al. Enterobius vermicularis: specific detection by amplification of an internal region of 5S ribosomal RNA intergenic spacer and trans-splicing leader RNA analysis. E. vermicularis: specific detection by PCR and SL1 RNA analysis. Experimental Parasitology, 102: 218-222, 2002.

JONES, A. K. G. Recent finds of intestinal parasite ova at York, England. In: EUROPEAN MEMBERS MEETING, 4, 1982a, Middelburg, Antwerpen. (Papers on Paleopathology)

JONES, A. K. G. Human parasite remains: prospect for a quantitative approach. In: HALL, A. R. \& KENWARD, H. K. (Eds.). Environmental Archaeology in the Urban Context. London: Council for British Archaeology, 1982b. (Research Report, 43)

JONES, A. K. G. Intestinal parasite ova from archaeological deposits. Paleopathology Association. In: EUROPEAN MEETING, 5, 1984, Siena.

JONES, A. K. G. Coprolites and faecal concretions. In: BELL, M. (Ed.). Brean Down Excavations 1983-1987. London: English Heritage, 1990. (Archaeological Report, 15)

JONES, A. K. G. Coprolites and faecal material in archaeological deposits: a methodological approach. Quaderni del Dipartimento di Archeologia e Storia delle Arti, sez. archeologica - Università di Siena, 1992.

JOUY-AVANTIN, F. A standardized method for the description and study of coprolites. Journal of Archaeological Science, 30: 367-372, 2003.

JOUY-AVANTIN, F. et al. Helminth eggs in animal coprolites from a Middle Pleistocene site in Europe. The Journal of Parasitology, 85: 376-379, 1999.

KAMINSKY, R. D. Manual de Parasitología. Tegucigalpa: Universidad Nacional Autónoma de Honduras, 2003.

KELLOGG, J. A. \& ELDER, C. J. Justification for use of a single trichrome stain as the sole means for routine detection of intestinal parasites in concentrated stool specimens. Journal of Clinical Microbiology, 37: 835-837, 1999.

KLIKS, M. M. Helminths as heirlooms and souvenirs: a review of New World paleoparasitology. Parasitology Today, 6(4): 93-100, 1990.

LE BAILly, M. Evolution de la Relation Hôte/Parasite dans les Systèmes Lacustres Nord Alpins au Néolitique (3900-2900BC), et Nouvelles Données dans la Détection des Paléoantigènes de Protozoa, 2005. Thésis Doctoral, Reims: Université de Reins Champagne-Ardenne.

LE BAILLY, M. et al. Diphyllobothrium: Neolithic parasite? The Journal of Parasitology, 91: 957-959, 2005. 
LE BAILLY, M. et al. New finding of Giardia intestinalis (Eukaryote, Metamonad) in Old World archaeological site using immunofluorescence and enzyme-linked immunosorbent assays. Memórias do Instituto Oswaldo Cruz, 103: 298-300, 2008.

LEGENDRE, P. \& LEGENDRE, L. Numerical Ecology. $2^{\text {nd }}$ Ed. Amsterdam: Elsevier Science, 1998.

LEGUíA, P. G. Enfermedades Parasitarias de Camélidos Sudamericanos. Lima: Editorial del Mar, 1999.

LEGUíA, P. G.; CASAS, A. E. \& JANE, W. Parasitismo en camélidos prehispánicos. Parasitología al Día, 19: 435, 1995.

LOREILLE, O. et al. Ancient DNA from Ascaris: extraction amplification and sequences from eggs collected in coprolites. International Journal for Parasitology, 31: 1.101-1.106, 2001.

LUTZ, A. Schistosoma mansoni e a schistosomatose segundo observações feitas no Brasil. Memórias do Instituto Oswaldo Cruz, 11: 121-155, 1919.

MARDER, G. et al. Determinación Parasitaria en Materia Fecal de Perros y Gatos de la Ciudad de Corrientes. Chaco: Universidad Nacional del Nordeste, 2000. (Comunicación Científica y Tecnológica)

MARTI, C. D. Raptor food habits studies. In: PENDLETON, B. A. et al. (Eds.). Raptor Management Techniques Manual. Washington: National Wildlife Federation, 1987. (Scientific Technique Series, 10)

MARTín, L. \& BEAVER, P. Evaluation of Kato thick-smear technique for quantitative diagnosis of helminth infections. American Journal of Tropical Medicine and Hygiene, 17: 382-391, 1968.

MIYAZAKI, I. An Illustrated Book of Helminthic Zoonoses. Tokyo: International Medical Foundation of Japan, 1991.

MOORE, J. G. Thorny-headed worm infection in North American prehistoric man. Science, 163: 1.324-1.325, 1969.

MOORE, P. D. Life seen from a medieval latrine. Nature, 294: 614, 1981.

MORAVEC, F. Trichillenoid Nematodes: Parasitic in Cold-Blooded Vertebrates. Prague: Academia, 2001.

MUMCUOGLU, K.Y. et al. Body louse remains found in textiles excavated at Masada, Israel. Journal of Medical Entomology, 40: $585-587,2003$

NAROSKY, Y. \& IZURIETA, D. Guia para la Identificación de las Aves de Argentina y Uruguay. Buenos Aires: Asociación Ornitológica del Plata, 1987.

NAVONE, G. T. et al. Estudio comparativo de recuperación de formas parasitarias por tres diferentes métodos de enriquecimiento coproparasitológico. Parasitología Latinoamericana, 60: 178-181, 2005.

NORONHA, D. et al. Echinopardalis sp. (Acanthocephala, Oligacanthorhynchidae) eggs in felid coprolites dated from 9000 years before present, found in the Brazilian northeast. Memórias do Instituto Oswaldo Cruz, 89: 119-120, 1994.

ORTEGA, Y. R. \& BONAVIA, D. Cryptosporidium, Giardia, and Cyclospora in ancient Peruvians. The Journal of Parasitology, 89: 635-636, 2003.

PEREZ TORT, D. \& SIGAL ESCALADA, G. Demodicosis en Caninos y Felinos. Buenos Aires: Inter-Médica, 2006.

PERSING, D. H. et al. Detection of Borrelia burgdoferi DNA in museum specimens of Ixodes dammini ticks. Science, 249: 1.4201.423, 1990.

PIKE, A. W. Recovery of helminth eggs from archaeological excavations, and their possible usefulness in providing evidence for the purpose of an occupation. Nature, 219: 303-304, 1968.

REINHARD, K. J. Parasitology as an interpretative tool in archaeology. American Antiquity, 57: 231-245, 1992.

REINHARD, K. J.; AMBLER, J. R. \& MCGUfFIE, M. Diet and parasitism at Dust Devil Cave. American Antiquity, 50: 819-824, 1985.

REINHARD, K.; HEVLY, R. H.; ANDERSON, G. A. Helminth remains from prehistoric Indian coprolites on the Colorado Plateau. The Journal of Parasitology, 73: 630-639, 1987. 
REINHARD, K. J. et al. Recovery of parasite remains from coprolites and latrines: aspects of paleoparasitological technique. Homo, 37: 217-239, 1988.

REINHARD, K. et al. Discovery of colon contents in a skeletonized burial: soil sampling for dietary remains. Journal of Archaeological Science, 19: 697-705, 1992.

ROCHA, G. C. et al. Paleoparasitological remains revealed by seven historic contexts from Place d'Armes, Namur, Belgium. Memórias do Instituto Oswaldo Cruz, 101, supl. 2: 43-52, 2006.

RUAS, J. L. et al. Infecção por Capillaria hepatica em carnívoros silvestres (Lycalopex gymnocercus e Cerdocyon thous) na região sul do Rio Grande do Sul. Arquivos do Instituto do Biologia, 70: 127-130, 2003.

RUFFER, M. A. Note on the presence of Bilharzia haematobia in Egyptian mummies of the Twentieth Dynasty (1250-1000 BC). British Medical Journal, 1: 16, 1910.

RUZIN, S. E. Plant Microtechniques and Microscopy. New York: Oxford University Press, 1999.

SANTORO, C.; VINTON, S. H. D. \& REINHARD, K. J. Inca expansion and parasitism in the Lluta Valley: preliminary data. Memórias do Instituto Oswaldo Cruz, 98, supl. 1: 161-163, 2003.

SOCIEDADE ESPAÑOLA DE ENFERMEDADS INFECCIOSAS Y MICROBIOLOGÍA CLÍNICA (SEIMC). Control de calidad de parasitología P-1/98, 1998. Available at: <www.seimc.org>. Accessed 6 Sept. 2010.

SHAFER, H. J.; MAREK, M. \& REINHARD, K. J. A Mimbres burial with associated colon remains from the NAN Ranch Ruin, New Mexico. Journal of Field Archaeology, 16:17-30, 1989.

SIANTO, L. et al. The finding of Echinostoma (Trematoda: Digenea) and hookworm eggs in coprolites collected from a Brazilian mummified body dated 600-1,200 years before present. Journal of Parasitology, 91: 972-975, 2005.

SOULSBY, E. J. Helminths, Arthropods, and Protozoa of Domesticated Animals. Lond: Ballère Tindall, Division of Cassell Ltd., 1982.

TAEK HAN, E. et al. Detection of parasite eggs from archaeological excavations in the Republic of Korea. Memórias do Instituto Oswaldo Cruz, 98, supl. 1: 123-126, 2003.

TAYLOR, E. L. Parasitic helminthes in medieval remains. Veterinary Records, 67: 218-228, 1955.

THIENPONT, D.; ROCHETTE, F. \& VANPARIJS, O. F. J. Diagnosing Helminthiasis through Coprological Examination. Beerse: Janssen Research Foundation, 1979.

UBELAKER, J. E. \& ALLISON, V. F. Scanning electron microscopy of the eggs of Ascaris lumbricoides, A. suum, Toxocara canis, and T. mystax. The Journal of Parasitology, 61: 802-807, 1975.

VALERO, M. A. et al. Patterns in size and shedding of Fasciola hepatica eggs by naturally and experimentally infected murid rodents. The Journal of Parasitology, 88: 308-313, 2002.

VAN CLEAVE, H. J. \& ROSS, J. A. A method for reclaiming dried zoological specimens. Science, 105(2.725): $318,1947$.

WARNOCK, P. J. \& REINHARD, K. J. Methods for extracting pollen and parasite eggs from latrine soils. Journal of Archaeological Science, 19: 261-264, 1992.

YE, X. P. et al. The non-randomness of the distribution of Trichuris trichiura and Ascaris lumbricoides eggs in faeces and the effect of stirring faecal specimens. Tropical Medicine and International Health, 2: 261-264, 1997. 


\title{
Coprolite diagnosis, or who made the coprolite?
}

\author{
Marcia Chame • Luciana Sianto
}

\en we find a lost pen drive, open it, and read some of the files, we can definitely speculate on the owner's
personality. The data saved on it often suggest the person's profession, interests, places they have visited, family relations, and even a guess at their sex.

The same is true for biological remains found in nature, which are veritable data storage units. With focus, skill, and adequate techniques, we can learn and reconstruct a great deal from some samples. The object of our research may sound unheard-of or even disgusting. However, following any odd reaction upon initial impact, we find surprising information in the fecal remains left by individuals of any species. Such information extends beyond eating habits and items ingested in the last meals. The data contained in coprolites are like files that we can open and peruse, much like the chapters of this book.

For example, parasite findings reveal a set of adaptations by the coprolites' producers to the ecosystems in which they lived. If we succeed in reassembling the data like pieces in a jigsaw puzzle, they can tell us the evolutionary history, phylogeny, processes and paths in dispersal over time, and intricate food webs in the populations, vectors, and host species (Araújo, Rangel \& Ferreira, 1993; Ley et al., 2008).

"Coprolite" (from the Greek kopros, feces, and lithos, rock) may sound odd. The name dates to the early $19^{\text {th }}$ century, when the British Reverend William Buckland (1829a, 1829b, 1830), a geologist, paleontologist, and "dinosaur hunter" recognized naturally fossilized feces and coined the term. However, interest in the analysis of naturally preserved, fossilized, or simply desiccated feces only developed in the late $19^{\text {th }}$ and early $20^{\text {th }}$ centuries.

In Brazil, the first record of the term "coprolite" and the possibility of coprolites as objects of research dates to 1866, in comments by physician Otto Edward Henry Wucherer on a speech in 1865 by Benjamin E. Cotting, Secretary of Foreign Affairs of the Medical Society of Massachusetts and former member of the Agassiz Expedition to Brazil Commenting on Cotting's speech at the Society's Annual Meeting, published in Gazeta Médica da Bahia, Wucherer (1866: 129) states: 
...coprolites, petrified feces found inside and outside fossil animals, often reveal to us not only the nature of the ingestion, displaying parts of other animals that were consumed, but even the nature of the mucosal surface of the gut and prove that the ingestion was done in those times more as less as in our times.

From then on, the growing publication of scientific articles on coprolites (Harshberger, 1896) demonstrated that the understanding (albeit incipient) that the analysis of partially or totally undigested remains in human excreta can reveal habits and ecological data on prehistoric populations.

Finding coprolites during archaeological excavations requires expertise in their identification. Located in sedimentary layers, they must be distinguished from the surrounding soil by their shape and texture. This is not always a simple task, since such layers contain various shapes (not always obvious). Paleoparasitology also involves the finding of coprolites from extinct species such as dinosaurs, for which there are no parameters for comparison with the current fauna. Considering that the presence of phosphate in the feces facilitates their mineralization and preservation, the museum collections tend to contain more carnivore coprolites, naturally rich in phosphate and calcium from the bones and teeth of their prey.

Herbivores feces contain plant lignin and cellulose and require the minerals needed for better preservation from the environment. During mineralization or desiccation, the feces also serve as the habitat for many species. This colonization, typical of the decomposition process, can alter or distort the feces' original shape, drawing in external elements that contaminate the sample, such as insects, fungi, and mites, among others (Guerra et al., 2003; Dormont et al., 2007). The association of coprolites with artifacts, human or animal skeletons, or other remains can aid and facilitate the coprolite's on-site identification. The first difficulty for the study of coprolites results from the dispersal and preservation of the sedimentary layers. Problems arise mainly from geological processes, distinct modes of preservation of the coprolites, and lack of knowledge of the local fauna. Still, the dispersal and preservation of coprolites in the sedimentary layers (resulting from geological processes and distinct modes of preservation) lead to the first difficulty in studying this material. This includes not only the archaeological sites themselves but the usage areas around them, often combined with lack of knowledge on the local fauna. How to identify the coprolite's source? Was it human or animal? In the latter case, which species made it? This is not a recent problem, and many researchers have grappled with it. We are still searching for the best solution when we begin the analysis of a sample from an archaeological site or the soil. For the most precise and easiest identification of the remains, we need a clue to begin searching for our information. What universe of information and forms do we expect to find in the material that will allow us to infer who or what inhabited that place? What did they eat, which parasites did they harbor, which diseases may have existed in that setting, and which habits could be attributed indirectly to those populations?

The first research to identify the source of coprolites used the most obvious parameters, like their appearance and shape, after correlating them to recent fecal samples. Eames (1930) used this methodology to study coprolites from the extinct giant sloth, based on shape and food content. Likewise, based on the appearance and microscopic remains, Grzywinski (1959-1960) analyzed 36 coprolites from the $11^{\text {th }}, 12^{\text {th }}$, and $13^{\text {th }}$ centuries from Opole, Poland, including small ruminants (sheep and goats), dogs, horses, and probably pigs. Heizer \& Napton (1969), however, mentioned the particular difficulty in identifying human and bear coprolites, emphasizing the need to systematize parameters for their identification.

During coprolite analyses, Callen \& Cameron (1960) noticed that $0.5 \%$ trisodium phosphate solution, used to rehydrate samples, turned an opaque dark brown or black and gave off a fetid odor when the feces were from humans. This parameter was used from then on to diagnose human coprolites (Fry \& Hall, 1969; Fry, 1970), which no doubt leads to errors of interpretation when applied to fecal samples from any region. 
As the range of coprolite findings began to reflect the diversity of animal species (in addition to humans) that inhabited the study areas, other parameters were incorporated into the factors used jointly to elucidate the human origin of coprolites. Thus, Fry \& Moore (1969), analyzing 142 coprolites collected at Hogup Cave, Colorado (USA) and dated $7,837 \pm 630$ to $650 \pm 100 \mathrm{BP}$, included the samples' position in the site's archaeological context, findings of remains from plants that might already be undergoing domestication, and bones and charcoal as parameters for identifying the coprolite.

However, the color pattern in the rehydration solution is still an important parameter for identifying the coprolite, since other studies have corroborated the pattern of dark brown or black for humans, translucent yellow for herbivores, and translucent light brown for carnivores (Bryant \& Williams-Dean, 1975).

In parallel with these studies, other researchers already identified problems with this standardization. For example, Wilke \& Hall (1975) in California studied human material from 1,000 to 1,500 years ago and noted that some samples turned the rehydration solution lighter in color than the standardized solution. At the time, the researchers attributed this reaction to the fact that these samples were the driest among those examined.

As research and rehydration of coprolites and feces from other species proceeded, these patterns began to lose consistency. Tests by Fry (1976) with samples from zoo animals showed that feces of coatis (Nasua sp.) displayed the same staining attributed to human samples, associated with an omnivorous diet. Chame (1991), in a study of mammalian feces and coprolites collected from the archaeological region of São Raimundo Nonato in Piauí State, Brazil, identified feces and coprolites of non-omnivorous species that turned the rehydration solution opaque dark brown/black. The species included the collared anteater (Tamandua tetradactyla), an insectivorous species, and rock cavy (Kerodon rupestris), a rodent that feeds on tree leaves and bark.

Other parameters were incorporated, including the finding of parasites that were easy to identify down to the species level, which alone determined the coprolite's zoological origin, for example, findings of the nematodes Enterobius vermicularis and Trichuris trichiura published by Fry (1976), Araújo (1980), Ferreira et al. (1980, 1991), Araújo, Ferreira \& Confalonieri (1981), and Rey (2008).

However, parasite diagnosis is not always simple or amenable to species identification. Jones (1982) questioned the identification of helminth eggs found in coprolites that were diagnosed by morphometric patterns, since alterations in the eggs' morphometry may have occurred during desiccation. Still, such changes were tested by Confalonieri (1983) in Trichuris trichiura and by Araújo (1987) in hookworms and did not occur to a significant extent.

The taxonomic literature still includes little work on egg morphometry and larval forms of helminth species and protozoan morphometry. Such research would allow the identification of coprolites and the parasites found in them. Taxonomic studies have focused basically on adult individuals and often overlook relevant information on the hosts, the number of individuals found during the necropsy, biocenosis, an accurate description of the collection site (both the site where the host was found and the specific place where the individuals were collected inside the host), the male/female ratio in findings, and other biologically and ecologically important information.

\section{DIAGNOSIS OF HELMINTH EGGS}

The accumulated parasitological analyses of coprolites have produced a large data set of egg measurements (length and width, with and without the operculum, when applicable). This allows distributional analysis of measurements for each species. This simple statistical treatment, among others, is essential for the identification of helminth eggs 
from two similar species that may be present in the same sample (which may be suggested by a bimodal distribution in the sample's set of measurements). It also allows identifying the characteristic range and metric variation of the species or of some populations.

The identification of overlapping helminth egg measurements and morphological characteristics such as the appearance of the embryonic mass and presence of larvae, number of cuticles, type of shell, opercula, and other internal structures builds consistent parameters that can be used to identify helminth families, genera, and species. A clear example is the difficulty in identifying eggs from hookworm species and trematodes of genus Echinostoma, the eggs of which display a complex overlapping of sizes (Araújo, 1987; Chame, 1988; Sianto, 2004) (Graphs 1 and 2).

On the other hand, Trichuris egg morphometry provides a reliable parameter for approximate species diagnosis in this genus (Confalonieri, 1983; Ferreira et al., 1991). The same is true for some acanthocephalans.

Graph 1 - Variation in the range of length of Echinostoma eggs (Trematoda: Echinostomatidae) described in Brazil

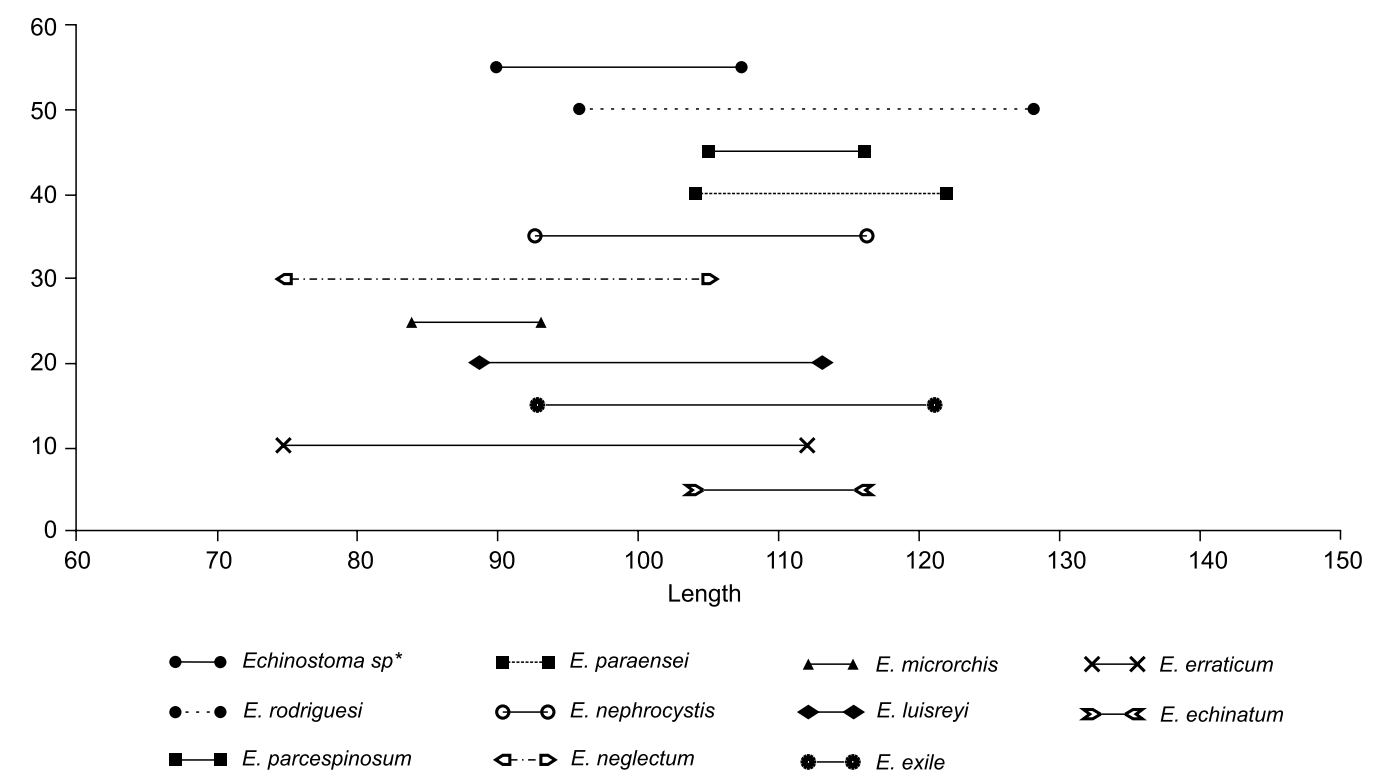

* Echinostoma sp. found in mummified body in the Lapa do Boquete archaeological site, Peruaçu Valley, Januária, Minas Gerais, Brazil. Source: Sianto (2004). 
Graph 2 - Variation in the range of width of Echinostoma eggs (Trematoda: Echinostomatidae) described in Brazil

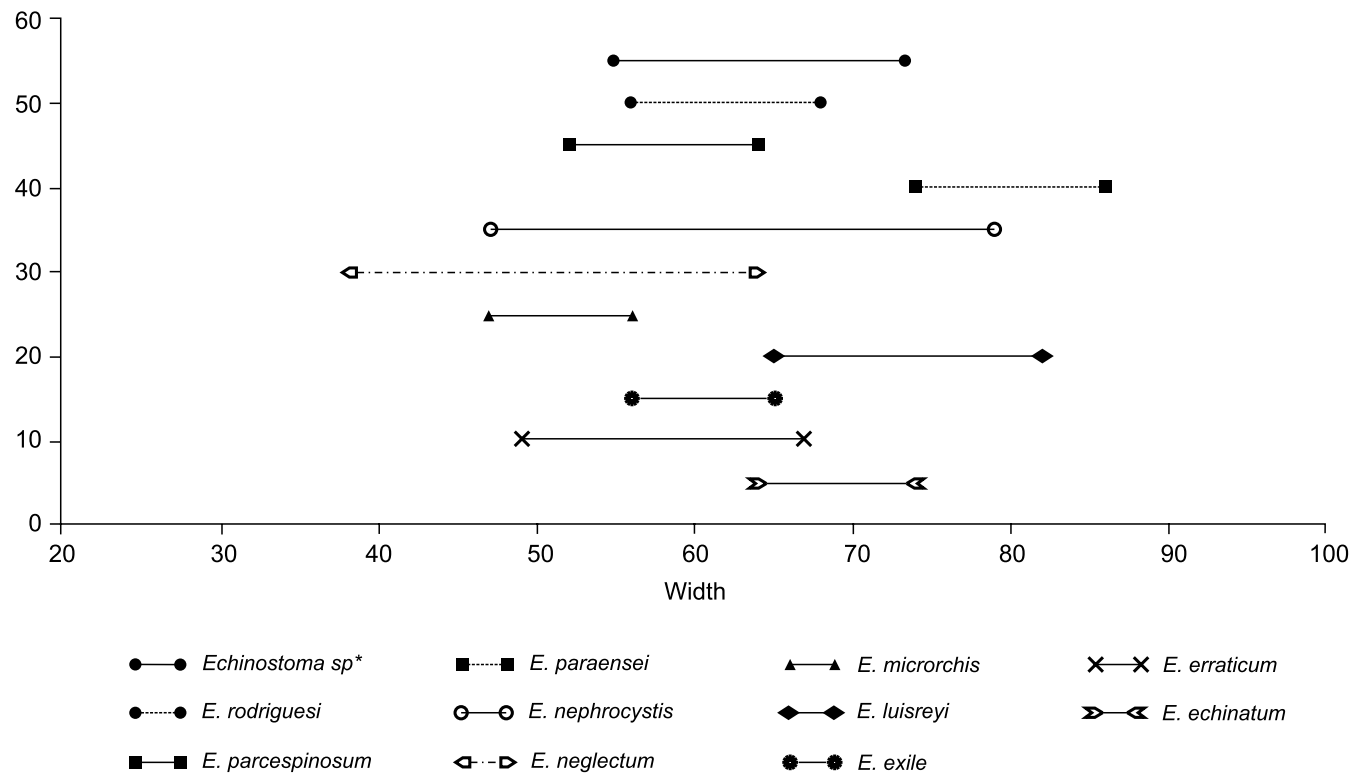

* Echinostoma sp. found in mummified body in the Lapa do Boquete archaeological site, Peruaçu Valley, Januária, Minas Gerais, Brazil. Source: Sianto (2004).

The identification of a helminth egg often becomes confusing when one observes a range of similar shapes. In such cases, accurate observation of the morphological variations should concentrate on the possibility of a variation resulting from ontogenesis (Plate 1).

Plate 1 - Eggs of Trichuris sp. (Nematoda: Trichuridae) in different embryonic stages. Magnification 400x

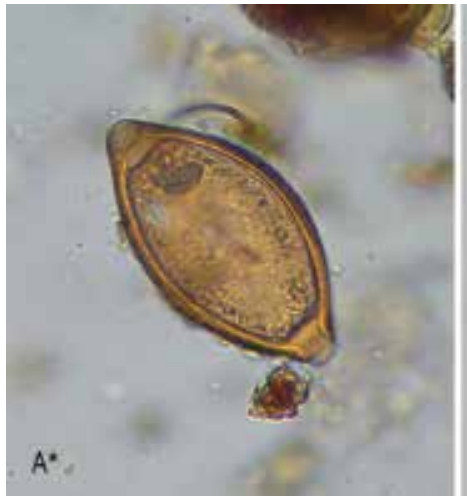

Eggs with embryonic mass

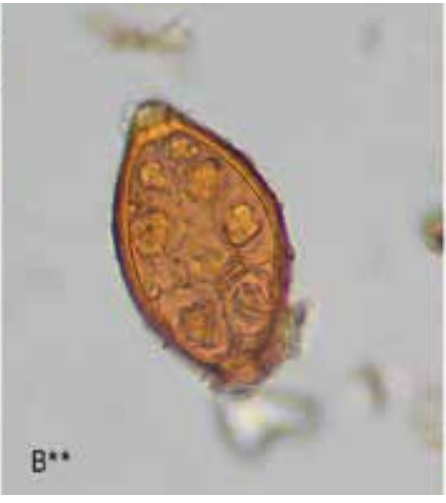

Eggs with cells undergoing division

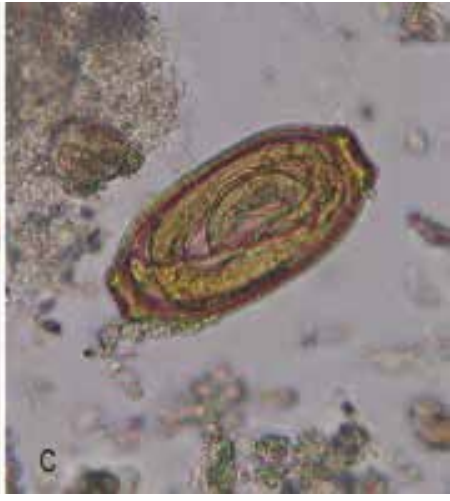

Embryonated egg

* Trichuris sp (62-70 x 32-37 $\mu \mathrm{m}$ ) in coprolites from Kerodon rupestris (rock cavy) (Rodentia: Caviidae). Serra da Capivara National Park, Piauí, Brazil.

** Trichuris sp (54 × 27 m $)$ in feces of Cerdocyon thous (crab-eating fox) collected in the Ipanema National Forest, Iperó, São Paulo, Brazil. Photograph: Rita Soares Nunes. 
Changes in eggs due to taphonomic processes, such as flattening or folding due to drying, are reasonably easy to detect when there are adequate numbers of eggs in the sample. However, it is common to observe the loss of membranes, cuticles, and shells and the opening of opercula, possibly caused by rehydration of the samples. In such cases, if it is not possible to find some eggs that prove these intermediate stages, identification may become impossible or even incorrect (Plates 2 and 3).

Plate 2 - Eggs of unidentified acanthocephalans (81-96.8 x 47-60 $\mu \mathrm{m})$ in coprolites from collared anteater (Tamandua tetradacytla) (Pilosa: Myrmecophagidae) in different phases including complete breaking of the shell and exposure of the acanthor. Serra da Capivara National Park, Piauí, Brazil. Magnification 400x
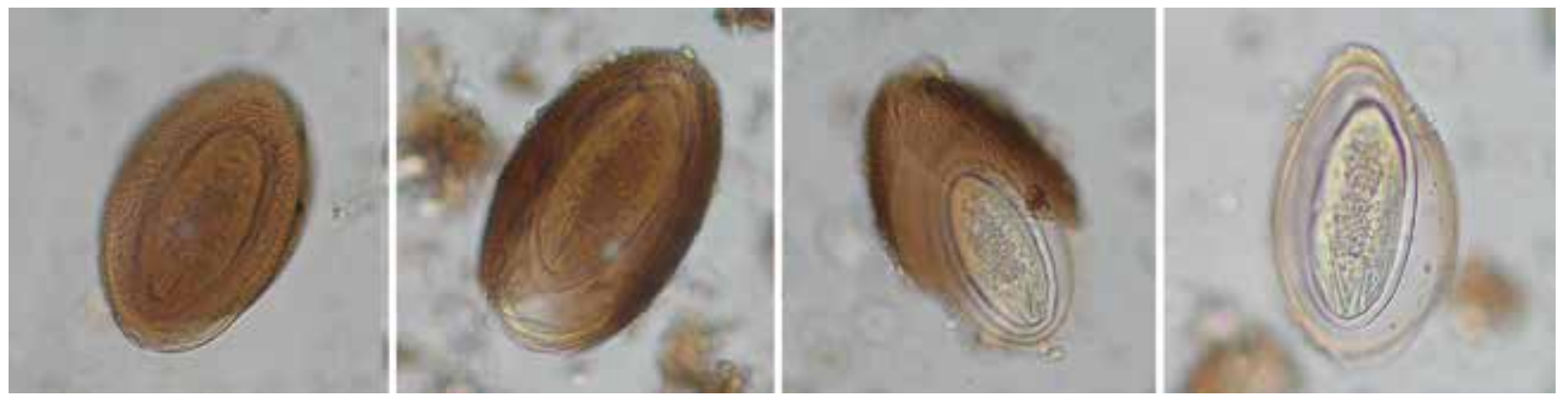

Plate 3 - Ascarid eggs (69 × $39 \mu \mathrm{m}$ with shell) (Nematoda: Ascaridae) in recent feces of Kerodon rupestris (rock cavy) (Rodentia: Caviidae) in different embryonic stages. Serra das Confusões National Park, Piauí, Brazil. Magnfication 400x
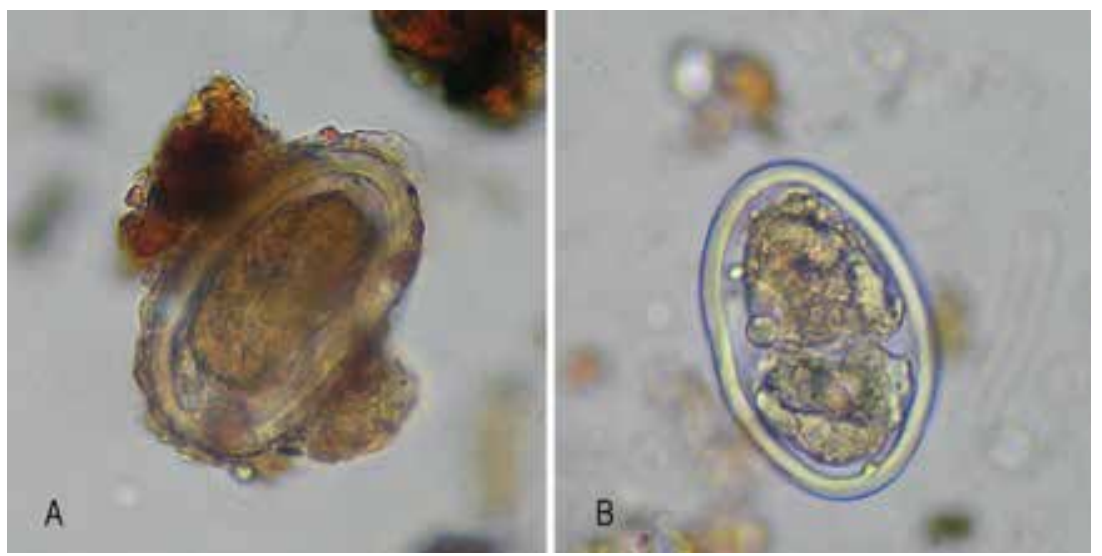

(A) egg with mamillated thickened shell; (B) egg without shell, with a reduction of approximately $3 \mu \mathrm{m}$ in both measurements.

\section{DIAGNOSIS OF ANIMAL FECES}

It interesting that discussion of coprolite identification has lasted for so long, since feces had already been used since the early $20^{\text {th }}$ century in biological studies of many mammalian species. Seton (1925) already noted that the shape and content of feces are excellent clues for identifying mammalian orders. Feces of species from the same order have characteristics that allow grouping them, and that reflect their peculiar anatomy. The shape of feces appears not 
to be useful for diagnosing the family and genus. However, although it may appear contradictory, the shape of feces is a valuable tool for species diagnosis, as are the size and food content, which sometimes separate proximate species (Riney, 1957). Most authors still use feces as a research source, but most do not describe the criteria used for their identification (Eddy, 1961; Neff, 1968; Batcheler, 1975; Dzieciolowski, 1976; Floyd, Mech \& Jordan, 1978; Johnson \& Hansen, 1978; Von Gadow, 1978; Fitzgerald \& Waddington, 1979; Strong \& Freddy, 1979; Arthur III \& Alldredge, 1980; White \& Eberhart, 1980; Bailey \& Putman, 1981; Dinerstein \& Dublin, 1982; Andelt et al., 1987; Rogers, 1987; Fox \& Smith, 1988; Hominger, Dale \& Bailey, 1988; Cáceres et al., 2007).

However, ecological studies using feces as a primary research source have multiplied over time, meaning that they have been identified in some way (Welch, 1982; Mitchell et al., 1985; Rabinowitz \& Nottingham, 1986; Patton et al., 1986; Green, 1987; Emmons, 1987; Lancia, Nichols \& Pollock, 1996; Kohn \& Wayne, 1997; Anacleto et al., 2007).

Meanwhile, some authors have studied parameters to characterize and identify fecal findings. Bowden, Andersen \& Medin (1969) describe the feces of mule deer (Odocoileus hemionus) as a group of five or more units, generally with the same weight, size, consistency, shape, and color. Voth \& Black (1973) used histological studies of plants ingested by small herbivores to characterize the feces of mountain beaver (Aplodontia rufa) according to size and weight.

Grant (1974) uses shape to differentiate the shape of Megaleia rufa (red kangaroo) fecal pellets from those of Macropus giganteus (gray kangaroo). The author compares feces collected from the colon of dead animals to pellets collected in the field and states that the results show considerable reliability, allowing their use to identify the two species of marsupials. According to other studies, such as Brunner, Lloyd \& Comam (1975) with carnivores in Australia, it is not always possible to identify the scats of cats, dogs, and fox (Vulpes vulpes) by size, shape, and odor, but they estimate their diagnostic confusion at less than $5 \%$.

The diameter of scats often facilitates their identification (Gree \& Flinders, 1981; Danner \& Dodd, 1982). Weaver $\&$ Fritts (1979) use diameter to distinguish between scats of Canis latrans (coyote) and Canis lupus (wolf) where the two species are sympatric. Canis lupus scats are greater than $3 \mathrm{~cm}$ in diameter, and the odds of identifying Canis lupus scats as Canis latrans are 4.9\%. Like Huson \& Davis (1980) in a study of droppings from Rattus rattus and Rattus norvegicus, they emphasize that the volume of food ingested can alter the size of feces.

Anacleto (2007), studying the eating habits of armadillo species (Dasypodidae) in the Mato Grosso cerrado, distinguish feces of Priodontes maximus (giant armadillo) from those of Euphractus sexcinctus (six-banded armadillo) by the shape, consistency, odor, and food composition, while the other species also require association with the remains of animals observed in the collection sites.

Bang \& Dahlström (1974) made a huge contribution to solving the question when they published their illustrated field guide of tracks and signs of animals in Europe. The book also contains a detailed analysis of the shape, size, color, and food content of mammalian feces. Other field guides, although rarely mentioned in the scientific literature, are excellent aids for identifying animal feces from the region for which they were developed, and obviously also for coprolites, including the keys by Burt \& Grossenheider (1976), Murie (1974), Halfpenny \& Biesiot (1986), Russo \& Olhausen (1987), Estes (1992), Walker (1996), Stuart \& Stuart (1998), Lienbeberg (2000), and Kingdon (2001), among others.

In order to combine the existing information on the identification of feces and make it available in a scientific publication to support paleoparasitology, Chame (2003) conducted a morphometric compilation of the available data on feces of European, North American, and African mammals and original data from Brazil. This article's analysis corroborates observations by Seton (1925), with a classification of the shapes of feces from the orders of land 
mammals. Many years of research experience with mammalian feces from the São Raimundo Nonato archaeological region in southeastern Piauí State, Brazil, allowed establishing a series of patterns for identifying feces, including other ecosystems (Plate 4).

Plate 4 - Shapes of feces from Brazilian land mammals

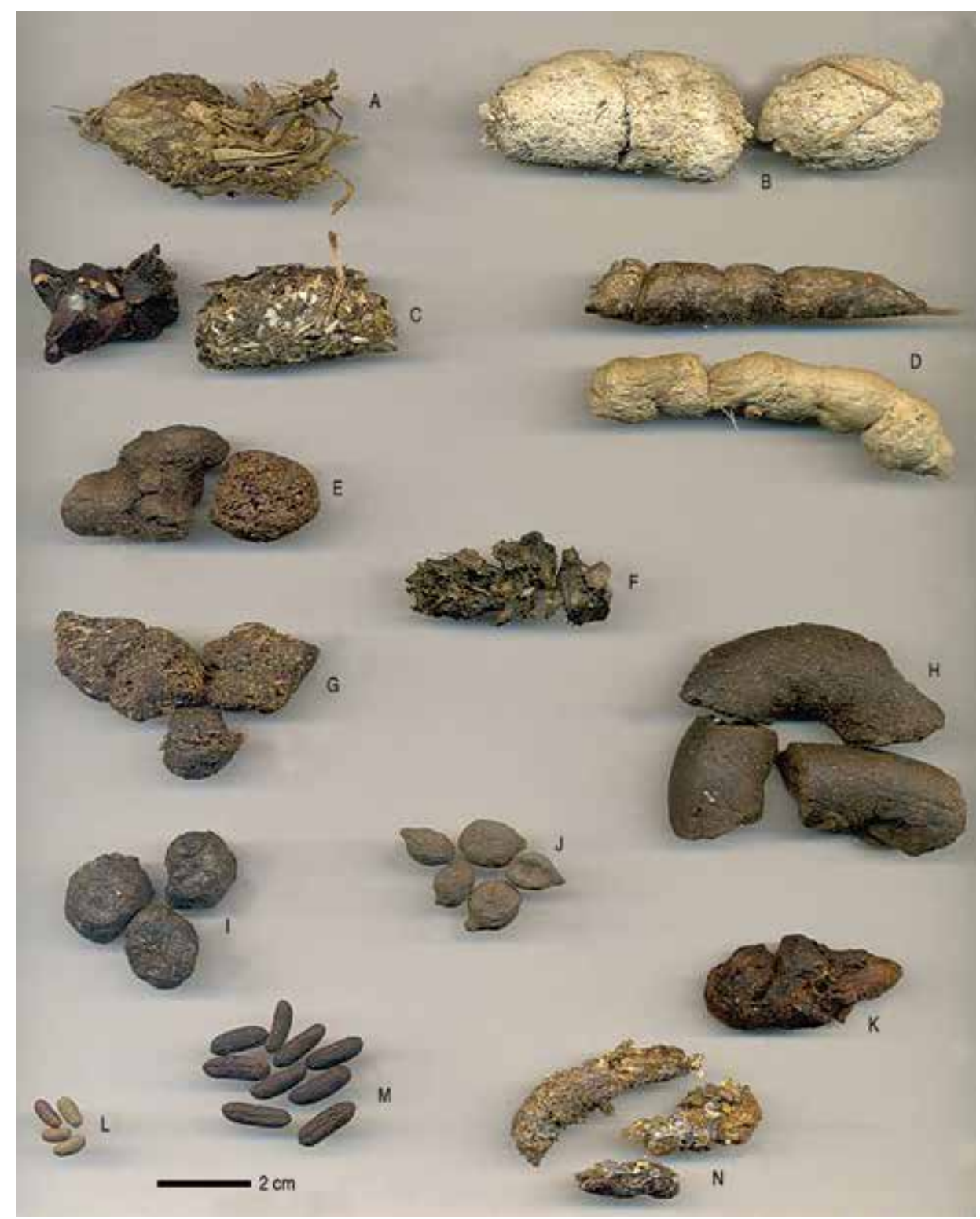

(A) Puma concolor (cougar), Serra da Capivara National Park, Piauí (PNSC, PI); (B) Panthera onca (jaguar), PNSC, PI; (C) Cerdocyon thous (fox), PNSC, PI; (D) Leopardus sp. (small spotted wildcats), PNSC, PI; (E) Dasypus novemcinctus (nine-banded armadillo), PNSC, PI; (F) Lutra longicaudis (neotropical river otter), Ipanema National Foresta, SP; (G) Tayassu pecari (white-lipped peccary), PNSC, PI; (H) Tamandua tetradactyla (collared anteater), PNSC, PI; (I) Pecari tajacu (collared peccary), PNSC, PI; (J) Mazama sp. (deer), PNSC, PI; (K) Alouatta caraya (black howler monkey), PNSC; (L) Galea spixii (yellow-toothed cavy), PNSC, PI; (M) Kerodon rupestris (rock cavy), PNSC, PI; (N) Cebus libidinosus (black-striped capuchin), PNSC, PI. 
Other efforts have been made to determine the set of parameters and necessary measures for diagnosing the origin of coprolites. In addition to the work mentioned above, Chame et al. (1991) established a methodology for comparing recent feces and coprolites from the Serra da Capivara National Park in Piauí State, which allowed developing the issue from a regional approach. Reinhard \& Bryant (1992) consolidated the systematization of a set of diagnostic parameters, and Jouy-Avantin et al. (2003) later proposed a detailed protocol of parameters for recording samples, including not only the date and location of the collection but a detailed external and internal description of the coprolites.

In addition to direct identification and microscopy, other techniques were developed to distinguish between feces of similar appearance, with methodological advances over previous proposals. In Mississippi, Major et al. (1980) analyzed biliary acids in feces to distinguish between scats from felids (Lynx rufus), canids (Canis latrans and Vulpes vulpes), raccoons (Procyon lotor), and domestic dogs and cats. According to these same authors, whatever the technique used to identify feces, it should allow distinguishing between morphometrically similar feces, the identification keys should be stable over time and resist chemical degradation, and analysis should be simple and relatively inexpensive.

According to Fernández, Corley \& Capurro (1997), the composition of biliary acids in feces is specific and is thus especially useful for distinguishing between carnivore species. The authors developed a methodology to determine the origin of feces using chromatography layers from the biliary acid patterns. They tested the methodology in feces from cougars (Felis concolor) and jaguars (Panthera onca), two sympatric species in the Paraguayan Chaco, and found it the best technique for identifying feces from these two species.

Some immunological diagnoses, when specific, can also be effective for determining the origin of coprolites and parasites. An example is the detection of Giardia intestinalis in coprolites and feces using immunofluorescence techniques and ELISA (enzyme-linked immunosorbent assay), available in commercial kits (Gonçalves et al., 2004; Bailly et al., 2008).

The available techniques and methods now include molecular biology tools. The first studies of ancient DNA were done on bone and tissue samples. A case with great repercussion was the Tyrolean Iceman, whose DNA analysis verified his European origin (Poinar, 1999). However, analyses of coprolites by molecular methods are more recent and involve the detection of DNA fragments that are already extensively degraded, which requires a bit of luck. Currently, vestiges of ancient DNA have been recovered from coprolites, and their identification aids facilitates the latter's zoological identification, determination of food items consumed, and even the identification of parasites where these have not been preserved morphologically due to taphonomic processes.

With the same diagnostic objective, this methodology has made strides in ecological studies using feces as a sampling unit (Reed et al., 1997; Farrel, Roman \& Sunquist, 2000; Fedriani \& Kohn, 2001). Miotto et al. (2007a, $2007 \mathrm{~b}$ ) consider the results of this identification essential for studying the population dynamics of rare, threatened, or large species that are difficult to capture and indicate the technique's efficiency and accuracy.

The main concern when seeking to recover ancient DNA in coprolites involves the steps to avoid the sample's contamination with current DNA from the environment or from the researchers collecting and handling the sample, from the field to the laboratory.

Contamination should be avoided by using disposable and sterile material in all stages and processes involved in analyzing the sample. The laboratories should be specially prepared with clean equipment and environments. Analyses should be replicated, have a control group, and be performed in different laboratories for comparison and control. Proper packing of the sample is also essential, because after samples are removed from the archaeological site they can be exposed to variations in temperature, humidity, and other physical and chemical factors that can potentially degrade the molecular remains. 
A solution for containing degradation is refrigeration of the sample, which requires planning and infrastructure proportional to the distance between the archaeological site (usually in a difficult-to-access rural area) and the laboratory, located in a large city. The conditions should be guaranteed during transportation from the field to the laboratory and in the installations of the biological collection responsible for the material.

Proper attention to these measures has produced encouraging results with coprolite specimens from various regions of the world. Sutton (1996) identified human coprolites as to the sex of the individuals that produced them, highlighting the importance of these results for studies aimed at distinguishing variations in diet between the sexes. Wood et al. (2008) identified coprolites of extinct bird species from New Zealand. Meanwhile, Gilbert et al. (2008) recovered human mitochondrial DNA from coprolites in Oregon, USA, thereby moving the dating of human occupation of North America back to 12,300 BP. The coprolites belonged to Amerindians that lived in the period prior to the Clovis culture, more than 11,000 BP. To guarantee the results' veracity, the samples were analyzed in different laboratories, and all the researchers handling the material had their DNA tested and compared to the results in order to rule out contamination.

DNA from Enterobius vermicularis and Ascaris lumbricoides has already been identified in old World and New World human coprolites (Iñiguez et al., 2006; Leles et al., 2008), and DNA from chloroplasts of plants found in them was recovered by Reinhard et al. (2008), performing identification of plants with medicinal properties used by ancient populations. Since most coprolite specimens are not found together with skeletons, artifacts, and remains, the results described above show the potential of DNA analyses for zoological identification of coprolites, leaving no doubt as to their origin.

Although the techniques continue to improve, the first and perhaps most important diagnosis of a coprolite will certainly continue to be the decision by the field researcher to collect it into his rucksack or leave it in nature. At this moment, the shape, size, and visible food remains are undoubtedly the factors that influence this decision. Likewise, what else would lead us to pick up a lost pen drive, if not its size, shape, color, brand, make, and state of preservation, and above all the desire to unveil the secrets stored inside it?

\section{IDENTIFICATION OF ZOOLOGICAL ORIGIN BY DIETARY STUDIES: THE MODEL FROM THE SERRA DA CAPIVARA NATIONAL PARK IN PIAUÍ, BRAZIL}

Laboratories will probably not be able to conduct more sophisticated analyses of all the samples received, and the simpler methodologies will probably not become obsolete, at least for the initial workup. It is therefore useful to discuss how a set of basic information can provide an approximate diagnosis of the coprolite's origin, and how the sample can then be submitted to more in-depth investigation if it proves interesting.

However, in some situations the coprolite's identification is not conclusive with available methods, sometimes even with DNA analysis. One may also want more information beyond diagnosis of the origin, such as remains that may indicate the species' way of life.

In such cases, nothing is more comprehensive than studies on diet, since they position the coprolite's producer within its food web, reflecting the environment in which it lived. Thus, at least 50,000 years ago, coprolites were deposited in the sedimentary layers in the region that served as the birthplace of American humans - the Serra da Capivara National Park and its surrounding area in southeastern Piauí, now characteristic of the Brazilian semiarid region. The excavations launched there in the 1970s allowed the collection and study of a major sampling of coprolites, in addition to comparison with modern mammalian feces. The region underwent various climatic transformations 
since then, from more humid periods, with forests and fields, to the present semiarid caatinga or scrub forest, thus influencing the occurrence of the species found there (Araújo et al., 1998) and preservation of the coprolites.

The elements in this transition can be observed in the macro and microfossils found in the coprolite specimens from the Serra da Capivara National Park in Piauí. The currently known vertebrate fauna in this site consists of 33 species of non-flying mammals, 24 bats, 208 birds, 19 lizards, 17 snakes, and 17 amphibians (Araújo et al., 1998). The most extensively studied coprolites are those of mammals, since they are the easiest to identify and the most likely to be confused with those of humans. Identification of coprolites from this region has been facilitated by the pioneering work of Chame (1988). However, their morphometry becomes useless when the coprolite is too degraded by taphonomic processes or destroyed during transportation.

Archaeology teams do not habitually draw or photograph coprolites in excavation layers, which would greatly facilitate the material's zoological identification, but would also doubtless increase their fieldwork time. Under such conditions, without the sample's shape and size, identification depends on studying food elements found in the coprolite. The composition and specificity of the food items obviously vary according to the target region, seasonality (as reflected by the food supply), and especially each group's eating and cultural habits. The work is thus greatly facilitated by knowing the dynamics of the region's occupation, factors limiting survival, and the local fauna and flora.

The most frequently found coprolite in the Serra da Capivara National Park is definitely from the species Kerodon rupestris (rock cavy). This medium-sized rodent inhabits rocky mountain ledges and has the habit of defecating in large dropping sites that last for generations and are used by various individual animals.

The analysis of macrofossils typically reveals abundant plant fibers, which tell little about the species in question. Microfossils show the greatest differences. Rock cavy droppings display a wealth of plant tissues not seen in other species and feature large amounts and good preservation. Charcoal fragments are common, possibly indicating that these animals consumed food scraps from humans. The feces are resinous due to the consumption of tree bark, such as angico (Anadenanthera macrocarpa), common in the region. Importantly, among the species of even-toed ungulates (deer and peccaries), the shape of feces from white-lipped and collared peccaries needs to be well-preserved, or they easily be confused with human feces. The main difference is the almost complete digestion of all the microscopic remains, which is not common in the microscopic examination of human feces.

Meanwhile, pellets from brocket deer (Mazama sp.) are rich in plant tissues. Microscopic examination shows entire plant structures and a wealth of small seeds and pollen (deer are flower eaters), but a slighter smaller variety of leaf epidermis than in feces of rock cavy, a leaf-eating species. Charcoal is also less common, although it does occur in some samples.

Coprolites from the collared anteater (Tamandua tetradactyla) are easy to identify, since the species feeds basically on termites and ants, the structures of which, such as pieces of chitin, heads, thoraces (sometimes whole), legs, and antennae are easily recognized in macrofossils. Fragments of other insects can also be observed under the microscope, although in smaller amounts.

Coprolites of small and large felines are easily identified macroscopically because they contain large amounts of hairs, bones, teeth, and occasionally feathers and a few arthropods (in small cats), in addition to their peculiar shape. Microscopic analysis of the diet shows virtually no microfossils, consisting basically of cell remains from digested foods, commonly referred to as debris. 
Guard hairs, ingested during grooming, and the hair of consumed prey are key elements, allowing the specific identification of the diet's composition in these species (Figure 1).

Coprolites often show masses of leaves ingested to facilitate digestion and formation of the food bolus when there is excess hair and bones to eliminate (Plate 4, Figure A).

It is possible to find intact teeth and tiny mandibles, long bones of rodents, and armadillo claws and shells. Some coprolites from cougars or jaguars (Puma concolor and/or Panthera onca) from this region display a considerable amount of shellfish remains. The typical whitish color of coprolites from large cats is due to the important amount of calcium from ingested bones, which allows identification even when the coprolite is totally fragmented.

Figure 1 - Microscopic appearance of the diet in a coprolite from a small cat in the Serra da Capivara National Park, Piauí, with the presence of hair. Magnification 400x

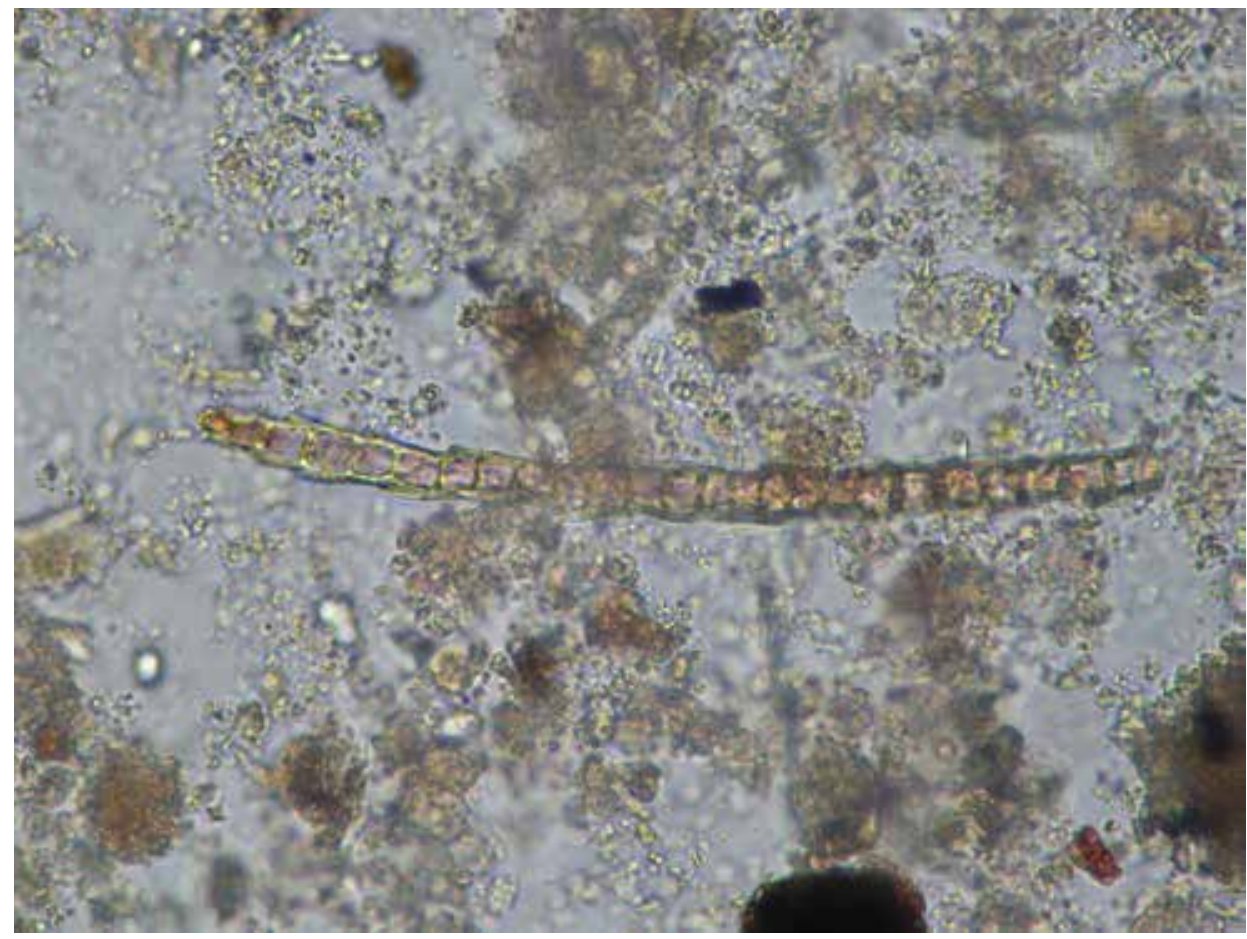

Coprolites of wild canids display a characteristically brittle ("granola"-like) appearance (Plate 4, Figure C). They consist of large amounts of arthropod fragments, sometimes entire parts like the post-abdomen of a scorpion, feathers, bird claws and bones, scales, reptile claws and bones, and abundant seeds. The remains of small mammals are only found rarely. Due to these characteristics, these coprolites tend to crumble easily during transportation, but are still identifiable without major difficulties. The microfossils consist mostly of arthropod remains and plant tissues.

Primate coprolites (when dry) have a denser texture as compared to those of canids, due to their higher moisture content when excreted. Their composition varies from species to species due to eating habits. They all consist basically of fruits and leaves. However, coprolites of black howler monkeys (Alouatta caraya) display mostly intact seeds (they are seed dispersers), abundant plant epidermis remains (since they are basically leaf-eaters), and rarely arthropod remains 
(Moura \& McConkey, 2007). Coprolites of black-striped capuchins (Cebus libidinosus) have the same appearance, but are smaller. Intact seeds are infrequent (they are seed predators), arthropod and leaf remains are abundant, and small bones of amphibians or even small mammals, including bats, are common (Moura \& McConkey, 2007; Falótico, 2008)

Coprolites of armadillos (Dasypodidae) are frequently confused in appearance with human coprolites, sometimes in both the macroscopic and microscopic analyses. There is a strong presence of Isoptera insect remains (ants and termites) and other arthropods in fecal samples of all armadillo species, in addition to plant remains, although amounts of the latter vary according to the species. An example is Euphractus sexcinctus (six-banded armadillo), which has the most varied feeding habits, including fruits and invertebrates, among species of Dasypodidae. In the other species, the differences are difficult to systematize such as to allow an approximation of the species.

It is important to recall the ant-eating habits of some human populations, which in some situations can complicate the diagnosis. In this case the diet does not apply to identification.

Human coprolites are definitely the greatest challenge. To positively identify a human coprolite without morphometry requires a detailed analysis of all the items found. Omnivorous eating habits mean that human coprolites can be confused with those of other animals. Attention to details, even subtle ones, can make the difference. Authors like Bryant \& Willians-Dean (1975) and Ferreira, Araújo \& Confalonieri (1980) report that the presence of charcoal in coprolites indicates human origin.

Unfortunately, this parameter does not apply to the coprolites studied in Piauí. Rock cavy, feline, canid, and deer coprolites also contain charcoal, so the simple finding of charcoal does not suffice to indicate the coprolite's zoological origin. A common structure in microscopic analysis of human samples is a kind of spherically-shaped fat. It is not possible to state whether it is really ingested and degraded fat, but it has served as a potential clue for identifying the material's human origin.

Figure 2 - Microscopic appearance (400x) of a human coprolite from Piauí, rich in plant remains, including starch and various charcoal fragments

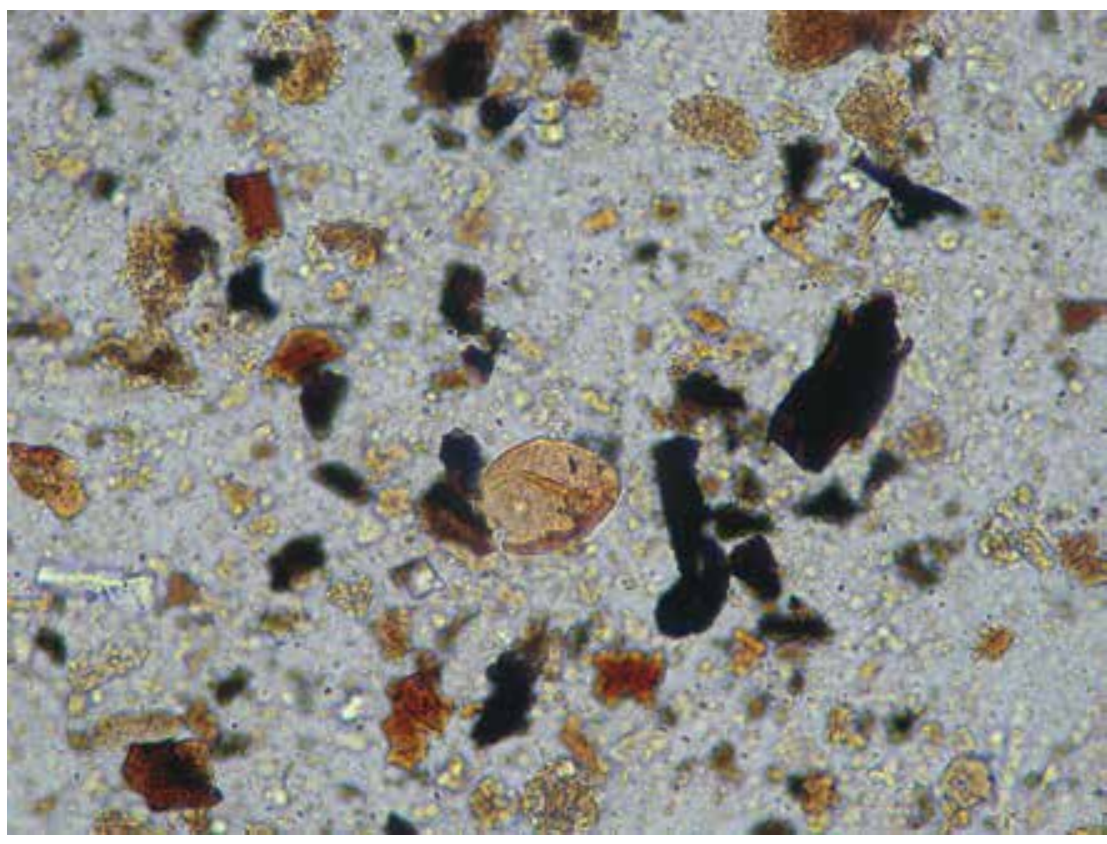


Starch grains are a relevant finding in coprolite specimens. Starch ingestion indicates important food sources and reflects relevant aspects of a species' paleoecology.

However, finding starch in a sample should be interpreted with caution. In Brazil, commercially sold laboratory gloves are powdered with corn starch. Thus, in the attempt to avoid contamination of coprolites for DNA testing, contamination with starch occurs, which compromises diet studies in coprolites. Therefore, in both the field and the laboratory, gloves should be starch-free, since starch is light and disperses easily in the environment.

\section{ACKNOWLEDGEMENTS}

The authors wish to thank Rita Soares Nunes for assisting in selecting and authorizing the use of the photographs and Dr. Norma Wollmer Labarthe for revising and making suggestions to the manuscript.

\section{REFERENCES}

ANACLETO, T. C. S. Food habits of four armadillo species in the Cerrado area, Mato Grosso, Brazil. Zoological Studies, 46: 529537, 2007.

ANDELT, W. F. et al. Variation in coyote diet associated with seasonal and successional changes in vegetation. Journal of Wildlife Management, 51: 273-277, 1987.

ARAÚJO, A. Contribuição ao Estudo de Helmintos Encontrados em Material Arqueológico no Brasil, 1980. Master's thesis, Rio de Janeiro: Fundação Oswaldo Cruz.

ARAÚJO, A. Paleoepidemiologia da Ancilostomose, 1987. PhD dissertation, Rio de Janeiro: Fundação Oswaldo Cruz.

ARAÚJO, A.; FERREIRA, L. F. \& CONFALONIERI, U. A contribution to the study of helminth findings in archaeological material in Brazil. Revista Brasileira de Biologia, 41: 873-881, 1981.

ARAÚJO, A. J. G.; RANGEL, A. \& FERREIRA, L. F. Animal parasitic infection and climate change in Northeastern Brazil. Memórias do Instituto Oswaldo Cruz, 88(4): 577-579, 1993.

ARAÚJO, A. et al. Parque Nacional Serra da Capivara. Piauí: Fumdham, 1998.

ARTHUR III, W. J. \& ALLDREDGE, A. W. Seasonal estimates of masses of mule deer fecal pellets and pellets groups. Journal of Wildlife Management, 44: 750-752, 1980.

BAILEY, R. E. \& PUTMAN, R. J. Estimation of fallow deer (Dama dama) populations from faecal accumulation. Journal of Applied Ecology, 18: 697-702, 1981.

BAILLY, M. L. et al. New finding of Giardia intestinalis (Eukaryote, Metamonad) in Old World archaeological site using immunofluorescence and enzyme-linked immunosorbent assays. Memórias do Instituto Oswaldo Cruz, 103: 298-300, 2008.

BANG, P. \& DAHLSTRÖM, P. Animal Tracks and Signs. Collins, 1974.

BATCHELER, C. L. Development of a distance method of deer census from pellet group. Journal of Wildlife Management, 39: 641652, 1975.

BOWDEN, D. C.; ANDERSEN, A. E. \& MEDin, D. E. Frequency distribution of mule deer fecal group counts. Journal of Wildlife Management, 33: 895-905, 1969.

BRUNNER, H.; LLOYD, J. W. \& COMAN, B. J. Fox scat analysis in a forest park in Southeastern Australia. Australian Wildlife Research, 2: 147-154, 1975.

BRYANT, V. M. \& WILLIAMS-DEAN, G. The coprolites of man. Scientific American, 232 (1): 100-109, 1975. 
BUCKLAND, W. On the discovery of coprolites, or fossils faeces, in the Lias at Lyme Regis, and in other formations. Transactions of the Geological Society of London, II, 3: 223-236, 1829a.

BUCKLAND, W. On the discovery of a new species of pterodactyl; and also of the faeces of the Ichthyosaurus; and of a black substance resembling sepia, or Indian ink, in the Lias at Lyme Regis. Proceedings of the Geological Society of London, I: 96-98, 1829b.

BUCKLAND, W. Letter from the Rev. Dr. W. Buckland, F. R. S. \& c. Professor of Mineralogy and Geology in the University of Oxford, on the discovery of coprolites in North America. Philosophical Magazine, 7(41): 321-323, 1830.

BURT, W. H \& GROSSENHEIDER, R. P. A Field Guide to the Mammals. $3^{\text {rd }}$ Ed. Boston: Houghton Mifflin Company, 1976.

CÁCERES, N. C. et al. Mammals of the Bodoquena Mountains, southwestern Brazil: an ecological and conservation analysis. Revista Brasileira de Zoologia, 24 (2): 426-435, 2007.

CALLEN, E. O. \& CAMERON, T. W. M. A pre-historic diet revealed in coprolites. New Scientist, 7: 35-40, 1960.

CHAME, M. Estudo Comparativo das Fezes e Coprólitos não Humanos da Região Arqueológica de São Raimundo Nonato, Sudeste do Piauí, 1988. Master's thesis, Rio de Janeiro: Museu Nacional, Universidade Federal do Rio de Janeiro.

CHAME, M. Terrestrial mammal feces: a morphometric summary and description. Memórias do Instituto Oswaldo Cruz, 98, supl. I: 71-94, 2003.

CHAME, M. et al. Experimental paleoparasitology: an approach to the diagnosis of animal coprolites. Paleopathology Newsletter, 76: 7-9, 1991.

CONFALONIERI, U. Paleoparasitologia do gênero Trichuris Roederer, $1768 \mathrm{com}$ um estudo paleoepidemiológico sobre a origem do Trichuris trichiura (Linn) na América (Nematoda: Trichuridae), 1983. PhD dissertation, Rio de Janeiro: Universidade Federal Rural do Rio de Janeiro.

DANNER, D. A. \& DODD, N. Comparison of coyote and gray fox scat diameters. Journal of Wildlife Management, 46: $240-241,1982$.

DINERSTEIN, E. \& DUBLIN, H. T. Daily defecation rate of captive axis deer. Journal of Wildlife Management, 46: 833-835, 1982.

DORMONT, L. et al. Influence of dung volatiles on the process of resource selection by coprophagous beetles. Chemoecology, 17: 23-30, 2007.

DZIECIOLOWSKI, R. Roe deer census by pellet-group counts. Acta Theriologica, 21: 351-358, 1976.

EAMES, A. J. Report on ground sloth coprolite from Dona Ana County, New Mexico. American Journal of Science, 20: 353-356, 1930.

EDDY, T. A. Foods and feeding patterns of the collared peccary in Southern Arizona. Journal of Wildlife Management, 25: 248-257, 1961.

EMMONS, L. H. Comparative feeding ecology of felids in a Neotropical Rainforest. Behavioral Ecology and Sociobiology, 20: 271283, 1987.

ESTES, R. D. The Behavior Guide to African Mammals: including hoofed mammals, carnivores, primates. Los Angeles: University of California Press, 1992.

FALÓTico, T. Macacos-prego: Parque Nacional Serra da Capivara. Piauí: Fumdham, 2008.

FARREL, L. E.; ROMAN, J. \& SUNQUIST, M. E. Dietary separation of sympatric carnivores identified by molecular analysis of scats. Molecular Ecology, 9(10): 1.583-1.590, 2000.

FEDRIANI, J. M. \& KOHN, M. H. Genotyping faeces links individuals to their diet. Ecology Letters, 4(5): 477-485, 2001.

FERNÁNDEZ, G. J.; CORLEY, J. C. \& CAPURRO, A. F. Identification of cougar and jaguar faeces through bile acid chromatography. Journal of Wildlife Management, 61(2): 506-510, 1997.

FERREIRA, L. F.; ARAÚJO, A. \& CONFALONIERI, U. The finding of eggs and larvae of parasitic helminthes in archaeological material from Unaí, Minas Gerais, Brazil. Transactions of the Royal Society of Tropical Medicine and Hygiene, 74: 798-800, 1980.

FERREIRA, L. F. et al. Trichuris eggs in animal coprolites dated from 30,000 years ago. The Journal of Parasitology, 77: $491-493,1991$. 
FITZGERAlD, A. E. \& WADDINGTON, D. C. Comparison of two methods of fecal analysis of herbivore diet. Journal of Wildlife Management, 43: 468-473, 1979.

FLOYD, T. J.; MECH, L. D. \& JORDAN, P. A. Relating wolf scat content to prey consumed. Journal of Wildlife Management, 42: 528-532, 1978.

FOX, J. L. \& SMITH, C. A. Winter mountain goat diets in Southeast Alaska. Journal of Wildlife Management, 52: 362-365, 1988.

FRY, G. F. Preliminary analysis of the Hogup Cave coprolites. In: AIKENS, C. M. Hogup Cave. Salt Lake City: University of Utah Press, 1970. (University of Utah Anthropological Papers, 93)

FRY, G. F. Analysis of Prehistoric Coprolites of Utah. Utah: University of Utah Press, 1976. (Anthropological Papers, 97)

FRY, G. F. \& HALL, H. J. Parasitological examination of prehistoric human coprolites from Utah. Proceedings of the Utah Academy of Science, Arts, and Letters, 46(2): 102-105, 1969.

FRY, G. F. \& MOORE, J. G. Enterobius vermicularis: 10,000 year-old human infection. Science, 166: 1.620, 1969.

GILBERT, A. T. P. et al. DNA from Pre-Clovis human coprolites in Oregon, North America. Science, 320: 786-789, 2008.

GONÇALVES, M. L. C. et al. Detection of Giardia duodenalis antigen in coprolites using a commercially available enzyme immunoassay. Transactions of the Royal Society of Tropical Medicine and Hygiene, 98: 88-91, 2004.

GRANT, T. R. The shape of fecal pellets of red and grey kangaroos. Australian Mammalogy, 1: 261-263, 1974.

GREE, J. S. \& FLINDERS, J. T. Diameter and pH comparisons of coyote and red fox scats. Journal of Wildlife Management, 45: 765-767, 1981.

GREEN, M. J. B. Diet composition and quality in Himalayan musk deer based on fecal analysis. Journal of Wildlife Management, 51: 880-892, 1987.

GRZWINSKI, L. Analyses of feces from the middle age period. Zoologica Poloniae, 10: 195-199, 1959-1960.

GUERRA, R. M. S. N. C. et al. Ecological analysis of Acari recovered from coprolites from archaeological site of Northeast Brazil. Memórias do Instituto Oswaldo Cruz, 98, supl.1: 181-190, 2003.

HALFPENNY, J. \& BIESIOT, E. A Field Guide to Mammal Tracking in North America. $2^{\text {nd }}$ Ed. Colorado: Johnson Publishing, 1986.

HARSHBERGER, J. W. The purposes of ethno-botany. Botanical Gazette, 21: 146-154, 1896.

HEIZER, R. F. \& NAPTON, L. K. Biological and cultural evidence from prehistoric human coprolites. Science, 165: 563-568, 1969.

HOMingER, E. M.; DALE, A. R. T. \& BAILEY, J. A. Shrubs in the summer diet of Rocky Mountain bighorn sheep. Journal of Wildlife Management, 52: 47-50, 1988.

HUSON, L. W. \& DAVIS, R. A. Discriminant functions to aid identification of faecal pellets of Rattus novergicus and Rattus rattus. Journal of Stored Products Research, 16: 103-104, 1980.

IÑIGUEZ, A. M. et al. SL1 RNA gene recovery from Enterobius vermicularis ancient DNA in pre-Columbian human coprolites. International Journal for Parasitology, 36: 1.419-1.425, 2006.

JOHNSON, M. K. \& HANSEN, R. M. Estimating dry weights per occurrence for taxa in coyote scats. Journal of Wildlife Management, 42: 913-915, 1978.

JONES, A. K. G. Human parasite remains: prospects for a quantitative approach. In: HALL, A. R. \& KENWARD, H. K. Environmental Archaeology in the Urban Context. Research Report 43, Council for British Archaeology, 1982.

JOUY-AVANTIN, F. A standardized method for the description and the study of coprolites. Journal of Archaeological Science, 30: $367-$ 372, 2003.

KINGDON, J. The Kingdon Field Guide to African Mammals. Princeton: Academic Press, 2001.

KOHN, M. H. \& WAYNE, R. K. Facts from faeces revisited. Trends in Ecology and Evolution, 12: 223-227, 1997. 
LANCIA, R. A.; NICHOLS, J. D. \& POLLOCK, K. H. Estimating the number of animals in wildlife populations. In: BOUKHOUT, T. A. Research and Management Techniques for Wildlife and Habitats. Bethesda: The Wildlife Society Inc., 1996.

LELES, D. et al. Molecular paleoparasitological diagnosis of Ascaris sp. from coprolites: new scenery of ascariasis in pre-Columbian South American times. Memórias do Instituto Oswaldo Cruz, 103(1): 106-108, 2008.

LEY, R. E. et al. Evolution of mammals and their gut microbes. Science, 320: 1.647-1.651, 2008.

LIEBENBERG, L. Tracks and Tracking in Southern Africa. Cape Town: Struik Publishers, 2000.

MAJOR, M. et al. Identifying scats by recovery of bile acids. Journal of Wildife Management, 44: 290-293, 1980.

MIOTTO, R. A. et al. Identification of pumas (Puma concolor (Linnaeus, 1771) through faeces: a comparison between morphological and molecular methods. Brazilian Journal of Biology, 67: 963-965, 2007a.

MIOTTO, R. A. et al. Determination of the minimum population size of Pumas (Puma concolor) through fecal DNA analysis in two protected cerrado areas in the Brazilian southeast. Biotropica, 39: 647-654, 2007b.

MITCHELL, B. et al. Defecation frequency in roe deer (Capreolus capreolus) in relation to the accumulation rates of fecal deposits. Journal of Zoology (A), 207: 1-7, 1985.

MOURA, A. C. A. \& McCONKEY, K. R. The Capuchin, Howler, and the Caatinga: Seed dispersal by monkeys in a threatened Brazilian Forest. American Journal of Primatology, 69: 220-226, 2007.

MURIE, O. J. Animal Tracks. $2^{\text {nd }}$ Ed. New York: National Audubon Society, 1974. (Peterson Field Guide Series)

NEFF, D. J. The pellet-group count technique for big game trend, census, and distribution: a review. Journal of Wildlife Management, 32 (3): 597-614, 1968.

PATTON, S. et al. A coprological survey of parasites of Neotropical Felidae. The Journal of Parasitology, 72(4): 517-520, 1986.

POINAR, H. N. DNA from fossils: the past and the future. Acta Paediatrica, 433: 133-140, 1999.

RABINOWITZ, A. R. \& NOTTINGHAM JR, B. G. Ecology and behaviour of the jaguar (Panthera onca) in Belize. Central America. Journal of Zoology (A), 210: 149-159, 1986.

REED, J. et al. Molecular scatology: the use of molecular genetic analysis to assign species, sex and individual identity to seal faeces. Molecular Ecology, 6: 225-234, 1997.

REINHARD, K. J. \& BRYANT JR, V. M. Coprolite analysis: a biological perspective on archaeology. In: SCHIFFER, M. B. Advances in Archaeological Method and Theory. New York: Academic Press, 1992. v. 4.

REINHARD, K. J. et al. Evaluating chloroplast DNA in prehistoric Texas coprolites: medicinal, dietary, or ambient ancient DNA? Journal of Archaeological Science, 35: 1.748-1.755, 2008.

REY, L. Parasitologia. $4^{\text {th }}$ Ed. Rio de Janeiro: Guanabara Koogan, 2008.

RINEY, T. The use of faeces counts in studies of several free-ranging mammals in New Zealand. New Zealand Journal of Science and Technology Sec B, 38: 507-532, 1957.

ROGERS, L. L. Seasonal changes in defecation rates of free-ranging white-tailed deer. Journal of Wildlife Management, 51:330333, 1987.

RUSSO, R. \& OLHAUSEN, P. A Guide to Mammals of the Pacific Coast States, their Tracks, Skulls and other Signs (Nature Study Guides). California: Wilderness Press, 1987.

SETON, E. T. On the study of scatology. Journal of Mammalogy, 6: 47-49, 1925.

SIANTO, L. Parasitismo por Echinostoma sp. (Trematoda: Digenea: Echinostomatidae) em Populações Pré-Colombianas: um estudo de caso, 2004. Master's thesis, Rio de Janeiro: Fundação Oswaldo Cruz. 
STRONG, L. L. \& FREDDY, D. J. Number of pellets per mule deer defecation. Journal of Wildlife Management, 43: 563-565, 1979.

STUART, C. \& STUART, T. A Field Guide to the Tracks and Signs of Southern and East African Wildlife. Cape Town: Southern Books Publishers, 1998.

SUTTON, M. Q. Experiments on the determination of gender from coprolites by DNA analysis. Journal of Archaeological Science, 23: 263-267, 1996.

VON GADOW, K. A pellet count of Bleu Druiker and Bushbuck in the Knysna Forest. South African Forestry Journal, 107: 77-81, 1978.

VOTH, E. H. \& BLACK, H. C. A histologic technique for determining feeding habits of small herbivores. Journal of Wildlife Management, 37: 223-231, 1973.

WALKER, C. Signs of the Wild. Cape Town: Struik Publishers, 1996.

WEAVER, J. L. \& FRITTS, S. H. Comparison of coyote and wolf scat diameters. Journal of Wildlife Management, 43: 786-788, 1979.

WELCH, D. Dung properties and defecation characteristics in some Scottish herbivores, with an evaluation of dung-volume method of assessing occupance. Acta Theriologica, 27: 191-212, 1982.

WHITE, G. C. \& EBERHARDT, L. E. Statistical analysis of deer and elk pellet-group data. Journal of Wildlife Management, 44:121-131, 1980.

WILKE P. J. \& HALL, H.J. Analysis of Ancient Feces: a discussion and annotated bibliography. California: Department of Anthropology, University of California, Berkeley, 1975. (Archaeological Research Facility)

WOOD, J. R. et al. Coprolite deposits reveal the diet and ecology of the extinct New Zealand megaherbivore moa (Aves, Dinornithiformes). Quaternary Science Reviews, 27: 2.593-2.602, 2008.

WUCHERER, O. E. H. A moléstia como parte do plano da creação. Gazeta Médica da Bahia, 1: 129, 1866. 


\title{
Paleoserology
}

\author{
Carlos Maurício de Andrade
}

$\mathrm{T}_{\mathrm{r}}^{\mathrm{h}}$

he application of serological techniques to paleobiological material from ancestral populations is highly relevant

for the identification of antigenic molecules from parasites, allowing the diagnosis of extant infections in these populations. The main molecular targets are the proteins present in ancient material, of both animal origin and human origin.

Working with samples in a good state of preservation, containing proteins or peptides with preserved epitopes, it is possible to identify these molecules with serological techniques using polyclonal or monoclonal antisera against specific target antigens.

Before the emergence of modern serological techniques, pioneering studies were developed by Boyd \& Boyd (1933, 1934a, 1934b), aimed at determining the ABO blood group in preserved muscle tissue. The same authors (Boyd \& Boyd, 1937), applying the precipitin test to tissues from 94 Egyptian mummies, found only four positive samples and one indeterminate sample in the ABO system. Using the same approach in 159 samples from ancient Americans, they only found two positive samples and seven indeterminate ones.

Candela (1936) observed inconsistent reactions in A and B group serotyping, working with ancestral human skeletons and using high-titer antisera that did not react with A or B antigens present in low concentrations. The conclusion in these cases was false-positive group 0.

These results showed the need to improve the serological methods used at that time. Thus, serological techniques were developed that allowed more precise determination of the $\mathrm{ABO}$ system, the identification of which can now be done with greater precision in mummified tissues. Given that this identification depends on specific antigens present in the red blood cells and other tissues, and since optimized production became possible for antisera with specific antibodies using the Freund adjuvant in their elaboration, anti-ABO antisera with higher sensitivity were developed.

The use of these antisera in precipitation, agglutination inhibition, and cell mixture agglutination tests serves as a precious tool when applied to ancestral tissues, aimed at finding this system's antigen markers. 
Rather than components of the $\mathrm{ABO}$ system, in some circumstances anti-ABO antibodies are found in the materials tested, and this procedure is thus called a reverse or indirect test. The agglutination test in a cell mixture, developed by Coombs, Bedford \& Rouillard (1956), aimed at identifying the blood group in blood-deficient material, allowed Otten $\&$ Florey (1963) to determine the blood group in tissues from Chilean mummies.

Lippold (1971) later used the agglutination technique applied to cell mixture and demonstrated the perpetuation of the $\mathrm{ABO}$ system among current indigenous populations and prehistoric populations from the Aleutian Islands, Southwest United States, Peru, and Chile.

Stastny (1974), using agglutination inhibition for characterization of the HL-A system, found similarities between prehistoric Amerindian populations and modern indigenous populations. The author also observed that the profile of the HL-A system in mummies found on the Peruvian coast perfectly matched the general profile of Amerindian populations.

The principal modern immunedetection techniques feature immunoenzymatic, immunofluorescence, and immunochromatography (dipstick) assays, which have been used in paleoserology with high sensitivity and specificity in the diagnosis of parasitic and non- parasitic diseases.

Faulkner, Patton \& Johnson (1989) used indirect immunofluorescence to examine eight desiccated human fecal samples from a cave in Van Buren County, Tennessee, USA, and identified Giardia cysts, among other enteroparasites. These findings were in material from prehistoric populations dated to approximately 2,177 BP. According to the authors, this was the first report of this finding in the New World.

Cattaneo et al. (1992) used ELISA (enzyme-linked immunosorbent assay) with monoclonal anti-albumin IgG and with sensitivity to detect $10 \mu \mathrm{g}$ of protein, applied to bone extracts from periods corresponding to the English Civil War (1644 AD), Middle Age (1100-1400 AD), early Saxon period (450-600 AD), Roman period (100-200 AD), Iron Age (approximately $400 \mathrm{BC}$ ), and Bronze Age (2200-1700 BC). The method proved sensitive and reproducible and can be used for the identification of other molecules such as HLA and ABO and as an ancillary tool in the identification of racial origin and predisposition to diseases in ancestral populations.

Immunoprecipitation tests by Lewin (1995) suggest, according to the author, that the lesions found on the face of the mummy of Pharaoh Ramses V (1156 to $1151 \mathrm{BC}$ ) were due to smallpox.

Allison, Bergman \& Gersten (1999), using direct immunofluorescence, identified Cryptosporidium sp. and Giardia sp. in feces from the intestine of mummies ranging from 500 to 3,000 BP. These findings were confirmed by immuneenzymatic tests in the same material. In a fecal sample of the same origin, the authors concurrently demonstrated the presence of Helicobacter pylori antigens in paleofeces dated circa 3,000 BP.

Cerutti et al. (1999), examining skin, muscle, and bone samples from Egyptian mummies dated to the pre-Dynastic period $(3200 \mathrm{BC}$ ) from the Gebelen region, found a Plasmodium falciparum antigen, histidine rich protein-2 (Pf HRP2). The analysis was done with immunoenzymatic assay, and the results suggest malaria prevalence on the order of $40 \%$ in mummies from the Gebelen group. The data are consistent with populations living in ecological conditions similar to malaria-endemic areas.

Gonçalves et al. (2002) examined feces from latrines situated in Medieval archaeological sites in France and diagnosed the presence of Giardia lamblia coproantigens using ELISA. Ortega \& Bonavia (2003) used immunofluorescence to examine 22 human coprolites from excavations along the northern coast of Peru and found three positive samples for Giardia sp. cysts in material dated between 2375 and 1525 BC. Another coprolite, dated between 770 and $830 \mathrm{AD}$, contained Cryptosporidium sp. oocysts, and a third coprolite, dated between 500 and $900 \mathrm{BP}$, also contained Giardia sp. cysts. 
Also using ELISA, Gonçalves et al. (2004), working with the same material used in the diagnosis of Giardia sp (Gonçalves et al., 2002), identified Entamoeba histolytica coproantigens. The target antigen was Gal-lectin from Entamoeba histolytica, an adhesin present in large amounts in the parasite membrane. In this case, a commercial Entamoeba histolytica anti-lectin monoclonal antibody kit was used (an antibody that specifically recognizes a single epitope of immunogenic proteins). This test is normally used in the parasite's specific routine laboratory diagnosis to distinguish between Entamoeba histolytica and Entamoeba dispar, morphologically identical species that constitute the so-called "histolytica complex".

Biannucci et al. (2007) used immunochromatography as a rapid diagnostic test for plague in ancient material, for the detection of Yersinia pestis F1 antigen.

Józsa (2008) made an interesting finding of glomerular lesions consistent with Berg's sub-acute focal glomerulonephritis in preserved tissues from Prince Joseph Palatinus of the Habsburg Dynasty, who died in 1847 at 71 years of age. Using immunohistochemistry, the author observed an IgA precipitate in both the glomerular mesangium and Bowman's capsule in the kidneys preserved in rosemary oil and stored with other organs in metal canisters. The precipitate was located by marking with avidin-biotin-peroxidase, conjugate, with diaminobenzidine as the chromophore.

\section{BASIS FOR THE TECHNIQUES USED IN PALEOSEROLOGY}

The most widely cited techniques for identifying antigens in paleobiological material have been ELISA and immunofluorescence. Their main advantage is the existence of diagnostic kits that facilitate laboratory procedures, with either polyclonal antibodies or monoclonal antibodies targeting a single antigen epitope, which in this case guarantees high sensitivity and specificity.

Each variant of ELISA has modifications described in the manufacturer's instructions for performing the respective technique.

As described above, the serological techniques used to identify parasite antigens in ancestral material prove sensitive and specific. The results thus allow a reliable diagnostic approach in materials of ancestral origin in order to make important paleoepidemiological inferences on currently observed parasitic diseases.

\section{REFERENCES}

ALLISON, M. J.; BERGMAN, T. \& GERSTEN, AND. Further studies on fecal parasites in antiquity. American Journal of Clinical Pathology, 112: 595-596, 1999.

BIANUCCI, R. et al. A rapid diagnostic test for plague detects Yersinia pestis antigen in ancient remains. Comptes Rendues de Biologie, 330: 747-754, 2007.

BOYD, W. C. \& BOYD, L. G. Blood grouping by means of preserved muscle. Science, 78: 578-579, 1933.

BOYD, W. C. \& BOYD, L. G. Group specificity of dried muscle and saliva. Journal of Immunology, 26: 489-494, 1934a.

BOYD, W. C. \& BOYD, L. G. An attempt to determine the blood groups of mummies. Proceedings of the Society of Experimental Biology and Medicine, 31: 671-672, 1934b.

BOYD, W. C. \& BOYD, L. G. Blood grouping tests on 300 mummies. Journal of Immunology, 32: 307-319, 1937. 
CANDELA, P. B. Blood group reactions in ancient human skeletons. American Journal of Physical Anthropology, 21: 429-432, 1936.

CATTANEO, C. et al. Reliable identification of human albumin in ancient bone using ELISA and monoclonal antibodies. American Journal of Physical Anthropology, 87: 365-372, 1992.

CERUTTI, N. et al. Immunological investigation of malaria and new perspectives in paleopathological studies. Bollettino della Società Italiana di Biologia Sperimentale, 75: 17-20, 1999.

COOMBS, R. R. A.; BEDFORD, D. \& ROUILLARD, L. M. A and B blood group antigens on human epidermal cells demonstrated by mixed agglutination. The Lancet, 270: 416-463, 1956.

FAULKNER, C. T.; PATTON, S. \& JOHNSON, S. S. Prehistoric parasitism in Tennessee: evidence from the analysis of desiccated fecal material collected from Big Bone Cave, Van Buren County, Tennessee. The Journal of Parasitology, 75: 461-463, 1989.

GONÇALVES, M. L. C. et al. Detection of Giardia duodenalis antigen in coprolites using a commercial available enzyme-linked immunosorbent assay. Transactions of the Royal Society of Tropical Medicine and Hygiene, 96: 640-643, 2002.

GONÇALVES, M. L. C. et al. Amoebiasis distribution in the past: first steps using an immunoassay technique. Transactions of the Royal Society of Tropical Medicine and Hygiene, 98: 88-91, 2004.

JóZSA, L. G. Histologic diagnoses of tissues from two nineteenth century Habsburgs. Paleopathology Newsletter, 141: 12-18, 2008.

LEWIN, P. K. Ventures in paleopathology: ‘mummy’ riddles unraveled. Germs Ideas, 1: 10-14, 1995.

LIPPOLD, L. K. The mixed cell agglutination method for typing mummified human tissue. American Journal of Physical Anthropology, 34: 377-383, 1971.

ORTEGA, Y. R. \& BONAVIA, D. Cryptosporidium, Giardia, and Cyclospora in ancient Peruvians. The Journal of Parasitology, 89: 635-636, 2003.

OTTEN, C. M. \& FLOREY, L. L. Blood typing of Chilean mummy tissue: a new approach. American Journal of Physical Anthropology, 21: 383-385, 1963.

STASTNY, P. HL-A antigens in mummified pre-Columbian tissues. Science, 183: 864-846, 1974. 


\title{
18
}

\section{Paleoparasitology and Ancient DNA}

\author{
Katharina Dittmar
}

Tnsights into the presence and composition of parasite fauna through time can be obtained either by direct specimen

evidence from fossil or archaeological material or by identifying or sequencing parasite DNA from the samples.

Direct evidence prevailed in the early days of paleoparasitology and was advanced by the development of coprolite rehydration techniques (Callen \& Cameron, 1960) and the modification and refinement of regular parasitological diagnostic techniques for paleoparasitological purposes (Reinhard, et al., 1986; Reinhard, 1988; Reinhard, 1992).

Evidence from direct methods mainly concerns parasite eggs and protozoan cysts. However, issues of taxonomic resolution often limit these techniques, since many parasite remains cannot be identified to the genus or species level.

The development of ancient DNA techniques allowed tracing parasitic diseases at the molecular level, sometimes without direct clues of parasitic infection or disease. Sequencing of parasite DNA began with Trypanosoma cruzi DNA from Chilean mummies (Guhl et al., 1999). Reports now cover a wide range of parasites, including protozoans, helminthes, and arthropod ectoparasites. This chapter reviews paleoparasitological DNA studies in the context of phylogenies, population genetics, and phylogeography.

\section{SAMPLES AND ANCIENT DNA PRESERVATION}

Ancient DNA pertains to specimens that range from a few decades old (e.g., museum specimens) to roughly 100,000 years (Knapp et al., 2008). According to Pääbo et al. (2004), any DNA reported to be millions of years old is actually an artifact.

The most conspicuous materials used in paleoparasitological research are coprolites and latrine sediments. Only occasionally, ectoparasites, soft tissues (e.g., from mummies), and bones are available. In mummy studies, the parasite's life cycle should be considered in order to choose the tissue that most likely contains developmental stages or DNA. An example is intestinal or heart tissue for Trypanosoma cruzi. In this case, crushed bone can also be used 
in the search for vestiges of preserved bone marrow, since T. cruzi reproduces in hematopoietic tissue (there is a high likelihood of recovering its genetic material from various tissues, especially those that produce or accumulate blood).

Most currently used paleoparasitological evidence concentrates on human samples (Horne, 1985). However, tremendous potential exists to study parasitism of animals, both domesticated and wild. Sources of animal paleoparasitological evidence include animal mummies (Dittmar, 2000; Shapiro \& Cooper, 2003; Beckman, 2004; Knudson et al., 2006). Other samples pertain to animal burials or preserved animal enclosures (Jones et al., 1988; Hall \& Kenward, 1998; Nielsen et al., 2000; Dittmar \& Teegen, 2003). Most of these examples are from domesticated or semi-domesticated animals. However, material from wild animals includes fecal materials accumulated over long periods of time in protected environments (such as permafrost or caves), like packrat or caribou middens, owl pellets, or bat guano, holding potentially important parasitological clues (Betancourt et al., 1990; Scott et al., 1996; Bell, 2000; Kuch et al., 2002; Smith \& Betancourt, 2006; Leroy \& Simms, 2006; Maher, 2006).

Several palynological and dietary studies have also been performed on hyena coprolites (Horwitz \& Goldberg, 1989; Carrión et al., 2000; Carrión et al., 2001; Yll et al., 2006).

Depending on the age and state of preservation, these samples may still contain DNA in varying stages of degradation. Specifically, this means that DNA is fragmented (100-500bp) and only present in low concentrations (Knapp et al., 2004). Additionally, mitochondrial DNA is preserved better than nuclear DNA, presumably due to endogenous differences in copy number (Pääbo et al., 2004). For instance, analysis of a 700 year-old Amerindian cemetery found that only $15 \%$ of the samples yielded single-copy nuclear DNA (Stone \& Stoneking, 1999).

Several methods have been developed to exclude samples that are unlikely to yield any results (Knapp et al., 2008). One approach assesses the biochemical preservation of a sample through amino acid conservation and concentrates on the evaluation of aspartic acid levels in the sample (Poinar \& Stanckiewicz, 1999; Pääbo et al., 2004). If a significant reduction beyond a certain level occurred, the sample may not contain amplifiable DNA. However, higher levels do not guarantee that DNA is preserved (Poinar \& Stanckiewicz, 1999; Kolman \& Tuross, 2000; Burger et al., 2007). This approach is also limited by the available sample size and is not recommended for coprolites. Among paleoparasitological samples, Dittmar et al. (2003) used this test to assess the possibility of DNA amplification from a mummified flea (Pulex irritans).

Another test uses competitive or real time PCR to assess the amount of starting template. According to current experience, with less than 1,000 template molecules, recovery of aDNA is highly unlikely (Pääbo et al., 2004). Specific damage to DNA molecules includes: strand breaks, DNA crosslinks, hydrolytic damage, and oxidative lesions (Pääbo et al., 2004). Therefore, strict adherence to established protocols is necessary, an issue reviewed elsewhere (Austin et al., 1997; Yang, 1997; Wayne et al., 1999; Cooper \& Poinar, 2000; Pääbo et al., 2004, Willerslev \& Cooper, 2005).

\section{COLLECTION AND STORAGE OF MATERIAL}

As with any other organic material, care should be taken when collecting paleoparasitological samples and storage conditions should be optimized to avoid further degradation of the material. Use of gloves is recommended while handling specimens. To avoid premature and uncontrolled rehydration, coprolites should be stored under dry conditions at cool or freezing temperatures.

When working with latrine sediments, control samples from the adjacent (non-latrine) environment should be taken to establish a comparative baseline sample. With latrine sediments, the possibility of recent parasite contamination 
should also be taken into account. This is especially important when settlement sites were continuously occupied through long timeframes, and contamination of older layers from younger deposits is possible. Arthropod remains (e.g., lice, ticks, fleas, or mites) should be stored according to standard entomological techniques (Bouchet et al., 2003).

\section{ANCIENT DNA TECHNIQUES}

Generally, aDNA techniques vary little from standard modern DNA studies. However, usually very little aDNA starting template is available, additionally complicated by the fact that aDNA is fragmented into short pieces (see above). When working on human aDNA, surface decontamination has been applied to samples (e.g., mechanical removal of the surface; Knapp et al., 2008), but this is not always effective (Kolman \& Tuross, 2000).

Similar techniques using surface UV light exposure have been applied to coprolite studies (Iñiguez et al., 2003a) and are warranted if one suspects surface contamination with closely related extant parasite species or DNA. In fact, little is known about the possibility of water percolation and particle or DNA movement through sediment layers (Pääbo et al., 2004), and systematic studies to this effect are currently lacking.

Methods for the extraction of ancient DNA depend on the materials used. If bone samples are involved, a decalcification step is recommended. Most historical or ancient samples are also known to contain substances that potentially inhibit polymerase chain reactions (PCR). Membrane filtration or resin binding techniques work best for cleaning the extracted DNA (Roland \& Hofreiter, 2007).

Research on coprolites has identified the presence of Maillard products, which are the result of reactions between sugars and primary amino groups and hinder the activity of polymerase (Pääbo et al., 2004). The reagent $\mathrm{N}$-phenacylthiazolium bromide (Vasan et al., 1996) was successfully used on coprolites (Poinar et al., 1998) and Neanderthal bones (Krings et al., 2000) to break down Maillard products and allow DNA amplification.

Ancient DNA amplification employs the regular steps of denaturation, annealing, and extension, but multiple positive and negative controls are applied to check for contamination. In addition, all reactions should always be independently replicated by different researchers in other laboratories, or the results will remain doubtful.

The recent development of multiplex DNA techniques provides the opportunity to increase the length of obtainable sequence fragments from limited amounts of starting template (Krause et al., 2006; mitochondrial genome of Pleistocene wooly mammoth).

Multiplex DNA uses multiple primer pairs in one PCR reaction to target subsequences within the total DNA sample. In a follow-up simplex PCR the regions of interest can then be sequenced from an already multiplied DNA fragment pool (Krause et al., 2006; Römpler et al., 2006).

Another recent technological advance is ancient genomics, where the total DNA of a sample is amplified (rather than individual sequences) (Lambert \& Millar, 2006). The success of these methods can be seen in recent reports on the ability to generate genome data from ancient material (Noonan et al., 2006; Green et al., 2006).

Contrary to the previously mentioned multiplex approach, these techniques amplify the target DNA, together with all other DNA, including contaminants. The idea of analyzing "bulk" samples is not new and has been described as a metagenomics approach for environmental samples (Handelsman, 2004; Venter et al., 2004).

A typical metagenomics project starts with the construction of a bacterial clone library from random DNA of different origins from an environmental sample. 
For the often scarce ancient DNA in samples, cloning provides the advantage of enhancing the total number of available template copies. However, statistically speaking, rare "ancient" inserts will still only provide a minimal proportion of all obtained clones, since most contain the more common DNA template copies (contaminants). Therefore, many clones have to be sequenced in order to identify the insert of interest.

This approach was used initially by Noonan et al. (2005) to sequence Neanderthal DNA. In order to save time and resources in sequencing the more abundant contaminant DNA, they also developed a new approach using biotinylated sequence fragment probes devised from known human DNA to "highlight" particular clones of interest, which were then selectively sequenced.

This approach works well in paleoparasitological samples if one is interested in obtaining the sequence of a particular parasite in a sample. In the case of typing the entire parasitological DNA in a coprolite, latrine sediments, or mummy tissue, the environmental shotgun sequencing (ESS) approach should be performed (Venter et al., 2004; Eisen, 2007).

To obtain a comprehensive overview of all preserved parasite DNA in a sample, statistically representative sequencing of many clones is necessary. This has become more feasible with the onset of a high throughput technique called "pyrosequencing" (Margulies et al., 2006). Green et al. (2006) used pyrosequencing to perform direct large-scale sequencing of Neanderthal DNA. In this approach, single-stranded DNA fragments were paired with common adapters and amplified by bead-based emulsion PCR (solid-phase pyrosequencing). Each bead contains several million copies of DNA fragments, which are then sequenced [GS20 454 sequencing system].

The advantage of this method is that it avoids bacterial cloning (common in the traditional metagenomics approach) and therefore prevents the loss of copies during transformation in the vector and subsequent growth of the colonies (Green et al., 2006). The approach generates thousands of sequence reads per run, thus increasing the odds of sequencing aDNA over contaminants (Green et al., 2006; Stiller et al., 2006). Additionally, patterns of artificial substitutions (due to misincorporations in the sequencing process) can be used to assess the probability of the resulting sequence being authentic. This is not possible with traditional Sanger sequencing, since it uses doublestranded DNA, where one does not know the template strand from which the final sequence (single-stranded) was generated (Stiller et al., 2006).

Currently, aDNA evidence exists for a variety of parasites, including Trypanosoma cruzi (Guhl et al., 1999; Madden et al., 2001; Aufderheide et al. 2004, Lima et al., 2008), Leishmania sp. (Zink et al., 2006), parasitic helminths (Loreille et al., 2001; Iñiguez et al., 2003a, Iñiguez et al., 2003b, Leles et al., 2008), and ectoparasites (Dittmar et al., 2003; Raoult et al., 2006; Raoult et al., 2008). None of these studies uses a genomics approach, but all are based on sequencing individual genes.

When working with extant parasite DNA, sometimes RFLP (Restriction Fragment Length Polymorphism) or microsatellite data are used, especially in population studies. However, these approaches are not recommended for paleoparasitological population studies. Due to the degraded nature of the template DNA, nucleotide misincorporations (errors) during amplification are possible, and are unlikely to be detected with RFLP or microsatellite analyses (Knapp et al., 2008).

In some cases, ELISA (enzyme-linked immunosorbent assay) techniques have been used to trace a parasite in paleoparasitological samples. ELISA techniques detect the presence of proteins (i.e., enzymes, surface proteins of viruses or bacteria, etc.). Therefore, the approach is only suitable for detecting a parasite, and does not allow for evolutionary analyses (i.e. phylogenies). 
For instance, Deelder et al. (1999) employed ELISA techniques to detect parasite antigens in mummy remains from Egypt, to verify the presence of Schistosoma sp.. Mitchell et al. (2008) recently used ELISA to study for dysentery in two medieval latrines in the city of Acre.

However, as with DNA, protein degradation is a progressive and consistent phenomenon after death. Therefore, multiple negative and positive controls should be applied to check for false positives and potential cross-reactions.

\section{EVOLUTIONARY ANALYSES}

Molecular evidence from paleoparasitological samples can provide insight into the evolutionary history of parasites and diversity of parasite populations over time. Crucial to the endeavor of analyzing ancient DNA is the fragment assembly and identification of the obtained sequences.

For mixed sequences from multiple species (i.e., from metagenomic approaches), analysis is usually performed by putting homologous sequences together with a comparative assembler, or a program that can deal with draft sequence.

Basic local alignment search tool (BLAST) searches (e.g., GenBank) and subsequent analysis of all homologous sequences by phylogenetic approaches then allow for the identification of the obtained sequences. However, identification is often only possible at higher taxonomic levels, and genus and species identification is only feasible if similar or identical sequences are available for the gene of interest.

Therefore, in genomic approaches, a majority of recovered DNA may remain unidentifiable for the time being (Green et al., 2006; Noonan et al., 2006). If a particular parasite species is targeted in a paleoparasitological sample, it is recommended to search for genes that have known extant representation in GenBank. Genes or regions that are known to be informative for the question at hand should be sequenced, as derived from alignments with extant sequences (Dittmar et al., 2007).

The relevant current methods of phylogenetic analysis are maximum parsimony, distance methods, maximum likelihood, and Bayesian inference. Ideally, the inference method used will extract the maximum amount of information available in the sequence data. Phylogenetic analyses mainly aim to infer the evolutionary history of a group of species, or groups of genes (i.e., gene family evolution). When working with aDNA, such analyses often serve the purpose of sequence validation and identification. In other words, the fact that aDNA sequences group with homologous extant genes on a phylogeny identifies the sequenced piece as closely related and thus allows the researcher to assess whether the aDNA belongs to the species (or taxonomic group) of interest.

Because aDNA samples are generally not older than ca. 100,000 years, many genes will lack an accumulation of informative variation to distinguish them from their extant counterparts (in other words, they are too closely related). This problem is aggravated by the fact that often only certain genes are obtainable, which may not be suitable for the question asked and may prevent phylogeny estimation from multiple independent loci (Pääbo et al., 2004). For instance, the study by Raoult et al. (2008) on pre-Conquistador head lice (Pediculus humanus capitis) from Peruvian mummies employed two mitochondrial genes, cytochrome B and cytochrome oxidase subunit I. This provided enough information to cluster the sequenced lice with the worldwide haplotype (phylotype A) in a phylogeny derived from extant louse data.

While this allowed rejection of the long-held hypothesis of head louse introduction into the Americas by the Spanish Conquista and supports the hypothesis that body lice may also have been present in the pre-Hispanic Americas, it did 
not support further interpretation regarding the specific geographic origin of South American lice by an earlier human migration, due to lack of resolution at the intra-population level.

Similarly, the study by Dittmar et al. (2003) on pre-Hispanic Pulex irritans (human fleas) clearly showed grouping of the historical sample with extant Pulex from the same geographic area, but the obtained genes did not show intraspecific variation.

In the paleoparasitological realm, the phylogenetic study of higher taxonomic levels (families, orders) and the relationship of extinct to extant species are difficult, simply because the preservation of parasites through time is very rare. Soft-bodied endoparasites are especially unlikely to be preserved.

Furthermore, parasites tend to occupy niches on their hosts that do not readily lend themselves to preservation (e.g., fur, feathers, digestive tract, soft tissue). Consequently, parasites are certainly underrepresented in the fossil record, which poses a continuous problem for the calibration of divergence time studies on parasite phylogenies. The occasional evidence of fossil parasites mainly concerns arthopods (Poinar \& Poinar, 2007).

Other fossil data include amber-preserved nematode parasites (Mermithidae) from Neotropical ants (Poinar et al., 2006) and trace evidence from polychaete borings in pelecypod, gastropod, cephalopod, coral, stromatoporoid, crinoid, brachiopod, ectoproct, and calcareous algal skeletons from the Ordovician to the Permian, and from the Paleozoic (Cameron, 1969). However, none of the above is likely to yield remnants of DNA.

Currently underexplored avenues of DNA-grade parasitological evidence are permafrozen mammoth remains (importantly, the odds of their discovery are likely to increase with rising annual temperatures). Several studies on genetic data from mammoths and mastodons (Cooper et al., 2001; Poinar et al., 2005) and their dietary remains (Hofreiter et al., 2000) have proven the feasibility of DNA recovery from this material, and parasite eggs may also be preserved.

An example for the successful phylogenetic study of extinct remains comes from the sequencing of the mitochondrial ND2 and cytochrome B genes of the giant Haast's eagle (Harpagornis moorei), which not only showed an unexpected relationship to a group of small eagles but also supported a rapid morphological change over a small evolutionary time frame (0.7 - $1.8 \mathrm{my}$ ) (Bunce et al., 2005). If carried out on paleoparasitological material, results may similarly be informative on parasite divergence times and plasticity of morphological adaptation.

Another promising area with ancient parasite DNA is the study of animal domestication, or in a broader sense, the cultural association between humans and animals (e.g., rats, mice). Domestication not only increases the number of available hosts in a defined habitat, but also fosters contact between animal parasites and human hosts, and vice versa (Araújo et al., 2000; Cox, 2002; Kloos \& David, 2002). Domestication thus provides parasites with a relatively stable number of readily available hosts and expands the potential to find new hosts. Familiar examples include many secondary human parasites, which are in fact primary parasites of other animal hosts, such as Trichinella spp. (primarily found in rats and pigs), Trypanosoma cruzi (sylvatic and domesticated mammals), Balantidium spp. (pigs), or Pulex irritans (guinea pigs).

Domesticated animals are often suspected as the origin of human parasitoses. However, Taenia provides an example of how genetic evidence from extant samples suggests acquisition of the infection by human ancestors before domestication of the respective ungulate hosts (Hoberg et al., 2001). Therefore, paleoparasitological evidence can be informative on multiple fronts. First, it can help identify parasitic infections that are common to both animal and human samples by microscopic parasitological diagnostics, or genetic sampling. Second, in most cases, the paleoparasitological sample can be dated, that is, within the context of other evidence. It thus provides a time point 
that can be used to calibrate molecular dating efforts, which is particularly valuable given the persistent lack of parasite fossils. This will subsequently aid determination of the original host and the direction of host switches.

Occasionally, aDNA studies center on the species or population level. Not all samples lend themselves to this type of analysis, since a statistically satisfactory sample is needed to effectively assess haplotype frequencies. For instance, Burger et al. (2007) studied two nuclear loci for lactase persistence from 10 Neolithic, Mesolithic, and Medieval individuals.

Lactase is necessary to digest lactose (milk sugar), and most mammals lose this ability after weaning. Only the Medieval individuals showed the required heterozygosity for lactase persistence. Therefore, this trait was probably only acquired by humans in the last 8,000 years, due to strong positive selection.

Crucial to this type of study is the comparative combination of extant and ancient (or historical) samples from the same geographic area. This provides for a comprehensive diachronic observation and may also allow assessing recent host switches in the case of paleoparasitological samples.

No comprehensive study of this type exists for paleoparasitological samples, although Loreille \& Bouchet (2003) highlighted the possibility of assessing speciation patterns, introgression, and hybridization with Ascaris spp. samples from extant material and a $14^{\text {th }}$-century latrine from Belgium. The proposals by Loreille \& Bouchet (2003) are interesting in the context of coalescent approaches, which seek to retrospectively trace extant alleles to their most common recent ancestors (MRCA) through time (Edwards \& Beerli, 2000) and thus gain an understanding of genealogic and population history, including events of hybridization or introgression. Time points of coalescence are estimated from the extant data, and having a dated sampling point from a potentially extinct allelic type (from the paleoparasitological sample) will likely improve the model's accuracy.

However, closely related species (populations) often display shallow coalescence times, and thus many alleles will be impossible to distinguish between species (e.g., Neanderthals versus humans, Knapp et al., 2008). Therefore, this type of study is subject to limitations, depending on the available material and the ability to find and amplify the right markers.

\section{PALEOPARASITOLOGY AND PHYLOGEOGRAPHY}

Host and parasite evolution are intricately linked. Genetically and morphologically, they engage in a constant race, each trying to gain advantage over the other. These connections persist through time and space. In this process, parasites are passed on from parents to offspring, and from ancestors to descendants.

Together with their hosts, parasites move around, and in due time adapt to new ecosystems. Paleoparasitological research provides a glimpse into these past events and may thus inform us directly on host migration routes and host switches, or indirectly on climate conditions, host nutrition, and cultural practices (Reinhard \& Bryant, 2008). This is important, because the study of extant populations alone can lead to misperceptions concerning temporal distribution patterns of parasites or their hosts.

For example, paleoparasitological data on hookworms, threadworms, and whipworms provide solid evidence of non-Beringian human travel routes into the New World, thus refueling an intense debate on the issue (Hawdon \& Johnston, 1996; Sianto et al., 2005; Montenegro et al., 2006; Araújo et al., 2008). These studies particularly support the idea that in some cases the Arctic environment may have acted as a barrier to certain Old World diseases (Dillehay, 1991). 
Araújo et al. (2008) argue that hookworms (Necator sp. and Ancylostoma sp.), whipworms (Trichuris trichiura), and other helminths require specific conditions to complete their life cycle, which were not met in the hostile Beringian climate. Specifically, they point out that human hookworm and whipworm, which are host-specific and lack intermediate hosts, favor high moisture and moderate temperatures for egg and larval development.

Combining the paleoparasitological data with migration models that consider parameters such as human dispersal, it is unlikely that humans crossed Beringia fast enough to introduce these parasites into the New World. Therefore, the Clovis migration may not have been the only route for human arrival, and coastal or transoceanic migrations are possible (Araújo et al., 1988; Montenegro et al., 2006).

Montenegro et al. (2006) draw on direct parasitological evidence in the form of parasite eggs. Direct evidence is equivalent to morphological (phenotypic) data, which often does not provide resolution at the population level. For instance, the study by Araújo et al. (2008) cannot determine from which old World population of whipworms or hookworms their New World counterparts descended. Similarly, although Raoult et al. (2008) used molecular data, their genes did not provide the appropriate resolution to resolve the genealogic history of lice.

In order to study sequence variation among individuals from a given species, DNA data from appropriate genes are necessary. However, such studies are only feasible if samples from multiple individuals are available (rarely the case for paleoparasitological samples).

Studies on human samples included DNA from early Europeans to study the ancestry of modern Europeans (Haak et al., 2005). Haplotypes from 24 skeletons showed that the current European genetic composition likely derives from Paleolithic hunter-gatherers inhabiting the area some 40,000 years ago (Knapp et al., 2008).

Paleoparasitological data may have implications for our understanding of global warming and its influence on the transmission of parasitic diseases. Because most parasites require certain conditions for their successful development, temperature fluctuations may allow or drive parasites to migrate and colonize areas other than their extant distribution (see above, Araújo et al., 2008). Combining paleoparasitological and paleoclimatic data with information on extant climate and parasite distribution could thus improve the long-term predictive power regarding the parasitological consequences of climate change on the local and global geographic scales.

For instance, Lima et al. (2008) recently found DNA from Trypanosoma cruzi I genotype in human remains 4,500 to 7,000 years old from the Peruaçu Valley in Brazil. This genotype is currently absent from the area and indicates the recent emergence of a new epidemiological profile, due to shifts in host availability, which may (according to the authors) be linked to deforestation and microclimate shifts.

Additionally, most paleoparasitological samples also contain remnants or DNA sequences of plants, invertebrates, or vertebrates, thus allowing us to directly link parasite data to other fauna and flora at the spatial and temporal levels (Nielsen et al., 2000). Connecting these useful glimpses into the past to the present is important, since it can provide clues to a variety of processes, such as alternative transmission cycles, coevolution, feedback relationships between diet and infestation levels, and the impact of human activity on infestation cycles.

\section{CONCLUSIONS}

Technical advances in experimental and computational analyses continue to inspire the field of paleoparasitology. In particular, the ability to sequence ancient DNA has led to major advances in the field. However, a critical attitude towards aDNA results from paleoparasitological material is necessary, and above all, the limitations of aDNA research 
have to be taken into account. These problems concern the sample's age and the conditions of its preservation, as well as contamination, sequencing artifacts, and computational analyses.

\section{REFERENCES}

ARAÚJO, A. Dessecação experimental de fezes contendo ovos de ancilostomídeos. In: FERREIRA, L. F; ARAÚJO, A. \& CONFALONIERI, U. Paleoparasitologia no Brasil. Rio de Janeiro: PEC/Ensp, 1988.

ARAÚJO, A.; REINHARD, K. \& FERREIRA, L. F. The role of mummy studies in paleoparasitology. Chungará - Revista de Antropología Chilena, 32: 111-115, 2000.

ARAÚjo et al. Hookworms and the peopling of America. Cadernos de Saúde Pública 2: 226- 233, 1988.

ARAÚJO, A. et al. Parasites as probes for prehistoric human migrations. Trends in Parasitology, 24: 112-115, 2008.

AUfDERHEIDE, A. C. et al. A 9,000-year record of Chagas' disease. Proceedings of the National Academy of Sciences, 101: 2.034$2.039,2004$.

AUSTIN, J. J.; SMITH, A. B.; THOMAS, R. H. Paleontology in a molecular world: the search for authentic ancient DNA. Trends in Ecology and Evolution, 12: 303-306, 1997.

BECKMAN, M. Keeping kitty under wraps. Science, 915: 3, 2004.

BELL, C. J. Bichronology of North American microtine rodents. In: NOLLER, J. S.; SOWERS, J. M. \& LETTIS, W. R. (Eds.). Quaternary Geochronology: methods and applications. Washington: American Geophysical Union, 2000.

BetAncourT, J. L.; VAN DEVEnder, T. R. \& MARTIN, P. S. Packrat Middens: the last 40,000 years of biotic change. Tucson: University of Arizona Press, 1990.

BOUCHET, F. et al. Parasite remains in archaeological sites. Memórias do Instituto Oswaldo Cruz, 98, supl. 1: 47-52, 2003.

BUCKLAND, W. On the discovery of a new species of pterodactyl; and also of the faeces of the Ichthyosaurus; and of a black substance resembling sepia, or Indian ink, in the Lias at Lyme Regis. Proceedings of the Geological Society of London, I: 96-98, 1829.

BUNCE, M. et al. Ancient DNA provides new insights into the evolutionary history of New Zealand's extinct giant eagle. PLoS Biology, 3: e9, 2005.

BURGER, J. et al. Absence of the lactase-persistence-associated allele in early Neolithic Europeans. Proceedings of the National Academy of Sciences, 104: 3.736-3.741, 2007.

CALLEN, AND. O. \& CAMERON, T. W. M. A prehistoric diet revealed in coprolites. New Scientist, 8: 35-40, 1960.

CAmeron, B. Paleozoic shell-boring annelids and their trace fossils. American Zoologist, 9: 689-703, 1969.

CARRIón, J. S. et al. Palynology and palaeoenvironment of Pleistocene hyaena coprolites from an open-air site at Oyster Bay, Eastern Cape Coast, South Africa. South African Journal of Science, 96: 449-453, 2000.

CARRIÓN, J. S. et al. Pollen in hyaena coprolites reflects late glacial landscape in Southern Spain. Palaeogeography, Palaeoclimatology, Palaeoecology, 176: 193-205, 2001.

COOPER, A. \& POINAR, H. N. Ancient DNA: do it right or not at all. Science, 289: 1.139, 2000.

COOPER, A. et al. Complete mitochondrial genome sequences of two extinct moas clarify ratite evolution. Nature, 409: 704-707, 2001.

COX, F. E. G. History of human parasitology. Clinical Microbiology Reviews, 15: 595-612, 2002.

DEELDER, A. M. et al. Detection of schistosome antigen in mummies. The Lancet, 335: 724-725, 1990.

DILLEHAY, T.D. Disease ecology and initial human migration. In: DILLEHAY, T. D. \& MELTZER, D. J. The First Americans: search and research. Boca Raton: CRC Press, 1991. 
DITTMAR, K. Evaluation of ectoparasites on the guinea pig mummies of El Yaral and Moquegua valley, in Southern Peru. Chungará, Revista de Antropología Chilena, 32: 123-127, 2000.

DITTMAR, K. \& TEEGEN, W.R. The presence of Fasciola hepatica (liver-fluke) in humans and cattle from a 4500 year old archaeological site in the Saale-Unstrut-Valley, Germany. Memórias do Instituto Oswaldo Cruz, 98, supl. 1: 141-145, 2003.

DITTMAR, K.; MENDONÇA DE SOUZA, S. \& ARAÚjo, A. Challenges of phylogenetic analyses of aDNA sequences. Memórias do Instituto Oswaldo Cruz, 101, supl. 2: 9-13, 2006.

DITTMAR, K. et al. Techniques of DNA-studies on prehispanic ectoparasites (Pulex sp., Pulicidae, Siphonaptera) from animal mummies of the Chiribaya Culture, Southern Peru. Memórias do Instituto Oswaldo Cruz, 98, supl. 1: 53-59, 2003.

EDWARDS, S. V. \& BEERLI, P. Perspective: gene divergence, population divergence, and the variance in coalescence time in phylogeographic studies. Evolution, 54: 1.839-1.854, 2000.

EISEN, J. Environmental shotgun sequencing: its potential and challenges for studying the hidden world of microbes. Plos Biology, 5: e82, 2007.

FERREIRA, L. F; ARAÚJO, A. \& DUARTE, A. N. Nematode larvae in fossilized animal coprolites from lower and middle Pleistocene sites, central Italy. The Journal of Parasitology, 79: 440-442, 1993.

GREEN, A. et al. Analysis of one million base pairs of Neanderthal DNA. Nature, 444: 330-336, 2006.

GUHL, F. et al. Isolation of Trypanosoma cruzi DNA in 4,000-year-old mummified human tissue from northern Chile. American Journal of Physical Anthropology, 108: 401-412, 1999.

HAAK, W. et al. Ancient DNA from the first European farmers in 7500-year-old Neolithic sites. Science, 310: 1.016-1.018, 2005.

HALL, A. \& KENWARD, H. Disentangling dung: Pathways to stable manure. Environmental Archaeology, 1: 123-126, 1998.

HANDELSMAN, J. Metagenomics: Application of genomics to uncultured microorganisms. Microbiology and Molecular Biology Reviews, 68: 669-685, 2004.

HAWDON, J. M. \& JOHNSTON, S. A. Hookworms in the Americas: an alternative to trans-Pacific contact. Parasitology Today, 12: $72-74,1996$.

HOBERG, E. P. et al. Out of Africa: origins of the Taenia tapeworms in humans. Proceedings of the Royal Society, Biological Sciences, 268: 781-787, 2001.

HOFREITER, M. et al. A molecular analysis of ground sloth diet through the last glaciation. Molecular Ecology, 9: 1.975-1.984, 2000.

HORNE, P. D. A review of the evidence for human endoparasitism in the pre-Columbian New World through the study of coprolites. Journal of Archaeological Science, 12: 299-310, 1985.

HORWITZ, L. K. \& GOLDBERG, P. A study of Pleistocene and Holocene hyaena coprolites. Journal of Archaeological Science, 16: 71-94, 1989.

IÑgUEZ, A. M. et al. Enterobius vermicularis: Ancient DNA from North and South American Human Coprolites. Memórias do Instituto Oswaldo Cruz, 98, supl. 1: 67-69, 2003a.

IÑIGUEZ, A. M. et al. Analysis of ancient DNA from coprolites: a perspective with random amplified polymorphic DNA-polymerase chain reaction approach. Memórias do Instituto Oswaldo Cruz, 98, supl. 1: 63-65, 2003b.

JONES, A. K. G.; HUTCHINSON, A. R. \& NICHOLSON, C. The worms of Roman horses and other finds of intestinal parasite eggs from unpromising deposits. Antiquity, 62: 275-276, 1988.

KLOOS, H. \& DAVID, R. The palaeoepidemiology of Schistosomiasis in ancient Egypt. Human Ecology Review, 9: 14-25, 2002.

L. \& HOFREITER, M. Ancient DNA: phylogenetic applications. In: HOFREITER, M. \& VIGILANT, L. Encyclopedia of Life Sciences (ELS). Chichester: John Wiley and Sons, 2008. 
KNUDSON, K.; AUFDERHEIDE, A. \& BUIKSTRA, J. Seasonality and palaeodiet in the Chiribaya polity of Southern Peru. Journal of Archaeological Science, 34: 451-462, 2007.

KOLMAN, C. J. \& TUROSS, N. Ancient DNA analysis of human populations. American Journal of Physical Anthropology, 111: 5-23, 2000.

KRAUSE, J. et al. Multiplex amplification of the mammoth mitochondrial genome and the evolution of Elephantidae. Nature, 439: 734-737, 2006.

KRINGS, M. et al. A view of Neanderthal genetic diversity. Nature Genetics, 26: 144-146, 2000.

KUCH, M. et al. Molecular analysis of an 11,700-year-old rodent midden from the Atacama Desert, Chile. Molecular Ecology, 11: 913-924, 2002.

LAMBERT, D. M. \& MILLAR, C. D. Evolutionary biology: ancient genomics is born. Nature, 444: 275-276, 2006.

LELES, D. et al. Molecular paleoparasitological diagnosis of Ascaris sp. from coprolites: new scenery of ascariasis in pre-Columbian South America times. Memórias do Instituto Oswaldo Cruz, 103: 106-108, 2008.

LEROY, S. A. G. \& SIMMS, M. J. Iron Age to Medieval entogamous vegetation and Rhinolophus hipposideros roost in South-Eastern Wales (UK). Palaeogeography, Palaeoclimatology, Palaeoecology, 237: 4-18, 2006.

LIMA, V. S. et al. Chagas disease in ancient hunter-gatherer population, Brazil. Emerging Infectious Diseases 14: 1001-1002, 2008.

LOREILLE, O. \& BOUCHET, F. Evolution of ascariasis in humans and pigs: a multi-disciplinary approach. Memórias do Instituto Oswaldo Cruz, 98, supl. 1: 39-46, 2003.

LOREILLE, O. et al. Ancient DNA from Ascaris: extraction amplification and sequences from eggs collected in coprolites. International Journal of Parasitology, 31: 1.101-1.106, 2001.

MADDEN, M. et al. Hybridization screening of very short PCR products for paleoepidemiological studies of Chagas' disease. Biotechniques, 30: 102-104, 2001.

MAHER, L. J. Environmental information from the palynology of bat guano. Palaeogeography, Palaeoclimatology, Palaeoecology, 237: 19-31, 2006.

MARGULIES, M. et al. Genome sequencing in microfabricated high-density picolitre reactors. Nature, 437: 376-380, 2006.

MITCHELL, P. D.; STERN, E. \& TEPPER, Y. Dysentery in the crusader kingdom of Jerusalem: an ELISA analysis of two medieval latrines in the city of Acre (Israel). Journal of Archaeological Science, 35: 1.849-1.853, 2008.

MONTENEGRO, A. et al. Parasites, paleoclimate and the peopling of the Americas: using the hookworm to time the Clovis migration. Current Anthropology, 47: 193-200, 2006.

NIELSEN, B. O.; MAHLER, V. \& RASMUSSEN, P. An arthropod assemblage and the ecological conditions in a byre in the Neolithic settlement of Weier, Switzerland. Journal of Archaeological Science, 27: 209-218, 2000.

NOONAN, J. P. et al. Sequencing and Analysis of Neanderthal Genomic DNA. Science, 314: 1.113-1.118, 2006.

PÄÄBO, S. et al. Genetic analyses from ancient DNA. Annual Review of Genetics, 38: 645-679, 2004.

POINAR, G. \& POINAR, R. What Bugged the Dinosaurs? Insects, Disease, and Death in the Cretaceous. Princeton: Princeton University Press, 2007.

POINAR, H. N. \& STANKIEWICZ, B. A. Protein preservation and DNA retrieval from ancient tissues. Proceedings of the National Academy of Sciences, 96: 8.426-8.431, 1999.

POINAR, H. N. et al. Molecular coproscopy: dung and diet of the extinct ground sloth Nothrotheriops shastensis. Science, 281: 402406, 1998.

POINAR, H. N. et al. Nuclear gene sequences from a late Pleistocene sloth coprolite. Current Biology, 12: 1.150-1.152, 2003. 
POINAR, H. N. et al. Metagenomics to paleogenomics: large-scale sequencing of mammoth DNA. Science, 311: 392-394, 2005.

POINAR, G. et al. Recent and fossil nematode parasites (Nematoda: Mermithidae) of Neotropical ants. Journal of Invertebrate Pathology, 91: 19-26, 2006.

RAOULT, D. et al. Evidence for louse-transmitted diseases in soldiers of Napoleon's grand army in Vilnius. Journal of Infectious Diseases, 193: 112-120, 2006.

RAOULT, D. et al. Molecular identification of lice from pre-Columbian mummies. Journal of Infectious Diseases, 197: 535-543, 2008.

REINHARD, K. J. Cultural ecology of prehistoric parasitism on the Colorado Plateau as evidenced by coprology. American Journal of Physical Anthropology, 77: 355-366, 1988.

REINHARD, K. J. Parasitology as an interpretive tool in archaeology. American Antiquity, 57: 231-245, 1992.

REINHARD, K. J. \& BRYANT, V. M. Pathoecology and the future of coprolite studies in bioarchaeology. In: STODDER, A. W. M. (Ed.). Bioarchaeology: Reanalysis and Reinterpretation in Southwestern Bioarchaeology. Tempe: Arizona State University Press, 2008.

REINHARD, K. J. et al. Recovery of parasite remains from coprolites and latrines: aspects of paleoparasitological technique. Homo, 37: 217-239, 1986.

ROLAND, N. \& HOFREITER, M. Ancient DNA extraction from bones and teeth. Nature Protocols 2: 1756- 1762, 2007.

RÖMPLER, H. et al. Multiplex amplification of ancient DNA. Nature Methods, 1: 720-728, 2006.

SCOTT, L.; FERNÁNDEZ-JALVO, Y. \& DENYS, C. Owl pellets, pollen and the palaeoenvironment. South African Journal of Science, 92 : 223-224, 1996.

SHAPIRO, B. \& COOPER, A. Beringia as an Ice Age genetic museum. Quaternary Research, 60: 96-100, 2003.

SIANTO, L. et al. The finding of Echinostoma spp. (Trematoda: Digenea) and hookworm eggs in coprolites collected from a Brazilian mummified body dated of 600-1,200 years before present. The Journal of Parasitology, 91: 972-975, 2005.

SMITH, F. A. \& BETANCOURT, J. L. Predicting woodrat (Neotoma) responses to anthropogenic warming from studies of the palaeomidden record. Journal of Biogeography, 33: 2.061-2.076, 2006.

STILLER, M. et al. Patterns of nucleotide misincorporations during enzymatic amplification and direct large-scale sequencing of ancient DNA. Proceedings of the National Academy of Sciences, 103: 13.578-13.584, 2006.

STONE, A.C. \& STONEKING, M. Analysis of ancient DNA from a prehistoric Amerindian cemetery. Philosophical Transactions of the Royal Society of London, Series B, Biological Sciences 354: 153-159, 1999.

VASAN, X. et al. An agent cleaving glucose-derived protein crosslinks in vivo and in vitro. Nature, 382: 275-278, 1996.

VENTER, J. C. et al. Environmental genome shotgun sequencing of the Sargasso Sea. Science, 304: 66-74, 2004.

WAYNE, R. K.; LEONARD, J. A. \& COOPER, A. Full of sound and fury: the recent history of ancient DNA. Annual Review of Ecology and Systematics, 30: 457-477, 1999.

WILLERSLEV, E. \& COOPER, A. Ancient DNA. Proceedings of the Royal Society of London B, 272: 3-16, 2005.

YANG, H. Ancient DNA from Pleistocene fossils: preservation, recovery, and utility of ancient genetic information for quaternary research. Quaternary Science Reviews, 16: 1.145-1.161, 1997.

YLL, R. et al. Vegetation reconstructions on the basis of pollen in Late Pleistocene hyena coprolites from San Teodoro cave (Sicily, Italy). Palaeogeography, Palaeoclimatology, Palaeoecology, 237: 32-39, 2006.

ZINK, A. R. et al. Leishmaniasis in ancient Egypt and Upper Nubia. Emerging Infectious Diseases, 12: 1.616-1.617, 2006. 


\title{
Molecular Paleoparasitology
}

\author{
Alena Mayo Iñiguez
}

\section{ANCIENT DNA: CONCEPTS}

$\mathrm{M}$

olecular biology techniques have been used for more than two decades to recover and analyze DNA in biological materials preserved from the recent or distant past, thereby establishing ancient DNA as a line of research.

The term "ancient DNA" (aDNA) was first used to designate DNA fragments found in some type of preserved or fossilized biological material (Brown \& Brown, 1994), such as human or animal bones, teeth, tissues, hair, and coprolites, insects preserved in amber, and plant seeds and other plant materials (including those found in plant collections and permafrost).

A more comprehensive concept for this term refers to any DNA vestige or trace from a dead organism or parts of it, as well as extracorporeal DNA (Herrmann \& Hummel, 1994). Other terms involving the study of aDNA are also used, such as "paleogenetics" or "molecular paleontology" (Marota \& Rollo, 2002; Loreille \& Bouchet, 2003), or molecular paleoparasitology (Ferreira et al., 2000) and paleomicrobiology (Drancourt \& Raoult, 2005), the latter specifically for the study of aDNA from parasite microorganisms that cause human diseases. Finally, "paleogenomics" (Poinar et al., 2006) involves the determination and analysis of long segments of nuclear aDNA, on the order of millions of base pairs (bp), or even complete mitochondrial genomes (mitogenomics).

\section{ANCIENT DNA: HISTORY}

The first attempts to recover biological material from ancestral remains specifically involved proteins. Protein residues were identified in different fossil remains, such as shells (Weiner, Lowenstam \& Hood et al., 1976), stone tools (Loy, 1983), and bones (Ascenzi et al., 1985). However, the pioneering evidence in detecting ancestral proteins emerged with the use of immunological techniques (Lowenstein, 1980) currently used in parasite diagnosis with commercial kits (Gonçalves et al., 2002; Le Bailly et al., 2008). 
The first report of ancient DNA and RNA extraction was presumably from 1980, by a group of Chinese researchers, based on rib cartilage from a mummy from Mawangtui, preserved for nearly 2,000 years (Herrmann \& Hummel, 1994). However, Higuchi et al. (1984) published the first convincing demonstration of the recovery of aDNA sequences from an extinct animal. They showed the cloning of a 29 bp fragment of mitochondrial DNA (mtDNA) from a museum specimen of the quagga, a zebra-like species (Equus quagga) that became extinct in 1883. This huge study (25 thousand colonies analyzed for only two fragments of cloned E. quagga mtDNA) was a milestone in aDNA research, demonstrating for the first time the long survival of DNA after death (Chart 1).

Chart 1 - History of ancient DNA studies

\begin{tabular}{|l|l|l|}
\hline Year & \multicolumn{1}{|c|}{ Study } & \multicolumn{1}{|c|}{ Reference } \\
\hline 1984 & mtDNA from Equus quagga (1884) & Higuchi et al., 1984 \\
\hline 1985 & ntDNA from Egyptian mummy (2600 BC) & Pääbo, 1985 \\
\hline 1989 & Criteria for authentication of aDNA results & Pääbo, 1989 \\
\hline 1990 & cpDNA from Miocene Magnolia & Golemberg et al., 1990 \\
\hline 1991 & Determination of sex in 17th-century human bones & Hummel \& Hermann, 1990 \\
\hline 1993 & ntDNA from maize (4,700 BP) & Goloubinoff, Pääbo \& Wilson, 1993 \\
\hline 1994 & Pre-Columbian tuberculosis & Salo et al., 1994 \\
\hline 1997 & Neanderthal mtDNA (not our direct ancestor). & Krings et al., 1997 \\
\hline 1998 & Giant sloth coprolite (11,000 BP): host and diet & Poinar et al., 1998 \\
\hline 2000 & 16s rDNA from bacteria in Ötzi (5,530-5,100 BP) & Cano et al., 2000 \\
\hline 2003 & Paleoenvironmental analysis of permafrost & Willerslev et al., 2003 \\
\hline 2006 & Complete mtDNA genome of mammoth & Krause et al., 2006 \\
\hline 2007 & Detection of live ancestral bacteria in permafrost & Johnson et al., 2007 \\
\hline 2008 & Genotyping of $T$. cruzi in mummy (7,000-4,500 BP) & Lima et al., 2008 \\
\hline
\end{tabular}

Shortly thereafter, the first results were published on human DNA recovered from an Egyptian mummy dated c. 2,600 BC. The study described cloning a $3400 \mathrm{bp}$ fragment of nuclear DNA and the identification of repeat sequences in human DNA (Pääbo, 1985).

Previous aDNA studies were limited to DNA extraction from extraordinarily well-preserved material. However, technical difficulties in cloning DNA from ancestral remains were minimized by applying the polymerase chain reaction (PCR) (Saiki et al., 1985; Mullis \& Fallona, 1987). With PCR, theoretically a single intact strand of DNA suffices to produce thousands of copies of the segment, making it an ideal tool for targeting aDNA.

The first decade of aDNA research witnessed an increase in interest by diverse groups and reports of aDNA recovery, exploring different types of preserved biological materials (Chart 2), mainly bones and tissues from mummies (Hagelberg et al., 1991; Merriwether; Rothhammer \& Ferrell, 1994; Handt et al., 1996), insects in amber (De Salle et al., 1992; Cano et al., 1993), and fossilized plants (Golemberg et al., 1990; Brown et al., 1994). 
Chart 2 - Ancient DNA in different biological materials

\begin{tabular}{|l|l|r|}
\hline \multicolumn{1}{|c|}{ Origin } & \multicolumn{1}{|c|}{ Type of material } & Maximum recorded age (years) \\
\hline \multirow{4}{*}{ Human } & Bones and teeth & 38,000 \\
& Mummies & 5,000 \\
& Bog bodies & 7,500 \\
& Hair & 0.3 \\
\hline \multirow{5}{*}{ Animal } & Bones & 25,000 \\
& Naturally preserved tissues & 13,000 \\
& Tissues preserved in museum & 140 \\
& Plumage & 130 \\
& Fur & $>1$ \\
\hline Bacterial & Specimens in amber & $135,000,000$ \\
\hline Viral & Permafrost & 30,000 \\
\hline Fungal & Permafrost & $3,000,000$ \\
\hline & Permafrost & 140,000 \\
\hline Plant & Permafrost & 750,000 \\
\hline & Specimens in plant collections & 118 \\
& Seeds and cobs & 4,500 \\
& Mummified seeds and embryos & 44,600 \\
& Specimens in amber & $40,000,000$ \\
& Permafrost & 400,00 \\
\hline
\end{tabular}

Source: Iñiguez et al. (2006).

From then on, numerous studies focused on standardizing PCR for studying aDNA, allowing the use of biological samples with degraded or minimal amounts of DNA. The studies featured the work by the group of Svante Pääbo, a leading figure in this research area from early on. His work in the extraction, enzyme amplification, cloning, and phylogenetic analysis of aDNA sequences revealed the peculiarities and problems of its manipulation and the possibility of obtaining proven ancestral gene sequences by applying various molecular techniques. Pääbo also pioneered aDNA characterization based on tissues from specimens representing a wide variety of geographic regions and periods, identifying the nature of chemical alterations in aDNA (Pääbo, Gifford \& Wilson, 1988; Pääbo et al., 2004; Pääbo, 1989; Pääbo, Irwin \& Wilson, 1990; Handt et al., 1994; Krings et al., 1997; Greenwood et al., 1999; Hofreiter et al., 2001, 2002; Hofreiter, 2008).

Ancient DNA research thus evolved and matured in the identification of problems and solutions. It moved from the mere amplification of DNA fragments from fossilized or extinct organisms to amplification of DNA from fossil material and the application of these studies to shed light on questions in other areas of knowledge. As of 1995, six extinct species had been analyzed phylogenetically. Currently, more than 20 extinct species of birds, humans, and other mammals have been elegantly studied and their mitochondrial genomes have been completed (Cooper et al., 2001; Poinar et al., 2006). One of the most relevant studies in human evolution was the mtDNA sequencing of Neanderthal, using sophisticated experiments to show that this species was not the direct ancestor of the modern human species as previously believed (Krings et al., 1997).

Finally, the scientific community showed growing interest in analyzing bacterial aDNA (Marota \& Rollo, 2002; Cano et al., 2000; Rollo et al., 2000) from different human parasites such as Mycobacterium tuberculosis, Yersinia pestis, Trypanosoma cruzi, and mainly coprolites as a rich source of information on behavior, eating habits, and 
parasites of ancient animals and humans (Cooper \& Poinar, 2000; Hofreiter et al., 2001; Poinar et al., 1998, 2001; Loreille et al., 2001; Iñiguez et al., 2003, 2006; Leles et al., 2008; Gilbert et al., 2008).

\section{ANCIENT DNA: APPLICATIONS}

Until recently the study of evolutionary genetics was based mainly to extrapolate information from living organisms to reconstruct the past, or to interpret morphological analyses of well-preserved fossil specimens. DNA recovery from animal, plant, and human remains provided a new tool for obtaining primary evidence of ancient genetic information on these organisms. Ancient DNA analysis is definitely an innovative, high-impact, and extremely useful field of investigation that has led to progress in various areas of science.

Ancient DNA studies also apply to parasitology in a broader sense. The investigation of aDNA has been particularly successful in paleontology (Höss, 1995; Greenwood et al., 1999; Poinar, 2002), archaeology (Burger et al., 2000; Relethford, 2001), forensic medicine (Goodwin, Linacre \& Vanezis, 1999; Góes et al., 2002), and even agriculture (Brown, 2001; Willmann, 2001) (Chart 3).

Chart 3 - Ancient DNA in various fields of knowledge

\begin{tabular}{|l|l|}
\hline \multicolumn{1}{|c|}{ Lines of research } & \multicolumn{1}{c|}{ Principal studies } \\
\hline Anthropology & $\begin{array}{l}\text { Sex prevalence and determination of behaviors } \\
\text { Determination of diet and eating habits } \\
\text { Origin and evolution of the human species }\end{array}$ \\
\hline Archaeology & $\begin{array}{l}\text { Human migrations and peopling patterns } \\
\text { Identification of sex in human populations }\end{array}$ \\
\hline Agriculture & $\begin{array}{l}\text { Origin and dispersal of cultivars } \\
\text { Domestication of maize and potato species }\end{array}$ \\
\hline Conservation & Phylogenetic relations in mammalian populations \\
\hline Forensic sciences & $\begin{array}{l}\text { Identification of murder and accident victims } \\
\text { Identification of war victims }\end{array}$ \\
\hline Paleontology & Taxonomy of extinct plants and animals \\
\hline Bacteriology & Determination of ancestral strains \\
\hline Zoology & Taxonomy of recently extinct animals \\
\hline Medicine & Origin of infectious diseases, tuberculosis, plague, leprosy \\
\hline Parasitology & Intestinal parasites, Chagas disease, viral disease \\
\hline
\end{tabular}

\section{CHARACTERISTICS OF ANCIENT DNA}

The DNA in living cells remains intact through continuous processes of DNA repair, while the catabolic enzymes are restricted to cell compartments. When an organism dies, its DNA begins to be degraded by endogenous nucleases, reducing the DNA molecule to mononucleotides. Organisms that feed on or degrade macromolecules, such as bacteria, fungi, and insects, also attack the DNA. But this action can be prevented by the destruction or inactivation of these 
enzymes under special conditions of rapid desiccation, low temperature, and high salt concentration (Lindahl, 1993; Hofreiter et al., 2001). Even so, processes persist that slowly affect the DNA, such as oxidation, depurination, deamination, and others like hydrolysis, the products of which modify nitrogenous bases and sugar-phosphate, and/ or destabilize and break the DNA molecule. Degradation into small fragments, generally 100-500bp, is the most obvious damage to aDNA (Pääbo et al., 2004).

We now know that the extent of degradation does not depend only on the antiquity of the environments and the conditions under which the different archaeological materials were collected. The conditions and time of preservation following excavation and collection are central to the process of aDNA degradation (Pruvost et al., 2007). In tissue aDNA, oxidation and even the direct and indirect effect of background radiation frequently cause oxidative alterations in pyrimidine bases (cytosine $\mathrm{C}$ and thymine $\mathrm{T}$ ), generating a high proportion of residues (hydantoins) that can inhibit the action of DNA-polymerase and consequently PCR. Deamination, or spontaneous hydrolysis of cytosine and its homologue 5-methylcytosine to uracil (U) and thymine, is also frequently found in aDNA, causing erroneous insertions during PCR (Lindahl, 1993; Hofreiter, 2008).

Based on data from oxidative and hydrolytic modifications, Hofreiter et al. (2001) showed that aDNA can be reasonably recovered from specimens as old as 100,000 BP under ideal conditions of physiological salt concentrations, neutral $\mathrm{pH}$, and temperatures around $15^{\circ} \mathrm{C}$.

This line of research thus entails extreme technical difficulties, for example when working with tiny amounts of DNA or degraded DNA. Studies of material from temperate environments or permafrost have demonstrated the possibility of pushing the limits of antiquity in DNA recovery and of the size of aDNA sequences.

Genetic analysis of permafrost showed that plant and animal aDNA can be preserved for long periods of time, even in the absence of macrofossils (Willerslev et al., 2003; Lydolph et al., 2005; Willerslev et al., 2007). For example, slices of permafrost from Siberia dated to 400,000 to 10,000 BP contained aDNA from at least 19 different plant taxa, including the oldest authentic aDNA sequence identified to date (Willerslev et al., 2003). A highly fascinating study of permafrost material showed the long survival of bacteria (Actinobacteria) in a detailed experiment that demonstrated metabolic activity and DNA repair in ancient microbial cells (Johnson et al., 2007).

\section{AUTENTICATION OF RESULTS IN ANCIENT DNA}

Current aDNA studies entail some certainties and many doubts (Marota \& Rollo, 2002). In the mid-1990s, when several relevant aDNA studies proved to be irreproducible, the need to authenticate aDNA became evident. In addition, the recovery of DNA from specimens dated to more than 100 million years and the apparent identification of long aDNA sequences indicated contamination with modern DNA.

Unfortunately, it is now known that reports of false DNA have occurred ever since this line of research began. The first cloning of human aDNA from a fragment of approximately $3 \mathrm{~kb}$ (Pääbo, 1985) and the recovery of $0.8 \mathrm{~kb}$ of DNA from Magnolia chloroplast dated 17-20 million years (Golemberg et al., 1990) later proved to have resulted from contamination with modern DNA.

Likewise, reexamination of the pioneering study of the quagga specimen identified incorrect positions in the aDNA sequence in the original study. Some criteria for aDNA authenticity have been defined by the main research groups in this area and by specialists in nucleic acid biochemistry, thereby leading to greater rigor in publishing aDNA studies. 
Pääbo (1989) provided the first definition of authenticity in amplified DNA. He basically highlighted the use of extraction controls, the detection of a strong inversely proportional correlation between efficiency of amplification and size of the amplified fragment, and reproduction of the aDNA sequence obtained in a second extract from the same sample. Subsequent studies defined steps and conditions for obtaining truly ancient DNA. They also suggested a series of control tests and techniques to be used in molecular experiments. The following is a description of various criteria for aDNA authenticity defined by the main research groups. For more details, see Cooper \& Poinar (2000) and Pääbo et al. (2004).

\section{Biochemical assays in macromolecular preservation}

Since preservation of amino acids is consistent with that of DNA, biochemical assays in aDNA samples allow accessing the material's state of preservation and thus the classification of samples with possible DNA recovery. The most widely used method is the analysis of the amount, composition, and racemization of amino acids, used especially in bones and teeth, but also applied to coprolites. Poinar et al. (1996) were the first to demonstrate that specimens with high levels of amino acid racemization do not contain sufficient aDNA for analyses. Other methods include pyrolysis-gas chromatography, mass spectrophotometry, histological analysis, and transmission electron microscopy. However, we still lack extensive studies on the correlation between macromolecular preservation detected by these techniques and preservation of aDNA (Pääbo et al., 2004).

\section{Physically isolated working area for aDNA}

Before performing PCR, it is essential that work with aDNA be done in areas or laboratories restricted to this purpose. Physical and/or temporal segregation of the pre-PCR and post-PCR stages is essential to reduce the risks of exogenous contamination. It is obviously inappropriate to use a laboratory setting that routinely works with large amounts of DNA from the study's target.

\section{Extraction and amplification controls}

DNA extraction and PCR controls must be done in parallel for each experiment. The extraction control (in which the sample is replaced with autoclaved Millio or bidistilled $\mathrm{H}_{2} \mathrm{O}$ ) detects contamination of the procedure, reagents, and extraction facilities. When contamination is detected, work flows should be redesigned, including chemical and physical sterilization and disposal of reagents. PCR controls detect contamination of the PCR hood and primer. Positive controls are not recommended, and when necessary the amplification should be done outside the environment of the target aDNA amplification.

\section{Quantification of molecules}

The number of aDNA molecules in the extract should be determined whenever possible. This should be standardized for each set of primers, since primers differ in terms of efficiency in initial amplification. If this procedure shows a high number of molecules ( $>1,000$ molecules has been established as a good basis), multiple amplification or cloning will not be necessary. It is unlikely that changes in the sequence will occur, especially if a single target is expected (e.g., bone marrow extract - amplification of human mtDNA). However, with a small number of molecules $(<1,000$ molecules) at the start of PCR, it is nearly impossible to rule out contamination, especially in human aDNA studies. In 
this case the study requires new amplification, cloning, and sequencing with at least three clones to authenticate the result. The most widely used methods are competitive PCR and, more recently, real-time quantitative PCR.

\section{APPROPRIATE MOLECULAR APPROACHES}

As mentioned, an inverse relationship between the size and intensity of the PCR product is characteristic of aDNA. The recovery of 500 to $1,000 \mathrm{bp}$ fragments is uncommon, and small fragments $(<500 \mathrm{bp})$ are generally considered original aDNA. Likewise, if fragments are not more easily amplified than larger fragments when compared to modern DNA, this strongly suggests contamination. In analyses of simple copy targets (e.g., nDNA) or pathogens, reproducible amplifications of the host should be demonstrated, as in the detection of Enterobius vermicularis and human mtDNA in coprolites (Iñiguez et al., 2006). Nested PCR and reconstructive polymerization (Golemberg, Bickel \& Weihs, 1996) are recommended.

The aDNA sequences should make phylogenetic sense, especially in studies of aDNA from extinct animals. When the small size of the aDNA fragment does not indicate it for this purpose, it is recommended to use overlapping sequences from small fragments, with confirmation of the sequences in the overlapping position.

The analysis of various overlapping fragments of aDNA provided the first analysis of Neanderthal DNA (Krings et al., 1997) and determination of complete mitochondrial genomes, as in the case of the mtDNA genome from extinct animals like the moa and mammoth (Cooper et al., 2001; Krause et al., 2006).

\section{REPRODUCTION OF RESULTS}

Ideally, a positive result of amplification is repeated in the same way and from other independent extractions of the specimen to verify sequence errors caused by aDNA damage. The result of aDNA sequences obtained from direct sequencing should be based on sequence analysis of 3 to 10 products cloned by amplification per sample, as mentioned.

\section{INDEPENDENT REPLICATION}

New, ambiguous, or unexpected aDNA results should be replicated in a second laboratory, specifically for human aDNA research. The work should be done from the aDNA extraction stage to the determination of the nucleotide sequence, preferably following the same experimental design and protocols. This eliminates the possibility of intra-laboratory contamination. Ideally, a subsample is sent directly from the museum or archaeological site to the second laboratory.

Nevertheless, studies are still published that fail to follow the criteria for aDNA research (Zischler et al., 1995; Monsalve et al., 1996; Nickle et al., 2002). This may be due to disagreement as to the applicability of the proposed criteria to a given study, as in biochemical assays of macromolecular preservation, possibly unnecessary when working with samples with visible preservation, recent dating, and adequate preservation after excavation. Adherence to such criteria in routine laboratory practice also makes the work expensive and extremely painstaking. For example, reproduction of results is not always easy, due both to the high cost of the experiments and the lack of specialized laboratories and professionals capable of reproducing the analyses (Cooper \& Poinar, 2000; Montiel, Malgosa \& Francalacci, 2001). It also appears practically impossible to totally eliminate the risk of contamination. Contamination has been detected, described, and discussed in the most highly specialized laboratories in the area (Handt et al., 1996; Kring et al., 1997; Marota \& Rollo, 2002). 


\section{MOLECULAR PALEOPARASITOLOGY: BACKGROUND AND APPROACHES}

The diseases that affected past civilizations and their etiological agents can also be studied by recovering original genetic material from the pathogenic agents.

One of the first such studies detected Mycobacterium tuberculosis aDNA in bones and discussed the importance of PCR for osteoarchaeological research (Spigelman \& Lemma, 1993). The same methodology allowed identifying $M$. tuberculosis in lung tissue from a Peruvian mummy approximately 1,000 years old (Salo et al., 1994). Arriaza et al. (1995) later discussed the pre-Columbian origin of tuberculosis in Chile, presenting molecular evidence of the microbe in vertebral lesions. $M$. tuberculosis was also successfully amplified in vertebrae from the ossuary of an indigenous community in Canada (1400 AD) and an indigenous cemetery in Mississippi (1040 AD). These studies prove that tuberculosis was not introduced into the New World by the European explorers and colonizers, as previously believed.

The presence of tuberculosis in the Old World during pre-contact times was confirmed by identification of $M$. tuberculosis in a calcified structure in lung tissue from a body found in a Byzantine chapel dated $600 \mathrm{AD}$ (Donoghue et al., 1998). To date, $M$. tuberculosis is the most widely explored microorganism in aDNA studies, not limited to diagnosis of the $M$. tuberculosis complex, but extending to genotyping of $M$. tuberculosis or $M$. bovis isolates and making important contributions to understanding the history of this disease (Taylor, 1996; Donoghue et al., 1998; Zink et al., 2001a; Fletcher et al., 2003; Zink, Grabner \& Nerlich, 2005; Taylor et al., 2007).

Ancient DNA studies have been conducted to verify Yersinia pestis in the plague epidemics in Europe. Drancourt et al. (1998) were the first to demonstrate the bacteria in ancient human skeletons using molecular detection of $Y$. pestis in teeth from individuals dated to two epidemic periods (1590 and 1722). However, an analysis of 108 teeth collected from five archaeological sites potentially related to the plague in three European countries failed to yield positive results (Gilbert et al., 2004).

Different molecular targets have been used to attempt to explain discrepancies in results between aDNA studies (Drancourt et al., 1998, 2004; Raoult et al., 2000). Another question elucidated by aDNA studies was the determination of the genotype in $Y$. pestis isolates in ancient human remains from the same period in France and Germany during the plague pandemic. Multiple spacer typing (MST) and characterization of the glpD gene allowed concluding that the Orientalis biotype, now distributed worldwide, was the cause of the last epidemics in Europe (Drancourt et al., 2004, 2007).

The recovery of aDNA from bacteria and protozoa has also provided information on a variety of other infectious diseases such as leprosy (Rafi et al., 1994; Montiel et al., 2003), syphilis (Kolman et al., 1999), typhoid fever (Papagrigorakis et al., 2006), diphtheria (Zink et al., 2001b), gastrointestinal infection (Zink et al., 2000), and malaria (Nerlich et al., 2008).

By applying a molecular technique originally designed to detect $T$. cruzi in tissues of experimentally desiccated mice (Bastos et al., 1996), Felipe Guhl et al. (1999) obtained T. cruzi aDNA from tissues of mummies from the Atacama Desert, thereby concluding that 4,000 years ago, the prehistoric populations of southern Peru and northern Chile suffered from American trypanosomiasis (Chagas disease). The presence of pre-Columbian T. cruzi was also confirmed in the Atacama Desert of Chile, in mummies dated to 2,000 BP (Ferreira et al., 2000). A study established the diagnostic methodology based on hybridization of $70 \mathrm{bp} \mathrm{PCR} \mathrm{products} \mathrm{from} \mathrm{the} \mathrm{minicircle} \mathrm{region} \mathrm{and} \mathrm{showed} \mathrm{that}$ 25 of 27 various tissues from four Andean mummies were positive for this target (Madden et al., 2001). This approach later served to determine the prevalence rate of infection (41\%) in populations from northern Chile to southern Peru, concluding that American trypanosomiasis has been present in the Americas for 9,000 years (Aufderheide et al., 2004). 
A pioneering study in Brazil recovered a mini-exon fragment of T. cruzi aDNA from the rib bone of a female mummy dated 7,000-4,500 BP from the Peruaçu Valley in Minas Gerais State. This landmark study was the first to identify an ancient isolate as genotype T. cruzi I, suggesting that changes have occurred in the spatial and temporal distribution of Chagas disease, since Minas Gerais currently displays genotype T. cruzi II (Lima et al., 2008).

Finally, Fernandes et al. (2008) showed for the first time the link between T. cruzi aDNA genotyping and Chagas disease, studying a mummy with megacolon, suggestive of the disease.

Bacterial aDNA results were obtained from tissues of the Tyrolean Iceman Ötzi, dated to 4,546 17 BP in the Neolithic period. The bacterial flora and pathogenic bacteria were identified by amplification of $16 \mathrm{~S}$ ribosomal DNA obtained from tissue fragments of the stomach, colon, clothing, and others (Cano et al., 2000; Rollo et al., 2000).

However, this approach had to be carefully adjusted for aDNA studies, since we now know that 16S rDNA, widely used in bacterial taxonomy, only allows determination to the genus level, which could shed doubt on paleomicrobiological diagnosis.

Further interesting information was recovered on Ötzi by aDNA analyses, including his human mtDNA haplogroup (Rollo et al., 2006) and the content of his last meal before death (Rollo et al., 2002). The use of generic targets such as ribosomal RNA genes $12 \mathrm{~S}$ and $18 \mathrm{~S}$ and chloroplast DNA (cpDNA), which can determine the diet's plant origin, has been corroborated by phylogenetic analyses that provide taxonomic support for the diagnosis (Rollo et al., 2002). This work's main revelation was discerning between the origin of the plant aDNA from the gut content and that of the environment, i.e., diet versus pollen inhalation, using different molecular targets.

\section{MOLECULAR PALEOPARASITOLOGY AND COPROLITES}

The application of molecular techniques to the analysis of fecal material has served to produce individual and population information on diet, genus, filiation, and presence of pathogenic agents (Höss et al., 1992; Kohn et al., 1995, 1999; Kohn \& Wayne, 1997).

Fricker, Spigelman \& Fricker (1997) used PCR to detect Escherichia coli aDNA in the intestinal content of Iron Age mummies, dated $300 \mathrm{BC}$. The study revealed several inherent methodological difficulties in working with feces (inhibition of enzyme amplification) and DNA (degradation of the aDNA and contamination with modern DNA). The authors also highlighted how coprolites can serve as a source for analyzing infectious diseases in prehistoric civilizations, besides providing alternative information on the evolution of these pathogens.

Leading aDNA experts failed in their initial attempts to recover DNA from coprolites (Höss et al., 1996). However, Vasan et al. (1996) demonstrated the presence of large amounts of ligand structures between groups of amino acids and reduced sugar (Maillard products) in coprolites and showed that phenacylthiazolium bromide (PTB) cleaves this structure, thereby facilitating aDNA amplification.

Thus, it was not until 1998 that aDNA from animal coprolites nearly 19,000 years old were analyzed to determine their origin and the composition of the animals' diet (Poinar et al., 1998). The technique was amplification of ribosomal genes from the chloroplast and mitochondrial genes and subsequent species identification by nucleotide sequence analysis of various clones. Poinar et al. (2001) also demonstrated the diversity of Amerindian diet using three coprolite samples more than 2,000 years old.

However, despite its rigorous methodology, the latter study was flawed in pointing to species in the plant diet since it failed to consider the region's macromolecular findings and palynological studies (Reinhard et al., 2008). The 
latter authors emphasize two basic critiques of the study: 1) the small cpDNA fragment that was analyzed would only allow taxonomic classification to the family level and 2) the approach for species identification was simple selection of the highest percentage of similarity between sequences after comparison with the international nucleotide sequence databank (Blast/GenBank), where data on the cpDNA sequence that correspond to the species from the Amerindian plant diet may not have been studied or deposited.

Coprolites are mainly used as a source for paleoparasitological research. Loreille et al. (2001) recovered aDNA from Ascaris eggs isolated from medieval coprolites. This detailed study used citB and 16S genes as the target and performed comparisons with DNA sequences from modern Ascaris lumbricoides and Ascaris suum, parasites of humans and swine, respectively. Although the archaeological analysis did not determine the origin of the coprolites (human origin was only suggested), it is now known that cross-infection exists and that species classification is much more complex. At any rate, confirmation of the presence of Ascaris sp. in $14^{\text {th }}$-century coprolites recovered from a latrine at the Place d'Armes archaeological site in Namur, Belgium, was the first encouraging molecular evidence of nematode enteroparasites in ancient European populations.

Iñiguez et al. $(2003,2006)$ studied pre-Columbian coprolites from four archaeological sites in North and South America, dated to $4110 \mathrm{BC}-900 \mathrm{AD}$. They recovered E. vermicularis aDNA using the 5S rRNA spacer region as the molecular target. The study was the first to show the possibility of accessing genetic material from the parasite even without prior isolation of eggs and in samples that were negative on paleoparasitological analysis. It featured a genetic analysis of the intergenic region that proved to be highly conserved temporally and spatially, due to the presence of an inserted gene (SL1 RNA) that imprinted conservation on the target region (Iñiguez et al., 2006).

Direct molecular paleoparasitological diagnosis of coprolites and sediments has shown positive results in samples that were negative for Ascaris sp. under light microscopy. Unlike microscopic analyses, molecular techniques based on the method proposed by Loreille et al. (2001) showed that Ascaris and Trichuris were widely distributed in preColumbian South America and that the distribution pattern of these infections at the time did not differ greatly from the current pattern (Leles et al., 2008). Molecular diagnosis has proven more sensitive than light microscopy for diagnosing Ascaris sp and E. vermicularis and can be expected to make important contributions to the evolutionary history of these parasites. It should thus be extended to the study of other parasitic infections.

\section{ACKNOWLEDGMENTS}

I wish to thank Dr. Ana Carolina Paulo Vicente for her orientation and suggestions and for the opportunity to conduct this work.

\section{REFERENCES}

ARRIAZA, B. T et al. Pre-Columbian tuberculosis in Northern Chile: molecular and skeletal evidence. American Journal of Physical Anthropology, 98: 37-45, 1995.

ASCENZI, A. et al. Immunological detection of hemoglobin in bones of ancient Roman times and of Iron and Eneolithic Ages. Proceedings of the National Academy of Sciences USA, 82: 7.170-7.172, 1985.

AUFDERHEIDE, A. C. et al. 9,000-year record of Chagas' disease. Proceedings of the National Academy of Sciences USA, 101: 2.0342.039, 2004. 
BASTOS, O. M. et al. Experimental paleoparasitology: identification of Trypanosoma cruzi DNA in desiccated mouse tissue. Paleopathology Newsletter, 94: 5-8, 1996.

BROWN, K. Archaeology: new trips through the back alleys of agriculture. Science, 292: 631-633, 2001.

BROWN, T. A. \& BROWN, K. A. Ancient DNA: using molecular biology to explore the past. Bioessays, 16: 719-726, 1994.

BROWN, T. A. et al. DNA in wheat seeds from European archaeological sites. Experientia, 50: 571-555, 1994.

BURGER, J. et al. Palaeogenetic analysis of (pre)historic artifacts and its significance for anthropology. Anthropology, 58: 69-76, 2000.

CANO, R. J. et al. Amplification and sequencing of DNA from a 120-135-million-year-old weevil. Nature, 363: 536-538, 1993.

CANO, R. J. et al. Sequence analysis of bacterial DNA in the colon and stomach of the Tyrolean Iceman. American Journal of Physical Anthropology, 112: 297-309, 2000.

COOPER, A. \& POINAR, H.N. Ancient DNA: do it right or not at all. Science, 289: 1.139, 2000.

COOPER, A. et al. Human origins and ancient human DNA. Science, 292: 1.655-1.656, 2001.

DE SALLE, R. et al. DNA sequences from a fossil termite in Oligo-Miocene amber and their phylogenetic implications. Science, 257: 1.933-1.936, 1992.

DONOGHUE, H. D. et al. Mycobacterium tuberculosis complex DNA in calcified pleura from remains 1400 years old. Letters in Applied Microbiology, 27: 265-269, 1998.

DRANCOURT, M. \& RAOULT, D. Sequence-based identification of new bacteria: a proposition for creation of an orphan bacterium repository. Journal of Clinical Microbiology, 43: 4.311-4.315, 2005.

DRANCOURT, M. et al. Detection of 400-year-old Yersinia pestis DNA in human dental pulp: an approach to the diagnosis of ancient septicemia. Proceedings of the National Academy of Sciences USA, 95: 12637-12640, 1998.

DRANCOURT, M. et al. Genotyping, Orientalis-like Yersinia pestis, and plague pandemics. Emerging Infectious Disease, 10: 1.5851.592, 2004.

DRANCOURT, M. M. et al. Yersinia pestis Orientalis in remains of ancient plague patients. Emerging Infectious Disease, 13: 332333, 2007.

FERNANDES, A. et al. Pre-Columbian Chagas disease in Brazil: Trypanosoma cruzi I in the archaeological remains of a human in Peruaçu Valley, Minas Gerais, Brazil. Memórias do Instituto Oswaldo Cruz, 103: 514-516, 2008.

FERREIRA, L. F. et al. Paleoparasitology of Chagas disease revealed by infected tissues from Chilean mummies. Acta Tropica, 75: 79-84, 2000.

FLETCHER, H. A. et al. Widespread occurrence of Mycobacterium tuberculosis DNA from $18^{\text {th }}-19^{\text {th }}$ century Hungarians. American Journal of Physical Anthropology, 120: 144-152, 2003.

FRICKER, E. J.; SPIGELMAN, M. \& FRICKER, C. R. The detection of Escherichia coli DNA in the ancient remains of Lindow Man using the polymerase chain reaction. Letters in Applied Microbiology, 24: 351-354, 1997.

GILBERT, M. T. P. et al. Absence of Yersinia pestis-specific DNA in human teeth from five European excavations of putative plague victims. Microbiology, 150: 341-354, 2004.

GILBERT, M. T. et al. DNA from pre-Clovis human coprolites in Oregon, North America. Science, 320: 786-789, 2008.

GóES, A. C. et al. Identification of a criminal by DNA typing in a rape case in Rio de Janeiro, Brazil. São Paulo Medical Journal, 120: 77-79, 2002.

GOLEMBERG, E. M.; BICKEL, A. \& WEIHS, P. Effect of highly fragmented DNA on PCR. Nucleic Acids Research, 24: 5.026-5.033, 1996. GOLEMBERG, E. M. et al. Chloroplast DNA sequence from a Miocene Magnolia species. Nature, 344: 656-658, 1990. 
GOLOUBINOFF, P.; PÄÄBO, S. \& WILSON, A. C. Evolution of maize inferred from sequence diversity of an Adh2 gene segment from archaeological specimens. Proceedings of the National Academy of Sciences USA, 90: 1997-2001, 1993.

GONÇALVES, M. L. et al. Detection of Giardia duodenalis antigen in coprolites using a commercially available enzyme-linked immunosorbent assay. Transactions of the Royal Society of Tropical Medical and Hygiene, 96: 640-643, 2002.

GOODWIN, W.; LINACRE, A. \& VANEZIS, P. The use of mitochondrial DNA and short tandem repeat typing in the identification of air crash victims. Electrophoresis, 20: 1.707-1.711, 1999.

GREENWOOD, A. D. et al. Nuclear DNA sequences from late Pleistocene megafauna. Molecular Biology and Evolution, 16: 1.466$1.473,1999$.

GUHL, F. C. et al. Isolation of Trypanosoma cruzi DNA in 4,000-year-old mummified human tissue from northern Chile. American Journal of Physical Anthropology, 108: 401-407, 1999.

HAGELBERG, E. et al. Analysis of ancient bone DNA: techniques and applications. Philosophical Transactions of the Royal Society B: Biological Sciences, 333: 399-407, 1991.

HANDT, O. et al. Ancient DNA: methodological challenges. Experientia, 50: 524-529, 1994.

HANDT, O. et al. The retrieval of ancient human DNA sequences. American Journal of Human Genetics, 59: 368-376, 1996.

HERRMANN, B. \& HUMMEL, S. Introduction. In: HERRMAN, B. \& HUMMEL, S. Ancient DNA: recovery and analysis of genetic material from paleontological, archaeological, museum, medical, and forensic specimens. New York: Springer, 1994.

HIGUCHI, R. et al. DNA sequences from the quagga, an extinct member of the horse family. Nature, 312: 282-284, 1984.

HOFREITER, M. Palaeogenomics. Série Palévolution des Comptes Rendus de l'Académie des Sciences, 7: 113-124, 2008.

HOFREITER, M. et al. Ancient DNA. Nature Reviews Genetics, 2: 353-335, 2001.

HOFREITER, M. et al. Ancient DNA analyses reveal high mitochondrial DNA sequence diversity and parallel morphological evolution of late Pleistocene cave bears. Molecular Biology and Evolution, 19: 1244-1250, 2002.

HÖSS, M. Ancient DNA. Hormone Research, 43: 118-120, 1995.

HÖSS, M. et al. Excrement analysis by PCR. Nature, 359: 199, 1992.

HÖSS, M. et al. DNA damage and DNA sequence retrieval from ancient tissues. Nucleic Acids Research, 24: 1.304-1.307, 1996.

HUMMEL, S. \& HERRMANN, B. Y-chromosome-specific DNA amplified in ancient human bone. Naturwissenschaften, 78: 266$267,1991$.

IÑIGUEZ, A. M. et al. Enterobius vermicularis: ancient DNA from North and South American Human Coprolites. Memórias do Instituto Oswaldo Cruz, 98, supl. 1: 67-69, 2003.

IÑIGUEZ, A. M. et al. SL1 RNA gene recovery from Enterobius vermicularis ancient DNA in pre-Columbian human coprolites. International Journal of Parasitology, 36: 1.419-1.425, 2006.

JOHNSON, S. et al. Ancient bacteria show evidence of DNA repair. Proceedings of the National Academy of Sciences USA, 104: 14.401-14.405, 2007.

KOHN, M. H. \& WAYNE, R. K. Facts from feces revisited. Trends in Evolution, 12: 223-227, 1997.

KOHN, M. et al. Conservation genetics of the European brown bear: a study using excremental PCR of nuclear and mitochondrial sequences. Molecular Ecology, 4: 95-103, 1995.

KOHN, M. H. et al. Estimating population size by genotyping faeces. Proceedings of the Royal Society B: Biological Sciences, 266: 657-663, 1999.

KOLMAN, C. J. et al. Identification of Treponema pallidum subspecies pallidum in a 200-year-old skeletal specimen. Journal of Infectious Disease, 180: 2.060-2.063, 1999. 
KRAUSE, J. et al. Multiplex amplification of the mammoth mitochondrial genome and the evolution of Elephantidae. Nature, 439: 724-727, 2006.

KRING, M. et al. Neanderthal DNA sequences and the origin of modern humans. Cell, 90: 19-30, 1997.

LE BAILlY, M. et al. New finding of Giardia intestinalis (Eukaryote, Metamonad) in Old World archaeological site using immunofluorescence and enzyme-linked immunosorbent assays. The Journal of Parasitology, 103: 298-300, 2008.

LELES, D. et al. Molecular paleoparasitological diagnosis of Ascaris sp. from coprolites: new scenery of ascariasis in pre-Columbian South America times. Memórias do Instituto Oswaldo Cruz, 103: 106-108, 2008.

LIMA, V. S. et al. Chagas disease in ancient hunter-gatherer population, Brazil. Emerging Infectious Diseases, 14(6): 1.001-1.002, 2008.

LINDAHL, T. Instability and decay of the primary structure of DNA. Nature, 362: 709-715, 1993.

LOREILLE, O. \& BOUCHET, F. Evolution of ascariasis in humans and pigs: a multi-disciplinary approach. Memórias do Instituto Oswaldo Cruz, 98, supl. 1: 39-46, 2003.

LOREILLE, O. et al. Ancient DNA from Ascaris: extraction amplification and sequences from eggs collected in coprolites. International Journal of Parasitology, 31: 1.101-1.106, 2001.

LOWENSTEIN, J. M. Species-specific proteins in fossils. Naturwissenschaften, 67: 343-346, 1980.

LOY, T. H. Prehistoric Blood Residues: detection on tool surfaces and identification of species of origin. Science, 220: 1.269-1.271, 1983.

LYDOLPH, M. C. et al. Beringian paleoecology inferred from permafrost-preserved fungal DNA. Applied Environmental Microbiology, 71: 1.012-1.017, 2005.

MADDEN, M. et al. Hybridization screening of very short PCR products for paleoepidemiological studies of Chagas' disease. Biotechniques, 30: 102-104, 106, 108-109, 2001.

MAROTA, I. \& ROLLO, F. Molecular paleontology. Cellular and Molecular Life Sciences, 59: 97-111, 2002.

MERRIWETHER, D. A.; ROTHHAMMER, F. \& FERRELL, R. E. Genetic variation in the New World: ancient teeth, bone, and tissue as sources of DNA. Experientia, 50: 592-601, 1994.

MONSAlVE, M. V. et al. Phylogenetic analysis of mtDNA lineages in South American mummies. Annals of Human Genetics, 60: 293-303, 1996.

MONTIEL, R.; MALGOSA, A. \& FRANCALACCI, P. Authenticating ancient human mitochondrial DNA. Human Biology, 73: 689$713,2001$.

MONTIEL, R. et al. DNA sequences of Mycobacterium leprae recovered from ancient bones. FEMS Microbiology Letter, 226: 413$414,2003$.

MULLIS, K. B. \& FALLONA, F. A. Specific synthesis of DNA in vitro via a polymerase-catalysed chain reaction. Methods in Enzymology, 155: 335-350, 1987.

NERLICH, A. G. et al. Molecular evidence for tuberculosis in an ancient Egyptian mummy. The Lancet, 350: 1.404, 1997.

NERLICH, A. G. et al. Plasmodium falciparum in ancient Egypt. Emerging Infectious Diseases and Society, 14: 1.317-1.319, 2008.

NICKLE, D. C. et al. Curiously modern DNA for a '250 million-year-old' bacterium. Journal of Molecular Evolution, 54: 134-137, 2002.

PÄÄBO, S. Molecular cloning of ancient Egyptian mummy DNA. Nature, 314: 644-645, 1985.

PÄÄBO, S. Ancient DNA: extraction, characterization, molecular cloning, and enzymatic amplification. Proceedings of the National Academy of Sciences USA, 86: 1.939-1.943, 1989.

PÄÄBO, S.; GIFFORD, J. A. \& WILSON, A. C. Mitochondrial DNA sequences from a 7000-year old brain. Nucleic Acids Research, 16: 9.775-9.787, 1988. 
PÄÄBO, S.; IRWIN, D. M. \& WILSON, A. C. DNA damage promotes jumping between templates during enzymatic amplification. Journal of Biological Chemistry, 265: 4718-4721, 1990.

PÄÄBO, S. et al. Genetic analyses from ancient DNA. Annual Review of Genetics, 38: 645-679, 2004.

PAPAGRIGORAKIS, M. J. et al. DNA examination of ancient dental pulp incriminates typhoid fever as a probable cause of the Plague of Athens. International Journal of Infectious Disease, 10: 206-214, 2006.

POINAR, H. N. The genetic secrets some fossils hold. Accounts of Chemical Research, 35: 676-684, 2002.

POINAR, H. N. et al. Amino acid racemization and the preservation of ancient DNA. Science, 272: 864-866, 1996.

POINAR, H. N. et al. Molecular coproscopy: dung and diet of the extinct ground sloth Nothrotheriops shastensis. Science, 281: 402406, 1998.

POINAR, H. N. et al. A molecular analysis of dietary diversity for three archaic Native Americans. Proceedings of the National Academy of Sciences USA, 98: 4.317-4.322, 2001.

POINAR, H. N. et al. Metagenomics to paleogenomics: large-scale sequencing of mammoth DNA. Science, 311: 392-394. 2006.

PRUVOST, M. et al. Freshly excavated fossil bones are best for amplification of ancient DNA. Proceedings of the National Academy of Sciences USA, 104: 739-744, 2007.

RAFI, A. et al. Mycobacterium leprae DNA from ancient bone detected by PCR. The Lancet, 343: 1.360-1.361, 1994.

RAOULT, D. et al. Molecular identification by 'suicide PCR' of Yersinia pestis as the agent of Medieval Black Death. Proceedings of the National Academy of Sciences USA, 97: 12.800-12.803, 2000.

REINHARD, K. J. et al. Evaluating chloroplast DNA in prehistoric Texas coprolites: medicinal, dietary, or ambient ancient DNA. Journal of Archaeological Science, 35: 1.748-1.755, 2008.

RELETHFORD, J. H. Absence of regional affinities of Neanderthal DNA with living humans does not reject multiregional evolution. American Journal of Physical Anthropology, 115: 95-98, 2001.

ROLLO, F. et al. Analysis of bacterial DNA in skin and muscle of the Tyrolean Iceman offers new insight into the mummification process. American Journal of Physical Anthropology, 111: 211-219, 2000.

ROLLO, F. et al. Ötzi's last meals: DNA analysis of the intestinal content of the Neolithic glacier mummy from the Alps. Proceedings of the National Academy of Sciences USA, 99: 12.594-12.599, 2002.

ROLLO, F. et al. Fine characterization of the Iceman's mtDNA haplogroup. American Journal of Physical Anthropology, 130: 557564, 2006.

SAIKI, R. K. et al. Enzymatic amplification on $\square$-globulin genomic sequences and restriction site analysis for diagnosis of sickle cell anemia. Science, 230: 1.350-1.354, 1985.

SALO, W. L. et al. Identification of Mycobacterium tuberculosis DNA in ancient mummy. Proceedings of the National Academy of Sciences USA, 91: 2.091-2.094, 1994.

SPIGELMAN, M. \& LEMMA, E. The use of the polymerase chain reaction (PCR) to detect Mycobacterium tuberculosis in ancient skeletons. International Journal of Osteoarchaeology, 3: 137-143, 1993.

TAYLOR, G. M. et al. Rapid detection of Mycobacterium bovis DNA in cattle lymph nodes with visible lesions using PCR. BMC Veterinary Research, 3: 12, 2007.

TAYLOR, P. G. Reproducibility of ancient DNA sequences from extinct Pleistocene fauna. Molecular Biology and Evolution, 13: 283285, 1996.

VASAN, S. et al. An agent cleaving glucose-derived protein crosslinks in vitro and in vivo. Nature, 382: 275-278, 1996.

WEINER, S.; LOWENSTAM, H. A. \& HOOD, L. Characterization of 80-million-year-old mollusk shell proteins. Proceedings of the National Academy of Sciences, 73: 2541-2545, 1976. 
WILLERSLEV, E. et al. Diverse plant and animal genetic records from Holocene and Pleistocene sediments. Science, 300: 791 -795, 2003.

WILLERSLEV, E. et al. Ancient biomolecules from deep ice cores reveal a forested southern Greenland. Science, 317: 111-114, 2007.

WILLMANN, M. R. Studying the historic migrations of the Irish potato famine pathogen using ancient DNA. Trends in Plant Science, 6: 450, 2001.

ZINK, A. R.; GRABNER, W. \& NERLICH, A. G. Molecular identification of human tuberculosis in recent and historic bone tissue samples: the role of molecular techniques for the study of historic tuberculosis. American Journal of Physical Anthropology, 126: 32-47, 2005.

ZINK, A. et al. Molecular evidence of bacteremia by gastrointestinal pathogenic bacteria in an infant mummy from ancient Egypt. Archives of Pathology and Laboratory Medicine, 124: 1.614-1.618, 2000.

ZINK, A. et al. Molecular analysis of skeletal tuberculosis in an ancient Egyptian population. Journal of Medical Microbiology, 50: 355-366, 2001a.

ZINK, A. et al. Corynebacterium in ancient Egypt. Medical History, 45: 267-272, 2001b.

ZISCHLER, H. et al. A nuclear 'fossil' of the mitochondrial D-loop and the origin of mode. Nature, 378: 489-492, 1995. 
part III

Parasite Findings in Archeological Remains:

a paleogeographic view 


\title{
The Findings in South America
}

\author{
Luiz Fernando Ferreira • Léa Camillo-Coura • Martín H. Fugassa \\ Marcelo Luiz Carvalho Gonçalves • Luciana Sianto • Adauto Araújo
}

In South America, paleoparasitology first developed with studies in Brazil, consolidating this new science that

reconstructs past events in the parasite-host relationship. Many studies on parasites in South American archaeological material were conducted on human mummies from the Andes (Ferreira, Araújo \& Confalonieri, 1988). However, interest also emerged in parasites of animals, with studies of coprolites found in archaeological layers as a key source of ancient climatic data (Araújo, Ferreira \& Confalonieri, 1982).

Callen \& Cameron (1960) conducted pioneering studies in human coprolites from Huaca Prieta, Peru, dated to circa 5,000 BP, describing Diphyllobothrium sp. eggs. The authors demonstrated the usefulness of rehydrating coprolites in trisodium phosphate aqueous solution, a technique still widely used to recuperate desiccated material and allow microscopic examination of structures preserved in the fecal matter.

Paleoparasitology in South America began with isolated studies, mainly when archaeologists referred the material to parasitologist colleagues, who described the results, as commented by Ferreira, Araújo \& Confalonieri (1988). Research groups developed gradually and interest grew in archaeological material, followed by studies in Chile (Arriaza, 1995), Peru (Ortega \& Bonavia, 2003), and Argentina (Fugassa \& Guichón, 2005). These three countries currently have dedicated research groups in paleoparasitology that collaborate with each other and with the group from the Oswaldo Cruz Foundation in Brazil. Colombian and Bolivian researchers have also participated in seminars and workshops like the international meeting in 2008 at the University of Tarapacá, Arica, Chile, headed by Bernardo Arriaza, with the theme paleoenvironment and paleoparasitology. Bolivian paleoparasitology began with Sotomayor, Burgos \& Arango (2004) and Nancy Orellana, with her Master's thesis presented at the Oswaldo Cruz Institute in Rio de Janeiro, Brazil (Orellana, 2008).

The three meetings of the Paleopathology Association in South America, held in Rio de Janeiro, Brazil (2005), Santiago, Chile (2007), and Necochea, Argentina (2009), organized by Sheila Mendonça, Mario Castro, and Ricardo Guichón, respectively, featured symposia in paleoparasitology, with papers presented by students and experienced researchers. 
Archaeology in South America has developed both in studies of the human groups that inhabited the Pacific Coast and the Andean Region (Silverman \& Isbell, 2008) as well as in Patagonia and Brazil (Borrero, 2001; Pessis, 2003; Martin, 2005). Each new discovery demonstrates the growing need for exploration by specialists with multidisciplinary approaches.

Archaeological sites in South America feature those situated on the Pacific Coast of the Andean Region. Highly organized societies developed there, succeeding each other over time and finally dying out, mostly at the hands of the Spanish Conquerors. These societies were well-documented in reports from the time of the Conquest and by the archaeological record, due to the great interest they attracted. Importantly, there are still groups today that guard traditions from the ancient peoples, as the depositories of these ancient customs (Silverman \& Isbell, 2008).

Less has been published on other lands of South America. Since the beginning of the colonial period, European chroniclers left the Atlantic Coast for various reasons and ventured out across forests and wilderness towards the other side of the continent. However, it was the archaeology of the peoples that inhabited Brazil before its discovery that highlighted the way of life and cultures of these peoples on the Brazilian and international research scene (Tenório, 1999; Gaspar, 2000; Gaspar et al., 2008; Martin, 2005; Prous, 2006; Neves, 2006). For example, recent studies have shown that even the forests had villages with large groups of individuals (Heckenberger, Petersen \& Neves, 1999) that practiced diversified agriculture (Olsen \& Schaal, 1999; Clarke et al., 2006; Montenegro, Avis \& Weaver, 2008).

Controversies have arisen, for example with the wealth of findings in the archaeological sites of Serra da Capivara National Park in Piauí State, Brazil (Guidon, 2007). Dating on the human presence differs from the current wisdom, or rather, from what was conventionally accepted based on data from other regions (Lima, 2006; Neves, 2006; Silva \& Rodrigues-Carvalho, 2006). Other sites with ancient dates, such as Monte Verde in Chile, were also featured in the discussion on the human presence in Prehistoric America (Dillehay, 2008). This new knowledge, added to established theories, confront and create new paths for understanding the evolution and dispersal of the human species, especially with new findings in South America (Guichón et al., 2006; Hubbe et al., 2007).

The peoples that inhabited the coast of Brazil were described in documents by the first European travelers that reached America. They also left abundant archaeological remains (Gaspar et al., 2008). These coastal peoples moved and interacted with those of the hinterland, in peaceful or belligerent relations, the latter intensified by the arrival of the Europeans (Medeiros, 2002). The historical documentation suggests hypotheses on the circulation of parasitic diseases in the Americas, before and after the great navigations, as discussed in this book. Paleoparasitological findings contribute scientific data to interpretations on each archaeological context.

Despite the conditions of preservation in a major part of South America, with a hot and humid climate and fauna and flora capable of taking advantage of all organic residues launched into the soil without leaving a trace, there is a considerable accumulation of data on the region's occupation, dating to remote times. Thus, it is not a general rule that a constantly hot and rainy climate impedes the preservation of organic archaeological remains capable of yielding data on the past. The neotropical region includes extensive areas with arid or semiarid climates and others with cold temperatures, thus favoring the preservation of organic remains. Organic remains from ancient populations were preserved even in the Amazon, which was believed to be impossible until recently (Neves, 2006, 2008).

Pizzi \& Schenone (1954) made one of the first paleoparasitological findings in South America, in a pre-Columbian Chilean mummy. The authors made what have proven to be erroneous speculations on a possible South American origin of Trichuris trichiura infection, later discussed by Confalonieri (1988) in his thesis on this parasite's origin in ancestral humans and its introduction into the Americas. 
Current findings from ancient South American sites are important for understanding prehistoric occupation of territories and peopling of the Americas. Paleoparasitology provides an evolutionary perspective on the interaction between parasites, human hosts, and the environment, contributing findings to various fields that study the past (Araújo et al., 2003).

The birth of Brazilian paleoparasitology had a strong influence on the organization of other similar groups in various parts of the world, leading to evolution and change in knowledge on parasitic diseases and infection in remote periods of humankind. Cockburn (1971) predicted this when he discussed the possibilities for studying diseases in ancient populations as a way of understanding prehistoric events, and even later in time, whenever written records or documents did not exist or had been lost.

Paleoparasitological data in South America are fascinating and varied. They provide clear evidence of prehistoric intestinal parasitic infections and overturn the classical concept by which these infections were brought to the Americas by the European Conquerors or the African slave trade. The data thus disprove established concepts according to which most so-called tropical diseases were brought to the Americas (previously blessed by a totally healthy environment) from Africa (Freitas, 1935; Carvalho, 2006). The picture emerging from the data are that tuberculosis and the most common helminth infections, such as ascariasis, hookworm, whipworm, and pinworm already infected indigenous groups in pre-Columbian America, ever since the first migratory waves in remote times, persisting in successive indigenous populations.

These parasitic infections probably existed at lower levels in pre-Columbian hunter-gatherer peoples, due to their nomadic habits and dietary characteristics, unfavorable to the maintenance of helminth life cycles or the transmission of certain bacteria, viruses, and other parasites. In some human groups, coprolite analysis has identified the ingestion of plants with anthelminthic properties (Chaves \& Reinhard, 2003). The situation changed in farming and herding societies with the transmission of other parasites facilitated by human agglomeration (Reinhard, 1992).

Studies on parasitic infections in ancient populations can be compared to those in current indigenous peoples. This helps establish a continuum or sequence of events over time, reconstructing human history (Coimbra Jr. \& Santos, 1992). Various research groups now study parasites in archaeological material from different countries of South America. Interpretation of the findings and their meaning for understanding the life of ancient peoples began to emerge in articles based on cooperation among the research groups. For example, studies in southern Patagonia have aimed to elucidate the living and health conditions of Patagonian indigenous peoples and the consequences of contact with early Europeans colonialists (Fugassa \& Guichón, 2005; Casali, Fugassa \& Guichón, 2006).

We will now summarize the parasite findings in South American archaeological material, highlighting the paleoparasitological record of each species or group of parasites. We aim not to provide an exhaustive record of the findings, because the list would be obsolete by the time this book is published. Rather, readers will find it useful as a record of how much information can be gleaned by finding a simple worm egg in preserved feces or a fragment of genetic material from a protozoan or bacteria in the mummified tissue of some individual that died thousands of years ago.

\section{GEOHELMINTH INFECTIONS AND HELMINTH PARASITES AS MARKERS OF PREHISTORIC MIGRATIONS}

Since most of the parasitic infections discussed here involve helminths, we will present details on those transmitted by soil contamination. These generally originated in ancient Africa, have parasitized humans since our pre-hominid ancestors, and reached the Americas with humans long before the Iberian navigators. They serve as interesting biological markers of prehistoric migrations (Araújo, Ferreira \& Confalonieri, 1981; Araújo et al., 2008). 
Geohelminth infections in humans are transmitted through soil contamination (Camillo-Coura, 1970, 1985a, 1985b). The most prevalent geohelminth species in the global population are Ascaris lumbricoides, Trichuris trichiura, Ancylostoma duodenale, Necator americanus, and Strongyloides stercoralis, followed by species from the family Trichostrongylidae, Ternidens diminutus, Oesophagostomum brumpti, and Toxocara canis. A third group includes helminths whose transmission can occur by other routes, but also by soil: Enterobius vermicularis (currently one of the most frequent helminth infections on all the continents), Hymenolepis nana, and Echinococcus granulosus. Cases of human infection with other species are much rarer, such as those of genus Coenurus, Capillaria hepatica, Syngamus laringeus, Ancylostoma braziliense, and others.

These parasites display complex life cycles, resulting from parasite-host-environment adaptations that occurred over a long evolutionary process. A detailed description would be both tiresome and repetitive, since they appear in easily accessible parasitology textbooks (Rey, 2008). Still, we will summarize some aspects that should help even the non-specialized reader to interpret their paleoepidemiological implications. The following outlines of their respective clinical presentations help understand possible health problems caused by these helminth infections.

\section{Ankylostomiasis - Hookworms (Ancylostoma duodenale and Necator americanus)}

The clinical presentation in hookworm infection in humans features different degrees of anemia and occasionally edema. Infected individuals lose blood through the stools due to the worms' attachment to the intestinal mucosa and the resulting microscopic ulcerations. The degree of anemia relates directly to the worm burden and inversely to the individual's iron replacement capacity.

Symptoms thus result from various factors including number of parasites (worm burden), the human hosts' nutritional status and diet, and the surrounding environment, with greater or lesser odds of constant infection.

Ancylostoma duodenale and Necator americanus can present indistinguishable clinical pictures, but with important differences in their biology, leading them to withstand greater or lesser environmental variation, thereby influencing their geographic distribution (Hoagland \& Schad, 1978). Ancylostoma duodenale resists colder temperatures than Necator americanus, and its geographic distribution thus reaches higher latitudes.

Classic cases occurred during construction of the St. Gotthard Tunnel between Italy and Switzerland. In 1879, Edoardo Perroncito, Camillo Bozzolo \& Luigi Pagliani identified infection with Ancylostoma duodenale (a species described by Angelo Dubini in 1843) as the cause of anemia in workers building the railway through the tunnel. The parasite maintained its life cycle inside the tunnel, where the temperature was higher and more constant than outside. Since the environment was closed with many individuals circulating and conditions favoring super-infection, workers presented extremely severe clinical conditions, some fatal (Peduzzi \& Piffaretti, 1983).

Where prehistoric hookworm infection was prevalent, it may have particularly impacted cave-dwelling human groups that stayed inside their caves for long periods. El-Najjar et al. (1976), Stuart-Macadam (1992), Grauer (1993), and Rothschild (2002) raised this hypothesis, specifically related to porotic hyperostosis (characterized by bone marrow growth and thinning of the bony layer as a reaction to anemia), but the hypothesis requires more definitive evidence.

The number of hookworm eggs per coprolite or gram of latrine sediment in archaeological material in South America is small when compared to modern samples. Some samples show larvae in various stages of development which require morphological identification to avoid confusing them with free-living nematode larvae or other parasite species such as Strongyloides stercoralis. 
The climatic conditions under which the dung was deposited may have facilitated egg eclosion and larval development. This explains finding the three larval stages in coprolites from the Gentio II Cave in Unaí, Minas Gerais State, dated to 3,500 BP (Ferreira, Araújo \& Confalonieri, 1980). The semiarid climate of the cerrado and caatinga in Northeast Brazil leads to rapid water loss on the surface of excreted feces, while retaining some moisture inside. This allows egg eclosion and changes in larval stages but prevents them from migrating into the soil due to the dry outer crust. We tested this possibility in our laboratory by drying dog feces containing hookworm eggs in ovens for various periods of time, at $40-45^{\circ} \mathrm{C}$. The larvae evolved to the infective stage without abandoning the fecal matter and were easily identified under the microscope after rehydration (Araújo, 1987).

Specific regional environmental conditions represent another key point in hookworm paleoepidemiology. Thus, Ancylostoma duodenale infection was diagnosed in $20 \%$ of the modern population in small villages around the Serra da Capivara National Park, but with no cases of infection with Necator americanus. The region is located in the so-called Northeast Brazilian "drought triangle" in semiarid southeastern Piauí State. A hot temperature but low relative humidity (depending on the season, rainy versus dry) hinders larval development in the soil in certain areas. The website of the Foundation of the Museum of the American Man (www.fumdham.org.br) provides climatic data on the Serra da Capivara National Park and surrounding area.

However, on-site observation and laboratory experiments have demonstrated that the use of water holes called caldeirões (literally "big caldrons") provided a source of infection and maintenance of local infection, with the necessary biological conditions for the parasite. The current villages grew around these reservoirs at the same sites chosen by prehistoric groups. Water flows around these natural reservoirs during the rainy season, and during the dry season humans and animals use them for water. They contain abundant feces, both prehistoric and modern. From past to present, they have acted as sites for contact between humans and animals, with parasitic infections transmitted over time, facilitated by the environment's microclimatic conditions and use by the species inhabiting the region, including humans. These "big caldrons" have thus been natural hookworm foci from prehistory to the present, perpetuating infection from the remote past to modernity in a 7,000-year continuum.

Other researchers have tested hookworm infectivity in numerically small human groups. Marasciulo (1992) simulated the transmission rate of parasitic infection by an infected individual with a male and female worm in a population of approximately 300 individuals, isolated from any outside contact. The entire population would be exposed to the parasite within one year, even under the most adverse semiarid climatic conditions. Attraction of human groups to the water holes would thus explain transmission. Larvae released in the feces would enjoy sufficient odds of finding new hosts.

The simulation provided a model for hookworm infection in prehistoric populations and concluded that a single infected individual in contact with a population of some 300 individuals could infect everyone within a year.

In prehistoric conditions, infected persons arriving by boat from Asia would be fully capable of contaminating humans already living in South America, especially under more favorable conditions for transmission (Figures 1 and 2). 
Figure 1 - Caldeirão do Urubu, Serra Branca, Serra da Capivara National Park, Piauí State, Brazil. In this semiarid region in Northeast Brazil, humans and animals use reservoirs that retain rainwater throughout the year. The ground around the water hole tends to be wetter than the surrounding area, especially when people use the water to wash clothes and supply the local villages

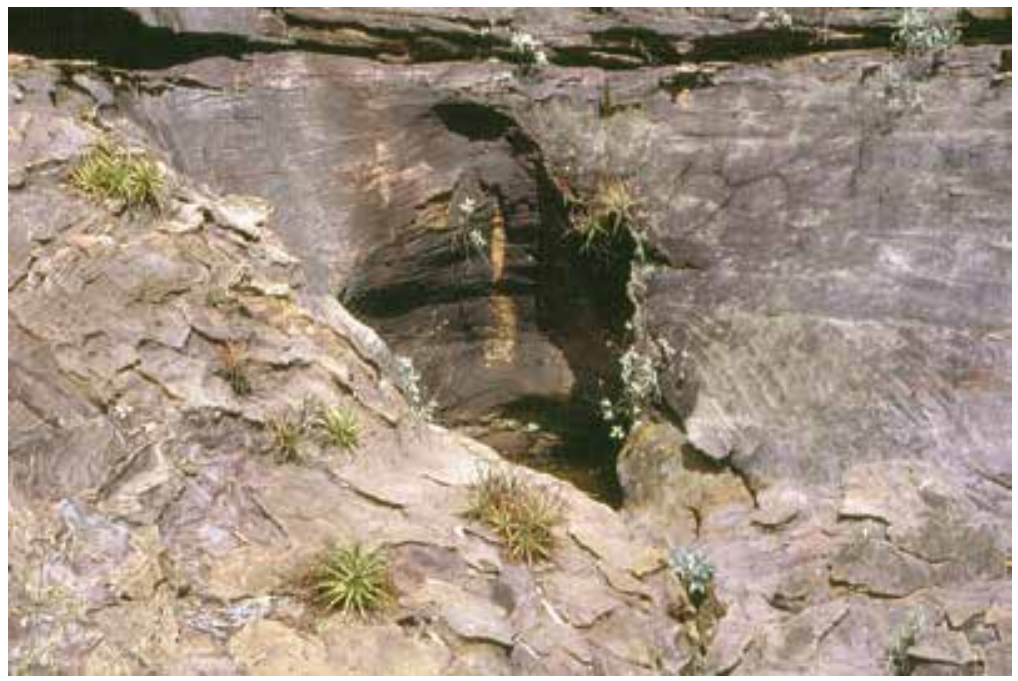

Photograph: Paleoparasitology Laboratory (ENSP/FIOCRUZ).

Figure 2 - Caldeirão (Water Hole), Serra da Capivara National Park, Piauí. When humans and animals use water from the reservoir, the soil becomes prone to transmission of hookworm larvae, since the site also contains human feces

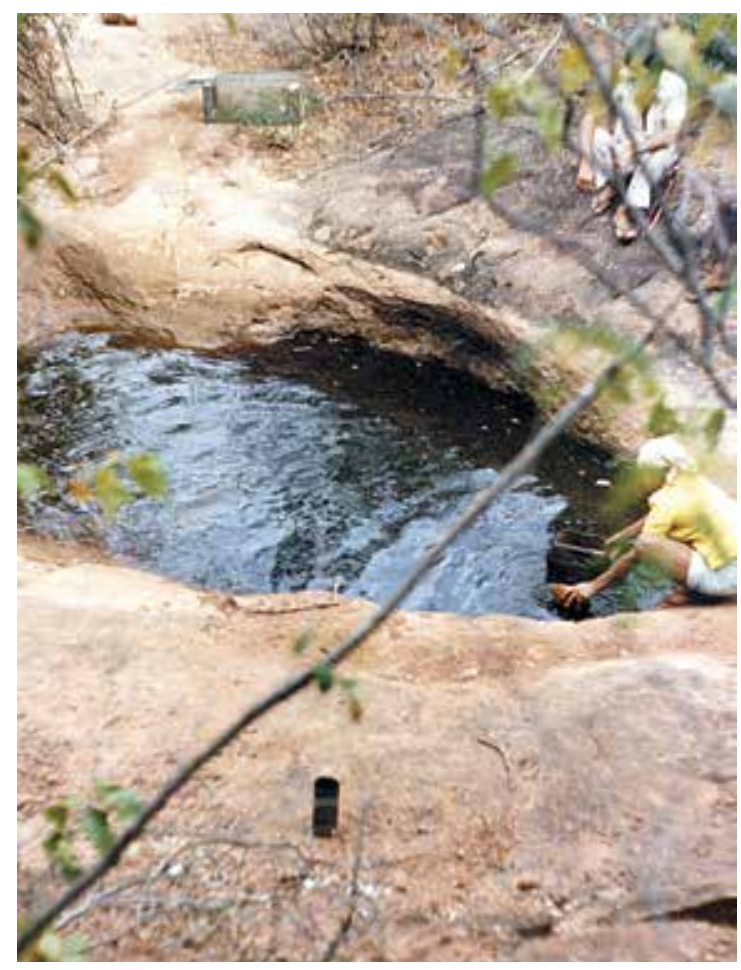

Photograph: Paleoparasitology Laboratory (ENSP/FIOCRUZ). 
Human coprolites found in archaeological sites in South America (Figures 3 and 4) show the oldest dates for hookworm infection in pre-Columbian peoples. One of the oldest is in Piauí, in the Serra da Capivara National Park (Ferreira et al., 1987), at the Boqueirão da Pedra Furada site, dated by radiocarbon to $7,230 \pm 80 \mathrm{BP}$, and the Meio site, dated between 9,000 and 7,000 BP (Gonçalves, Araújo \& Ferreira, 2003) (see Record of Archaeological Sites at www.fumdham.org.br).

Figure 3 - Human coprolite dated to 7,230 \pm 80 BP from the Boqueirão da Pedra Furada archaeological site, Piauí State

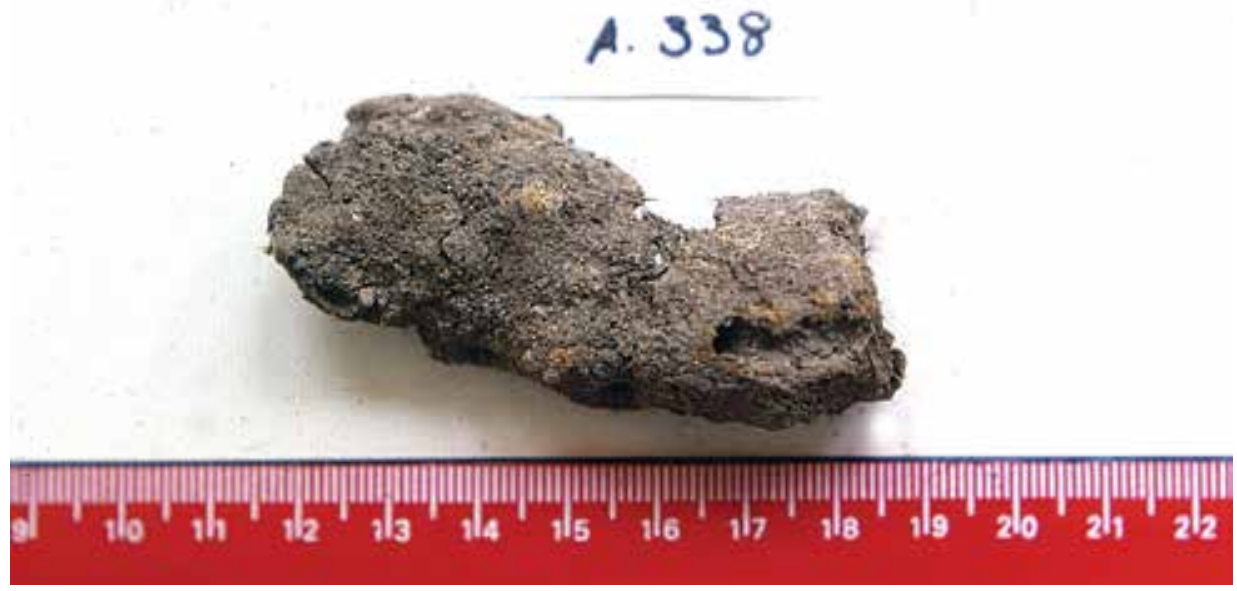

Photograph: Paleoparasitology Laboratory (ENSP/FIOCRUZ).

Figure 4 - Hookworm egg from human coprolite dated to 7,230 280 BP, Boqueirão da Pedra Furada archaeological site, Piauí State

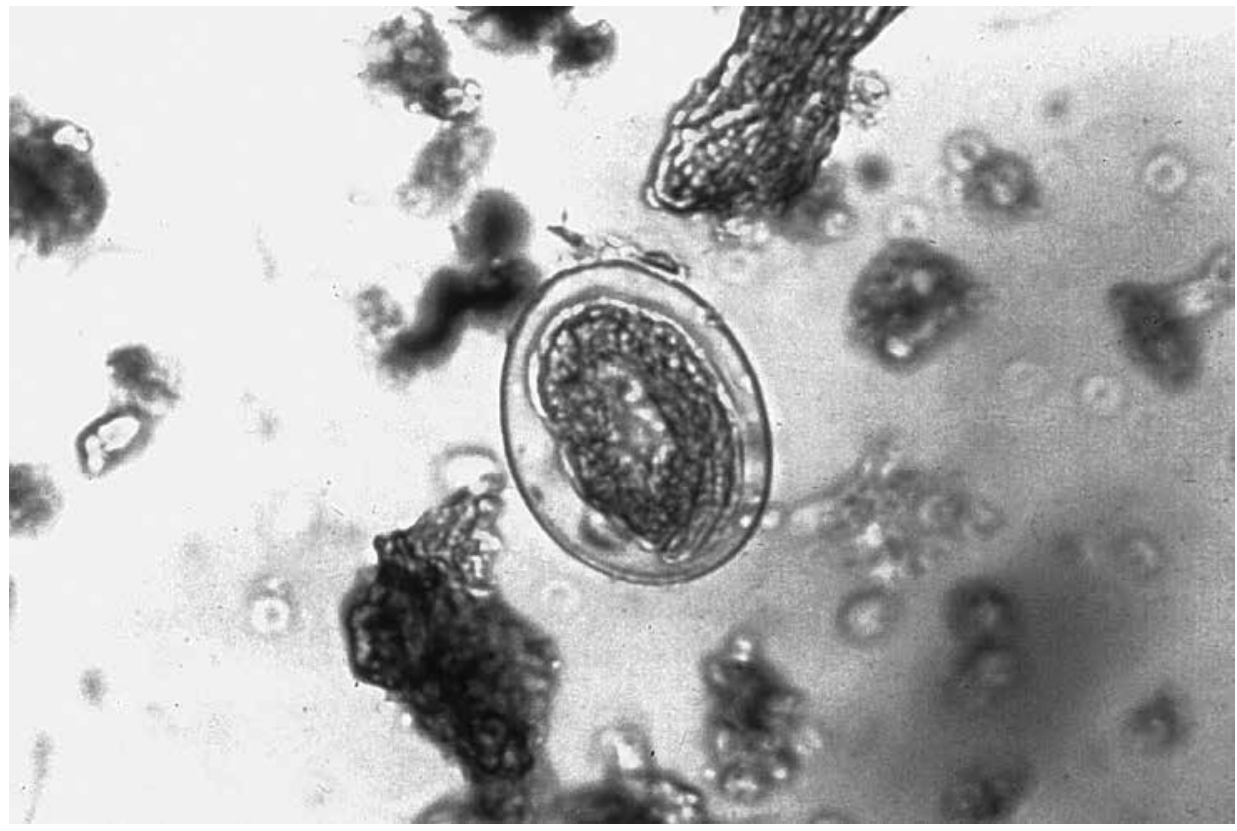

Photograph: Paleoparasitology Laboratory (ENSP/FIOCRUZ). 
The Boqueirão Soberbo archaeological site in Minas Gerais State yielded hookworm eggs in human coprolites dated between 4,905 \pm 85 and 1,325 \pm 60 BP. The Gentio II cave in the same state of Brazil also contained coprolites with hookworm eggs dated between $3,490 \pm 120$ and $430 \pm 70 \mathrm{BP}$, collected from loose archaeological sediment and removed from inside a partially mummified body (Figure 5) found in the cave and dated to circa 2,500 BP (Ferreira, Araújo \& Confalonieri, 1983).

Figure 5 - Partially mummified body from the Gentio II cave, Unaí, Minas Gerais State, Brazilian Institute of Archaeology, Rio de Janeiro

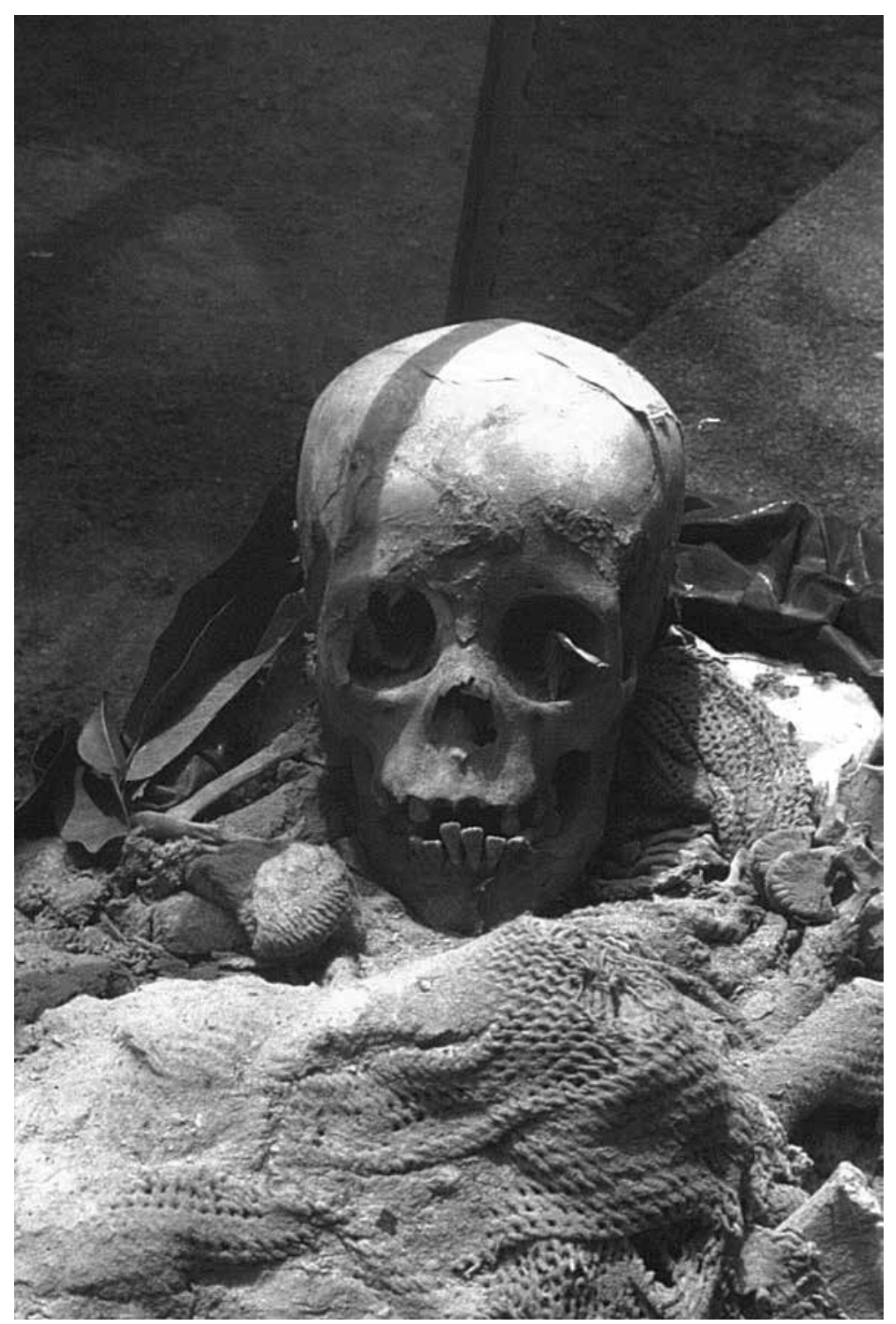

Photograph: Paleoparasitology Laboratory (ENSP/FIOCRUZ). 
The two regions have similar environmental conditions. Southeastern Piauí is located in the semiarid zone of Northeast Brazil, with rainfall limited to three to four months a year and different precipitation patterns for each season, with an annual average of $690 \mathrm{~mm}$ (Najar, Chame \& Chaves, 2000). The cerrado of Minas Gerais shows similar conditions.

Despite the previous comments on favorable microenvironmental conditions for the transmission of hookworm infection, such conditions do not suffice to maintain Necator americanus. The life cycle of Necator americanus and Ancylostoma duodenale, studied in populations in India in regions subject to heavy monsoons (Schad et al., 1973; Hoagland \& Schad, 1978; Nawalinski, Schad \& Chowdhury, 1978a, 1978b), led to the conclusion that Ancylostoma duodenale adapts better to harsher environmental conditions and resists them better than Necator americanus. This explains the higher prevalence rates for Ancylostoma duodenale in semiarid regions of India when compared to Necator americanus, more prevalent in regions with a humid climate.

The hookworm species prevailing in prehistoric Piauí and Minas Gerais has not been identified thus far, but this may be possible using molecular biology. However, the conclusions from research in India could apply to the conditions in the cerrado in Minas Gerais and the Northeast caatinga, especially since Ancylostoma duodenale is still prevalent in the modern population, with no cases of Necator americanus reported (Marasciulo, 1992; Alves et al., 2003).

Precise data from Peru demonstrate Ancylostoma duodenale infection in a pre-Columbian population. Allison et al. (1974) found adult Ancylostoma duodenale worms still attached to the intestinal mucosa in a mummified body dated to 890 to $950 \mathrm{AD}$. Two records from Chile date to 6,100-3,950 BP in the Tiliviche site, Iquique, and 2,500-2,100 BP in Toconao Oriente, San Pedro de Atacama (Gonçalves, Araújo \& Ferreira, 2003).

Another finding in Argentina dates closer to the European Conquest, between 1,000 to $500 \mathrm{BP}$, in the Encantado Valley (Gonçalves, Araújo \& Ferreira, 2003). Other records of larvae and eggs consistent with hookworms in Patagonia belong to samples dated $8,920 \pm 200 \mathrm{BP}$, from the forest-steppe ecotone, one of the oldest on the American continent (Fugassa, 2006a, 2006b). Importantly, these findings correspond to the Early Holocene, when the relative humidity was higher than at present (Borrero, 1999).

By way of comparison, eggs from genus Uncinaria were found in canid coprolites dated to 6,540 1110 BP (Fugassa et al., 2006). Although the human groups in this region were small, the intensive use of rock shelters may have served as foci for infection by these parasites.

The combined data from South and North America (Reinhard et al., 2001) confirm the antiquity of hookworm infection, probably resulting from introduction by individuals infected with Ancylostoma duodenale during remote times in the peopling of the Americas (Montenegro et al., 2006; Araújo, Ferreira \& Confalonieri, 1981; Araújo et al., 2008).

\section{Ascaris lumbricoides}

South American archaeological sites have yielded only a few findings of Ascaris lumbricoides eggs in human coprolites (Gonçalves, Araújo \& Ferreira, 2003). This appeared paradoxical, since A. lumbricoides is now one of the most highly prevalent intestinal helminths, and data also suggest that it occurred in ancient Europe (Bouchet, Harter \& Le Bailly, 2003).

Data from molecular biology have recently changed this scenario. Although A. lumbricoides eggs are rarely found in organic material from archaeological sites in the Americas, Leles et al. (2008) succeeded in recovering the parasite's genetic material. 
Ascaris lumbricoides infection existed in pre-Columbian peoples in the Andes and the Brazilian lowlands, as shown by molecular paleoparasitological data (Leles et al., 2008). The results show the importance of new techniques and recommend caution in interpreting negative data in paleoparasitology. For example, Fonseca Filho (1972) cited the absence (or low prevalence rates) of $A$. lumbricoides infection in populations of Melanesia and Micronesia to explain the transpacific origin of South American populations in prehistoric times. Some 60 to 70 years ago there was no record of A. lumbricoides infection in these Asian populations, but it did occur in South American indigenous peoples during the same period. The author thus used the "negative data" argument (namely absence of $A$. lumbricoides infection) as indicative of transpacific contact between Asians and South Americans in pre-Columbian times.

The negative data hypothesis was challenged by recent findings (although rare) of A. lumbricoides in South American archaeological material, combined with molecular paleoparasitology data (Leles et al., 2008). Contacts prior to the European Conquest require considerable further investigation, and parasitic infections can provide inestimable data to elucidate them.

For example, thus far Patagonia lacks any pre-Columbian record of A. lumbricoides. The only records are from 1584, corresponding to the first European settlement in the Strait of Magellan (Guichón et al., 2006). The finding suggests the probable European origin of a skeleton initially believed to be indigenous. To date, records of $A$. lumbricoides in Patagonia are consistent with predictions of low prevalence rates for this nematode among local indigenous peoples, characterized by small, highly-mobile bands. One can predict interesting findings of different lineages in $A$. lumbricoides and possibilities for using molecular techniques to identify those that were already present and others introduced during contact with Europeans.

\section{Trichuris trichiura}

Along with Ascaris lumbricoides, Trichuris trichiura was the most common parasitic infection in ancient Europe (Bouchet, Harter \& Le Bailly, 2003). However, in pre-Columbian America, Trichuris trichiura eggs are common, while those of Ascaris lumbricoides are quite rare (Gonçalves, Araújo \& Ferreira, 2003).

Trichuris trichiura and Ascaris lumbricoides eggs appear to show equivalent resistance to environmental conditions. However, $A$. lumbricoides eggs apparently suffer the effects of the taphonomic process more intensely than those of $T$. trichiura. Both have thick shells capable of maintaining an adequate inner microenvironment over sufficient time for larval evolution. Transmission is similar, by ingestion of eggs in food and water, but their internal cycles differ. While A. lumbricoides larvae pass through the bloodstream and lungs before reaching the adult stage in the small intestine, T. trichiura evolves directly in the intestine, with the eggs hatching as they pass through the stomach and releasing the larvae that reach the large intestine and attach to the mucosa to attain the adult stage.

Egg morphometry is an important diagnostic parameter. Eggs of Trichuris species can be distinguished by their size and shape, according to the species of hosts in the target region (Figure 6). Knowing the hosts and their given Trichuris species facilitates diagnosis of the coprolites' zoological origin (Chame, 2003). However, identification becomes more difficult when egg sizes from this parasite's species overlap in hosts with concurrent regional occurrence (Fugassa, 2006a).

However, in most cases, Trichuris egg morphometry is a diagnostic factor for species parasitizing humans, as exemplified in Europe (Jones, 1982; Fernandes et al., 2005) and in the Americas during the pre-Columbian period (Ferreira, Araújo \& Confalonieri, 1980; Araújo, Ferreira \& Confalonieri, 1981) and during the period of contact between Europeans and indigenous peoples (Fugassa, 2006b). 
Figure 6 - Trichuris trichiura egg in coprolite from a mummy dated to the Brazilian colonial period, $17^{\text {th }}$ century, Itacambira, Minas Gerais State, Brazil

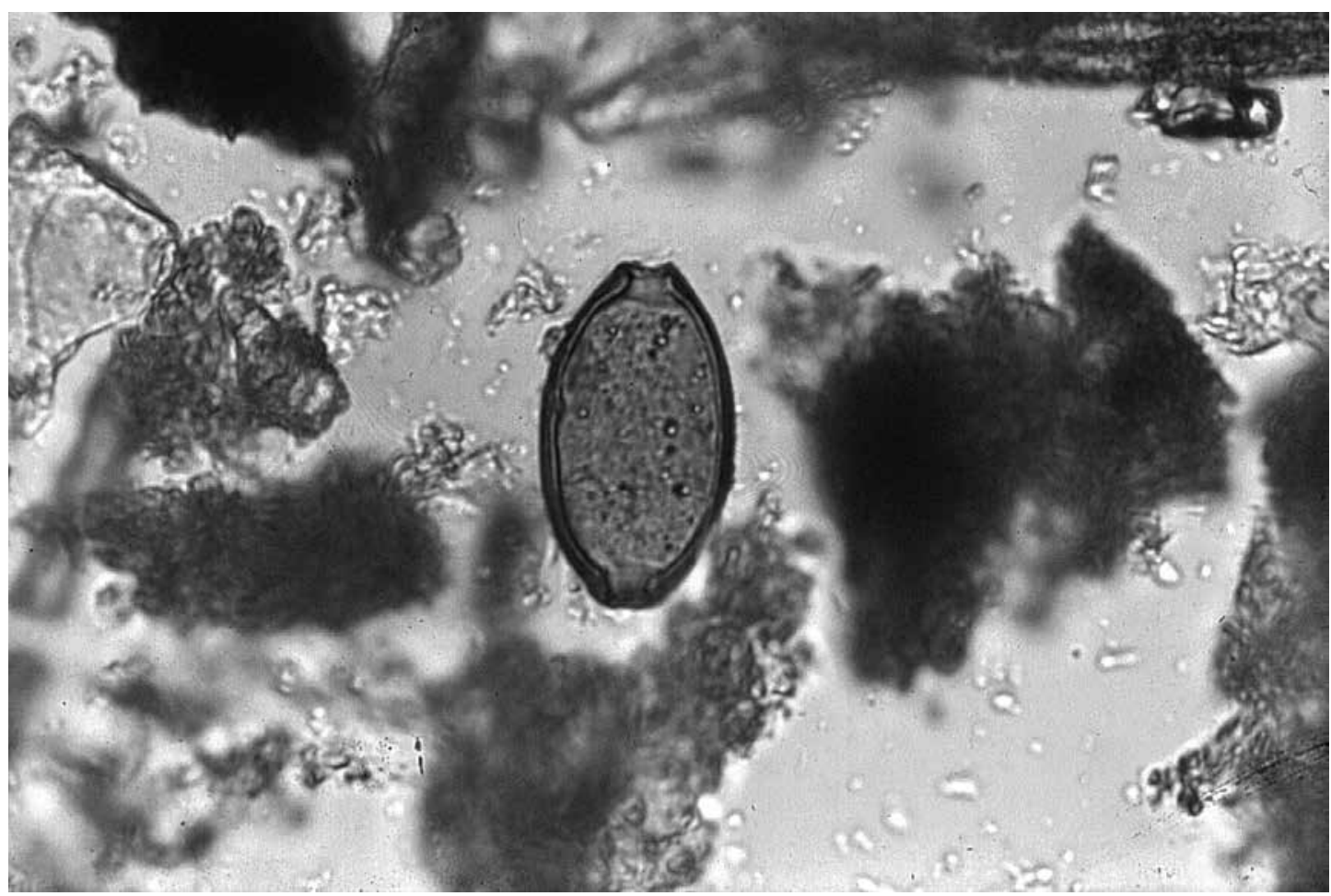

Photograph: Paleoparasitology Laboratory (ENSP/FIOCRUZ).

Like A. lumbricoides, T. trichiura infection existed in prehistoric South America, but was much more prevalent than the former. T. trichiura findings in Brazil, Peru, and Chile showed the infection's wide territorial distribution (Gonçalves, Araújo \& Ferreira, 2003). The oldest finding, from Minas Gerais, Brazil, dates between 8,000 and 7,000 BP, from the Lapa Pequena archaeological site (Gonçalves, Araújo \& Ferreira, 2003).

In some situations, egg morphometric parameters from Trichuris species can distinguish between species of given hosts, particularly humans, but in other cases this is not possible. Fugassa (2006a) demonstrated that coprolites attributed to humans in Patagonia can contain Trichuris eggs with different morphometric patterns from the human host's Trichuris species. The case could be associated with eating uncooked rodents and thus represent false parasitism.

In the Nombre de Jesús archaeological site, the first Spanish settlement in Patagonia, the record showed T. trichiura eggs with dimensions consistent with those in eggs found in medieval Europe (Fernandes et al., 2005), agropastoral groups in pre-Columbian America, and the current population of Patagonia (Thienpont, Rochette \& Vanparijs, 1979).

Studies on whipworm infection in current populations showed eggs measuring between 50.0-65.0 and 54.0-60.0 $\mu \mathrm{m}$ (Jones, 1982). In sediments collected from human skeletons in Santa Cruz, Trichuris eggs measured 51.25-62.5 $\mu \mathrm{m}$ x 28.75-32.5 $\mu \mathrm{m}, 61.75 \mu \mathrm{m} \times 28.75 \mu \mathrm{m}$, and 55.0-65.0 $\mu \mathrm{m}(60.76 \pm 3.37 ; \mathrm{n}=16) \times 28.75-32.5 \mu \mathrm{m}(30.55 \pm 1.37 ; \mathrm{n}=16)$. In coprolites attributed to humans, Trichuris egg measurements varied from 52.5-67.5 $\mathrm{m}(61.12 \pm 3.19 ; \mathrm{n}=20) \times 27.5$ $33.75 \mu \mathrm{m}(29.61 \pm 1.66 ; \mathrm{n}=20)$ to $57.5-58.7 \mu \mathrm{m}(58.1 \pm 0.85 ; \mathrm{n}=2) \times 30-40 \mu \mathrm{m}(35 \pm 7.07 ; \mathrm{n}=2)$. This means greater variability than is known for T. trichiura. This variability can be explained by methodological error, such as small samples or error in host identification, or by the biogeographic history of Trichuris sp. In this case, the morphometric 
variability would assume an unknown species in indigenous groups or the presence of T. trichiura populations with eggs displaying different morphometric patterns, possibly due to some process of genetic drift.

False parasitism can occur both in humans and in canids and felines, namely, parasite eggs in transit after ingestion of animals infected with Trichuris species. Species have been described in rodents (Chart 1), so one should consider the possibility of cases of false parasitism in prehistoric populations. Rodents and other mammals from Patagonia show high specificity (Babero, Cattan \& Cabello, 1975), as do hosts elsewhere in the world.

Chart 1 - Trichuris species in Patagonian hosts

\begin{tabular}{|c|c|c|c|c|}
\hline Species & Length $(\mu \mathrm{m})$ & Width $(\mu \mathrm{m})$ & Host & Reference \\
\hline Trichuris tenuis & $46-50$ & $28-30$ & Camelids & Chandler, 1930 \\
\hline T. bradleyi & $57-65$ & $29-34$ & Octodon sp.* & Babero, Cattan \& Cabello, 1975 \\
\hline T. fulvis & $65-72$ & $28-31$ & Ctenomys sp.* & Babero \& Murua, 1987 \\
\hline T. robusti & $57-65$ & $29-36$ & Ctenomys sp.* & Babero \& Murua, 1990 \\
\hline T. chilensis & $60-67$ & $32-34$ & Akodon sp.* & Babero, Cattan \& Cabello, 1976 \\
\hline T. bursacaudata & $60-70$ & $20-30$ & Ctenomys sp.* & Suriano \& Navone, 1994 \\
\hline T. pampeana & $50-60$ & $20-30$ & Ctenomys sp.* & Suriano \& Navone, 1994 \\
\hline T. myocastoris & $53-60$ & $30-34$ & Myocastor coipus* & Barós, Majumdar \& Mikailov, 1975 \\
\hline T. dolichotis & 75 & 45 & Dolichotis patagonum* & Morini, Boero \& Rodriguez, 1955 \\
\hline
\end{tabular}

* Rodents.

The finding of Trichuris eggs with morphometric patterns consistent with the species Trichuris trichiura indicates that the sample was human in origin. This assertion is tested by molecular biology techniques (Leles et al., 2008), which can reach conclusions that are closer to reality than by morphological comparisons.

Trichuris eggs with larger measurements than usual have been found in humans. According to some authors (Dunn et al., 2002, Rinaldi et al., 2006), the size was closer to Trichuris vulpis, a specific parasite of canids and other carnivores which could occasionally parasitize humans. According to Yoshikawa et al. (1989), such findings could simply represent variations in the size of eggs from the same species identified in humans. Little current research has focused on this issue, but our laboratory is attempting to answer this question using molecular biology techniques. Leles et al. (2008) are testing protocols to answer the question of Trichuris sp. cross-infection versus size variation in T. trichiura eggs.

Trichuris trichiura, Ascaris lumbricoides, hookworm, and Enterobius vermicularis are among the oldest intestinal helminth infections in the human species. They shared significant moments in host species' evolution and probably underwent important changes in ancient times.

Both T. trichiura and A. lumbricoides eggs are highly abundant in medieval European material (Bouchet, Harter \& Le Bailly, 2003). The same is not true for prehistoric America, although some specimens of these parasites have been found in pre-Columbian archaeological sites (Gonçalves, Araújo \& Ferreira, 2003).

Preliminary data on Patagonia prior to the Europeans' arrival show abundant eggs of parasites of animals in human coprolites, representing either zoonotic diseases or simply parasite eggs in transit, called false parasitism. 
A small group of Spaniards that occupied southern Patagonia in the $19^{\text {th }}$ century showed $A$. lumbricoides and $T$. trichiura eggs in sediment collected in the pelvic region, thus differentiating them from the parasitic status of the local population (Fugassa, 2006a).

\section{Enterobius vermicularis}

Enterobius vermicularis infection was present 6,000 years ago in human groups that inhabited Tiliviche in northern Chile (Ferreira et al., 1989, Figure 7). South American archaeological material has yielded few eggs from this parasite. All of them thus far have been from organic remains of human groups that lived on the Pacific Coast (Patrucco, Tello \& Bonavia, 1983; Ferreira et al., 1985; Araújo et al., 1985), with one rare, undated finding in Neuquén, northern Patagonia, Argentina (Zimmerman \& Morilla, 1983).

Figure 7 - Enterobius vermicularis egg in pre-Columbian human coprolite from the Atacama Desert, Chile

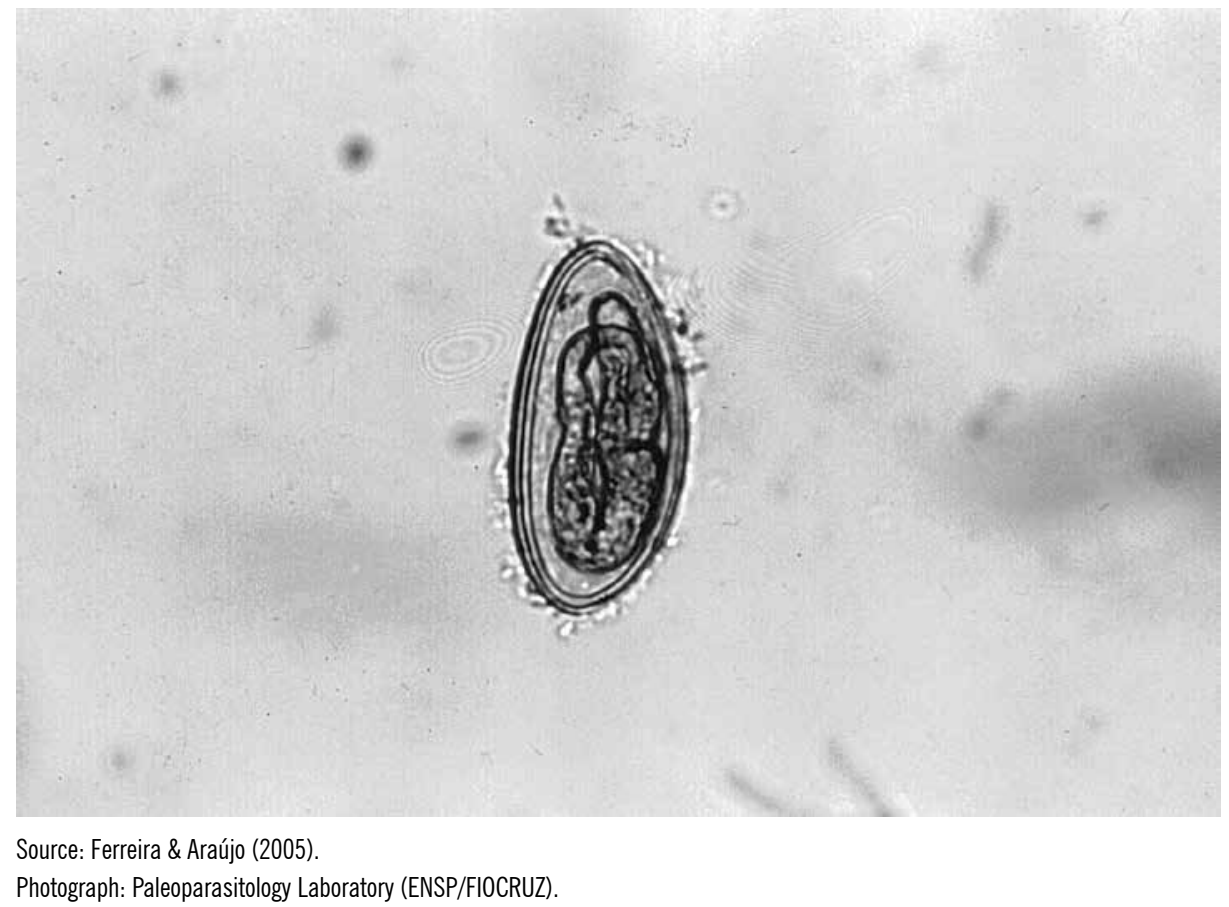

Adult Enterobius vermicularis worms live in the human host's large intestine. From there, the gravid female pinworms migrate to the perianal region when the host is resting. Oviposition occurs there, causing intense itching from the worms' movement, causing hosts to scratch and destroy the worms, releasing large amounts of eggs. The eggs in turn contaminate the individual's hands, especially under the fingernails, facilitating both autoinfection and infection of new hosts. The eggs also disperse in the environment, and some are found on the surface of the individual's stools, contaminated during defecation.

Finding eggs in feces is thus fortuitous, requiring adequate methods to increase the odds of a positive diagnosis. Such methods include the use of adhesive tape to capture females and eggs in the perianal region, obviously not applicable to archaeological material (although one can scrape the region in mummified bodies in an attempt to 
find pinworm eggs). In the case of coprolites, only luck would result in finding eggs, but one should search the sediments collected from the pelvic region in skeletons, with special attention to the sacral foramina after careful washing and collecting the material (Fugassa, 2006).

Further refinement of molecular biology techniques (Iñiguez et al., 2006) should also yield more precise data on the distribution of this parasitic infection in South America. Pinworm infection is prevalent in modern human groups in closed environments such as daycare centers, orphanages, and barracks, but its biological transmission characteristics means that it is scarcely dependent on the environment. Pinworm infection exists in all types of climates, wherever human groups occupy territories. It has been found in hunter-gatherers and sedentary groups in North America (Reinhard, Hevly \& Anderson, 1987). The fact that it has not been found in the prehistoric populations that inhabited Brazil can only be explained by technical shortcomings or the scarcity of findings.

\section{PARASITES OF ANIMALS IN HUMAN COPROLITES: DOMESTICATION AND CONTACT WITH WILD ANIMALS}

Agriculture was not adopted in the New World in the same way as in the Old World. Various prehistoric populations either continued their hunting and gathering habits despite knowledge of agricultural techniques adopted by other groups in the same region, or used them concurrently (Diamond, 2002; Reinhard, 2006).

Pickersgill (2007) cites four independent areas with vestiges of the development of agriculture in the Americas: Southeast North America, Mesoamerica, Andean Region, and tropical lowlands of South America. Pre-Columbian crops included maize (Zea mays), beans (Phaseolus vulgaris), potatoes (Solanum tuberosum), manioc (Manihot esculenta), squash (Cucurbita spp.), and peanuts (Arachis hypogaea), among others (Martin, 2005; Pickersgill, 2007; Prous, 2006; Reinhard, 1990; Smith, 1997).

Domestication of animals in the Americas differed greatly from domestication in the Old World (Brothwell \& Brothwell, 1971). Diamond (2002) explains this difference basically by local geography and climate. Most large herbivores were located in Eurasia, which was also the largest continent. The Americas were home to only a few large animal species that could be domesticated, especially after the mass extinction of mammals in the Late Pleistocene.

On the other hand, the large herds of Old World herbivores were migratory or occupied large areas. This forced human populations to shift constantly in search of game, sometimes across harsh areas or those used by other human groups, a phenomenon known as transhumance. Efforts at domestication thus produced advantageous results (Kormondy \& Brown, 1998). Meanwhile, in the Americas, despite the existence of medium-sized and large social herbivores such as the Rocky Mountain goat (Ovis canadensis), American bison (Bison bison), and moose (Alces alces), among others in North America (Geist, 1985) there is no evidence that these species were ever domesticated, although they were hunted for food.

The domestication of animals in the New World occurred mainly in the Andean region and Mexico, where native groups domesticated ducks (Cairina moschata), turkeys (Meleagris gallopavo), guinea pigs (Cavia porcellus), and llamas (Lama glama) (from which they obtained milk and meat), and alpaca (L. pacoS), used mainly for wool (Brothwell \& Brothwell, 1971; Stahl, 2003).

Dogs were raised in Mexico for food (Wing \& Brown, 1979), but they were not originally domesticated in the Americas. Dogs arrived already domesticated in the company of prehistoric human groups that entered the continent some 14,000 years ago (Savolainen et al., 2002). 
Most native groups in the South American lowlands did not domesticate animals for food. In Brazil, for example, various indigenous groups kept wild animals as pets, or in the case of birds, to obtain feathers (Prous, 1992). Although there was no abundance of large social herbivores as in Eurasia, North America, and Africa, some of them such as the white-lipped peccary (Tayassu pecari), collared peccary (Pecari tajacu), and tapir (Tapirus anta) could have been domesticated. However, since these species used relatively small areas and were not migratory (Tiepolo \& Tomas, 2006; Michalski \& Peres, 2007), they were permanently available as food, in addition to the plentiful supply of fish in many regions (Melatti, 1993).

Unlike the Old World, in the New World there are coprolite samples available from populations of both huntergatherers and agriculturists. This allows expanding knowledge on the consequences of domestication of animals and especially plants as food sources for prehistoric populations, even though in different scenarios and situations.

In Brazil, there are only records of helminths of animals in human coprolites. Araújo, Confalonieri \& Ferreira (1984) made the first discovery, namely Trichostrongylus sp. eggs associated with T. trichiura eggs in a mummified body from the colonial period. Gonçalves, Araújo \& Ferreira (2003) found acanthocephalan eggs in material dated to 4,905-1,325 BP in Minas Gerais. Another parasite of animals was found in coprolites removed from a naturally mummified adult body in the State of Minas Gerais, dated to 1,200-600 BP and allowing the correct identification of Echinostoma sp. eggs and the certainty of their occurrence in humans (Sianto et al., 2005).

This parasite causes echinostomiasis, an endemic zoonosis in Asia that produces debilitating symptoms in infected individuals (Graczyk \& Fried, 1998; Fry, 1970). Humans are infected by eating raw snails, fish, or amphibians, the parasite's intermediate hosts (Roberts \& Janovy, 2009). This was the first record of Echinostoma sp. in humans in Brazil, and the finding enriched the data on the circulation of other zoonotic parasites in ancient peoples.

The helminths Echinostoma sp., Paragonimus sp., Diphyllobothrium sp., Diphyllobothrium pacificum, Capillaria spp., Trichostrongylus sp., and Acanthocephala species were etiological agents of zoonotic diseases in South American populations, considering the findings dated close to contact with Europeans.

McMichael (2004) argued that the transitions experienced by our ancestors, even in prehistory, such as descending from trees to the savannahs, the incorporation of meat into the diet, and more recently since the emergence of species Homo sapiens, the development and conquest of new territories and civilizations favored emergence of and exposure to infectious agents of animal origin. Armelagos, Brown \& Turner (2005) analyzed the epidemiological transitions experienced by humankind and concluded that a new transition is currently taking place, in which parasitic infections that were common 10,000 years ago, at the time of the first transition (development of techniques for plant cultivation and domestication of animals), are reemerging, with the potential to cause huge economic impact. This reemergence can be explained by encroachment of the agricultural frontier on natural areas and parasites' resistance to conventional treatments.

Paleoparasitological findings provide important clues to human adaptive progress since prehistory, in addition to revealing eating habits of extinct populations and the domestication of animals. The data show that currently known zoonotic diseases have occurred in humans since prehistoric times. Knowing which parasites circulated in the past and their geographic distribution helps understand whether a zoonosis is emerging or reemerging (MasComa, Bargues \& Valero, 2005). Thus, the fact that Dipylidium caninum, Capillaria sp., and other parasites have not been found in human archaeological material in South America does not mean that they did not exist or that such infections did not occur. 
Genus Spirometra (Cestoda) was recently identified in feline coprolites in the Serra da Capivara National Park, Piauí State, Brazil (Sianto, 2009). Spirometra sp. is the causative agent of sparganosis in humans, and one cannot rule out the possibility that this and other parasites were circulating in the prehistoric human population.

Few authors have conducted studies on archaeological material of animal origin. This could represent missed information, since the parasite's presence in the local fauna, associated with environmental and sociocultural factors such as diet and type of dwelling, could indicate the transmission routes of parasites to human populations.

The availability of more sensitive diagnostic techniques facilitates the identification of more parasitic infections from the past and recording of new paleoparasitological findings around the world. Further studies on zoonotic infections of the past will expand knowledge on biological and social aspects of the health-disease process and coevolution of parasites and animal and human hosts. In addition, identifying zoonotic diseases that affected ancestral peoples, understanding their transmission mechanisms and the biogeographic, ecological, cultural, historic, and social factors that affect this dynamic, can build predictive models to help control parasitic diseases soon after their emergence or prevent them from becoming public health problems.

Geographic, biotic, and abiotic factors from the environment (biocenosis) in which prehistoric populations lived and their cultural characteristics can be used to design models of predictability and transmission of parasite fauna in these groups. Studies include Martinson et al. (2003) and Reinhard (2008), based on models formulated according to the theory of natural nidality (Pavlovsky, s.d.; Silva, 1997). Such studies apply especially to zoonotic diseases, when biocenosis in certain natural ecosystems is well-defined (Silva, 1997). The following are examples of helminth parasites of animals found in human coprolites, discussing their significance.

\section{SOUTHERN PATAGONIA}

In Argentina, much of Southern Patagonia, including the provinces of Santa Cruz and Tierra del Fuego, is dominated by a steppe environment, while near the Cordillera an ecotone zone precedes the forest. Due to the harsh climate throughout most of the year, rock shelters became the predominant archaeological sites. Most samples examined so far come from rock shelters, cliffs, and caves.

Paleoparasitological findings in Patagonia were obtained from human and animal coprolites and sediment from areas of archeological occupation and showed a wide diversity of parasite species, with a predominance of capillarid eggs (Chart 2). Coprolites and sediments from caves and shelters yielded 15 nematode genera, including Trichostrongylidae, Eucoleus sp., Toxocara sp., Physaloptera sp., Uncinaria sp., possibly Oesophagostomum sp., and Calodium sp. (Moravec, 1982, proposed a new classification for the Capillariidae family, changing the genus Capillaria to Calodium) (Figure 8). The material also contained eggs of Hymenolepis sp. and Monoecocestus sp., in addition to eggs similar to genus Taenia. The protozoa included oocysts of Coccidia, among them Eimeria sp. (Figure 9), with the largest number of oocysts in the samples (Aschero 1981; Civalero \& Aschero, 2003). 
Figure 8 - Calodium (Capillaria) sp. egg in animal coprolite, Patagonia, Argentina

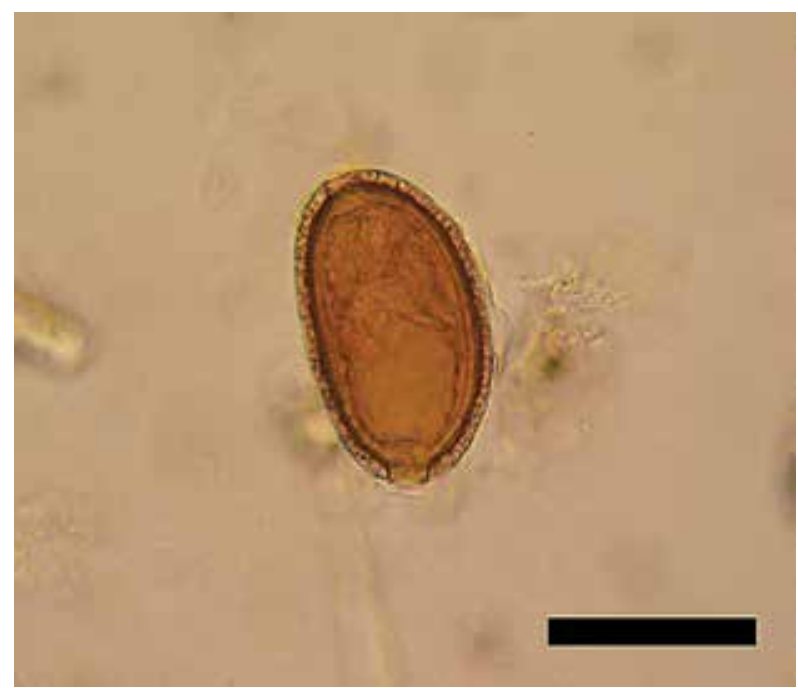

Photograph: Martín Fugassa.

Figure 9 - 0ocyst, Eimeria sp., animal coprolite, Patagonia, Argentina

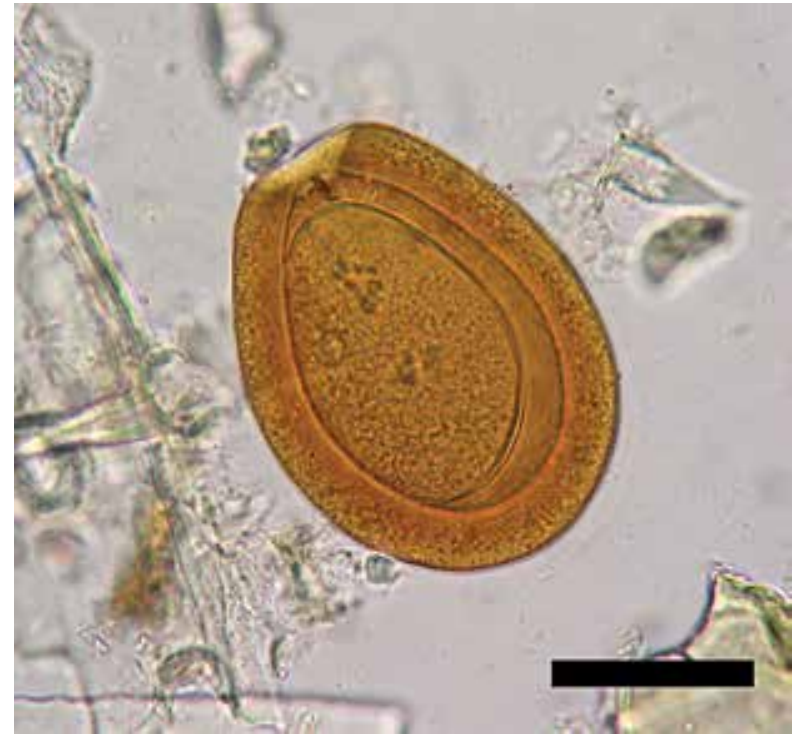

Photograph: MX Senatore.

These records suggest occupation not only by humans, but also by other species such as canids, camelids, felines, and birds of prey, depending on regional climatic conditions. Coprolites from these animals were found in archeological layers with important evidence of human occupation.

Although Patagonia measures some $800,000 \mathrm{~km}^{2}$, with low apparent human density during the Holocene, the concentration and reutilization of caves and shelters by humans and other animals may have facilitated the exchange of parasite species. In Southern Patagonia, the demographic characteristics known thus far and the 
biocultural habits of these groups suggest that zoonotic parasitism may have played a predominant role in the region's ancient epidemiology.

As mentioned previously, the paleoparasitological records of sediments and coprolites attributed to humans in Patagonia yielded eggs of Trichuris sp. with measurements consistent with Trichuris trichiura. As an alternative explanation, other species that parasitize rodents may have become zoonotic in ancient human groups in the region.

Chart 2 - Parasites of animal origin found in samples from Patagonia, South America

\begin{tabular}{|c|c|c|c|c|}
\hline Sample & Archeological site & $\begin{array}{l}\text { Host's zoological } \\
\text { origin }\end{array}$ & $\begin{array}{c}\text { Date } \\
\text { (years BP) }\end{array}$ & Parasites found \\
\hline \multicolumn{5}{|c|}{ European contact } \\
\hline NJ-1 & \multirow{4}{*}{$\begin{array}{l}\text { Nombre de Jesús, } \\
\text { Cabo Vírgenes, } \\
\text { Santa Cruz }\end{array}$} & \multirow{5}{*}{ Human } & \multirow{4}{*}{$475 \pm 45$} & Ascaris lumbricoides \\
\hline NJ-2 & & & & $\begin{array}{l}\text { Trichuris sp., } \\
\text { Eimeria macusaniensis }\end{array}$ \\
\hline NJ-3 & & & & Trichuris sp. \\
\hline NJ-4 & & & & Trichuris trichiura, Diphyllobothrium sp. \\
\hline M-84 & $\begin{array}{c}\text { Cerro Norte XI, } \\
\text { Pali Aike, Santa Cruz }\end{array}$ & & $19^{\text {th }}$ century & $\begin{array}{c}\text { Trichuris sp., Eucoleus sp., Calodium sp., } \\
\text { other capillarids, Taenia sp. }\end{array}$ \\
\hline \multirow[t]{2}{*}{$\begin{array}{l}M-75 \\
M-76\end{array}$} & \multirow[t]{2}{*}{$\begin{array}{l}\text { Alero Mazquiarán, } \\
\text { Rio Mayo, Chubut }\end{array}$} & Rodent & \multirow[t]{2}{*}{$212 \pm 35$} & $\begin{array}{l}\text { Taenia sp., Monoecocestus sp.*, } \\
\text { Pterygodermatites sp.* } \\
\text { Trichosomoides sp.* }\end{array}$ \\
\hline & & Human & & Trichuris sp., Monoecocestus sp.* \\
\hline M-85 & $\begin{array}{l}\text { Cerro Norte III, Pali Aike, } \\
\text { Santa Cruz }\end{array}$ & Sheep & Historic & $\begin{array}{l}\text { Toxocara sp., Strongyloides sp., } \\
\text { Haemonchus sp., Trichostrongylus sp., } \\
\text { Eimiera ovina, Mesocestoides sp. }\end{array}$ \\
\hline CF & $\begin{array}{c}\text { Caleta Falsa, Península Mitre, } \\
\text { Tierra del Fuego }\end{array}$ & \multirow{2}{*}{ Human } & 850 & Capillarids, Anoplocephalidae? \\
\hline LM & $\begin{array}{l}\text { Las Mandíbulas, } \\
\text { northern Tierra del Fuego }\end{array}$ & & Historic & Calodium sp. \\
\hline \multicolumn{5}{|c|}{ Late and Middle Holocene } \\
\hline M-1 & \multirow{4}{*}{ Orejas de Burro I, Pali Aike, Santa Cruz } & Human & \multirow{3}{*}{$3565 \pm 45$} & $\begin{array}{l}\text { Capillarids, Trichuris sp., } \\
\text { unidentified nematode larva }\end{array}$ \\
\hline$M-2^{*}$ & & Rodent & & E. macusaniensis \\
\hline$M-2$ & & Human & & $\begin{array}{c}\text { Capillarids, E. macusaniensis, } \\
\text { T. trichiura, ascarid? }\end{array}$ \\
\hline$M-3$ & & Waste & $3490 \pm 50$ & Capillarids, Trichuris sp., E. macusaniensis \\
\hline M-6 & $\begin{array}{l}\text { La Arcillosa II, } \\
\text { northern Tierra del Fuego }\end{array}$ & Waste & $5205 \pm 58$ & Diphyllobothrium sp., Eimeria sp. \\
\hline
\end{tabular}


Chart 2 - Parasites of animal origin found in samples from Patagonia, South America (continued)

\begin{tabular}{|c|c|c|c|c|}
\hline Sample & Archeological site & $\begin{array}{l}\text { Host's zoological } \\
\text { origin }\end{array}$ & $\begin{array}{c}\text { Date } \\
\text { (years BP) }\end{array}$ & Parasites found \\
\hline \multicolumn{5}{|c|}{ Late and Middle Holocene } \\
\hline M-8 & \multirow{9}{*}{$\begin{array}{c}\text { CСP5, } \\
\text { Perito Moreno National Park, } \\
\text { Santa Cruz }\end{array}$} & Canid & \multirow{9}{*}{$6540 \pm 110$} & $\begin{array}{c}\text { Eucoleus sp., Calodium sp., } \\
\text { outer capillarids, Trichuris sp., } \\
\text { Uncinaria sp., Physaloptera sp., } \\
\text { Moniezia sp., A. Iumbricoides }\end{array}$ \\
\hline M-24 & & Human? & & Calodium sp., Nematodirus sp., hookworm \\
\hline M-40 & & \multirow[b]{2}{*}{ Feline } & & Calodium sp. \\
\hline M-43 & & & & $\begin{array}{l}\text { Calodium sp., Anoplocephalidae, } \\
\text { Trichuris serrata, Oesophagostomum sp. }\end{array}$ \\
\hline M-41 & & Bird of prey & & Calodium sp., Demodex sp. \\
\hline M-44 & & Human & & $\begin{array}{l}\text { E. macusaniensis, Calodium sp., } \\
\text { other capillarids, Nematodirus sp. }\end{array}$ \\
\hline M-46 & & Feline & & $\begin{array}{l}\text { Calodium sp., Nematodirus sp., } \\
\text { E. macusaniensis, hookworm }\end{array}$ \\
\hline M-47 & & Human & & $\begin{array}{c}\text { Calodium sp., other capillarids, } \\
\text { Habronema sp., E. macusaniensis, } \\
\text { E. ivitaensis }\end{array}$ \\
\hline$M-50$ & & & & Acanthocephala, Calodium sp., Coccidia \\
\hline M-21 & $\begin{array}{l}\text { CCP7, Perito Moreno National Park, } \\
\text { Santa Cruz }\end{array}$ & Human & $6150 \pm 05$ & $\begin{array}{c}\text { Trichuris sp., Calodium sp., Eucoleus sp., } \\
\text { other capillarids, E. vermicularis }\end{array}$ \\
\hline \multicolumn{5}{|c|}{ Early Holocene } \\
\hline M-22 & \multirow{3}{*}{$\begin{array}{c}\text { CCP7, Perito Moreno National Park, } \\
\text { Santa Cruz }\end{array}$} & Human & $7880 \pm 150$ & $\begin{array}{c}\text { Trichuris sp., Hymenolepis nana, } \\
\text { E. macusaniensis, Calodium sp., } \\
\text { Nematodirus sp., Physaloptera sp., } \\
\text { trematodes }\end{array}$ \\
\hline M-11 & & \multirow{2}{*}{ Canid } & $7920 \pm 130$ & $\begin{array}{l}\text { E. macusaniensis, Nematodirus sp., } \\
\text { Calodium sp. }\end{array}$ \\
\hline M-9 & & & $8300 \pm 115$ & $\begin{array}{l}\text { Trichuris tenuis, Eucoleus sp., } \\
\text { other capillarids, Nematodirus sp. }\end{array}$ \\
\hline
\end{tabular}


Chart 2 - Parasites of animal origin found in samples from Patagonia, South America (continued)

\begin{tabular}{|c|c|c|c|c|}
\hline Sample & Archeological site & $\begin{array}{l}\text { Host's zoological } \\
\text { origin }\end{array}$ & $\begin{array}{c}\text { Date } \\
\text { (years BP) }\end{array}$ & Parasites found \\
\hline \multicolumn{5}{|c|}{ Pleistocene-Holocene Transition } \\
\hline M-39 & \multirow{9}{*}{$\begin{array}{c}\text { CCP7, Perito Moreno National Park, } \\
\text { Santa Cruz }\end{array}$} & \multirow{5}{*}{ Human } & $9730 \pm 100$ & $\begin{array}{l}\text { Trichuris sp., Calodium sp., } \\
\text { Nematodirus sp., E. macusaniensis }\end{array}$ \\
\hline M-37 & & & \multirow{3}{*}{$8920 \pm 200$} & $\begin{array}{c}\text { Ancylostoma sp., Calodium sp. } \\
\text { Anoplocephalidae }\end{array}$ \\
\hline M-30 & & & & Calodium sp., Nematodirus sp. \\
\hline M-34 & & & & $\begin{array}{l}\text { Eimeria sp., Calodium sp., } \\
\text { Hymenolepis nana }\end{array}$ \\
\hline M-33 & & & $9640 \pm 190$ & Toxocara sp., Dipylidium sp. \\
\hline$M-16$ & & Camelid & $9640 \pm 190-9100 \pm 150$ & $\begin{array}{c}\text { Eimeria sp., Nematodirus sp., } \\
\text { Calodium sp. }\end{array}$ \\
\hline M-23 & & Canid & $10530 \pm 60$ & $\begin{array}{l}\text { Calodium sp., other capillarids, } \\
\text { Moniezia sp.?, Nematodirus sp. }\end{array}$ \\
\hline M-36 & & Human & $10530 \pm 620$ & Strongyloides sp. \\
\hline$M-15$ & & $\begin{array}{l}\text { Mylodon sp. } \\
\text { (giant ground sloth) }\end{array}$ & $10530 \pm 628$ & Oxyuris equi, cestode \\
\hline
\end{tabular}

* Source: Sardella \& Fugassa (2009).

European contact generally led to epidemics of microparasites (smallpox, measles, tuberculosis, and influenza, among others). Osteological and ethnographic studies have shown the importance of nutritional deficiencies in indigenous peoples confined in missions in North America (Dobyns, 1993). The combination of various factors like the increase in the number of domestic animals, especially dogs, poor hygiene, increase in nutritional deficiencies and sedentarism, provided an ideal pathoecological scenario for the increase in enteroparasitic infections and the emergence of multiple parasitic infections. These scenarios should be considered in the paleoepidemiological reconstruction of these infections and provided the substrate in which other infectious diseases may have found a favorable niche during contact.

Eggs from nematode parasites of herbivores were also found, such as Lamanema sp. and Nematodirus sp. The larvae of these two parasites develop inside the eggs, making them resistant to drought, allowing survival of the larvae in pasture for up to two years (Leguía, 1999). Such characteristics may explain why many Patagonian coprolites only display this genus of herbivore nematode.

As observed by Navone \& Merino (1989), the eggs of other nematode genera are delicate and undergo hypobiosis in the intestinal tract of guanacos during the winter, to synchronize oviposition under favorable climatic conditions. These parasites would thus be underrepresented in Patagonian coprolites due to taphonomic effects. Although fewer in number, eggs from these ascarids were found in canid, feline, and human coprolites, indicating the consumption of guanacos by these species of carnivores.

For human groups, the above-mentioned findings and those of Eimeria sp. are associated with the ingestion of viscera. One cannot rule out the possibility of human infections, since some cases have been reported at present (Taylor, Lathan \& Woolhouse, 2001). 
Trichostrongylidae infection causes enteritis that can include internal hemorrhage and hepatic lesions due to larval migration (Leguía, 1999). Although no cases of infection with Lamanema sp. have been described in humans, there are cases of parasitism with Nematodirus sp. (Rea et al., 2003). In humans, infections by other nematodes of herbivores are normally asymptomatic and only rarely cause diarrhea, bleeding, and secondary anemia (Atías, 1998). The latter author reports the formation of intestinal helminthomas or nodules due to nematodes of genus Oesophagostomum sp.

The presence of Uncinaria sp. and probable presence of Toxocara sp. indicate exposure to parasites that can cause atypical infections, since humans are not usual hosts. Uncinaria sp. larvae penetrate the skin, causing an infection known as cutaneous larva migrans or creeping eruption. The accidental ingestion of embryonated Toxocara sp. eggs produces larvae that lodge in various organs, called visceral larva migrans. Currently, parasites of genus Toxocara cause hundreds of cases of unilateral blindness in children in the United States, due to their intraocular localization (Robertson \& Thompson, 2002).

Recently, human cases of intestinal infection have been reported with Ancylostoma caninum, another canid hookworm, raising the possibility of infection by this parasite in caves inhabited alternately by wild dogs and humans. In historical times, the late introduction of dogs among indigenous peoples in Patagonia would have exposed humans to this zoonosis with a higher than normal prevalence.

Hookworm eggs and larvae found in human coprolites from the Pleistocene-Holocene transition and other possible records prove important for various reasons: i) they provide data for discussing the introduction of hookworms into the Americas; ii) the disease associated with these helminths involves anemia and protein loss (Atías, 1998), which can correlate with hyperostosis in paleopathological examination; and iii) they allow inferring the region's environmental conditions during the respective time period. In this case, the record corresponds to forest expansion due to increasing humidity.

As mentioned previously, paleoparasitological findings in sediments and coprolites attributed to humans in Patagonia included Trichuris sp. eggs differing in size from those of Trichuris trichiura. An explanation is that other species that parasitize rodents may have become zoonotic in ancient human groups in the region.

Paleoparasitological findings of capillarids are rare in the Americas. In Brazil, in Lapa da Angélica IV, Goiás State, they were found in coprolites of wild animals (Confalonieri, 1988). Meanwhile, in Patagonia, the majority of the samples of free sediments and coprolites tested positive for capillarid eggs, with morphology consistent with Calodium hepaticum (Capillaria hepatica). Although the parasite is widely distributed in rodents (e.g., $60 \%$ prevalence in urban sewer rats), $44 \%$ of children in poor neighborhoods in Salvador, Bahia, Brazil, tested positive for Calodium hepaticum according to fluorescence (Assis et al., 2004).

Although the medical literature reports these parasitic infections as accidental or sporadic, such situations depend on both ecological and local socioeconomic conditions. Although it is recommended to discriminate the morphology of the eggs lodged in the vulvae of the females in these nematodes, due to differences between immature and totally developed eggs (Moravec, 2001), the reported findings refer to eliminated eggs, thus mostly mature. The observed morphological variability of eggs in sediments and coprolites is purportedly due to the presence of more than one capillarid species, although it could mean true parasitism or simply parasite eggs in transit.

Capillarid infections mostly represent accidental ingestion of eggs due to poor hygiene and contact with fecal matter. However, they could correspond to the consumption of infected prey as part of the eating habits of huntergatherers, although with less significance, since the eggs require a prior maturation period before becoming infective 
for the new host, except in the case of Calodium hepaticum. Alternatively, some capillarid species, such as those that parasitize birds, have worms as their intermediate host (Moravec, 2001), which human groups in Patagonia could have consumed, thereby leading to infection.

Importantly, detailed morphometric studies are useful for producing statistical analyses. A more precise diagnosis allows better interpretation of the evidence. The combination of morphometric studies with light microscopy and scanning electron microscopy, statistical analysis, and modern comparative samples should allow progress in diagnosing this genus.

A hypothesis for the wide ecological distribution of parasites from this genus is that the success was due to species with a direct cycle, with numerous rodent species inhabiting the region as the reservoir. Findings in humans would be a combination of patent infections and ingestion of rodents. Capillarids are biologically resistant, even when exposed to different environmental conditions. As discussed, their eggs have been found in a wide range of contexts, including resistance to the application of palynological techniques using acids (Burry, personal communication).

Intestinal infections with Pseudocapillaria philippinensis can cause severe diarrhea and intestinal malabsorption syndrome, occasionally leading to dehydration and death (Atías, 1998). Parasitism of the respiratory tract with Eucoleus aerophilla or of the liver with Calodium hepaticum can cause severe disease in humans (Benenson, 1995; Miyazaki, 1991).

As for tapeworms, the most frequent paleoparasitological records in Patagonia were of Anoplocephalidae. These tapeworms parasitize reptiles, birds, and mammals and are more numerous in the latter group (Denegri et al., 1998). They are heteroxenous parasites that require oribatid mites as intermediate hosts. These mites are important components of the edaphic fauna, and their populations display daily and seasonal variations (Denegri, 2001). Bertiella sp. infection has been recorded in humans (Denegri, 2001). Rothman \& Bowman (2003) report Anoplocephala sp. infection in gorillas. Infection with Inermicapsifer madagascariensis has been reported in Cuba and Africa (Frean \& Dini, 2004; Soulsby, 1982). Taylor, Latham \& Woolhouse (2001) include Moniezia expansa as a zoonotic species.

Current data on Anoplocephalidae in the Patagonian fauna mention Moniezia expansa in guanacos in the province of Chubut, Argentina (Beldomenico et al., 2003; Robles, personal communication), Moniezia sp. and Thysanosoma actinoides in sheep (Robles \& Olaechea, 2001), Moniezia sp. in guanacos in Tierra del Fogo (Navone \& Merino, 1989), and Cittotaenia quadrata in the southern viscacha (Lagidium viscacia), a rodent from southern South America (Denegri et al., 2003).

Findings of Anoplocephalidae in wild hosts from other regions of Argentina include species that accidentally ingest oribatid mites. For example, Martinez et al. (1999) report that among the most common tapeworm infections in Edentata, those involving Anoplocephalidae are important and caused by species of the genera Anoplocephala, Paranoplocephala, Moniezia, Cittotaenia, Bertiella, Oochoristica, Mathevotaenia, and Monoecocestus. Navone (1990) reported Mathevotaenia surinamensis in Dasypus novemcinctus, Mathevotaenia matacus in Tolypeutes matacus, and Mathevotaenia diminuta in Chaetophractus vellerosus, and Navone \& Suriano (1992) reported genus Mathevotaenia in Didelphys albiventris. Sutton (1973) described Monoecocestus myopotami in Myocastor coypus, and Boero, Klusas \& Boehringer (1967) detected Monoecocestus hidrochoeri in Hydrochoerus hydrocoeris.

Paleoparasitological findings provide evidence for evolutionary discussions. For example, according to Beldomenico et al. (2003), the presence of $M$. expansa in Patagonian guanacos could be due to interaction with sheep. If the eggs found in Patagonian coprolites (Fugassa et al., 2006) belong to a species from genus Moniezia, then the hypothesis 
proposed by Beldomenico et al. (2003) would be less consistent and could be refuted by paleoparasitological studies of coprolites from Patagonian camelids.

Tenora (1976) contended that the cosmopolitan distribution of Moniezia was due to the domestication of animals. The findings could refute this hypothesis and allow that Anoplocephalidae were present in America long before European colonization. The finding of Anoplocephalidae in wild fauna from 6,000 BP raises the possibility that genus Moniezia was also present in pre-Columbian America.

Tapeworms identified in various archaeological and paleontological contexts belong to the genera Taenia, Hymenolepis, and Diphyllobothrium and are reviewed by Gonçalves, Araújo \& Ferreira (2003). Bathurst (2005) reported finding Diphyllobothrium sp. and eggs attributable to the Taenidae family in a shell midden in Canada. For the Anoplocephalidae family, Hidalgo Arguello et al. (2003) recorded a single egg from Anoplocephala perfoliata in medieval tombs in Spain, although with measurements that were scarcely representative and with an image that was unclear as to the presence of hooks and the pyriform apparatus. Rodent coprolites found in the pelvic cavity of a human skeleton yielded numerous eggs attributed initially to Moniezia sp. (Fugassa, 2006b). The diagnosis was revised by Sardella \& Fugassa (2009), concluding that it was Monoecoestus sp.

Finally, the observation of probable Taenia eggs in Cerro Norte XI, Patagonia, Argentina, is associated with European contact and probably indicates consumption of sheep, since the eggs are consistent in size and shape with Taenia ovis (Soulsby, 1982).

The presence of Anoplocephalidae in diverse archaeological samples from Patagonia suggests that the low representativeness of other cestodes such as Taenia cannot be attributed to problems of preservation. Other possible explanations should be investigated, related to epidemiological issues and diagnostic methodology.

As for tapeworm disease from Anoplocephalidae in Edentata, anoplocephalid infection with high worm burden can cause enteritis and diarrhea (Martinez et al., 1999). Infection with Bertiella (an anoplocephalid) in humans is generally asymptomatic, but cases have been recorded with intermittent diarrhea, gastroenteritis, decreased appetite, weight loss, general fatigue, and abdominal pain (Denegri \& Perez-Serrano, 1997). Although anoplocephalid infection can cause weakness and predispose to various diseases, it is not expected to have left traces in ancient bones (for paleopathological studies).

Hymenolepis infection can be associated with enteritis (Atías, 1998) and other mild symptoms such as abdominal pain and weight loss (Benenson, 1995). Symptoms associated with taeniasis are mild and variable (Atías, 1998), and can include increased appetite, abdominal pain, headache, and nausea. Cestodes of genus Diphyllobothrium can cause systemic symptoms similar to those of taeniasis and occasionally lead to anemia (Atías, 1998), which can leave osteological traces such as porotic hyperostosis (Aufderheide \& Rodríguez-Martín, 1998).

Many parasites found in coprolites could have been transmitted to humans by various routes, mainly through their water intake or accidental ingestion of contaminated foods or invertebrates due to unhygienic eating habits.

Currently, children are more susceptible to acquiring zoonotic diseases (Robertson \& Thompson, 2002). However, in ancient human groups, contact with contaminated elements may have affected all age brackets, as described in ethnographic reports in Patagonia.

The estimation of exposure to zoonotic diseases should obviously consider the animal species that occupied the sites. The representation left in bones serves as an indicator of zoonotic diseases by handling and consumption of prey but not of zoonotic diseases by contact with species, since the zooarchaeological remains may only come 
from consumption of prey, while the presence of animal coprolites is a more consistent indicator of the presence of animals in the same site occupied by humans. The caves in the Perito Moreno National Park (Santa Cruz, Argentina) were occupied by humans, large canids, felines like cougars, camelids, rodents, mustelids, and large birds of prey, as shown by analysis of coprolites and bird regurgitation pellets. Paleoparasitological studies on sediments from the fauna associated with sites occupied by humans produced evidence on the parasitic infections in animals, to which the humans were also exposed.

Most of the oldest sites in Patagonia are rock shelters and caves (Civalero \& Franco, 2003) occupied by humans more than 10,000 years ago (Borrero, 2001), but also alternatingly by other animals. Even if the site was not used simultaneously by humans and canids, parasites could have persisted under specific environmental conditions, even for months or years. Toxocara cati and T. canis eggs can survive in the environment for months (Robertson \& Thompson, 2002). Although there are no records of domestication in Patagonia, alternating occupation by humans and carnivores could have caused exposure to toxocariasis.

Likewise, Uncinaria sp. infection, described in carnivores and found in M-8, a canid coprolite from CCP5 (Perito Moreno National Park, Santa Cruz, Argentina), can cause skin lesions. More rarely, Ancylostoma caninum can infect the human intestine. Among the many zoonotic diseases caused by nematodes, modern cases have been reported of humans infected with Trichuris vulpis, a parasite of canids (Dunn et al., 2002). The authors call attention to the fact that similar cases may be missed by laboratories that fail to use egg measurements as diagnostic parameters. Paleoparasitology thus calls attention to possibilities in the realm of current parasitic infections, as shown by infections with parasites of animals.

According to the proposed models, although bands of hunter-gatherers were parasitized by fecal-borne species, even though at lower levels than in sedentary groups (Dillehay, 1991), the rock shelters displayed distinct scenarios. There are few records of typical fecal-borne parasites of humans (Trichuris trichiura, Ascaris lumbricoides, Enterobius vermicularis, etc.), but cases have been identified of less common fecal-borne enteroparasites, such as Calodium sp., Ascaris sp., and Physaloptera sp.

The hypothesis on the role of caves and rock shelters in Patagonia as centers of concentration for numerous species of enteroparasites and potentially for their dispersal should include not only helminths but also protozoa, viruses, and bacteria. The transition of Chagas disease from enzootic to zoonotic is an example that merits investigation (Ferreira et al., 2000).

The presence of numerous camelid coprolites in all layers of the archaeological sites suggests that these animals served as reservoirs for various parasitic infections, including those caused by bacteria. Camelids are reservoirs of Trypanosoma cruzi (Alcaíno \& Gorza, 1999; Teixeira, Nascimento \& Sturn, 2006), and if vector distribution allowed, the caves could have served as centers for the spread of Chagas disease. Food storage, the existence of latrines, consumption of undercooked meat, and long-term occupation of the caves would have produced ideal pathoecological conditions for spreading Chagas infection (Reinhard, 2005).

The paleoepidemiological models of sedentary versus nomadic, hunter versus farmer, terrestrial versus maritime, and pre-contact versus post-contact should be expanded experimentally to include rocky versus non-rocky, related to the habit of occupying rock shelters and caves. For example, in Patagonia, non-rocky includes the historical nomadic groups such as the Yámanas and Selk'nam, who lived in open-air shelters and tents. Thus, from the trophic point of view, occupation of the forest and ecotones with forest involves differences in the specific wealth and abundance of resources, especially plant resources, abundant in the western forests (Rapaport, Ladio \& Sanz, 2003). This could 
mean exposure to diverse parasites whose infective stages are found in the vegetation and to other parasites ingested with invertebrate intermediate hosts also existing there, such as orbatid mites.

The non-simultaneous development of paleoepidemiological models and paleoparasitological tests is a necessary strategy for reconstructing possible paleoepidemiological scenarios during different moments of the Holocene in Patagonia.

\section{HELMINTH INFECTIONS ON THE PACIFIC COAST OF SOUTH AMERICA}

In addition to infection with T. trichiura, E. vermicularis, and hookworms and the rare cases of infection with A. lumbricoides, parasitism by Diphyllobothrium pacificum is striking from the pre-Columbian period to the present on the Pacific Coast of South America (Ferreira, Araújo \& Confalonieri, 1984; Gonçalves, Araújo \& Ferreira, 2003). This zoonosis was described by Swiss parasitologist Jean Baer, who was called to Peru to study the parasites found in individuals with clinical intestinal symptoms. He identified the species Diphyllobothrium pacificum, a parasite of sea lions whose larvae contaminate saltwater fish and crustaceans (Baer, 1969). The presence of this parasite in the population is explained by the consumption of cebiche, a traditional raw seafood dish among the peoples of the Pacific Coast of South America.

When he saw examples of the prehistoric pottery in which the ancient peoples of the Pacific Coast served food, Jean Baer raised the hypothesis that they also suffered from this parasitic infection. Years later, when the parasite's eggs were found in Chilean coprolites dated to 4,000 BP, Ferreira, Araújo \& Confalonieri (1984) commented that Baer's assumption was correct. Other researchers have also confirmed the parasite's presence in prehistoric peoples of the Pacific Coast (Callen \& Cameron, 1960; Patrucco, Tello \& Bonavia, 1983; Reinhard \& Barnum, 1991; Reinhard $\&$ Urban, 2003).

Due to the wealth and diversity of the human cultures that inhabited the Pacific Coast of South America, paleoparasitology has contributed greatly to understanding the parasite-human host relationship. A recent example is the study by Arriaza et al. (2010) on the influence of climatic phenomena on parasitic infections. The authors show evidence that infection with Diphyllobothrium pacificum and Anisakis sp. probably had varying prevalence rates in prehistoric populations according to climatic oscillations resulting from the El Niño phenomenon.

The conclusion on intestinal helminths that infected prehistoric South American populations is that the archaeological record bears witness both to parasites introduced by human migrations since the peopling of the continent and others, acquired from animals with whom they lived (and with whom their descendants still live). These helminths include species that infect animals, but which can be transmitted to (and parasitize) humans.

It is interesting to examine modern human groups that maintain ancestral habits, like indigenous groups in some regions of Brazil. For example, cases of false parasitism by Calodium hepaticum (Capillaria hepatica) have been described when examining feces of persons that ingested animal viscera and eliminated eggs of these helminths (Coimbra \& Mello, 1981; Carvalho-Costa et al., 2009). These are examples in which studies on ethnicity and health in both modern and prehistoric peoples show similar situations and can illustrate change or permanence in the disease profile over time. 


\section{REFERENCES}

AlCAínO, H. \& GORZA, T. Parásitos de los animales domésticos en Chile. Parasitología al Día, 23: 1-18, 1999.

ALLISON, M. J. et al. A case of hookworm infestation in a Pre-Columbian American. American Journal of Physical Anthropology, 41(1):103-106, 1974.

ALVES, J. R. et al. Parasitoses intestinais em região semiárida do Nordeste do Brasil: resultados preliminares distintos das prevalências esperadas. Cadernos de Saúde Pública, 19(2): 667-770, 2003.

ARAÚjo, A. Paleoepidemiologia da Ancilostomose, 1987. PhD dissertation, Rio de Janeiro: Escola Nacional de Saúde Pública, Fundação Oswaldo Cruz.

ARAÚJO, A.; CONFALONIERI, U. \& FERREIRA, L. F. Encontro de ovos de Trichostrongylidae e Trichuris trichiura em corpo mumificado do período colonial brasileiro. Revista do Centro de Ciências Biológicas e da Saúde, 1: 11-16, 1984.

ARAÚJO, A.; FERREIRA, L. F. \& CONFALONIERI, U. A contribution to the study of helminth findings in archaeological material in Brazil. Revista Brasileira de Biologia, 41: 873-881, 1981.

ARAÚJO, A.; FERREIRA, L. F. \& CONFALONIERI, U. Oxyurid (Nematoda) egg from coprolites from Brazil. The Journal of Parasitology, 68: 511-512, 1982 .

ARAÚJO, A. et al. The finding of Enterobius vermicularis eggs in pre-Columbian human coprolites. Memórias do Instituto Oswaldo Cruz, 80: 141-143, 1985.

ARAÚJO, A. et al. Parasites, the diversity of life, and paleoparasitology. Memórias do Instituto Oswaldo Cruz, 98, supl. 1: 5-11, 2003.

ARAÚjo, A. et al. Parasites as probes to human migrations? Trends in Parasitology, 24: 112-115, 2008.

ARMELAGOS, G. J.; BROWN, P. J. \& TURNER, B. Evolutionary, historical and political economic perspectives on health and disease. Social Science and Medicine, 61(4): 755-765, 2005.

ARRIAZA, B. Beyond Death: the Chinchorro mummies of ancient Chile. Washington: Smithsonian Institution Press, 1995.

ARRIAZA, B. T. et al. Possible influence of ENSO Phenomenon on the pathoecology of diphyllobothriasis and anisakiasis in ancient Chinchorro populations. Memórias do Instituto Oswaldo Cruz, 105(1): 66-72, 2010.

ASCHERO, C. Nuevos datos sobre la arqueología del Cerro Cassa de Piedra, Sítio CCP5. Relaciones, 14: 267-284, 1981.

ASSIS, B. et al. A contribution to the diagnosis of Capillaria hepatica infection by indirect immunofluorescence test. Memórias do Instituto Oswaldo Cruz, 99: 173-177, 2004.

ATÍAS, A. Parasitología Médica. Santiago de Chile: Mediterrâneo, 1998.

AUfDERHEIDE, A. \& RODRÍGUEZ-MARTín, C. The Cambridge Encyclopedia of Human Paleopathology. Cambridge: Cambridge University Press, 1998.

BABERO, B. B. \& MURUA, R. The helminth fauna of Chile. X. A new species of whipworm from a Chilean rodent. Transactions of the American Microscopical Society, 106: 190-193, 1987.

BABERO, B. B. \& MURUA, R. A new species of whipworm from South American hystricomorph rodent. Memórias do Instituto Oswaldo Cruz, 85: 211-213, 1990.

BABERO, B. B.; CATTAN, P. E. \& CABELLO, C. Trichuris bradleyi sp. n., a whipworm from Octodon degus in Chile. The Journal of Parasitology, 61: 1.061-1.063, 1975.

BABERO, B. B.; CATTAN, P. E. \& CABELLO, C. A new species of whipworm from the rodent Akodon longipilis in Chile. Transactions of the American Microscopical Society, 95: 232-235, 1976.

BAER, J. G. Diphyllobothrium pacificum, a tapeworm from sea lions endemic in man along the coastal area of Peru. Journal of the Fisheries Research Board of Canada, 26: 717-723, 1969. 
BARós, V.; MAJUmDAR, G. \& MIKAILOV, T. K. Morphology and taxonomy of Trichocephalus myocastoris (Enigk, 1933). Folia Parasitologica, 22: 207-213, 1975.

BATHURST, R. R. Archaeological parasites of coastal hunter-gatherers from coastal shell middens. Journal of Archaeological Science, 32: 115-123, 2005.

BELDOMENICO, P. M. et al. Internal parasites of free-ranging guanacos from Patagonia. Veterinary Parasitology, 118: 71-77, 2003.

BENENSON, A. S. Control of Communicable Diseases in Man. Washington: Pan-American Health Organization, 1995.

BOERO, J. J.; KLUSAS, D. E. \& BOEHRINGER, I. El parasitismo de nuestra fauna autóctona. Revista de la Facultad de Veterinaria de La Plata, 21: 161-172, 1967.

BORRERO, L. A. Human dispersal and climatic conditions during Late Pleistocene times in Fuego-Patagonia. Quaternary International, 53-54: 93-99, 1999.

BorRero, L. A. El Poblamiento de la Patagonia. Buenos Aires: Emece, 2001.

BOUCHET, F.; HARTER, S. \& LE BAILLY, M. The state of the art of paleoparasitological research in the Old World. Memórias do Instituto Oswaldo Cruz, 98, supl. 1: 95-101, 2003.

BROTHWELL, D. \& BROTHWELL, P. A Alimentação na Antiguidade. Lisbon: Editorial Verbo, 1971.

CALLEN, E. O. \& CAMERON, T. W. M. A prehistoric diet revealed in coprolites. New Scientist, 8: 35-40, 1960.

CAMILlo-COURA, L. Contribuição ao Estudo das Geo-helmintíases, 1970. PhD dissertation, Rio de Janeiro: Universidade Federal do Rio de Janeiro.

CAMILLO-COURA, L. Control of soil-transmitted helminthiasis: co-ordinated control projects. In: CROMPTON, D. W. T.; NESHEIM, M. C. \& PAWLOWSKI, Z. S. Ascariasis and its Public Health Significance. London, Philadelphia: Taylor and Frances, $1985 \mathrm{a}$.

CAMILlO-COURA, L. Latin America. In: CROMPTON, D. W. T.; NESHEIM, M. C. \& PAWLOWSKI, Z. S. Ascariasis and its Public Health Significance. London, Philadelphia: Taylor and Frances, 1985b.

CARVALHO, D. M. Doenças dos escravizados; doenças africanas? In: ENCONTRO REGIONAL DE HISTÓRIA - Usos do Passado, XII, 2006, Niterói. Anais... Rio de Janeiro: Associação Nacional de História (Anpuh), 2006. v. 1.

CARVAlHO-COSTA, F. A. et al. Pseudoparasitism by Calodium hepaticum (syn. Capillaria hepatica; Hepaticola hepatica) in the Negro River, Brazilian Amazon. Transactions of the Royal Society of Tropical Medicine and Hygiene, 103(10): 1.071-1.073, 2009.

CASALI, R.; FUGASSA, M. \& GUICHÓN, R. Aproximación epidemiológica al proceso de contacto interétnico en el norte de Tierra del Fuego. Magallania, 34: 87-101, 2006

CHAME, M. Terrestrial mammal feces: a morphometric summary and description. Memórias do Instituto Oswaldo Cruz, 98 , supl. 1: 71-94, 2003.

CHANDLER, A. C. Specific characters in the genus Trichuris, with a description of a new species, Trichuris tenuis, from a camel. The Journal of Parasitology, 16: 198-206, 1930.

CHAVES, S. A. M. \& REINHARD, K. Paleopharmacology and pollen: theory, method, and application. Memórias do Instituto Oswaldo Cruz, 98, supl. 1: 207-211, 2003.

CIVAlERo, M. T. \& ASCHERO, C. A. Early occupations at Cerro Casa de Piedra 7, Santa Cruz Province, Patagonia, Argentina. In: MiotTi, L.; SAlEmme, M. \& FlEGHEIMER, N. (Eds.). Center for the Study of the First Americans. College Station: Texas A\&M University Press, 2003.

CIVAlERO, M. T. \& FRANCO, N. V. Early human occupations in Western Santa Cruz Province, Southernmost South America. Quaternary International, 109-110: 77-86, 2003.

CLARKE, A. C. et al. Proceedings of the SMBE Tri-National Young Investigators' Workshop 2005. Reconstructing the origins and dispersal of the Polynesian bottle gourd (Lagenaria siceraria). Molecular and Biology Evolution, 23: 893-900, 2006. 
COCKBURN, T. A. Infectious diseases in ancient populations. Current Anthropology, 12: 45-62, 1971.

COIMBRA JR., C. E. \& MELLO, D. A. Enteroparasitoses e Capilaria sp. entre os Suruí, Parque Indígena Aripuanã, Rondônia. Memórias do Instituto Oswaldo Cruz, 76(3): 299-302, 1981.

COIMBRA JR., C. E. A. \& SANTOS, R. V. Paleoepidemiologia e epidemiologia de populações indígenas brasileiras: possibilidades de aproximação. In: ARAÚJO, A. \& FERREIRA, L. F. Paleopatologia e Paleoepidemiologia: estudos multidisciplinares. Rio de Janeiro: Panorama, PEC-Ensp/Fiocruz, 1992.

CONFALONIERI, U. Paleoepidemiologia de Trichuris trichiura na América. In: FERREIRA, L. F.; ARAÚJO, A. \& CONFALONIERI, U. Paleoparasitologia no Brasil. Rio de Janeiro: PEC-Ensp/Fiocruz, 1988.

DENEGRI, G. M. Cestodosis de Herbivoros Domésticos de la República Argentina de Inportancia en Medicina Veterinária. Mar del Plata: Martín, 2001.

DENEGRI, G. M. \& PEREZ-SERRANO, J. Bertiellosis in man: a review of cases. Revista do Instituto de Medicina Tropical de São Paulo, 39: 123-127, 1997.

DENEGRI, G. M. et al. Anoplocephalid cestodes of veterinary and medical significance: a review. Folia Parasitológica, 45: 1-8, 1998.

DENEGRI, G. M. et al. Viscachataenia n.g., with the redescription of V. quadrata (von Linstow, 1904) n. Comb. (Cestoda: Anoplocephalidae) in Lagidium viscacia (Rodentia: Chichiliidae) from Argentina. Systematic Parasitology, 54: 81-88, 2003.

DIAMOND, J. Evolution, consequences and future of plant and animal domestication. Nature, 118: 700-707, 2002.

DILLEHAY, T. D. Disease ecology and initial human migration. In: DILLEHAY, T. D. \& MELTZER, D. J. (Eds.). The first Americans: search and research. Boca Raton: CRC Press, 1991.

DILlEHAY, T. D. Profiles in Pleistocene history. In: SILVERMAN, H. \& ISBELL, W. H. Handbook of South American Archaeology. New York: Springer, 2008.

DOBYNS, H. F. Disease transfer at contact. Annual Review of Anthropology, 22: 273-291, 1993.

DUNN, J. J. et al. Trichuris vulpis recovered from a patient with chronic diarrhoea and five dogs. Journal of Clinical Microbiology, 40: 2.703-2704, 2002 .

EL-NAJJAR, M. Y. et al. The etiology of porotic hyperostosis among the prehistoric and historic Anasazi Indians of Southwestern United States. American Journal of Physical Anthropology, 44: 477-487, 1976.

FERNANDES, A. et al. Intestinal parasite analysis in organic sediments collected from a $16^{\text {th }}$ Century Belgian archaeological site. Cadernos de Saúde Pública, 21: 329-332, 2005.

FERREIRA, L. F. \& ARAÚJO, A. Parasitos, parasitismo e paleoparasitologia. In: COURA, J. R. Dinâmica das Doenças Infecciosas e Parasitárias. 2 v. Rio de Janeiro: Guanabara Koogan, 2005.

FERREIRA, L. F; ARAÚJO, A. \& CONFALONIERI, U. Finding of helminth eggs in human coprolites from Unaí, Minas Gerais, Brazil. Transactions of the Royal Society of Tropical Medicine and Hygiene, 76: 798-800, 1980.

FERREIRA, L. F.; ARAÚJO, A. \& CONFALONIERI, U. The finding of helminth eggs in a Brazilian mummy. Transactions of the Royal Society of Tropical Medicine and Hygiene, 77: 65-67, 1983.

FERREIRA, L. F.; ARAÚJO, A. \& CONFALONIERI, U. The finding of Diphyllobothrium pacificum in human coprolites (4100-1950 BC) from Northern Chile. Memórias do Instituto Oswaldo Cruz, 79: 175-180, 1984.

FERREIRA, L. F.; ARAÚJO, A. \& CONFALONIERI, U. Paleoparasitologia no Brasil. Rio de Janeiro: PEC-Ensp/Fiocruz, 1988.

FERREIRA, L. F. et al. Infecção por Enterobius vermicularis em populações pré-colombianas do Chile. Cadernos de Saúde Pública, 1: $112-113,1985$.

FERREIRA, L. F. et al. Encontro de ovos de ancilostomídeos em coprólitos humanos datados de $7.230 \pm 80$ anos, Piauí, Brasil. Anais da Academia Brasileira de Ciências, 59: 280-281, 1987. 
FERREIRA, L. F. et al. Infecção por Enterobius vermicularis em populações agro-pastoris pré-colombianas de San Pedro de Atacama, Chile. Memórias do Instituto Oswaldo Cruz, 84: 197-199, 1989.

FERREIRA, L. F. et al. Paleoparasitology of Chagas disease revealed by infected tissues from Chilean mummies. Acta Tropica, 75: $79-84,2000$.

FONSECA FILHO, O. Parasitismo e Migrações Pré-históricas. Rio de Janeiro: Mauro Familiar, 1972.

FREAN, J. \& DINI, L. Unusual anoplocephalid tapeworm infections in South Africa. Annals of the Australian College of Tropical Medicine, 5: 8-11, 2004.

FREITAS, O. Doenças Africanas no Brasil. São Paulo: Cia Editora Nacional, 1935. (Coleção Brasiliana, 51)

FRY, G. Preliminary analysis of the Hogup Cave coprolites. In: AIKENS, C. M. (Ed.). Hogup Cave. Salt Lake City: University of Utah Press, 1970. (University of Utah Anthropological Papers, 93)

FUGASSA, M. Enteroparasitosis en Poblaciones Cazadoras-Recolectoras de Patagonia Austral, 2006a. PhD dissertation, Mar del Plata: Universidade Nacional de Mar del Plata.

FUGASSA, M. Examen paleoparasitológico de sedimentos de un sitio arqueológico, Río Mayo, Chubut, Argentina. Parasitología Latinoamericana, 61: 172-175, 2006b.

FUGASSA, M. \& GUICHÓN, R. Análisis paleoparasitológico de coprolitos hallados en sitios arqueológicos de Patagonia austral: definiciones y perspectivas. Magallania, 33: 13-19, 2005.

FUGASSA, M. H. et al. Paleoparasitological records in a canid coprolite from Patagonia, Argentina. The Journal of Parasitology, 92: 1.110-1.113, 2006.

GASPAR, M. D. Sambaqui: a arqueologia do litoral brasileiro. Rio de Janeiro: Jorge Zahar, 2000.

GASPAR, M. D. et al. Sambaqui (Shell Mound) societies of coastal Brazil. In: SILVERMAN, H. \& ISBELL, W. H. Handbook of South American Archaeology. New York: Springer, 2008.

GEIST, V. On Pleistocene bighorn sheep: some problems of adaptation, and relevance to today's American megafauna. Wildlife Society Bulletin, 13 (3): 351-359, 1985.

GONÇALVES, M. L. C.; ARAÚJO, A. \& FERREIRA, L. F. Human intestinal parasites in the past: new findings and a review. Memórias do Instituto Oswaldo Cruz, 98, supl. 1: 103-118, 2003.

GRACZYK, T. K. \& FRIED, B. Echinostomiasis: a common but forgotten food-borne disease. American Journal of Tropical Medicine and Hygiene, 58(4): 501-504, 1998.

GRAUER, A. L. Patterns of anemia and infection from medieval York, England. American Journal of Physical Anthropology, 91: 203213, 1993.

GUICHÓN, R. A. et al. Health at the time of Native-European contact in Southern Patagonia: first steps, results, and prospects. Memórias do Instituto Oswaldo Cruz, 101, supl. 2: 97-105, 2006.

GUIDON, N. Parque Nacional Serra da Capivara: sítios rupestres e problemática. Fumdhamentos, 5: 77-108, 2007.

HECKENBERGER, M. J.; PETERSEN, J. B. \& NEVES, E. G. Village size and permanence in Amazonia: two archaeological examples from Brazil. Latin American Antiquity, 10: 353-376, 1999.

HIDALGo ARGUELLO, M. R. et al. Parasitological analysis of Leonese royalty from Collegiate-Basilica of St. Isidoro, Leon (Spain): helminths, protozoa, and mites. The Journal of Parasitology, 89: 738-743, 2003.

HOAGLAND, K. E. \& SCHAD, G. A. Necator americanus and Ancylostoma duodenale: life history parameters and epidemiological implications of two sympatric hookworms of humans. Experimental Parasitology, 44: 36-49, 1978.

HUBBE, M. et al. Brief communication: 'Zuzu' strikes again-morphological affinities of the Early Holocene human skeleton from Toca dos Coqueiros, Piauí, Brazil. American Journal of Physical Anthropology, 134(2): 285-291, 2007. 
IÑIGUEZ, A. M. et al. SL1 RNA gene recovery from Enterobius vermicularis ancient DNA in pre-Columbian human coprolites. International Journal for Parasitology, 36: 1.419-1.425, 2006.

JONES, A. Human parasite remains: prospects for a quantitative approach. In: HALL, A. R. \& KENWARD, H. L. Environmental Archaeology in the Urban Context. London: Council for British Archaeology, 1982. (Research Report, 43)

KORMONDY, E. J. \& BROWN, D. E. Fundamentals of Human Ecology. Prentice Hall, 1998.

LEGUÍA, G. P. Enfermedades Parasitarias en Camélidos Sudamericanos. Lima: Ediciones del Mar, 1999.

LELES, D. et al. Molecular paleoparasitological diagnosis of Ascaris sp. from coprolites: new scenery of ascariasis in pre-Columbian South America times. Memorias do Instituto Oswaldo Cruz, 103: 106-108, 2008.

LIMA, T. Nos Mares do Sul: a pré-história do litoral centro-meridional brasileiro. Antes: histórias da pré-história. Rio de Janeiro: Centro Cultural Banco do Brasil, 2006.

MARASCIULO, A. C. E. Dinâmica da Infecção por Ancilostomídeos em Região Semiárida do Nordeste Brasileiro, 1992. Master's thesis, Rio de Janeiro: Escola Nacional de Saúde Pública, Fundação Oswaldo Cruz.

MARTIN, G. Pré-História do Nordeste do Brasil. 4. Ed. Recife: Editora da UFPE, 2005.

MARTINEZ, F. A. et al. Presencia de Mathevotaenia sp. en edentados (Mammalia: Dasypodidae y Mimercophagidae). Comunicaciones Científicas y Tecnológicas, 4: 55-57, 1999.

MARTINSON, E. et al. Pathoecology of Chiribaya parasitism. Memórias do Instituto Oswaldo Cruz, 98, supl. 1: 195-205, 2003.

MAS-COMA, S.; BARGUES, M. D. \& VALERO, M. A. Fascioliasis and other plant-borne trematode zoonoses. International Journal for Parasitology, 35: 1.255-1.278, 2005.

McMiCHAEL, A. J. Environmental and social influences on emerging infectious diseases: past, present and future. Philosophical Transactions of the Royal Society of London, Serie B, 359: 1.049-1.058, 2004.

MEDEIROS, R. P. Povos indígenas do sertão nordestino no período colonial: descobrimento, alianças, resistência e encobrimento. Fumdhamentos, 2: 7-52, 2002.

MELATTI, J. C. Índios do Brasil. 7. Ed. São Paulo, Brasília: EdUnb, Hucitec, 1993.

MICHALSKI, F. \& PERES, C. A. Disturbance-mediated mammal persistence and abundance-area relationship in Amazonian forest fragments. Conservation Biology, 21(6): 1.626-1.640, 2007.

MIYAZAKI, I. An Illustrated Book of Helminthic Zoonoses. Tokyo: International Medical Foundation of Japan, 1991.

MONTENEGRO, A.; AVIS, C. \& WEAVER, A. J. Modelling the pre-historic arrival of the sweet potato in Polynesia. Journal of Archaeological Science, 35: 355-367, 2008.

MONTENEGRO, A. et al. Parasites, paleoclimate and the peopling of the Americas: using the hookworm to time the Clovis migration. Current Anthropology, 47: 193-198, 2006.

MORAVEC, F. Proposal of a new systematic arrangement of nematodes of the family Capillariidae. Folia Parasitologica (Praha), 29: 119-132, 1982.

MORAVEC, F. Parasitic in Cold-Blooded Vertebrates. Praha: Academia, 2001.

MORINI, E. G.; BOERO, J. J. \& RODRIGUEZ, A. Parásitos intestinales en el 'mara' (Dolichotis patagonum patagonum). Misión de Estudios de Patología Regional Argentina, 26: 83-89, 1955.

NAJAR, A.; CHAME, M. \& CHAVES, S. A. M. A GIS application for environmental management in the semi-arid ecosystem of Serra da Capivara National Park, Piaú, Northeast Brazil. In: BREBBIA, C. A. \& PASCOLO, P. (Orgs.). Management Information Systems 2000. Southhampton: WIT Press, 2000. v. 1.

NAVONE, G. T. Estudio de la distribución, porcentaje y microecología de los parásitos de algunas especies de edentados argentinos. Studies on Neotropical Fauna and Environment, 25: 199-210, 1990. 
NAVONE, G. T. \& MERINO, M. L. Contribución al conocimiento de la fauna endoparasitaria de Lama guanicoe Muller 1776, de Península Mitre, Tierra del Fuego, Argentina. Boletín Chileno de Parasitología, 44: 46-51, 1989.

NAVONE, G. T. \& SURIANO, D. M. Species composition and seasonal dynamics of the helminth community parasitizing Didelphis albiventris (Marsupialia: Didelphidae) in savannas of Central Argentina. Ecologia Austral, 2: 95-100, 1992.

NAWALINSKI, T.; SCHAD, G. A. \& CHOWDHURY, A. B. Population biology of hookworms in children in rural West Bengal. I. General parasitological observations. American Journal of Tropical Medicine and Hygiene, 27: 1.152-1.161, 1978a.

NAWALINSKI, T.; SCHAD, G. A. \& CHOWDHURY, A. B. Population biology of hookworms in children in rural West Bengal. II. Acquisition and loss of hookworms. American Journal of Tropical Medicine and Hygiene, 27: 1.162-1.173, 1978b.

NEVES, E. G. Arqueologia da Amazônia. Rio de Janeiro: Jorge Zahar, 2006.

NEVES, E. G. Ecology, ceramic chronology and distribution, long-term history, and political change in the Amazonian floodplain. In: SILVERMAN, H. \& ISBELL, W. H. Handbook of South American Archaeology. New York: Springer, 2008.

NEVES, W. Origens do homem nas Américas: fósseis versus moléculas. In: SILVA, H. P. \& RODRIGUES-CARVALHO, C. (Orgs.). Nossa Origem: o povoamento das Américas: visões multidisciplinares. Rio de Janeiro: Vieira \& Lent, 2006.

OLSEN, K. M. \& SCHAAL, B. A. Evidence on the origin of cassava: phylogeography of Manihot esculenta. Proceedings of the National Academy of Sciences, 96: 5.586-5.591, 1999.

ORELlAnA, N. Paleogenética de Populações Pré-Colombianas da Bolivia: análises do mtDNA humano, e infecções por Trypanosoma cruzi e vírus linfotrópico das células Thumanas (HTLV), 2008. Master's thesis, Rio de Janeiro: Instituto Oswaldo Cruz, Fundação Oswaldo Cruz.

ORTEGA, Y. R. \& BONAVIA, D. Cryptosporidium, Giardia, and Cyclospora in ancient Peruvians. The Journal of Parasitolology, 89: 635-636, 2003.

PATRUCCO, R.; TEllo, R. \& BONAVIA, D. Parasitological studies of coprolites of pre-Hispanic Peruvian populations. Current Anthropology, 24: 393-394, 1983.

PAVLOVSKY, E. Natural Nidality of Transmissible Diseases in Relation to Landscape Epidemiology of Zooanthroponoses. Moscow: Peace Publishers, s.d.

PEDUZZI, R. \& PIFFARETTI, J. C. Ancylostoma duodenale and the Saint Gothard anaemia. British Medical Journal, 287: 1.942$1.945,1983$.

PESSIS, A. M. Imagens da Pré-História: Parque Nacional Serra da Capivara. 1. ed. São Paulo: Fumdham, Petrobras, 2003.

PICKERSGILL, B. Domestication of plants in the Americas: insights from Mendelian and molecular genetics. Annals of Botany, 100: 925-940, 2007.

PIZZI, T. \& SCHENONE, H. Hallazgo de huevos de Trichuris trichiura en contenido intestinal de un cuerpo arqueológico arcaico. Boletín Chileno de Parasitología, 9(3): 73-75, 1954.

PROUS, A. Arqueologia Brasileira. Brasília: Editora Universidade de Brasília, 1992.

PROUS, A. O Brasil antes dos Brasileiros: a pré-história de nosso país. Rio de Janeiro: Jorge Zahar, 2006.

RAPAPORT, E. H.; LADIO, A. \& SANZ, E. H. Plantas Comestibles de la Patagonia Andina. Parte I. Rio Negro: Universidad Nacional de Comahue, 2003.

REA, M. J. F. et al. Strongyloiodes stercoralis, estudio en pacientes sintomáticos y en un área rural de San Luís del Palmar, Corrientes, Argentina. Comunicaciones Científicas y Técnicas, 2003.

REINHARD, K. J. Archaeoparasitology in North America. American Journal of Physical Anthropology, 82: 145-163, 1990.

REINHARD, K. J. Parasitology as an interpretative tool in archaeology. American Antiquity, 57: 231-245, 1992. 
REINHARD, K. J. Cave living and transmission of Chagas disease in ancient times. Paleopathology Newsletter, 131, suppl.: $32,2005$.

REINHARD, K. J. A coprological view of Ancestral Pueblo cannibalism: debate over a single fecal fossil offers a cautionary tale of the interplay between science and culture. American Scientist, 94: 254-261, 2006.

REINHARD, K. J. Pathoecology of two Ancestral Pueblo villages. In: REITZ, E. J.; SCUDDER, S. J. \& SCARRY, C. M. (Eds.). Case Studies in Environmental Archaeology. $2^{\text {nd }}$ Ed. New York: Springer, 2008.

REINHARD, K. J. \& BARNUM, S. V. Parasitology as an interpretative tool in archaeology. American Antiquity, 57: 231-245, 1991.

REINHARD, K. J. \& URBAN, O. Diagnosing ancient Diphyllobothriasis from Chinchorro mummies. Memórias do Instituto Oswaldo Cruz, 98, supl. 1: 191-193, 2003.

REINHARD, K. J.; HEVLY, R. H. \& ANDERSON, G. A. Helminth remains from prehistoric Indian coprolites on the Colorado Plateau. The Journal of Parasitology, 73: 630-639, 1987.

REINHARD, K. J. et al. American hookworm antiquity. Medical Anthropology, 20: 96-101, 2001.

REY, L. Parasitologia. Rio de Janeiro: Guanabara Koogan, 2008.

RINALDI, L. et al. Canine faecal contamination and parasitic risk in the city of Naples (Southern Italy). BMC Veterinary Research, 2: 29, 2006.

ROBERTS, L. S. \& JANOVY JR., J. Foundations of Parasitology. Boston: McGraw-Hill International Edition, Higher Education, 2009.

ROBERTSON, I. D. \& THOMPSON, R. C. Enteric parasitic zoonoses of domesticated dogs and cats. Microbes and Infection, 4: 867873,2002 .

ROBLES, C. \& OLAECHEA, F. Salud y enfermedad de las manadas. In: BORRELLI, P. \& OLIVA, G. (Eds.). Ganadería Sustentable en la Patagonia Austral. Santa Cruz: Inta, 2001.

ROTHMAN, J. \& BOWMAN, D. D. A review of the endoparasites of mountain gorillas. In: BOWMAN, D. D. (Ed.). Companion and Exotic Animal Parasitology. Ithaca: International Veterinary Information Service, 2003.

ROTHSCHILD, B. Porotic hyperostosis as a marker of health and nutritional conditions. American Journal of Human Biology, 14: 417-418, 2002.

SARDELLA, N. H. \& FUGASSA, M. H. Paleoparasitological analysis of rodent coprolites in holocenic samples from Patagonia, Argentina. The Journal of Parasitology, 95(3): 646-651, 2009.

SAVOLAinen, P. et al. Genetic evidence for an East Asian origin of domestic dog. Science, 298(5.598): 1.610-1.613, 2002.

SCHAD, G. A. et al. Arrested development in human hookworm infections: an adaptation to a seasonally unfavorable external environment. Science, 180: 502-504, 1973.

SIANTO, L. Parasitismo em Populações Pré-colombianas: helmintos de animais em coprólitos de origem humana do Parque Nacional Serra da Capivara, PI, Brasil, 2009. PhD dissertation, Rio de Janeiro: Escola Nacional de Saúde Pública, Fundação Oswaldo Cruz.

SIANTO, L. et al. The finding of Echinostoma (Trematoda: Digenea) and hookworm eggs in coprolites collected from a Brazilian mummified body dated 600-1,200 years before present. The Journal of Parasitology, 91(4): 972-975, 2005

Silva, H. P. \& RODRIGUES-CARVAlHo, C. (Orgs.). Nossa Origem: o povoamento das Américas. Visões multidisciplinares. Rio de Janeiro: Vieira \& Lent, 2006.

SILVA, L. J. O conceito de espaço na epidemiologia das doenças infecciosas. Cadernos de Saúde Pública, 13(4): 85-93, 1997.

SILVERMAN, H. \& ISBELL, W. H. Handbook of South American Archaeology. New York: Springer, 2008.

SMITH, B. D. The initial domestication of Cucurbita pepo in the Americas 10,000 years ago. Science, 276: 932-934, 1997.

SOTOMAYOR, H.; BURGOS, J. \& ARANGO, M. Demonstración de tuberculosis en una momia prehispánica por la ribotipificación del ADN de Mycobacterium tuberculosis. Biomédica, 24, supl.: 18-26, 2004. 
SOULSBY, E. J. Helminths, Arthropods, and Protozoa of Domesticated Animals, Ballère Tindall, Division of Cassell Ltd., London UK, 1982.

STAHL, P. W. Pre-Columbian Andean animal domesticates at the edge of empire. World Archaeology, 34(3): 470-483, 2003.

STUART-MACADAM, P. Porotic hyperostosis: a new perspective. American Journal of Physical Anthropology, 87: 39-47, 1992.

SURIANO, D. M. \& NAVONE, G. T. Three new species of the genus Trichuris Roederer, 1761 (Nematoda: Trichuridae) from Cricetidae and Octodontidae rodents in Argentina. Research and Reviews in Parasitology, 54: 39-46, 1994.

SUTTON, C. A. Un nuevo eucestode parásito de Myocastor coypus bonariensis Comerson. Neotrópica, 19: 38-42, 1973.

TAYLOR, L. H.; LATHAM, S. M. \& WOOLHOUSE, M. E. J. Risk factors for human disease emergence. Transactions of the Royal Society of London B, 356: 983-989, 2001.

TENORA, F. Tapeworms of the family Anoplocephalidae Cholodwky, 1902: evolutionary implications. Acta Scientarum Naturalium Academiae Scientiarum Bohemicae Brno, 10: 1-37, 1976.

TENÓRIO, M. C. Pré-História da Terra Brasilis. Rio de Janeiro: Editora UFRJ, 1999.

TEIXEIRA, A. R. L.; NASCIMENTO, R. J. \& STURN, N.R. Evolution and pathology in Chagas disease: a review. Memórias do Instituto Oswaldo Cruz, 101: 463-491, 2006.

THIENPONT, D.; ROCHETTE, F. \& VANPARIJS, O. F. J. Diagnóstico de las Helmintiasis por Medio del Examen Coproparasitológico. Beerse: Janssen Research Foundation, 1979.

TIEPOLO, L. M \& TOMAS, W. M. Ordem Artidactyla. In: REIS, N. R. et al. (Eds.). Mamíferos do Brasil. Londrina: Edifurb, 2006.

WING, E. S. \& BROWN, A. B. Paleonutrition: method and theory in prehistoric foodways. New York: Academic Press, 1979.

YOSHIKAWA, H. et al. Variations in egg size of Trichuris trichiura. Parasitology Research, 75: 649-654, 1989.

ZIMMERMAN, M. R. \&, MORILLA, R. E. Enterobiasis in pre-Columbian America. Paleopathology Newsletter, 42: 8, 1983. 


\title{
The Findings in North America
}

\author{
Karl Jan Reinhard
}

$\mathrm{O}$ de Eric Callen, a Canadian botanist, and Thomas Wright Moir Cameron, a parasitologist, launched interest in the study of coprolites. In addition to studies in their specialties, they made pioneering contributions to the study of organic remains preserved in archaeological feces by introducing the technique of rehydration in trisodium phosphate aqueous solution (Callen \& Cameron, 1960).

Fry \& Hall (1969) compared the rehydration techniques previously used in coprolites, which included distilled water, sodium hydroxide aqueous solution, and others, with trisodium phosphate solution and concluded that the latter was superior. They examined 193 samples dated between 9,500 and 2,000 before present (BP) from Danger Cave, Utah, and found eggs of Moniliformis clarcki and Enterobius vermicularis. The presence of this acanthocephalan species in human feces was discussed by Moore, Fry \& Englert (1969), and Fry \& Moore (1969) discussed the ancient dating of coprolites with Enterobius vermicularis eggs, reaching close to 10,000 BP. The coprolites found in the Great Basin archaeological region, which covers an extensive area in the Western United States, continued to be an important source of data on diet and parasites and the object of study and reviews, for example Wilke \& Hall (1975) and Fry (1977), summarizing the accumulated studies.

Chart 1 shows the parasites found in coprolites in North America. The chart shows that certain parasites are concentrated in specific regions. For example, Diphyllobothrium sp. is limited more to the north, while infection with Acantocephalae is limited to the Great Basin. Both infections appear to have been highly common in huntergatherers, differing from hookworm infections and Strongyloides stercoralis, found in the southern part of North America in agricultural societies, with more favorable environmental conditions for their transmission. However, as shown by Fry \& Hall (1969), Enterobius vermicularis infection is ancient among hunter-gatherer groups and was ubiquitous among the Ancestral Puebloans of the Southwest and in other regions. Other intestinal helminths, such as Ascaris lumbricoides and Trichuris trichiura, commonly found in humans at present, were rarer in Prehistoric America. 
Chart 1 - Parasites, antiquity, and archaeological sites. Prehistoric North America

\begin{tabular}{|c|c|c|}
\hline Parasite & Date & Site \\
\hline A. lumbricoides & 322-177 B.C. & Big Bone Cave, TN \\
\hline A. Iumbricoides & 570-290 B.C. & Upper Salts Cave, KY \\
\hline A. lumbricoides & A.D. $1075-1140$ & Antelope House, AZ \\
\hline A. lumbricoides & A.D. $1100-1250$ & Elden Pueblo, AZ \\
\hline A. lumbricoides & A.D. $1127-1207$ & Adak Island, AK \\
\hline Ancylostomidae & A.D. 600 & Rio Zape, Durango, Mexico \\
\hline Ancylostomidae & A.D. $1075-1140$ & Antelope House, AZ \\
\hline Ancylostomidae & 322-177 B.C. & Big Bone Cave, TN \\
\hline Ancylostomidae (?) & 1300-1700 B.C. & Daws Island, SC \\
\hline Ancylostomidae (?) & A.D. $700-1200$ & Grenado Cave, Texas \\
\hline E. vermicularis & c.a. 8000 B.C. & Danger Cave, UT \\
\hline E. vermicularis & 4833-4300 B.C. & Dirty Shame Shelter, OR \\
\hline E. vermicularis & 4010 B.C. & Hogup Cave, UT \\
\hline E. vermicularis & 2100-600 B.C. & Hinds Cave, TX \\
\hline E. vermicularis & 1250 B.C. & Hogup Cave, UT \\
\hline E. vermicularis & 650 B.C. & Hogup Cave, UT \\
\hline E. vermicularis & 322-177 B.C. & Big Bone Cave, TN \\
\hline E. vermicularis & A.D. 400 & Turkey Pen Cave, UT \\
\hline E. vermicularis & A.D. 600 & Antelope House, AZ \\
\hline E. vermicularis & A.D. 600 & Rio Zape, Durango, Mexico \\
\hline E. vermicularis & A.D. $700-1000$ & Antelope Cave, AZ \\
\hline E. vermicularis & A.D. $900-1250$ & Big Horn Sheep Ruin, Utah \\
\hline E. vermicularis & A.D. $500-1200$ & Clyde's Cavern, UT \\
\hline E. vermicularis & A.D. $920-1020$ & Pueblo Bonito, NM \\
\hline E. vermicularis & A.D. $1080-1130$ & Pueblo Bonito, NM \\
\hline E. vermicularis & A.D. $1000-1200$ & Step House, CO \\
\hline E. vermicularis & A.D. $1000-1200$ & Glen Canyon, UT \\
\hline E. vermicularis & A.D. $1075-1140$ & Antelope House, AZ \\
\hline E. vermicularis & A.D. $1100-1250$ & Elden Pueblo, AZ \\
\hline E. vermicularis & A.D. $1100-1250$ & Salmon Ruin, NM \\
\hline E. vermicularis & A.D. $1250-1300$ & Inscription House, AZ \\
\hline
\end{tabular}


Chart 1 - Parasites, antiquity, and archaeological sites. Prehistoric North America (continued)

\begin{tabular}{|c|c|c|}
\hline Parasite & Date & Site \\
\hline S. stercoralis & A.D. $1075-1140$ & Antelope House, AZ \\
\hline S. stercoralis & A.D. $1080-1130$ & Pueblo Bonito, NM \\
\hline S. stercoralis & A.D. $500-1200$ & Clyde's Cavern, UT \\
\hline T. spiralis & A.D. 1550 & Point Barrow, AL \\
\hline T. trichiura & A.D. 600 & Rio Zape, Durango, Mexico \\
\hline T. trichiura & A.D. $1100-1250$ & Elden Pueblo, AZ \\
\hline Trematode unknown & A.D. $1250-1300$ & Glen Canyon, UT \\
\hline Cryptocotyle lingua & A.D. 400 & St. Lawence Island, AK \\
\hline Fascioloid & $500 B C-1150 A D$ & Lovelock Cave, NV \\
\hline Fascioloid & Unknown & Sudden Shelter, Coahuila, Mexico \\
\hline Paragonimus & A.D. 600 & Rio Zape, Durango, Mexico \\
\hline Diphyllobothrium & $300 B C-200 A D$ & Schultz Site, MI \\
\hline Diphyllobothrium & A.D. $1127-1207$ & Adak Island, AK \\
\hline Diphyllobothrium & A.D. $1400-1700$ & Buildir Island, AK \\
\hline Hymenolepidid & A.D. $1100-1250$ & Elden Pueblo, AZ \\
\hline Hymenolepidid & A.D. $1075-1140$ & Antelope House, AZ \\
\hline Hymenolepidid & A.D. 600 & Rio Zape, Durango, Mexico \\
\hline Echinococcus granulosis & Precontact & Kodiak Island, AK \\
\hline Echinococcus granulosis & A.D. 600 & North Dakota \\
\hline Taeniid eggs & 4500 B.C. & Hogup Cave, UT \\
\hline Taeniid eggs & 4200 B.C. & Hogup Cave, UT \\
\hline Taeniid eggs & 2000 B.C. & Hogup Cave, UT \\
\hline Taeniid eggs & 330 B.C. - A.D. 200 & Schultz Site, MI \\
\hline Taeniid eggs & A.D. 20 & Danger Cave, UT \\
\hline Taeniid eggs & A.D. $1100-1250$ & Elden Pueblo, AZ \\
\hline Taeniid eggs & A.D. $1250-1300$ & Glen Canyon, UT \\
\hline Taeniid eggs & A.D. $700-1000$ & Antelope Cave, AZ \\
\hline Acanthocephalan & A.D. $460-1500$ & Clyde's Cavern, UT \\
\hline Acanthocephalan & A.D. $900-1100$ & Black Mesa, AZ \\
\hline Acanthocephalan & A.D. $900-1100$ & Clen Canyon, UT \\
\hline Moniliformis clarki & 10000-8500 B.C. & Danger Cave, UT \\
\hline
\end{tabular}


Chart 1 - Parasites, antiquity, and archaeological sites. Prehistoric North America (continued)

\begin{tabular}{|c|c|c|}
\hline Parasite & Date & Site \\
\hline Moniliformis clarki & 8000 B.C. & Danger Cave, UT \\
\hline Moniliformis clarki & $6400-4856$ B.C. & Hogup Cave, UT \\
\hline Moniliformis clarki & $4300-5090$ B.C. & Dirty Shame Shelter, OR \\
\hline Moniliformis clarki & $4800-4300$ B.C. & Dirty Shame Shelter, OR \\
\hline Moniliformis clarki & 2000 B.C. & Hogup Cave, UT \\
\hline Moniliformis clarki & 1869 B.C. & Danger Cave, UT \\
\hline Moniliformis clarki & A.D. 20 & Danger Cave, UT \\
\hline Moniliformis clarki & A.D. 600-900 & Dirty Shame Shelter, OR \\
\hline
\end{tabular}

B.C. - Before Christ; A.D. - After Death.

Antelope House and Antelope Cave are different sites. Antelope Cave is located in the farthest corner of Northwest Arizona, close to the Great Basin. Antelope House is located in Northeast Arizona, on Colorado Plateau.

\section{CHARACTERISTICS OF PATHOECOLOGY IN THE SOUTHWEST UNITED STATES: APPLICATION OF THE NATURAL DISEASE NIDALITY CONCEPT TO THE STUDY OF HEALTH IN PREHISTORY}

One aim of this chapter is to propose that bioarchaeologists adopt the concept of natural nidality of disease (Pavlovsky, s.d.) Editor's note as a tool to reconstitute the pathoecology of infectious diseases in prehistoric communities. The nidus is a geographic or other special area containing pathogens, vectors, reservoir hosts, and recipient hosts that can be used to predict infections based on one's knowledge of ecological factors related to infection. Ecological factors include the presence of vectors, reservoir hosts, humans, and a favorable external environment for the transmission of parasites. An individual nidus therefore reflects the limits of transmission of a given parasite or pathogen within specific areas of interaction: bedbugs in a bedroom, for example. A nidus or a focus of infection can be as confined as a single room containing a bed and with access to the room by rodents carrying plague-infected fleas. Nidality can also be as large as the community and its surrounding area in which there is a transmission of a given helminth species or any other parasite.

Puebloans were a complex of overlapping nidi. For example, at Antelope House the grain storage and processing rooms could be identified as a nidus for tapeworm infections. The habitation rooms within the shelter formed a nidus for pinworm infection. The water sources were nidi for whipworm, Giardia, and amoeba infections. Finally, the defecation and/or agricultural areas were nidi for hookworm and wireworm transmission (Figure 1).

Editor's Note The author of this chapter uses the term "pathoecology" in a somewhat different sense from that of "natural nidus of disease", proposed by Pavlovsky. A natural nidus of disease exists when there are specific favorable climate, vegetation, soil, and microclimate in regions where there are vectors, infected hosts, and hosts susceptible to infection. In other words, a natural nidus of diseases is related to a specific geographic landscape, such as the taiga with its botanical composition, a hot sand desert, the steppe, etc., i.e., a biogeocenosis (Pavlovsky, s.d.: 19). In the original concept of "nidality", disease outbreaks occur when persons invade or modify a site where a given parasite circulates in its natural environment (Lemos \& Lima, 2002). 
Figure 1 - Antelope House, where the cliff on the left shows the dwellings of the Ancestral Puebloans, Chelley Canyon, Arizona, USA

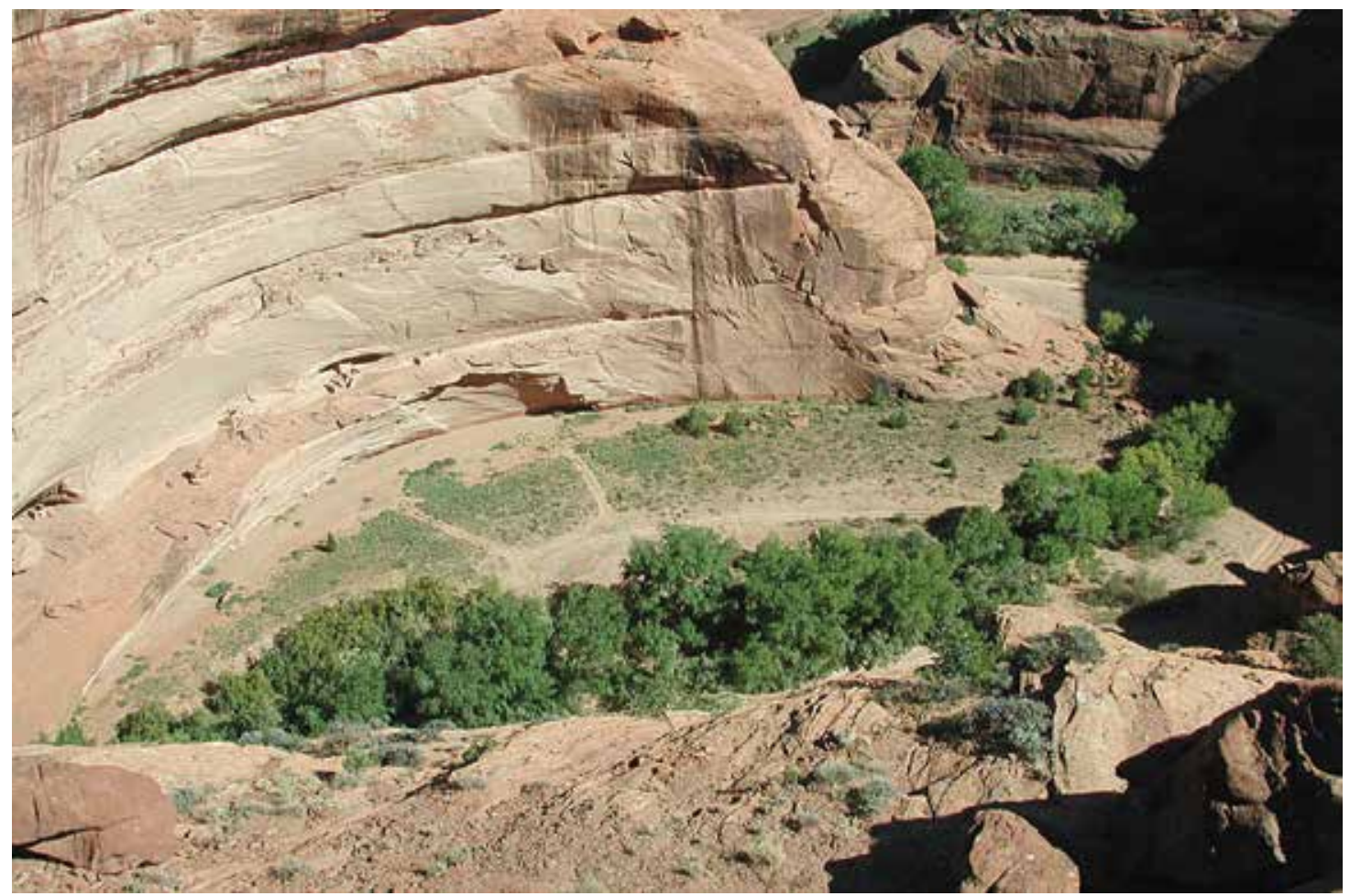

Hymenolepis nana is a tapeworm that has only been recovered from agricultural sites among the Puebloans. The parasite species is found in humans, but other animals such as rats and mice become infected with a very proximate species called Hymenolepis fraterna, which however has also been diagnosed sometime in humans. The life cycle and host-to- host transmission occur through the ingestion of eggs eliminated in the feces of infected individuals; these eggs eclode and release the hexacanth embryo, or larva with three pairs of hooks, which attach to the intestinal mucosa in the so-called cysticercoid form. Some ten to 12 days later the cysticercoid larva migrates to the ileum, passing to the adult stage and producing proglottids. This cycle, from egg to egg, takes approximately one month. It is more common in children than in adults, reflecting a certain degree of immunity resulting from the parasite's passage through the intestinal mucosa and the production of serum antibodies. The parasite's eggs in human feces can be ingested by coprophagous insects such as various species of fleas, as well as coleopters. The cysticercoid larva develops in the insects, and infection can occur when the latter are ingested by mammals such as rodents, dogs, and other carnivores. Humans can become infected this way by ingesting small coleopters of genus Tenebrio, found in grain, or genus Tribollium, found in flour. In these cases, since the cysticercoid is ingested, immunity does not develop and the number of parasites is usually much higher than in infection transmitted by the ingestion of Hymenolepis nana eggs.

Thus, among the Puebloans, parasitism by Hymenolepis nana must have occurred by direct transmission among humans, as well as autoinfection, but also by ingestion of arthropods inadvertently crushed during the preparation of foods with stored grain.

Hookworm and wireworm larvae penetrate the skin of humans. Nidi for these parasites probably were in agricultural fields and/or in or around toilet areas in the sites. The most common method for controlling hookworms is to use 
footwear. Ancestral Puebloans wore sandals, but Behnke et al. (2000) document problems in hookworm infection with the wearing of sandals among modern agriculturalists in Mali. They report that the soil sticks to sandals, making them uncomfortable and frustrating to wear when tilling soil, leading people to take them off. As a result, those who wear sandals are infected just as often as those who go barefoot (Behnke et al. 2000).

This same situation may have plagued Puebloan horticulturalists, and larval skin penetration could have occurred in cornfields. Schad et al. (1983) suggest another scenario for hookworm infection that is also applicable to Puebloan pathoecology, when they showed that in West Bengal, villagers defecated in areas around the village peripheries. People used the same areas day after day for this purpose. As a result, hookworm larvae proliferated in those areas and the time spent by humans in the contaminated areas was sufficient to maintain hookworm infection in the population.

At Antelope House, hundreds of small concentrations of coprolites were found within the rock shelter. This pattern of coprolite remains shows that the Antelope House residents had a similar sanitation pattern as the people living in West Bengal, but used abandoned rooms rather than the peripheral regions around the village. Therefore, the nidi for hookworm and wireworm infections could have been in the peripheries of the village or in the abandoned rooms, used to defecate. Wireworm larvae were found in Antelope House dog coprolites (Reinhard 1985b, 1985c). Although it has not been proven that the species parasitizing dogs was the same as in humans, experimental infection with Strongyloides stercoralis occurs in dogs and rats in the laboratory, suggesting that they may serve as reservoirs or alternative hosts.

By building a multi-room, stone-walled village within a rock shelter, Puebloans at Antelope House established a large nidus for pinworm transmission. Pinworms are transmitted both by hand-to-hand contact between humans and by airborne dissemination when a population is occupying a closed space. The apartment-like pueblos with their closed spaces and stagnant air would have been ideal areas for the dissemination of eggs (Hugot et al. 1999; Reinhard 2007a). Proof for this is noted at Antelope House, which has one of the highest prevalence rates of pinworm infection in prehistory due to airborne contamination.

Whipworm, Giardia duodenalis, and amoebas are transferred in contaminated water, although hand-to-hand transfer of Giardia is known. This would have been a serious problem during a period of drought in the Canyon de Chelly region in Pueblo III times (Morris 1986; Reinhard 1985). During the drought the number of pueblos in the canyon grew as people moved closer to the remaining reliable sources of water in the canyon floor. As a result of overcrowding and poor sanitation, the local water sources became contaminated and thus could be considered as nidi for fecal-borne diseases.

\section{PARASITES, DISEASE, AND ANCESTRAL PUEBLOAN PALEOPATHOLOGY}

Parasitic infection means the parasite's presence in the host, and parasitic disease does not necessarily result from infection. Disease results from the pathogen's pathogenicity and virulence, associated with the host's characteristics and those of the environment in which both are found. Virulence refers to the parasite's ability to multiply. Pathogenicity refers to the parasite's capacity to cause disease symptoms and mortality in the host population (Araújo et al. 2003). Infection can be transmitted vertically, from mother to child, or horizontally, from one host to another.

Among the various worm types of parasites that infected Ancestral Puebloans, the most virulent included Trichuris trichiura (whipworms) which have the potential for each female to lay as many as 20,000 eggs per day, and Ascaris lumbricoides (giant intestinal roundworms), which lay 200,000 eggs per day. Perhaps the least virulent 
worm parasite was Strongyloides stercoralis (wireworm). Female wireworms lay only hundreds of larvae per day. However, the pathogenic potential of these worms is reversed. Whipworms and giant intestinal roundworms rarely cause debilitating long-term problems or death (except intestinal obstruction caused by a bolus of worms in the case of Ascaris lumbricoides). In contrast, wireworms are more pathogenic. Wireworms enter the body by penetrating the skin. In their migration toward the intestine they work their way through the heart and lungs and can cause serious pathology in these organ systems. When they enter the intestine they plow through the intestinal mucosa and damage the intestinal tract. Mothers infected with wireworms can potentially infect their nursing babies in vertical transmission via breast milk. Whipworms and giant intestinal roundworms can be transferred only by fecal contamination of the environment. These are "geohelminths", or parasites whose eggs need to mature to the infective stage in soil.

The number of parasite species infecting a host population relates to their ability to combine into conditions that create a disease. One advantage of coprolite analyses is that they provide the potential for identifying the number and diversity of parasites that are infecting a single host (Reinhard et al. 1988; Reinhard, Ambler \& McGuff, 1985).

The level and intensity of parasitic diseases in a population is affected by many conditions. These include the population's past experience with parasitic infection, nutritional and immune status, and the behavioral patterns of the population that increase or decrease risk. Two of these, susceptibility to infection and the nutritional needs of the host, can be assessed through examination of the archaeological record. An example of this can be seen in the studies of sites in the American Southwest. A number of coprolite studies reported that the breadth of Ancestral Pueblo diets were generally nutritionally sound (Cummings 1994; Fry 1980; Minnis 1989). However, beginning in 1992, coprolite evidence emerged for substantial variation in the consumption of wild plants at Ancestral Puebloan sites, suggesting that agricultural failures at some locations may have forced a much higher reliance on wild foods.

To test this assumption, the ancient diets of the populations living at Antelope House and at Salmon Ruin were reconstructed and compared to determine whether clues of starvation could be identified in coprolite data (Reinhard 2008b). These coprolite studies included identification and evaluation of starvation foods based on phytoliths, or silica crystals formed in the epidermis of plants, found in various archaeological remains, such as dental arches (in the spaces between teeth), coprolites, etc. (Reinhard \& Danielson 2005), pollen concentrations (Reinhard et al. 2006), and starch and macrofossils (LeRoy-Toren \& Reinhard 2004; Reinhard 2008b; Reinhard et al. 2006; Sutton \& Reinhard 1995). Data from both sites covered the time period during the recorded environmental deterioration in Pueblo III Canyon de Chelly (Reinhard 2004, 2008b). Starvation foods, including yucca leaf bases and prickly pear pads, became very common foods at Antelope House but not so at Salmon Ruin and other Pueblo sites in Utah and New Mexico (Reinhard \& Danielson 2005). Pollen concentrations in coprolites reveal that stored maize was eaten less often and in smaller quantities at Antelope House than at Salmon Ruin, and that people at Antelope House were relying more heavily on wild foods like cattail heads and horsetail strobili. Finally, starch grains were much less common in the coprolites from Antelope House than those found at Salmon Ruin. Macrofossil remains show the widest variety of wild plant use at Antelope House. When combined, all of these data support the apparent dietary impact of environmental deterioration in the Antelope House region of Canyon de Chelly, which undermined local agricultural yields and forced the residents to diversify and increase their reliance on wild plant foods (Reinhard 1996, 2008b).

During that same stressful period a greater diversity of parasite species infected the population living at Antelope House. Some of these parasites, like hymenolepidid tapeworms and pinworms, are neither very virulent nor pathogenic but their presence suggests that the population, perhaps already suffering from various forms of malnutrition, was 
generally in poor health. Whipworms were also present, and although this parasite is virulent (i.e., it produces an enormous amount of eggs eliminated in the feces), it is not very pathogenic. Hookworm and wireworm infections were also common at Antelope House during this period. Neither of these is particularly virulent, but they both have the capability of vertical transmission from mother to fetus or newborn and the ability to infect the most susceptible portion of the population (infants) with regard to helminths. In addition, two species of diarrhea-causing protozoan parasites were found that are both highly virulent and pathogenic, Entamoeba histolytica and Giardia lamblia. Overall, the image that emerges of the people living at Antelope House during this period is one of a physiologically stressed, highly infected population among whom some individuals in the poorest health were more susceptible to infection by many parasites.

The widespread infection levels indicated by the Antelope House coprolites raise other important questions, such as the level of interaction between the host's nutritional needs and parasitism and at what point those levels become critical or even life-threatening. One example of this important relationship between nutritional needs and parasitism was discussed by Crompton $\&$ Whitehead (1993). In their discussion they constructed a model predicting the effects of hookworm infection on a non-pregnant versus a pregnant woman. Their model predicts that hookworm infection will deplete stored iron in the host's body because of the hookworm's destruction of red blood cells thus reducing their density per milliliter of blood. Thus the effect of this iron depletion becomes much more acute in pregnant women because they must also provide iron for their growing fetus. Each hookworm in a person's body can consume 0.27 $\mathrm{ml}$ of blood per day (MacLeod 1988). After only 20 weeks of hookworm infection the host may show symptoms of hypochromic and macrocytic anemia.

A major problem among pregnant women is that the minor symptoms of hookworm infection are often indistinguishable from normal complaints of pregnancy such as epigastric pain, heartburn, etc. When the hookworm infection is more severe, the pregnant woman may show symptoms of low-grade fever, fatigue, dyspnea, heart palpitations, flow murmurs, and anemia. In cases of heavy infection, constipation or diarrhea, jaundice, emaciation, cardiac failure, or preeclampsia can occur. If an infected woman survives labor, she often cannot recover easily from postpartum hemorrhage, which can contribute to maternal death. Overall, in hookworm-infected populations, the increased physiological needs of pregnancy put women at much higher risk.

When multiple infections occur in a pregnant woman, as they most probably did at Antelope House during this period of severe stress, serious consequences result. Of the parasites at Antelope House, hookworm, G. lamblia, and $E$. histolytica were the most serious challenges to maternal and infant health. In pregnant women, hookworm causes severe iron deficiency anemia, nutrient malabsorption, alimentary bleeding, fatigue, diarrhea, preeclampsia, and heart failure during labor. E. histolytica and G. lamblia cause iron deficiency anemia, nutrient malabsorption, diarrhea, dehydration, and shock.

These parasites cause problems for mothers and fetuses, leading to major effects on the population.

The presence of these three parasites in nutritionally stressed Puebloan populations is an important factor in the prevalence of porotic hyperostosis in Ancestral Puebloan skeletal assemblages, especially in concert with nutritional stress when changing environmental conditions resulted in reduced food and nutrient intakes (Reinhard 1992). Longterm droughts, such as recorded in the Antelope House region, resulted in an aggregation of human populations around the dwindling water sources. This in turn led to a proliferation of crowd diseases and diseases associated with contaminated water and inadequate sanitation. Bioarchaeologically, this suite of phenomena are expressed as elevated levels of porotic hyperostosis in skeletal remains. 


\section{INSECTS AND PARASITISM IN THE PREHISTORIC SOUTHWEST}

Some of the most intriguing pathoecological data come from areas and archaeological sites where ancient people ate the intermediate insect hosts that were carrying acanthocephalans and tapeworms. In these cases, specific aspects of prehistoric diet or hygiene resulted in human infection, but which should be distinguished from false parasitism. Parasites of animals can infect the human host and sometimes cause parasitic disease, which is called zoonosis. However, some parasites are unable to establish themselves in the host, and their ingested infective forms, larvae or eggs, cross the intestinal tract and are eliminated in the feces. In such cases, so-called false parasitism occurs.

Acanthocephalans rarely parasitize humans in the modern world. We know that ancient Americans were infected because we have found acanthocephalan eggs in human coprolites. These finds are most common in the Great Basin from coprolites found at archaic sites including Dirty Shame Rockshelter in Oregon (Hall 1977), Clyde's Cavern in Utah (Hall 1972), and Danger and Hogup Caves in Utah (Fry 1977) (for review see Reinhard 1990). Acanthocephalan eggs have also been recovered from Ancestral Pueblo coprolites found in sites located in the Glen Canyon, Utah, and Black Mesa Arizona (Fry 1977; Gummerman et al. 1972:191; Reinhard 1990). The Ancestral Pueblo infections probably resulted from accidental or purposeful consumption of flour beetles, camel crickets, roaches, and perhaps other similar insects.

A different type of infection may have resulted from eating ectoparasites (parasites outside the body such as lice, fleas, and ticks). Fry (1977) and Napton \& Heizer (1970) found lice in human coprolites recovered from Danger Cave, Utah, and Lovelock Cave, Nevada. Recently, Johnson et al. (2008) found a tick in a human coprolite from Antelope Cave, an Ancestral Pueblo Site in northwestern Arizona near the Virgin River. Apparently, the tick had been bitten and swallowed and then became part of a coprolite. Fry (1977) presented a case suggesting that prehistoric people ate ectoparasites as a hygienic measure. This assumption makes good sense and we believe that Fry made a good case for this type of behavior.

Taeniid tapeworm eggs have been found in coprolites from Danger Cave, Hogup Cave, Glen Canyon, and Antelope Cave. The exact species of taeniid that is represented by these finds is unknown. In the modern world, humans are most commonly infected by two species, Taenia solium from pork and T. saginata from beef. These species of taeniids were almost certainly absent in the prehistoric New World because the host animals are native to the Old World. There is one other known taeniid that can infect humans, although it is much more common to find it as a parasite of dogs. This is Dipylidium caninum (cucumber tapeworm). D. caninum uses fleas and lice as intermediate hosts. Therefore, if a person ate fleas and lice in an effort to prevent the ectoparasites from feeding on humans, it is possible they could have eaten an ectoparasite (Ctenophalides canis) that had fed on an infected dog. Since there is coprolite evidence that prehistoric people did eat fleas and lice, we suspect that the taeniid eggs found in Southwestern human coprolites may be from $D$. caninum infections.

\section{SOUTHWEST PALEOPARASITOLOGY, THE GENERAL PICTURE}

The origin for Pathoecology studies in the Southwest was to gain an understanding of the relation of human cultural evolution to parasite evolution. The central question has related to the difference in parasitism between hunter-gatherers, simple horticulturalists, and complex horticulturalists or agriculturalists. For the studies of western North America, the data are robust enough to draw some generalities. First, parasitism by intestinal helminths was a very rare event for hunter-gatherers. Indeed, of some 150 archaic coprolites from the Colorado Plateau, none have convincing evidence of infection. Of some 200 coprolites from the Chihuahuan desert of Texas, only one was positive 
for pinworm. In the Great Basin, hunter-gatherer coprolites are often positive for acanthocephalan and taeniid eggs but rarely positive for pinworm eggs. This indicates that for hunter-gatherers, regionally specific subsistence habits opened or closed the opportunity for zoonotic parasitism.

The earliest horticultural site, Turkey Pen Ruin, had one of the highest pinworm prevalence rates in coprolites (29\%). Pinworm was present in almost all subsequent Ancestral Pueblo horticultural sites. One general conclusion that we can draw is that human-specific parasitism, which was rare in hunter-gatherer times and absent in the region of the Ancestral Pueblos, became a significant problem for horticulturalists. In evolutionary time, this happened very suddenly, and the paleoparasitological data can contribute to new studies on the theme.

Some Ancestral Pueblos developed more complex methods of food production and apartment-style buildings. The Chaco Canyon Ancestral Pueblos had these developments. Hookworm and Strongyloides stercoralis emerged as health problems for these agriculturalists. These parasites spread to more distant sites such as Antelope House. It thus appears from the coprolite data that each advancing stage in agricultural production added species of parasites to human populations. This increasing spectrum of parasites included fewer zoonotic species and more human-specific species.

\section{TRACING THE PATTERN TO NORTHERN MEXICO}

This also seems to be the pattern for northern Mexico. Analysis of 32 hunter-gatherer coprolites from Frightful Cave, Coahuila, Mexico, revealed just one positive for a fascioloid fluke. No other contained parasite eggs. In contrast, current analysis of agricultural coprolites from the Cueva de los Chiquitos Muertos reveals pinworm, whipworm, and hookworm. There is also potential evidence of hymenolepidid and fluke infection of a zoonotic origin. The hymenolepidids could be false parasitism. The pattern of hunter-gatherer zoonosis followed by horticultural humanspecific infection holds for the arid region of Northern Mexico.

\section{COLONIAL IMPACT ON NEW WORLD PARASITISM}

Since the beginning of paleopathology in the Americas, researchers have posed the question of how European colonization of the Americas affected health. This is a pathoecological question on a global scale. Among early $20^{\text {th }}$ century parasitologists, the general consensus was that most or even all parasite species arrived in the Americas after 1492. There was a consensus that the Americas before colonization were largely free of parasites that were prevalent in the Old World.

This changed in the latter part of the $20^{\text {th }}$ century when analysis of prehistoric coprolites showed that the most common human roundworm and protozoan parasites arrived in the Americas millennia before Columbus. In addition, endemic zoonoses infected prehistoric Indian populations.

The question was modified to: "How was the pathoecological spectrum of parasite infection affected by Colonial settlements?" Long-standing research with prehistoric coprolites showed that fecal-borne parasitism was relatively rare in the prehistoric Americas. In contrast, extensive studies of Medieval and Renaissance latrines in Europe by many authors showed that fecal-borne parasites were an unavoidable aspect of European pathoecology. The answer to this question awaited the analysis of Colonial American sediments.

In the 1990s several analyses of colonial sites were conducted. These included a 1620s-1673 latrine from Newfoundland (Horne \& Tuck, 1993); barrel latrines from the Meadows site, an early colonial 1600s Swedish colony 
in Philadelphia (see below); surface sediments from the mid-1600s Dutch Colony of Albany, New York (see below); and latrines from 1720 Colonial Williamsburg (Reinhard, 1990). Researchers focused on the recovery and quantification of geohelminth eggs that have direct anal-oral life cycles. Geohelminths are parasites that produce eggs and larvae that are laid in an uninfective state. The eggs need several days to weeks in the open environment to reach infective stage. The two geohelminth species of particular interest are Trichuris trichiura, the whipworm, and Ascaris lumbricoides, sometimes called the maw-worm or the giant intestinal roundworm. Mature Trichuris trichiura worms are whip-shaped and the tiny adults burrow into the intestinal mucosa with only the posterior portion projecting into the intestinal lumen. In contrast, $A$. lumbricoides adults are around a foot in length and a quarter inch in width. The adults live in the intestinal lumen and maintain their place against peristaltic movement by their own muscular exertions.

All of these studies showed the presence of fecal-borne parasites. Ascaris lumbricoides, which is especially rare in the prehistoric Americas, was present in all of these analyses (see the chapter on molecular diagnosis in Ascaris lumbricoides). Trichuris trichiura was found in all of the latrines. As shown in Table 1, this pathoecological association persisted in all Colonial cities and villages studied by Reinhard. These data show that the Colonial period introduced fecal-borne parasitism as a public health hazard and this persisted for many years after initial colonization.

Table 1 - North American archaeological sites, maximum concentration of Ascaris and Trichuris eggs per milliliter of sediment

\begin{tabular}{|c|c|c|c|}
\hline Site & Ascarid & Trichurid & Author \\
\hline Albany River Walk, NY & 12,432 & 1,243 & Reinhard ** \\
\hline Caltrans, CA & 3,374 & 3,552 & Reinhard ** \\
\hline Colonial Williamsburg, VA & 144 & 1,056 & Reinhard ** \\
\hline Fayette, MI & * & * & Faulkner et al. 2000 \\
\hline Five Points, NY & 3,896 & 5,340 & Reinhard ** \\
\hline Frederick Douglas, NY & 512 & 73 & Reinhard ** \\
\hline Gateway Mall, PA & 51,422 & 8,779 & Reinhard ** \\
\hline Greenwich Village, NY & * & * & Reinhard ** \\
\hline Howard Street, NY & 33,561 & 1,243 & Reinhard ** \\
\hline Independence Mall 1, PA & 4,754 & 12,639 & Reinhard ** \\
\hline Lincoln, NE & 0 & 0 & Reinhard ** \\
\hline Meadows Site, PA & 6,700 & 4,800 & Reinhard ** \\
\hline Pearl Street 1, NY & 207 & 2,900 & Reinhard ** \\
\hline Pearl Street 2, NY & 12,153 & 6,145 & Reinhard ** \\
\hline Picotte-Dec, NY & 223,248 & 3,763 & Reinhard ** \\
\hline Providence, RI & * & * & Reinhard et al. 1986 \\
\hline Quackenbush Square, NY & 38,947 & 829 & Reinhard ** \\
\hline Queen Anne Square, RI & * & * & Reinhard ** \\
\hline
\end{tabular}


Table 1 - North American archaeological sites, maximum concentration of Ascaris and Trichuris eggs per milliliter of sediment (continued)

\begin{tabular}{c|r|r|c}
\hline Site & Ascarid & Trichurid & Author \\
\hline Raritan Landing, NJ & 8,997 & 18,112 & Reinhard ** \\
\hline Ravensford, NC & 400 & 100 & Reinhard ** \\
\hline Rural Farms, IA & 0 & 0 & Reinhard ** \\
\hline Sleepy Hollow, NY & 6,500 & 300 & Reinhard ** \\
\hline SUFC Site, NY & 310,999 & 12,181 & Reinhard ** \\
\hline Troy, NY & 746 & 497 & Reinhard ** \\
\hline Tweed Courthouse, NY & 118 & 335 & Reinhard ** \\
\hline Wheeling Annex, VA & 2,072 & 2,072 & Reinhard ** \\
\hline
\end{tabular}

* Eggs present but not quantified; ** new data.

\section{CONTROL OF PARASITE INFECTION}

The emergence and control of parasitic disease has been a central theme in historic pathoecology (Jones 1985; Herrmann, 1986; Reinhard 1994). We can conclude that geohelminth species emerged as public health hazards in the squalid urban conditions of Medieval Europe (Bouchet, Harter \& Le Bailly, 2003; Jones, 1985; Herrmann, 1986). Until colonial times, they were relatively rare parasites in the Americas. However, they are ubiquitous in historic colonial and post-colonial sites (Gonçalves, Araújo \& Ferreira, 2003; Horne \& Tuck, 1996; Reinhard, 1990, 1994, 2000; Reinhard et al., 1986). The new question in historic pathoecology regarding geohelminths is: "When did they become controlled?"

The analysis of well-dated sediment series from historic sites offers an answer to this question. Recent excavations in New Brunswick, New Jersey, and Albany, New York, provided such contexts.

\section{New Brunswick}

New Brunswick represents control of disease in the post-Colonial period. The ascarid egg counts are presented in Table 2. It is clear that through the 1860s, there was a large variance in parasitism. This indicates that parasitism was controlled at the household level. Some households were very successful in controlling parasitism and therefore had very few eggs per milliliter of latrine sediment. However, other households were more heavily parasitized and exhibited tens of thousands of eggs per milliliter of sediment. In humans, a number of household-level factors influence the degree of parasitism (Herrmann \& Schultz 1986). The demographic nature of the household is very important. Parasites, especially those that have direct life cycles (e.g., Enterobius vermicularis), tend to infect children more than adults. Therefore, households with more young children have greater levels of parasitism than those with few young children.

Economics also play a major role in the level of household parasitism. Part of this is obvious. Households that can afford medicine and medical visits will have a greater chance of controlling parasitism. Other factors are more subtle. For example, Reinhard, Mrozowski \& Herrmann (1986) found that the artisan class of the Revolutionary Period in 
Providence, Rhode Island, had household gardens and open latrine pits compared to the merchant class which had closed privies and no gardens. The open latrine near gardens promoted the contamination of food plants with parasite eggs.

Crowding is more associated with poorer classes. Since direct life cycle diseases are density-dependent, then poorer crowded families are trapped in the parasite life cycles. Hygiene is a final consideration. For households in which hand washing is customary, parasitism is reduced, according to the findings of remains.

After 1860, it appears that parasitism was controlled at a community level.

The five latrines that date to the first third of the $19^{\text {th }}$ century have an average of 13,920 ascarid eggs per milliliter of night soil sediment. The five latrines that date to the middle third of the century have an average of 10,260 ascarid eggs per milliliter of night soil sediment. In contrast, the four latrines that date to the last third of the century have an average of 894 ascarid eggs per milliliter of night soil sediment.

These data indicate that in the latter third of the $19^{\text {th }}$ century, fecal-borne helminth parasites came under control. This implies a community level of parasite control. It is very likely that sanitation measures such as supplying clean water to the population, channeling and sequestering sewage, or increasing restrictions on building and maintaining latrines occurred late in the century. This level of community control, combined with the preexisting household control, served to reduce fecal-borne disease. This does not mean the worms were eliminated, for trichuriasis and ascariasis still occur today. However, they were reduced to a level that produced very little overt disease.

Table 2 - Night soil helminth egg counts in New Brunswick, USA, in the $18^{\text {th }}$ and $19^{\text {th }}$ centuries

\begin{tabular}{c|c|c|c|c}
\hline Sample \# & Stratum & Date & A. lumbricoides & T. trichiura \\
\hline 7 & 3 & 1790 & 150 & 150 \\
\hline 26 & 6 & 1805 & 28,950 & 3,100 \\
\hline 29 & 3 & 1805 & 17,050 & 3,750 \\
\hline 25 & 5 & 1823 & 13,300 & 4,800 \\
\hline 9 & 2 & 1830 & 5,400 & 2,850 \\
\hline 28 & 4 & 1830 & 4,900 & 750 \\
\hline 19 & 4 & 1835 & 22,650 & 1,000 \\
\hline 21 & 6 & 1849 & 1,000 & 150 \\
\hline 17 & 5 & 1850 & 14,400 & 1,850 \\
\hline 5 & 9 & 1853 & 9,050 & 350 \\
\hline 14 & 2 & 1860 & 4,200 & 2,150 \\
\hline 3 & 7 & 1870 & 2,800 & 650 \\
\hline 20 & 4 & 1887 & 450 & 300 \\
\hline 12 & 7 & 1890 & 325 & 25 \\
\hline 10 & 4 & 1898 & 0 & 0 \\
\hline
\end{tabular}


Albany

The sediments from Albany were recovered from many different contexts including latrines, drains, roads, yards, and wells (Tables 3 and 4). Therefore, we can get an idea of the general level of town contamination with parasite eggs. Seven years of study of Albany resulted in the accumulation of the largest data set for any historic site. The data show that geohelminths arrived with colonization. It appears that parasitism grew rapidly with the population growth. Indeed the 1700 s and early 1800 s show a growing concentration of parasite eggs in latrines. The concentrations of eggs exhibit a sharp decline after 1810 and then after 1860 most latrines are negative for parasite eggs.

The non-latrine contexts (Table 4) explain these trends. Surface refuse was positive for parasite eggs from the 1600 s and 1700s. Nine of 21 non-latrine contexts and over half of the surface contexts are positive for parasite eggs. This shows that infected feces were scattered with trash in the area. One of the highest concentrations comes from a street in the 1740 s to 1760 s, suggesting that feces contaminated the streets.

In the 1800 s, drains and culverts were established in the city. Parasite eggs are commonly found in these as well, but this signals a more successful way of sequestering human waste from the population.

Over all, the average concentration of eggs in latrines declines through time at Albany (Table 3). For A. lumbricoides, the average concentration of eggs from the latter half of the $18^{\text {th }}$ century is 51,460 eggs per milliliter of latrine sediment. This declines to 7,890 for the first half of the $19^{\text {th }}$ century and 3,979 for the latter half of the $19^{\text {th }}$ century. Similarly, for T. trichiura, the average concentration of eggs for the latter half of the $18^{\text {th }}$ century is 2,492 eggs per milliliter of latrine sediment. This declines to 399 for the first half of the $19^{\text {th }}$ century and 185 for the latter half of the $19^{\text {th }}$ century.

Table 3 - Parasite egg concentrations from latrines in Albany, New York, $18^{\text {th }}$ and $19^{\text {th }}$ centuries

\begin{tabular}{c|c|c|c|c}
\hline Site & Feature & Date & A. Iumbricoides & T. trichiura \\
\hline Picotte-DEC & $7 / 42$ privy & 1740 & 0 & 0 \\
\hline Pearl Street north & Surface privy & $1740-1760$ & 12153 & 6145 \\
\hline Picotte-DEC & $4 / 112$ privy & 1760 & 62,710 & 2,508 \\
\hline State Univ. Const. & surface privy & 1760 & 2,019 & 621 \\
\hline Pedestrian Bridge & below stockade & 1760 s & 1,249 & 0 \\
\hline Lutheran Church Lot & 3 & $1770-1790$ & 266 & 444 \\
\hline Lutheran Church Lot & 1 & $1780-1790$ & 207 & 2900 \\
\hline Picotte-DEC & 5/126 privy & 1785 & 223,248 & 3,763 \\
\hline Picotte-DEC & $1 / 96$ privy & 1790 & 89,675 & 3,763 \\
\hline Picotte-DEC & 6/148 privy & 1800 & 1,254 & 314 \\
\hline State Univ. Const. 1/20 & Stone-lined privy & 1800 & 4,972 & 104 \\
\hline State Univ. Const. 5/9 & Well, reused as privy & 1800 & 310,999 & 12,181 \\
\hline State Univ. Const. 7/38 & Wooden box privy & 1800 & 5,150 & 1,598 \\
\hline 116 Sheridan & Privy, barrel & 1800 & 6,550 & 550 \\
\hline Court of Appeals 13 & Unlined cesspit & $1800-1830$ & & 0 \\
\hline
\end{tabular}


Table 3 - Parasite egg concentrations from latrines in Albany, New York, $18^{\text {th }}$ and $19^{\text {th }}$ centuries (continued)

\begin{tabular}{|c|c|c|c|c|}
\hline Site & Feature & Date & A. lumbricoides & T. trichiura \\
\hline Court of Appeals 15 & Wood-lined privy & $1800-1830$ & 0 & 0 \\
\hline State Univ. Const. 3 & Stone-lined privy & $1810 s$ & 25,199 & 678 \\
\hline 116 Sheridan & Privy, wooden vault & $1820 s-1840 s$ & 5,250 & 700 \\
\hline Court of Appeals 14 & Unlined cesspit & 1825 & 497 & \\
\hline 40 Howard Street & 2 & 1830 & 1709 & 444 \\
\hline 40 Howard Street & 3 & 1830 & 11311 & 1119 \\
\hline 40 Howard Street & 6 & 1830 & 249 & 0 \\
\hline 40 Howard Street & 8 & 1830 & 124 & 62 \\
\hline Picotte-DEC & $3 / 113$ privy & 1830 & 251 & 0 \\
\hline Quackenbush Square & Barrel privy & $1830 \mathrm{~s}$ & 31,607 & 829 \\
\hline 40 Howard Street & 5 & 1840 & 33561 & 1243 \\
\hline 112 \&114 Sheridan & Privy, wooden vault & $1840 s-1860 s$ & 100 & 50 \\
\hline 40 Howard Street & 10 & 1850 & 13851 & 888 \\
\hline Picotte-DEC & 2/108 privy & 1850 & 1,505 & 250 \\
\hline Picotte-DEC & 12/147 privy & $1850 s$ & 1,026 & 114 \\
\hline 116 Sheridan * & Privy, wooden vault & $1850 s-1890 s$ & 2,750 & 200 \\
\hline Picotte-DEC & 11/97 privy & 1855 & 60,202 & 2,090 \\
\hline Picotte-DEC & $9 / 40$ privy & 1860 & 448 & 0 \\
\hline Picotte-DEC & 10/122 privy & $1860 \mathrm{~s}$ & 228 & 0 \\
\hline State Univ. Const. 6/31 & Large, wood-lined privy & $1860 \mathrm{~s}$ & 2,260 & 0 \\
\hline Troy & 69 & 1864 & 39 & 0 \\
\hline 112 Sheridan & Privy vault, Concrete & 1870s-1890s & 0 & 0 \\
\hline 114 Sheridan & Privy, wooden vault & $1870 s-1890 s$ & 0 & 0 \\
\hline 114 Sheridan & Privy, wooden vault & $1870 s-1890 s$ & 0 & 0 \\
\hline Troy & 34 & $1870 s-1890 s$ & 0 & 0 \\
\hline Troy & 38 & $1870 s-1890 s$ & 207 & 41 \\
\hline Quackenbush Square & Wood-lined privy & $1880 \mathrm{~s}$ & 179 & 0 \\
\hline Troy & 77 & 1881 & 249 & 99 \\
\hline Troy & 89 & 1885 & 249 & 497 \\
\hline Troy & 71 & 1895 & 97 & 129 \\
\hline Troy & 87 & 1896 & 0 & 0 \\
\hline Troy & 74 & 1903 & 746 & 99 \\
\hline
\end{tabular}


Table 4 - Parasite egg concentrations from non-latrine sediments in Albany, New York, $18^{\text {th }}$ and $19^{\text {th }}$ centuries

\begin{tabular}{|c|c|c|c|}
\hline Context & Date & A. lumbricoides & T. trichiura \\
\hline Surface, Brickyard & $1600 \mathrm{~s}$ & 0 & 0 \\
\hline Surface, Brickyard & $1600 \mathrm{~s}$ & 0 & 0 \\
\hline House yard & 1600s, mid- & 37 & 0 \\
\hline Surface refuse near house & $1640-1700$ & 60 & 0 \\
\hline Surface refuse near house & $1640-1700$ & 10 & 1 \\
\hline Surface refuse near house & $1640-1700$ & 0 & 0 \\
\hline Surface refuse near house & $1650-1670$ & 0 & 0 \\
\hline Street, beneath surface & $1740-1760$ & 12,153 & 6,145 \\
\hline distillery, below vat & $1750-1800$ & 0 & 0 \\
\hline distillery, vat sediment & $1750-1800$ & 0 & 0 \\
\hline distillery, vat sediment & $1750-1800$ & 0 & 0 \\
\hline Surface, dismantled stockade & $1750 s$ & 113 & 0 \\
\hline Surface near stockade & 1760 & 2,019 & 621 \\
\hline Dog burial, pelvic area & 1760 & 1,065 & 355 \\
\hline Surface, dismantled stockade & 1760 s & 1,249 & 0 \\
\hline Ground Surface 2 & 1780 & 0 & 0 \\
\hline Ground Surface 3 & 1780 & 0 & 0 \\
\hline Surface along wharf & $1780 \mathrm{~s}$ & 219 & 0 \\
\hline cleaned log drain & $1780 \mathrm{~s}$ & 75 & 0 \\
\hline stone culvert & $1790 s$ & 70 & 0 \\
\hline Surface, dismantled stockade & $1790 s$ & 0 & 0 \\
\hline stone culvert & 1800 & 0 & 0 \\
\hline stone culvert & 1805 & 14,918 & 1,243 \\
\hline Ground Surface 1 & 1820 & 155 & 0 \\
\hline Wooden drain & $1820 \mathrm{~s}$ & 5 & 0 \\
\hline Drain & 1830 & 124 & 62 \\
\hline
\end{tabular}




\section{IMMIGRATION AND SPREAD OF EXOTIC PARASITES}

The data from Albany and New Brunswick show that common roundworm parasites were introduced into the Americas and persisted until the latter part of the $19^{\text {th }}$ century when they were largely controlled. More exotic parasites were introduced, but because of the absence of intermediate host, they could not become established in North America. One of these is the Chinese liver fluke (Clonorchis sinensis), found in Chinese historic latrines in California.

I summarize the data from the Chinese property in San Berardino California, where there is evidence of transcontinental introduction of the Chinese liver fluke to California with historic migrations. This study confirms an earlier, unpublished report of Chinese liver flukes from a historic Chinese community in Sacramento, CA (Hall, personal communication, 1982).

Chinese moved to San Bernardino in 1867 (Costello \& Hallaran, 2004). By 1880, the county-wide Chinese population was about 150. Initially, they lived in various places throughout the town of San Bernardino. They farmed, operated laundries, worked in restaurants and hotels, and were employed as domestic servants or farm laborers. In 1878, the city prohibited laundries within the town limits, and subsequently a Chinese quarter was established. By the turn of the $20^{\text {th }}$ century, as many as 600 Chinese lived in Chinatown. Chinatown was virtually all male. It was composed of shops, boarding houses, gambling parlors, a temple, labor contractors, and other establishments. With regard to modernization and sanitation, Chinatown had electricity by 1893 and piped water by 1900. Human waste disposal was managed by construction of backyard latrines.

Three artifact-filled latrines were discovered during excavations. They were located on property purchased by California-born Wong Nim in 1900. Wong Nim was born in Alameda County, California, and moved to San Bernardino about 1875 . He was successful. He first worked as a laundryman, but eventually opened a mercantile shop and acted as a labor contractor. He also opened a temple. Wong remained on the corner of Third and B streets until his death at age 89 in 1941. At that time he had earned the honorary title of "Mayor of Chinatown".

When the State purchased Wong Nim's property in 1943, all of the remaining buildings on his property were demolished. At least one latrine (number 1035) was filled at this time with debris from the abandoned buildings. The privies were used by people who built residences and businesses on Wong's original property. However, Wong's house, store, and temple were located a half block away from the latrines and associated houses.

Most interesting was the discovery of the delicate eggs of Clonorchis sinensis, the Chinese liver fluke. The discovery of these eggs shows that the Chinese immigrants in California brought with them at least one species of parasite from Asia. Latrine 1035 contained 710 C. sinensis eggs per ml and 1056 contained 533 eggs per ml.

The three latrines were used at different times by the same Chinese community. It is noteworthy that the earliest latrine deposits (1880-1900) and the latest latrine deposit (1910-1941) were positive for parasite eggs but the 1900-1910 latrine sediment contained no eggs. The Chinese liver fluke, like many flukes, has a multi-host life cycle including fish and snails. These intermediate hosts have important roles in the life cycle of the parasite. The parasite undergoes asexual reproduction in the snails. Thus, the number of parasites produced by a single egg is amplified by the snail stage of the life cycle. The fish is important in conveying the parasites to their definitive host, a human. The definitive host is the animal that harbors the sexually active stages of the parasite. If the parasite survives the culinary preparation of the fish, it will eventually migrate to the liver of the definitive host and live there for many years, mating and laying eggs. The eggs pass through the bile duct into the digestive tract and then onward to the open environment. 
However, the introduction of this parasite to California was a dead end. The intermediate snail hosts to which it is adapted in Asia are absent in the Americas. The archaeological identification of parasite eggs in latrines that date from the late $19^{\text {th }}$ century to the early $20^{\text {th }}$ century shows that the parasite was possibly introduced by immigrants during this period that may have lived long lives with their infections. If infections were light, the human hosts probably had no symptoms or mild indigestion with light abdominal pain. If they had heavy infections, then they could have suffered from pronounced abdominal pain, diarrhea, jaundice, enlarged and tender livers, and/or anorexia. In chronic cases, liver cancer could have resulted from infection. No traditional Chinese remedies for this ailment are known to us. However, many bottles from various medicines were found in the Chinese latrines (Reinhard et al., 2008). These may be related to the symptoms of parasitic disease.

Asia is home to many parasites that did not exist in the New World, even after European colonization. These parasites included the Chinese liver fluke (C. sinensis), the intestinal fluke (Fasciolopsis buski), the oriental lung fluke (Paragonimus westermani), and the Asian blood fluke (Schistosoma japonicum). These parasites were present in Asia in ancient times as indicated by paleoparasitology in Korea, China, and Japan. They infected many people and undoubtedly some immigrants entered the Americas with these parasites. For this reason, the analysis of sediments from the San Bernardino Chinatown latrine is particularly important in demonstrating the cross-continental introduction of parasites into North America. For Chinese liver flukes, this was a pathoecological dead end.

\section{WHERE TO FIND PARASITE EGGS IN HISTORIC SITES}

The studies of Albany show that any area in a historic site can be contaminated with parasite eggs. For ideal pathoecological study, many samples should be taken to identify "hotspots" for transmission. In Albany, streets and surface trash were such hotspots as well as drains leading to the streets and to rivers. How parasite eggs are distributed stratigraphically in latrines was explored in analyses of latrines from Philadelphia.

The paleoparasitological analysis of 35 archived sediment samples excavated from historic Philadelphia was undertaken. The analysis of these samples had several goals. First, I wanted to assess various proveniences for parasite egg abundance to determine the prevalence of parasite eggs in sediments from the site. Secondly, the fact that several samples were stratigraphically controlled provided an opportunity to explore how parasite eggs are vertically distributed in archaeological features. Third, the presence of samples recovered from inside vessels allowed assessing the value of such samples with regard to parasite egg recovery.

One interesting result was that the concentration of eggs from the two parasite species did not always correlate. As the concentration of eggs declined towards the center for one species, the concentrations declined for the other. This can be explained by the relative ease of treatment for A. lubricoides which lives in the intestinal lumen versus T. trichiura which burrows into the mucosa of the intestine. There are more effective remedies for lumen-dwelling nematodes, especially $A$. lubricoides, which is a noticeable parasite. People are much more likely to be aware of their ascarid infection when they pass foot-long white worms. Therefore, decline in ascarid egg count could easily be explained by medical treatment. Another factor to be considered is relative egg production. Ascaris lubricoides females lay about 200,000 to 240,000 eggs per day versus T. trichiura females which lay an estimated 20 thousand eggs per day.

Therefore, elimination of even one ascarid female will result in a dramatic drop in ascarid eggs relative to trichurid. I think that the strata, features, and rooms that have relatively low ascarid counts represent people who have access to vermifuges. 
This analysis provided me with the first opportunity to evaluate the content of vessels for parasite eggs. Vessels were found in the sediment, ranging from a pitcher to a 600 mil bottle. The pitcher contained three thousand Ascaris lumbricoides and 3,300 Trichuris trichiura eggs. These are among the highest egg concentrations. A redware vessel contained 150 Ascaris lumbricoides and 400 Trichuris trichiura eggs, relatively low levels in this area of the excavation. A green bottle contained 1,350 Ascaris lumbricoides and 3,400 Trichuris trichiura eggs. These are very interesting concentrations because sediment from the same stratigraphic level contained only 550 A. lumbricoides and $900 \mathrm{~T}$. trichiura eggs per $\mathrm{ml}$.

These three vessel samples suggest that sampling sediment from inside of ceramic or glass vessels provides good archaeological data, especially if the vessels have narrow apertures such as the pitcher and bottle. Apparently with the glass bottle, the sediment inside the bottle retains higher parasite concentrations, perhaps because sediment outside the bottle was altered by post-depositional processes that removed or destroyed eggs. However, the eggs that entered the bottle mixed with the original contents of the bottle such that the eggs were trapped in a brown, organic matrix and ended up being preserved in this medium.

The stratigraphic distribution of eggs was first explored by Reinhard, Mrozowski \& Oloski (1986) and by Reinhard et al. (1986). In these articles, but especially in the latter, it was discovered that the vertical distribution of parasite eggs is highly concentrated in the upper or lower levels of latrines. This is in part because deposition of infected feces oversaturates confined areas with parasite eggs. This oversaturation becomes even more extreme as latrine sediments decompose and compress in the post-depositional phase of archaeological site formation. However, I have had little opportunity to explore the distribution of eggs in the past four years because archaeologists generally send night soil deposits identified in the field without samples from above or below the night soil. This project allowed me to look at the distribution of parasite eggs in stratigraphic association.

In one area, total concentration of eggs is highest in the uppermost stratum (29,250 eggs per ml), declines in the next lowest stratum (26,334 eggs per $\mathrm{ml}$ ), and is lowest in the bottom of the feature (2,750 eggs per $\mathrm{ml})$.

In another room, total concentration of eggs has the reverse pattern in relation to the previous area, in that the eggs are most concentrated in the lowest level. There were no eggs in the uppermost level and 5,375 eggs per $\mathrm{ml}$ in the lower level.

For still another room, the data are most interesting because of the depth of the feature. There is a general congruence of egg concentration for the two parasite species. The maximum concentration is at the top of the feature. However, there is a spike of parasite eggs in a lower level. Whether this represents secondary deposition of eggs to a lower level by post-occupation, archaeological site formation processes, or an actual early use of the feature as a latrine is unknown.

In general, the stratigraphic distribution of the eggs follows previously reported observations in which eggs are concentrated in well-defined areas. It is important for archaeologists to collect samples from every $10 \mathrm{~cm}$ in a stratigraphic column within latrines. It is also important to collect samples from water sources for the community, from household drains, community drains, and from yards and streets.

The measures discussed in this chapter increase the possibilities for a more plausible nosological picture of parasite infections at different moments in the past, with a better observational basis, more differentiated and closer to reality. The picture is developed little by little, with an increasingly clear and solid basis in the parasite records from archaeological material. 


\section{REFERENCES}

ARAÚJO, A. et al. Parasitism, the diversity of life, and paleoparasitology. Memórias do Instituto Oswaldo Cruz, 98, supl. 1: 5-11, 2003.

BEHNKE, J. M. et al. The epidemiology of human hookworm infections in the southern region of Mali. Tropical Medicine and International Health, 5: 343-354, 2000.

BOUCHET, F.; HARTER, S. \& LE BAILLY, M. The state of the art of paleoparasitological research in the Old World. Memórias do Instituto Oswaldo Cruz, 98, supl. 1: 95-101, 2003.

CALLEN, E. O. \& CAMERON, T. W. M. A prehistoric diet revealed in coprolites. New Scientist, 7: 35-40, 1960.

COSTELLO, J. G. \& HALLARAN, K. The Luck of Third Street: historical archaeology data recovery report for the Caltrans District 8 San Bernardino Headquarters Demolition Project: preliminary final. San Bernardino: California Department of Transportation District 8, 2004.

CROMPTON, D. W. \& WHITEHEAD, R. R. Hookworm infections and human iron metabolism: review. Parasitology, 107, supl.: S137-S145, 1993.

CUMMINGS, L. S. Anasazi Diet: variety in the hoy house and the lion house coprolite record and nutritional analysis. In: SOBOLIK, K. D. Paleonutrition: the diet and health of prehistoric Americans. Carbondale: Center for Archaeological Investigations, Southern Illinois University, 1994. (Occasional Paper n. 22)

FAULKNER, C. T. et al. Archaeological evidence of parasitic infection from the $19^{\text {th }}$ century company town of Fayette, Michigan. The Journal of Parasitology, 86(4): 846-849, 2000.

FRY, G. F. Analysis of prehistoric coprolites from Utah. In: JENNINGS, J. D. (Ed.). University of Utah Anthropological Papers 97. Salt Lake City: University of Utah Press, 1977.

FRY, G. F. Prehistoric diet and parasites in the desert west of North America. In: BROWMAN, D. (Ed.). Early Native Americans. The Hague: Mouton Press, 1980.

FRY, G. F. \& HALL, H. J. Parasitological examination of prehistoric human coprolites from Utah. Proceedings of Utah Academy of Science, Arts, and Letters, 46: 102-105, 1969.

FRY, G. F. \& MOORE, J. G. Enterobius vermicularis: 10,000-year-old human infection. Science, 166: 1.620, 1969.

GONCALVES, M. L. C.; ARAÚJO, A. \& FERREIRA, L. F. Human intestinal parasites in the past: new findings and a review. Memórias do Instituto Oswaldo Cruz, 98, supl. 1: 103-118, 2003.

GUMERMAN, G. J.; WeSTFALL, D. \& WEED, C. S. Archaeological Investigations on Black Mesa: the 1969-1970 seasons. Prescott: Prescott College Press, 1972.

HALL, H. J. Diet and Disease at Clyde's Cavern, Utah. M.A., 1972. Thesis, Salt Lake City: University of Utah.

HALL, H. J. A paleoescatological study of diet and disease at Dirty Shame Rockshelter, southwest Oregon. Tebiwa, 8: 1-15, 1977.

HEIZER, R. F. \& NAPTON, L.K. (Eds.). Archaeology and the Prehistoric Great Basin Lacrustrin Subsistence Regime as Seen from Lovelock Cave. Nevada: University of California Archeological Research Facility, 1970. (Contributions 10)

HERRMANN, B. Parasitologische Untersuchung mittelalterlicher Kloaken. In: HERRMANN, B. (Ed.). Mensch und Umwelt im Mittelalter. Stutgart: Deutsche Verlag-Anstalt, 1986.

HERRMANN, B. \& SCHULTZ, U. Parasitologische untersuchungen eines spatmittelalterlich-fruhneuzeitlichen kloakeninhaltes aus der Lubecker Fronerei. Lubecker Schriften Archaologie Kulturgeschichte, 12: 167-172, 1986.

HORNE, P. D. \& TUCK, J. A. Archaeoparasitology at a $17^{\text {th }}$ century colonial site in Newfoundland. The Journal of Parasitology, 82 : 512-515, 1996.

HUGOT, J. P. et al. Human enterobiasis in evolution: origin, specificity and transmission. Parasite, 6(3): 201-208, 1999. 
JOHNSON, K. L. et al. A tick from a prehistoric Arizona coprolite. The Journal of Parasitology, 94: 296-298, 2008.

JONES, A. K. G. Trichurid ova n archaeological deposits: their value as indicators of ancient feces. In: FIELLER, N. J. R.; GILBERTSON, D. D. \& RALPH, N. G. A. (Eds.). Paleobiological Investigations: research designs, methods and a data analysis. Heslington: B.A.R., 1985. (Symposium of the Association for Environmental Archaeology, 5b)

LEMOS, J. C. \& LIMA, S. C. A geografia médica e as doenças infectoparasitárias. Caminhos da Geografia, 3: 74-86, 2002.

LEROY-TOREN, S. \& REINHARD, K.J. A current view of Ancestral Puebloan diet: starvation vs. dietary stability. American Journal of Physical Anthropology, supl. 40: 141, 2004.

MACLEOD, C. L. Intestinal nematodes. In: MACLEOD, C. L. (Ed.). Parasitic Diseases in Pregnancy and the Newborn. Oxford: Oxford University Press, 1988.

MARTINSON, E. et al. Pathoecology of Chiribaya parasitism. Memórias do Instituto Oswaldo Cruz, 98, supl. 1: 195-205, 2003.

MINNIS, P. Prehistoric diet in the northern Southwest: macroplant remains from Four Corners feces. American Antiquity, 54: 543$563,1989$.

MOORE, J. G.; FRY, G. F. \& ENGLERT JR., E. Thorny-headed worm infection in North American prehistoric man. Science, 163: 1.324$1.325,1969$.

MORRIS, D. P. Archaeological Investigations at Antelope House. Washington: National Park Service, 1986.

PAVLOVSKY, E. N. Natural Nidality of Transmissible Diseases. Moscou: Peace Publishers, s.d.

REINHARD, K. J. Parasitism at Antelope House: a Puebloan village in Canyon de Chelly, Arizona. In: MERBS, C. F. \& MILLER, R.J. (Eds.) Health and Disease in the Prehistoric Southwest. Tempe: Arizona State University, 1985. (Anthropological Research Papers, 34)

REINHARD, K. J. Cultural ecology of prehistoric parasitism on the Colorado Plateau as evidenced by coprology. American Journal of Physical Anthropology, 77: 355-366, 1988.

REINHARD, K. J. Archaeoparasitology in North America. American Journal of Physical Anthropology, 82: 145-163, 1990.

REINHARD, K. J. Parasitology as an interpretative tool in archaeology. American Antiquity, 57: 231-245, 1992.

REINHARD, K. J. Sanitation and parasitism at Harpers Ferry, Virginia. Journal of Historic Archaeology, 28: 62-67, 1994.

REINHARD, K. J. Parasite ecology of two Anasazi Villages. In: REITZ, E. J.; NEWSOM, L. A. \& SCUDDER, S. J. Case Studies in Environmental Archaeology. New York: Plenum Press, 1996.

REINHARD, K. J. Coprolite analysis. In: ELLIS, L. (Ed.). Archaeological Method and Theory: an encyclopedia. New York: Garland Publishing, 2000.

REINHARD, K. J. Effects of parasitism on ancestral Pueblo maternal and infant health. American Journal of Physical Anthropology, 40, supl.: $179,2004$.

REINHARD, K. J. Parasite pathoecology of Chacoan great houses: the healthiest and wormiest ancestral Puebloans. In: REED, P. F. Chaco's Northern Prodigies: Salmon, Aztec, and the ascendancy of the middle San Juan Region after AD 1100. Salt Lake City: University Press, 2008a.

REINHARD, K. J Pathoecology of two ancestral Pueblo Villages. In: REITZ, E. J.; SCARRY, C. M. \& SCUDDER, S. J. Case Studies in Environmental Archaeology. $2^{\text {nd }}$ Ed. New York: Springer, 2008b.

REINHARD, K. J. \& DANIELSON, D. R. Pervasiveness of phytoliths in prehistoric southwestern diet and implications for regional and temporal trends for dental microwear. Journal of Archaeological Science, 32: 981-988, 2005.

REINHARD, K. J.; AMBLER, J. R. \& McGUFF, I. E. Diet and parasitism at Dust Devil Cave. American Antiquity, 50: 819-824, 1985.

REINHARD, K. J.; LEROY-TOREN, S. \& DANIELSON, D. R. Salmon Ruins coprolites: San Juan diet. In: REED, P. F. (Ed.). Thirty-Five Years of Archaeological Research at Salmon Ruins. Tucson: Center for Desert Archaeology and Salmon Ruins Museum, 2006. v. 3. 
REINHARD, K. J.; MROZOWSKI, S. A. \& HERRMANN, B. Privies, pollen, parasites and seeds: a biological nexus in historic archaeology. Masca Jornal, 4: 31-36, 1986.

REINHARD, K. J. et al. Recovery of parasite remains from coprolites and latrine: aspects of paleoparasitological technique. Homo, 37: 217-239, 1986.

REINHARD, K. J. et al. Pollen concentration analysis of Salmon Ruins and Antelope House: documenting Anasazi dietary variation. Journal of Palaeogeography, Palaeoclimatology, and Palaeoecology, 237: 92-109, 2006.

REINHARD, K. J. et al. Chinese liver flukes in latrine sediments from Wong's Nim's property, San Bernardino, California: archaeoparasitology of the Caltrans district headquarters. The Journal of Parasitology, 94: 300-303, 2008.

SCHAD, G. A. et al. Arrested development in human hookworm infections: an adaptation to a seasonally unfavorable external environment. Science, 180: 502-504, 1973.

SUTTON, M. Q. \& REINHARD, K. J. Cluster analysis of the coprolites from Antelope House: implications for Anasazi diet and cuisine. Journal of Archeological Science, 22: 741-750, 1995.

WILKE, J. P. \& HALL, H. G. Analysis of Ancient Feces: a discussion and annotated bibliography. University of California at Berkeley, 1975. (Archaeological Research Facility, Department of Anthropology). 


\title{
The Findings in Europe
}

\author{
Françoise Bouchet • Matthieu Le Bailly
}

\section{EARLY PALEOPARASITOLOGY IN EUROPE}

F ew parasitologists had experienced the opportunity to study the life of extinct populations through the discovery of parasitic infections that affected such populations. This possibility became a reality when paleoparasitology emerged, launching the search for vestiges of parasites in archaeological material and other remains from ancient cultures.

During the period of "Egyptomania" that so fascinated Europe in the late $19^{\text {th }}$ and early $20^{\text {th }}$ centuries, numerous studies focused on diseases diagnosed in Egyptian mummies. Research on diseases in Ancient Egypt featured the work of Sir Marc Armand Ruffer, including his description of the first parasite find in archaeological material, namely Schistosoma haematobium eggs in kidney tissue from a body dated to 3200 BC (Ruffer, 1921, 1910).

Until the mid-20th century, few finds were added to Ruffer's work. One example is an article in which Szidat (1944) describes Trichuris trichiura and Ascaris lumbricoides eggs in the mummified bodies of a man and girl found in a bog in Prussia, dated between 600 BC and 500 AD.

The classical divide between the human and medical sciences, common in Europe at the time, may have discouraged cooperation between scientists from the two sides of these major fields (Bouchet, Harter \& Le Bailly, 2003). Initial collaboration between parasitologists and archaeologists was only sporadic. Studies were done when some special necropsy was organized in a mummified body in a museum. Perhaps through prior knowledge or friendship, experts from various areas met to complete the study in mummies or in latrine sediments or coprolites (Bouchet et al., 2003).

Nevertheless, Europe has a long tradition of parasite studies in archaeological material. Mummified bodies have always provided an important source of study, and the peat fields, swampy places with high acidity and thus excellent conditions for preservation of organic matter, are an important source of material. Various mummified bodies have been found in these bogs, some very well preserved. Parasite eggs are also found in sediments from archaeological sites, especially in permanently wet or even flooded areas in France and Switzerland (Bouchet et al., 1996).

The following is a review of parasites found in Old World archaeological material, along with some relevant comments. 


\section{A REVIEW OF THE INITIAL FINDS}

Eleven years after publication of the article by Szidat (1944), other studies began to emerge. Taylor (1955) published interesting results from material collected in excavations in England, where archaeologists discovered a cesspit used at the time of Roman occupation. The find consisted of layers of fecal material deposited for years in a specific location. Microscopic examination revealed Ascaris lumbricoides, Trichuris trichiura, and Dicrocoelium dendriticum eggs. The author discusses the presence of Dicrocoelium dendriticum in human feces and concludes that this parasite may have been introduced by slaves or soldiers from other regions.

Another Trichuris trichiura find was in the Netherlands, based on necropsy tests in a body offered in sacrifice during the $3^{\text {rd }}$ or $4^{\text {th }}$ century AD (Helbaek, 1958).

In Poland, Fasciola hepatica eggs were found in samples sent by archaeologists that identified the material as feces preserved by desiccation. The samples were dated to the $11^{\text {th }}$ to $13^{\text {th }}$ centuries. Based on the coprolites' shape and alimentary content, Grzywinski (1960) concluded that they were not from human hosts, but may have been excreted by rodents, pigs, dogs, and horses.

Jansen Jr. \& Over (1962) examined archaeological material from Germany, dated between 100 BC and 500 AD, and described Ascaris lumbricoides, Trichuris trichiura, Trichuris ovis, and Trichuris globulosa, Fasciola hepatica, Taenia solium or Taenia saginata, Diphyllobothrium latum, Toxocara canis, and Oxiuris equi eggs. They concluded that human feces were mixed with those of other animals in a single common deposit.

Also in Germany, Specht (1963) obtained positive results in night soil from a cesspit built by Romans and dated to between 140 and 150 BC. He found Trichuris trichiura eggs and concluded that soldiers were infected.

Ascaris lumbricoides and Trichuris trichiura were found again in a Roman military camp in Germany (Jansen Jr. \& Over, 1966). This study was presented at the $1^{\text {st }}$ International Congress of Parasitology, in Rome, drawing attention from experts concerning the potential for finding parasites in archaeological remains.

Pike \& Biddle (1966) and Pike (1967) analyzed parasite finds in ancient material, based on parasite forms and bone and tissue lesions suggestive of parasitic infections, artistic or ritualistic depictions, and intermediate hosts or vectors of parasitic diseases in archaeological sites. The authors found Ascaris sp., Trichuris sp., and Dicrocoelium dendriticum eggs in coprolites from Winchester, England, dated 1000 AD. Pike (1967) further commented on the zinc phosphate flotation technique, which he used to analyze material from latrine sediments. The material had been preserved wet, apparently since it was deposited in the latrines, but the author also recommends the spontaneous sedimentation technique to avoid damaging the eggs.

Pike (1968) refers again to examination of coprolites dated to the period of Roman occupation in England and finds ascarid, trichurid, and capillarid eggs, in addition to Dicrocoelium dendriticum eggs and nematode rhabditoid larvae.

In England, Gooch (1972) published the first review of all the helminth finds in archaeological material as of that year.

Aspöck, Flamm, \& Picher (1973) reported Trichuris trichiura and Ascaris lumbricoides eggs in coprolites dated 2000 to $3000 \mathrm{BP}$, belonging to the Hallstatt culture and found in a salt mine in the Austrian Alps. The following year, the authors observed high infection rates with Trichuris trichiura and Ascaris lumbricoides in an Austrian population, with coprolites also dating between 2000 and 3000 BP and containing high egg counts for these helminths (Aspöck, Flamm \& Picher, 1974). 
Boersema \& Jansen (1975) again described the association of Ascaris lumbricoides and Trichuris trichiura in fecal material from two cesspits from the $13^{\text {th }}$ and $14^{\text {th }}$ centuries in the Netherlands, which began to call scientists' attention. Years later this association became the object of research at both the Paleoparasitology Laboratory at the University of Reims (Loreille et al., 2001; Loreille \& Bouchet, 2003) and at FIOCRUZ in Rio de Janeiro (Leles et al., 2008).

Pike (1975) found eggs of these same parasites in excreta from the $13^{\text {th }}$ and early $14^{\text {th }}$ centuries in Southampton, England, but raised the hypothesis that the coprolites were from pigs, since the samples were obtained from what had been yards at the time. This showed the need for techniques capable of separating parasite species according to their specific hosts.

Nansen \& Jørgensen (1977) reported finding Fasciola hepatica, Ascaris sp., Taenia sp., and Trichuris sp. eggs in coprolites from the $8^{\text {th }}$ and $9^{\text {th }}$ centuries in Denmark, during the Viking period, but did not define their origin, whether from humans or other animals.

Roever-Bonnet et al. (1979) described Trichuris sp. eggs in an archaeological deposit dated to $5400 \mathrm{BP}$, but without commenting on the possible host or recording the eggs' size.

The 1980s were particularly productive for paleoparasitology studies in Europe. In England, Andrew Jones published a series of studies on coprolites and latrine sediments found in archaeological sites in York, as well as reports on the examination of a mummified body found in a peat field (Jones, 1982, 1983, 1985). During this period, Jones (1983) introduced the use of hydrochloric acid to disaggregate mineralized coprolites, yielding positive parasite finds.

Greig (1981, 1982), examined medieval latrine sediments from $15^{\text {th }}$ and $16^{\text {th }}$ century England and found Ascaris sp. and Trichuris sp. eggs. Moore (1981) found similar results in other medieval latrines in England, from the $10^{\text {th }}$ to the $15^{\text {th }}$ centuries, thus demonstrating continuing infection with these geohelminths.

Weiss \& Möller-Christensen (1971) and Ortner \& Putschar (1981) also published interesting articles on lesions caused by helminth infections, especially echinococcosis, in skeletons and scattered bones found in archaeological strata.

Gooch (1983) conducted a broad commentated review on coprolite studies, showing that the search for parasites, food remains, and other elements from the diet of ancient peoples could provide important information on the past. Paleoparasitology began to be consolidated in various parts of the world.

In Germany, Herrmann $(1986,1987)$ published a series of articles with an epidemiological approach. Reinhard et al. (1987) provided an in-depth commentary on these studies in a review article containing an analysis of paleoparasitological methods and techniques. No significant differences were found in helminth egg counts in latrines in which the pH varied between 5.8 and 9, but the attempt was made to establish the best quantitative technique for a paleoepidemiological study. Herrmann (1986) commented that none of the techniques for concentration of parasite eggs (sodium chloride flotation, zinc phosphate or the Telemann method - or concentration in mercury, iodine, formalin, and ether) is really efficient for processing archaeological material.

Legendre, Marie \& Rieb (1986) examined medieval latrine sediments from $15^{\text {th }}$ and $16^{\text {th }}$-century France and found Ascaris sp and Trichuris sp. eggs. A year later, Rouffignac (1987) published a review of parasite finds in human material from medieval Europe, including not only nematodes, but also Fasciola sp., Dicrocoelium sp., and Diphyllobothrium sp.

Jones, Hutchinson \& Nicholson (1988) published an interesting article that discussed parasite findings in human and equine archaeological material dated to the Roman period. They referred to deposits in which one would not usually expect the presence of archaeological remains, but which yielded parasite eggs. Jones \& Nicholson (1988) commented again on Ascaris sp. and Trichuris sp. eggs in archaeological material from England. 
Bouchet et al. (1989) published an initial study of parasites in sediments and coprolites from three closed structures on Rue de Lutèce, Paris, with Ascaris sp., Trichuris sp., and Taenia sp. eggs.

Bouchet (1991) published a paleoparasitological study of sediment from an archaeological excavation yard in Beauvais (Oise), Picardy, dated to the medieval period ( $13^{\text {th }}$ to $17^{\text {th }}$ centuries), where they found Trichuris sp., Ascaris sp., Heterakis sp., and Capillaria sp. eggs.

The 1990s witnessed growing interest in paleoparasitology in Europe. Various specialized laboratories emerged in France, for example at the University of Reims (Bouchet, Harter \& Le Bailly, 2003) and Perpignan (Jouy-Avantin et al., 1999). New finds were made, and partnerships grew between the paleoparasitology laboratories, involving both exchange between researchers and graduate students and participation in specialized congresses. This same decade also featured the articles by Aspöck, Auer \& Picher $(1995,1996)$ on the finding of intestinal parasites (Trichuris trichiura) in the mummified body found in the Alps, known as Ötzi, the Tyrolean Iceman.

These pioneering articles opened the way for paleoparasitology in Europe. The following is a brief summary, dividing the helminth finds in flatworms or platyhelminths (tapeworms or cestodes and flukes or trematodes) and roundworms (nematodes).

\section{FLATWORMS (PLATYHELMINTHS)}

\section{Flukes (Trematodes)}

Dicrocoeliidae and Fasciolidae eggs have been found in archaeological sites ranging from the Pleistocene to historical times. The oldest dates for these parasites go back 550,000 years, with Dicrocoelium sp. eggs found in sediment from the archaeological site in Tautavel, southern France (Jouy-Avantin et al., 1999). The possible hosts, both extinct, belonged to either a species of hyena (Crocuta spelaea) or bear (Ursus speleaeus or Ursus ringeri).

These finds raise interesting questions due to their antiquity and the host's extinction, as discussed by Ferreira, Araújo \& Duarte (1993) upon finding nematode larvae in coprolites from an extinct hyena in Italy, dated to 1.5 million years. The first is that the parasites' cycles may have changed over time, and the second is that the intermediate or definitive hosts may have disappeared and been replaced by new hosts. At any rate, finding parasites in such ancient material, often completely mineralized, is extremely rare, requiring great patience and persistence by the examiner.

Fasciola hepatica and Dicrocoelium sp. eggs were found in Arbon, dated to 3384-3370 BC, as well as in Chalain, dated to 3200-2900 BC, both in France (Bouchet et al., 1996; Dommelier-Espejo, 2001; Le Bailly, 2002). These trematode eggs were also found in the Hallstatt mines in Austria, in coprolites dated to before and during the Bronze Age (Aspöck, Flamm \& Picher, 1973, 1974; Aspöck \& Auer, 1998), as well as in the underwater site in Gresine, France (Le Bailly, 2001).

These trematodes were present in humans and their domestic animals during the Gallic-Roman period and Middle Ages. Material from archaeological sites in the French cities of Paris, Montbéliard, Reims, and Bordéus also show the presence of Fasciola hepatica and Dicrocoelium sp. eggs (Bouchet, 1993, 1994, 1995; Bouchet et al., 1997; Bouchet, Bentrad \& Paicheler, 1998).

The ancient Europeans were hosts to Fasciola hepatica, and therefore they probably ate raw salads with such green leaves as water cress (Nasturtium officinale), chicory (Cichorum intybus), lettuce (Valerianella olitoria), dandelion 
(Taraxacum dens leonis), and other green vegetables. A book by Guillaume de Villeneuve written in 1545 provides a description of water cress vendors in Paris who cried, "Vey ci bon cresson Orlénois" ("Come get the good original Orleans water cress") (Pitrat \& Foury, 2003).

Dicrocoelium sp. infection is very rare in humans but common in various other hosts, including domestic animals. Its occurrence in human feces can result from false parasitism or more rarely from true infection (Helmy \& Al-Mathal, 2003; Rana et al., 2007).

As for flukes, Schistosoma haematobium eggs were found in Egyptian mummies spanning a period from 3200 BC to 500 AD (Ruffer, 1910; Reyman, 1976; Deelder et al., 1990; Miller et al., 1992; Contis \& David, 1996). East Africa appears to have been the center for dispersal of schistosomiasis haematobium; from there, the infection spread to other parts of the world where both the human host and intermediate host existed (Chamot \& Amat-Roze, 1993). The emergence and dispersal of Schistosoma haematobium infection along the Nile were described by Harter (2003), who found the parasite's eggs in Nubian mummies dated to 2400 BC. According to Nozais (1987, 2003), the parasite dispersed gradually with nomadic caravans and the slave trade along the Nile, since prehistory in the Sahara Desert.

During the Middle Age, individuals infected with Schistosoma species were already found in Europe, demonstrating the migration of persons carrying the parasite, but without evidence that the life cycle was established among Europeans. Schistosoma haematobium eggs were found in a latrine dated to the $15^{\text {th }}$ or $16^{\text {th }}$ century in France (Bouchet \& Paicheler, 1995). Schistosoma mansoni eggs were also found in the same latrine (Bouchet et al., 2002).

It is important to discuss the presence of these two species of parasites in the same archaeological context. Both the urogenital and intestinal forms of schistosomiasis are believed to have originated in Africa; based on the paleoparasitological data, it is possible that a European returned from Africa infected with both parasites. But it is also possible that an individual of African origin brought these eggs and eliminated them in France. It was common during the $15^{\text {th }}$ and $16^{\text {th }}$ centuries to bring Africans to exhibit them in circuses or in the nobility's ballrooms, even caged like animals (Gould, 1985).

\section{Tapeworms (Cestodes)}

The oldest records of Taenia eggs in human remains in Europe date to the Neolithic, from coprolites found in the archaeological site in Chalain, France, dated from 3200 to 2900 BC (Dommelier et al., 1998). Taenia sp. eggs were also found in the Hallstatt salt mines, dated to the Upper Neolithic (Aspöck, Flamm \& Picher, 1973).

Mummified bodies of Egyptian origin are housed in museums worldwide. Horne \& Lewin (1977) prepared histological sections of intestine from an Egyptian mummy in the Royal Ontario Museum and found Taenia sp. eggs. These were also described by Harter (2003) in Nubian mummies from what is now Sudan, dated to 2400 BC. These findings raised discussions on the introduction of human infection into Europe.

Interesting observations were made on the European historic period, especially in France. Taenia sp. eggs have frequently been found in archaeological remains recovered from houses of the nobility, in the regions of Louvre, Marly le Roi, and Montbéliard (Bouchet, 1995; Bouchet \& Paicheler, 1995; Bouchet, Bentrad \& Paicheler, 1998). At that time it was common for nobles to eat raw meat. In contrast, Taenia sp. eggs have not been found in remains from the rural and poor regions of France, where the main dish was soup containing small bits of very well cooked meat. 


\section{Pseudophyllid cestodes}

Diphyllobothrium sp. eggs have been recorded, dated as far back as Neolithic times in the sites of Chalain and the wetlands and bogs of Concise and Arbon, in France (Dommelier-Espejo, 2001; Le Bailly, 2002). This is a parasite of freshwater fishes, from which the larvae are transmitted to carnivores, where they develop into adults in the gut. The eggs are eliminated in the feces, and when they come into contact with water they are ingested by crustaceans or fish. Humans acquire the infection by ingesting raw or poorly cooked fish.

In Germany and France, Diphyllobothrium sp. eggs have been found in human coprolites from the Gallic-Roman and Medieval periods (Jansen Jr. \& Over, 1962; Herrmann, 1987; Bouchet et al., 2000). Again, these parasites were only found in latrines in well-to-do homes, since it was a custom to eat beef and fish either raw or dried with salt, which does not eliminate the parasite's larvae.

\section{ROUNDWORMS (NEMATODES)}

\section{Ascaris lumbricoides}

Ascaris eggs, extremely abundant in European archaeological sites, are indicative of fecal pollution (Taylor, 1955; Pike, 1967; Greig, 1981, 1982; Bouchet, 1994, 1995; Bouchet \& Paicheler, 1995). The number and abundance of eggs allow identifying different degrees of fecal pollution and can be used to differentiate archaeological remains such as latrines, cesspits, wells, silos, sewage drains, stables, and other structures (Bouchet, 1994; Fernandes et al., 2005).

Ascaris lumbricoides is considered to be present in nearly all paleoparasitology studies in historical sites. However, the findings in Europe do not confirm the hypothesis of this parasite's antiquity. Ascaris sp. eggs are absent in organic remains dated to the Neolithic both in Switzerland and France (Bouchet, Harter \& Le Bailly, 2003). Their absence has not been explained. Even in the Ötzi mummy, no eggs of this parasite were found (Aspöck, Auer \& Picher, 1996).

The oldest records of Ascaris lumbricoides eggs in human coprolites were found in the Hallstatt salt mines, dated to the Iron Age, circa 800 to 350 BC (Aspöck, Flamm \& Picher, 1973), and from mummies in Prussia from 600 BC (Szidat, 1944). Ascaris lumbricoides eggs were also found in Egyptian mummies from the Ptolemaic period, circa 170 BC (Cockburn et al., 1975).

Ascaris sp. eggs were found in coprolites from Pleistocene, in the Arcy-sur-Cure cave in France, which was inhabited by Neanderthals. However, the origin of these eggs was not confirmed, whether from humans, bears, or other animals (Bouchet et al., 1996). One school of parasitologists proposes the origin of parasitism with Ascaris lumbricoides in the human species following the domestication of pigs. However, the fact that this parasite was found in populations from the Pleistocene, a period prior to domestication of pigs, invalidates the assumption that the species found in humans originated from Ascaris summ. This finding in France is thus highly important. The material is extremely precious, and if molecular biology techniques confirm its human origin, it will provide interesting answers to questions concerning the origin of ascariasis. Tests have begun to be designed concerning the Ascaris species involved (Loreille et al., 2001; Loreille \& Bouchet, 2003; Leles et al., 2008) in order for the definitive diagnosis to be based on the origin of the archaeological remains (whether human or from another animal). 


\section{Trichuris trichiura}

Well-preserved Trichuris sp. eggs were found in flooded regions of Western Europe, some with the embryo wellpreserved inside and others filled with pyrite crystals, proving their antiquity (Bouchet, 1995). Trichuris trichiura was also found in the mummy known as Ötzi, found in Hauslabjoch, in the Alps, dated 3200 BC. (Aspöck, Auer \& Picher, 1995, 1996).

Trichuris trichiura and Ascaris lumbricoides infection is one of the most common combined infections at present in most regions lacking minimum sanitation. In order to reach the adult form, both parasites require a development phase in the soil with sufficient moisture and heat. Ascaris lumbricoides, Trichuris trichiura, and fecal contamination appear to have been interlinked. This also occurred in historic times in Europe, but not in more ancient times.

\section{Capillaridae}

Abundant Capillaria sp. eggs were found in three Neolithic archaeological sites, dated to 10,000 BP, from the Alps and the Jura Valley in France (in Chalain, Arbon, and Concise). Of 23 human coprolites in Chalain, 21 were positive for Capillaria spp. eggs (Bouchet, 1997; Bouchet et al., 1997).

The eggs' outer membrane varied considerably, and three species were identified as parasitizing humans: Capillaria aerophila, Capillaria hepatica, and Capillaria philippinensis. The first two species have rats and mice as intermediate hosts. It is known that these rodents were introduced into Europe after the Neolithic. Thus, more research is needed to elucidate the origin of infection by this parasite in such ancient periods.

It is not easy to explain the human species' participation in the life cycle of Capillaria species. Were humans definitive, intermediate, false, or paratenic hosts in the past? In the case of obligate heteroxeny, the same animal could have been the definitive host if the larva was ingested or the intermediate host if the egg was ingested. As suggested by Combes (1995), changes in the life cycle of parasites are possible over time, with the acquisition of new hosts, especially considering such long periods. The paleoenvironment may have provided other possibilities for parasites to complete their life cycles. In this context, it is important to mention the egg shells' characteristics in different species of Capillaria as a diagnostic element, according to Fugassa et al. (2008).

\section{PROTOZOA}

There is growing paleoparasitological evidence of the presence of intestinal protozoa in archaeological material. Although easily destroyed, their vestiges can be recovered by immunological techniques, as in the case of infection with Giardia duodenalis and Entamoeba histolytica (Gonçalves et al., 2002, 2004; LeBailly et al., 2008).

\section{PALEOPARASITOLOGY AND PATHOCENOSIS}

A paleoparasitological record has been constructed little by little, although it was believed in the past that parasite fossils would never be found. Still, the more ancient the material, the more difficult it is to find well-preserved eggs, larvae, and even cysts. The taphonomic process puts strong pressure on parasite form, and large amounts of them are lost, or only unrecognizable elements are left. One must also consider the extinction of parasite species over 
time, making diagnosis more difficult. Meanwhile, such cases raise the possibility of studying extinct species and comparing them to current ones in phylogenetic studies.

Human agglomerations appear to have facilitated the preservation of parasite forms in archaeological sites. The epidemiological transition during the change from nomadic hunting and gathering habits to sedentary agriculture led to many changes in the disease profile of prehistoric groups. In Neolithic sites, the effect of agglomeration and the presence of domestic animals contributed to changes in the human parasitic fauna. Anthropozoonotic diseases emerged and established themselves, circulating in humans and in their domestic animals (Bouchet, Harter \& Le Bailly, 2003).

As for the preservation of helminth eggs and larvae, it is important to highlight the exceptional conditions in wet or flooded environments. European archaeological sites that are close to bodies of water or even submerged display the best preservation of eggs. These are the sites most visited by malacologists, archaeozoologists, palynologists, and other specialists, now including paleoparasitologists, in search of well-preserved organic remains.

The European historic period appears to have been written on a parchment made of Ascaris sp. and Trichuris sp. eggs. The well-known chronostratigraphy of the European archaeological sites allows interpretations on the sanitary conditions and hygienic habits of very well-studied human clusters. There are major contrasts between the eating habits of rich and poor, or between living in cities or in the countryside, thus influencing the preservation and finding of parasites.

Some parasites are not necessarily associated with humans but may have infected them in the past. Eggs of some species such as Metastrongylus sp., Passalurus sp., Paramphistomum sp., Alaria sp., and Parascaris sp. were found by Beeching \& Moulin (1983), Bouchet \& Bentrad (1997), and Bouchet et al. (2000). One needs a broad idea of the environment in the past and the parasites that circulated in animals in order to better interpret the context in which human parasitic infections were found (Ferreira et al., 1991).

The following is a case description exemplifying situations that human groups experienced in Europe in ancient times, recovered from the paleoparasitological record (adapted from Le Bailly, 2005).

\section{Evolution of intestinal parasitic infections in European archaeological sites dated between 6000 and 5000 years BP}

Most intestinal parasitic infections are alimentary in origin. The study of parasites preserved in archaeological material, particularly intestinal helminths, thus provides important information on the eating habits of ancient peoples. Paleoparasitology thus produced data on ancient populations, for example from the Neolithic period, when diet was not very diversified and major nutritional changes had still not occurred.

Paleoparasitological data allow precise clues to populations' eating patterns. Changes in eating habits are induced by different factors: climatic, ecological, environmental, and sociological. Variations in parasitic infections result from modifications in eating habits or ways of storing foods. By inverse reasoning, it is therefore possible, when studying parasitic infections, to construct hypotheses on the origin of these variations. To investigate parasite variation, a qualitative and quantitative study was conducted in several archaeological sites in France and Germany.

The samples discussed here are from ancient lacustrine villages from the Middle and Upper Neolithic, dated between 3900 and 2900 BC, therefore between circa 6000 to 5000 BP. The sites are located in northeast Switzerland, in the canton of Thurgau, and in southwest Germany, in the Baden-Württemberg region. Two lacustrine zones were chosen, one at Lake Constance (or Bodensee) and the other at Lake Federsee. 
The Middle and Upper Neolithic period in this region of Europe corresponds mainly to the chronological development of two cultures, Pfÿn (dated to circa 3900 to 3400 BC) and Horgen (dated between 3400 and 2850 BC). The following is a brief presentation of the study sites.

\section{HORNSTAAD-HöRNLE I}

Excavated between 1983 and 1993, this site is located in Germany on the banks of Lake Constance (Bodensee). Precise dates were obtained on the occupation strata by dendrochronology (Billamboz, 1998) (dendrochronology uses the sequence of tree rings to obtain dates). The site's occupation dates between 3917 and 3905 BC, corresponding to a local culture belonging to the so-called "Hornstaad group", which predates the Pfÿn culture (Dieckmann, 1990; Schlichtherle, 1990). It is the oldest lacustrine site from the Upper Neolithic in the Lake Constance region. It measures $14,000 \mathrm{~m}^{2}$, consisting of the charred remains of 50 houses measuring an average of $24.5 \mathrm{~m}^{2}$ each and facing the water. Based on the recovered archaeological remains and average size of the dwellings, the population is estimated at 240 individuals (Dieckmann, Maier \& Vogt, 2001).

\section{ARBon-Bleiche 3}

Located on the banks of Lake Constance in the Swiss canton of Thurgau, it was excavated from 1993 to 1995. It is an ancient Neolithic lacustrine village, occupied during a short period of 15 years, from 3384 to $3370 \mathrm{BC}$ (dating by dendrochronology). It is one of the only currently known sites from this particular period corresponding to the transition phase between the two cultures discussed here, Pfÿn and Horgen.

This is a lacustrine station, known for its excellent state of preservation. The 1,100 $\mathrm{m}^{2}$ studied in the site are exceptionally well-preserved. The village was abandoned at the time because of a fire in $3370 \mathrm{BC}$. Twenty years later there was a considerable rise in the lake's water level, submerging the site under several meters of freezing water. This submersion was accompanied by debris and various sediments that created anaerobic conditions, favoring the preservation of organic matter. Thus, an enormous amount of precious material was extracted for various studies, including paleoparasitology.

\section{TORWIESEN}

The Neolithic site of Torwiesen is located around the Federsee swamp, on the ancient island of Bad Buchau in southwest Germany. Dated by dendrochronology to 3283-3281 BC, it corresponds to the early Horgen culture (Schlichtherle, 2002; Schlichtherle \& Hohl, 2002).

The village consists of 12 large houses and three smaller ones, open on one side and lined facing each other on the central street. Due to its imposing proportions, one of the houses stands out from the rest. As in the other sites, some stakes used in the construction are very well-preserved and were used in the tree-ring dating.

The terrain is boggy, with acid pH. Preservation of animal bones and wooden remains is generally poor. To collect samples from the site, PVC tubes were inserted through the full thickness of the strata, extracting material for biological and chemical tests, including phosphates, pollen, parasites, insects, and macroscopic remains.

\section{SIPPLINGEN}

The Sipplingen station is located in southwest Germany, next to the northern tributary river of Lake Constance. It was occupied for a long period, from the Hornstaad culture to the Schnurkeramik culture (Kolb, 1997). Dendrochronology dates the site between 3912 and 2417 BC (Billamboz, 1985). The site has been known since 
the $19^{\text {th }}$ century, and large amounts of material have already been removed, thereby improving knowledge on the transition from the Pfÿn to the Horgen culture.

\section{SEEKIRCH-STOCKWIESEN}

Located in the Federsee Swamp in Germany, in the Biberach region, close to the county of Seekirch, this site was discovered in 1991 by Erwin Keefer while digging a drainage pit. The absence of oak did not allow tree-ring dating, but radiocarbon dates were obtained, situating the site's occupation between 3036 and 2703 BC, i.e., in the Late Horgen culture.

A total of 11 houses were found on $280 \mathrm{~m}^{2}$, representing $20 \%$ of the total area. The houses are longer than in the other sites, thus becoming their distinguishing characteristic. The site has yielded abundant archaeological artifacts (Kolb, 1997).

\section{WaLLHAUSEN-ZieGELhÜTTE}

This site is located in southwest Germany, in the Baden-Württemberg region, on the banks of Lake Constance. Part of the site remains underwater all year round. It has been known since the mid-19 $9^{\text {th }}$ century (Staub, 1864), and much of its material was removed without proper scientific rigor. Scientific work began in 1982, in a salvage operation known as the Bodensee-Oberschwaben Project.

The excavated strata were dated between 3800 and $3700 \mathrm{BC}$, using radiocarbon, and the remains show the transition between the two cultures of the region.

\section{Study samples}

Table 1 shows the results of this paleoparasitological analysis, obtained from 137 samples of coprolites and sediments of supposedly manmade origin.

Table 1 - Number of samples analyzed per archaeological site. Europe, Neolithic period

\begin{tabular}{c|c|c|c}
\hline Sites & Cultures & Dates (BC) & Number of samples \\
\hline Hornstad-Hörnle I & Early Pfÿn & $3917-3905$ & 26 \\
\hline Sipplingen & Early Pfÿn & $3911-3909$ & 07 \\
\hline Wallhausen-Ziegelhütte & Middle Pfÿn & 3700 & 05 \\
\hline Arbon-Bleiche 3 & Transition & $3384-3370$ & 41 \\
\hline Sipplingen & Early Horgen & $3317-3306$ & 04 \\
\hline Wallhausen-Ziegelhütte & Early Horgen & $3300-3050$ & 06 \\
\hline Torwiesen & Early Horgen & $3283-3281$ & 04 \\
\hline Wallhausen-Ziegelhütte & Middle Horgen & $3300-2900$ & 06 \\
\hline Wallhausen-Ziegelhütte & Late Horgen & $3100-2900$ & 16 \\
\hline Seekirch-Stockwiesen & Late Horgen & $3000-2900$ & 137 \\
\hline Total & & & \\
\hline
\end{tabular}


Next, Tables 2, 3, and 4 show the parasites found in the archaeological sites for each culture and their respective dates.

Table 2 - Parasites found in sites from the Pfÿn culture. Europe, Neolithic period

\begin{tabular}{c|c|c|c}
\hline Parasites & Hornstaad-Hörnle la (3917-3905 BC) & Sipplingen (3711-3709 BC) & Wallhausen-Ziegelhütte (3700 BC) \\
\hline Diphyllobothrium sp. & Yes & Yes & Yes \\
\hline Taenia sp. & - & - & Yes \\
\hline Fasciola sp. & Yes & - & - \\
\hline Dicrocoelium sp. & Yes & - & - \\
\hline Opistorchis sp. & - & Yes & Yes \\
\hline Trichuris sp. & Yes & Yes & - \\
\hline Capillaria sp. & - & - & - \\
\hline Dioctophyma sp. & - & 4 & 3 \\
\hline Total & 4 & & \\
\hline
\end{tabular}

Table 3 - Parasites found in Arbon-Bleiche and in the Horgen culture sites. Europe, Neolithic period

\begin{tabular}{|c|c|c|c|}
\hline Parasites & Arbon-Bleiche (3384-3370 BC) & Sipplingen (3317-3306 BC) & Torwiesen II (3283-3281 BC) \\
\hline Diphyllobothrium sp. & Yes & Yes & Yes \\
\hline Taenia sp. & Yes & Yes & Yes \\
\hline Fasciola sp. & Yes & Yes & - \\
\hline Dicrocoelium sp. & - & Yes & - \\
\hline Opistorchis sp. & Yes & - & Yes \\
\hline Trichuris sp. & Yes & Yes & Yes \\
\hline Capillaria sp. & Yes & - & - \\
\hline Dioctophyma sp. & Yes & - & 5 \\
\hline Total & 7 & 5 & 2 \\
\hline
\end{tabular}

Table 4 - Parasites found in other sites from the Horgen culture. Europe, Neolithic period

\begin{tabular}{|c|c|c|c|}
\hline Parasites & $\begin{array}{l}\text { Wallhausen-Ziegelhütte } \\
\quad(3300-3050 \mathrm{BC})\end{array}$ & $\begin{array}{l}\text { Wallhausen-Ziegelhütte } \\
\quad(3100-2900 \text { BC) }\end{array}$ & $\begin{array}{l}\text { Seekirch-Stockwiesen } \\
(3000-2900 \mathrm{BC})\end{array}$ \\
\hline Diphyllobothrium sp. & Yes & Yes & Yes \\
\hline Taenia sp. & Yes & - & - \\
\hline Fasciola sp. & Yes & Yes & Yes \\
\hline Dicrocoelium sp. & - & $?$ & - \\
\hline Opistorchis sp. & - & - & - \\
\hline
\end{tabular}


Table 4 - Parasites found in other sites from the Horgen culture. Europe, Neolithic period (continued)

\begin{tabular}{|c|c|c|c|}
\hline Parasites & $\begin{array}{l}\text { Wallhausen-Ziegelhütte } \\
\quad(3300-3050 \mathrm{BC})\end{array}$ & $\begin{array}{l}\text { Wallhausen-Ziegelhütte } \\
\quad(3100-2900 \mathrm{BC})\end{array}$ & $\begin{array}{l}\text { Seekirch-Stockwiesen } \\
\quad(3000-2900 \mathrm{BC})\end{array}$ \\
\hline Trichuris sp. & Yes & Yes & Yes \\
\hline Capillaria sp. & Yes & Yes & Yes \\
\hline Dioctophyma sp. & - & - & - \\
\hline Total & 5 & 4 & 5 \\
\hline
\end{tabular}

The Middle and Upper Neolithic period in the region features ancient lacustrine villages, dated between 3900 and 2900 BC, located in northeast Switzerland (canton of Thurgau) and southwest Germany (Baden-Württemberg region), with special attention to two lacustrine zones, Lake Constance (Bodensee) and Lake Federsee. The Pfÿn culture dates from 3900 to $3400 \mathrm{BC}$ and the Horgen culture from 3400 to $3850 \mathrm{BC}$. All sites listed in the tables are situated on this chronological scale, which allows comparing the populations, observing the evolution of parasitic infections over time. The tables' graphic representation clearly shows a huge explosion in the number of parasites around $3380 \mathrm{BC}$, namely during the assumed transition from the Pfÿn culture to the Horgen culture (Graph 1).

Graph 1 - Number of parasite species found in archaeological sites. Europe, 3900-2900 BC

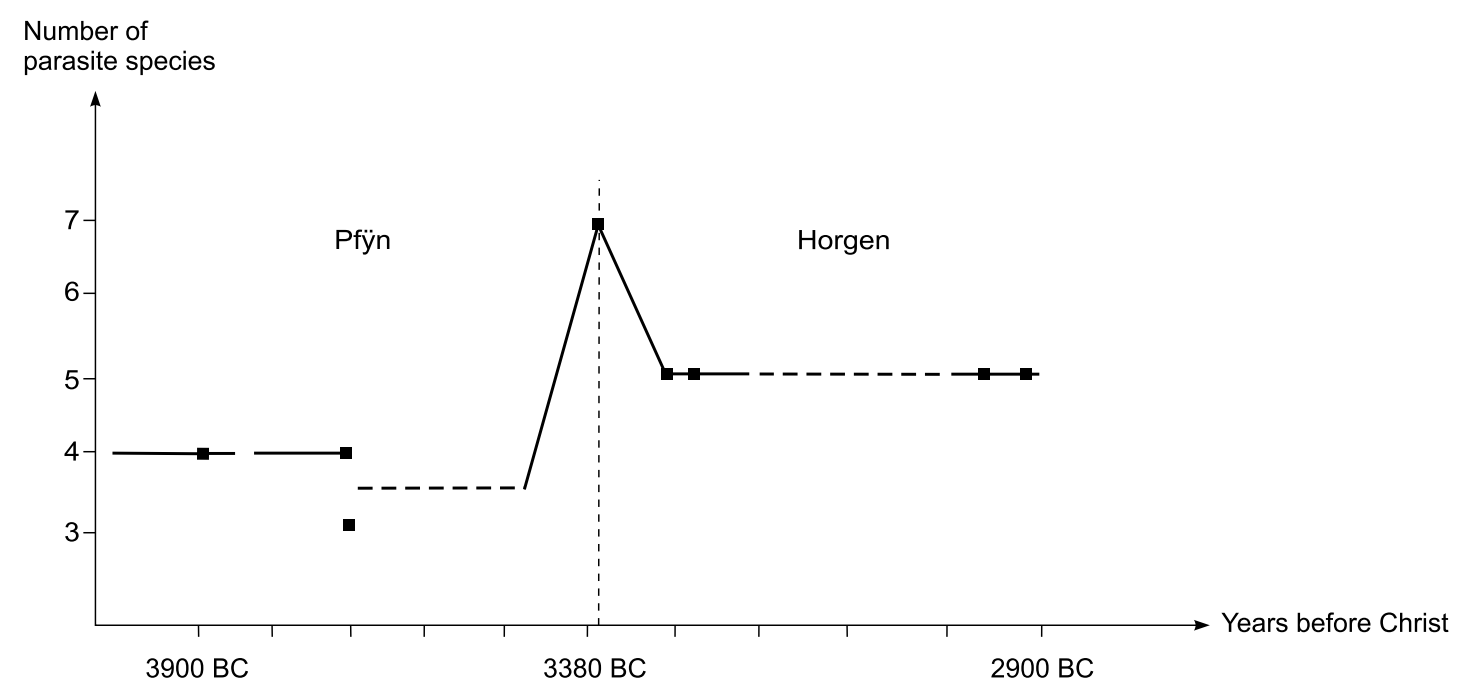

The peak between 3900 and 2900 BC may have various origins, such as climate, dietary, and cultural changes, among others. The answer to this question requires examining each parasitic infection in detail. The parasitic infections listed in the previous graph have different alimentary origins and may be related to fishing, hunting, gathering, or storage of plant foods. 


\section{Parasitic infections related to fishing}

The above-mentioned study showed the consumption of fish based on the presence of four parasites: Diphyllobothrium sp., the most frequent parasite; Opistorchis sp., found only at the Arbon-Bleiche 3 site; Dioctophyma sp., also found only in the Swiss occupation strata and coprolites; and Capillaria sp. eggs with ornate shells, belonging to species with freshwater intermediate hosts.

Among the parasitic infections constituting the infection peak, four are transmitted by ingesting freshwater fish or frogs: bothriocephaliasis, opistorchiasis, dioctophymiasis, and capillariasis.

\section{DIPHYLLOBOTHRIUM SP.}

Diphyllobothrium sp. eggs are present in all the sites studied. The graph on infection with Diphyllobothrium sp. also shows a higher peak frequency in the samples from Arbon-Bleiche 3 (transition period), persisting until Torwiesen II (early Horgen culture) (Graph 2). The graph suggests important fish consumption during the transition period.

\section{Graph 2 - Frequency of Diphyllobothrium sp. eggs in samples from the archaeological sites. Europe, 3900 to 2900 BC}

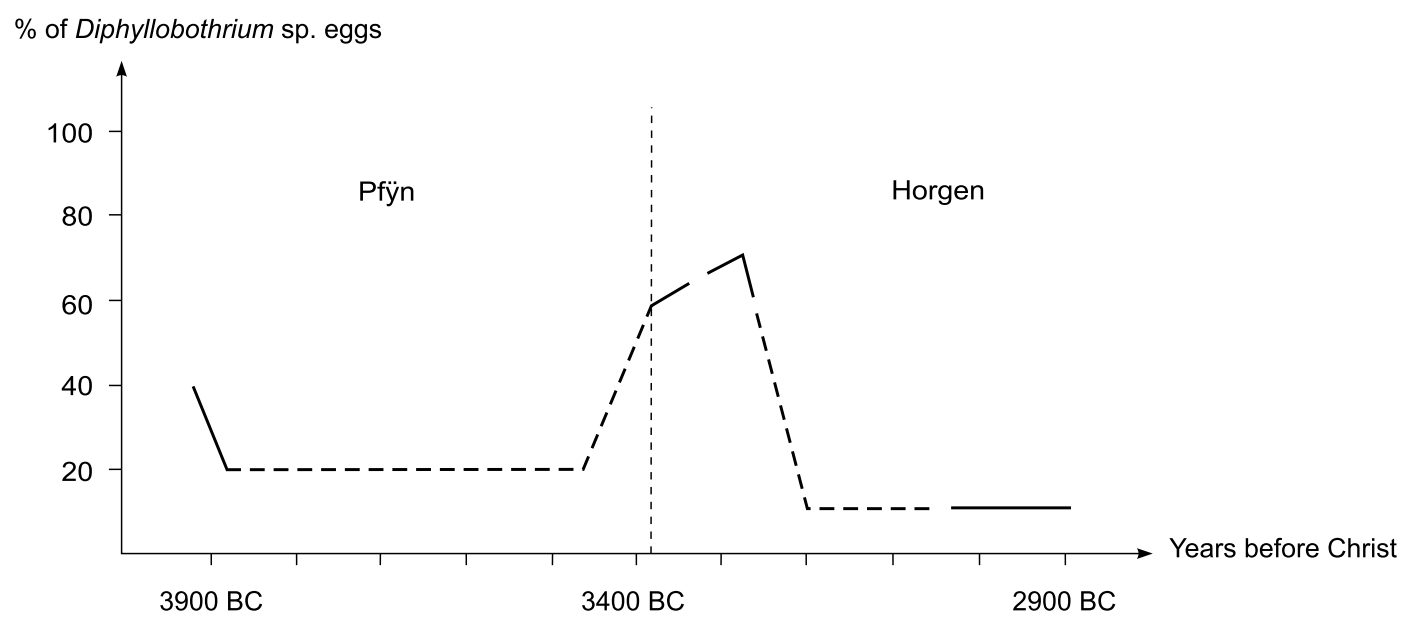

Source: Adapted from Le Bailly et al. (2005).

\section{OPISTORCHIS SP. AND DIOCTOPHYMA SP.}

Opistorchis sp. and Dioctophyma sp. eggs were found in the Arbon-Bleiche 3 site (Le Bailly, Leuzinger \& Biuchet, 2003). The appearance of these two parasites reinforces the hypothesis of an increase in fishing (and thus of fish consumption). But the diagnosis of Opistorchis sp. and Dioctophyma sp. only in the Swiss site, around $3400 \mathrm{BC}$, raises questions, particularly because these parasites were not found in the other sites. Two relevant questions are sampling and the diversification of fishing.

Since this region harbors numerous Neolithic sites, further research is necessary. Few sites have been studied so far, and the results of paleoparasitological tests are still recent and scanty.

As for the diversification of fishing, the appearance of new parasitic infections may be explained by the obligate consumption of new fish species that were previously overlooked. The consumption of these new fish species, potentially infected with Opistorchis sp. and/or Dioctophyma sp., then began causing disease in the human population. 
The extensive consumption of frogs, identified in the Swiss archaeological site, could explain the presence of Dioctophyma sp. However, frog-eating was recorded in the other sites, such as in Chalain (Bailon, 1997), while the paleoparasitological analyses failed to detect this parasite. It thus appears that fish were the most important source of contamination with Dioctophyma sp., which reinforces the hypothesis of diversification of fish species consumed during this period.

Importantly, infection with Dioctophyma sp. can result directly from the ingestion of annelid worms such as Lumbriculus variegatus, the host of the parasite's larval form. Worm-eating by the inhabitants of these Arbon-Bleiche 3 sites is thus possible.

\section{Capillaria SP.}

Capillaria sp. eggs with speckled shells, attributed to species that parasitize freshwater fish, appeared in the samples from Arbon-Bleiche 3, corresponding to the cultural transition period (Graph 3). The parasite's appearance lends further credence to the preceding hypotheses on the increasing diversification of fishing.

Graph 3 - Frequency of samples with Capillaria sp. eggs from the archaeological sites in Hornstaad-Hörnle I (3917 to 3905 BC), Arbon-Bleiche 3 (3384 to $3370 \mathrm{BC}$ ), Torwiesen II (3283 to $3281 \mathrm{BC}$ ), and Seekirch-Stockwiesen (3000 to $2900 \mathrm{BC}$ )

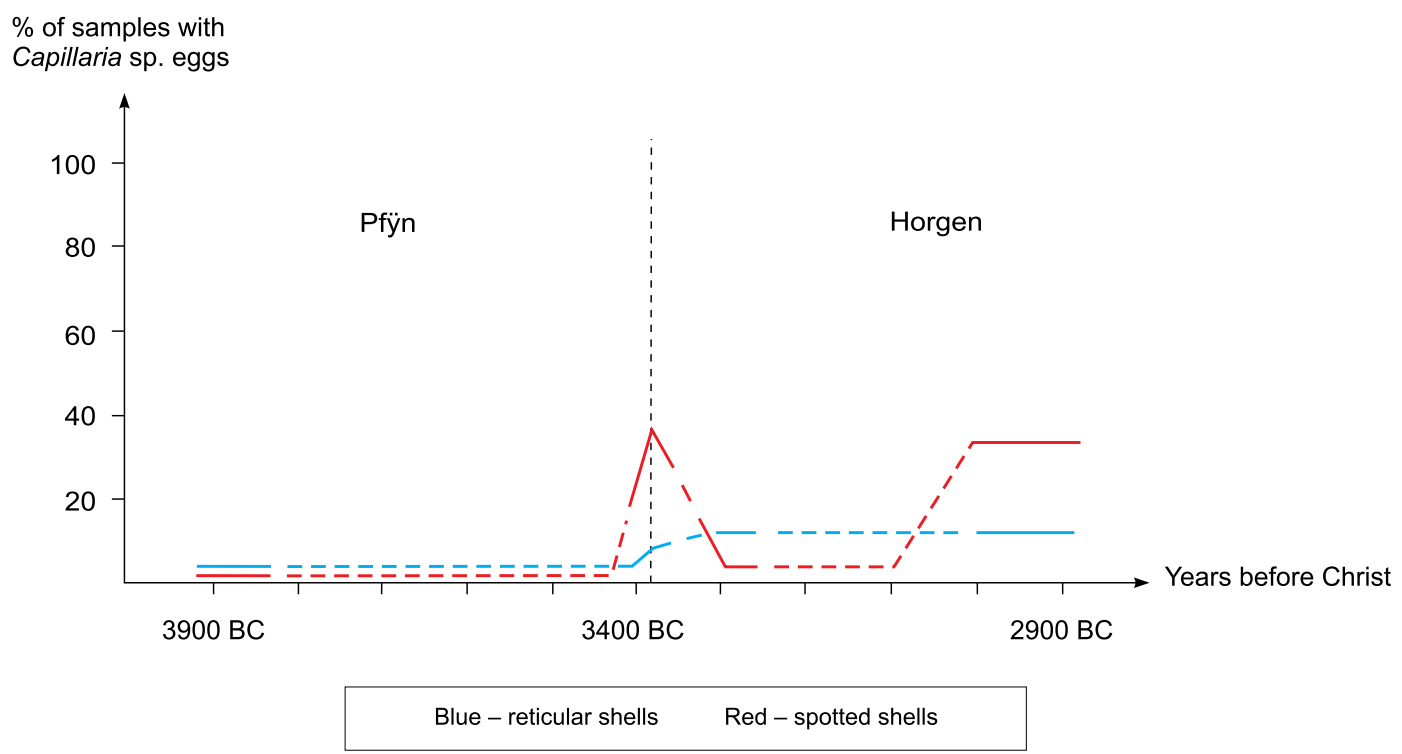

We can conclude that fish were eaten in nearly all of the sites. In Hornstaad-Hörnle I, fish remains were recovered, representing $14.8 \%$ of the bone remains of other animals.

Arbon-Bleiche 3 yielded abundant fish remains, including redfin perch (Perca fluviatilis), pike (Esox lucius), Wels catfish (Silurus glanis), burbot (Lota lota), whitefish (Coregonus sp.), trout (Salmo trutta, Salmo trutta fario), and various small freshwater fishes (Rutilus rutilus, Scardinius erythroptalmus, Leusiscus sp., Barbus barbus, Tinca tinca). Fish consumption was estimated at 22\% of the population's total diet at the site (Hüster-Plogmann \& Leuzinger, 1995).

Some fish remains were found at the Sipplingen site, but without defining the genus or species. At Torwiesen II, some remains of pike, bream (Blicca (Abramis) brama, B. bjoerkna), and other minnows were found. In Wallhausen- 
Ziegelhütte the list of fish remains is more varied. Finally, at the Seekirch-Stockwiesen site no information is available on fish remains.

\section{Frog-eating}

Frog-eating (batracophagy) is one possible hypothesis in certain Neolithic populations, particularly that of ArbonBleiche 3. This hypothesis is backed by the discovery of numerous fragments of digested frog bones from genus Rana sp. The large amount of hind leg bones suggests the preferential consumption of frog legs. This assumption is reinforced by the presence of Dioctophyma sp., the food source of which can be the consumption of either fish or frogs. The hypothesis of frog-eating by Neolithic populations has raised several times (Bailon, 1993, 1997).

The presence of frog remains demonstrates the ingestion of this host at the Arbon-Bleiche 3 site. The bone fragments included remains from Rana esculenta, or common water frog or green frog, Rana lessonae, pool frog, and Rana ridibunda, or marsh frog.

\section{Parasites associated with hunting}

Eggs identified as genus Paramphistomum sp. were found in the Hornstaad-Hörnle I and Seekirch-Stockwiesen sites. These flukes parasitize deer, with no record of cases in humans. Paramphistomum sp. eggs in human samples probably resulted from a pseudoparasitic infection, or pseudoparasitism. The eggs were probably in transit through the human intestine, following the slaughtering of deer and consumption of venison.

\section{Capillaria SP.}

Capillaria sp. eggs with reticulate shells can be attributed to the species Capillaria bovis, a specific parasite of deer. The importance of hunting during the Neolithic and consumption of red deer (Cervus elaphus) and European roe deer (Capreolus capreolus) reinforces the identification of eggs belonging to this species. Findings of eggs with reticulate shells begin at the level of the Swiss site and the parasite's frequency appears to remain stable throughout the Horgen culture (between 10 and 13\%) (Graph 3). This parasite's presence in human samples may have resulted from an increase in hunting, but especially from a narrow selection of game animals, since young deer are more heavily parasitized than adults.

Concerning hunting by Neolithic peoples in these regions, remains of wild animals are present in all the sites. In Hornstaad-Hörnle I, wild animals represented $50 \%$ of the archaeozoological remains. The red deer (Cervus elaphus) and wild boar (Sus scrofa) are present in all the sites discussed here. Roe deer was found in all the sites except Seekirch-Stockwiesen.

\section{Parasitic infections associated with livestock}

The consumption of domestic animals is ancient and was known to all the cultures discussed here. It is a source of contamination by some intestinal parasites, such as tapeworms, including the species found in swine, Taenia solium, and in bovines, Taenia saginata. Other parasites may not cause infections and are considered pseudoparasites or cases of false parasitism. An example is Dicrocoelium sp., the eggs of which can be found in human feces following consumption of liver from ruminants, especially sheep and goats. 


\section{TAENIA SP.}

The peak in parasite finds was followed by a drop around 3200 BC (Graph 4). Opistorchiasis and a dioctophymiasis decreased from $70 \%$ a $10 \%$. The temperature rose and another parasite emerged, with an increase in the number of tapeworm infections. The curve on Taenia sp. egg finds in the Neolithic archaeological sites shows a slight increase during the early Horgen culture.

Pig-raising was a key characteristic of the Horgen culture (Furger, 1980). The Neolithic Horgen culture sites yielded a high percentage of pig remains (Schibler \& Jacomet, 1999). The emergence and evolution in the frequency of Taenia sp. eggs beginning in the cultural transition appears to reflect the importance of pig-raising in the Horgen culture. Various questions were raised before reaching a conclusion on this hypothesis.

Pig-raising did not begin with the Horgen culture. Previously, during the Pfÿn culture, pigs had already been raised for domestic consumption. Curiously, no Taenia sp. eggs were found in the coprolites and sediments from the Pfÿn sites.

Graph 4 - Frequency of Taenia sp. eggs in samples from Neolithic archaeological sites. Europe, 3900 to 2900 BC

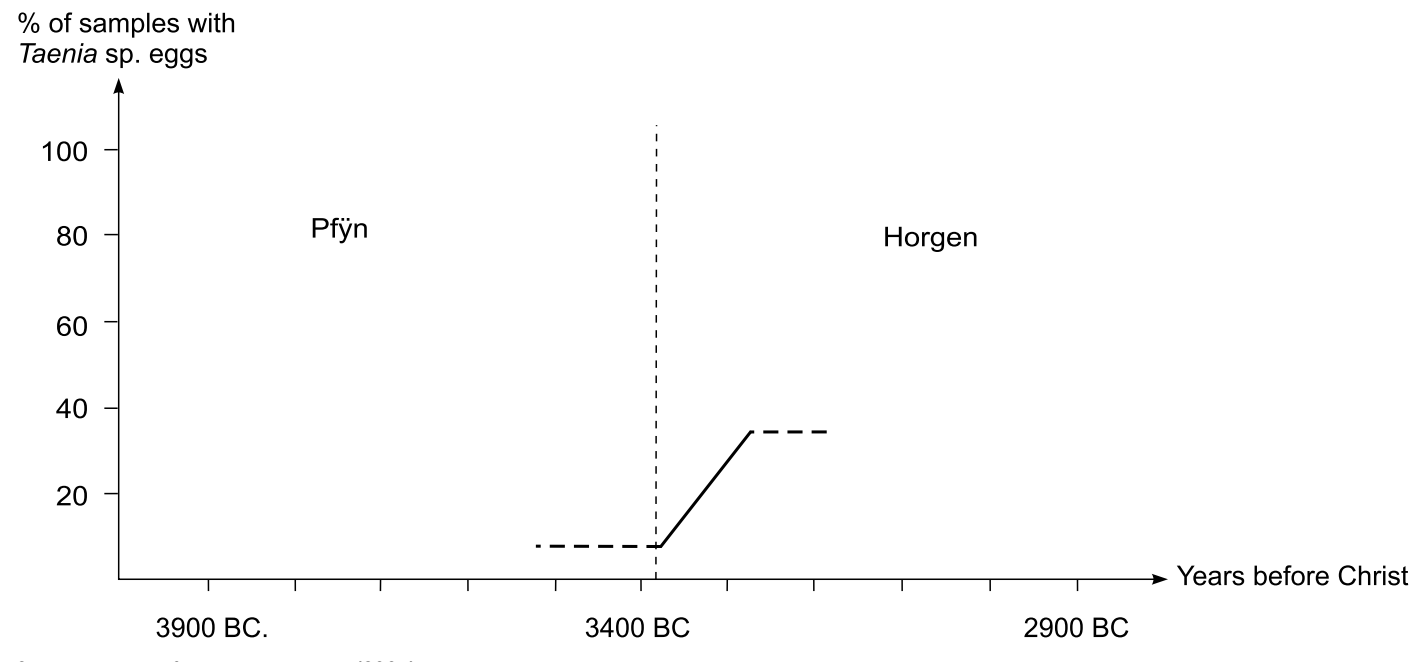

Source: Adapted from Le Bailly et al. (2005).

Tapeworms from genus Taenia that parasitize humans are transmitted by ingesting raw or poorly cooked pork (Taenia solium) or beef (Taenia saginata). The embryophores found in the strata of the archaeological sites are identical for the two species, and the parasite's species cannot be distinguished by the eggs.

Remains from domesticated cattle (Bos taurus) were found in both the Pfÿn and Horgen cultures. Due to the presence of the intermediate host, the absence of Taenia sp. eggs in the Pfÿn sites is surprising, suggesting the ingestion of well-cooked meat. Taenia eggs found in the Arbon-Bleiche 3 site correspond to the oldest dates for this parasite's association with human organic remains.

\section{DICROCOELIUM SP.}

Dicrocoelium sp. eggs were found in Hornstaad-Hörnle I, Arbon-Bleiceh 3, and Seekirch-Stockwiesen, but not in Torwiesen II, possibly due to sampling problems. There was a decrease from 3900 to 3280 BC., to $4 \%$ in HornstaadHörnle I and 0\% in Torwiesen II. This was followed by an important increase, reaching 13\% in Seekirch-Stockwiesen. 
This parasitic infection, closely linked to sheep raising, showed a considerable increase around 3000-2900 BC (Graph 5), coinciding with the known resurgence of raising small ruminants around 2800 BC (Schibler \& Chaix, 1995).

Graph 5 - Frequency of Dicrocoelium sp. eggs in samples from archaeological sites. Europe, 3900 to 2900 BC

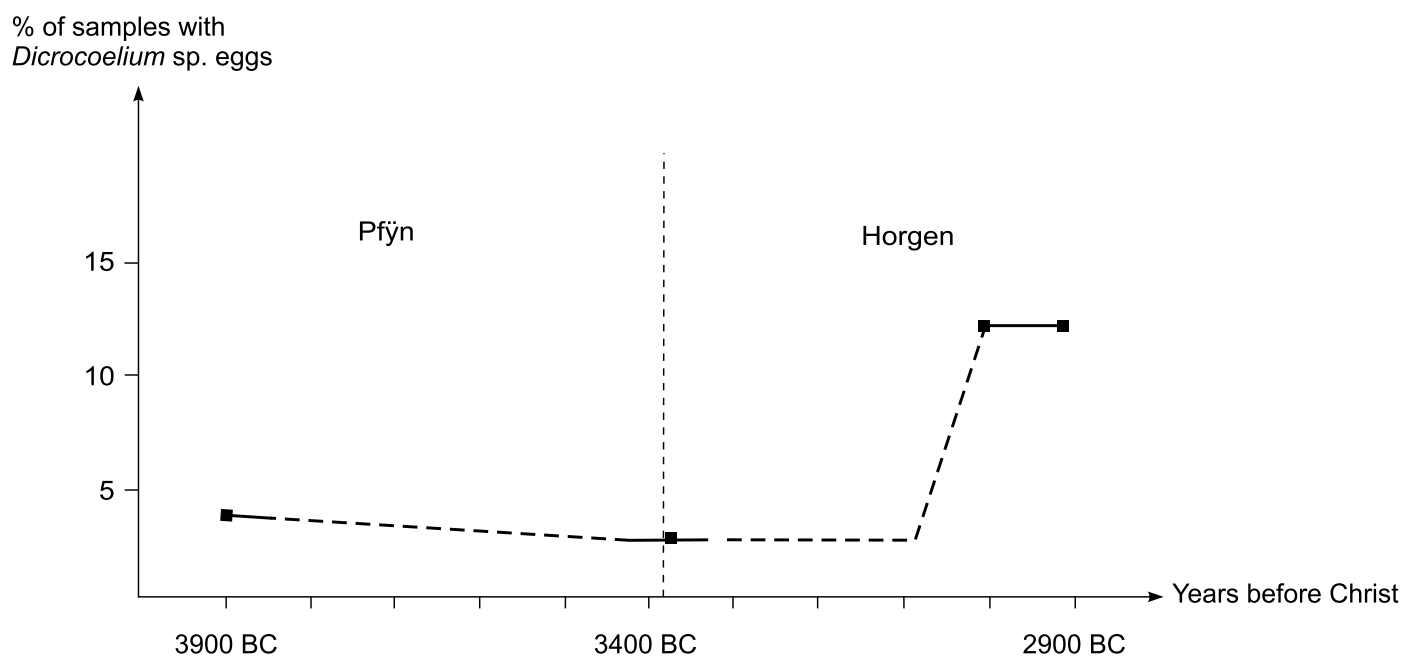

FASCIOLA SP.

Fasciola sp. mainly parasitizes ruminants, and human infection only occurs accidentally due to the consumption of vegetables contaminated with encysted metacercariae. The parasite's presence is thus associated with that of bovines in the same environment. However, cattle-raising was not very widespread between the $36^{\text {th }}$ and $27^{\text {th }}$ centuries BC (Schibler \& Chaix, 1995). It is thus surprising and especially contradictory that there was an increase in findings of this parasite's eggs around $3380 \mathrm{BC}$ (Graph 6).

Fasciola sp. infection can be transmitted by other animals besides bovines. In fact, wild ruminants such as red deer and roe deer can carry adult forms of the parasite (Shimalov \& Shimalov, 2000). Likewise, lagomorphs and rodents can be definitive hosts of the parasite (Ménard et al., 2000). The coypu or river rat (Myocastor coypus) transmits fascioliasis as readily as bovines (Ménard et al., 2001) [Editor's Note. The species Myocastor coypus was originally from South America, but was taken to Europe, where it reproduced in nature]. 
Graph 6 - Frequency of Fasciola sp. eggs in samples from archaeological sites. Europe, 3900 to 2900 BC

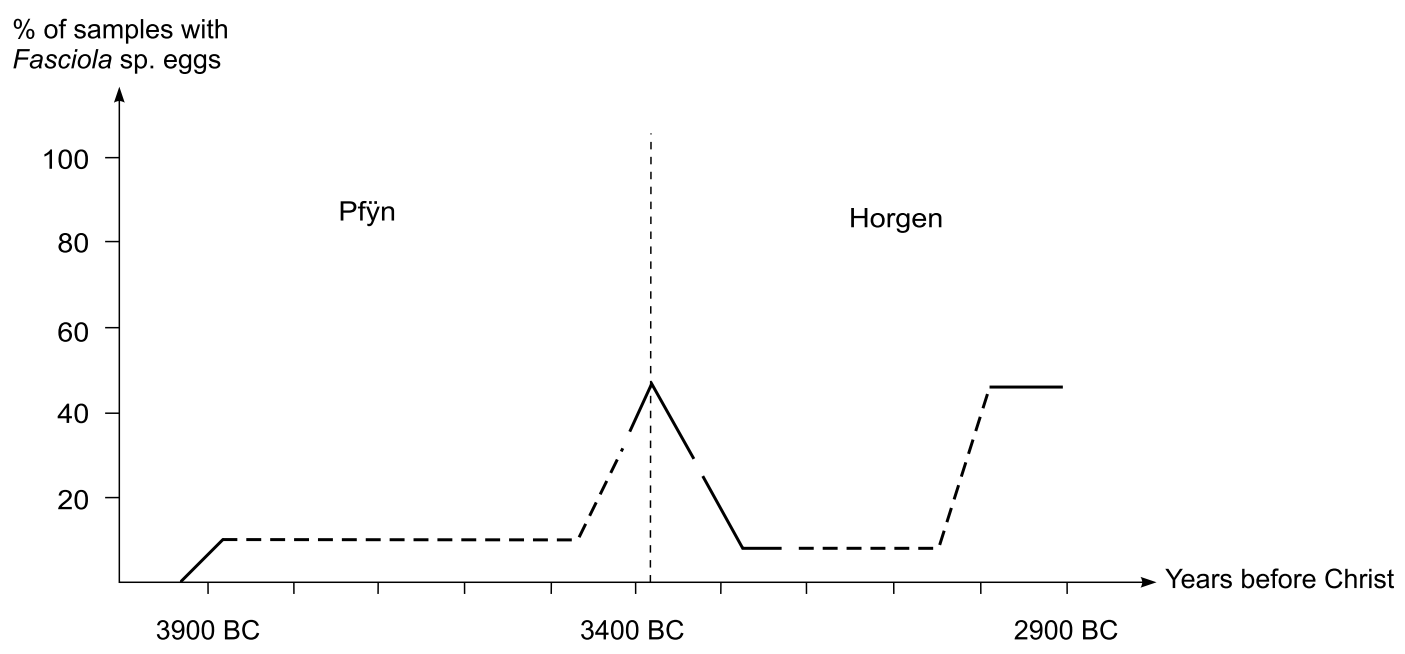

The proven presence of numerous wild ruminants and mustelids at the Arbon-Bleiche 3 site may explain the importance of this parasitic infection during this period. Consumption of these animals may have caused infection with Fasciola sp., causing a pseudoparasitic infection, which would explain the presence of so many eggs in the samples.

\section{Parasitic infections related to the consumption of vegetables}

\section{FASCIOLA SP.}

This parasite uses aquatic plants or those growing on the banks of rivers and lakes for the encystment of its larval form. Such plants include some edible ones for both animals and humans, like water cress. The discovery of Fasciola sp. eggs in human coprolites thus demonstrates the consumption of these plants by humans. In this case, ingestion of the parasite's infective forms, metacercariae, would lead to the fluke's development in the digestive system, with the appearance of symptoms associated with fascioliasis.

It is difficult to distinguish pseudoparasitic infection from true parasitic infection based on the data. All hypotheses for the presence of Fasciola sp. eggs in samples should be explored.

\section{TRICHURIS SP.}

The presence of Trichuris sp. eggs in modern stool samples suggests ignorance of elementary rules of hygiene as wells as the risks involved in the contamination of food or water with fecal matter. Such basic notions were likely unknown during the Neolithic. Thus, the discovery of Trichuris sp. eggs in numerous samples dated to this age appears to fall within normalcy.

However, such findings provide some information. The parasite's developmental cycle requires a passage through the external environment. Transmission thus occurs by accidental ingestion of earth, called geophagy, or consumption of fruits or vegetables contaminated with feces and the parasite's eggs. The use of human fecal matter as fertilizer could have increased the parasite's presence, but as far as we know such fertilization was not used in the Neolithic. 
Unlike the other curves, finds of Trichuris sp. eggs show a downward trend during the transition between the two cultures (Graph 7). This decrease is surprising, and no explanation has been proposed thus far. The sampling issue could also be raised here, but no conclusion is possible to date.

Graph 7 - Frequency of Trichuris sp. eggs in samples from archaeological sites. Europe, 3900 to 2900 BC

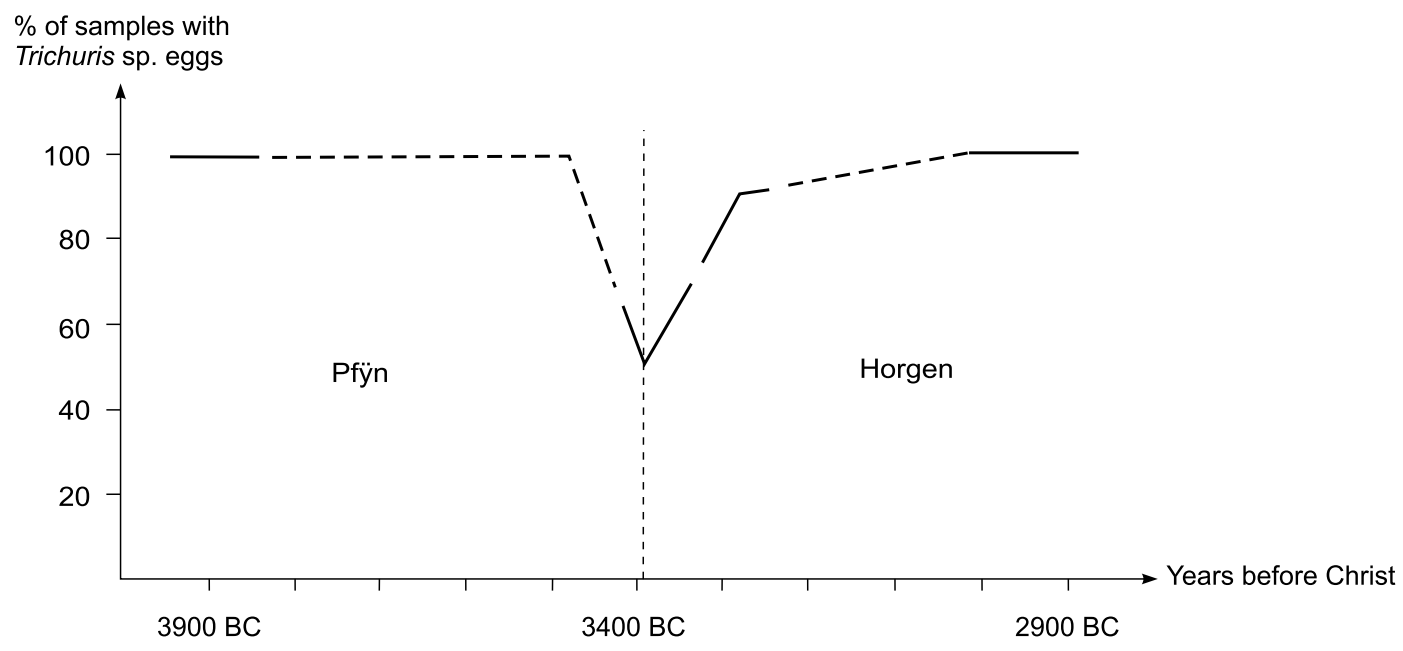

Potential hypotheses

There at least three hypotheses for the increase in fish consumption: cultural changes, a population increase, or even an economic crisis.

A sudden, significant change may have occurred with the arrival of an outside cultural group, in this case the Horgen culture, with different eating habits, e.g., greater fish consumption, which could explain the findings in Arbon-Bleiche 3.

However, according to archaeologists specializing in this transition period, the passage from the Pfÿn to the Horgen culture resulted more from accumulation than dominant colonization. Important exchanges in the Baden culture highlighted this as the possible reason for the emergence of the Horgen culture in Arbon-Bleiche, (Leuzinger, 2000; De Capitani et al., 2002).

A population increase in the region could explain the growing importance of fishing in Arbon-Bleiche 3, as well as infection with Diphyllobothrium sp. But population growth would also impact the size of the villages, for which no archaeological record has been found (Schibler \& Chaix, 1995).

The third hypothesis (an economic crisis) can draw on information from such fields as archaeobotany, paleoclimatology, and archaeology. Between the $38^{\text {th }}$ and $33^{\text {rd }}$ centuries $\mathrm{BC}$, the region underwent an important climate fluctuation known in the Alps as Piora 2 or Rotmoos 2 (Zoller, 1977; Jacomet, Magny \& Burga, 1995). Precipitation increased and temperatures dropped (Magny, 2004). This climatic phenomenon is visible in sediments in the lakes around the Alps and in the Jura region (Magny, 1992, 1993).

In the sites from this period located around Lake Zurich, this climate change was followed by an increase in hunting. Deer were identified in more than $60 \%$ of the archaeozoological remains. In parallel, archaeobotanical 
studies showing declining percentages of cultivated grains due to the climate fluctuation, accompanied by an increase in the use of wild plants.

The archaeozoological and archaeobotanical results suggest an attempt at compensating for nutritional losses due to climate change by simultaneously increasing hunting and gathering (Schibler \& Chaix, 1995; Schibler et al., 1997).

The Arbon-Bleiche 3 site is situated in the cold period following the period between the $37^{\text {th }}$ and $33^{\text {rd }}$ centuries $\mathrm{BC}$. Inhabitants turned to hunting and fishing to survive this phase of climate crisis, with a drop in grain reserves. Important proportions of bones from game animals were found, particularly deer, with venison representing $50 \%$ of the meat consumed by the Arbon-Bleiche population. Fish accounted for $22 \%$ of the overall diet (Hüster-Plogmann \& Leuzinger, 1995). Wild plants also played an important part in diet, representing nearly $40 \%$ of the sustenance of plant origin.

The climate crisis and obligatory return to an economy based heavily on fishing and hunting probably triggered the development of parasitic diseases associated with the consumption of freshwater fish. The paleoparasitological findings appear to corroborate the hypothesis of an economic crisis during the European Neolithic, but cultural changes may have played a greater role in intestinal parasitic infections, especially due to the diversified consumption of fish species (Le Bailly, 2005).

\section{A HISTORY OF PARASITES IN OCCUPATIONS OF ARCHAEOLOGICAL SITES IN BELGIUM}

The occupation of the region where the Namur archaeological site is located dates to the Neolithic period, with remains of various origins following a chronological sequence, including the Gallic-Roman ( $2^{\text {nd }}-3^{\text {rd }}$ centuries) and Carolingian periods $\left(9^{\text {th }}-11^{\text {th }}\right.$ centuries) and proceeding until the $19^{\text {th }}$ century (Chaves da Rocha et al., 2006).

The region where the current province of Namur is located has always been a strategic location for human presence. Situated where the Meuse and Sambre Rivers join, it was occupied ever since the Neolithic. A first Gallic village developed shortly before the Roman occupation, which established a fort surrounded by the small fishermen's village. Various forts were built from then until the Middle Age, thus characterizing the site as a military zone (for some time there was even a prison there) (Plumier \& Vannechelen, 1996). The site includes seven different archaeological contexts. Sediments collected from latrines and other deposits are well-preserved, despite the successive overlaying of occupation layers (Plumier, Mees \& Vanmechelen, 1997; Loreille \& Bouchet, 2003).

Parasites found at the Namur site include eggs from Ascaris suum, Trichuris suis, Ascaris lumbricoides, Capillaria sp., Oxyuris equi, Fasciola hepatica, Diphyllobothrium sp., and Taenia sp., with a conspicuously high concentration of Trichuris trichiura eggs. Species identification drew on statistical treatment, measuring the eggs' length and width. Chaves da Rocha et al. (2006) discussed the findings, showing which structures in the archaeological site had been used as pits to dump household garbage and other waste, latrines with human fecal matter, stables, and cleaning ditches.

The site was the object of the PhD thesis by Gino Chaves da Rocha, who at the time was a doctoral student at the National School of Public Heath (ENSP/FIOCRUZ) in Rio de Janeiro, and who spent a year doing thesis research under the Paleoparasitology Laboratory of the University of Reims, with a grant from Programa Coordenação de Aperfeiçoamento de Pessoal de Nível Superior (CAPES) and Comité Français d'Évaluation de la Coopération Universitaire et Scientifique avec le Brésil (COFECUB).

Another site studied by the paleoparasitology team from the University of Reims in collaboration with the FIOCRUZ team was the Belgian site of Raversijde, dated to the medieval period, at the time a fishing village. The material 
analyzed by Fernandes et al. (2005) was removed from the layer corresponding to the $16^{\text {th }}$ century. The structures were full of organic material, from which 20 samples of sediment were collected (ten each). The archaeology team investigated whether the structures had been used as privies, deposits for human garbage, or waste accumulated from stables or some other source. The paleoparasitological analysis was elucidative, since the Trichuris eggs found there were identified (based on their size and shape) as belonging to Trichuris trichiura, an exclusively human parasite species, thus revealing the origin of the constructions' content.

\section{FUTURE PALEOPARASITOLOGY RESEARCH IN EUROPE}

Much remains to be studied on parasites and their human hosts in Europe. Various questions have still gone unanswered, while others have emerged in the wake of new findings. For example: which infections were brought to Europe by the first humans to arrive from Africa, and where did they spread in the old World? Which parasites were acquired after the domestication of animals and plants? How many remained as zoonotic infections transmitted occasionally to humans and how many adapted to the new host and diversified into new species? The most interesting questions appear to be: how did parasites change the profile of parasitic infections in the New World? And how did they change the profile of parasitic infections when Europeans left the Old World for the New World? This research perspective raises curious questions, capable of producing knowledge on the evolution of parasitic diseases at different moments in the history of humankind.

\section{REFERENCES}

ASPÖCK, H. \& AUER, H. Tabellen un Illustraationen zur Laboratoriumsdiagnostik von Parasitosen. Teil 2: Biologische Grundlagen und übersicht der Untersuchungsmethoden. Labor Aktuell (Roche Austria), 5: 9-16, 1998.

ASPÖCK, H.; AUER, H. \& PICHER, O. The mummy from the Hauslabjoch: a medical parasitology perspective. Alpe Adria Microbiology Journal, 2: 105-114, 1995.

ASPÖCK, H.; AUER, H. \& PICHER, O. Trichuris trichiura eggs in the Neolithic glacier-mummy from the Alps. Parasitology Today, 12: 255-256, 1996.

ASPÖCK, H.; FLAMM, H. \& PICHER, O. Darmparasiten in Menschlichen Exkrementen aus prähistorichen Salzberg werken der Hallstatt Kultur (800-350 v.Chr.). Zentralblatt für Bakteriologie, Parasitenkunde, Infektions-krankheiten und Hygiene, 223: 549-558, 1973.

ASPÖCK, H.; FLAMM, H. \& PICHER, O. Prehistoric Ascaris and Trichuris infection in man (abstract). In: Proceedings of $\mathcal{3}^{\text {rd }}$ International Congress of Parasitology, 3, 1974, Vienna. Anais... Vienna: Facta Publishers, 1974.

BAILON, S. Quelques exemples de la consommation d'amphibiens à travers le temps. In: RENCONTRES INTERNATIONALS D'ARCHEOLOGIE ET D'HISTOIRE D'ANTIBES, 13, 1992, Juan-les-Pins. Exploitation des animaux sauvages à travers les temps. Juan-les-Pins: APDCA, 1993.

BAILON, S. La grenouille rousse (Rana temporaria): une source de nourriture pour les habitants de Chalain 3. In: PETREQUIN, P. Les Sites Littoraux Néolithiques de Clairvaux-Les-Lacs et de Chalain (Jura). Paris: Maison des Sciences de l'Homme, 1997. v. 2. Tomo III: Chalain Station 3, 3.200-2.900 av. J.-C.

BEECHING, A. \& MOULIN, B. Sédiments anthropiques et coprolithes animaux: modestes contributions à des grandes problèmes? Bulletin de la Societé Préhistorique Française, 80: 72-74, 1983.

BILLAMBOZ, A. Stand der Jahrringchronologien Oberschwabens und des Bodensees. In: BECKER, B. Dendrochrologie in der Ur- und Frühegeschichte. Antiqua, 11: 30-35, 1985. 
BILlAMBOZ, A. Die jungneolitischen Dendrodaten der Pfahlbausiedlungen Südwestdeustchlands als Zeeitrahmen für die Einflüsse der Michelsberg Kultur in ihren südlichen Randgebiet. In: LÜNING, J. \& BIEL, J. Die Michelsberg und ihre Randgebiert: probleme der entstehung, chronologie und des siedlungswesens. Stuttgart: Kommissionsverlag K. Theiss, 1998.

BOERSEMA, J. H. \& JANSEN, J. Helminth infections in Mediaeval Utrecht. Tropical and Geographical Medicine, 27: 441, 1975.

BOUCHET, F. Étude parasitologique des chantiers archéologiqques de Beauvais (Oise). Revue Archéologique Picardie, 3/4: 293$294,1991$.

BOUCHET, F. Apport de la parasitologie sur les chantiers archéologiques: l'exemple de la ville de Paris. Mémoires du Groupement d'Archéologie de Seine-et-Marne, 1: 55-61, 1993.

BOUCHET, F. Analyse parasitologique des logis de la Cour des Suisses. Archéologia: les dossiers d'archéologie, 190: 87/92-93, 1994.

BOUCHET, F. Recovery of eggs from archaeological excavations of the Grand Louvre (Paris, France). The Journal of Parasitology, 80: 785-786, 1995.

BOUCHET, F. Intestinal capillariasis in Neolithic inhabitants of Chalain (Jura, France). The Lancet, 349: 256, 1997.

BOUCHET, F. \& BENTRAD, S. Recovery of equine helminth eggs in a mediaeval lacustrine settlement (Charavines, Isère, France). Veterinary Record, 141: 601-602, 1997.

BOUCHET, F. \& PAICHELER, J.C. Paleoparasitology: presumption of a case of bilharzia of the $15^{\text {th }}$ century at Montbéliard (Doubs, France). Comptes Rendus de l'Académie de Sciences Série III, 318: 811-814, 1995.

BOUCHET, F.; BENTRAD, S. \& PAICHELER, J. C. Enquête épidémiologique sur les helminthiases à la cour de Louis XIV. Médecinel Sciences, 14: 463-466,1998.

BOUCHET, F. HARTER, S. \& LE BAILLY, M. The state of the art of paleoparasitological research in the Old World. Memórias do Instituto Oswaldo Cruz, 98, supl. 1: 95-101, 2003.

BOUCHET, F. et al. Étude parasitologique des coprolithes et des sediments de trios ensembles clos de la rue de Lutèce (Île de la Cité) à Paris. Archéometrie, 13: 13-21, 1989.

BOUCHET, F. et al. Palaeoparasitology in a Pleistocene context: initial observations in the Grande Grotte at Arcy-sur-Cure (Department of the Yonne, France). Comptes Rendus de la Société Française de Parasitologie Série III, 319: 147-151, 1996.

BOUCHET, F. et al. Capillarioses intestinales: nématodes du Néolitique? Bulletin de la Société Française de Parasitologie, 15: 49$54,1997$.

BOUCHET, F. et al. Étude de la parasitofaune du site médiéval de Charavines (Lac de Paladru, Isère, France). Bulletin de la Société de Zoologie Française, 125: 205-215, 2000.

BOUCHET, F. et al. The first recovery of Schistosoma mansoni eggs from a latrine in Europe (15-16). The Journal of Parasitology, 88: 404-405, 2002.

BOUCHET, F. et al. Parasite remains in archaeological sites. Memórias do Instituto Oswaldo Cruz, 98, supl. 1: 47-52, 2003.

CHAMOT, G. \& AMAT-ROSE, J. M. Les bilharziosis. Revue du Praticien, 43: 401-404, 1993.

CHAVES DA ROCHA, G. et al. Paleoparasitological remains revealed by seven historic contexts from 'Place d'Armes', Namur, Belgium. Memórias do Instituto Oswaldo Cruz, 101, supl. 2: 43-52, 2006.

COCKBURN, A. et al. Autopsy of an Egyptian mummy. Science, 187: 1.155-1.160, 1975.

COMBES, C. Interactions Durables: écologie et evolution du parasitisme. Paris: Masson, 1995. (Collection Écologie, 26)

CONTIS, D. \& DAVID, A. R. The epidemiology of bilharzias in ancient Egypt: 5000 years of schistosomiasis. Parasitology Today, 12: 253-255, 1996.

DE CAPITANI, A. et al. Die Jungsteinzeitliche Seefersiedlung, Arbon-Bleiche 3. Funde. Frauenfeld: Archäologie im Thurgau, 2002.

DEELDER, A. M. et al. Detection of schistosome antigen in mummies. The Lancet, 335: 724, 1990. 
DIECKMANN, B. Zum Strand der archäologischen Untersuchungen in Hornstaad. Ber rom German Kommiss, 70: 84-109 1990.

DIEKMANN, B.; MAIER, U. \& VOGT, R. Horstaad - Zur inneren Dynamik einer Jungneolitischen Dorfanlage am Westlichen Bodensee. Neue Ergebnisse der Archäologie, Botanik und Bodenkunde. In: LIPPERT, A. et al. (Eds.). Mensch und Umwelt während des Neolithikums und Frühebronzenzeit in Mitteleuropa. Ergbnisse Interdisciplinärer Zusammenarbeit Zwischen Archäologie, Klimatologie, Biologie und Medizin. Rahden: Verlag Marie Leidorf, 2001.

DOMELIER-ESPEJO, S. Contribution à l'Étude Paléoparasitologique des Sites Néolitiques en Environnement Lacustre dans les Domains Jurassien et Péri-Alpin, 2001. Phd Thesis, Reims: U.F.R. des Sciences Exactes et Naturelles, Université de Reims Champagne-Ardenne.

DOMmELIER, S. et al. Parasitoses liées à l'alimentation chez les populations du site néolithique de Chalain (Jura, France). Antropozoologica, 27: 41-49, 1998.

FERNANDES, A. et al. Intestinal parasite analysis in organic sediments collected from a $16^{\text {th }}$ century Belgian archaeological site. cadernos de Saúde Pública, 21: 329-332, 2005.

FERREIRA, L. F.; ARAÚJO, A. \& DUARTE, N. A. Nematode larvae in fossilized animal coprolites from lower and Middle Pleistocene sites, Central Italy. The Journal of Parasitology, 79: 440-442, 1993.

FERREIRA, L. F. et al. Trichuris eggs in animal coprolites dated from 30,000 years ago. The Journal of Parasitology, 77: $491-493$.

FUGASSA, M. H. et al. Capillaria spp. eggs in Patagonian archaeological sites: statistical analysis of morphometric data. Memórias do Instituto Oswaldo Cruz, 103: 104-105, 2008.

FURGER, A. R. Die Siedlungsreste der Horgener Kultur. Grabungbericht und Auswertung unter Besonderer Berücksichtigung der Naturwissenschaftlichen Untersuchungen. Bern: Verlag, 1980.

GONÇALVES, M. L. C. et al. Detection of Giardia duodenalis antigen in coprolites using a commercially available enzyme immunoassay. Transactions of the Royal Society of Tropical Medicine and Hygiene, 96: 640-643, 2002.

GONÇALVES, M. L. C. et al. Amoebiasis distribution in the past: first steps using an immunoassay technique. Transactions of the Royal Society of Tropical Medicine and Hygiene, 98: 88-91, 2004.

GOOCH, P. S. Helminths in Archaeological and Prehistoric Deposits. St. Albans: Commonwealth Institute of Helminthology, 1972. (Annotated Bibliography, 9)

GOOCH, P. S. Helminth parasites. In: HARD, G. D. (Ed.). Disease in Ancient Man. Toronto: Clarke Irwin, 1983.

GOULD, S. J. The Flamingo's Smile. New York: W. W. Norton, 1985.

GREIG, J. The investigation of a medieval barrel-latrine from Worcester. Journal of Archaeological Science, 8: 265-282, 1981.

GREIG, J. Garderobes, sewers, cesspits, and latrines. Current Archaeology, 85: 49-52, 1982.

GRZYWINSKI, L. Analysis of feces from the Middle Age period. Zoologica Poloniae, 10: 195-199, 1960.

HARTER, S. Implication de la Paléoparasitologie dans l'Etude des Populations Anciennes de la Vallée du Nil et du Proche-Orient: étude de cas, 2003. Thése Docteur, Reims: de l'Université de Reims Champagne-Ardenne, Sciences Pharmaceutiques, Specialité Paléoparasitologie, U.F.R. Pharmacie, Université de Reims Champagne-Ardenne.

HELBAEK, H. Grauballemandens Sidste Måltid. Kuml, 83-116, 1958.

HELMY, M. M. \& AL-MATHAL, AND. M. Human infection with Dicrocoelium dendriticum in Riyadh district (Saudi Arabia). Journal of the Egyptian Society of Parasitology, 33: 139-144, 2003.

HERRMANN, B. Parasitologische Untersuchung Mittelalterlicher Kloaken. In: HERRMANN, B. (Ed.). Mensch und Umwelt im Mittelalter. Stuttgart: Verlag, 1986.

HERRMANN, B. Parasitologisch-epidemiologische Auswertungen Mittelalterlicher Kloaken. Zeitschrift für Archäologie des Mittelalters, 13: 131-161, 1987. 
HORNE, P. D. \& LEWIN, P. K. Electron microscopy of mummified tissues: autopsy of an Egyptian mummy. Canadian Medical Association Journal, 117: 472-473, 1977.

HÜSTER-PLOGMANN, H. \& LEUZINGER, U. Fischerei und Fischereste in der Jungsteinzeitlichen Seefersiedelung in Arbon (TG). Archäologie Schweiz, 18: 109-117, 1995.

JACOMET, S.; MAGNY, M. \& BURGA, C. Klima und Seespiegelschwankungen im Verlauf des Neolithikums und ihre Auswirkungen auf die Besiedlung der Seeufer. In: STÖKLI, W. AND.; NIFFELER, U. \& GROSS-KLEE, E. (Eds.). Die Schweiz vom Paläolithikum zum Miteralter, SPM 2: Neolithikum. Basel: SGU Verlag, 1995.

JANSEN JR, J. \& OVER, H. J. Het Voorkomen van Parasieten in Terpmateriaal uit Noordwest Duitsland. Tijdschrift voor Diergeneeskunde, 87: 1.377-1.379, 1962.

JANSEN JR, J. \& OVER, H. J. Observations on helminth infections in a Roman army-camp. In: INTERNATIONAL CONGRESS OF PARASITOLOGY, 1, 1964, Roma. Anals... Rome, 1966.

JONES, A. K. G. Recent finds of intestinal parasite ova at York, England. In: EUROPEAN MEMBERS MEETING, 4, Middelburg, Anwerpen, 1982. (Papers on Paleopathology)

JONES, A. K. G. A coprolite from 6-8 pavement. The archaeology of York: the past environment of York. In: HALL, A.R. Environment and Living Conditions at two Anglo-Scandinavian sites. London: Council for British Archaeology, 1983.

JONES, A. K. G. Trichurid ova in archaeological deposits: their value as indicators of ancient faeces. In: FIELLER, R. J.; GILBERTSON, D. D. \& RALPH, N. G. A. Palaeobiological Investigations: research design, methods and data analysis. Heslington: British Archaeological Reports, 1985. (BAR International Series, 266; Symposia of the Association for Environmental Archaeology, 5b)

JONES, A. K. G. \&, NICHOLSON, A. R. Recent finds of Trichuris and Ascaris ova from Britain. Paleopathology Newsletter, 62: 5-6, 1988.

JONES, A. K. G.; HUTCHINSON, A. R. \& NICHOLSON, C. The worms of Roman horses and other finds of intestinal parasite eggs from unpromising deposits. Antiquity, 62: 275-276, 1988.

JOUY-AVANTIN, F. et al. Helminth eggs in animal coprolites from a Middle Pleistocene site in Europe. The Journal of Parasitology, 85: 376-379, 1999.

KOLB, M. Die Seeufersiedlung Sipplingen und die Entwicklung der Horgener Kultur am Bodensee. In: SCHLICHTHERLE, H. Pfahlbaten Rund um die Alpen. Stuttgart: Theiss-Verlag, 1997.

LE BAILlY, M. Étude de l'Helminthofaune du Site de Grésine (Lac du Bourget, France), 2001. Mémoire de Maîtrise, Reims: Biologie Cellulaire et Physologie, Biologie Génerale et Sciences de la Terre et d l'Univers, U.F.R. Sciences Exactes et Naturelles, Université de Reims Champagne-Ardenne.

LE BAILlY, M. Étude Paleoparasitologique du Site Néolitique d'Arbon-Bleiche 3 (Thurgovie, Suisse). Paris: Muséum National d'Histoire Naturel, 2002. (Mémoire de Diplôme d'Études Approfondies)

LE BAILLY, M. Évolution de la Relation Hôte/Parasite dans les Systèmes Lacustres Nord Alpines au Néolithique (39900-2900 BC), et Nouvelles Données dans la Détection des Paléoantigenes de Protozoa, 2005. Thèse, Reims: Unité de Formation et de Recherche de Pharmacie, École Doctorale ‘Science, Technologie, Santé', Université de Reims Champagne-Ardenne.

LE BAILlY, M.; LEUZINGER, U. \& BOUCHET, F. Dioctophymidae eggs from coprolites from Neolithic site of Arbon-Bleiche 3 (Switzerland). The Journal of Parasitology, 89: 1.073-1.076, 2003.

LE BAILLY, M. et al. Diphyllobothrium: Neolithic parasite? The Journal of Parasitology, 91: 957-959, 2005.

LE BAILLY, M. et al. New finding of Giardia intestinalis (Eukaryote, Metamonad) in Old World archaeological site using immunofluorescence and enzyme-linked immunosorbent assays. Memórias do Instituto Oswaldo Cruz, 103: 298-300, 2008.

LEGENDRE, J. P.; MARIE, J. \& RIEB, J. P. Contribution à l'Etude de l'Etat Sanitaire de la Population Strasbourgeoise à la Fin du MoyenÂge. Juan-le-Pins: Archéologie et Médecine, APDCA, 1986.

LELES, D. et al. Molecular paleoparasitological diagnosis of Ascaris sp. from coprolites: new scenery of ascariasis in pre-Columbian South American times. Memórias do Instituto Oswaldo Cruz, 103: 106-108, 2008. 
LEUZINGER, U. Die Jungsteinzeitliche Seefersiedlung arbon-bleiche 3. Befunde. Frauenfeld, Amt für Archäologie (Archäologie im Thurgau 9), Department Erziehung und Kultur des Kantons Thurgau, Switzerland, 2000.

LOREILLE, O. \& BOUCHET, F. Evolution of ascariasis in humans and pigs: a multi-disciplinary approach. Memórias do Instituto Oswaldo Cruz, 98, supl. 1: 39-46, 2003.

LOREILLE, O. et al. Ancient DNA from Ascaris: extraction amplification and sequence from eggs collected in coprolites. International Journal for Parasitology, 31: 1.101-1.106, 2001.

MAGNY, M. Holocene lake-level fluctuations in Jura and sub-Alpine ranges, France: regional pattern and climatic implications. Boreas, 21: 319-334, 1992.

MAGNY, M. Holocene fluctuations of lake levels in the French Jura and sub-Alpine ranges, and their implications for past general circulation patterns. Holocene, 3: 306-313, 1993.

MAGNY, M. Holocene climate variability as reflected by mid-European lake-level fluctuations and its probable impact on prehistoric human settlements. Quaternary International, 113: 65-79, 2004.

MÉNARD, A. et al. Inventory of wild rodents and lagomorphs as natural hosts of Fasciola hepatica on a farm located in a humid area in Loire Atlantique (France). Parasite, 7: 77-82, 2000.

MÉNARD, A. et al. Myocastor coypus as a reservoir host of Fasciola hepatica in France. Veterinary Research, 32: 499-508, 2001.

MILLER, R. L. et al. Paleoepidemiology of schistosoma infection in mummies. British Medical Journal, 304: 555-556, 1992.

MOORE, P. D. Life seen from a medieval latrine. Nature, 294: 614, 1981.

NANSEN, P. \& JøRGENSEN, R. J. Fund af Parasitaeg I arkaeologisk materiale fra det vikigetidige Ribe. Nordisk Veterinaer Medicin, 29: 263-266, 1977.

NOZAIS, J. P Hypothèses sur le rôle du Sahara préhistorique dans la répartition de certaines affections parasitaires et hématologiques. Bulletin de la Société de Pathologie Éxotique, 80: 121-131, 1987.

NOZAIS, J. P. The origin and dispersion of human parasitic diseases in the Old World (Africa, Europe, and Madagascar). Memórias do Instituto Oswaldo Cruz, 98, supl. 1: 13-19, 2003.

ORTNER, D. J. \& PUTSCHAR, W. G. J. Identification of Pathological Conditions in Human Skeletal Remains. Washington: Smithsonian Institution Press, 1981. (Smithsonian Contributions to Anthropology, 28).

PIKE, A. W. The recovery of parasite eggs from ancient cesspit and latrine deposits: an approach to the study of early parasite infections. In: BROTHWELL, D. \& SANDISON, A. T. (Eds.). Diseases in Antiquity. Springfield: CC Thomas, 1967.

PIKE, A. W. Recovery of helminth eggs from archaeological excavations, and their possible usefulness in providing evidence for the purpose of an occupation. Nature, 219: 303-304, 1968.

PIKE, A. W. Parasite eggs. The organic contents of cesspit soil from Southampton and their significance for the archaeologist and biologist. In: PLATT, C. \& COLEMMAN-SMITH, P. (Eds.). Excavations in Mediaeval Southampton. Leicester: Leicester University Press, 1975.

PIKE, A. W. \& BIDDLE, M. Parasite eggs in Medieval Winchester. Antiquity, 40: 293-296, 1966.

PITRAT, M. \& FOURY, C. Histoires de Légumes: des origines à l'orée du XXIe siècle. Versailles: Éditions Quae, 2003.

PLUMIER, H. N. \& VANMECHELEN, R. 'Place d'Armes, place aux fouilles' l'archéologie Namuroise dans le sillage d'un parking souterrain. Namur Magazine, 12: 14-15, 1996.

PLUMIER, H. N.; MEES, N. \& VANMECHELEN, R. Namur: eléments de topographie urbaine au Bas Moyen Age. In: CORBIAU, M. H. Le Patrimoine Archéologique de Wallonie. Namur: Ministère de la Région Wallonne, Division du Patrimoine, 1997.

RANA, S. S. et al. Parasitic infestations of the biliary tract. Current Gastroenterology Reports, 9: 156-164, 2007. 
REINHARD, K. J. et al. Recovery of parasite remains from coprolites and latrines: aspects of paleoparasitological technique. Homo, 37: 217-239, 1987.

REYMAN, T. A. Schistosomal cirrhosis in an Egyptian mummy. Yearbook of Physical Anthropology, 20: 356-358, 1976.

ROEVER-BONNET, H. et al. Helminth eggs and gregarines from coprolites from the excavations at Swifterbant. Helinium, 19:7$12,1979$.

ROUFFIGNAC, C. Mediaeval man and his worms. Biologist, 34: 187-190, 1987.

RUFFER, M. A. Note on the presence of 'Bilharzia haematobia' in Egyptian mummies of the Twentieth Dynasty (1250-1000 B.C.). British Medical Journal, 1: 16, 1910.

RUfFER, M. A. Studies on the Paleopathology of Egypt. Chicago: Chicago University Press, 1921.

SCHIBLER, J. \& CHAIX, L. Lévolution économique sur la base de données archaéozoologiques. In: STÖKLI, W. E.; NIFFELER, U. \& GROSS-KLEE, E. Die Schweiz vom Paläolithikum zum Mitterlater, SPM 2, Neolithikum. Basel: SGU Verlag, 1995.

SCHIBLER, J. \& JACOMET, S. Archaeozoological and archaeobotanical evidence of human impact on Neolithic environments in Switzerland. In: BENECKE, N. (Ed.). The Holocene History of the European Vertebrate Fauna. Rahden: Verlag Marie Leidorf, 1999.

SCHIBLER, J. et al. Ökonome und Ökologie Neolithischer und Bronzezeitlicher Ufersiedlungen am Zürichsee: Ergebnisse der Ausgrabungen Mozartstrasse, Kanalisationssanierung Seefeld, AKAD, Zürich, DOB des Kantons Zürich. Zürich: Seefeld, Akad, 1997. (Monographien der Kantonsarchäologie Zürich, 20)

SCHLICHTHERLE, H. Die Sondagen 1973-1978 in den Ufersiedlung Hornstaad-Hörnle I. In Siedlungsarchäologie im Alpenvorland I. Stuttgart: Landesdenkmalmat Baden-Württemberg, Kommissionverlag K. Theiss, 1990. (Forsch. U. Ber. Vor- und Frühgeschicte, 36)

SCHLICHTHERLE, H. Neue Baudefinde und eine Scherbe der Badener Kultur in der endneolithischen Moorsiedlung Torwiesen II, Bad Buchau, Kreis Biberach. In Archäologische Ausgrabung in Baden-Württemberg 2001. Stuttgart: Landesdenkmalamt BadenWürttemberg, Theiss, 2002.

SCHLICHTHERLE, H. \& HOHL, W. Fortschritte der Ausgrabung in der Endneolithischen Moorsiedlung Torwiesen II in Bad Buchau am Federsee, Kreis Biberach, Baden-Württemberg. Nachrichtenblatt Arbeitskreis Unterwasserarchäologie, 9: 61-65, 2002.

SHIMALOV V. V. \& SHIMALOV V. Findings of Fasciola hepatica Linnaeus 1758, in wild animals in Belorrusian Polesie. Parasitological Research, 86: 342, 2000.

SPECHT, K.W. Eine interessante Erdprobe aus einer Abortgrube im Römerkastell Künzing. Saalburg-Jahrbuch, 21: 90-94, 1963.

STAUB, J. Die Pfahlbauten in Die Schweizer Seen. Zurich: Verlag des Verfassers, 1864.

SZIDAT, L. Uber die Erhaltungsfähigkeit von Helmintheneierm in Vor-undfrühgeschchtlichen Moorleichen.Zeitschrift für Parasitenkunde, 13: $265-274,1944$.

TAYLOR, E. L. Parasitic helminths in mediaeval remains. Veterinary Record, 67: 216-218, 1955.

WEISS, D. L. \& MÖLLER-CHRISTENSEN, V. An unusual case of tuberculosis in a medieval leper. Danish Medical Bulletin, 18:11-4, 1971.

ZOLLER, H. Alter und Ausmass Postglazialer Klimaschwankungen in den Schweizer Alpen. In: FRENZEL, B. Dendrochronologie und postglaziale Klimaschwangen in Europa. Wiesbaden: Steiner Verlag, 1977. 


\title{
The Findings in Asia
}

\author{
Adauto Araújo • Luiz Fernando Ferreira
}

$\mathrm{T}$

This chapter discusses the importance of paleoparasitology studies in Asia and the need for data to expand our understanding of the paths trod by human hosts and the traces left by their specific parasites. Such traces can be recovered in places where human migrants passed during the thousands of years that preceded the peopling of the Americas (Araújo et al., 2008).

Paleoparasitology has a long history in Asia. It may not be as old as the studies on Ancient Egypt or the European and American traditions, but it emerged with expert researchers. Although rarely cited by Western scholars, Chen (1956) published one of the first articles on parasites in archaeological remains from Asia, describing Clonorchis sinensis eggs in coprolites from a corpse dated to the Ming dynasty, buried in 1513 on the outskirts of Guangzhou.

Another Chinese researcher, Ou Wei (1973), published the autopsy findings from a Chinese mummy dated to 2100 $\mathrm{BP}$, belonging to the Han dynasty (206 BC to $220 \mathrm{AD}$ ). Based on the archaeological analyses, the individual was the widow of the Marquis of Tai. The study is highly detailed, with tissues examined under both light microscopy and transmission electron microscopy. The woman had a severe coronary lesion, and various parts of her corpse presented atherosclerotic alterations. The hepatic duct was blocked by a gallstone, and since there were no signs of lesion causes by extended bedridden time, Wei (1973) concluded that the woman had died of a heart attack caused by biliary colic.

Radiological examination showed a calcified TB lesion. Wei (1973) reported finding eggs from whipworms (Trichuris trichiura) and pinworms (Enterobius vermicularis) in intestinal content and Schistosoma eggs (without identifying the species) in the liver. Hall (1974) and later Freedman \& Proust (1978) cited the autopsy in this same mummy, confirming the presence of the parasites described by Ou Wei (1973) in the gut and liver and the pulmonary lesions from tuberculosis.

According to Han et al. (2003), eggs of Clonorchis sinensis, Ascaris lumbricoides, Trichuris trichiura, Enterobius vermicularis, and Schistosoma japonicum were found in mummified bodies corresponding to the Han and Chu dynasties in China (Chen \& Hung, 1981; Wei et al., 1981; Hu, 1984; Yang et al., 1984; Su, 1987; Wu, Guan \& Zhou, 1996), dating as far back as 2,100 years. 
Witenberg (1961) described Trichuris trichiura eggs and cysts of Entamoeba coli, Entamoeba histolytica, Giardia lamblia, and Chilomastix mesnili in coprolites excavated in an area close to the Dead Sea and dated to 1800 BP. The article reports the first protozoan find in ancient material but lacks a precise description of the techniques used or photographs of the parasites. However, the precise identification of each protozoan, differentiating the amoebic cysts, and of Chilomastix mesnili cysts, leads one to assume an accurate diagnosis and adequate use of staining techniques (although not described). Still, it is extremely difficult to find protozoa in coprolites, so alternative diagnostic techniques should always be used.

None of the articles subsequently published in paleoparasitology managed to show the presence of protozoan cysts, except in extremely rare cases (Le Bailly et al., 2008). This makes the report by Witenberg (1961) one of the most exceptional findings in paleoparasitology due to the diversity of protozoan species (although the study can be criticized for lack of precise methodological description and photographic documentation).

A fascinating article by Dubinina (1972) reports the presence of Alfortia edentatus eggs in horse coprolites dated to the Pleistocene in Russia.

Liangbiao \& Tao (1981) showed Opistorchis sp. and Clonorchis sinensis eggs in detail using electron microscopy. The eggs were found in a mummified body in China. Cheng (1984) comments on this and other finds in Chinese mummified bodies. In one of them, the Marchioness of Tai, described previously, Cheng (1984) confirms death from myocardial infarction following coronary occlusion.

In another mummified body belonging to the Han dynasty and examined 2,142 years after the individual's death, various intestinal helminth eggs were found, such as tapeworm, whipworm, and Clonorchis sinensis. Cheng (1984) makes a curious comment on the presence of Schistosoma japonicum. According to him, the parasite's name is inappropriate, since it already parasitized the Chinese long before Japan even emerged as a country. The autopsy results also showed that although this individual also presented severe arterial lesions, the causes of death were diffuse peritonitis due to a perforated gastric ulcer complicated by septic shock and disseminated intravascular coagulation.

Mikhailov, Kuznetsov \& Zhdanov (1984) describe the necropsy of a mammoth found in Siberia and dated to 10,000 BP. Examination of the animal's intestinal content under scanning electron microscopy showed spherical particles identified as viral particles, but despite the authors' attempts, they were unable to isolate the organism in cell culture.

Zias \& Mumcuoglu (1991) report finding a calcified hydatic cyst when examining a funeral chamber culturally associated with the Roman period from the first century AD. The findings were two hollow, calcified structures measuring some $2.5 \mathrm{~cm}$ in diameter. Based on comparison with descriptions by other authors (Møller-Christensen, 1971; Wells \& Dallas, 1976), they made the diagnosis of hydatic cysts resulting from infection with Echinococcus granulosus. They call the attention of parasitologists and archaeologists to this finding, potentially overlooked by specialists due to the structures' great similarity to common pebbles.

Hershkovitz et al. (1992) describe a lesion in a partially preserved corpse as a possible case of maduromycosis. The lesion is characterized by mycelial nodules formed by grains of bacteria or fungi that cause vesicles and abscesses with chronic swelling mainly in the feet and hands. The skeleton was found in Bet Gruvin, Israel, and dated to 1500 BP. According to the authors, the lesions were consistent with maduromycosis, possibly from infection with Nocardia caviae. Due to its rarity in the region, they conclude that the case was not autochthonous. However this diagnosis can raise doubts, since some mycologists prefer to use the maduromycosis for cases caused by fungi, or eumycetomas, while cases involving actinomycetes as the etiological agents are referred to simply as mycetomas. 
Morimoto (1993) describes a study performed in Buddhist mummies in Japan, remarking that the preservation of organic material is unusual in such a humid region as that in which the mummies were found (Saishoji Temple, Teradomari, Niigata Prefecture). However, the three types of mummification reported by Vreeland Jr. \& Cockburn (1980) - natural, intentionally natural, and artificial - can be found in the Japanese Buddhist mummies.

Mitchell (1993) studied the occurrence of leprosy in Israel during the Crusades in the $12^{\text {th }}$ and $13^{\text {th }}$ centuries, presenting the case of King Baldwin IV, who died in 1185 AD (Anno Domini). He discusses the theories on the entry of Mycobacterium leprae infection in the Middle East and its names in antiquity: what was referred to as leprosy in King Baldwin's time could have been either Hansen disease itself or endemic syphilis, since the physicians of the time did not distinguish one from the other, or either of them from other skin lesions.

The author also says that King Baldwin's disease may have been a treponematosis and not Hansen disease, as discussed previously by other authors when referring to the antiquity of syphilis (Baker \& Armelagos, 1988). The evolution of his disease was described by his preceptor, William of Tyre, who refers numbness in the young boy's hands. After he was crowned, Baldwin could barely remain standing, had lost his sight, and his hands and feet were covered with ulcers. The king died young, at just 24.

However, Mitchell (1993) rules out syphilis in King Baldwin's case, for various reasons. First, Baldwin was treated by one of the most highly respected Egyptian physicians of the time, who did not prescribe any of the remedies indicated for syphilis or for other skin diseases, which could have improved his condition. Second, the distribution of his lesions, affecting the extremities and face, is characteristic of leprosy, not syphilis. Finally, the nature of the lesions suggests leprosy much more than endemic syphilis. Although both produce skin ulcers, the lepromatous form of leprosy is associated with numbness and loss of extremities, which does not occur with syphilis.

Mitchell (1993) discusses the theory that the tuberculoid form of leprosy developed gradually, only emerging after several centuries. He comments on descriptions of the disease in skeletons and mummies, where the distribution pattern of the lesions resembles that described in King Baldwin, concluding that his case was lepromatous leprosy, as expected in his time.

Rao, Vasulu \& Rector Babu (1996) describe a possible case of treponematosis in India, dated to the Megalithic period.

Tayles (1996) studies factors that could lead to bone lesions characteristic of anemia in prehistoric Southeast Asia. He examined skeletons dated to 4000 BP found on the coast of Thailand, with evidence of severe anemia, and concluded that hemoglobinopathies could have produced the lesions found in this prehistoric population. This could mean that both malaria and the resulting genetic response by the human host had a long and profound influence on the life of peoples in Southeast Asia.

Mitchell \& Stern (2000) describe eggs from Trichuris trichiura, Ascaris lumbricoides, and Diphyllobothrium latum found in latrines in a Crusade hospital in what is now Israel. The hospital was used by both Crusaders and sick pilgrims, but the latrines were destroyed and never used again after the assault by Muslim troops in 1291. The final commentary is fascinating, highlighting that Diphyllobothrium latum, transmitted to the human host by eating raw or poorly cooked fish, is not endemic to the Middle East but to countries of northern Europe. The period ranged from the $13^{\text {th }}$ to the $15^{\text {th }}$ century.

Han et al. (2003) describe a series of parasites in material of human origin in Korea, including eggs of Trichuris trichiura, Ascaris lumbricoides, and Clonorchis sinensis, among other unidentified parasites. The age varied from 668 to $935 \mathrm{AD}$, corresponding to the Shilla dynasty, but one site dated to 2000-1000 BC, corresponding to the Bronze Age, 
material dated from $100 \mathrm{BC}$ to $650 \mathrm{AD}$, corresponding to the Shilla, Koguryo, and Paekje reigns, and material dated from 1400 to $1900 \mathrm{AD}$, representing the Chosen dynasty. The authors report an interesting history of paleoparasitology in Korea, little known in the West. The first studies were done in 1997 in organic sediments excavated from a swampy terrain and dated to circa $100 \mathrm{BC}$, yielding Ascaris sp. and Trichuris sp. eggs. The material is stored at the Kwangju National Museum. Finally, the authors refer to infection with Ascaris lumbricoides, Clonorchis sinensis, and Trichuris trichiura in both Korea and China for at least 2,300 years.

Matsui, Kanehara \& Kanera (2003) tell the history of paleoparasitology in Japan, especially dedicated to the study of latrine sediments and coprolites. The studies began with the return of Akira Matsui from England, where he learned paleoparasitological techniques from Andrew Jones at the University of York. The initial work was difficult, since residues from excavations were not kept, particularly the content of latrines and other waste found in archaeological sites, discarded from the objects before the latter were exhibited. However, Akira Matsui was called in to participate in the excavations at the Fujiwara Palace in the late 1980s, where he managed to collect samples from cesspits and latrines and took them for testing by other specialists. The dates corresponding to the excavations ranged from 600 to 710 AD. Parasite finds included Ascaris lumbricoides, Trichuris trichiura, Metagonimus yokogawai, Clonorchis sinensis, and Taenia eggs, indicating the eating habits of the time, especially referring to parasites transmitted by ingesting uncooked fish. The authors comment on the introduction of $A$. lumbricoides in Japan, coinciding with the introduction of rice-growing by the Chinese.

Donoghue et al. (2004) describe the history of tuberculosis with the use of molecular biology techniques, recovering genetic material from the bacillus in archaeological remains. They refer particularly to the Middle East, but review material from the entire planet. They use the term "paleomicrobiology", a new discipline, to refer to the study of bacteria in archaeological material. However, if one adopts the broader definition of parasite (Ferreira \& Araújo, 2005) as we do in this book, the terms "paleoparasitology" and "paleomicrobiology" mean the same thing. Donoghue et al. (2004) discuss the results obtained with molecular biology techniques and the limitations for the recovery of genetic material from parasites in archaeological remains. They comment on the origin of infection with Mycobacterium tuberculosis, ruling out the hypothesis that it was associated with the domestication of bovines some 10 to 15 thousand years ago. Their studies conclude that the modern strains of Mycobacterium tuberculosis emerged some 15 to 20 thousand years ago, before spreading throughout the globe. The authors highlight the need for more studies, especially in archaeological material from long-distance maritime voyages.

Seo et al. (2007) describe parasite findings in the mummified body of a Korean child from the $15^{\text {th }}$ century, considered the medieval period, which includes the $10^{\text {th }}$ to the $19^{\text {th }}$ centuries, corresponding to the Joseon dynasty. The search for intestinal helminths was conducted in coprolites removed from the rectum with the use of an endoscope and rehydrated with the conventional method using trisodium phosphate aqueous solution. The results showed Trichuris trichiura, Ascaris lumbricoides, and Clonorchis sinensis eggs, while the first species called attention because it was far more numerous than the other two.

Paleoparasitology in Asia particularly relevant to paleoparasitological data in the Americas, since the theories and knowledge on the prehistoric peopling of the New World show close links between populations of Asian origin and those that gave rise to the various American population groups. Paleoparasitology has made a relevant contribution to studies of prehistoric migrations to the Americas, as discussed several times in other chapters of this book. Sorenson \& Johannessen $(2004,2009)$ collect evidence of transoceanic contacts with an emphasis on transportation of plant species, but also considering intestinal parasites (Araújo, Ferreira \& Confalonieri, 1981). They refer to species of helminths, bacteria, viruses, fungi, and what they call micropredators. They also show 
the sharing of at least six different animal parasite species between Asia and the Americas, providing purported evidence of intentional maritime voyages from one continent to the other.

However, the evidence obtained from plant species outnumbers all the other forms of evidence. The authors quote Stephan Jay Gould (1994) when he states, "A species will arise in a single place and time." Sorenson \& Johannessen (2004) comment that when a species is found in the Americas before the arrival of Columbus in 1492 and early $16^{\text {th }}$-century navigators, as well as in other parts of the world like Oceania, Asia, Europa, or Africa, this requires an explanation. They rule out (as implausible) the possibility of species having been carried by the wind or other natural mechanisms. They list 98 species of plants which they consider decisive evidence of organisms that existed in both the Western and Eastern hemispheres before Columbus' first voyage.

The evidence comes from macrofossils, pollen, phytoliths, and DNA, showing the presence, on both continents, of plant species in locations other than their places of origin. They also use information from ancient texts and artistic depictions than can be defined reliably down to the species level.

One of the issues explored by Montenegro, Avis \& Weaver (2007) is the introduction of sweet potato (Ipomoea batatas), originally from South America and probably domesticated around 4,000 years ago, into Polynesia, possibly by accidental voyages. In this case the direction would have been the reverse, from the Americas to Asia, which could also have led to the circulation of parasites. These seafaring voyages have been reconstructed with modeling and simulations, in keeping with the probabilities of shorter voyages, more feasible for the sailors' survival.

The relations between Asian and American peoples in the past remain to be elucidated, and many attempts have been made. Montenegro et al. (2006a) recreate transoceanic voyages and estimate the fastest times from one continent to the other, whether across the Pacific or the Atlantic. This reconstitution is still under way. Studies in bioarchaeology, especially with the contribution by paleoparasitology, combined with other sciences such as paleoclimatic modeling (Montenegro et al., 2006b), are one of the surest ways to obtain a realistic picture of the past.

Much remains to be explored in paleoparasitology on the Asian continent, as the path for prehistoric migrations to the Americas. Human groups left Asia with their parasites. Many parasites were able to cross the cold, icy Bering Bridge, at least 15,000 years ago.

However, other parasites died along the way because they were unable to maintain their life cycle in the harsh climate between Siberia and Alaska (Araújo et al., 2008). This issue alone has been extensively explored but still sparks the curiosity of various researchers, including parasitologists, archaeologists, bioanthropologists, and others. Yet other scenarios remain to be elucidated, including the introduction of parasites from the continent to the islands, as discussed by Matsui, Kanehara \& Kanehara (2003). and the changes in parasitism found in archaeological sites in Korea (Shin et al., 2009a). In addition, new techniques in electron microscopy and the resulting morphological detail allow identifying food remains and parasite species with increasing precision (Shin et al., 2009b). 


\section{REFERENCES}

ARAÚJO, A.; FERREIRA, L. F. \& CONFALONIERI, U. A contribution to the study of helminth findings in archaeological material in Brazil. Revista Brasileira de Biologia, 41: 873-881, 1981.

ARAÚJO, A. et al. Parasites as probes of human migrations? Trends in Parasitology, 24: 112-115, 2008.

BAKER, B. J. \& ARMELAGOS, G. J. The origin and antiquity of syphilis. Current Anthropology, 29: 703-737, 1988.

CHEN, X.T. Medical parasitology. Public Health Publications (Beijing, China), s/n: 155-156, 1956.

CHEN, L. B. \& HUNG, T. Scanning electron microscopic view of parasitic worm ova in ancient corpse. Acta Chinese Academy of Medical Science, 3: 64-65, 1981.

CHENG, T. O. Glimpses of the past from the recently unearthed ancient corpses in China. Annals of Internal Medicine, 101: 714715, 1984.

DONOGHUE, H. D. et al. Tuberculosis from prehistory to Robert Koch as revealed by ancient DNA. Lancet Infectious Diseases, 4: 584-592, 2004.

DUBININA, M. N. [The nematode Alfortia edentatus (Looss 1900) from the intestine of an upper Pleistocene horse]. Parazitologyia, 6: $441-443,1972$.

FERREIRA, L. F. \& ARAÚJO, A. Parasitismo, doença parasitária e paleoparasitologia. In: CoURA, J. R. (Org.). Dinâmica das Doenças Infecciosas e Parasitárias. Rio de Janeiro: Guanabara Koogan, 2005.

FREEDMAN, A. \& PROUST, A. Nothing new under the sun. Medical Journal of Australia, Apr. 8: 392, 1978.

GOULD, S. J. In the mind of the beholder. Natural History, 103: 14-23, 1994.

HALL, A. J. A Lady from China's past. National Geographic Magazine, 145: 660-681, 1974.

HAN, E. T. et al. Detection of parasite eggs from archaeological excavations in the Republic of Korea. Memórias do Instituto Oswaldo Cruz, 98: 123-126, 2003.

HERSHKOVITZ, I. et al. Unusual pathological condition in the lower extremities of a skeleton from ancient Israel. American Journal of Physical Anthropology, 88: 23-26, 1992.

HU, S.Y. Study on the parasite eggs in an ancient corpse from Zhangguo Chu Tomb n. 1 in Mashan brick-field of Jiangling County, Hubei. Chinese Journal of Parasitology and Parasitic Diseases, 2: 8, 1984.

LE BAILLY, M. et al. New finding of Giardia intestinalis (Eukaryote, Metamonad) in Old World archaeological site using immunofluorescence and enzyme-linked immunosorbent assays. Memórias do Instituto Oswaldo Cruz, 103(3): 298-300, 2008.

LIANGBIAO, C. \& TAO, H. Scanning electron microscopic view of parasite worm ova in an ancient corpse. Acta Academiae Sinicae, 3: 64-65, 1981 .

MATSUI, A.; KANEHARA, M. \& KANEHARA, M. Paleoparasitology in Japan: discovery of toilet features. Memórias do Instituto Oswaldo Cruz, 98, supl. 1: 127-136, 2003.

MIKHAILOV, M. I.; KUZNETSOV, S. V. \& ZHDANOV, V. M. Electron microscopy of the intestinal content of a mammoth. The Lancet, 2: 111-112, 1984.

MITCHELL, P. D. Leprosy and the case of King Baldwin IV of Jerusalem: mycobacterial disease in the crusader states of the $12^{\text {th }}$ and $13^{\text {th }}$ centuries. International Journal of Leprosy and Other Mycobacterial Diseases, 61: 283-291, 1993.

MITCHELL, P. D. \& STERN, E. Parasitic intestinal helminth ova from the latrines of the $13^{\text {th }}$-century crusader Hospital of St. John in Acre, Israel. In: PALEOPATHOLOGY ASSOCIATION, BIENNIAL EUROPEAN MEETING, 13, 2000, Chieti, 2000.

MØLLER-CHRISTENSEN, V. Leprosy, echinococcosis, and amulets: a study of medieval Danish inhumation. Medical History, 15: 260-267, 1971. 
MONTENEGRo, A.; AVIS, C. \& WEAVER, A.J. Modelling the pre-historic arrival of the sweet potato in Polynesia. Journal of Archaeological Science, 35: 355-367, 2007.

MONTENEGRO, A. et al. Modelling pre-historic transoceanic crossings into the Americas. Quaternary Science Reviews, 25: 1.323$1.338,2006 \mathrm{a}$.

MONTENEGRO, A. et al. Parasites, paleoclimate and the peopling of the Americas: Using the hookworm to time the Clovis migration. Current Anthropology, 47: 193-200, 2006b.

MORIMOTO, I. Buddhist mummies in Japan. Acta Anatomica Nipponica, 68: 381-398, 1993.

RAO, V. V.; VASULU, T.S. \& RECTOR BABU, A. D. W. Possible paleopathological evidence of treponematosis from Megalithic site at Agripalle, India. American Journal of Physical Anthropology, 100: 49-55, 1996.

SHIN, D. H. et al. Finding ancient parasite larvae in the sample from a male living in the late $17^{\text {th }}$ century Korea. The Journal of Parasitology, 95: 768-771, 2009a.

SHIN, D. H. et al. Scanning electron microscope study of ancient parasite eggs recovered from Korean mummies of the Joseon Dynasty. The Journal of Parasitology, 95(1): 137-145, $2009 \mathrm{~b}$.

SEO, M. et al. Paleoparasitological report on the stool from a medieval child mummy in Yangju, Korea. The Journal of Parasitology, 93: 589-592, 2007.

SORENSON, J. L. \& JOHANNESSEN, C. L. Scientific evidence for pre-Columbian transoceanic voyages to and from the Americas. SinoPlatonic Papers 133, 2004. Available at <http://farms.byu.edu/publications/transcripts/?id=154>. Accessed on Sept.20, 2010.

SORENSON, J. L. \& JOHANNESSEN, C. L. World trade and biological exchanges before 1492. Available at: <iUniverse.com>. Accessed in 2009.

SU, T. C. A scanning electron microscopic study on the parasite eggs in an ancient corpse from a tomb of Chu dynasty, the Warring State, in Jiangling County, Hubey Province. Journal of Tongji Medical University, 7: 63-64, 1987.

VREELAND JR., J. M. \& COCKBURn, A. Mummies of Peru. In: COCKBURN, A. \& COCKBURN, E. (Eds.). Mummies, Disease and Ancient Cultures. Cambridge: Cambridge University Press, 1980.

TAYLES, N. Anemia, genetic diseases and malaria in prehistoric Mainland Southeast Asia. American Journal of Physical Anthropology, 101: 11-27, 1996.

WEI, O. Internal organs of a 2,100 year old corpse. The Lancet, 7839: 1198, 1973.

WEI, D. X. et al. Parasitological investigation on the ancient corpse of the western Han dynasty unearthed from tomb $\mathrm{n}$. 16 on Phoenix Hill in Jiangling County. Acta of the Academy of Medicine Wuhan, 1: 16-23, 1981.

WELLS, C. \&, DALLAS, C. Romano-British pathology. Antiquity, 50: 53-55, 1976.

WITENBERG, G. Human parasites in archaeological findings. Bulletin of the Israel Exploration Society, 25: 86, 1961.

WU, Z.; GUAN, Y. \& ZHOU, Z. Study of an ancient corpse of the Warring States period unearthed from Tomb n. 1 at Guo-Jia Gang in Jingmen City (a comprehensive study). Journal of the Tongji Medicine University, 16: 1-5, 10, 1996.

YANG, W. Y. et al. Parasitologic investigations on the ancient corpse of Chu dynasty the warring states unearthed from the Ma-zhuan tomb n. 1, Jiangling County. Acta of the Academy of Medicine Wuhan, 14: 43-45, 1984.

ZIAS, J. \& MUMCUOGLU, K. Y. Case reports on paleopathology: calcified hydatid cysts. Paleopathology Newsletter, 73: 7-8, 1991. 


\title{
24
}

\section{The Findings in Oceania}

\author{
Luiz Fernando Ferreira • Adauto Araújo
}

$\mathrm{O}$

f all regions of the world, Oceania has the least research on parasites in archaeological remains. A few reports have discussed paleopathological aspects, including the description of lesions attributed to bacteria, especially Mycobacterium leprae.

For example, Trembly (1994) discusses the antiquity of Mycobacterium leprae infection in Micronesia. In a note published in the Symposium of the Society of Paleopathology, he discusses his role in examining 700 pre-Hispanic skeletons on the Mariana Islands. The author identified pathognomonic lesions of leprosy in eight individuals, confirmed by specialists, thereby attesting to the oldest cases of the disease in this region of the world.

One of the first articles on intestinal parasites discusses the finding of Ascaris lumbricoides eggs in coprolites from New Zealand (Andrews, 1979), dated from 150 to 200 years before present (BP). The author comments that no information existed on parasites that the Maori might have introduced into New Zealand, but highlights that such data could be obtained by examining material collected from archaeological sites. Andrews (1979) reports finding Ascaris eggs in human coprolites, the measurements of which were consistent with eggs of species $A$. lumbricoides ( $50 \mu \mathrm{X} 35 \mu$ ), dated to 150-200 BP. These would purportedly show that the Maori brought this parasite from their original homeland to New Zealand. However, his assertion is not definitive, since the dates are very close to the first contact with Europeans.

Andrews (1976a) had commented previously on these finds, discussing parasitic infections among the Maori prior to European contact and emphasizing the relevance for knowledge of infections on the continent, both introduced and autochthonous. He divides the parasitic infections recorded in New Zealand into three types: those he considers typical of humans, those transmitted from animals to humans, and those typical of humans, but introduced by humans from other continents during their migratory movements.

The author separates data on native populations from those referring to groups of European origin, emphasizing findings of Enterobius vermicularis and Trichuris trichiura as autochthonous, i.e., prior to European contact. However, the evidence is not the same for infection with Ascaris lumbricoides, found at much lower prevalence rates in the 
native population and apparently more common among individuals of European origin, thus raising the hypothesis that ascariasis was introduced during the European period.

Infestation with head lice (Pediculus humanus capitis) appears to have been common in the past, although body lice (Pediculus humanus corporis) were no longer found. This assertion on head lice (Andrews, 1976b) is based on the historical record of Joseph Banks, in his diary during the voyage with Captain Cook, from 1768 to 1771 . In the diary, Banks reports his alarm at the amount of lice, which he had never seen on anyone before meeting the native Maori. This must have been truly amazing, given that lice on human hair or on the wigs of elegant Europeans from the previous centuries were actually quite common. Such infestation even led to the use of little hooks that allowed people to scratch their wigs and their own hair. Andrews (1976a) suggests that malaria, hookworm infection, and filariasis (Loa loa and Wuchereria bancrofti) were introduced by immigrants.

These and other parasitic infections suggest interpretations on the possible origins of such infections in New Zealand or elsewhere, with repercussions for interpretations on prehistoric migrations and the peopling of other continents, especially the Americas (Araújo, Ferreira \& Confalonieri, 1981).

The study by Andrews (1976a) is especially important because it explores clues on the presence of parasitic infections in the region's indigenous peoples and those introduced by immigration, although it does not explore the paleoparasitological record. Importantly, the author again reported finding Ascaris lumbricoides eggs in human coprolites (Andrews, 1979), but dated to post-European contact.

Goldsmid (1984) takes a historical perspective to extend the discussion on diseases and vectors introduced into Australia, but without the proper basis in paleoparasitological evidence.

Don Brothwell (1976) cites the descriptions by Stewart \& Spoehr (1952) of diseases in skeletons dated to 800 $\mathrm{AD}$, and specifically the presence of yaws in prehistoric Oceania. The author reports on new evidence of this disease prior to the arrival of Europeans. Although the bones were mixed together, it was possible to identify at least 169 individuals. Of these, at least $2 \%$ had lesions consistent with treponematosis. Brothwell (1976) thus concluded that when Australia was discovered, Treponema infection already circulated among the Aborigines, as well as in other areas of the Pacific. However, there is no evidence of syphilis. The researcher mentions the hypothesis (raised by other researchers and based on the existence of native words) of the introduction of yaws by Portuguese traffickers of African slaves. However, the paleopathological findings confirm the antiquity of yaws prior the arrival of Europeans.

According to Talhari \& Talhari (2005), yaws emerged in Africa with Homo erectus around 1.5 million years ago. This antiquity is confirmed by findings in skeletons from Micronesia, in which Trembly (1998) shows a high prevalence of yaws (17 to $27 \%$ of adults and $10 \%$ of children with bone lesions), dating to around 800 AD. With these findings, the author challenges the theory that treponematosis was carried from the New World to Europe by Nordic navigators, showing that it was already present in Oceania long before these contacts. The results corroborate previous findings by Hope, Goldson \& Allen (1983), who demonstrated bone lesions typical of anemia, leprosy, and yaws, dated to 1,000 to $300 \mathrm{BP}$.

Clark \& Kelly (1993) discuss the implications of relations between the genetics of gamma globulin, the paleoenvironment, malaria, natural selection, and prehistoric occupation of the Bismarck Archipelago in Oceania. Around 3,600 years ago, prehistoric groups from the region developed a style of pottery called Lapita, which later spread across Melanesia. The archaeological sites are located mainly along the coast of endemic malaria areas.

The article's discussion centers on the natives' resistance to Plasmodium infection, resistance which is not found in groups from other regions. The arguments are based on linguistics and human biology, showing that in fact 
Lapita pottery originated among Austronesian (Australo-Asian) speakers. The authors thus reach the conclusion that multidisciplinary studies provide mutually complementary data to support or refute theories on humankind's past.

One obligatory citation is a Master's thesis, innovative but difficult to access, since the author (Byrne, 1973) never published any further work on coprolite analysis. Byrne compares diets on the basis of food remains in human and dog coprolites from the North Island of New Zealand. Although the thesis failed to achieve the objective of identifying all the plant remains consumed by humans, the animal bones in the dog coprolites were diagnosed, showing a wide diversity in their diet.

One interesting aspect of paleoparasitological data in Oceania (besides producing knowledge on infections in native populations prior to outside contact) is their possible relationship to maritime migrations or contacts with prehistoric American peoples. Fonseca Filho (1930) called attention to this issue when studying and comparing parasitic infections in native peoples that were relatively isolated from contact with colonizers in the Americas, Asia, and Oceania. One example he studied was Tinea imbricata, a lesion caused by Trichophyton concentricum, called tokelau in Asia and Oceania and chimberê by Brazilian indigenous peoples. When European navigators reached the islands of Oceania and the coast of the Asian continent, they were impressed by the lesion's peculiar appearance. There, tokelau is known by various names in different dialects, thus attesting to its origin in the region, according to the author.

Fonseca Filho (1930) studied a Brazilian indigenous people called Purú-Borá living in the hinterlands of Mato Grosso and at the time still quite isolated from contact with any other human group. Lesions characteristic of Tinea imbricata were found in all fifty members of the group, from children to the oldest adults. The Purú-Borá called the disease chimberê, characterized by circinate, confluent, scaly, and pruritic plaques with marked achromia (clinical diagnosis should be accompanied by direct mycological examination and culture).

The two groups of diseases, tokelau and chimberê, display a well-defined geographic distribution. Fonseca Filho (1930) explains their existence in two such distant locations based on prehistoric human migrations from Oceania to South America. He was the first author to raise the hypothesis of transpacific migrations of Asian peoples to the Americas, based on the absence of infection with Ascaris lumbricoides among isolated tribes in South America and Oceania. This argument is based on negative data: the fact that the most isolated human groups of the two continents are not parasitized by this helminth, one of the most common in the entire world, although other intestinal parasites (hookworms, see Chapter 8) were introduced by maritime migrations, would serve as counter-proof of this contact.

However, this negative counter-proof proved erroneous when the molecular paleoparasitological data began to show that infection with Ascaris lumbricoides, although rare, already existed in pre-Columbian America (Leles et al., 2008).

The case of malaria also merits reflection. Human infection with genus Plasmodium is believed to have occurred first in Africa, spreading thence to other regions with favorable environmental conditions, including vectors. Humans are parasitized by three exclusive (thus stenoxenic) species: Plasmodium vivax, Plasmodium falciparum, and Plasmodium ovale. A fourth species, Plasmodium malariae, is shared by humans and chimpanzees.

In Africa, Plasmodium vivax infection led to selection of the Duffy-negative genetic trait, which makes carriers resistant to the infection. Other genetic factors affect susceptibility to malaria. Heterozygous individuals for abnormal hemoglobin S have benign infections from Plasmodium falciparum, since the parasite is unable to complete its cycle in sickle red cells. In some populations in malaria-endemic areas, natural selection increases the frequency of genetic traits that protect individuals, making them more resistant to infection (Rey, 2008). 
The discussion by Clark \& Kelly (1993) concerning malaria resistance in regions of Oceania (as occurred in regions of the Mediterranean) raises issues on the dispersal of Plasmodium species that parasitized prehistoric humans. The paths travelled by migrants must always have crossed regions with vectors, which are indispensable for completing the cycle and maintaining the parasite's transmission. However, maintenance of the disease in populations led to changes and to the selection of individuals with genetic traits capable of maintaining the infection with low parasitemia.

The paths of malaria in prehistoric populations can also be followed by the genetic characteristics imposed by the parasite-host relationship, as long as properly recovered from the archaeological material.

Although few articles have reported parasite finds in archaeological material throughout the vast territory of Oceania, there are interesting cases such as the description of ocular lesions typical of trachoma, resulting from infection with Chlamydia species (Webb, 1990). Euber, Spencer \& Cook (2007) discuss the occurrence of trachoma in prehistoric populations in North America and conduct a review of other findings, citing Webb (1990) on trachoma in aboriginal populations in Australia, on which they based their description of the lesions.

Another case is that of elephantiasis, caused by the filaria Wuchereria bancrofti. The disease is known for lesions in the lymphatic circulation, leading to deformity of the affected parts, especially the lower limbs, but also occasionally affecting other areas of the body. Laurence (1968) discusses the diagnosis of elephantiasis among Polynesians at the time of the arrival of the first explorers and the way Wuchereria bancrofti infection was introduced into Polynesia.

Captain Abel Tasman described lesions in inhabitants of the region in 1643, followed by Captain Cook more than a hundred years later. The characteristic swelling (edema) of the limbs was known as "the curse of St. Thomas". Laurence (1968) especially discusses filarial transmission by vectors from genera Aedes and Culex, showing that the parasite circulated both during the day and at night, according to presence of the respective mosquito species.

Paleoparasitology has made comparatively little progress thus far in Oceania, and many fascinating aspects remain to be studied.

\section{REFERENCES}

ANDREWS, J. R. H. The parasitology of the Maori in pre-European times. New Zealand Medical Journal, 84: 62-65, 1976a.

ANDREWS, J. H. R. Parasites of man in New Zealand: a review. New Zealand Medical Journal, 3: 59-67, 1976b.

ANDREWS, J. H. R. Ascaris egg in coprolite material. New Zealand Medical Journal, 89: 274, 1979.

ARAÚJO, A.; FERREIRA, L. F. \& CONFALONIERI, U. A contribution to the study of helminth findings in archaeological material in Brazil. Revista Brasileira de Biologia, 41: 873-881, 1981.

BROTHWELL, D. R. Further evidence of treponematosis in a pre-European population from Oceania. Bulletin of Historical Medicine, 50: 435-442, 1976.

BYRNE, D. R. Prehistoric Coprolites: A Study of Human and Dog Coprolites from Prehistoric Archaeological Sites in the North Island of New Zealand. MA Thesis, University of Auckland, 1973.

CLARK, J. T. \& KELLY, K. M. Human genetics. Paleoenvironment and malaria: relationships and implication for the settlements of Oceania. American Anthropologist, 95: 612-630, 1993.

EUBER, J. K.; SPENCER, S. D.; COOK, D. C. Incidence of trachoma in two prehistoric Lower Illinois River Valley populations. Paleopathology Newsletter, 138: 9-12, 2007.

FONSECA FILHO, O. Afinidades parasitológicas e clínicas sobre o Tokelau da Azia e da Oceania e o Chiberê dos indígenas de MatoGrosso. Revista Médico-Cirúrgica do Brasil, 38: 281-291, 1930. 
FONSECA FILHO, O. Parasitismo e Migrações Humanas Pré-Históricas. Rio de Janeiro: Mauro Familiar Editor, 1972.

GOLDSMID, J. M. The introduction of vectors and disease into Australia: an historical perspective and present day threat. In: LAIRD, M. (Ed.). Commerce and the Spread of Pests and Disease Vectors. New York: Praeger, 1984.

HOPE, G. S.; GOLSON, J. \& ALLEN, J. Palaeocology and prehistory in New Guinea. Journal of Human Evolution, 12: 37-60, 1983.

LAURENCE, B. R. Elephantiasis and Polynesian origins. Nature, 219: 561-563, 1968.

LELES, D. et al. Molecular paleoparasitological diagnosis of Ascaris sp. from coprolites: new scenario of ascariasis in pre-Columbian South American times. Memórias do Instituto Oswaldo Cruz, 103: 106-108, 2008.

REY, L. Parasitologia Médica. Rio de Janeiro: Guanabara Koogan, 2008.

STEWART, T.D. \& SPOEHR, A. Evidence on the paleopathology of yaws. Bulletin of Historical Medicine. 26(6): 538-553, 1952.

TAlHARI, S. \& TAlHARI, C. Bouba. In: COURA, J. R. (Ed.). Dinâmica das Doenças Infecciosas e Parasitárias. Rio de Janeiro: Guanabara Koogan, 2005.

TREMBLY, D. On the antiquity of leprosy in Western Micronesia. Papers on Paleopathology, $21^{\text {st }}$ Annual Meeting of the Paleopathology Association, Denver, Colorado. Paleopathology Newsletter, 86, suppl.: 11, 1994.

TREMBLY, D. L. Treponematosis in pre-Spanish Western Micronesia. International Journal of Osteoarchaeology, 6: 397-402, 1998.

WEBB, S. G. Prehistoric eye disease (trachoma?) in Australian aborigines. American Journal of Physical Anthropology, 81: 91100, 1990. 


\title{
25
}

\section{The Findings in Africa}

\author{
Adauto Araújo • Luiz Fernando Ferreira
}

$\mathrm{I}_{\mathrm{H}}^{\mathrm{n}}$

Africa, there are no established research groups in paleoparasitology with researchers from the continent itself.

However, the immense treasures from Africa's ancient civilizations have always attracted researchers from around the world. There is a longstanding tradition of international research groups dedicated to the study and preservation of mummies and other ancient relics from Egypt and elsewhere in Africa (Ikram \& Dodson, 1998). With its Egyptian mummies, Africa has attracted scientists to investigate evidence of health and disease revealed in preserved bodies, both in the tombs of nobles and pharaohs and in the cemeteries where poor commoners were buried. In the latter corpses (buried without any artificial mummification), climate was the main determinant of preservation.

The first published paleoparasitology study usually cited is that of Ruffer (1910a), who found Schistosoma haematobium eggs in histological sections of kidneys from two mummies dated 1250-1000 BC, out of a total of six examined. The article refers to the medical record known as the Ebers Papyrus, which mentions hematuria, the most characteristic symptom of $S$. haematobium infection.

Although the eggs were calcified, they were perfectly identifiable due to the spicule on the extremity. The diagnosis was confirmed by Patrick Manson and Arthur Looss, famed early $20^{\text {th }}$-century experts. Ruffer (1910b) further describes the histological techniques for recovering the mummified tissue's consistency, in order to allow the use of paraffin sections and specific staining. The following year, Ruffer \& Ferguson (1911) published a study on a possible case of smallpox in a mummy from the $20^{\text {th }}$ Egyptian dynasty, the diagnosis of which was later challenged by Unna (Lowenstein, 2004).

Egyptian papyri mention pathological conditions that can be attributed to various parasitic diseases. SánchezMartín et al (2005) discuss aspects of the Ebers Papyrus, which mentions hematuria and other clinical manifestations interpreted as resulting from Schistosoma haematobium infection, already mentioned by Armand Ruffer. They quote a phrase from the Book of the Dead in which the followers of Ra drink the blood of his phallus, presumably a form of religious adoration. The pharaoh, considered a god, suffered from hematuria, which was not recognized as a disease at the time, and drinking such blood would be a way of worshipping him (Hoeppli, 1972). 
Before Ruffer (1910a), Hope (1834) had described arthropods found during the examination of Egyptian mummies. Later, Mitchell (1900) described a case of poliomyelitis in an Egyptian mummy, with the description of typical lesions.

More than eight thousand mummified bodies were found during construction of the Aswan Dam in Egypt in the early $20^{\text {th }}$ century. Many were studied, but only superficially, as commented by Moodie (1923). The dam construction and numerous mummies fueled even greater interest in mummy studies, since most were commoners whose families could not afford to embalm their relatives' corpses as the nobles and priests did.

Moodie (1923), editor of the anthology of articles by Armand Ruffer published shortly after his death (Ruffer, 1921), published his own studies of Egyptian mummies, describing lesions and interpreting the findings. The book is recommended reading for all those interested in paleopathology. Another recommended book is that of paleopathologist Theodore A. Sandison, also on diseases in Ancient Egypt (Sandison, 1959).

Aidan Cockburn $(1963,1967)$ published two editions of his book on the origin and evolution of parasitic diseases, highlighting a section on Egypt and Nubia (now Sudan). Concerning the origin of human parasites, we should always recall that the ancestral humans came from Africa, and with them their parasites, many of which were inherited from ancestral primates. Others were acquired over the course of their evolution (Araújo et al., 2003). As emphasized by Cockburn (1963), this makes the study of parasites in archaeological remains one of the scientific fields most capable of providing data on the origin and evolution of parasitic infections and their dispersal with human hosts (as discussed in Chapter 1, since 1979 this field has been known as paleparasitology, according to the term first used by Ferreira et al, 1979).

Morse, Brothwell \& Ucko (1964) studied tuberculosis in Ancient Egypt, referring to evidence from the Old and New Worlds. At the time their studies were published, reference was made to the low reliability of American cases, while the Egyptian mummies deposited in museums since the early $20^{\text {th }}$ century display typical lesions of tuberculosis, showing irrefutably that the disease existed in Ancient Egypt. The authors used human remains (bones and mummified bodies) and texts and artistic works (frescos and sculptures) to prove their findings.

Møller-Christensen \& Hughes (1966) and Møller-Christensen (1967) described cases of leprosy in Egyptian mummies, in pioneering studies in archaeological remains (mummified bodies and bone lesions) on infection and disease caused by Mycobacterium leprae.

Giacometti \& Chiarelli (1968) published studies on lesions and other dermatological characteristics of Egyptian mummies. The mummies belonged to the pre-Dynastic Period, dated to $4000 \mathrm{BC}$ (or 6,000 years before present). Although they do not refer to parasites, they include a review of Egyptian embalming techniques and the conclusion that the dry climate was decisive for preserving histological structures. The authors recall that studies on diseases in archaeological remains data as far back as medieval times, but that it was Johan Czermack in 1852 who first obtained satisfactory histological preparations of tissues from Egyptian mummies (although they consider Armand Ruffer the pioneer). The article comments on the resistance of skin tissue to the elements and time, highlighting the preservation observed in histological sections. One of the most interesting finds was well-preserved red blood cells, providing a source for other authors to search for vestiges of parasitism by Plasmodium sp., as discussed in greater detail below.

Hoeppli (1969) wrote on the origins of infectious diseases in Africa and their subsequent spread to other continents with the slave trade. The book, describing each parasite in detail, is essential reading for studies on the origin and evolution of parasitic infections.

The 1970s witnessed growing interest in diseases identified during autopsies of Egyptian mummies, coinciding with the creation of the Paleopathology Association in 1973, led by Aidan Cockburn, Eve Cockburn, Robin A. Barraco, 
William, H. Peck, and Theodore A. Reyman. Mummified bodies in museums were studied by multidisciplinary teams, and various articles were published.

The society grew and prospered, and since the first year it began publishing a scientific journal, the Paleopathology Newsletter, convening members from all over the world and holding biannual congresses in the United States, Europe, and South America.

Harrison (1973) published a letter with comments on some articles, referring to possible lesions in one of the most famous mummies from Egypt, then on exhibit at the British Museum. It was the body of Tutankhamun, which the author had the opportunity to study, ruling out any possibility of suprarenal tumor, Klinefelter syndrome, Wilson disease, or flat feet, as suggested by other authors. Gray (1973) also commented on the purported gynecomastia depicted in statues and paintings of Akhenaten and Tutankhamun (father and son, respectively). Although neither author referred to parasitic infections, this debate sparked several letters and articles due to the exhibit in the British Museum.

Lewin et al. (1974) described a multidisciplinary autopsy performed on an Egyptian mummy in the Royal Ontario Museum, dated 3200 BP. They focused attention on the hepatic lesions, which they attributed to what they called cirrhosis resulting from schistosomiasis.

Cockburn et al. (1975) described in detail the third multidisciplinary study in an Egyptian mummy dated to circa $170 \mathrm{BC}$ and the finding of Ascaris lumbricoides eggs. The study is a complete guide to the stages needed for optimum yield from archaeological material. The mummified body was called PUM II, then on deposit in the Philadelphia Art Museum. The same mummy was the object of various scientific articles, described further below.

Reyman (1976) described as schistosomal cirrhosis (currently hepatic fibrosis) the lesions he found in an Egyptian mummy dated 3200 BP, in addition to Taenia eggs found in the intestine. He and colleagues conducted histopathological analyses in this same Egyptian mummy, called PUM-2 (or PUM II), donated for autopsy by the Pennsylvania University Museum (hence its denomination) to the Philadelphia Art Museum (Reyman, Barraco \& Cockburn, 1976). This autopsy was performed at the Wayne State University School of Medicine by a multidisciplinary team as part of a symposium entitled Death and Disease in Ancient Egypt. Although of unknown origin, it was identified as a man approximately 35 to 40 years of age who had lived in the Ptolemaic period around 170 BC. A series of lesions had been identified previously by radiological examination, including Harris lines, associated with periods of food restriction in the individual. In addition to histopathological details like atheromatous plaques and a diagnosis of silicosis, the authors found embryonated eggs of Ascaris lumbricoides, thus demonstrating the antiquity of infection with this parasite in the human host. The eggs were located in the intestinal mucosa, and the larvae in their interior were clearly visible.

The authors call attention to the improvement and development of new histopathological techniques for mummified tissues, also useful in forensic medicine.

In 1977, the Canadian Medical Association Journal published a series of short articles on studies performed by a multidisciplinary team on the Egyptian mummy dated to 3200 BP and called Nakht - ROM I (Royal Ontario Museum). The study included participation by numerous researchers from various specialties, possibly the largest team until then and coordinated by Gerald Hart and Aidan Cockburn, among others (Hart et al., 1977). Rideout (1977) headed the radiological examination. Scott, Horne \& Hart (1977) described the macroscopic anatomy, while Lynn \& Benitez (1977) provided details on the examination of the outer and inner ears. The parasites were described in short articles. Reyman, Zimmerman \& Lewin (1977) reported finding eggs from Schistosoma hematobium and possibly Schistosoma 
mansoni, totally calcified but still showing the remains of the lateral spicule. The researchers found numerous Taenia eggs and discussed whether the infection (according to the species) was from ingesting pork or beef. De Boni, Lenczner \& Scott (1977) recorded finding Trichinella spiralis in histological sections. Horne \& Lewin (1977) used electron microscopy to study histological sections from the mummy, describing Taenia eggs in the intestinal mucosa in great detail. Interestingly, the body was that of a young Egyptian some 14 to 18 years of age whose sarcophagus shows characteristics of inscriptions and a style indicating that he belonged to the working class. He thus represented the majority of the Egyptian people (Millet, 1977).

In another well-known article from the late 1970s, Peter Lewin describes "the mummies that I have known" (Lewin, 1977), a review of the autopsies performed by the group from the Paleopathology Association.

Tapp (1979) recorded the presence of Dracunculus medinensis and Strongyloides in mummies dated from 1000 to 2160 BC, and later described hydatic cyst in a mummy dated 1000 BC (Tapp, 1984).

Dzierzykray-Rogalski (1978) reported a case of leprosy in an Egyptian mummy. He then published a summary of his studies in mummies from the Egyptian Ptolemaic period, dated to the second century before Christ. The author used paleopathology data to support demographic conclusions (Dzierzykray-Rogalski, 1980).

Zimmerman (1979) described a fatal case of tuberculosis in Ancient Egypt in a child approximately 5 years of age, from the Dynastic Period. He adopted the technique recommended by Armand Ruffer for rehydrating and staining mummified tissues and used Ziehl-Neelsen staining to investigate acid-fast bacilli, with positive results both in vertebrae and in blood found in the trachea and lungs. He commented on the lack of evidence of tuberculosis in previous periods and suggested that the infection emerged in the early Dynastic Period some 5,000 years ago, coinciding with the domestication of cattle.

Cockburn et al. (1980) described the autopsy of an Egyptian mummy, with details on the preparation and preservation of the body. This was the mummified body called PUM II, in which the authors found a single parasite egg, seen by various helminthologists. According to the article, helminthologists confirmed that it was an Ascaris egg. Some claimed a definitive diagnosis of an Ascaris lumbricoides egg. The mummy was attributed to the Ptolemaic period, circa $170 \mathrm{BC}$.

Millet et al. (1980) described the mummification of individuals belonging to the non-noble population of Ancient Egypt, showing that the main factor for preservation was always the climate, as opposed to the techniques employed in nobles.

Sandison (1980) commented on parasite findings in Ancient Egypt, referring to the autopsies conducted by the group of paleopathologists from the Paleopathology Association in mummies from museum collections in Canada. He concluded that infections with Ascaris sp., Schistosoma haematobium, and Taenia sp. already occurred in ancient Egyptians.

Armitage \& Clutton-Brock (1981) published a curious article on mummies of domesticated animals, such as cats from Ancient Egypt, belonging to the British Museum. Due to their rarity, we should mention that the Brazilian National Museum (Federal University of Rio de Janeiro) houses several such mummies in its collection. Our team examined samples collected from a mummified cat, with negative results for parasites under light microscopy. However tests for other parasites remain to be performed, such as Toxoplasma gondii, using molecular biology techniques.

Aidan Cockburn (1981) sent a letter to the editor of The Lancet in response to criticism for the book he published with other researchers, Mummies, Diseases, and Ancient Cultures. He commented on the parasite finds described in the book and the care with which the diagnoses had been performed. 
Cockburn's letter especially focuses on parasitic infections in the ancient Nile River Valley, commenting on possible positive malaria results in the autopsy performed on the ROM I mummy, mentioned previously. He provided experts with samples that contained red blood cells, along with other tissues, to investigate the parasite directly or using serological techniques. One such group was that of Guy, Krotosky \& Cockburn (1981). Fluorescent antibody tests were performed at the London School of Hygiene and Tropical Medicine, but proved inconclusive.

Lewin (1982) described a possible case of smallpox in an Egyptian mummy in a paper delivered to the Paleopathology Association during its regular meeting.

Deelder et al. (1990) used serological techniques to diagnose schistosomiasis in Egyptian mummies but did not define the species, whether Schistosoma mansoni or Schistosoma haematobium. The mummy was dated 1198-1150 BC.

Miller et al. (1992, 1993) then published interesting arguments on the paleoepidemiology of schistosomiasis in Africa, based on results with serological techniques and the parasite's eggs found in Egyptian mummies. They examined the two possibilities of infection, by species $\mathcal{S}$. haematobium and $\mathcal{S}$. mansoni, but with positive results only for the former. The authors used tissue from Chilean mummies as the control for serological reactions.

Palma (1991) described nits found on combs from mummies dated to the $5^{\text {th }}$ and $6^{\text {th }}$ centuries AD in Egypt.

Strouhal (1991) published two cases of vertebral tuberculosis, one of which in an adult individual 45 to 55 years of age, found in Egypt and dated to the $21^{\text {st }}$ dynasty. The lesion involved fusion of T9-L1 and deformity of the T8 vertebral body, but with complete healing and adaptation of the spinal column to the resulting position. The other case, described in a young individual (22 to 24 years) dated to the $6^{\text {th }}$ to $10^{\text {th }}$ century AD in Nubia, showed a progressive process involving the entire thoracic and lumbar column.

The author conducted a review of tuberculosis in Egypt and nearby regions, gathering six TB cases depicted in iconographies, 30 in skeletons, and two in mummies, in addition to the two cases described in his article, in both Ancient Egypt and Nubia. The review was presented during the symposium of the Paleopathology Association in Zagreb, Yugoslavia, in 1988, entitled Human Paleopathology, current syntheses and future options, coordinated by Donald Ortner and Arthur Aufderheide.

Buikstra, Baker \& Cook (1993) discussed infectious diseases in Ancient Egypt, possible origins, and dissemination to other regions. They also analyzed the impact of these diseases on the population.

Spigelman \& Lemma (1993) used molecular biology techniques to diagnose TB in Egyptian mummies. Their proposal was innovative, testing bones on the assumption that they could retain residual DNA from the bacillus. The results were promising and opened new paths for molecular paleoparasitology.

Miller et al. (1994) described malaria in Egyptian mummies dated 3200 BC, diagnosing infection with Plasmodium falciparum using immunological diagnostic kits. This highly interesting study opened new doors for research.

Fulcheri et al. (1994) conducted an inventory of Egyptian mummies in Italian museums, with a total of 29 recorded collections. The remains were assessed for their status, and treatments were proposed for their preservation. Analyses were performed in histological sections, with the identification of contaminant fungi and bacteria.

Rafi et al. (1994) described the presence of the leprosy bacillus in mummified bodies, using molecular biology. The material with positive results for leprosy, dated $600 \mathrm{AD}$, was collected at the site of a massacre of Christians perpetrated by Persians in the year 614 .

Horne \& Redford (1995) found evidence of Dracunculus medinensis and infection with Aspergillus fumigatus in mummies of Egyptian nobles dated circa 1450 BC. They also mentioned helminths found in the bladder, with 
morphological characteristics that could not guarantee a specific diagnosis, but whose localization suggested adult Schistosoma haematobium.

Evans et al. (1996) conducted the first studies in coprolites outside of the Egyptian region and opened a new line of studies in paleoparasitology in South Africa. They examined coprolites dated from 12,000 to 9,000 BP, found in the Kruger Cave site, probably inhabited by ancestors of the modern San. The results showed Ascaris sp. and Trichuris sp. eggs and free-living larvae. These finds were very interesting, demonstrating the presence of these parasites in human groups in the sub-Saharan region and the antiquity of the Ascaris-Trichuris association.

Baron, Hummel \& Herrmann (1996) succeeded in extracting sequences of the tuberculosis bacillus from the bones of Egyptian mummies. This team of researchers is known for its pioneering and elegant studies, especially in the field of molecular paleoparasitology. Their study focused on the bones of three individuals with TB lesions using polymerase chain reaction (PCR), with positive results in bones both with and without macroscopic lesions. The authors used controls and showed that the technique can be applied to any blood-borne parasite.

Contis \& David (1996) reported on a collaborative project for historical and epidemiological studies on schistosomiasis in Africa, involving the Medical Service Corporation International of Arlington, Virginia, USA, and the Manchester Egyptian Mummy Project from the University of Manchester, UK.

The project's principal researchers reviewed the 5,000 years of Schistosoma infection in humans and described the proposed methodology, including discovery of evidence in Egyptian mummies, description of the disease in papyri, and the current status of schistosomiasis. The project aimed to retrace the history of infection by Schistosoma species by studying collections of Egyptian material from various institutions around the world.

David (1997) updated the data on the use of new diagnostic technologies in archeological remains, exemplified by the identification of diseases in Egyptian mummies dated as far back as 5000 years before present. The mummies were part of the research project cited in the preceding paragraph. As for the presence of parasites, David referred to evidence of infection with Schistosoma haematobium and Dracunculus medinensis. He also found evidence of hydatic cyst (Echinococcus granulosus) and fragments of adult Fasciola hepatica, besides eggs of Ascaris lumbricoides, Taenia sp., and Schistosoma sp. and possible larvae of Strongyloides sp. The article emphasized that one of the least studied aspects of Egyptian mummies is paleodontology (with the description of dental and periodontal lesions).

Cockburn, Cockburn \& Reyman (1998) published a revised edition of the book Mummies, Diseases, and Ancient Cultures and included a special chapter to update previous studies in Egyptian mummies. The book contains the stateof-the-art from the 1990s and serves as a reference for any study on diseases in the past.

Panagiotakopulu \& Buckland (1999) described ectoparasites associated with Egyptian mummified bodies. These ectoparasites were specimens of Cimex lectularius, known as the common bedbug, which has fed on human blood for 3,500 years and has adapted to human dwellings. This may be the only report of this parasite in archaeological material, which makes it quite interesting, since bedbugs have been found all over the world wherever humans have wandered. In a review of Cimicidae, Forattini (1990) reports that Cimex lectularius currently shows a wide geographic distribution and that it must have parasitized prehistoric cave-dwelling humans, considering that the species originated in the Middle East.

Cerutti et al. (1999) described infection with Plasmodium falciparum in an Egyptian mummy dated 3200 BC. The mummies are from the Museum of Turin, studied by the team headed by Eva Rabino Massa of the University of Turin and president of the World Congress on Mummy Studies in 2003. Applying ELISA (enzyme-linked immunosorbent 
assay), Cerutti et al. compared the positive results in $42 \%$ of the mummies with macroscopic and radiological evidence of bone lesions consistent with severe anemia.

Strouhal \& Horácková (1999) examined a series of bodies with the aim of conducting a demographic survey requested by the team of archaeologists excavating tombs in Saqqara, dated to the New Empire (19 ${ }^{\text {th }}$ and $20^{\text {th }}$ dynasties). The article does not refer to parasites, but only to inflammatory processes in some skeletons, but it is interesting because of its demographic survey, relevant to the epidemiological analysis of infectious diseases.

Rutherford (1999) conducted a retrospective study of schistosomiasis, drawing on descriptions of signs and symptoms in Egyptian papyri. Hieroglyphs, artistic depictions, and various texts on the daily life of young Egyptians demonstrate their constant contact with water, the source of Schistosoma transmission. The author used immunochemistry techniques (indirect fluorescence staining) to test the hypothesis of schistosomiasis in Ancient Egypt, thereby describing cases of infection with Schistosoma mansoni and Schistosoma haematobium in Egyptian mummies and confirming the antiquity of these parasitic infections in African populations.

Zink et al. (2000) described a case of bacteremia in the mummified body of an Egyptian child, found during excavations by the Deutsche Archaeologische Institut, Cairo, Egypt. The mummy dates to the reign of Pharaoh Amenophis II (14241398 BC). The authors extracted genetic material from the marrow of bones previously treated to prevent modern contamination. PCR amplification identified the species of intestinal bacteria Escherichia coli, Frauteria auranta, and Halobacillus spp. The researchers also found genetic material from the bacteria Halobacillus spp., Sporosarcina spp., and Bacillus panthothenicus in the gingival tissue. Few studies have focused on intestinal bacteria in archaeological remains, and this one is particularly outstanding because of the technique's detailed description.

Numm \& Tapp (2000) reviewed the parasitic infections attributed to the tropical climate prevailing in Ancient Egypt, commenting on infections with Strongyloides stercoralis, filariae, and Schistosoma sp. This was a comprehensive review of parasitic infections in Egypt, described in the ancient documents listed in a table, which calls attention to the potential difficulty in translating and interpreting the description of symptoms in words and phrases. The authors traced the history of studies in mummies and skeletons from Egypt, especially those from museum collections in England, highlighting the first study, conducted in Manchester in 1907.

The authors discussed some indications of infections and lesions caused by parasites. The interpretations of texts that may refer to the presence of Dracunculus medinensis were accompanied by two pieces of evidence from autopsies in mummified bodies. The authors further discussed the presence of filariae in histological sections of lower limbs. Next, they commented on schistosomiasis haematobium, the Strongyloides infection described in an Egyptian mummy from the Manchester collection in which the larvae were found in the intestinal mucosa, and other helminth parasites, such as Ascaris lumbricoides, Taenia sp., and Trichinella sp. They reviewed the evidence of malaria, plague, leprosy, tetanus, and other infectious diseases in the papyri, thereby highlighting the importance of multidisciplinary research.

Rabino-Massa et al. (2000) described cases of malaria in Ancient Egypt. They associated the immunoenzymatic assay for malaria with the description of thalassemia and sickle cell disease in the mummies, identifying target cells and sickle cells by microscopy. Of the 80 bodies examined, $42 \%$ of the mummies were positive for malaria, and $61 \%$ presented lesions consistent with severe anemia. Following on these studies, Bianucci et al. (2008) used immunochromatographic and immunohistochemical assays in the skin and muscles to confirm cases of Plasmodium falciparum malaria in Ancient Egypt.

Patrick Horne (2002) described eggs from Enterobius vermicularis and one species of Acanthocephala for the first time in an Egyptian mummy. Horne called attention to the fact that E. vermicularis (pinworm) is probably the 
most ancient helminth parasite in humans, in addition to being very common at present, and that it has rarely been found in Old World archaeological remains. The same is not true in the Americas, where E. vermicularis eggs have been recorded in various archaeological sites. In Egypt, there were no previous reports of the parasite in mummified bodies or coprolites. However, paleoparasitological examination by the author showed very well-preserved eggs of E. vermicularis associated with eggs of Acanthocephala, raising an interesting discussion on the presence of this parasite in the human host (Horne, 2002). The species described in human coprolites resulted from the ingestion of arthropods, the remains of which were seen under microscopy.

Zink et al. (2003) studied tuberculosis in Egyptian mummies based on the characterization of genetic material extracted from bones and soft tissues. This research group had previously described Corynebacterium infection in Ancient Egypt (Zink et al., 2001) and cases of tuberculosis in Ancient Egypt, comparing the results from molecular biology techniques with modern material (Zink, Grabner \& Nerlich, 2002).

Harter (2003) described various parasites found in mummified bodies from Ancient Egypt and Nubia, showing (for the first time with extremely clear microphotographs) eggs of Schistosoma mansoni dated as far back as 6000 BP, with excellent preservation, showing details of the miracidium in the egg's interior. Harter's PhD research included mummified bodies from Nubia, Egypt, Cyprus, and Israel.

The finds date as far back as 6000 BP, including Ascaris sp., Trichuris sp., Enterobius vermicularis, Syphacia obvelata, Toxocara cati, Toxocara canis, hookworm eggs, Taenia sp., Diphyllobothrium sp., Hymenolepis sp., Schistosoma haematobium, Schistosoma mansoni, Fasciola hepatica, Fasciola gigantica, Dicrocoelium sp. eggs, and Pediculus capitis eggs. The eggs found in the mummified bodies, preserved for thousands of years and by various processes, were mostly in excellent state, both externally and internally, as observed in the figures in Harter's PhD dissertation (2003). Many display the embryo perfectly preserved inside the eggs, which can further facilitate relevant studies with molecular biology techniques.

Harter's findings (2003) are very important and merit on-going revisions and confirmations, since they attest to the antiquity of the majority of intestinal helminth infections believed to have originated in Africa. Some of the infections originated in pre-hominids, while others must have been acquired over the course of human evolution. Even so, although not having originated by the phylogenetic route, they may have had an African origin and spread from this continent to other parts of the world.

Harter et al. (2003) described parasites in objects found alongside Egyptian mummies. One case was an embalming rejects jar dated to the $25^{\text {th }}$ dynasty, circa 715 to $656 \mathrm{BC}$, found in 2001 during excavations in the mastaba, or funeral complex, at Akhthetep in Saqqara, studied by Ziegler et al. (1997). Priests used the jars to place the inner organs of individuals being prepared for embalming and later sealed them with packed earth. The jars contained everything from fragments of linen to the fetid liquid resulting from the body's putrefaction. The authors identified some of the contents, examining them separately by rehydrating each one in trisodium phosphate aqueous solution, as with any other sample for paleoparasitological examination. The studies yielded eggs from Ascaris sp. and Taenia sp., probably Taenia saginata due to the Egyptian habit of avoiding pork, according to the article. Both the tapeworm and roundworm eggs contained perfectly preserved embryos; the larva inside the Ascaris egg showed the anatomical structures on the cephalic portion, allowing study in great detail. The same is true for the hexacanth embryo in the Taenia saginata egg, with the aculei visible in the figure published in the article. One of this study's most interesting aspects is the analysis of the embalming rejects jar from the mummification process, yielding such well-preserved parasites. Harter-Lailheugue \& Bouchet (2004) referred again to parasites found in 
funeral settings left by civilizations along the Nile River, from Ancient Egypt to Nubia. The parasites eggs found were: Schistosoma mansoni, Schistosoma haematobium, Taenia sp., Enterobius vermicularis, Ascaris lumbricoides, and Trichuris trichiura. Dates varied from 3500 BP to 1500 AD.

Dittmar \& Steyn (2004) described findings from paleoparasitological assays in seven coprolites of human origin, yielding eggs from Trichuris sp. and Dicrocoelium sp. They discussed the significance of these finds in relation to environmental conditions and interaction between humans and animals in the region. The morphometry of the trichurid egg defines the species as Trichuris trichiura, while the Dicrocoelium species could not be determined. However, its presence in human coprolites from 1900 BP shows the infection's antiquity in the region, probably maintained in a wild cycle and occasionally infecting humans.

Brier (2004) discussed the parasitic infections in Ancient Egypt, reinforcing the motto of the Paleopathology Association: "Mortui Viventes Docent", or "The Dead Teach the Living".

Zink et al. (2004) used molecular biology to distinguish between different Mycobacterium species in mummified soft tissues and bones from Ancient Egypt, dating as far as back 4000 BP. They found Mycobacterium africanum, leading them to challenge the origin of $M$. tuberculosis in the domestication of cattle (according to which the human tuberculosis bacillus had originated from the bovine bacillus, M. bovis).

Lowenstein (2004) provided the following definition: "Mummies, the preserved remains of living beings from former times, bear witness across millennia to the maladies plaguing humankind." His own research focuses on skin diseases detected in mummified bodies from different cultures, involving both the Old and New Worlds, but reviews the entire range of studies focusing on mummified bodies from all over the world, along with an extensive bibliography.

Harter-Lailheugue \& Bouchet (2006) called attention to parasite findings in what they referred to as "atypical elements" from the Lower and Upper Nile, corresponding to Ancient Egypt and Nubia (now Sudan), respectively. The elements were an embalming rejects jars, a shroud, and a canopic package. They found numerous eggs of Schistosoma mansoni, Schistosoma haematobium, Taenia sp., Enterobius vermicularis, Ascaris lumbricoides, and Trichuris trichiura. Dates varied from 2700 BP in Nubia and from 3700 BP to 1500 AD in Egypt.

Zink et al. (2006) described the first case of leishmaniasis found in mummies in Egypt and Nubia. They used molecular biology techniques for amplification of genetic material and successfully identified Leishmania donovani in Ancient Egypt and Christian Nubia. The infection was prevalent in Ancient Egypt, dating as far back as 4000 BP, and was presumably transmitted by trade contact with the Nubians, due to the absence of vectors for the disease in Egypt.

Bruschi et al. (2006) described a case of cysticercosis in an Egyptian mummy, a young woman who died around age 20 during the Ptolemaic Period, between the first and second centuries AD. The lesion was identified by autopsy, confirmed by histological sections. This diagnosis implies pork consumption in Egypt during the Hellenistic period, leading to transmission of Taenia solium, according to artistic representations of the time, which contradicts the hypothesis by Harter et al. (2003) concerning the interdiction on pork consumption among Egyptians during this period.

Tuon, Amato Neto \& Amato (2008) discussed the origin and evolution of leishmaniases, concluding that they were associated with the origins of the human species itself in Africa and emphasizing the importance of paleoparasitology studies to better elucidate the evolution of Leishmania species in the human host.

Finally, and of course without pretending to exhaust the topic, we should mention the non-invasive techniques for analyzing archaeological remains, especially recommended for mummified bodies. Examples include the 3D images used to study the collection of Egyptian mummies at the Brazilian National Museum of the Federal University of Rio de Janeiro (Mendonça de Souza, 2008), enabling various precise diagnoses without destroying the material. 
Most of the articles on paleoparasitology in Africa describe parasites in archaeological remains from Egypt, with detailed descriptions of eggs and even larvae and adults in histological sections. Many studies associate descriptions of symptoms in papyri with suggestive lesions identified during autopsy and parasite finds. Many articles are based on research performed in mummified bodies belonging to museums outside of Egypt. There is an on-going effort to encourage multidisciplinary studies, and the authors have presented the findings in various scientific journals. The effort at multidisciplinary studies is interesting, since it provides different contributions on parasitic infections, viewed from diverse angles, according to the respective researchers' expertise.

The African countries lack teams dedicated to systematic studies of parasites in archaeological remains, especially those harboring remains of ancestral humans and the first species of genus Homo. As listed in this chapter, the findings are concentrated in the Nile River Valley and are repeated in various publications, either by the same authors or others. The list of intestinal parasites, although extensive, may not represent all of the infections that affected ancient African populations, especially if one considers the contacts between peoples of distinct cultures occupying nearby territories but with different potential for infection. An example is the situation studied by Zink et al. (2006) in relation to leishmaniasis, showing contacts between diverse cultures in which the infection circulated. The research possibilities are immense, but thus far no African groups have been formed with a focus on paleoparasitology (which however is expected to happen soon). One of the most important potential topics for exploration is that the majority of the helminth species now found all over the world originated in ancestral humans in Africa (e.g., Trichuris trichiura as well as Ancylostoma duodenale and Necator americanus, possibly the two most common hookworm species in humans). Some, like Enterobius vermicularis (Horne, 2002), have already been recorded in African material, but much further research is needed. Phylogenetic studies based on the recovery of ancient DNA (Dittmar, 2009) will unveil interesting approaches for understanding parasite-host evolutionary relations since the dawn of humankind.

According to Buzon (2006), studies that aimed to reconstruct life in the ancient Nile Valley failed to take the organic remains into account, focusing (with few exceptions) on historical texts and the artifacts left by the ancient inhabitants. The author showed the importance of studying paleopathological evidence on the lives of ancient peoples. He concentrated particularly on the epidemiological transition during the Egyptians' colonization of the Upper Nile (Nubia), by studying skeletons and single bones from common people.

He commented briefly on infectious diseases, but they were not the main focus of his study. However, not only the marks of bone lesions caused by injuries or even chronic diseases, but also those from parasitic infections (whether detected by parasite finds or the recovery of their genetic material in archaeological remains) are extremely helpful for recovering data to reconstruct the past.

Many of the most common human helminth infections were already present in peoples of the ancient Nile Valley at least 6,000 years ago (Harter, 2003). These include Ascaris sp., Trichuris sp., Enterobius vermicularis, hookworms, Taenia sp., Diphyllobothrium sp., Hymenolepis sp., Schistosoma haematobium, and Schistosoma mansoni, besides others that are now rarer, such as Fasciola hepatica, Fasciola gigantica, and Dicrocoelium sp. However, it is not possible to suggest changes in the profile of these parasitic infections with the limited data currently available. It is possible to raise questions concerning eating habits that may have facilitated the transmission of infection by the ingestion of specific foods or certain ways of preparing them.

Paleoparasitology thus makes important contributions to these studies, especially considering the life cycles of parasites together each species' environmental needs (Lafferty et al., 2008; Byers, 2009). 


\section{REFERENCES}

ARAÚJO, A. et al. Parasitism, the diversity of life, and paleoparasitology. Memórias do Instituto Oswaldo Cruz, 98, supl. 1: 5-11, 2003.

ARMITAGE, P. L. \& CLUTTON-BROCK, J. A radiological and histological investigation into the mummification of cats from ancient Egypt. Journal of Archaeological Science, 8: 185-196, 1981.

BARON, H.; HUMMEL, S. \& HERRMANN, B. Mycobacterium tuberculosis complex DNA in ancient bones. Journal of Archaeological Science, 23: 667-671, 1996.

BIANUCCI, R. et al. Immunological evidence of Plasmodium falciparum infection in an Egyptian child mummy from the Early Dynastic period. Journal of Archaeological Science, 35: 1.880-1.885, 2008.

BRIER, B. Infectious diseases in ancient Egypt. Infectious Disease Clinics of North America, 18: 17-27, 2004.

BRUSCHI, F. et al. Short report: cysticercosis in an Egyptian mummy of the late Ptolemaic period. American Journal of Tropical Medicine and Hygiene, 74: 598-599, 2006.

BUIKSTRA, J. E.; BAKER, B. J. \& COOK, D. C. What diseases plagued the ancient Egyptians? A century of controversy considered. In: WALBER, R. (Ed.). Biological Anthropology and the Study of Ancient Egypt. London: British Museum Press, 1993.

BUZON, M. R. Health of the non-elites at Tombos: nutritional and disease stress in New Kingdom Nubia. American Journal of Physical Anthropology, 130: 26-37, 2006.

BYERS, J.E. Including parasites in food webs. Trends in Parasitology, 25: 55-57, 2009.

CERUTTI, N. et al. Immunological investigation of malaria and new perspectives in paleopathological studies. Journal of Biological Research, 75: 17-20, 1999.

COCKBURN, A. The Evolution and Eradication of Infectious Diseases. Baltimore: The Johns Hopkins Press, 1963.

COCKBURN, A. (Ed.). Infectious Diseases: their evolution and eradication. Springfield: Charles C. Thomas, 1967.

COCKBURN, A. Ancient parasites on the west bank of the Nile. The Lancet, 2: 938, 1981.

COCKBURn, A.; COCKBURn, E. \& REYMAn, T. Mummies, Disease, and Ancient Cultures. $2^{\text {nd }}$ Ed. Cambridge: Cambridge University Press, 1998

COCKBURN, A. et al. Autopsy of an Egyptian mummy. Science, 187: 1.155-1.160, 1975.

COckBurn, A. et al. A classic mummy: PUM II. In: COCKBURN, A. \& COCKBURN, E. (Ed.). Mummies, Disease and Ancient Cultures. Cambridge: Cambridge University Press, 1980.

CONTIS, G. \& DAVID, A. R. The epidemiology of bilharzia in Ancient Egypt: 5,000 years of schistosomiasis. Parasitology Today, 12:253-255, 1996.

DAVID, A. R. Disease in Egyptian mummies: the contribution of new technologies. The Lancet, 349: 1.760-1.763, 1997.

DE BONI, U.; LENCZNER, M. M. \& SCOTT, J. W. Autopsy of an Egyptian mummy (Nakhat - ROM I). 6. Trichinella spiralis cysts. Canadian Medical Association Journal, 117: 461-476, 1977.

DEELDER, A. M. et al. Detection of schistosome antigen in mummies. The Lancet, 335: 724-725, 1990.

DITTMAR, K. Old parasites for a new world: the future of palaeoparasitological research. The Journal of Parasitology, 95(2): 365$371,2009$.

DITTMAR, K. \& STEYN, M. Paleoparasitological analysis of coprolites from K2, an Iron Age archaeological site in South Africa: the first finding of Dicrocoelium sp. eggs. The Journal of Parasitology, 90: 171-173, 2004.

DZIERZYKRAY-ROGALSKI, T. Un cas de la lèpre à un stade avancé découvert dans le nécropole musulmane de Kôn El-Dikka, à Alexandrie. Africana Bulletin, 28: 140-146, 1978. 
DZIERZYKRAY-ROGALSKI, T. Paleopathology of the Ptolomaic inhabitants of Dakhlah Oasis (Egypt). Journal of Human Evolution, 9: $71-74,1980$.

EVANS, A. C. et al. Late stone-age coprolite reveals evidence of prehistoric parasitism. South African Medical Journal, 86: 274$275,1996$.

FERREIRA, L. F.; ARAÚJO, A. \& CONFALONIERI, U. Subsídios para a paleoparasitologia do Brasil I. Parasitos encontrados em coprólitos no município de Unaí, MG. In: CONGRESSOS BRASILEIROS DE PARASITOLOGIA, IV, Campinas, 1979. Resumos... Campinas, 1979.

FORATTINI, O. P. Os cimicídeos e sua importância em saúde pública (Hemiptera-Heteroptera; Cimicidae). Revista de Saúde Pública, supl.: $1-37,1990$.

FULCHERI, E. et al. De mummie dell'antico Egitto custodite nei musei italiani. Museological Science, 11(1-2): 1-11, 1994.

GIACOMETTI, L. \& CHIARELLI, B. The skin of Egyptian mummies. Archives of Dermatology, 97: 712-716, 1968.

GRAY, J. E. Tutankhamun postmortem. The Lancet, 1: 259, 1973.

GUY, M. W.; KROTOSKY, W. A. \& COCKBURN, A. Malaria and an Egyptian mummy. London School of Hygiene and Tropical Medicine, 75: 601, 1981.

HARRISON, R.G. Tutankhamun postmortem. The Lancet, 1: 259, 1973.

HART, G. D. et al. Autopsy of an Egyptian mummy (Nakht - ROM I). Canadian Medical Association Journal, 117: $461,1977$.

HARTER, S. Implication de la Paléoparasitologie dans l'Étude des Populations Anciennes de la Vallée du Nil et du Proche-Orient: études de cas, 2003. Thèse, Reims: UFR de Pharmacie, Université de Reims Champagne-Ardènne.

HARTER, S. et al. First paleoparasitological study of an embalming rejects jar found in Saggara, Egypt. Memórias do Instituto Oswaldo Cruz, 98, supl. 1: 119-121, 2003.

HARTER-LAilheuge, S. \& BOUCHET, F. Paleoparasitological investigation in funerary contexts along the Nile. Paleopathology Newsletter, 128: 5-9, 2004.

HARTER-LAILHEUGE, S. \& BOUCHET, F. Paleoparasitological study of atypical elements of the low and high Nile Valley. Bulletin de la Société de Pathologie Éxotique, 99: 53-57, 2006.

HOEPPLI, R. Parasitic Diseases in Africa and the Western Hemisphere: early documentation and translation by the slave trade. Basel: für Recht und Wissenschaft, 1969.

HOEPPLI, R. Haematuria parasitaria and urinary calculi: early indications from Africa. Acta Tropica, 29: 205-217, 1972.

HOPE, F. W. Several species of insects found in the heads of Egyptian mummies. Journal of the Proceedings of the Royal Entomological Society of London, 1: 11-13, 1834.

HORNE, P. D. First evidence of enterobiasis in ancient Egypt. The Journal of Parasitology, 88: 1019-1021, 2002.

HORNE, P. D. \& LEWIN, P. K. Electron microscopy of mummified tissue: autopsy of an Egyptian mummy. Canadian Medical Association Journal, 117: 472-473, 1977.

HORNE, P. D. \& REDFORD, S. Aspergillosis and dracunculiasis from the tomb of Parennefer. Paleopathology Newsletter, 92: 10$12,1995$.

IKRAM, S. \& DODSON, A. The Mummy in Ancient Egypt: equipping the dead for eternity. London: Thames and Hudson, 1998.

LAFFERTY, K. D. et al. Parasites in food webs: the ultimate missing links. Ecology Letters, 11: 533-546, 2008.

LEWIN, P. K. Mummies that I have known. American Journal of Diseases of Children, 131: 349-350, 1977.

LEWIN, P. K. Ramses V: smallpox victim? Paper presented at the $9^{\text {th }}$ annual meeting of the Paleopathology Association, Toledo, OH, USA. Abstracts in Paleopathology Newsletter, 36: 10, 1982. 
LEWIN, P. K. et al. Nakht, a weaver of Thebes. Rotunda (The Journal of the Royal Ontario Museum), 7: 15-19, 1974.

LOWENSTEIN, E. Paleodermatoses: lessons learned from mummies. Journal of the American Academy of Dermatology, 50: 919 936, 2004.

LYNN, G. E. \& BENITEZ, J. T. Examination of ears. Canadian Medical Association Journal, 117: 469, 1977.

MENDONÇA DE SOUZA, S. M. Diagnóstico não invasivo em múmias milenares. In: WERNNER JR., H. \&, LOPES, J. (Ed.). Paleontologia, Arqueologia, Fetologia, Tecnologias 3D. Rio de Janeiro: Revinter, 2008.

MILLER, R. L. et al. Paleoepidemiology of schistosome infection in mummies. British Medical Journal, 304: 555-556, 1992.

MILLER, R. I. et al. Predynastic schistosomiasis. In: DAVIS, W. V. \& WALKER, R. (Eds.). Biological Anthropology and the Study of Ancient Egypt. London: British Museum Press, 1993.

MILLER, R. L. et al. Diagnosis of Plasmodium falciparum infections in mummies using the rapid manual ParaSight TM-F test. Transactions of the Royal Society of Tropical Medicine and Hygiene, 88: 31-32, 1994.

MILLET, N. B. Archaeologic background. Canadian Medical Association Journal, 117: 462, 1977.

MILLET, N. B. et al. ROM I: mummification for the common people. In: COCKBURN, A. \& COCKBURN, E. (Eds.). Mummies, Disease and Ancient Cultures. Cambridge: Cambridge University Press, 1980.

MITCHELL, J.K. Study of a mummy affected with anterior poliomyelitis. Transactions of the Association of American Physicians, 15: $134-136,1900$.

MØLLER-CHRISTENSEN, V. Evidence of leprosy in earlier peoples. In: BROTHWELL, D. \& SANDISON, T. A. (Eds.). Diseases in Antiquity. Springfield: Charles C Thomas, 1967.

MøLLER-CHRISTENSEN, V. \& HUGHES, D. R. An early case of leprosy from Nubia. Man (London), 1: 242-243, 1966.

MOODIE, R. L. Paleopathology: an introduction of the study of ancient evidence of disease. Urbana: University of Illinois Press, 1923.

MORSE, D.; BROTHWELL, D. \& UCKO, P. J. Tuberculosis in ancient Egypt. American Review of Respiratory Diseases, 90: 524-530,

NUMM, J. F. \& TAPP, E. Tropical diseases in ancient Egypt. Transactions of the Royal Society of Tropical Medicine and Hygiene, 94 : 147-153, 2000.

PALMA, R. L. Old comb reveals nits on the Nile: mummified head lice found on ancient Egyptian comb. The Journal of Egyptian Archaeology, 77: 194, 1991.

PANAGIOTAKOPUlU, E. \& BUCKLAND, P. C. Cimex lectularius the common bedbug from Pharaonic Egypt. Antiquity, 73: 908-911,

RABINO-MASSA, E. et al. Malaria in Ancient Egypt. Paleoimmunological investigation on predynastic mummified remains. Chungará, 32: 7-9, 2000.

RAFI, A. et al. DNA of Mycobacterium leprae by PCR in ancient bone. International Journal of Osteoarchaeology, 4: 287-290, 1994.

REYMAN, T. A. Schistosomal cirrhosis in an Egyptian mummy. Yearbook of Physical Anthropology, 20: 356-358, 1976.

REYMAN, T. A.; BARRACO, R. A. \& COCKBURN, A. Histopathological examination of an Egyptian mummy. Bulletin of the New York Academy of Medicine, 52: 506-516, 1976.

REYMAN, T. A.; ZIMMERMAN, M. R. \& LEWIN, P. K. Histopathologic investigation. Canadian Medical Association Journal, 117: 470-471, 1977.

RIDEOUT, D. F. Radiologic examination. Canadian Medical Association Journal, 117: 463, 1977.

RUFFER, M. A. Note on the presence of 'Bilharzia haematobia' in Egyptian mummies of the twentieth dynasty (1250-1000 B.C.). British Medical Journal, I: 16, 1910 a.

RUFFER, M. A. Remarks on the histology and pathological anatomy of Egyptian mummies. The Cairo Scientific Journal, 10: 3-7, 
RUFFER, M. A. Studies on paleopathology of Egypt. In: MOODIE, R. (Ed.). Studies on Paleopathology of Egypt. Chicago: University of Chicago Press, 1921.

RUFFER, M. A. \& FERGUSON, A. R. Note on eruption resembling that of variola in the skin of a mummy of the Twentieth Dynasty (1200-1100 B.C.). The Journal of Pathology and Bacteriology, 15: 1, 1911.

RUTHERFORD, P. Immunochemistry and the diagnosis of schistosomiasis. Ancient and modern. Parasitology Today, 15: 390-391,

SÁNCHEZ-MARTín, F. M. et al. Sangre, hemorragia, hematuria, urología. Actas Urológicas Españolas, 29: 815-825, 2005.

SANDISON, T. A. Diseases in ancient Egypt. Rivista di Antropologia, 56: 225-227, 1959.

SANDISON, A. T. Diseases in ancient Egypt. In: COCKBURN, C. \& COCKBURN, E. Mummies, Disease, and Ancient Cultures. Cambridge: Cambridge University Press, 1980.

SCOTT, J. W.; HORNE, P. D. \& HART, G. Gross anatomic and miscellaneous studies. Canadian Medical Association Journal, 117: 464-465, 1977.

SPIGELMAN, M. \& LEMMA, E. The use of the polymerase chain reaction to detect Mycobacterium tuberculosis DNA in ancient skeletons. International Journal of Osteoarchaeology, 3: 137-143, 1993.

STROUHAL, E. \& HORÁCKOVÁ, L. Report from Egypt: anthropology and paleopathology. Paleopathology Newsletter, 106: 13-15, 1999.

STROUHAL, F. Vertebral tuberculosis in Egypt and Nubia. In: ORTNER, D. J. \& AUFDERHEIDE, A. C. (Eds.). Human Paleopathology: current synthesis and future options. Washington, London: Smithsonian Institute Press, 1991.

TAPP, E. Disease in the Manchester mummies. In: DAVID, A. R. The Manchester Museum Mummy Project. Manchester: Manchester Museum Press, 1979.

TAPP, E. Disease and the Manchester mummies: the pathologist's role. In: DAVID, A. R. (Ed.). Evidence Embalmed. Manchester: Manchester University Press, 1984.

TUON, F. F.; AMATO NETO, V. \& AMATO, V. S. Leishmania: origin, evolution and future since the Precambrian. FEMS Immunology and Medical Microbiology, 54: 158-166, 2008.

ZIEGLER, C. et al. La mission archéologique du musée du Louvre à Saqqara. Résultats de quatre campagnes de fouilles de 1993 à 1996. Bulletin de l'Institut Français d'Archéologie Orientale, 97: 269-292, 1997.

ZIMmerman, M. R. Pulmonary and osseous tuberculosis in an Egyptian mummy. Bulletin of the New York Academy of Medicine, 55: 604-608, 1979.

ZINK, A. R.; GRABNER, W. \& NERLICH, A. G. Molecular study of human tuberculosis in contemporary tissue samples and time delineated populations from ancient Egypt. Journal of Paleopathology, 14: 59-68, 2002.

ZINK, A. et al. Molecular evidence of bacteremia by gastrointestinal pathogenic bacteria in an infant mummy from Ancient Egypt. Archives of Pathology and Laboratory Medicine, 124: 1.614-1.618, 2000.

ZINK, A. et al. Corynebacterium in Ancient Egypt. Medical History, 45: 267-272, 2001.

ZINK, A. R. et al. Characterization of Mycobacterium tuberculosis complex DNAs, from Egyptian mummies by spoligotyping. Journal of Clinical Microbiology, 41: 359-367, 2003.

ZINK, A. R. et al. Molecular characterization of Mycobacterium tuberculosis complex in Egyptian mummy. International journal of Osteoarchaeology, 14: 404-413, 2004.

ZINK, A. R. et al. Leishmaniasis in Ancient Egypt and upper Nubia. Emerging Infectious Diseases, 12: 1.616-1.617, 2006. 



\title{
The Paleoepidemiology of Chagas disease
}

\author{
Adauto Araújo • Ana Maria Jansen • Karl Jan Reinhard • Luiz Fernando Ferreira
}

Tn 1909, Carlos Chagas first described a case of the disease that now bears his name. The patient was a 2-year-old

girl that survived the disease for more than seven decades, eventually dying in 1981, at 74 years of age. She lived with Trypanosoma cruzi infection for her entire life. However, for many people, Chagas disease means suffering and death. Many young adults die early from cardiac lesions. Chagas disease is one of the most important parasitic infections, and due to its high morbidity and mortality, many South and Central American countries consider it a serious public health problem.

Even in Brazil, which has succeeded in controlling intradomiciliary vector transmission of T. cruzi, Chagas disease is worrying health authorities again, due to the occurrence (mainly in the Amazon) of oral transmission through the ingestion of foods contaminated with the vector's infective forms (metacyclic trypomastigotes) (Dias, 2006).

Such cases occur as outbreaks and involve acute and sometimes severe forms of the disease. Chronic cases are equally important, requiring drug treatment that often results in serious secondary reactions, in addition to hospital or surgical care, beyond the reach of a major portion of the population in endemic areas.

\section{TRYPANOSOMATIDS OF MAMMALS}

Trypanosomatids are flagellate protozoa belonging to the Kinetoplastida order, which includes both free-living organisms and parasites. As parasites, the monogenetic and digenetic protozoa are characterized by extranuclear circular DNA in a peculiar array, namely maxicircles and minicircles.

Trypanosomes of mammals provide an excellent example of how molecular paleoparasitology can elucidate epidemiological and biological questions. Trypanosomatids are very ancient eukaryotic organisms, since they probably diverged from the first eukaryotes soon after their association with mitochondria.

Parasites from the order Kinetoplastida are characterized by kDNA, an extranuclear circular DNA arranged in maxicircles and minicircles inside the mitochondrion, close to the flagellar basal body. The Kinetoplastida include the 
Trypanosomatidae family, an exclusively parasitic taxon that infects a broad spectrum of animals and plants, and the Bodonidae family, exclusively free-living organisms.

Several biological characteristics are important for understanding T. cruzi, a parasite with broad heterogeneity and biological plasticity. The pioneering studies by Carlos Chagas and Brumpt already called attention to these characteristics, which represent an epidemiological maze even to this day.

The heterogeneity of T. cruzi, expressed by various biological, biochemical (differences in the infection pattern in mice and growth in axenic culture, differences in the capacity to colonize culture cells, and drug resistance, among others), and molecular markers results in the parasite's wide distribution in nature in distinct epidemiological scenarios. In fact, T. cruzi is capable of infecting more than a hundred species of mammals and nearly all their tissues.

Another important aspect of T. cruzi biology involves the parasite's multiple transmission mechanisms, e.g., transfusional, congenital, and oral, and by contamination of the skin and mucosa by feces of triatomines carrying the infective forms, called metacycical trypomastigotes.

T. cruzi is also a generalist parasite in relation to the vector, since it infects dozens of triatomine species from the Reduviidae family. The biological plasticity of $T$. cruzi results in transmission cycles in nature that are characterized as multivariate, complex, and peculiar on a spatial and temporal scale. This complexity means that the human host probably entered into contact with the parasite on different occasions over time and by different routes, depending mainly on interaction with the environment, that is, the ways by which the host was exposed to infection.

Since the pioneering work of Carlos Chagas, researchers have attempted to establish a correlation between some genotypic or phenotypic characteristic of the parasite and the disease profile, local epidemiological characteristic, or association with the vector or animal reservoir. Although many aspects of T. cruzi biology and ecology are known, there are still numerous unanswered questions. Scientists have never succeeded in robustly correlating a given type of isolate with the disease or its epidemiology.

T. cruzi is now known to be a protozoan parasite with a multiclonal population structure with high genetic diversity. Molecular tools have grouped different subpopulations of the parasite into two distinct and phylogenetically distant genotypes. The genotypes were named T. cruzi I and T. cruzi II. The first studies in biochemical characterization, analyzing different isolates of the parasite, identified three types of zymodemes. In Brazil, Z1 and Z3 are associated with the wild transmission cycles (Miles et al., 1977, 1978), while Z2 is associated with the domestic transmission cycle in the region below the Amazon (Anonymous, 1999).

More recently, six subpopulations were described in the taxon: TCI and TCII, with the latter genotype subdivided into TCIIa, TCIIb, TCIIC, TCII, and TCf, originating in part from two hybridization events in the parasite. However, a new proposal for T. cruzi denomination has already been presented, during a meeting of experts from the Brazilian Society of Protozoology in 2009 (Zingales et al., 2009).

\section{TRYPANOSOMATIDS OF MAMMALS, THEIR ORIGIN AND DISPERSAL, AND INTRODUCTION OF THE HUMAN HOST INTO THE TRANSMISSION CYCLE}

The origin and evolution of trypanosomatids have been discussed since long before the description of $T$. cruzi. Leger (1904) and Minchin (1908) launched the debate, beginning with opposing premises as to whether the ancestral host of Trypanosomatidae was a vertebrate or invertebrate. This debate swayed one way or the other, depending on new evidence produced by new techniques, and no conclusive result has been reached to date. 
It has been proposed that the cruzi clade originated on the supercontinent formed by South America, Australia, and Antarctica. Based on biogeographical events, it is currently accepted that the trypanosomes from the Salivaria group (Trypanosoma brucei) diverged in the Middle Cretaceous approximately 100 million years ago, when South America separated from Africa (Haag, O’Huigin \& Overath, 1998).

According to various authors, the human host only entered the T. cruzi transmission cycle after the domestication of plants and animals and acquisition of sedentary habits (Rothhammer et al., 1985; Coimbra Jr., 1988; Stevens, Noyes \& Gibson, 1998).

Thus, according to the accepted theory on the origin of Chagas disease in humans, some 8,000 to 6,000 years ago the Andean peoples began the domestication of rodents called cuyes or Cavia sp., known as guinea pigs by Europeans, for food and ritual purposes. The animals were raised indoors and purportedly attracted hematophagous insects, vectors of T. cruzi.

The beginning of grain storage and the resulting attraction of granivorous mammals contributed to this process. In human dwellings built of wood and packed earth, triatomine vectors of $T$. cruzi found the ideal conditions for colonization and blood meals, whether from the human inhabitants or their domestic animals. Importantly, triatomines probably adapted to this new habitat, human dwellings, over a very long period, involving irreversible genomic alterations. Interestingly, wild colonies of Triatoma infestans have never been reported in Brazil.

Triatoma infestans probably underwent domiciliation 8,000 to 6,000 years ago and later dispersed largely through human migrations to other regions of South America, including to the opposite side of the Andes, after the arrival of Europeans and Africans on the continent. The process accelerated with the dissemination of precariously built mudand-wattle dwellings, where the vector found the ideal conditions for colonization in the cracks, nooks, and crannies in the walls, so typical of such dwellings, and the intensification of trade. Chagas disease thus originated in the Andean Region in prehistoric populations 8,000 to 6,000 years ago, reaching other regions of the Americas beginning with the European colonial period.

Researchers originally believed that in what is now Brazil, where the indigenous peoples were mostly nomadic and used temporary dwellings to which the triatomines did not adapt well, prehistoric infection with $T$. cruzi would never have been a problem.

\section{PALEOPARASITOLOGY AND THE PARADIGM SHIFT}

The paleoparasitological data revealed an opposite situation and changed the classically accepted theory. A hundred years after Carlos Chagas' discovery, another history of Chagas disease began to emerge, having occurred thousands of years before discovery of the disease.

The scenario that has unfolded thus supports the hypothesis that Chagas disease is probably as old as human presence in the Americas. The description of lesions typical of Chagas disease and PCR-positive for T. cruzi in preColumbian 9,000-year-old mummies from Andean countries proves the antiquity of Chagas infection and disease in humans (Rothhammer et al., 1985; Fornaciari et al., 1992; Guhl et al., 1997, 1999, 2000; Ferreira et al., 2000; Aufderheide et al., 2004).

A similar question relates to Trypanosoma evansi, another trypanosome of mammals, widely distributed in nature. This salivary protozoan is included in the brucei clade, although mainly transmitted mechanically by horse flies 
(Tabanidae). In Brazil, it only occurs in the Pantanal; however, in this swampy biome it is highly prevalent in all the mammalian taxa. Its principal reservoir is the capybara (Hidrochoeris hidrochoeris), a caviomorph rodent.

The introduction of T. evansi into the American continent has also been attributed to the arrival of infected horses brought by the European colonizers. However, it is unlikely that horses infected with $T$. evansi could have survived extenuating transoceanic voyages under the precarious conditions of the time, followed by the march to the Pantanal. It is far more plausible to assume that the parasite was introduced into the continent with the arrival of primates and caviomorph rodents coming from Africa 35 million years ago. This question can be answered definitively by molecular analysis of organic remains.

The use of molecular tools to trace the origin and dispersal of trypanosomes of mammals, and particularly $T$. cruzi, requires much further research. There are many technical obstacles to overcome and numerous unanswered questions, but molecular paleoparasitology definitely allows tracing the parasite's dispersal since prehistory, plus identifying genomic changes resulting from evolution in the parasite-host-environment system.

\section{THE FIRST HYPOTHESES ON TRANSMISSION OF TRYPANOSOMA CRUZI INFECTION IN PREHISTORIC PEOPLES IN NORTHEAST BRAZIL}

In 1984, during excavations of the Boqueirão da Pedra Furada archaeological site in the region of the Serra da Capivara National Park in southeast Piauí State, Northeast Brazil, coordinated by Niéde Guidon (Guidon \& Delibrias, 1986; Guidon, 1989), we saw kissing bugs (triatomines) constantly attacking the archaeologists who were studying rock paintings on the sandstone walls in the rock shelters of the ancient prehistoric camp.

The paintings cover the entire wall, and at the time, without today's technology, they had to be copied by overlaying them with transparent plastic (Figure 1). Both in the early morning and at the hottest times of the day, with the temperature around 42-45 C, and at night, when the temperature drops to 8-10 C, nymphs and adults of Triatoma brasiliensis emerged, trying to feed on the blood of archaeologists, students, and laborers in the excavations Some specimens were infected with T. cruzi. On the occasion, we postulated that the ancient artists and other inhabitants of the rock shelters were also attacked by the vector and infected with the parasite (Ferreira et al., 2000).

Interestingly, Triatoma infestans never colonized this part of Northeast Brazil (Dias et al., 2000). In 1984 we were unable to test our hypothesis, since the few human remains found by then consisted of bones and coprolites, where the parasite leaves no pathological signs. 
Figure 1 - Excavations in Toca do Boqueirão at the Pedra Furada site in the Serra da Capivara National Park, Piauí, Brazil, 1984. Note the archaeologists copying the rock paintings on the sandstone wall

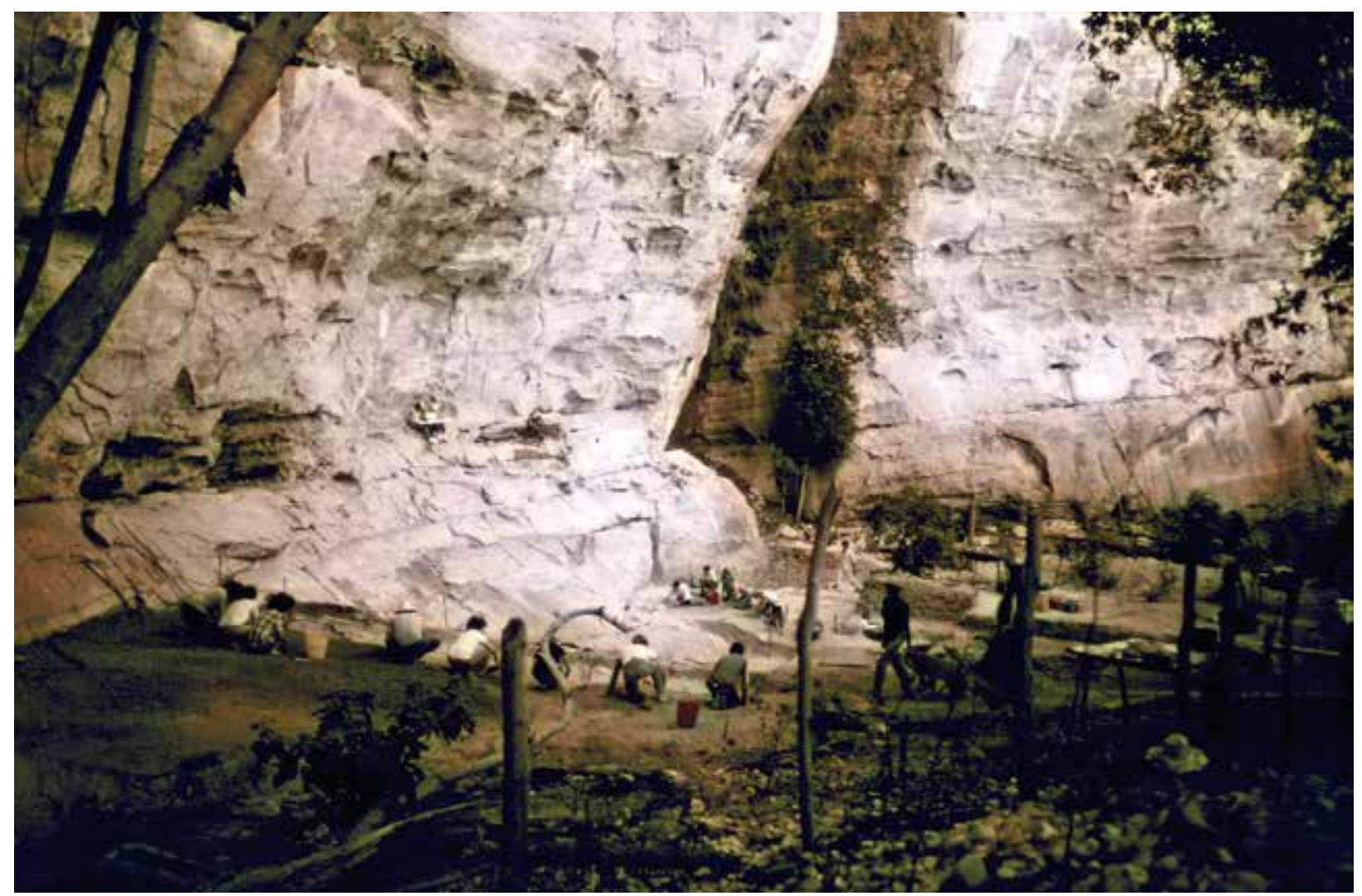

Photograph: Paleoparasitology Laboratory (Ensp/Fiocruz).

Not until several years later, with the introduction of molecular biology techniques for the diagnosis of infectious diseases in archaeological remains, Chagas infection was confirmed in Chilean and Peruvian mummies dated 4,000 BP (Guhl et al., 1999, 2000; Ferreira et al., 2000; Madden et al., 2001).

The first tests were conducted at the Oswaldo Cruz Foundation in Rio de Janeiro. Before applying them to archaeological material, experimental protocols were performed in mice infected with a known parasite burden. After sacrificing the animals, the organs were placed in a drying oven at $40^{\circ} \mathrm{C}$ until their complete desiccation. Following this experimental "mummification”, molecular biology was used until establishing a standard for use in archaeological material. This was the subject of the PhD dissertation by Otílio Machado Bastos, whose experiment was commented in the Journal of the Paleopathology Association (Bastos et al., 1996) and applied successfully to Chilean mummies by Guhl et al. (2000).

According to the findings in Northeast Brazil, the first prehistoric occupations in the region of the Serra da Capivara National Park occurred thousands of years before the 15,000-12,000 years previously assumed for the peopling of South America (Guidon \& Arnaud, 1991; Parenti et al., 1998). Although the dates still spark debate (Meltzer, Adovasio \& Dillehay, 1994), caves and rock shelters containing numerous rock paintings, some of which dated to 26,000 years, attest to the antiquity of these occupations. 
It is thus tempting to suggest that the artists that made these paintings and the other inhabitants of the caves were the first South Americans exposed to Chagas disease, transmitted by Triatoma brasiliensis. In fact, to this day, these rock shelters provide a habitat where small mammals, primates, and triatomines find favorable conditions for colonization.

Following recognition of the importance of understanding parasite evolution to better control infectious diseases in modern times (Ewald, 1996; Ewald et al., 1998), paleoparasitology assumed a key role in elucidating the evolutionary process from past to present.

This understanding can and should be achieved by combining paleoparasitology with molecular techniques. Paleoparasitology can document the presence of parasites at a given time in a prehistoric population, and molecular techniques can identify potential changes in the parasites' genome, resulting from evolutionary parasite-hostenvironment relations. Infectious diseases definitely changed from prehistory to today (Leal \& Zanotto, 2000), including modifications in virulence and pathogenicity associated with humankind's historical and social processes.

Based on these assumptions, we began studying T. cruzi infection in ancient North and South American peoples using molecular biology techniques to recover the parasite's genetic material in organic remains, both from humans and other animals. Our working hypothesis is that Chagas disease in humans is as ancient as human presence on the American continent, whenever or wherever there were favorable conditions for its transmission. This means a favorable environment, presence of the parasite circulating in vectors, and animals in contact with humans. Chagas disease thus dates back thousands of years, long before guinea pigs were domesticated in the Andes.

We tested human organic remains such as bones and mummified tissues from various North and South American archaeological sites. We also studied animal bones and other remains and attempted to find and identify fragments of arthropod vectors of $T$. cruzi in the archaeological layers. Importantly, human coprolites also need to be examined carefully, since evidence suggests that prehistoric groups in the Americas consumed various arthropods (accidentally or intentionally) (Reinhard, Fink \& Skiles, 2003; Johnson et al., 2008).

Results of the extraction and amplification of T. cruzi ancient DNA can shed light on key aspects of the parasite's lineages currently circulating in the Americas (Stevens \& Gibson, 1999; Stevens et al., 2001). For example, clinical differences were found between individuals infected with the parasite in modern Northeast Brazil, precisely in the region of the Serra da Capivara National Park in Piauí (Borges-Pereira et al., 2002), that can be explained by adaptive processes over time. Paleoparasitology can help trace the origin and evolution of infectious diseases and thus elucidate their emergence and dispersal (Cockburn, 1967).

This work involved researchers from South America and the United States in projects funded by various agencies. The results presented below are based on studies in the Lower Pecos region in Texas, USA, and in archaeological sites in Northeast Brazil and in northern Minas Gerais State, with a semiarid climate and favorable conditions for preservation of organic material. In addition, both these areas of Brazil, the Northeast caatinga and the cerrado in Minas Gerais, are (or until recently were) endemic for Chagas disease.

Before presenting the results, we will provide a brief review of the findings in the Andean Region, starting with the first descriptions of typical lesions in mummified bodies. The literature also reports the description of megas, histopathological evidence of amastigote nidi, and confirmation of the antiquity of Chagas infection in the oldest known human mummies, the Chinchorro mummies, in the Atacama Desert, dated to 9,000 BP (Aufderheide et al., 2004). 


\section{BRIEF REVIEW OF FINDINGS ON CHAGAS INFECTION IN SOUTH AMERICAN MUMMIES}

Rothhammer et al. (1985) published one of the first articles on Chagas disease in South American mummies, describing cardiac lesions consistent with chronic Chagas. The evidence was obtained from 35 mummified bodies from the Atacama Desert, but is also based on writings by chroniclers and the adaptation of Triatoma infestans to the domicile in past times. The article was a milestone for research on the disease and raises hypotheses that are still being tested, along with others that have already been proven by the paleoparasitological findings.

Fornaciari et al. (1992) autopsied a Peruvian Inca mummy and found evidence of Chagas disease in the lesions, including nidi of amastigotes. The authors used the alcohol rehydration technique proposed by Ruffer (1921) to recover mummified tissues and showed evidence of parasites in the heart muscle.

Bastos et al. (1996) and Guhl et al. (1999) then launched molecular studies in mummies from the Atacama Desert in Northern Chile. These researchers succeeded in isolating DNA from mummified tissues dated 4,000 BP. Less than a month later, Ferreira et al. (2000) published an article on Chilean mummies applying DNA techniques, also in the Atacama Desert, but in the area of the current city of San Pedro de Atacama, an oasis and center of intense trade in the past. This finding, following on the above-mentioned studies by Bastos et al., confirms the extent of Chagas infection in the region during a period of up to 2,000 years.

This served as a point of departure for the interesting article published by Guhl et al. (2000), discussing prehistoric human migrations and Chagas disease. Previously used techniques were discussed by Madden et al. (2001), and Aufderheide et al. (2004) finally published an article on the isolation of T. cruzi DNA in Chinchorro mummies dated 9,000 BP, thus several thousand years before the known time of domestication of rodents and camelids (Rothhammer et al., 1985).

There is thus no doubt that Chagas disease was present in pre-Columbian peoples of Chile and Peru. More recently, Orellana (2008) identified Bolivian mummies infected with T. cruzi, which backs the hypothesis that transmission by Triatoma infestans began in the Bolivian altiplano.

Humans probably entered into contact with the T. cruzi-infected vector on different occasions, on the American continent, simultaneously or not, depending on how they acted and interacted with the environment. Interaction with the environment is still known to be an important risk factor (Romaña, Emperaire \& Jansen, 2003; Emperaire $\&$ Romaña, 2006).

\section{BASIS AND SUPPORT FOR RESEARCH IN OTHER REGIONS: THE CURRENT SITUATION - LOWER PECOS, TEXAS, USA}

While Chagas disease is classified as hyperendemic in South America, human infections are rarely described in the United States or along the northern border of Mexico.

However, some T. cruzi transmission occurs in the natural environment in North America, mainly in the State of Texas. Seven species of Triatoma are known in Texas: Triatoma gerstaekeri, Triatoma indictiva, Triatoma lecticularius (syn. Triatoma heidemanni), Triatoma neotomae, Triatoma protracta, Triatoma rubida, and Triatoma sanguisuga (Elkins, 1951a; Lent \& Wygodzinsky, 1979). Most are widely distributed in Texas. Triatoma rubida is found in western Texas, close to New Mexico, while Triatoma neotomae is distributed mainly in the Rio Grande Valley (Elkins, 1951b; Eads, Trevino \& Campos, 1963). 
These seven triatomine species have been found infected with T. cruzi (Wood, 1941a, 1941b; Davis, McGregor \& De Shazo, 1943; De Shazo, 1943; Sullivan et al., 1949; Elkins, 1951a; Pippin, Law \& Gaylor, 1968). They are all considered potential vectors of Chagas disease. These species have also been found infected in other regions of North America (Wood, 1941a, 1941b, 1942; Usinger, 1944).

Some of the hosts of T. cruzi in Texas are the so-called woodrats (Neotoma micropus, Neotoma mexicana, Neotoma spp.) (Packchanian, 1942; Sullivan et al., 1949; Buckholder, Alysson \& Kelly, 1980; Ryckman, 1986), but many other rodents and small mammals serve as hosts. Examples include small wild rodents (Perognathus hispidus, Liomys irrorattus, and Onychomys leucogaster), mice (Mus musculus), North American opossum (Didelphis virginiana), ninebanded armadillo (Dasypus novemcinctus texanus), and bats (Pipistrellus hesperus) (Wood, 1941a; Packchanian, 1942; Burkholder, Allison \& Kelly, 1980).

Four detailed studies were conducted in the Rio Grande Valley from 1941 to 1980 (Wood, 1941; Sullivan et al., 1949; Eads, Trevino \& Campos, 1963; Burkholder, Allison \& Kelly, 1980). Five triatomine species were involved in Trypanosoma cruzi transmission, and 25\% of 861 captured specimens were infected. Known hosts in the Rio Grande Valley are the rodent species Neotoma micropus, Perognathus hispidus, Liomys irrorattus, and Onychomys leucogaster (Burkholder, Allison \& Kelly, 1980), but infections were also diagnosed in bats (Pipistrellus hesperus) (Wood, 1941a).

The possibility of T. cruzi causing disease in the human host in Texas was first demonstrated in 1942 by Packchanian (1943). Since then, five cases of Chagas disease in the region have been confirmed by laboratory tests (Woody \& Woody, 1955; Betz, 1984; Roberts \& Janovy, 2009). Serological surveys in southern Texas, including the Rio Grande Valley, showed at least 24 new cases by the late 1970s (Woody, Dedianous \& Woody, 1961; Woody, Hernandez \& Suchow, 1965; Kagan, Norman \& Allain, 1966; Burkholder, Allison \& Kelly, 1980). In addition, T. cruzi infection was detected in dogs and non-human primates, as well as in coyotes and other animals (Kasa et al., 1977; Williams et al., 1977; Meurs et al., 1998; Burkholder, Allison \& Kelly, 1980; Grögl et al., 1984).

In addition to the cases in Texas, autochthonous cases have been reported in California (Schiffler et al., 1984). Various species of domestic animals were infected experimentally with T. cruzi in Maryland (Diamond \& Rubin, 1958). It is currently known that $T$. cruzi infects numerous species of animals across a major part of the United States. The main concern among health authorities is that Chagas disease could also spread across the country through migratory movements, transfusions, and/or congenitally (Milei et al., 2009).

\section{THE SEMIARID REGIONS OF BRAZIL}

Although Brazil has eliminated intradomiciliary transmission of T. cruzi by Triatoma infestans throughout the country, transmission by wild species still occurs in some rural areas (Ramos Jr. \& Carvalho, 2001). T. infestans was found in some villages in southern Piauí, but not in the southeastern part of the State, including the city of São Raimundo Nonato, where only sylvatic species were recorded. In this part of Northeast Brazil, the main vector species identified around or even inside human dwellings are Triatoma brasiliensis and Triatoma sordida, both considered sylvatic.

Triatoma brasiliensis adapted well to the region's adobe houses and outbuildings, mostly built close to the mountains, near the natural waterholes. This poses a problem for vector control activities, since the insect's sylvatic/ domiciliated habits make control and eradication measures inefficient. Some economic development and basic technology have reached the villages and settlements, including electricity. Lighting at night began attracting more insects from the wild environment, thus increasing the risk of transmission. In the small villages surrounding the Serra 
da Capivara National Park, Triatoma brasiliensis routinely infests human dwellings (Dias et al., 2000). These kissing bugs are also readily found in the rock shelters and niches in the sandstone or limestone hills, the natural habitat of rodents and marsupials, found infected with T. cruzi (Gomes, 1993). The parasite's life cycle is thus maintained in both wild and domestic animals. The parasite circulates between two environments, natural and manmade, just a few meters apart (Xavier et al., 2007).

The current population living around the park originally migrated mainly from other States of the Northeast in the late $19^{\text {th }}$ and early $20^{\text {th }}$ centuries, when they fled prolonged droughts and settled in small villages in the region. In the early $20^{\text {th }}$ century, many families lived in caves or rock shelters, like the prehistoric peoples. They tapped rubber from maniçoba (Manihot glaziovii), for which a heavy demand developed during World War II.

The demand for maniçoba sustained these families for years. Many children were born in the caatinga and lived there for years without ever meeting any outsiders or experiencing any other way of life. Some of them still live in the villages, infected with the T. cruzi they acquired in the past (Ramos Jr. \& Carvalho, 2001). There are reports of sudden deaths in young adults, as well as chronic cardiac and/or digestive conditions (Borges-Pereira et al., 2002, 2006, 2007; Sarquis et al., 2006).

These characteristics, plus the fact that these small groups remained isolated for decades and intermarried, make the conditions particularly interesting for studying evolutionary aspects in the history of Chagas disease, related both to the pathogenesis of the disease and genetic traits in the human population. If it proves possible to recover T. cruzi genetic material in organic remains from archaeological sites and compare it to modern DNA, the information would certainly be valuable for understanding the evolutionary history of Chagas disease in the region.

\section{REGIONS UNDER STUDY: THE PREHISTORIC PICTURE - LOWER PECOS, TEXAS, USA}

In 2003, a case of prehistoric Chagas disease was confirmed in North America. It was the mummified body of an adult male who died with his intestine full of feces, suggestive of Chagas megacolon (Reinhard, Fink \& Skiles, 2003). The mummy was dated 1,150 BP, and the diagnosis was confirmed by recovering parasite DNA using molecular biology techniques (Dittmar et al., 2003). It became the most recently notified case and also the most ancient known case in the United States.

Since Chagas disease is rare in North America, documented human cases are important and deserve reporting, whether recent or ancient. Lesions found in a mummified body proved the seventh case of Chagas disease in Texas, providing important data for both paleoepidemiologists and modern-day epidemiologists (Reinhard, Fink \& Skiles, 2003).

The Rio Grande region (Rio Bravo) boasts a very rich bioarchaeology, especially between the towns of Ciudad Acuna, Coahuila, and Del Rio in Texas, reaching the tributaries of the Amistad International Recreation Area and both sides of the U.S.-Mexico border. Many mummified bodies have been found in this region with its semiarid climate, offering a prime opportunity for paleoepidemiological studies. This particular mummy, in which Chagas disease was confirmed (Reinhard, Fink \& Skiles, 2003), was studied by Turpin, Henneberg \& Bement (1986), who compared the results with those of four other mummies. Radiocarbon dating determined the death at 1,150 BP.

The mummy, identified as SMM, was a male individual that died between 35 and 45 years of age. The study of pollen and food remains (Turpin, Henneberg \& Bement, 1986) showed that grasses predominated at the time, followed by pollen from Asteraceae and small amounts of Pinus, Cheno Am, Celtis, and some unidentified species. Other taxa included Onagraceae, Umbelliferae, Juniperus, Malvaceae (malva), Dasylirion, Agave, Quercus, Prosopis, 
and fern spores. Macroscopically, Opuntia and grass seeds identified as Setaria were found, along with fiber, probably from Agave. The coprolites yielded a surprising variety of animal remains, including bone fragments from various fishes, snakes, bats, rodents (Peromyscus, Thomomys) and 250 fragments of grasshoppers. Analysis of the pollen and animal remains indicates that the individual died in the spring (Turpin, Henneberg \& Bement, 1986).

The mummy consists of a nearly complete skeleton, with hair, conjunctive tissues, and a large portion of the digestive tract. The corpse had been laid on its right side and was found with a mass of desiccated organic material, probably the contents of the small intestine, covering the right side of the thorax and abdominal area. These remains are still under study to determine their origin. The large intestine is nearly complete, and its appearance is consistent with megacolon (Reinhard, Fink \& Skiles, 2003).

This case of Chagas disease diagnosed in the SMM mummy may have resulted from natural infection by triatomine feces containing trypomastigote forms and by active penetration of the mucosa. Although the species has still not been determined, the evidence points to a limited range of possibilities. The infection rates found in triatomines in the Rio Grande Valley suggest Triatoma gerstaekeri and Triatoma neotomae as the most likely species. However, Triatoma neotomae prefers to feed on the blood of rodents, while Triatoma gerstaekeri is more opportunistic, feeding on various animals, including humans (Packchanian, 1939; Eads et al., 1963, Lent \& Wygodzinsky, 1979). One study in Texas showed that the latter species was involved in all the human cases (Woody, Dedianous \& Woody, 1961).

However, infection via triatomine feces is not the parasite's only form of transmission. The food contents of the SMM mummy actually suggest that this individual may have been infected by ingesting contaminated food or the vector itself. Cases of infection with T. cruzi can occur when the contaminated insects are swallowed, or animals are eaten raw (Usinger, 1944; Lent \& Wygodzinsky, 1979). The intestinal contents of the SMM mummy include fragments of the white-footed mouse (Peromyscus leucopus), pocket gopher (Thomomys sp.), a bat, and 250 grasshoppers. These gastronomic preferences raise the hypothesis that this individual might have swallowed a triatomine whole, infected with T. cruzi.

Analyses of other coprolites from the Southwest United States (Reinhard, 1990, 1992; Reinhard et al., 1992) show that the hunter-gatherers frequently ate a wide variety of insects such as grasshoppers, crickets, and ants. Although at present the ingestion of vectors or vertebrate hosts does not appear epidemiologically important, the case of this mummy suggests such a possibility in societies with different eating habits from those of modern Western society.

Another aspect of the pathoecology of Chagas disease in this area is the consumption of raw or undercooked rodents in prehistory. The consumption of rodents and a high dental abscess rate may have facilitated infection. The oral transmission route is known to be extremely efficient. Besides the fact that the metacyclic forms are perfectly capable of penetrating the intact mucosa, the stomach's acid environment exposes epitopes on the parasite's surface that increase its infectivity (Yoshida, 1997). In addition, $84 \%$ of the adults excavated in the Lower Pecos showed dental abscesses that could have served as a portal of entry for the parasite.

Pathological lesions in the intestine are clearly visible in the mummy. As in modern times, Chagas disease was endemic in the region in prehistoric times, although with low endemicity. Cave-dwelling provided ideal conditions for its pathoecology in the Lower Pecos region. Excavations of the caves have recovered large amounts of plant fibers, an ideal habitat for both rodents and triatomines. Humans used straw for bedding, which shows that they actually slept in the caves (Shafer, 1986). Such conditions would have led to the prevalence of Chagas disease in the population at that time.

In an interesting study, Dittmar et al. (2003) recovered T. cruzi 18S rDNA from muscle tissue in this mummified body. The resulting sequence was aligned manually with available sequences in GenBank (Sequencer 4.1.1.) and 
submitted to phylogenetic analysis using maximum likelihood (ML) analysis (Felsenstein, 1981). The finding confirms the digestive form of Chagas disease described by Reinhard, Fink \& Skiles (2003).

\section{THE STUDY OF PREHISTORIC CHAGAS DISEASE IN BRAZIL}

In the cerrado region of northern Minas Gerais State, in the Peruaçu Valley, Central Brazil, André Prous found the partially mummified body of an individual 35 to 40 years of age, buried in an oval grave under a rock shelter, close to the Peruaçu River (Kipnis, 2008).

Initial examination of coprolite fragments from this mummy yielded eggs of Echinostoma sp., an uncommon parasite in the human host, and hookworm eggs (Sianto et al., 2005).

Preservation of organic remains is very good in this part of Central Brazil. Although gallery forests line the rivers, the vegetation is typical of the cerrado. The body was placed in the fetal position, protected with leaves and covered with baskets. The individual's head was wrapped in leaves and his body was partially mummified. Arms, legs, abdominal skin, and some muscles are well-preserved. Many personal objects were found in the grave. Although healed fractures were identified in the foot bones, the skeleton shows no signs of violence. There are evident oral lesions such as tooth wear and a dental abscess. A large mass in the abdominal cavity was identified as accumulated feces, obstructing the descending and sigmoid colon. The shape of the fecal mass reproduces the intestine's circumvolutions.

Careful cleaning was performed and the mass was exposed after submitting the body to computed tomography (CT), obtaining detailed images of the inside of the mummy (Fernandes et al., 2008). To confirm the suspicion of Chagas megacolon, since the Peruaçu Valley is now endemic for the disease, PCR was performed to test for T. cruzi, with positive results. It was also possible to confirm the parasite's presence in various tissues, showing that the individual presented a high parasite burden, while T. cruzi DNA in the tissue adjoining the fecal mass confirms the disease as megacolon. This pathology is associated with the TCII genotype and is typical of the chronic phase of the disease, quite common in the area before control of transmission by Triatoma infestans. Nevertheless, characterization of the parasite from one of the samples showed a TCI profile.

In addition, this condition is attributed to human infection with genotype TCII. The presence of TCI in an individual with megacolon could be explained by a change in the epidemiological profile of the disease or by an undetected mixed TCI/ TCII infection. Importantly, the morbidity of infection with TCI or TCII in human species still poses unanswered questions such as the association between these genotypes and greater or lesser degrees of morbidity, or even different clinical manifestations of the disease.

Positive PCR results in nearly all the tissue fragments show that the parasite had spread systemically and that the individual presented a high parasite burden, typical of acute Chagas disease, but which apparently clashes with the presence of megacolon, typical of the chronic phase.

Araújo et al. (2005) studied the same material, with apparently contradictory findings. These authors used as the target $18 \mathrm{~S}$ rDNA (126bp and $159 \mathrm{bp}$ ) and mitochondrial 12S rDNA (148 bp) and confirmed infection with T. cruzi, but concluded that the parasites found were genotype TCII. This apparently contradictory result may mean a mixed TCI/ TCII infection in the same individual.

Studying another individual from this archaeological site, Lima et al. (2008) observed infection with genotype TCI in a human bone fragment dated 7000-4500 BP. The bone was described as that of a woman some 35-39 years of age from a hunter-gatherer group. 
Genotyping was obtained by amplifying and sequencing a mini-exon (339 bp) gene fragment. Hybridization of this DNA fragment with specific primers (sequences of mini-exon TcI and TcII and total k-DNA) confirmed the presence of T. cruzi in the material. The presence of genotype TCI in human bone tissue dated to 7000-4500 BP in Minas Gerais State, a region where this genotype is not reported infecting humans (Fernandes et al., 1998, 1999), shows that the distribution of $T$. cruzi genotypes is dynamic and varies in time and space.

The possibility of genotyping parasites found in archaeological remains opens the fascinating perspective of reconstituting the origin and dispersal of $T$. cruzi and its subpopulations, hopefully solving the question of the ancestral host of T. cruzi.

\section{CONCLUSIONS}

Many important vestiges of the parasite and host genomes survive during the co-evolutionary process of the parasite-host-environment system (Araújo et al., 2003). The genome transmits these vestiges, revealing important events in the evolutionary process.

Paleoparasitology, especially with the use of molecular biology techniques, offers new ways of studying parasitehost relations, unveiling the ancient genome of parasites and hosts and the ways by which they have changed or remained the same. Paleoparasitology can help elucidate issues pertaining to the antiquity of parasite-host relations, as well as their origin and evolution (Araújo \& Ferreira, 2000; Araújo et al., 2003).

Ujvari (2008) comments quite appropriately on these possibilities provided by paleoparasitology, discussing issues ranging from the origin of parasitism in trypanosomatids to the formation of species in the Americas. He comments that T. cruzi genetic material can help reconstruct 100 million years of the planet's geographic history, and that it can be used for the geographic history of the American continent. He reaches these conclusions based on studies of African and Australian trypanosomes, comparing them to American ones.

Studies on the paleoparasitology of Chagas disease can shed light on the antiquity of this disease in the Americas through extraction and amplification of T. cruzi DNA from human and other animal organic remains, including fragments of vectors and vertebrate hosts found in archaeological sites.

We can compare material extracted from different periods of human occupation, for example hunter-gatherers and agriculturalists, or cave and rock shelter dwellers and villagers. We can thus test and apply evolutionary approaches and cladistic analyses from the pre-Columbian period to modern times. We have begun to paint a paleoepidemiological picture, with interesting possibilities for emergence of the disease in the inhabitants (or occasional occupants) of caves and rock shelters, while it appeared to decrease or disappear completely in the groups that lived in villages and occasionally changed their place of occupation.

\section{REFERENCES}

ANONYMOUS. Anonymous recommendations from a satellite meeting. Memórias do Instituto Oswaldo Cruz, 94: 549-562, 1999.

ARAÚJO, A. \& FERREIRA, L. F. Paleoparasitology and the antiquity of human host-parasite relationship. Memórias do Instituto Oswaldo Cruz, 95, supl. 1: 89-93, 2000.

ARAÚJO, A. et al. Parasitism, the diversity of life, and paleoparasitology. Memórias do Instituto Oswaldo Cruz, 98, supl. 1: 5-11, 2003. 
ARAÚjO, A. et al. Paleoparasitology of Chagas' disease. Revista da Sociedade Brasileira de Medicina Tropical, 38: 490-490, 2005.

AUFDERHEIDE, A.C. et al. A 9,000-year record of Chagas' disease. Proceedings of the National Academy of Sciences, 101: 2,034$2,039,2004$.

BASTOS, O. M. et al. Experimental paleoparasitology: identification of T. cruzi DNA in desiccated mouse tissue. Paleopathology Newsletter, 94: 5-8, 1996.

BETZ, T. G. Chagas disease investigation. Texas Preventing Diseases Newsletter, 31: 1-4, 1984.

BORGES-PEREIRA, J. et al. Estudo da infecção e morbidade da doença de Chagas no município de João Costa, Parque Nacional Serra da Capivara, Piauí, Brasil. Revista da Sociedade Brasileira de Medicina Tropical, 35: 315-322, 2002.

BORGES-PEREIRA, J. et al. Soroprevalência da infecção chagásica no estado do Piauí, 2002. Revista da Sociedade Brasileira de Medicina Tropical, 39: 530-539, 2006.

BORGES-PEREIRA, J. et al. Prevalência de aneurismas de ventrículo esquerdo em duas áreas do estado do Piauí, Brasil. Revista da Sociedade Brasileira de Medicina Tropical, 40: 521-526, 2007.

BUCKHOLDER, J. E.; ALLISON, T. C. \& KELLY, V. P. Trypanosoma cruzi (Chagas) (Protozoa: Kinetoplastida) in invertebrate, reservoir, and human hosts of the Lower Rio Grande Valley of Texas. The Journal of Parasitology, 66: 305-311, 1980.

COCKBURN, A. Infectious Diseases: their evolution and eradication. Cambridge: Cambridge University Press, 1967.

COIMBRA JR., C.E.A. Human settlements, demographic pattern, and epidemiology in lowland Amazonia: the case of Chagas' disease. American Anthropologist, 90: 82-97, 1988.

DAVIS, D. J.; MCGREGOR, T. \& DE SHAZO, T. Triatoma sanguisuga (LeConte) and Triatoma ambigua Neiva as natural carriers of Trypanosoma cruzi in Texas. Public Health Reports, 58: 353-354, 1943.

DE SHAZO, T. A survey of Trypanosoma cruzi infection in Triatoma spp. collected in Texas. Journal of Bacteriology, 46: $219-220,1943$.

DIAMOND, L. S. \& RUBIN, R. Experimental infection of certain farm mammals with a North American strain of Trypanosoma cruzi from the raccoon. Experimental Parasitology, 7: 383-390, 1958.

DIAS, J. C. P. Doença de Chagas: sucessos e desafios. Cadernos de Saúde Pública, 22: 2.020-2.021, 2006.

DIAS, J. C. P. et al. Esboço geral e perspectivas da doença de Chagas no nordeste do Brasil. Cadernos de Saúde Pública, 16, supl. 2: $13-24,2000$.

DITTMAR, K. et al. Molecular diagnosis of prehistoric Trypanosoma cruzi in the Texas-Coahuila border region. In: ANNUAL MEETING OF THE PAlEOPATHOlogy ASSOcIATION, 13, 2003, Tempe, Arizona. Supplement of the Paleopathology Newsletter. Detroit: Paleopathology Association, 2003.

EADS, R. B.; TREVINO, H. A. \& CAMPOS, E. G. Triatoma (Hemiptera: Reduviidae) infected with Trypanosoma cruzi in South Texas wood rat dens. The Southwestern Naturalist, 8: 38-42, 1963.

ELKINS, J. C. Chagas' disease and vectors in North Central Texas. Arizona Medicine, 41: 159-161, $1951 \mathrm{a}$.

ELKINS, J. C. The Reduviidae of Texas. The Texas Journal of Science, 3: 407-412, 1951b.

EMPERAIRE, L. \& ROMAÑA, C. A. Triatominae et Cactaceae: un risque pour la transmission de la Trypanosomose americaine dans le peridomicile (nord-est du Brésil). Parasite, 13: 171-178, 2006.

EWALD, P. W. Evolution of Infectious Disease. Oxford: Oxford University Press, 1996.

EWALD, P. W. et al. Evolutionary control of infectious disease: prospects for vectorborne and waterborne pathogens. Memórias do Instituto Oswaldo Cruz, 93: 567-576, 1998.

FELSENSTEIN, J. Evolutionary trees from DNA sequences: a maximum likelihood approach. Journal of Molecular Evolution, 17: 368-376, 1981. 
FERNANDES, O. et al. The mini-exon gene: a genetic marker for zymodeme III of Trypanosoma cruzi. Molecular and Biochemical Parasitology, 95:129-133, 1998.

FERNANDES, O. et al. The complexity of the sylvatic cycle of Trypanosoma cruzi in Rio de Janeiro state (Brazil) revealed by the nontranscribed spacer of the mini-exon gene. Parasitology, 118: 161-166, 1999.

FERNANDES, A. et al. Pre-Columbian Chagas' disease in Brazil: Trypanosoma cruzi I in the archaeological remains of a human in Peruaçu Valley, Minas Gerais, Brazil. Memórias do Instituto Oswaldo Cruz, 103: 514-516, 2008.

FERREIRA, L. F. et al. Paleoparasitology of Chagas' disease revealed by infected tissues from Chilean mummies. Acta Tropica, 75: $79-84,2000$.

FORNACIARI, G. et al. Chagas' disease in a Peruvian Inca mummy. The Lancet, 339: 128-129, 1992.

GOMES, M. A. T. Potencial de Transmissão da Tripanossomíase Americana nas Localidades do Sítio do Mocó e Borda, Município de São Raimundo Nonato, Sudeste do Piauí, 1993. Master’s thesis, Rio de Janeiro: Escola Nacional de Saúde Pública, Fundação Oswaldo Cruz.

GRÖGL, M. et al. Antibodies to Trypanosoma cruzi in coyotes in Texas. The Journal of Parasitology, 70: 189-191, 1984.

GUHL, F. et al. T. cruzi DNA in human mummies. The Lancet, 349: 1.370, 1997.

GUHL, F. et al. Isolation of Trypanosoma cruzi DNA in 4,000-year-old mummified human tissue from northern Chile. American Journal of Physical Anthropology, 108: 401-407, 1999.

GUHL, F. et al. Chagas' disease and human migration. Memórias do Instituto Oswaldo Cruz, 95: 553-555, 2000.

GUIDON, N. On stratigraphy and chronology of Pedra Furada. Current Anthropology, 30: 641-642, 1989.

GUIDON, N. \& ARNAUD, B. The chronology of the New World: two faces of one reality. World Archaeology, 23: 524-529, 1991.

GUIDON, N. \& DELIBRIAS, G. Carbon 14 dates point to man in the Americas 32,000 years ago. Nature, 324: 167-178, 1986.

HAAG, J.; O'HUIGIN, C. \& OVERATH, P. The molecular phylogeny of trypanosomes: evidence for an early divergence of the Salivaria. Molecular and Biochemical Parasitology, 91: 37- 49, 1998.

JOHNSON, K. L. et al. A tick from a prehistoric Arizona coprolite. The Journal of Parasitology, 94: 296-298, 2008.

KAGAN, I. G.; NORMAN, N. \& ALLAIN, D. Studies on Trypanosoma cruzi isolated in the United States: a review. Revista de Biología Tropical, 14: 55-73, 1966.

KASA, T. J. et al. An endemic focus of Trypanosoma cruzi infection in a sub-human primate research colony. Journal of the American Veterinary Medical Association, 171: 850-854, 1977.

KIPNIS, R. Padrões de Subsistência dos povos forrageiros do Vale do Peruaçu. In: PROUS, A. P. \& RODET, J. (Ed.). Arqueologia do Vale do Peruaçu. Belo Horizonte: Museu de História Natural/UFMG, 2008.

LEAL, E. S. \& ZANOTTO, P. M. A. Viral diseases and human evolution. Memórias do Instituto Oswaldo Cruz, 95: 193-200, 2000.

LEGER, L. Les affinités de l'Herpetomonas subulata et la phylogenie des trypanosomes. Comptes Rendues de la Societé de Biologie, 67: 615, 1904.

LENT, H. \& WYGODZINSKY, P. Revision of the Triatominae (Hemiptera, Reduviidae), and their significance as vectors of Chagas' disease. Bulletin of the American Museum of Natural History, 163: 125-520, 1979.

LIMA, V. S. et al. Chagas' disease in ancient hunter-gatherer populations, Brazil. Emerging Infectious Diseases, 14: 1.001-1.002, 2008.

MADDEN, M. et al. Hybridization screening of very short PCR products for paleoepidemiological studies of Chagas' disease. Biotechniques, 30: 102-104, 2001.

MElTZER, D. J.; Adovasio, J. M. \& DillehAY, T. D. On a Pleistocene human occupation at Pedra Furada, Brazil. Antiquity, 68: 695-714, 1994. 
MEURS, K. M. et al. Chronic Trypanosoma cruzi infection in dogs: 11 cases (1987-1996). Journal of the American Veterinary Medical Association, 213: 497-500, 1998.

MILEI, J. et al. Prognostic impact of Chagas' disease in the United States. American Heart Journal 157: 22-29, 2009.

MILES, M. A. et al. The identification by isoenzyme patterns of two distinct strain-groups of $T$. cruzi, circulating independently in a rural area of Brazil. Transactions of the Royal Society of Tropical Medicine and Hygiene, 71: 217-225, 1977.

MILES, M. A. et al. Isozymic heterogeneity of T. cruzi in the first autochthonous patients with Chagas' disease in Amazonian Brazil. Nature, 272: 819-821, 1978.

MINCHIN, E. A. Investigations on the development of trypanosomes in tsetse flies and other Diptera. The Quarterly Journal of Microscopical Science, 52: 159, 1908.

OREllanA, N. C. H. Paleogenética de Populações Pré-Colombianas da Bolívia: análises do mtDNA humano, e infecções por Trypanosoma cruzi e vírus linfotrópico das células Thumanas (HTLV), 2008. Master's thesis, Rio de Janeiro: Instituto Oswaldo Cruz, Fundação Oswaldo Cruz.

PACKHANIAN, A. Natural infection of Triatoma gerstakeri with Trypanosoma cruzi in Texas. Public Health Reports, 55: 1.300-1.306,

PACKHANIAN, A. Reservoir hosts of Chagas' disease in the United States. American Journal of Tropical Medicine, 22: 623-631, 1942.

PACKHANIAN, A. Infectivity of the Texas strain of Trypanosoma cruzi to man. American Journal of Tropical Medicine, 23: 309$314,1943$.

PARENTI, F. et al. Chronostratigraphie des gisements archéologiques et paléontologiques de São Raimundo Nonato (Piauí, Brésil):

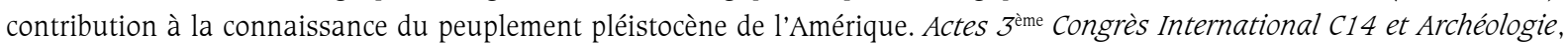
26: 327-332, 1998.

PIPPIN, W. F.; LAW, P. F. \& GAYLOR, M. J. Triatoma sanguisuga texana Usinger and Triatoma sanguisuga indictiva Neiva naturally infected with Trypanosoma cruzi Chagas in Texas. Journal of Medical Entomology, 5: 134, 1968.

RAMOS JR., A. N. \& CARVALHO, D. M. Os diferentes significados da certificação conferida ao Brasil como estando livre da doença de Chagas. Cadernos de Saúde Pública, 17: 1.403-1.412, 2001.

REINHARD, K. J. Archaeoparasitology in North America. American Journal of Physical Anthropology, 82: 145-162, 1990.

REINHARD, K. J. Parasitology as an interpretative tool in archaeology. American Antiquity, 57: 231-245, 1992.

REINHARD, K. J.; FINK, M. \& SKILES, J. A case of megacolon in Rio Grande Valley as a possible case of Chagas' disease. Memórias do Instituto Oswaldo Cruz, 98, supl. 1: 165-172, 2003.

REINHARD, K. J. et al. Recovery of parasite remains from coprolites and latrines: aspects of paleoparasitology techniques. Homo, 37: 217-239, 1987.

REINHARD, K. J. et al. Discovery of colon contents in a skeletonized burial: soil sampling for dietary remains. Journal of Archeological Science, 19: 697-705, 1992.

ROBERTS, L. S. \& JANOVY, J, J. Foundations of Parasitology. New York: McGraw-Hill Publishers, 2009.

ROMAÑA, C.; EMPERAIRE, L. \& JANSEN, A. M. Enfoques conceptuales y propuestas metodológicas para el estudio de las interacciones entre el medio ambiente y la salud: aplicación a un programa de investigación sobre la tripanosomiasis americana. Cadernos de Saúde Pública, 19: 945-953, 2003.

ROTHHAMmER, F. et al. Chagas' disease in pre-Columbian South America. American Journal of Physical Anthropology, 68: 495$498,1985$.

RUFFER, M.A. Studies on Paleopathology of Egypt. Chicago: University of Chicago Press, 1921.

RYCKMAN, R.E. The vertebrate hosts of the Triatominae of North and Central America and the West Indies (Hemiptera: Reduviidae: Triatominae). Bulletin of the Society of Vector Ecologists, 11: 221-241, 1986. 
SARQUIS, O. et al. Aspects of peridomiciliary ecotopes in rural areas of northeastern Brazil associated to triatomine (Hemiptera, Reduviidae) infestation, vectors of Chagas' disease. Memórias do Instituto Oswaldo Cruz, 101(2): 143-147, 2006.

SCHIFFLER, R. J. et al. Indigenous Chagas' disease (American trypanosomiasis) in California. Journal of American Medical Association, 251: 2.983-2.984, 1984.

SHAFER, H. J. Ancient Texans: rock art and lifeways along the Lower Pecos. Austin: Texas Monthly Press, 1986.

SIANTO, L. et al. The finding of Echinostoma (Trematoda: Digenea) and hookworm eggs in coprolites collected from a Brazilian mummified body dated 600-1,200 years before present. The Journal of Parasitology 91: 972-975, 2005.

STEVENS, J. R. \& GIBSON, W. The evolution of pathogenic trypanosomes. Cadernos de Saúde Pública, 15: 673-684, 1999.

STEVENS, J.; NOYES, H. \& GIBSON, W. The evolution of trypanosomes infecting humans and primates. Memórias do Instituto Oswaldo Cruz, 93: 669-676, 1998.

STEVENS, J. R. et al. The molecular evolution of Trypanosomatidae. Advances in Parasitology, 48: 1-56, 2001.

SUlLIVAN, T. et al. Incidence of Trypanosoma cruzi, Chagas, in triatoma (Hemiptera, Reduviidae) in Texas. American Journal of Tropical Medicine, 29: 453-458, 1949.

TURPIN, S. A.; HENNEBERG, M. \& BEMENT, L. C. Late Archaic mortuary practices of the Lower Pecos River region, southwest Texas. Plains Anthropologist, 31: 295-315, 1986.

UJVARI, S. C. A História da Humanidade Contada Pelos Vírus. São Paulo: Contexto, 2008.

USINGER, R. L. The Triatominae of the North and Central America and the West Indies and their public health significance. Public Health Bulletin, 288: 83, 1944.

WILLIAMS, G. D. et al. Naturally occurring trypanasomiasis (Chagas' disease) in dogs. American Journal of Veterinary Medical Association, 171: 171-177, 1977.

WOOD, S. F. New localities for Trypanosoma cruzi Chagas in southwestern United States. American Journal of Hygiene, 34: 1-13, 1941a.

WOOD, S. F. Notes on the distribution and habits of Reduviid vectors of Chagas' disease in the southwestern United States. PanPacific Entomologist, 27: 85-94, 1941 b.

WOOD, S. F. Observations on vectors of Chagas' disease in the United States. Bulletin (Southern California Academy of Sciences), 41: 61-69, 1942.

WOODY, N. C. \& WOODY, H. B. American trypanosomiasis (Chagas' disease). Journal of the American Medical Association, 159: 676-677, 1955.

WOODY, N. C.; DEDIANOUS, N. \& WOODY, H. B. American trypanosomiasis II: current serologic studies in Chagas' disease. The Journal of Pediatrics, 58: 738-745, 1961.

WOODY, N. C.; HERNANDEZ, A. \& SUCHOW, B. American trypanosomiasis III: the incidence of serologically diagnosed Chagas' disease among persons bitten by the insect vector. The Journal of Pediatrics, 66: 107-109, 1965.

XAVIER, S. C. et al. Mapping of the distribution of Trypanosoma cruzi infection among small wild mammals in a conservation unit and its surroundings (Northeast-Brazil). Parasitology International, 56: 119-128, 2007.

YOSHIDA, N. et al. Removal of sialic acid from mucin-like surface molecules of Trypanosoma cruzi. Molecular and Biochemical Parasitology, 84: 57-67, 1997.

ZINGALES, B. et al. A new consensus for Trypanosoma cruzi intraspecific nomenclature: second revision meeting recommends TcI to TcVI. Memórias do Instituto Oswaldo Cruz, 104: 1.051-1.054, 2009. 


\title{
Diseases Recorded in Historical Documents
}

\author{
Diana Maul de Carvalho
}

\section{THEORETICAL AND METHODOLOGICAL ISSUES}

$\mathrm{B}$ uilding interfaces between scientific fields involves the "translation" of propositions, among other problems. In order to establish a common language, it is necessary to explain the meaning of the concepts in this process. Otherwise, scientific polysemy can lead to an apparently complex discourse which is often merely confusing and with no analytical potential. The history of medicine and the discussion of diseases from a historical perspective demand dialogue between clinical practice, epidemiology, and the human sciences.

Natural history distinguishes man as a unique species among living beings. This man, the measure of all things, allows constructing the discourse of history. With a permanent view, man creates a collective past, future, and present. Nineteenth-century evolutionism situated man as the limit of evolution, fixing his characteristics as a species.

Such permanence, extending to the basic biological characteristics of physiological processes, allows constructing an epidemiological discourse. If we accept these assumptions, we can speak of a historical epidemiology or a history of diseases.

What is a "disease"? And why do we study its history? The study of diseases from a historical perspective involves the very concept of disease and its limits, among other questions. Grmek (1983) proposed to write not a history of knowledge on diseases or of social practices related to them, but rather a history of diseases themselves. In fact, he chose to define disease based on findings (or descriptions) of signs and symptoms and anatomopathological lesions that now correspond to known diseases, or to states classified as potentially pathological. The archaeological material that Grmek included in his studies on diseases in Classical Antiquity - tissues, especially bones, in addition to other findings - oriented the choice of a criterion that could have stability for a relatively long period of time, measured in thousands of years, and which could in a sense be ahistorical. 
The theoretical model proposed by Grmek - pathocenosis - originated in the discussions of pathobiocenosis by Pavlovsky (s.d.). However, by removing "bio" from the term, Grmek launched the challenge of including "social variables" in the analysis of diseases in human populations, akin to the concepts of "human ecology". ${ }^{1}$

According to this model, when discussing diseases in the past, we deal with the concepts of possibility and probability of the presence of a given disease entity by constructing it based on epidemiology. An important theoretical impasse has been the inclusion of "social variables" in this model. Thus, possibility is basically defined by comparing the signs and symptoms described in documents or found in mummified tissues with those constituting disease states as currently defined.

We can also use this procedure to discuss the presence of diseases that are now unknown. Just as we speak of "emerging diseases", we can also conceive of "submerged diseases". Meanwhile, the probability of occurrence is not defined primarily by the clinical picture, but rather by "epidemiological evidence", by the presence of factors called "determinants", "risk factors", and "associated variables" of the disease in question, depending on the model applied to it.

Signs and symptoms are considered direct expressions of the pathophysiological process and are thus relatively permanent and structural. Epidemiological evidence is circumstantial or contextual. Thus, across long periods of time, even tens of thousands of years, we expect possibilities to be stable and probabilities to vary. These issues apply to both paleopathological analyses and the study of texts and other documents. ${ }^{2}$

Other authors such as Charles Rosenberg $(1992)^{3}$ take a different approach. In constructing a social history of diseases, they define diseases by their "social recognition" and study the context and actors involved in this construction. ${ }^{4}$ However, the Grmek of AIDS (1989) is closer to Rosenberg than the Grmek of "archaeological" diseases. The methodological options in constructing this object are unexpectedly complex. At first sight, some choices appear largely oriented by the documental base itself: where only bones exist, we attempt to reconstruct a pathocenosis. Where there are abundant written documents, we choose to reconstruct the string of discourses pertaining to that disease. We suggest that such approaches are not mutually exclusive, although they involve different methodological challenges.

Other chapters of this book discuss the methodological issues involved in the construction of pathocenosis based on archaeological remains. Here, we pose several questions involved in the study of written documents - drawing on some examples - to construct the history of diseases, with Grmek and Rosenberg as possible theoretical and methodological references, but fundamentally considering the possibility of constructing pathocenosis.

For methodological developments, the "evidential paradigm" proposed by Carlo Ginzburg (1986) can serve as the guiding thread for studies on the history of diseases. Of course we do not intend to exhaust the discussion of these methodological questions, and the selection of examples is necessarily skewed by the attempt to present a range of situations illustrating the impasses and potential solutions. The examples should also illustrate our view that the history of diseases is not meant to identify "historical characters" that, when "personified" in microorganisms,

\footnotetext{
${ }^{1}$ For a discussion on the concepts of human ecology, see Follér \& Hansson (1996) and Coimbra Junior et al. (2002).

${ }^{2}$ Rothschild (1981) and Stanley \& Joske (1980) are two anthologies that represent the discussions and initiatives (as of the 1970s) on interdisciplinary studies, which at that time were markedly evolutionary and akin to the proposals of Grmek and other authors.

${ }^{3}$ See also Rousseau et al. (2003).

${ }^{4}$ For a review of the concepts and theoretical positions in the social history of diseases, see Nascimento \& Silveira (2004).
} 
acquire autonomy as agents and as a unique explanation for the events. ${ }^{5}$ We see the history of diseases as an important marker for the ways human societies are organized, their modes of production, and their interventions in the environment that allow defining territory as the space built by human movement (Santos, 1996) - a human creation, of which diseases are an essential component.

\section{DISEASES RECORDED IN TEXTS}

We define "texts" as a wide variety of documents, ranging from those where one would explicitly expect to see diseases described (or at least named), such as death certificates and patient records, to literary works, which can also contain evidence of their presence. Here, we only consider texts from the so-called "Western tradition" of medicine, in a few European languages, and recorded from the $15^{\text {th }}$ century to the present.

The interpretation of such texts should consider that our reading may not identify (as diseases) events that are not recognizable as such today (unless explicitly named). Meanwhile, events that were not considered abnormal in the past will also probably be underrepresented, even though they correspond to diseases that are now properly identified.

From the $18^{\text {th }}$ to the $19^{\text {th }}$ century, from classificatory to pathophysiological medicine, from Pinel to Claude Bernard, disease moved from a set of signs and symptoms that allow a phenotypic classification to an expression of altered functions with a definable "normal"; a pathophysiology with a material substrate.

The phenotypic classificatory medicine of the $18^{\text {th }}$ century only recognized disease based on the diseased individual, after the fact. Medicine with a pathophysiological basis, in the $19^{\text {th }}$ century, proposed to define "normal" positively, not only as absence of the perceived disease. It was thus possible to find the disease before the fact and "discover" the diseased individual by comparison with the "normal".

The operationalization of these concepts led to profound changes in medical practice. Medicine assumes that pathological phenomena are identical to the corresponding normal phenomena, except for quantitative variations (Canguilhem, 1990). In so doing, medicine assumes not only the capacity to recognize diseased individuals, to name diseases, and to treat them, but also to define the diseased individual (including the negation of his own recognition), embodying in the physician the role of defining a social value, namely health.

New issues emerged from the $19^{\text {th }}$ to the $20^{\text {th }}$ century. Diseases could now be seen not only as the result of changes in the internal milieu affected by external aggressors, but as the result of ecological relations. Cannon (1939), with the theory of homeostasis, signaled this issue by discussing the equilibrium between the internal and external milieus. Selye (1956), by developing the theory of stress and defining the general adaptation syndrome and diseases of adaptation, elaborated on questions raised by Broussais (1828) with his theory of irritation. Furthermore, expanding on the theory of homeostasis, he attempted to solve one of the impasses in pathophysiological clinical medicine (namely, that altered individuals are not always ill), to the point of proposing that some deficiencies can be protective.

The observation of patterns of death in the collective body also allowed the development of a human ecology, which immediately included social relations in the determination of disease. Disease now became an attribute that was no longer exclusively one of diseased individuals, but of a certain social formation. The realization that death is not a random, unpredictable event, but that there are different patterns for different sets of humans, different forms

\footnotetext{
${ }^{5}$ See, for example, Crosby (1986) and Diamond (1997).
} 
of illness and dying, had been recurrent in authors from "Western medicine" since Hippocrates. However, the $19^{\text {th }}$ century certainly witnessed new elements in this discussion (Chadwick, 1965; Engels, [1845] 2008).

The $20^{\text {th }}$ century ushered in a new theoretical and methodological development in the study of these issues through the incorporation of knowledge from biology, human and social sciences, mathematics, and statistics into a new discipline - epidemiology.

It thus became possible to study the disease without the patient. Of course bouts of a given disease occur in actual individuals, the ill. But this new vision allowed studying the determinants of the occurrence and distribution of diseases and patterns of illness without immediate reference to the patient (Terris, 2005). The $20^{\text {th }}$ century also witnessed an unprecedented "standardization" of diagnostic criteria and definition of diseases with the establishment of an International Classification of Causes of Death, now the International Classification of Diseases (ICD), already in its $10^{\text {th }}$ Revision and adopted by all the member countries of the World Health Organization (WHO) (1990). The consensus is so great in this classification that we tend to forget that fewer than a hundred years ago there were classificatory keys in dispute that could vary from one author to another. Furthermore, the same name could refer to what were different diseases (according to the current key), while different names could refer to the same disease.

\section{READING TEXTS AND PERFORMING DIAGNOSES}

We will provide examples to illustrate several issues raised by the use of written documental sources for discussing the history of diseases. We will leave aside problems in reading that arise from difficulty in comprehension due to "physical" problems with the text - the manuscripts' handwriting, fonts, deterioration of the material - as well as problems in translation. We will thus focus on issues related to changes in the theoretical basis for defining diseases and classificatory keys and the social context for the production of the documents.

The first example is scurvy, a name that has survived for centuries. What relationship can we establish between its current meaning and that of four hundred years ago? Are we talking about the same disease? The second example deals not with changes in the "medical context" but rather potential problems in identifying the possible meaning of absence of "expected diagnoses". In the third example, we discuss diagnoses that are impossible, at least based only on a reading of the texts.

\section{Diseases in mutation}

Carpenter (1988) wrote The History of Scurvy and Vitamin C, possibly the most complete review of the subject to date, citing 722 references in the text, including 298 books. The introduction states that next to hunger, scurvy is probably the nutritional deficiency that has caused the most suffering in human history. This means that scurvy has historically outstripped pellagra, beriberi, vitamin A deficiency, and even kwashiorkor. No small feat. Even today, populations submitted to major food restriction or alcoholics frequently present pellagra.

The World Health Organization considers vitamin A deficiency an important cause of blindness in the world, motivating a specific vitamin A supplementation program. Scurvy appears to have disappeared. Carpenter (1988), like other authors, situates scurvy's heyday at the time of the great seafaring voyages, the theme of his first chapter. As he reports, oranges were already known to cure scurvy. He mentions the diary by Fray Antonio de la Ascención in 1602 on an expedition along the coast of California, reporting that various sailors had come down with the same highly lethal disease that routinely attacked crews on route from the Philippines to Mexico, around Cape Mendocino. 
The first symptom was pain throughout the body, making the person extremely sensitive to touch. Some could not even bear the touch of their blankets.

Next, livid spots appeared (especially from the waist down), the gums swelled, the teeth came loose, and the person often died suddenly, while talking. ${ }^{6}$ Carpenter (1988) explains how in the $17^{\text {th }}$ century, scurvy, or the "scourge of the sea" ${ }^{7}$, became recognized as an important chapter in nosology, classified as acid or alkaline. Scurvy became so ubiquitous that Thomas Sydenham (1769) claimed that the two main subterfuges of ignorant physicians were malignancy and scurvy, which they blamed for disorders and symptoms that often resulted from their own prescriptions.

Henri van Holsbeek (1860), a Dutch physician experienced in the maritime routes to Asia, wrote a treatise on naval hygiene and medicine. The book has an interesting structure, because unlike most modern medical textbooks, it does not delve directly into the description of diseases. Rather, the first three chapters discuss the peculiarities of life at sea and its relationship to health. The author emphasizes the risks that differ from those on dry land, especially isolation, malnutrition, and poor accommodations, in addition to backbreaking work. He highlights differences in the environment, with high humidity and constant temperature changes. He describes the seas and the earth's climates.

Van Holsbeek's third chapter provides a detailed description of ships and highlights the risks due to problems in their construction, pointing out that ships built of green timber caused serious intermittent fevers among the crew. He identifies risks with the cargo and the various parts of the ship related to humidity, heat, stagnated air, and lack of light. Such insalubrious conditions were the purported cause of outbreaks of "ship fever" and other frequently epidemic diseases. He says that provisions were a frequent cause of diseases and that water should be stored in iron as opposed to wooden barrels, in which water acquired a loathsome stench and taste.

Van Holsbeek states that scurvy was now (i.e., in 1860) rare at sea, that it appeared to be endemic in all countries above 60 degrees latitude, on the Baltic coasts, in Iceland and Greenland, and that in the temperate parts of Europe it used to be epidemic, but had disappeared with progress in hygiene and civilization. He attributes scurvy to humidity, lack of light, stagnated air, poor nutrition, moodiness, overuse of dried and salted meats, lack of fresh vegetables, and consumption of rotten meat and spoiled water. He also claims that excessive use of spices that required large amounts of gastric juice for digestion contributed to scurvy. Fresh vegetables, citric fruit juices, and alcoholic beverages prevented scurvy.

James Lind's classic Treatise of the Scurvy in 1754 (edited by Stewart \& Guthrie, 1953) agreed with the theories then in vogue that attributed scurvy to humidity, poor diet, stagnated air, and lack of hygiene and exercise. His recommendations were basically bathing before embarking, clean and dry clothing, careening the ships, adequate water storage, and provision of fresh foods (greens, vegetables, and fruits). Since provisions were difficult to preserve, he suggested measures to concentrate and preserve orange and lemon juice, plus the use of onions, which kept better. Commenting on the last version of the treatise, from 1772, Carpenter (1988) shows that Lind's classical experiment was actually planned to demonstrate that sulfuric acid and vinegar had no effect against scurvy. Lemon and orange juices were the "positive control", since Lind had no doubt about their anti-scurvy properties. However, the sailors serving as negative controls, maintained under a diet that contained no vitamin C, were also cured just as quickly as those who drank fruit juices.

\footnotetext{
${ }^{6}$ Importantly, no modern physician would consider a diagnosis of scurvy based on this report, except as a remote possibility. ${ }^{7}$ For a discussion of this "construction" of disease, see Grmek (1968).
} 
Carpenter contends that the sailors had tricked Lind. For the cases he found of cure at sea, the author offers only three possible explanations: unwitting use of fruits, lying, or placebo effect. He never considers the possibility that the reported disease was not what we now call scurvy.

We now comment briefly on two classical reports of scurvy related to the early transoceanic voyages in the late $15^{\text {th }}$ and early $16^{\text {th }}$ centuries: Vasco da Gama's route to the Indies and Ferdinand Magellan's circumnavigation. In light of current diagnostic criteria, we attempt to establish points of agreement or disagreement in the voyagers' accounts and discuss possible alternative diagnoses. We use versions of the travel diaries that we consider reasonably trustworthy for the purposes of this work. We will not discuss the possible lack of correspondence between terms used in the description of plants, animals, or even signs and symptoms and their current meanings.

Vasco da Gama's vovage (Chaunu, 1969; Chandeigne, 1992; Velho, 1998)

On July 8, 1497, a fleet of four ships (one of which carrying provisions) set sail from Lisbon. On July 27 they anchored in Cape Verde, staying for a week. From August 3 to November 7 they sailed out across the open South Atlantic, without landing. They reached the Bay of St. Helena, where they stayed for eight days, careened the ships, mended the sails, took in wood, and made contact with the natives. They set sail again on November 16, rounding the Cape of Good Hope on the 22th. On November 25 they anchored for 12 days in what is now Mossel Bay. They took in water, distributed the provisions among the three main vessels, and destroyed the storage ship. On December 8 they set out to sea again, and on January 11, 1498, they took in water at Mozambique Island. On January 24 they reached the mouth of the Quelimane:

"We spent thirty-two days in the river, taking in water, careening the ships, and repairing the Raphael's mast. Here many of our men fell ill, their feet and hands swelling, and their gums growing over their teeth, so that they could not eat." (Velho, 1997: 168, our italics) ${ }^{8}$

They continued sailing along the coast till reaching Malindi, where they hired an Arab pilot to help guide them across the Indian Ocean. On April 24 they left Malindi and crossed the Indian Ocean, dropping anchor close to Calicut on May 20. They stayed there for three months, sailing next towards Anjediva. They began their return voyage to Portugal on October 5, 1498, reaching Malindi on January 2, 1499, where scurvy took new victims.

They set sail from Malindi on January 11, with two ships. They dropped anchor on March 3 and later on April 25. The first vessel reached Lisbon on July 10, 1499, bringing word of the newly-discovered maritime route to the Indies. Vasco da Gama, with his brother ill, was delayed and probably reached Portugal between August 29 and September 9.

\section{Ferdinand Magellan's Voyage (Pigafetta, [1524?] 1985)}

The circumnavigation of the globe started festively on Monday morning, August 10, 1519. Five ships with 237 men set sail from Seville for the maritime port of Sanlúcar. The crew slept onboard in Sanlúcar, getting off on land every morning. They set sail from this port on September 20, reaching Tenerife on September 26, where they stayed in port for three days to take in water and coal. They stayed for two more days in Monterroso, where they fished for shark. On an unknown date they reach a point on the Brazilian coast, where they took in abundant provisions, including chickens, potatoes, pineapples, sugar cane, tapir meat, geese, and fish.

\footnotetext{
${ }^{8}$ Interestingly, the editor of this ship's log, Eduardo Bueno, in his note 5 on page 143, assumes that this report is "the first mention of scurvy in the history of navigations by the European peoples" and that the disease is "the result of poor nutrition onboard and lack of vitamin C".
} 
On December 13 they reached Rio de Janeiro, where they described an animal consistent with a golden lion tamarin. They left Rio de Janeiro on December 27, sailing southward along the coast. They found and hunted penguins, storing abundant provisions. On May 19, 1520, they set into port for the winter, building a house for a forge and a warehouse for the victuals and other goods. They remained anchored for five months and captured two Patagonians. On October 21,1520 , they resupplied the ships with water, firewood, and fish and prepared to set sail across the open ocean.

One of the vessels set off to return to Spain, taking along a Patagonian who died during the voyage. On the Brazilian coast they had captured a native whom the fleet took along on the Pacific crossing. On November 28 they entered the Pacific, where they sailed for three months without tasting any fresh food. Their provisions ran out, including the hardtack. The crew reached the point of eating rats, leather, and sawdust. The water was putrid and fetid.

"Attacked by an illness, their gums swelled until they grew over the teeth, and nineteen died, and the Patagonian and the Brazilian. Besides those who died, twenty-five or thirty fell ill both in the arms and legs, but they were all healed." (Pigafetta, [1524] 1985: 82)

On March 6, 1521, they landed at Thieves' Island (Ladrões), and on the $17^{\text {th }}$ they got off at another island. They treated the sick with coconut water and coconut meat and supplied the ships with coconuts, oranges, palm wine, and chickens. On March 22 there were still sick crewmen on board. Two men died on April 10, but the report failed to specify the cause. Reaching the Philippines, they abandoned one of the ships and the crew was distributed between the remaining two. No longer with Ferdinand Magellan, who had been killed in a skirmish with a local chieftain, just one ship, the Victoria, began the return voyage to Spain, sailing from the Moluccas on December 21, 1521. On February 11, 1522, they passed Timor, apparently their last supply point until Cape Verde. They did not stop in Mozambique, although they only had water and rice onboard and several men were ill. They rounded the Cape of Good Hope on May 6, 1522, and continued to skirt Africa without calling into port, since the entire coast was under Portuguese control and they feared being taken prisoner. Twenty-two men starved to death, and there was widespread fear that they would all die of hunger. Finally, on July 9, they reached Cape Verde, where they managed to take in rice. They returned to Sanlúcar on September 6,1522, with only 18 men, mostly sick.

\section{POSSiBLE InterPRETATIONS OF SCURV}

The reports from the two voyages reveal striking differences in the circumstances in which "scurvy" purportedly occurred. Given their political importance, the two voyages probably shared many important characteristics for our discussion. The captain-generals of both fleets were highly experienced, and the sailors were probably selected from among the best. The ships were carefully fitted, as indicated by Chaunu (1984), reporting that Vasco da Gama laid up double the provisions and water per crewman as compared to Columbus' first voyage. ${ }^{9}$

We find no information on Ferdinand Magellan's provisions, but the ships must have been well stocked. Chaunu (1984) refers to the seaman's daily rations, consisting of 1.5 to 2 pounds of hardtack, 0.5 to 1 pound of salted meat (beef, pork, or codfish) or cheese, and for drinking and cooking, 1 liter of water, 3/4 liter of wine, 1/20 liter of vinegar, and 1/40 liter of olive oil. The victuals (and water) onboard had to last at least four months. The accounts of both these voyages upon their return and other evidence highlight their political importance.

On the return voyage from the Indies, in order to gain time, Vasco da Gama, with his brother dying, gave up arriving first and sent another ship ahead with the news to Portugal.

\footnotetext{
${ }^{9}$ At least in thesis, no one knew that Columbus would journey so much closer. Or did they?
} 
Concerning the last leg of the circumnavigation, Pigafetta gave a dramatic and exceedingly eloquent account upon returning in the Victoria without Magellan. The handful of starving survivors had refused to run the risk of landing in Portuguese-dominated African territory.

However, the reports on the disease called "scurvy" reveal different situations. In Vasco da Gama's voyage, no food shortages ever appear in the diaries, and the fleet never spent more than three months without calling into a port. During the longest periods at sea, no cases of disease or other crisis situations were reported onboard. Disease only struck previously healthy and well-fed crewmen while on land, at the mouth of the Quelimane River, on the East African coast.

João de Barros, apud Holanda (1992: 263), referring to the same voyage, says that scurvy began to strike around the mouth of the Zambeze River, with "erysipelas, and the gums swollen so that they hardly fit in the mouth, and rotted". Scurvy en route to the Indies became a constant scourge, described by Sassetti, apud Holanda (1992: 263), in 1585:

"Every year 2,500 to 3,000 men or boys arrive from Portugal, of the sorriest lot to be found; of these, a fourth or a third are thrown overboard, sometimes even half, mostly dead from scurvy."

Concerning the voyage he made in 1583 (apud Holanda, 1992: 263), Sassetti reports:

"On a single day 160 men fell ill, and among them the gums swelled up entirely, so that they had to be cut out in order for the patient to close his mouth, giving off an unbearable stench, followed by an inflammation of the knees and lower limbs. Finally there came a very strong pain in the chest, without preventing the man from breathing, but then putting an end to his life, snuffed out like a lamp's wick with no oil."

Sassetti's descriptions emphasize the acute, extremely severe, and epidemic nature of the disease from its onset. Such characteristics are inconsistent with the smoldering onset of a vitamin-deficiency disorder, and suggest other possible causes. Infectious diseases as the principal cause or at least as a triggering factor are highly likely: malaria, yellow fever, other arboviruses, or bacterial infections. There is a clear suggestion of the relationship between the disease and coastal areas in East Africa, where Vasco da Gama stopped and which later became an obligatory stopover en route to the Indies.

A vitamin-deficiency etiology is far more plausible on the circumnavigation, since the disease only appeared in the crew after five months of harsh Antarctic winter and three months and twenty days navigating with no taste of fresh food. More than eight months of monotonous food, then full-blown hunger. The account of various sick crewmen having recovered after eating fresh foods reinforces this hypothesis.

Still, other possible factors cannot be ruled out. A toxic etiology is feasible in both cases, at least as a contributing factor to the picture described above. Since water and its storage were the crew's main problem, the materials used to make the barrels, possible fungi and toxic algae growing inside, and substances added as preservatives could have played an important role in the development of diseases.

Scurvy, the principal scourge of the seas until the $17^{\text {th }}$ century, is now a rare disease, resulting from vitamin $\mathrm{C}$ deficiency. Even in situations of critical food shortage such as in Sub-Saharan Africa and the hinterlands of Northeast Brazil, with reports of pellagra and other nutritional disorders, scurvy is rare. This can be explained by the fact that vitamin-deficiency diseases almost never appear today in their "pure" form outside the laboratories, and that the most common disorders result from various factors, whether nutritional, toxic, or infectious. It is often impossible to determine the most important contributing cause. 
Hutchinson (1975) comments that Lind began his recommendations to the British Admiralty with: control of the filth that propagates infections, careening the ships, providing clean new clothing to the seamen, and isolating cases of infection. He recommended distilling water at high sea and consuming lemons. Meanwhile, scurvy was reclassified, based on the "recognition" of its vitamin C-deficiency etiology, during the general reclassification of infectious diseases according to their etiological agents and of other diseases based on pathophysiology. This reclassification split up and scattered the various disease states that comprised the old "scurvy" syndrome. Lind's treatment, which is often viewed today as a premonition of the discovery of scurvy's vitamin C-deficiency etiology, was in fact not specific, but related to altered humors and quality of the blood that the signs and symptoms indicated. Various other diseases were treated in similar fashion (Cullen, 1786; Holsbeek, 1860; Huxham, 1776; Sydenham, 1769).

Scurvy is now expected in individuals or populations submitted to chronic (and especially qualitative) nutritional deficiencies. It has been reported among followers of "fad diets" and elderly individuals that adopt monotonous eating patterns with near-exclusive ingestion of bread, pasta, and dairy products and practically no vegetables, greens, or fruit (Wilson, 1975). In both situations, scurvy only develops after many months or even more than a year of such a diet.

Scurvy epidemics are absolutely unexpected, except as part of severe malnutrition and associated with manifestations of other nutritional-deficiency disorders, as appears to have occurred in $19^{\text {th }}$ century Europe during the Potato Famine (Braudel, 1969; Dodds, 1966). One would not expect to find cases of a vitamin-deficiency disease manifested in its "pure state" on ships.

Beginning in the $16^{\text {th }}$ century, on the transatlantic route, scurvy was reported among the embarked slaves, where it became known as the "scourge of Loanda". What did ships and maritime voyages mean for the risk of a vitamindeficiency disease like scurvy? The most common association we found was with voyage time, thus highlighting the decisive role of steam engines in its disappearance. However, consulting travel reports (Boxer, 1969; Miceli, 1994), we find that total voyage time was shortened, but not total length-of-stay at sea. On the contrary, the latter increased constantly on the merchant marine and military routes.

The Indiamen, caravels, and galleons on the transatlantic or transpacific route to the Indies depended on the winds and the currents. They thus necessarily had preferential times for embarking and returning. They frequently spent months in port, waiting for cargo and friendly winds. A voyage to India could last six months or more, but the ships did not stay at sea for more than four months. Even in crossing the Pacific, it was common for vessels to spend no more than eight weeks without calling into port (Boxer, 1969; Chaunu, 1984).

Boxer's observation is interesting (1969: 218), quoting Diogo do Couto, that there were inevitably numerous diseases and deaths on the voyage in either direction, when the Indiamen stopped, “... as they very often did, whether voluntarily or otherwise, at Mozambique Island. Between 1528 and 1558 over 30,000 men died there, mainly from malaria and bilious fevers, after having landed from the Indiamen which called at this place in that thirty-year period."

Fray Jerônimo Lobo (apud Chandeigne, 1992: 161) reports on the conditions in an Indiaman's provisions in 1621 :

"The victuals were spoiled rotten. The pork was so bad that whole barrels were tossed overboard, as many as the crewmen opened, all rotten and rancid. They claimed it was because of salting too much, in order for the pork to weigh more, so that all of it was wasted. The wine had also gone sour, so they opened the spigots and let it pour out through the scuppers into the sea. I saw rice thrown on the deck that was so rotten and spoiled that I decided to take a closer look, and I would not have believed it was rice had they not told me."

Greed definitely played an important role, since it was common to over-salt meat so that it would "weigh more". Still, we cannot overlook the difference that steel and refrigeration made for onboard provisions. The baseline 
conditions were also significantly different. It is hard to imagine today (although possible) that anyone would supply a ship with untreated water. Yet the waters that routinely supplied Lisbon's population in the 1600 s did not exactly deserve a clean bill of health. Several other reports corroborate Pigafetta's description (1985) of putrid and stinking water, whenever the circumstances prevented frequent renewal of the water supply.

The conditions onboard were further aggravated by the limited experience of many crews at sea. We quote Boxer (1969: 211):

"Deep-sea sailors are not made in a day, and the wastage from death and disease in India was very high. As early as 1505 , completely raw crews were being recruited for service in the carreira, as instanced by the chronicler Castanheda's anecdote of João Homem's rustic seamen. These yokels could not distinguish between port and starboard when his ship left the Tagus until he tied a bundle of onions on one side of the ship and a bundle of garlic on the other. 'Now,' he said to the pilot, 'tell them to onion their helm, or garlic their helm, they will understand that quickly enough."”

Exaggerations aside, the author comments on the countless complaints arising among crews unaccustomed to working at sea. In addition to the poor overall hygiene and spoiled food and water, the crowding of young men from all walks of life doubtless facilitated outbreaks of infectious diseases. It is surprising that the reports were not more dramatic and frequent, that some voyages took place without serious diseases onboard, and that the average casefatality on the route to the Indies apparently did not exceed 50\% between 1500 and 1700 .

At any rate, onboard crew conditions should obviously be interpreted in light of their relationship to the prevailing conditions on land. Voyage time can obviously increase the inherent risks of life at sea. But it may also simply increase the probability of an onboard manifestation of phenomena that are not directly related to the crossing itself, due to the increase in observation time.

When we separate the voyage time from the periods before and after it, we introduce an important bias, implicitly assuming that whoever died onboard would not have died if they had stayed on land, and that all the onboard deaths bear a cause-and-effect relationship to seafaring. It is beyond the scope of this chapter to continue this discussion here, but numerous recent studies on the transatlantic traffic have pointed to new elements for elucidating this topic. ${ }^{10}$ The ships of discovery are examples of these diverse experiences; drawing on Grmek's concept (1983), we would say that they are noteworthy examples of pathocenosis in change.

We thus contend that the purported scurvy in Vasco da Gama's fleet and in later voyages to the Indies probably deserves to be reconsidered in favor of many more likely differential diagnoses. Meanwhile, Pigafetta's report of the Pacific crossing during the first circumnavigation contains elements suggesting much greater likelihood that the scurvy of that voyage was the same disease we know today.

\section{Hidden diseases}

Silva, Carvalho \& Souza (2006) report an interesting disease profile in workers from a textile factory in Cataguases, southeastern Minas Gerais State, Brazil, in the mid-20 $0^{\text {th }}$ century. In this case, our problems with identification of the diseases are not related to theories on diseases or the records' "reliability". The primary sources are all "official", namely the Death Registry of the Cataguases Municipal Government, books 5 and 6 (Municipal Archives), and the Registry of the Caixa Beneficente (Workers' Mutual Health Fund) at the Peixoto Brothers Textile Factory, no. 3, year 1941,

${ }^{10}$ See, for example, Florentino (1995), Alencastro (2000), and Soares (2007). 
containing records of visits to the company physician by workers and their families. The year was 1941 , so diseases were no longer attributed to miasmas, but to viral, bacterial, or parasitic infections or various pathophysiological disorders. Yet we face at least two relevant issues here: lack of uniform classification of diseases and the context for the production of diagnoses. We will not go into problems pertaining to death records or demographic issues. Rather, we will discuss "the search for tuberculosis".

Tuberculosis was present in the general population and was one of the main causes of death, especially in young adults, not only in Cataguases but in all major urban areas of Brazil (Nascimento, 2005). Oddly, it was only diagnosed in one worker from the textile factory in 1941. This "nosological silence" led to a search for the disease and the context in which it was recorded, as summarized below (Silva, Carvalho \& Souza, 2006).

During 1941, the Peixoto Brothers factory manufactured 6,080,585 meters of fabric. Average daily production (for 16 hours) was 21,483 meters, or 6.03 meters per loom-hour. The factory's equipment was in perfect state of maintenance, and there were an average of 470 employees for the year as a whole, including office staff, bricklayers, and carpenters. The books record expenses with the Workers' Mutual Health Fund, the IAPI (or Institute for Industrial Workers' Retirements and Pensions), workers' compensation, accident insurance, and even a brass band. ${ }^{11}$

To discuss the workers' health, we analyzed data on visits to the company physician from January 2 to December 31, recorded in book number three of the Caixa Beneficente. This was the only book located, and it records the date, the worker's or family member's name, factory sector, signs and symptoms, diagnosis, and treatment.

Of the 536 visits to the company physician, 435 were for factory floor workers. Of these, 271 factory employment records were found and analyzed (62.3\%), pertaining to 81 men and 190 women, containing other data such as nationality, color, and marital status.

Eighty-six per cent of these workers were between 15 and 39 years of age in 1941. According to the records, workers at the Peixoto Brothers factory had continuous access to healthcare, since the company physician was always on call, treating both the workers and their families, in addition to acting as "occupational physician" by signing sick leaves and investigating work-related accidents.

The 435 workers examined by the company physician included 238 women (54.7\%) and 197 men (45.3\%). Based on the description of signs and symptoms, the diagnoses were classified by chapters of the ICD-10 (WHO, 1989). A total of 1,466 diagnoses were recorded, classifiable as follows: diseases of the respiratory system, 463; diseases of the digestive system, 401; ill-defined causes, $308^{12}$; diseases of the genitourinary system, 96; infectious and parasitic diseases, 88; diseases of the blood, 59; diseases of the skin and subcutaneous tissue, 34; external causes, 14; and diseases of the musculoskeletal system, 3. As mentioned above, there was only one record of "tuberculosis". ${ }^{13}$

During the year 1941, 34 medical examinations were recorded in the book for purposes of job admissions, five for discharge, and eight for sick leave. Four job admissions were turned down by the physician: two due to "anemia" (sic), one due to a skin disease, and another for an unspecified reason. Records of diseases that affected female workers at

\footnotetext{
${ }^{11}$ Jornal Cataguases, official municipal register, Jan. 28, 1942; insert.

${ }^{12}$ In the ICD-10, this chapter is called "Symptoms, signs, and abnormal clinical and laboratory findings, not elsewhere classified", previously referred to as "ill-defined causes", the term used here.

${ }^{13}$ In this case, registered as such. The authors would also have classified as such other cases referred to as "phthisis" or other terms that we consider probable pulmonary tuberculosis.
} 
the factory included 30 cases of amenorrhea, probably pregnancy. Of the sick leaves, one was for two months duration for a female worker assigned to the weaving sector, diagnosed with concomitant anemia and pregnancy.

As a source for discussing the health situation in the overall Cataguases population, we consulted the death registry for 1940 to 1944 , since there was no regular record of diseases for the same period. The mortality profile for the years 1940 to 1944 drew on book number 5 of the Death Registry kept by the Cataguases Municipal Government, containing the official annotation of the death, transcribed from the statement completed by a physician and stating the underlying cause of death used to issue the death certificate. ${ }^{14}$ The underlying cause was coded according to the rules of ICD, $10^{\text {th }}$ review (some records were illegible).

In the five-year period, 1,439 deaths were recorded in the city of Cataguases and its townships. Males accounted for $55.3 \%$ of the deaths and females $44.7 \%$. As for nationality, Brazilians represented 1,418 of the deaths, or $98.5 \%$ of the total. Annotations on skin color showed that nearly half the individuals were white, 710 (49.3\%), followed by brown (i.e., mixed-race) with 373 (25.9\%), and black with 348 (24.2\%). Eight annotations were missing information on skin color.

Annual variation in mortality was slight, with a mean of 287 deaths per year. Thus, for this five-year period, we found no evidence of epidemic situations, at least with diseases involving high case-fatality. Death records by age bracket for 1940-1944 were used to calculate points for the Nelson de Moraes proportional mortality index ${ }^{15}$ : under 1 year of age, 23.6\%; $1-4$ years, $14.3 \%$; $5-19$ years, $8.2 \%$; $20-49$ years, $19.7 \%$; and 50 years and older, $34.2 \%$. Compared to the Brazilian curves for the year 1990 (Datasus, 2009), the authors observed important differences in all age brackets except 20 to 49 years. ${ }^{16}$

Deaths from ill-defined causes led the list, with 338 records, or $23.5 \%$ of all deaths during the five-year period, followed by infectious and parasitic diseases with 333 (23.1\%), diseases of the circulatory system with 223 (15.5\%), diseases of the respiratory system with 174 , and diseases of the digestive system with 104 . All other causes accounted for fewer than $5 \%$ of the deaths. Disaggregating the data by age bracket and sex, among infants (under 1 year of age), deaths from ill-defined causes led the list, followed by infectious diseases and diseases of the respiratory system. In the next age bracket (1 to 4 years), infectious diseases led the list, followed by ill-defined causes and diseases of the respiratory system.

In the 5 to 19 -year bracket, infectious and parasitic diseases continued to predominate, followed by diseases of the respiratory system and ill-defined causes. From 20 to 49 years, infectious and parasitic diseases predominated, followed by ill-defined causes, with diseases of the respiratory system in third. From 30 to 39 years, causes related to pregnancy, childbirth, and postpartum predominated among women. From this bracket upwards, diseases of the circulatory system were the leading causes of death, but infectious and parasitic diseases still ranked second.

An analysis of proportional mortality by causes shows an important difference between 1940 and 1990: the proportion may be similar, but in the 1980s and 1990s "external causes", basically homicides and traffic accidents, became the main factors for mortality in young adult Brazilians (Datasus 2009). ${ }^{17}$

\footnotetext{
${ }_{14}$ The Death Registry, Book no. 5, of the Cataguases Municipal Government contained name, sex, color, birthplace, age, marital status, parents' names, cause of death, and date of death.

${ }^{15}$ For this indicator, see for example Medronho et al. (2002).

${ }^{16}$ Less than 1 year, $11.86 \%$; 1 -4 years $2.20 \%$; 5 -19 years $3.79 \%$; 20-49 years $20.91 \%$, and 50 years and older, $61.25 \%$.

${ }^{17}$ For a discussion of the "epidemiological transition", see Medronho et al. (2002).
} 
There was a significant presence of diseases of the respiratory system, yet the explicit diagnosis of pulmonary TB was infrequent in the textile factory's obituaries and other records. This led the authors to discuss this diagnosis and the possible reasons for its absence from the documents. During the period in question, TB was one of the leading causes of death in Brazil, especially in young adults (Nascimento, 2005). This period immediately preceded the widespread introduction of antibiotics and chemotherapeutic agents (streptomycin, isoniazid, and PAS) developed in the 1940s and 1950s, which revolutionized TB treatment. The newspaper Gazeta de Leopoldina announced that the disease was spreading in Cataguases and surrounding towns, especially affecting the working class. BCG vaccination drives were launched in the region in children and bacillus-negative individuals. ${ }^{18}$ The Gazeta blamed wartime shortages for people's poor nutrition and claimed that "the 'breeding grounds for the bacillus' are the poor, people on diets, those with poor childhood nutrition, and those who exercise inadequately". ${ }^{19}$ Mortality records for Cataguases in the five-year period showed 92 deaths from tuberculosis, or $6 \%$ of all deaths, $63.3 \%$ of which in the 20 to 49 -year bracket. To put this figure in modern perspective, the same percentage (6\%) today would mean approximately six times the number of deaths from tuberculosis recorded in 2001 for the State of Rio de Janeiro, which currently has one of the highest TB incidence rates in Brazil.

Cases were recorded in individuals from 0 to 71 years, showing that the disease affected the entire population, although the largest number of cases occurred in young adults. The mean age, based on the age recorded on the TB death records, was 32 years for men and 33 for women.

As highlighted by Antunes, Waldman \& Moraes (2000: 376), “The age structure of these deaths was consistent with patterns in high-prevalence countries, with higher rates in children under 5 years and adults 20 to 49 years of age and 60 years or older, with a peak in the 20 to 49-year group." The records showed more of the pulmonary form, with 77 cases, or $83 \%$ of total, followed by TB deaths with site unspecified, then 7 cases of intestinal TB, and TB of the bones, larynx, and kidneys, with only 1 case each.

In the textile factory records, the only worker diagnosed with pulmonary TB had been assigned to the factory's machine shop. Before his TB diagnosis, he had been treated for flu and bronchitis. He was hired in 1940 at only 14 years of age, and by 15 he was already receiving treatment for tuberculosis. His contract was rescinded in 1944, with no record of the reason for his being laid off. This worker never returned to the company, nor do we find his name in the death registry for 1944. During the period there was only one record of a sputum test at the company, for an employee assigned to the fabric inspection room, and with a negative result. The absence of any recording of tuberculosis by the company physician may be due to deliberate underreporting, because if the disease were diagnosed, the worker would be forced to leave the factory and would thus lose his or her income, in addition to running the risk of not being rehired. Tuberculosis is also an important factor for social discrimination, which could help explain the absence of TB diagnosis in the factory records, despite the numerous diagnoses of respiratory diseases. Tuberculosis is evidently a possible confounding factor in any discussion of the determinants of these diseases and forces us to view its attribution to working conditions in a relative light. According to company records, this disease, which affected the entire population, only affected one of the factory workers, but it is not possible to exclude its "disguised" presence among the numerous respiratory signs and symptoms.

\footnotetext{
${ }^{18}$ Gazeta de Leopoldina, Oct. 19, 1941, no. 52, p. 1, Editorial.

${ }^{19}$ Gazeta de Leopoldina, Nov. 30, 1941, no. 63, p. 1, Editorial.
} 


\section{Impossible diseases}

Our last example focuses on diseases that cannot be diagnosed by analyzing the text. This does not mean that other studies (e.g., paleopathology) cannot contribute to the diagnosis. Often such diseases appear in the texts more as "symbolic entities" than as "disease entities". When the name of the disease traverses the time and space of classificatory paradigms and the signs and symptoms described in the text does not include elements that can be viewed today as pathognomonic of some currently recognizable disease, we may lack the basis for a helpful discussion of the current diagnosis. Leprosy is perhaps the most representative of these "disease entities" in the West.

Maria Carlota Rosa (2005a) ${ }^{20}$ discusses leprosy as depicted in a medieval work of fiction, Estoria do muy Nobre Vespesiano Emperador de Roma [The Story of the Very Noble Vespasian, Emperor of Rome]. We summarize this work next, with comments, notes, and references for the respective excerpts. According to the author, Vespesiano is an anonymous novel that circulated widely in 14th and 15th-century Europe. Mixing fact and fiction, the plot unfolds as a consequence of the search for a cure to Vespasian's disease.

There is only one incomplete extant copy of the Portuguese version of Estoria do muy Nobre Vespesiano Emperador de Roma, belonging to the National Library of Portugal (Inc. 571), and printed in Lisbon in 1496. The text tells how Vespasian, racked with leprosy, hears of Jesus Christ and his Passion and is cured by using the linen handkerchief that Veronica gave Jesus to wipe his face at the foot of the cross. To give thanks for this blessed gift, Vespasian makes good on his vows: he destroys Jerusalem to take revenge for the Lord's death and has himself baptized, along with all his people and knights.

Popular tradition appears to have been particularly fond of impious Emperors with leprosy that were cured by baptism, like Constantine I (306-337). Attacked by leprosy after defeating Maxentius, he purportedly refused the treatment prescribed by his physicians, who (like the Greeks) recommended bathing in the blood of innocent children (Bluteau, 1712-1721). Baptized by the Pope, Constantine was miraculously cured. ${ }^{21}$

All the action hinges on the Emperor's quest to restore his health. Although the word "leprosy" never appears in the text, Vespasian was in fact a leper. The Vespasian of the text has a severely mutilated face, as reported by his messenger (fol. a6 r-v):

"Thou shalt know that my Lord the Emperor suffers a terrible and ugly disease on his face. No physicians or surgeons in the world can make him well, because the disease grows so much every day it has worn and afflicted his face such that no man can look at his teeth or jaws."

The Western world had known leprosy for a long time. Its most obvious (and dreaded) symptom in the collective imagination was precisely mutilation, disfiguration. In the medieval Christian world that produced Vespasian, lepers were considered the devil's helpers and had to wear bells around their necks to announce their approach, in order for the healthy to take refuge (Margotta, 1968).

Against leprosy, all the might of the greatest empire on Earth was helpless, as was the best science to be recruited by someone with so much earthly power. The illness was incurable. Medicine was useless, and the hope for Vespasian's cure came from news of a woman who had lived in voluntary isolation due to her horrible illness, but was made well

\footnotetext{
${ }^{20}$ We thank the author and the editors of Cadernos de Saúde Coletiva for permission to use the text, and we take entire responsibility for any inaccuracies in our summary.

${ }^{21}$ Constantine was baptized in $337 \mathrm{AD}$ not by the Pope, but by a bishop of Aryan tendencies, and died soon afterwards (Di Berardino, 1983).
} 
by faith in Christ, materialized in the linen handkerchief she held out to Him to wipe his face at the foot of the cross. Vespasian could only be healed by a relic that had touched Christ (fol. a4v), with Veronica's handkerchief, with faith and baptism: "And if thou doeth not all these things, thou canst never be healed of thy illness and thy affliction." (fol. b2)

Touching a relic of Christ purified the afflicted. The sacrament of baptism, in turn, was a means of salvation from physical and spiritual death, in which the baptized broke with sin, giving rise to a new life. In Vespasian, salvation was extended to the entire people, purified by the baptismal water and healed of any and all disease:

"And when the people heard him they dove into that sacred water as far as they could and came out baptized, and they worshipped God Almighty Jesus Christ. And Our Lord performed a great miracle at that hour, and whoever became Christians marveled that whatever illness or disease they had before the baptism, no sooner were they baptized than they were cleansed and healed of the disease as if they had never been ill." (fol. f)

Vespasian exemplified disease as the consequence of sin. A pagan living such a dissolute life deserved an incurable and terrible disease as punishment. The individual could restore his health by persevering in the faith and in Christian practices, which bore little relationship to home remedies or a physician's skills. The physician could only relieve the physical suffering that resulted from such condemnable behavior, but not provide the true cure. But if the individual could avail himself of sacred relics or baptismal water, he could begin a new life, freeing himself from spiritual and corporeal death.

This text and many others did not primarily describe a disease. Although we may sometimes find more detailed descriptions of signs and symptoms, a possible diagnosis would probably add little to our understanding of the context. ${ }^{22}$ Relics or the royal touch (Bloch, 1924) have absolute curative powers that require no nosological classification.

\section{CONCLUSION}

The three examples discussed above represent only a minimum sample of the many questions that can be raised in reading texts to construct a history of diseases. Much remains for discussion. However, we highlight the need to establish interdisciplinary discourses. Without a plural dialogue, the complexity of such issues virtually impedes any competent discussion. Meanwhile, we should tackle the challenge, based on each object and objective, of defining the terms of this dialogue in order to produce a coherent dialogue that opens new questions, not merely a patchwork quilt. This is no simple task. We hope that the points discussed here, and especially the examples, will have sparked the reader's curiosity towards this evolving field and the desire to explore it.

\footnotetext{
${ }^{22}$ For other discussions of medieval texts, we refer the reader to Rosa et al. (2005b).
} 


\section{REFERENCES}

ALENCASTRO, L. F. O Trato dos Viventes. São Paulo: Cia das Letras, 2000.

ANTUNES, J. L. F.; WALDMAN, E. A. \& MORAES, M. A. Tuberculose através do século: ícones canônicos e signos do combate à enfermidade. Ciência \& Saúde Coletiva, 5: 367-379, 2000.

BLOCH, M. Les Rois Thaumaturges: étude sur le caractère surnaturel attribué à la puissance royale particulièrement en France et an Inglaterre. PhD dissertation, Faculty of Arts Press, University of Strasbourg, 1924.

BLUTEAU, R. Vocabulario Portuguez, e Latino: autorizado com exemplos dos melhores escritores Portuguezes, e Latinos. Coimbra: Collegio das Artes da Companhia de Jesus, 1712-1721. 9t.

BOXER, C. R. The Portuguese Seaborne Empire, 1415-1825. New York, A.A. Knopf, 1969.

BRAUDEL, F. Écrits sur l'Histoire. Paris: Champs Flamarion, 1969.

BROUSSAIS, F. J. V. De l'Irritation et de la Folie. Paris: Mlle Delaunay, 1828.

CANGUiLhem, G. Le normal et le pathologique. Paris, Galien, 1966.

CANNON, W.B. The Wisdom of the Body. $2^{\text {nd }}$ Ed. New York: W.W. Norton Co., 1939.

CARPENTER, K. J. The History of Scurvy and Vitamin C. Cambridge: Cambridge University Press, 1988.

CHADWICK, E. Report on the Sanitary Condition of the Labouring Population of Great Britain. Edinburgh: Edinburgh University Press, 1842. Reprint, 1965.

CHANDEIGNE, M. Lisboa Ultramarina 1415-1580: a invenção do mundo pelos navegadores portugueses, Rio de Janeiro: Jorge Zahar, 1992.

CHAUNU, P. Conquête et Explotation des nouveaux mondes, Paris, PUF, 1969.

COIMBRA JR., C. E. A. et al. The Xavánte in Transition: health, ecology and bioanthropology in Central Brazil. Ann Arbor: University of Michigan Press, 2002.

CROSBY, A. W. Ecological Imperialism: the Biological Expansion of Europe, 900-1900. New York: Cambridge UP, 1986.

CULLEN, W. First Lines of the Practice of Physic. Edinburgh: Elliot, C. \& Cadell, T., 1786.

DATASUS 2009. Available at: CENEPI/FNS, <www.inep.gov.br/download/enc/1999/gabaritos/medicina.pdf>. Accessed 2 Jan 2009.

Di BERARDIno, A. (Org.). Dizionario patristico e di antichità cristiane, Rome: Istituto Patristico Augustianum,1983.

DIAMOND, J. Guns, Germs, and Steel: the Fates of Human Societies. New York: W.W. Norton, 1997.

DODDS, K. The evolution of the cultivated potato. Endeavour, 25: 83-88, 1966.

ENGELS, F. The Condition of the Working Class in England [1845]. Oxford World's Classics, 2008.

FLoREnTINo, M. G. Em Costas Negras: uma história do tráfico atlântico de escravos entre a África e o Rio de Janeiro (séculos XVIII e XIX). Rio de Janeiro: Arquivo Nacional, 1995.

FOLLÉR, M. A. \& HANSSON, L. O. Human Ecology and Health: adaptation to a changing world. Göteborg University, 1996.

GAZETA de Leopoldina no. 52, Oct. 19, 1941, p. 1, Editorial.

GAZETA de Leopoldina no. 63, Nov. 30, 1941, p. 1, Editorial.

GINZBURG, C. Miti emblemi spie: morfologia e storia. Turin: Einaudi, 1986.

GRMEK, M. D. Les origines d'une maladie d'autrefois: le scorbut des marins. Bulletin du Institute de Océanographie Monaco, n. spécial 2: 505-523, 1968.

GRMEK, M. D. Les Maladies à l'Aube de la Civilisation Occidentale. Paris: Payot, 1983. 
GRMEK, M. D. Histoire du Sida. Paris: Payot, 1989.

HOLANDA, S. B. Visão do Paraíso. Rio de Janeiro: Brasiliense, 1992.

HOLSBEEK, H. Précis d'Hygiène et de Médecine Navales a l'Usage des Gens de Mer. Bruxelles: Auguste Schnée, 1860.

HUTCHINSON, A. Salud de los marinos. 1 - Antecedentes históricos y situación actual. Crónica de la OMS, 29: 418-431, 1975.

HUXHAM, J. Essai sur les Differentes Espèces de Fièvres, avec un Appendice Contenant une Méthode pour Guérir les Mariniers des Maladies dans les Voyages de Long Cours. Paris: Chez D`Houry, 1776.

JORNAL CATAGUASES, official municipal register, Jan. 28,1942; insert.

MARGOTTA, R. The Story of Medicine. Golden Press, 1968.

MEDRONHO, R. A. et al. Epidemiologia. Rio de Janeiro: Atheneu, 2002.

MICELI, P. O Ponto onde Estamos. São Paulo: Scritta, 1994.

NASCIMENTO, D. R. Imagens do Mal: a representação da tuberculose no início do século XX. Cadernos de Saúde Coletiva, 13: 493510, 2005.

NASCIMENTO, D. R. \& SILVEIRA, J. T. A doença revelando a história: uma historiografia das doenças. In: NASCIMENTO, D. R. \& CARVALHO, D. M. (Orgs.). Uma História Brasileira das Doenças. Brasília: Paralelo 15, 2004.

PAVLOVSKY, Y. N. Natural Nidality of Transmissible Diseases. Moscow: Peace Publishers, s.d.

PIGAFetTA, A. A Primeira Viagem ao Redor do Mundo: o diário da expedição de Fernão de Magalhães. Porto Alegre: L\&PM, 1985.

ROSA, M. C. et al. A lepra numa obra medieval de ficção: a história do mui nobre Vespasiano imperador de Roma. Cadernos de Saúde Coletiva, 13: 459-470, 2005a.

ROSA, M. C. et al. Pestilências e curas da medicina quinhentista: em torno de dois textos médicos antigos. História, Ciências, Saúde - Manguinhos, 12: 771-774, 2005b.

ROSENBERG, C. E. Explaining Epidemics and other Studies in the History of Medicine. New York: Cambridge University Press, 1992. ROTSCHILD, H. R. (Eds.). Biocultural Aspects of Disease. New York: Academic Press, 1981.

ROUSSEAU, G. S. et al. (Eds.). Framing and Imagining Disease in Cultural History. London: Palgrave MacMillan, 2003.

SANTOS, M. A Natureza do Espaço: técnica e tempo, razão e emoção. São Paulo: Hucitec, 1996.

SELYE, H. The Stress of Life. New York: McGraw-Hill, 1956.

SILVA, L.N.; CARVALHO, D.M. \& SOUZA J.L.P. A saúde do operário têxtil em Cataguases, Zona da Mata Mineira, 1941.In: NASCIMENTO, D. R.; CARVAlHO, D. M. \& MARQUES, R. (Orgs.). Uma História Brasileira das Doenças. Rio de Janeiro: Mauad, 2006. v. 2.

SOARES, M. C. Rotas Atlânticas da Diáspora Africana. Niterói: Eduff, 2007.

STANLEY, N. F. \& JOSKE, R. A. Changing Disease Patterns and Human Behaviour. London: Academic Press, 1980.

STEWART, C. P. \& GUTHRIE, D. (Eds.). Lind's Treatise on Scurvy. Edinburg: University Press, 1953.

SYDENHAM, T. The Entire Works. London: F. Newbery, 1769.

TERRIS, M. As relações dinâmicas da epidemiologia com a sociedade: a Conferência Robert Cruikshank. Cadernos de Saúde Coletiva, 13: 545-566, 2005.

VELHO, A. O Descobrimento das Índias: o diário da viagem de Vasco da Gama [1499]. Rio de Janeiro: Objetiva, 1998.

WILSON, L. G. The clinical definition of scurvy and the discovery of vitamin C. Journal of the History of Medicine and Allied Sciences, 30: 40-60, 1975. 1963.

WORLD HEALTH ORGANIZATION (WHO). International Classification of Diseases (ICD). 10 th Revision. Geneva: WHO, 1990. 


\title{
28
}

\section{Methods in Paleoepidemiology and New Perspectives in Paleoparasitology}

\author{
Francisco Inácio Bastos • Daniela Leles • Adauto Araúijo
}

$P^{a}$ aleoepidemiology is similar to other sciences that study long periods of time, such as evolutionary biology, in that it relies on historical reconstruction and the elaboration of plausible retrospective scenarios. Unlike experimental physics and chemistry, paleoepidemiology can never rely exclusively on controlled experiments, although it frequently draws on recent advances in other branches of science such as molecular biology.

As highlighted by Mayr (2004), the interaction between historical reconstruction, deductive reasoning, and exhaustive exploration of empirical findings makes biology a "unique science", an expression that serves as the title for his last book. Biology lies at the intersection between the natural sciences and history, especially in some of its branches such as evolutionary biology and diachronic ecology. The latter discipline focuses on the succession of ecosystems, analyzed by authors like Wilson (1999) in relation to the destruction and restoration of ecosystems, as with the volcanic eruption that shattered Krakatau Island in 1883.

What these branches of biology have in common with the sister science of paleontology and that of astronomy is the fact that they deal with phenomena produced by natural forces over thousands or even millions of years - in the case of astronomy, with time spans dating to the very origin of the universe (Sagan, 2006).

Modern epidemiology only recently began to analyze phenomena that spanned longer time periods. This was true for the epidemiology of infectious diseases, dealing with extended natural histories in chronic infections such as AIDS and hepatitis $\mathrm{C}$, or the epidemiology of non-communicable diseases in modern studies on life histories and the incidence of diabetes mellitus and some cardiovascular diseases (Morabia, 2004). Still, although long time spans in modern epidemiology refer to contemporary genetic epidemiology (Khouri, Little \& Burke, 2004), they reflect the time transpired in the life of only one or a few age cohorts.

Very recently, spectacular new techniques in molecular biology have spawned studies tracing genetic markers over many generations, combining data analysis from living tissues and the reconstruction of genetic material from deceased ancestors (Khouri, Little \& Burke, 2004). Such research, for example on the genetic origin of Huntington's 
chorea, mainly constitutes an exception to a markedly observational and prospective field of studies in terms of the nature and chronology of the phenomena under study.

The typical study designs of modern epidemiology - prospective cohorts and randomized clinical trials - aim to minimize the inferential biases of sampling procedures and risk estimation through designs that allow monitoring individuals over time, collecting and systematizing the findings in the course of observation periods. Modern epidemiology also includes studies in which information from the past is gathered and systematized. However, as mentioned above, such designs are usually limited to the time span of a single-generation cohort, and only more rarely to a few generations.

Epidemiology deals with short historical periods when compared to paleoepidemiology. Still, there is widespread agreement that retrospective studies are weaker than prospective ones and are more subject to various biases, such as those resulting from differential recall of past events and the correct attribution of the true exposure to parasites with high pathogenicity, or to harmful substances or sources of pollution (for a definition of the various biases in epidemiology, see Last, 1995).

Paleoepidemiology thus faces numerous challenges and great complexity, since it approaches phenomena that are observable after the fact, heavily determined by unique historical circumstances, and not amenable to exhaustive reconstruction. Furthermore, such phenomena suffer the wear imposed on compounds and beings by the same passing of historical time that shaped them, e.g., in the formation of fossils.

One of today's leading biologists, the physiologist and ecologist Jared Diamond, who circulates comfortably in both experimental biology and the analysis of phenomena with a long historical course, calls attention to the need for caution when using inferential statistical procedures in dealing with scarce observations, subject to the influence of different intervening variables (usually known only in part). Such methodological difficulties appear both in the sphere of their determination itself (causal determination chains) and in the transformation of their state over time, from the original occurrence to the recording of the event by the contemporary observer. Therefore, in Diamond's book dealing precisely with the collapse of ancient civilizations, the author recommends judicious use of empirical, descriptive, and/or statistical analysis and procedures from historical and anthropological studies, (re)constructing plausible scenarios by analyzing empirical evidence and formulating hypotheses (Diamond, 2005).

\section{CONTRIBUTIONS BY PALEOPARASITOLOGY AND THEIR PALEOEPIDEMIOLOGICAL IMPLICATIONS}

The possibility of interpreting scarce data from paleoparasitology is illustrated by the intestinal parasite eggs found in some archaeological sites in the Americas. As discussed in Chapters 20 and 21, the findings produced new evidence on prehistoric migrations and the peopling of the continent. Various authors have interpreted these findings for different purposes. Examples include Sorenson \& Johannessen (2009), who studied trade between the peoples of the New and Old Worlds before the Discovery, and Menzies (2008), with his study on Chinese seafaring voyages to America before the Europeans. Both drew on paleoparasitological data to support their theories on contacts between Asian and American populations before the Europeans "discovered" the New World.

Importantly, most paleoparasitological tests yield only scarce helminth egg finds. This paucity could result from taphonomic processes involving desiccation or even nematophagous fungi. The parasite burden may have been truly low in some cases, e.g., due to prehistoric peoples' use of plants with anthelminthic properties (Chaves \& Reinhard, 2006). Another possibility would have been variations in oviposition due to evolutionary strategies adopted by 
intestinal parasites in the parasite-host relationship. At any rate, the number of eggs found in coprolites or other ancient remains is generally very low. Several factors thus limit calculation of the parasite burden or formulation of consistent hypotheses on parasitic disease(s) in the individual. In the near future, such techniques as real-time polymerase chain reaction ( $\mathrm{PCR}$ ), allowing more precise quantification of the parasite's genetic material even in the absence of eggs, may provide an approximation of the true parasite burden and its impact on the host's health.

These inferences can be made more precise by combining data from historical documents with those obtained from paleoparasitology or paleopathology. For example, the description of epidemics and evidence of the parasite or its genetic material in organic remains reinforce studies on health aspects of a given human group.

Studies may also suffer from imprecision in the coprolite's origin. When researchers find diverse coprolites in a given site, they face doubts as to whether the feces were eliminated by various individuals during a given period, or even concerning the species of the animal that produced them, except when the host's diet is known in detail or the egg finds are from species-specific parasites (Chame, 2003), as discussed later in this chapter. Such imprecisions can be substantially minimized (although not eliminated) when the samples are processed painstakingly and according to the best excavation practices. Rigorous precautions must be taken when removing the material from its original site during excavation. Such measures increase the likelihood of determining whether the genetic material belonged to one or several hosts and help ensure its organic origin. This avoids wasting time and resources in collecting and analyzing what later proves to be useless material.

For some parasites, however, although the number of eggs found in coprolites is small in samples from preColumbian America, the same parasites are amply recorded elsewhere in the world. This is true for the intestinal parasites Ascaris and Trichuris, which allowed formulating a comprehensive paleoepidemiological perspective, potentially helping to reconstruct the evolutionary history of Ascaris and Trichuris.

Ascaris lumbricoides finds are especially rare in pre-Columbian South America, although recent molecular studies indicate that this parasite has been under-diagnosed (Leles et al., 2008). Even more intriguing is the large number of finds of Trichuris trichiura eggs when compared to A. lumbricoides, since females of these two nematode species lay an average of twenty thousand and two hundred thousand eggs per day, respectively. Assuming that the taphonomic effect could be eliminated, given that different processes prevailed in the various environments, and assuming that this difference still persisted, it would be possible to hypothesize an evolutionary change in these parasites in their strategies for reproduction and maintenance of infection in the human host.

Much speculation has focused on whether natural and synthetic medicines may be more effective against Ascaris as compared to Trichuris (Keiser \& Utzinger, 2008). For microparasites, it is known that long periods of parasite-host association do not necessarily result in beneficial associations or greater stability in this relationship, especially vis-àvis the parasite's reproduction rate (Ewald, 1994). However, little is known in relation to macroparasites (as Ascaris and Trichuris are classified). This dynamic proves to be complex and results from the interrelationship between the two species' adaptive capacity, the parasite's pathogenicity, the interaction between the parasite and the host's immune system, and the parasite's life cycle inside and outside the host, among other factors (Ewald, 1994; Frank, 2002).

One possible explanation for the fact that $A$. lumbricoides increased its egg production over time is that the increase resulted from the use of medicinal plants by prehistoric peoples, thereby producing selective pressure. Since $A$. lumbricoides is more easily eliminated from the intestinal tract than T. trichiura, it tended to develop an evolutionary strategy of increasing egg production to ensure its transmission when humans began to ingest anthelminthic plants (whether as food or for intentionally medicinal purposes). 
The question remains: is paleoparasitology pointing to a strategic change in the evolution of Ascaris, which increased its reproducibility, partly due to pharmacological pressure on its evolutionary trajectory? Such questions may soon be answered by studies of genetic material recovered directly from the archaeological record, as discussed in various chapters of this book. Whether or not changes occurred in gene sequences over time, and whether these are related to the parasite's behaviors, it will be possible to trace evolutionary processes in both the parasite and its host.

However, other aspects of paleoparasitology can be analyzed with greater precision. For example, the finding of human intestinal parasites that originated by the phylogenetic route and were thus inherited from African ancestors constitutes irrefutable proof that the hosts brought them from other lands during their prehistoric migrations.

As discussed in Chapter 8, geohelminths require specific climatic conditions to develop in the soil and be transmitted from host to host. Based on analysis of these restrictive conditions, one can infer (with a good degree of certainty) the paths taken by their hosts, that is, whether such paths favored maintenance of the infection over the course of the host-environment-host life cycle. What matters more in this case is an accurate diagnosis rather than the number of eggs. The fact that one correctly diagnoses eggs of Enterobius vermicularis, for example, means that this parasite, which definitely originated in African ancestors, followed the prehistoric migration routes of its human hosts, with whom it reached the territories it eventually occupied.

Equally interesting is that even rare egg finds of a given parasite in organic remains from humans or other animals means that this parasite was transmitted in this group of individuals. This can lead to a series of inferences. Cockburn (1967) was one of the first authors to use parasite biology to reconstruct ancient epidemiological scenarios. He studied the possibility of the measles virus having infected prehistoric populations, especially nomadic hunter-gatherers, discussing the minimum number of individuals capable of maintaining the virus in circulation without interrupting the transmission chain. Measles, among other viral infections, can only be maintained in population groups with more than two hundred thousand members, or the sufficient number of individuals to contain the minimum amount of susceptible and infected individuals capable of maintaining transmission to new hosts. Contemporary medical geography features classical studies on this subject, such as the work by Cliff and his research group on the emergence and extinction of epidemics on islands (Cliff, Hagget \& Smallman-Raynor, 2000).

Likewise, the wide dispersal of most felines in forests would explain why these animals display no major epidemics, but only infections caused by some parasites showing greater infectivity and resistance during their cycles outside the host, i.e., greater capacity to survive for prolonged periods in the environment (Anderson \& May, 1992).

Analogously, one can reconstruct the epidemiological scenario of the hunter-gatherers. Nomadic or seminomadic groups of hunter-gatherers consisted of small numbers of persons, some 25 to 30 individuals circulating in extensive, borderless territories, although the spaces might be occupied by different bands (Campbel, Loy \& Cruz-Uribe, 2005). First, the reduced number of persons would limit many parasitic infections. Assuming that in a band of 30 individuals, all were susceptible to (and exposed to) infection with the measles virus, they would soon all become infected and would quickly be cured and immune to new infection, or have died of the disease. The virus would no longer circulate (Cockburn, 1967).

Meanwhile, other parasites would have experienced no difficulty in surviving in these small groups, even with low parasitism. An example is Enterobius vermicularis: this parasite developed various modes of host-to-host transmission, quite effective for adaptation. E. vermicularis can transmit from one host to another, and its eggs remain infective in the soil for several months. Thus, even if bands of hunter-gatherers roamed across extensive territories, when they returned to camp at previously occupied sites, the eggs in the soil could infect new individuals or re-infect previously infected ones. 
Reinhard (1992) studied pinworm infection in seminomadic hunter-gatherer/agriculturalist peoples of the Arizona Desert in North America. He explains the parasite's transmission inside the adobe dwellings built in the rock shelters by the Ancestral Puebloans. Similar studies (Hugot et al., 1999) have discussed different transmission routes and parasite burdens, suggesting that the aerial route, considered a novelty in transmission to humans, was favored by the change in behavior from nomadic hunter-gatherers to a more sedentary lifestyle, initially associated with cavedwelling, with more limited ventilation.

Tuberculosis is also interesting for studying diseases in pre-Columbian America. Considered nonexistent among the native peoples of the Americas, TB was purportedly introduced by the Europeans when they discovered and colonized the New World. In the case of Brazil, it was assumed that Jesuit priests played a key role in transmitting Mycobacterium tuberculosis to indigenous peoples. When they came to catechize the natives, the Jesuits also intended to enjoy what they considered a healthy environment, favorable for curing their maladies, as in the case of Father Anchieta. The Jesuit priests were thus considered the main culprits in the introduction of M. tuberculosis to Native American peoples (Ruffino Netto, 1999).

Paleoparasitology has disproven the introduction of $M$. tuberculosis infection exclusively during the colonial period. Typical cases of skeletal tuberculosis and recovery of genetic material from the bacillus have been described in various archaeological sites in the Americas, dated far before the Europeans' arrival. Tuberculosis already existed in pre-Columbian America (Souza, Carvalho \& Lessa, 2003). At the time, there were huge differences between the various peoples inhabiting the continent (Heckenberger et al., 2008). The population contingent varied greatly from region to region.

The peoples that inhabited the Andean Region increased in number when compared to the groups in the South American lowlands. But there were also substantial differences among the latter population groups. For example, the Brazilian coast was inhabited by populations with considerable numbers of individuals, more than two hundred thousand, for example (Gaspar et al., 2008), capable of maintaining various parasites in circulation, including viruses, bacteria, protozoa, helminths, and others.

In fact, the Europeans' arrival produced enormous changes in the organization of the life of these peoples and their interaction with the natural and social environment. The Jesuit Reductions were one of these transformations. This form of protection of indigenous peoples led to the clustering of villages in cramped territories, facilitating circulation of parasites. Even if the priests cannot be blamed for introducing infections like tuberculosis into the New World, they contributed (although involuntarily) to facilitating its circulation.

Chapters 5 and 20 of this book present an interesting example. Chapter 5 discusses the peopling of Patagonia and its colonization process. Chapter 20 analyzes the transition resulting from changes in the diet of indigenous groups and the parasites found in the coprolites left by them. Extensive evidence in food remains indicates reliance on wild resources, with the presence of parasites of animals (whether or not establishing true infection in the human host) and the emergence, resurgence, and accumulation of other parasite eggs such as A. lumbricoides and T. trichiura after the Europeans' arrival.

Meanwhile, the first Spanish and English that arrived and set up colonies in southern Patagonia also attempted to adapt to the environment, but were not initially successful. The paleoparasitological record includes data that elucidate these events.

Another process of environmental modification in the social ecology of infectious diseases (Mayer \& Pizer, 2007) was perhaps more important and contributed considerably to the spread of infection among Amerindian peoples and 
colonizers. The reproduction of European urban models used houses whose architecture aimed to protect the residents from purported miasmas. The colonizers built their living quarters with the typical blinds or jalousies and the alcove (bedroom) located at the center of the residence, with no lighting, ventilation, or communication with the outdoors, and with virtually no facilities for running water or sewage disposal (Cavalcanti, 2003).

Brazilian colonial towns were built packed together, with people circulating in cramped spaces. The indigenous peoples also migrated to the towns, and there was a constant increase in the African slave trade, with the slaves living in abject servitude, under adverse health conditions (Sousa, 1998). The majority were occupied in urban labor, a context in which the "house slave" emerged. In the early $19^{\text {th }}$ century, an average colonial family in Rio de Janeiro had an estimated seven to eight negro slaves living in the home (Ruffino Netto \& Pereira, 1981), and with them, new parasites, habits, and customs.

Syphilis also has an old history in the Americas. Extensive literature discusses the origins of the different Treponema species. Whether syphilis originated in the Americas and spread from there to Europe with sailors in Columbus' returning fleet (the Columbian hypothesis) or already existed in the old World, with different clinical forms (the pre-Columbian hypothesis) is still subject to debate.

Epidemic syphilis irrefutably occurred in late $15^{\text {th }}$ century Europe, initially with a highly virulent form. However, there are two conflicting hypotheses for its origin. The first contends that syphilis already existed in the Old World before Columbus' voyage to the Americas, but that it was absent from New World indigenous groups. Infected sailors were responsible for spreading the infection when they reached the New World.

The second hypothesis is exactly the opposite: the indigenous peoples infected the sailors, who returned to Europe and spread syphilis, previously unknown in the old World. The support for this second hypothesis comes from the purported lack of European human remains with syphilitic lesions prior to 1493, in contrast to abundant evidence after this date. However, skeletons with signs of Treponema infection, some clearly suggestive of syphilitic lesions, have recently been discovered in the old World with dates prior to the $15^{\text {th }}$ century.

According to the Columbian hypothesis, syphilis was introduced into the Old World by Columbus' fleet upon their return from the Americas. In Europe, the infection found favorable cultural, social, and biological conditions for its spread, including urban crowding, major population shifts and contingents (mainly associated with wars), and changing sexual behaviors, favoring the establishment of a susceptible population in permanent interaction (Celentano et al., 2007). This hypothesis appears to be corroborated by the large number of findings of individuals with treponemal lesions in New World prehistoric material, contrary to the Old World, and by descriptions of lesions consistent with treponemal diseases in Native Americans by the first Europeans that reached the Americas (lesions that were considered nonexistent in Europe). Added to this was the sudden description of symptoms, contagion, and course of the infection that emerged in the European literature after the $15^{\text {th }}$ century.

Considering these two conflicting hypotheses in the international literature, this remains an open question. It may soon be answered using other tools, most recently from molecular biology (Steinbock, 1976; Rothschild et al., 2000; Sefton, 2001; Meyer et al., 2002). Molecular assays have been applied to skeletal archaeological material with syphilitic lesions. However, the results so far require a critical stance (Kolman et al., 1999; Bouwman \& Brown, 2005). The first studies with a phylogenetic approach in the attempt to elucidate the origin of syphilis point to the Columbian hypothesis (Harper et al., 2008).

One of the most interesting questions on the origin of treponemal diseases was raised by epidemiologist Robert Desowitz in his book Who Gave Pinta to the Santa Maria? (1998). He discusses the various clinical manifestations of 
syphilis, highlighting aspects of its pathogenicity, virulence, and case-fatality in the European population from 1493 to 1510 , in contrast to its purportedly benign course in the pre-Colombian Amerindian peoples.

As discussed in Chapter 26 (on Chagas disease in prehistoric America), Trypanosoma cruzi must have infected humans as soon as they occupied habitats favorable to the vector and animal reservoirs. Outside the Andean Region, in the United States and Brazil, cases of megacolon have been described in mummified bodies with a considerable accumulation of feces. This severe condition was the probable cause of death in the two individuals described by Reinhard, Fink \& Skiles (2003) and Fernandes et al. (2008). Chagasic infection existed in prehistoric groups in Brazil some 7,000 years ago (Lima et al., 2008). It affected both nomadic hunter-gatherers and agriculturalist huntergatherers as long as 1,200 years ago (Fernandes et al., 2008). For shelter, both types of groups used the caves in the limestone outcropping of the cerrado (savannah) in what is now Minas Gerais State. These caves are inhabited by wild triatomine species that transmit T. cruzi and by mammalian reservoirs. The caves and rock shelters served not only as the band's temporary dwellings or camps, but also for the agriculturists to store food and bury their dead.

The remains left by these groups included baskets of food, especially grain, which must have attracted small animals like rodents, some of which were efficient reservoirs for T. cruzi. The conditions thus existed in pre-Columbian groups for the transmission of T. cruzi and cases of acute or chronic Chagas disease. What manifestations or impact might Chagas disease have produced in these populations? Chronic cases are nicely illustrated by the North American finding described by Reinhard, Fink \& Skiles (2003). The individual died at around 35 to 45 years of age and received an elaborate funeral, with various accoutrements, the most evident of which was a leather band wrapped around his abdomen, showing the special care taken with that individual.

The body had a huge amount of feces accumulated in the intestine, and his companions apparently attempted to relieve his suffering by wrapping him with the leather band to contain his abdominal distension. Tests indicate that he died of a ruptured intestine and systemic infection (Reinhard, Fink \& Skiles, 2003). The case shows that this prehistoric group had the knowledge and experience to deal with a chronic health problem (specifically Chagasic megacolon) that must have been relatively common at the time.

Other situations illustrate the potential of paleoparasitology to elucidate longstanding questions. For example, the PhD dissertation by Diana Maul de Carvalho on the Athens plague (Carvalho, 1996) analyzes the different possible diagnoses for the disease while reconstructing life in ancient Greece. However, more recent findings suggest a different diagnosis for the epidemic, discussing the finding of genetic material from Salmonella enterica serovar typhi and its possible role in the Athens plague (Papagrigorakis et al., 2006).

Recent studies by Bianucci et al. $(2007,2008)$ point to new research paths using the rapid diagnostic dipstick test for Yersinia pestis F1 antigen to investigate the plague in ancient human remains. Samples studied thus far cover periods of the plague epidemic in $16^{\text {th }}, 17^{\text {th }}$, and $18^{\text {th }}$-century France. Such advances definitely open new and interesting analytical prospects, capable of answering questions on the parasite's evolution and possible changes in its pathogenicity over time (Bianucci et al., 2007, 2008). Chapters 18 and 19 of the current book explore these issues quite thoroughly, dealing with the recovery of genetic material from ancient remains, but the same issues cut across virtually all of the chapters. As highlighted in the opening chapters, the phenomenon of parasitism belongs to the domain of ecology and is thus eminently evolutionary. 


\section{FINAL REMARKS}

Despite all the potential shortcomings in the application of epidemiological methods to studies on infections and diseases of the past, as discussed by Souza, Carvalho \& Lessa (2003), the new findings in paleoepidemiology unveil absolutely unprecedented possibilities for the reconstruction of ancient events. The currently available techniques allow recovering genetic material to back interpretations dated to such times. There is no doubt that the past can be understood through reliable diagnostic methods for parasitic infections, reconstructing specific scenarios for each human group inhabiting the different environments where Homo sapiens roamed and settled.

Since the trajectory of parasites and hosts is inseparable, the future will reveal a new evolutionary history of paths that date back to the very origins of life (Araújo et al., 2003), when the intermolecular relations were shaped that allowed the emergence of life on the planet.

As invariably happens with the various fields of contemporary science, modern epidemiology has much to learn from the history of humankind and Earth, and especially from paleoepidemiology.

\section{REFERENCES}

ANDERSON, R. M. \& MAY, R. M. Infectious Diseases of Humans: dynamics and Control. Oxford: Oxford University Press, 1992.

ARAÚJO, A. et al. Parasitism, the diversity of life, and paleoparasitology. Memórias do Instituto Oswaldo Cruz, 98, supl. 1: 5-11, 2003.

BIANUCCI, R. et al. Détection de l'antigène F1 de Yersinia pestis dans les restes humains anciens à l'aide d'un test de diagnostic rapide. Comptes Rendus des Biologies, 330: 747-754, 2007.

BIANUCCI, R. et al. Technical note: a rapid diagnostic test detects plague in ancient human remains: an example of the interactions between archeological and biological approaches (Southwestern France, $16^{\text {th }}-18^{\text {th }}$ Centuries). American Journal of Physical Anthropology, 136: 361-367, 2008.

BOUWMAN, A. S., \& BROWN, T. A. The limits of biomolecular paleopathology: ancient DNA cannot be used to study venereal syphilis. Journal of Archaeological Science, 32: 703- 713, 2005.

CAMPBELL, B. G.; LOY, J. D.; CRUZ-URIBE, K. Humankind Emerging. Boston: Allyn \& Bacon, 2005.

CARVAlHo, D. M. História e Epidemiologia, Possibilidades e Limites: o caso do escorbuto e da peste de Atenas, 1996. PhD dissertation, Rio de Janeiro: Escola Nacional de Saúde Pública Sergio Arouca, Fundação Oswaldo Cruz.

CAVALCANTI, N. O Rio de Janeiro Setecentista: a vida e a construção da cidade, da invasão francesa até a chegada da corte. Rio de Janeiro: Jorge Zahar, 2003.

CELENTANO, D. D. et al. Changing sexual mores and disease transmission. In: MAYER, K.H. \& PIZER, H. F. (Eds.). The Social Ecology of Infectious Diseases. Amsterdam: Elsevier, 2007.

CHAME, M. Terrestrial mammal feces: a morphometric summary and description. Memórias do Instituto Oswaldo Cruz, 98, Supl. 1: 71-94, 2003.

CHAVES, S. A. M. \& REINHARD, K. J. Critical analysis of coprolite evidence of medicinal plant use, Piauí, Brazil. Palaeogeography, Palaeoclimatology, Palaeoecology, 237: 110-118, 2006.

CLIFF, A.D.; HAGGETT, P. \& SMALLMAN-RAYNOR, M. R. Island Epidemic. Oxford: Oxford University Press, 2000. (Oxford Geographical and Environmental Studies Series)

COCKBURN, A. Infectious Diseases: their evolution and eradication. Springfield: Thomas CC, 1967. 
DESOWITZ, R.S. Who Gave Pinta to the Santa Maria? Tracking the devastating spread of the lethal tropical diseases into America. New York: Harvest Book, 1998.

DIAMOND, J. Collapse. New York: Penguin Books, 2005.

EWALD, P. Evolution of Infectious Diseases. Oxford: Oxford University Press, 1994.

FERNANDES, A. et al. Pre-Columbian Chagas disease in Brazil: Trypanosoma cruzi I in the archaeological remains of a human in Peruaçu Valley, Minas Gerais, Brazil. Memórias do Instituto Oswaldo Cruz, 103: 514-516, 2008.

FRANK, S. A. Immunology and Evolution of Infectious Disease. Princeton: Princeton University Press, 2002.

HARPER, K. N. et al. On the origin of the treponematoses: a phylogenetic approach. PLoS Neglected Tropical Diseases, 2 (1): e148, 2008.

HECKEnBERGER, M. J. et al. Pre-Columbian urbanism, anthropogenic landscapes, and the future of the Amazon. Science, 321: 1214-1217, 2008.

HUGOT, J. P. et al. Human enterobiasis in evolution: origin, specificity and transmission. Parasite, 6: 201-208, 1999.

KEISER, J. \& UTZINGER, J. Efficacy of current drugs against soil-transmitted helminth infections: systematic review and metaanalysis. JAMA, 299: 1.937-1.948, 2008.

KHOURI, M. J.; LITTLE, J. \& BURKE, W. (Eds.). Human Genome Epidemiology. Oxford: Oxford University Press, 2004.

KOLMAN, C. J. et al. Identification of Treponema pallidum subspecies pallidum in a 200-year-old skeletal specimen. The Journal of Infectious Diseases, 180: 2.060-2.063, 1999.

LAST, J. M. A Dictionary of Epidemiology. New York: Oxford University Press, 1995.

LELES, D. et al. Molecular paleoparasitological diagnosis of Ascaris sp. from coprolites: new scenery of ascariasis in pre-Columbian South American times. Memórias do Instituto Oswaldo Cruz, 103: 106-108, 2008.

LIMA, V. S. et al. Chagas disease in ancient hunter-gatherer population, Brazil. Emerging Infectious Diseases, 14:1.001-1.002, 2008.

MAYR, E. What Makes Biology Unique? Cambridge: Cambridge University Press, 2004.

MAYER, K. H. \& PIZER, H. F. Social Ecology of Infectious Diseases. London: Academic Press, 2007.

MENZIES, G. 1421: the year China discovered America. New York: Harper Perennial, 2008.

MEYER, C. et al. Syphilis 2001: a paleopathological reappraisal. Homo, 53: 39-58, 2002.

MORABIA, A. A History of Epidemiologic Methods and Concepts. Basel: Birkhäuser Verlag, 2004.

PAPAGRIGORAKIS, M. J. et al. DNA examination of ancient dental pulp incriminates typhoid fever as a probable cause of the Plague of Athens. International Journal of Infectious Diseases, 10: 206-214, 2006.

REINHARD, K. J. Parasitology as an interpretative tool in archaeology. American Antiquity, 57: 231-245, 1992.

REINHARD, K. J.; FINK, T. M. \& SKILES, J. A case of megacolon in Rio Grande valley as a possible case of Chagas disease. Memórias do Instituto Oswaldo Cruz, 98 Supl. 1:165-72, 2003.

ROTHSCHILD, B. M. et al. First European exposure to syphilis: the Dominican Republic at the time of Columbian contact. Clinical Infectious Diseases, 31: 936-941, 2000.

RUFFINO NETTO, A. Impacto da reforma do setor saúde sobre os serviços de tuberculose no Brasil. Boletim de Pneumologia Sanitária, 7:7-18, 1999.

RUFFIno NETTO, A. \& PEREIRA, J. C. Mortalidade por tuberculose e condições de vida: o caso do Rio de Janeiro. Saúde em Debate, 12: 27-34, 1981.

SAGAN, C. The Varieties of Scientific Experience. New York: Penguin Books, 2006. 
Foundations of Paleoparasitology

SEFTON, A. M. The great pox that was... syphilis. Journal of Applied Microbiology, 91: 592-596, 2001.

SORENSON, J. L. \& JOHANNESSEN, C.L. World Trade and Biological Exchanges before 1492. Bloomington: iUniverse 1663 Liberty Drive, 2009.

STEINBOCK, R. T. Paleopathological Diagnosis and Identification. Illinois: Charles C. Thomas, 1976.

SOUSA, J. P. (Org.). Escravidão: ofícios e liberdade. $1^{\text {st }}$ Ed. Rio de Janeiro: Arquivo Público do Estado do Rio de Janeiro, 1998. vol. 1.

SOUZA, S. M.; CARVALHO, D. M. \& LESSA, A. Paleoepidemiology: is there a case to answer? Memórias do Instituto Oswaldo Cruz, 98, supl. 1: 21-27, 2003.

WILSON, E. O. The Diversity of Life. New York: WW Norton \& Company, 1999. 
Format: $21 \times 26 \mathrm{~cm}$

Set in: Caxton Lt Bt and NewsGoth Cn BT Paper: Offset $90 \mathrm{~g} / \mathrm{m}^{2}$ (text) and Supreme Card Stock 300g/m² (cover) CTP, Printing, and Finishing: Imos Gráfica e Editora Ltda.

Rio de Janeiro, Brazil, May 2014.

Our titles are available at bookstores and directly from: Editora Fiocruz

Av. Brasil, 4036, térreo, sala 112 - Manguinhos

CEP 21040-361 - Rio de Janeiro, RJ, Brazil

Telephones: (+5521) 3882-9039 and 3882-9041

Telefax: (+5521) 3882-9006

www.fiocruz.br/editora

editora@fiocruz.br 